UNIVERSIDADE DE SÃO PAULO

INSTITUTO DE GEOCIÊNCIAS

\title{
GEOLOGIA E PALEONTOLOGIA DAS FORMAÇÕES TATUÍ E IRATI NO CENTRO-LESTE DO ESTADO DE SÃO PAULO
}

\author{
Artur Chahud \\ Orientador: Prof. Dr. Setembrino Petri
}

\section{TESE DE DOUTORAMENTO}

Programa de Pós-Graduação em Geoquímica e Geotectônica

São Paulo

2011 
"Pain is temporary. It may last a minute, or an hour, or a day, or a year, but eventually it will subside and something else will take its place. If I quit, however, it lasts forever." (Lance Armstrong) 


\section{AGRADECIMENTOS}

Agradecimento especial ao Professor Doutor Setembrino Petri pela orientação neste doutoramento, apoio, dedicação, incentivo e principalmente por ter acredito em mim nestes anos em que trabalhamos juntos.

Ao Professor Doutor Thomas Rich Fairchild pela orientação durante o Mestrado e ter dado início a toda a caminhada desta pesquisa.

Aos proprietários do Sítio Santa Maria, Sr. Luis e Dona Bernadete Esposti, por permitirem o desenvolvimento dos trabalhos em suas terras. Sem eles nada disso seria possível.

Ao proprietário da Fazenda Ponte Nova 1, Sr. Airton Bartman que permitiu a coleta de material e de dados em suas terras.

A CAPES (Coordenação de Aperfeiçoamento de Pessoal de Nível Superior) pela bolsa de estudos no primeiro mês de doutorado no ano de 2007.

A FAPESP (Fundação de Amparo a Pesquisa do Estado de São Paulo) pela bolsa de estudos durante os anos de 2007, 2008 e 2009.

Aos professores da minha Banca de Qualificação Claudio Riccomini e Paulo Roberto dos Santos pelas valiosas dicas

Aos colegas, parceiros de pesquisa e de campo Annabel Pérez Aguilar, Evelyn Aparecida Mecenero Sanchez Bizan, Felipe van Enck Meira, Guilherme Raffaeli Romero, Johanna Mendez Duque, Mírian Liza Alves Forancelli Pacheco pelo auxílio e grande importância na minha vida acadêmica.

As turmas da disciplina GSA-5806-1 Ambientes de Sedimentação dos anos de 2007, 2008 e 2009. Um agradecimento especial aos alunos do ano de 2010: Johana, Nazaré, Oscar, Patrícia e Sara com ajuda e contribuição

A Professora e Doutora Mary E. C. Bernardes de Oliveira por permitir utilizar os recursos do Laboratório de Paleobotânica e a colega Renata Lourenço Lopes, pela iniciativa de reforma do Laboratório Paleobiologia, que facilitou o desenvolvimento desta pesquisa.

Aos meus parentes, incluindo os que faleceram durante o desenvolvimento da pós-graduação, em particular minhas tias Rosa e Nair que partiram durante o doutoramento e que sempre torceram por mim. 


\section{RESUMO}

A área de ocorrência das formações Tatuí e Irati, na região centro-leste do Estado de São Paulo, entre as cidades de Leme e Rio das Pedras é objeto desta pesquisa. São detalhadas as ocorrências destas duas formações, através de seções estratigráficas, caracterizando e analisando as sucessões de litotipos, conteúdo fossilífero, tafonomia dos fósseis, além de enfocar hipóteses paleoecológicas e paleoambientais. Na Formação Tatuí foram identificadas quatro fácies, a inferior de arenitos finos e paleoambiente incerto, duas refletindo contexto não marinho e a de topo com influência marinha. As duas fácies do contexto predominantemente não marinho são respectivamente siltitos arenosos com fósseis de água doce e arenitos grossos ou conglomeráticos, fácies Ibicatu, localmente com lenhos. A fácies de topo é caracterizada por depósitos de arenitos finos, ocasionalmente com grandes estratificações cruzadas, estratificações "hummockies", apropriado para um grande corpo d'água salino. O conteúdo fóssil da Formação Tatuí inclui três tipos de icnofósseis em três fácies diferentes (fácies basal do estudo, Ibicatu, e no topo), grandes caules vegetais (pteridófitas e espermatófitas) na fácies Ibicatu, crustáceos (conchostráceos e fragmentos indeterminados) ocorrem na fácies síltica, escamas, dentes e partes ósseas de peixes ósseos na fácies siltica e topo da Formação Tatuí. O Membro Taquaral é reconhecido por duas fácies e dois paleoambientes de salinidade variável. A fácies basal, composta de arenitos finos a conglomeráticos, granulometria irregular horizontal e verticalmente e com ictiofósseis, é interpretada como depositada em ambiente raso dominado por ondas. A segunda fácies, folhelhos sílticos, é típica de paleoambientes mais calmos, provavelmente com menor salinidade. Os fósseis da base arenosa do Membro Taquaral são peixes, representados por Chondrichthyes sob a forma de dentes cladodontes, espinhos de Euselachii (Amelacanthus e Iratiacanthus), espinhos Ctenacanthiformes (Sphenacanthus sanpauloensis e S. sp.), dentes de Xenacanthiformes, Diplodoselachidae (Taquaralodus albuquerquei) e Xenacanthidae, dentes de Orodontiformes, (Orodus ipeunaensis), Petalodontiformes (Itapyrodus punctatus e I. sp.) e Holocephali indeterminados. A fauna de Osteichthyes é a mais abundante em número de espécimes, sendo composta, predominatemente, de dentes e escamas paleoniscóides, raras escamas de Coelacanthimorpha, partes ósseas e dentes labirintodontes, estes atribuídos a Osteolepiformes e a tetrápodes Temnospondyli. Os fósseis estão normalmente dispersos e desarticulados e os elementos ósseos fragmentados e desgastados. O conteúdo fóssil da fácies folhelho síltico do Membro Taquaral é raro, os mais comuns são crustáceos, principalmente do gênero Clarkecaris, e restos muito fragmentados de Coelacanthimorpha e Palaeonisciformes.

Palavras-chave: Formação Tatuí, Formação Irati, Permiano, Crustacea, vertebrados 


\section{ABSTRACT}

The following Paraná Basin, Late Paleozoic lithoestratigraphic units, the upper part of the Tatuí Formation, located under the lower part of the Irati Formation, Taquaral Member are cropping out at center-eastern State of São Paulo, Brazil, between Rio das Pedras and Leme. The lithologies, fossil contents and taphonomy of these units are studied through stratigraphic sections, allowing the formulations of paleoecological and paleoenvironmental hypothesis. Four facies were recognized at the top of the Tatuí Formation stratigraphic sections which were interpreted as following; the basal an uncertain paleoenvironment of deposition, two paleoenvironmental contexts; mostly continental and one under deposits marine influence. The two facies interpreted as mostly continental are respectively, sandy-siltstones facies with freshwater fossils and coarse to conglomeratic sandstone, Ibicatu facies, locally with log plants. The top facies, interpreted as under a marine influence, is characterized by deposits of fine sandstones, occasionally with large cross beds, hummockies, and, locally, tidal deposits, suited for a large body, of saline water. The fossil content of Tatui Formation include three kinds of trace fossils in three different facies (basal, Ibicatu and top respectively), large stem plants (Pterydophyta and Spermatophyta) in the Ibicatu deposit, with indeterminated fragments of crustaceans and conchostraceans, found out in the siltstone facies and scales, teeth and bone pieces, found out in siltstone and of the top facies. Two facies were recognized at the Taquaral Member. The basal are fine to conglomeratic sandstone with irregularly grain size both horizontal and vertically, with ichthyofossils. It is interpreted as laid down in a salty shallow water dominated by waves. The second are silty shale laid down in low saline water. The fossils of the sandy facies are Chondrichthyes: cladodontes teeth, Euselachii finspines (Amelacanthus and Iratiacanthus santamariaensis), Ctenacanthiformes finspines (Sphenacanthus sanpauloensis and $S$. sp.), Xenacanthiformes teeth, Diplodoselachidae (Taquarodus albuquerquei) and Xenacanthidae, Orodontiformes: Orodus ipeunaensis, Petalodontiformes (Itapyrodus punctatus and I. sp.) and undetermined Holocephali. The fauna of Osteichthyes, the most abundant in number of specimens are predominantly paleoniscoid teeth and scales, rare Coelacanthimorpha scales, labyrinthodonts bones and teeth, assigned to Osteolepiformes and tetrapods Temnospondyli. The fossils are usually scattered, disorganized, fragmented and worn. The fossil content of the Taquaral silty-shale facies is meager, the most common are crustaceans, mainly of the genus Clarkecaris, and very fragmented remains of Coelacanthimorpha and Palaeonisciformes.

Keywords: Tatuí Formation, Irati Formation, Perrnian, Crustacea, vertebrates 


\section{LISTA DE FIGURAS}

Figura 1 - Distribuição das formações Tatuí e Irati no centro-leste do estado de São Paulo com

todos os afloramentos estudados e as principais vias de acesso (modificado de ASSINE et al., 2003)

Figura 2 - Diferentes graus de empacotamento dos bioclastos (KIDWELL \& HOLLAND,

1991).

Figura 3 - Estágios de desgaste de dente de Chondrichthyes (BENTON, 1997).

Figura 4 - Região entre Rio Claro e Ipeúna mostrando as principais rodovias de acesso em que

se localizam os principais afloramentos fossilíferos. Escala $2 \mathrm{~km}$. Fonte da foto de satélite:

Google Earth (2005)

Figura 5 - Área onde estão os afloramento 1-5 na região entre Rio Claro e Ipeúna. Escala $1 \mathrm{~km}$.

Fonte da imagem de satélite Google Earth (2005)

Figura 6 - Região onde ocorrem os afloramentos 6-8 na região de Piracicaba e Rio Das Pedras. Principais vias de acesso. Escala 4km. Fonte da foto de satélite Google Earth (2005).

Figura 7 - A) Localização do Afloramento 9 na Reodovia Elhiu Root nos arredores de Araras e

Leme. Escala 100m. B) Localização do Afloramento 11, Córrego do Veado. Escala 200m. Fonte da foto de satélite Google Earth (2005).

Figura 8 - Seção estratigráfica do Afloramento 1.

Figura 9 - Foto do Afloramento 1. No chão a fácies Iai do Membro Taquaral.

Figura 10 - Afloramento 1 região inferior da fácies Iai do Membro Taquaral, preservando o contato erosivo com a camada subjacente da fácies Taf da Formação Tatuí. Escala $20 \mathrm{~mm}$.

Figura 11 - Seção estratigráfica do Afloramento 2.

Figura 12 - Afloramento 2. Sítio Santa Maria 2. Degrau representando a fácies Iai. Acima

blocos rolados de diabásio e de calcários do Membro Assistência.

Figura 13 - Seção estratigráfica do Afloramento 3.

Figura 14 - Afloramento 3 na divisa de Rio Claro com Ipeúna. Destaque para a fácies Iai de coloração acinzentada.

Figura 15 - Afloramento 4: contato da fácies Taf (inferior) com a fácies Iai (superior).

Figura 16 - Amostra de rocha silicificada do Afloramento 4. Escala $1 \mathrm{~cm}$.

Figura 17 - Seção estratigráfica do Afloramento 4.

Figura 18 - Localização dos Pontos A e B do Afloramento 5. Escala 100m. Fonte da imagem de Satélite Google Earth (2005).

Figura 19 - Seção estratigráfica dos pontos A e B do Afloramento 5.

Figura 20 - Camada de arenito fino intercalando uma camada da base do Membro Taquaral da Formação Irati. Escala $1 \mathrm{~cm}$.

Figura 21 - Seção estratigráfica do Afloramento 6.

Figura 22 - Fácies basal arenosa da Formação Tatuí encontrada no Af. 6. Destaque para a fácies Taf.

Figura 23 - Seção estratigráfica do Afloramento 7.

Figura 24 - Afloramento 7. Km 152,5 da Rodovia do Açúcar. Destaque para os blocos rolados pertencentes a Fácies arenosa na porção superior do afloramento.

Figura 25 - Camada conglomerática encontrada intercalando camadas mais finas.

Figura 26 - Icnofósseis observados próximos da base da fácies arenosa.

Figura 27 - Seção estratigráfica do Afloramento 8.

Figura 28 - Estrada Elhiu Root onde estaria localizado o afloramento 9, seção tipo da cunha clástica de Ibicatu.

Figura 29 - Amostra da Fácies conglomerática. Escala 10mm.

Figura 30 - Contato entre as unidades de topo e base do Afloramento da Rodovia Irineu

Penteado. Martelo marca o contato.

Figura 31 - Seção estratigráfica do Afloramento 10.

Figura 32 - Ponto A do afloramento 11, Córrego do Veado. Próximo da Rodovia entre Limeira e 
Figura 33 - Ponto B do afloramento 11. Córrego do Veado.

Figura 34 - Seção estratigráfica dos dois pontos do Afloramento 11.

Figura 35 - Conglomerado silexítico do Ponto B.

Figura 36 - Estratificações cruzadas sigmoides e estratificação espinha de peixe no Ponto B.

Ponto também ilustrado por STEVAUX et al. (1986) e MOCHIZUKI (2001)

Figura 37 - Pontos A, B e C do Afloramento 12. Escala 200m. Fonte Google Earth 2005.

Figura 38 - Ponto A do Afloramento da Fazenda Ponte Nova.

Figura 39 - Ponto C do Afloramento da Fazenda Ponte Nova. Destaque para a localização das

fácies observadas.

Figura 40 - Seções colunares dos três pontos do Afloramento 12, Fazenda Ponte Nova.

Figura 41 - Estratificação da camada basal do Ponto A. Escala $4 \mathrm{~cm}$.

80

Figura 42 - Detalhe da fácies Tsa observada no Ponto A.

81

Figura 43 - Área de exposição do microconglomerado visto em planta dentro da camada 2.

Escala $2 \mathrm{~cm}$.

Figura 44 - A) Vista em perfil do icnofóssil encontrado na fácies 1, GP/7E-352. B) Vista em

planta de icnofóssil encontrado na fácies 1 . Escala $2 \mathrm{~mm}$.

Figura 45 - Icnofósseis encontrados no Km152,5 da Rodovia do Açucar. Escala 4cm.

Figura 46 - Icnofósseis encontrados no Afloramento do Sítio Santa Maria. A e B) exemplares

com preenchimentos contendo ictiólitos (GP7E/349b e GP7E/351a). C-D) Icnofósseis orientados (GP7E/350a e GP7E/349a). Escala 10mm.

Figura 47 - Fóssil na base da camada Ibicatu.

Figura 48 - Exemplar coletado na Facies Ibicatu do Afloramento $9(\mathrm{GP} / 3 \mathrm{E}-9183)$. Escala $1 \mathrm{~cm}$.

Figura 49 - Detalhes dos meristelos com contorno escleremquimático (GP/3E - 9183).. Escala

Figura 50 - Vista longitudinal do exemplar coletado na Facies Ibicatu do Afloramento 9 (GP/3E - 9184). Escala $1 \mathrm{~cm}$.

Figura 51 - Exemplar com manto radicular penetrando dentro do estelo (GP/3E - 9184). Escala $2 \mathrm{~cm}$.

Figura 52 - Lenho fóssil coletado na Fácies Ibicatu do Afloramento 9 (GP/3E - 9185). Escala $5 \mathrm{~cm}$.

Figura 53 - Acima, corte transversal do exemplar GP/3E - 9185 mostrando o aspecto raiado e a pequena medula. Abaixo detalhe do mesmo exemplar. Escala $2 \mathrm{~cm}$.

Figura 54 - Detalhe de falsos anéis em lâmina delgada. Escala $0,2 \mathrm{~mm}$.

Figura 55 - Anéis interrompidos em região próxima da medula. Escala 0,2mm.

Figura 56 - Região de borda da medula, destacando as celulas maiores não orientadas em lâmina delgada. Escala $0,2 \mathrm{~mm}$

Figura 57 - Exemplar deformado pela diagenêse distorcendo o manto radicular do lado esquerdo e direito, comprimindo-o (GP/3E - 9184). Escala $2 \mathrm{~cm}$.

Figura 58 - Conchostráceos provenientes do Ponto A da Fazenda Ponte Nova. A-B)

Conchostráceos de carapaça incompleta (A) GP/1E-6203; B) GP/1E-6197). C) Conchostráceos

com possíveis resíduos de matéria orgânica no interior da concha (GP/1E-6201). D)

Conchostráceo de valva desarticulada (GP/1E-6199). E) conchostráceo de valva deslocada

(GP/1E-6200). Escala $1 \mathrm{~mm}$.

Figura 59 - Acumulações de conchostráceos no Ponto A. A) Vista em planta de uma assembléia

fortemente empacotada de conchostráceos (GP/1E-6198). B) Vista em planta de uma assembléia mediamente empacotada (GP/1E-6196). C) Vista em planta de uma assembléia fracamente empacotada (GP/1E-6204). D) Vista em planta de uma assembléia que passa lateralmente de fortemente empacotada para fracamente empacotada (GP/1E-6200). Escala $2 \mathrm{~mm}$.

Figura 60 - Desenhos esquemáticos de vários crustáceos identificados na Formação Tatuí por MEZZALIRA \& MARTINS NETO (1992) (Protourda, Pseudopalaega granulifera e

Pseudopalaega microcelata). Escala $1 \mathrm{~mm}$.

Figura 61 - Fragmento de artrópode não identificável da Formação Tatuí do Afloramento 12 (GP/1E-6205). Escala 12mm.

Figura 62 - Dente fragmentado de Palaeonisciformes, proveniente do topo da Formação Tatuí no Afloramento 5. Escala 2mm. 
Figura 63 - Escama de Palaeonisciformes, associada aos conchostráceos, encontrado no

Afloramento 12 (GP/2E-6585). Escala $5 \mathrm{~mm}$.

Figura 64 - Petrodus (?) GP/2E-5935a. Escala 0,5mm.

115

Figura 65 - Variedade de dentes cladodontes, hibodontes e diplodontes (1. JANVIER, 1996; 2.

LONG, 1993; 3. BAIRD, 1978; 4. MOY-THOMAS \& MILES, 1971; 5. LONG, 1995; 6.

JOHNSON, 1981).

Figura 66 - Esquema de dente Cladodonte proposto por DUFFIN \& GINTER (2006).

Figura 67 - Cladodonte GP/2E-5918 encontrado na base da Formação Irati. A) vista labial; B)

vista lingual. Escala $2 \mathrm{~mm}$.

Figura 68 - Cladodonte GP/2E-5919 do Membro Taquaral. A) vista labial; B) vista lingual; C e D) vistas laterais. Escala $2 \mathrm{~mm}$.

Figura 69 - Cladodonte GP/2E-6306 do Membro Taquaral. A) Vista Labial; B) Vista Lingual. Escala $2 \mathrm{~mm}$.

Figura 70 - Características de diversos espinhos de Euselachii (MAISEY,1982).

Figura 71 - Fragmento de espinho de Acondylacanthus da Formação Minturn, Neocarbonífero da América do Norte (ITANO et al. 2003). 1) Corte transversal; 2) Vista lateral esquerda; 3) Vista inferior. Escala: $10 \mathrm{~mm}$.

Figura 72 - Espinho GP/2T-204 de Sphenacanthus sanpauloensis, encontrado na Base da Formação Irati. Escala $10 \mathrm{~mm}$.

Figura 73 - Espinho GP/2T-204 de Sphenacanthus sanpauloensis. A) região mediana superior; B) Região mediana inferior; C) Região de imbricação; D) costela bifurcada. Escala: $5 \mathrm{~mm}$.

Figura 74 - Exemplar de Sphenacanthus sanpauloensis GP/2E- 6583. A-B) faces laterais direita e esquerda. Escala $10 \mathrm{~mm}$.

Figura 75 - Exemplar de Sphenacanthus sp. GP/2E-6582. A-B) faces laterais direita e esquerda. Escala $10 \mathrm{~mm}$.

Figura 76 - Espinhos de Amelacanthus encontrados na base da Formação Irati. A) Exemplar GP/2E-6461; B-C) Exemplar GP/2E-6584. B) (GP/2E-6584A) parte centro distal de espinho; C) (GP/2E-6584B) parte centro proximal. Escalas 10mm.

Figura 77 - Faces laterais do espécime GP/2E-6579 de Hybodontiformes. Escala 10mm.

Figura 78 - Espécimes de Iratiacanthus santamariaensis. A) faces laterais do espécime GP/2E6455 ; B) face lateral do espécime GP/2E-6462. Escala 10mm.

Figura 79 - Detalhe do exemplar GP/2E-6455 de Iratiacanthus santamariaensis. A) Seção transversal; B) Diminuição gradual da largura das costelas do sentido anterior (superior na imagem) para posterior (Inferior na imagem). C) Bifurcação de costela; D) Costela frontal na parte central da imagem que separa as faces laterais do espécime. Escalas $5 \mathrm{~mm}$.

Figura 80 - Esquema de dente de Xenacanthiformes, adaptado de HAMPE (2003). A) Vista lingual; B) Vista labial; C) Vista lateral; D) Vista basal.

Figura 81 - Dentes de Diplodoselachidae. A) Diplodoselache woodi; B) Diplodoselache parvulus; C) Dicentrodus bicuspidatus; D - E) Orthacanthus gibbosus; F) Wurdigneria obliterata. A) Vista labial; B-F) Vista lingual. Escala 1 mm (HAMPE, 2003, A-E; RICHTER, 2005, apenas F).

Figura 82 - Dentes de Xenacanthidae. A) Xenacanthus elegans B) Xenacanthus tenuis; C) Xenacanthus laevissimus; D) Triodus serratus; E) Barbclabornia luedersensis. Todos em vista lingual. Escalas: $1 \mathrm{~mm}$ (HAMPE, 2003, A-D; JOHNSON, 2003, E).

Figura 83 - Esquema de dente de Taquaralodus (RAGONHA, 1978). A) vista lingual, B) vista labial, C) vista lateral. Escala $10 \mathrm{~mm}$.

Figura 84 - Dente de Taquaralodus indicando características morfológicas. 1) Cúspide principal,. 2) Cúspide secundária. 3) cúspide intermediária. Escala. $4 \mathrm{~mm}$.

Figura 85 - Detalhe das cúspides do exemplar tricuspidado de Taquaralodus albuquerquei (GP/2E-5931). A) cúspide principal maior. B) cúspide lateral secundária e cúspide intermediária menor. Exemplar $1 \mathrm{~mm}$.

Figura 86 - Dentes de Taquaralodus albuquerquei encontrados no Afloramento 1, Sítio Santa Maria. Dente tricuspidado A) vista superior. B) vista lingual. C) vista labial. D) vista lateral.(GP/2E-5931) Escala 4mm. Dente bicuspidado E) vista lingual. F) vista labial. G) vista lateral. $\mathrm{H})$ vista inferior. (GP/2E-5932). Escala $2 \mathrm{~mm}$. 
Figura 87 - Dentes de Taquaralodus albuquerquei encontrados no Afloramento 12, Fazenda

Ponte Nova A-F) Exemplar GP/2E-6581 . A) vista labial, B) vista lingual. C-D) vistas laterais, E) vista oclusal, F) vista inferior. Escala $2 \mathrm{~mm}$. G-L) Exemplar GP/2E-6580. G) vista labial, H) vista lingual. $\mathrm{I}-\mathrm{J}$ ) vistas laterais, $\mathrm{K}$ ) vista oclusal, L) vista inferior. Escala $5 \mathrm{~mm}$.

Figura 88 - Montagem de fotografias em MEV de Taquaralodus albuquerquei. Exemplar unicuspidado GP/2E-3754. A) vista lateral. B) vista superior. C) vista lingual. D) vista labial. GP/2E-3754. Exemplar GP/2E-6306. E) Face labial incompleta com destaque a cúspide maior fragmentada; F) Vista oclusal com destaque ao botão apical na parte inferior. Escalas: $2 \mathrm{~mm}$. Figura 89 - Taquaralodus albuquerquei exemplar GP/2E - 6314. A) Vista superior. B) Vista inferior. C) Vista lingual-lateral. D) Vista Labial. E-F) Vista lateral. Escala 2mm.

Figura 90 - Dente de Xenacanthus sp. Escala 1mm.

Figura 91 - Exemplar GP/2T-216 de Xenacanthidae preso a matriz rochosa. Escala 1mm.

Figura 92 - Exemplar GP/2E-6456 de Xenacanthidae indeterminado do Afloramento 3. A) Vista oclusal; B) Vista inferior. Escala $1 \mathrm{~mm}$.

Figura 93 - Exemplar GP/2T-217 de Xenacanthidae indeterminado do Afloramento 1. A) Vista oclusal; B) Vista inferior. Escala $1 \mathrm{~mm}$.

Figura 94 - Dente de Taquaralodus com a cúspide preservada na rocha. GP/2E-3753. Escala $2 \mathrm{~mm}$.

Figura 95 - Dente de Taquaralodus muito desgastado preso a rocha. GP/2E-6251. Escala $2 \mathrm{~mm}$. Figura 96 - Disposição dentária em Climaxodus. A) Arcada superior; B) Arcada inferior (WOODWARD, 1919). Escala 10mm.

Figura 97 - Dentes sinfisianos de Itapyrodus punctatus. Espécime GP/2E-5926: A) Vista labial; B) Vista lingual; C) Vista oclusal; D) e E) Vistas laterais; F) Vista inferior. Escala $2 \mathrm{~mm}$. Espécime GP/2E-3756: G) Vista lingual; H) Vista labial; I) Vista lateral; J) Vista oclusal; L) Vista inferior. Escala $10 \mathrm{~mm}$.

Figura 98 - Dentes de Itapyrodus punctatus. Sinfisiano espécime 3 (GP/2E-5927): A) Vista

lingual; B) Vista labial; C) Vista oclusal; D) e E) Vistas laterais; F) Vista inferior. Póstero-lateral (GP/2E-5928): G) Vista labial; H) Vista lingual; I) Vista lateral; J) Vista oclusal; K) Vista inferior. Escala $2 \mathrm{~mm}$.

Figura 99 - Exemplar 2 de dente póstero-lateral (GP/2E-6290). A) Vista labial - oclusal; B) Vista lingual; C) Vista labial; D) Vista inferior. Escala $5 \mathrm{~mm}$.

Figura 100 - Exemplar (GP/2E-6304) de dente póstero-lateral. A) Vista labial - oclusal; B) Vista inferior; C) Vista lingual; D) Vista lateral. Escala $2 \mathrm{~mm}$.

Figura 101 - Dente incomum de Itapyrodus punctatus (GP/2E-6258). A) Vista lingual; B) Vista labial oclusal; C) Vista inferior; D) e E) Vistas laterais. Escala 10mm

Figura 102 - Dente sinfisiano de Itapyrodus punctatus (GP/2E-5925) ainda na rocha. Escala $2 \mathrm{~mm}$.

Figura 103 - Espécime incomum de Itapyrodus (GP/2E-6307). A) Vista lingual; B) Vista labial; C) Vista lateral; D) Vistas inferior. Escala $2 \mathrm{~mm}$.

Figura 104 - Espécime incomum de Itapyrodus GP/2E-6308. A) Vista lingual; B) Vista inferior; C) Vista labial; D) Vistas lateral. Escala $2 \mathrm{~mm}$.

Figura 105 - Holocephali indeterminado (GP/2E-6263). Escala 2mm.

Figura 106 - Holocephali indeterminado (GP/2E-6432). Escala $2 \mathrm{~mm}$.

Figura 107 - Dentes de Orodus do Carbonífero dos EUA. A) Vista oclusal de O. ramosus. Escala: 10 mm (MOY-THOMAS \& MILES, 1971); B) Vista labial de O. micropterygius. Escala: $5 \mathrm{~mm}$ (ZANGERL, 1981); C) Vista lingual de Orodus sp. Escala $1 \mathrm{~mm}$ (ELLIOTT et al. 2004).

Figura 108 - Variação ontogenética de dentes ainda articulados de Orodontiformes. Escala 5mm (WPS, 2002).

Figura 109 - Dente de Orodus ipeunaensis GP/2E-3750: A)Vista labial; B) Vista lingual; C) Vista oclusal; D) Vista Inferior. Escala: $3 \mathrm{~mm}$.

Figura 110 - Dente de Orodus ipeunaensis. GP/2E-5933. A) vista lingual, B) vista labial, C) vista superior labial, D) vista inferior. Escala $2 \mathrm{~mm}$

Figura 111 - Dente de Orodontiformes indeterminado GP/2E-3751. A) vista lingual, B) vista labial, C) vista inferior. Escala $4 \mathrm{~mm}$. 
Figura 112 - Dentes de Chondrichthyes indeterminados Exemplar GP/2E-5929. A) vista labial.

B) vista lingual. C) vista lateral. Exemplar GP/2E-6459. D) vista labial. E) vista lingual. F) vista lateral. Escala $8 \mathrm{~mm}$.

Figura 113 - Características gerais de um dente Palaeonisciformes (RICHTER et al. 2004).

Figura 114 - Características gerais de um escama de Palaeonisciformes (1. MOY-THOMAS \& MILES, 1971; 2. RICHTER et al. 2004).

Figura 115 - Características internas de dentes e escamas de Palaeonisciformes. A) corte longitudinal de escama (GP/2E-5939). B) corte longitudinal de dente (GP/2E-5936). C) corte oblíquo (quase transversal) de escama (GP/2E-5940). D) cortes transversais de dentes (GP/2E5937 e $\mathrm{GP} / 2 \mathrm{E}-5938$ ). Escalas $1 \mathrm{~mm}$.

Figura 116 - Dentes de Palaeonisciformes. A-C) dentes retos lisos dos afloramento 1, 3 e 4, respectivamente (GP/2E-5941, GP/2E-5942, GP/2E-5943). D-H) dentes retos costelados dos afloramentos 1 (GP/2E-5944, GP/2E-5945) e 3-5 (GP/2E-5946, GP/2E-5935B, GP/2E-5947), em seqüência. Escala $1 \mathrm{~mm}$.

Figura 117 - Dentes de Palaeonisciformes. A) dente reto costelado do afloramento 1(GP/2E5948). B - D) dentes curvos costelados dos afloramentos 1 (GP/2E-5949, GP/2E-5950, GP/2E5951) e 5 E) (GP/2E-5952). Escalas $1 \mathrm{~mm}$.

Figura 118 - Características de dentes de Palaeonisciformes encontrados na Formação Teresina do Rio Grande do Sul (RICHTER, 1980 e RICHTER et al. 1985).

Figura 119 - Ictiodonte Palaeonisciformes curvo de grande porte. GP/2E-5973. Barra de escala $2 \mathrm{~mm}$.

Figura 120 - Dente de Palaeonisciformes curvo de base espessa GP/2E-6412. Escala $2 \mathrm{~mm}$

Figura 121 - Dentes retos muito alongados A) GP/2E-6450, escala 2mm; B) GP/2E-6409, escala $1 \mathrm{~mm}$.

Figura 122 - Dente de Palaeonisciformes (GP/2E-6389) com finas linhas na superficie da cúspide. Escala $2 \mathrm{~mm}$.

Figura 123 - Escamas lisas de Palaeonisciformes de superfície pontuada, encontradas nos afloramentos 1 e 3. GP/2E-5953, GP/2E-5954, GP/2E-5955, GP/2E-5956, GP/2E-5957, GP/2E5958. Escala $1 \mathrm{~mm}$.

Figura 124 - Escamas costeladas de Palaeonisciformes do Afloramento 1. GP/2E-5961, GP/2E5962, GP/2E-5963, GP/2E-5964. Escala $1 \mathrm{~mm}$.

Figura 125 - Escamas costeladas de grande porte provenientes da matriz arenosa do

Afloramento 1. GP/2E-3757, GP/2E-3758, GP/2E-3759, GP/2E-3760, GP/2E-5959, GP/2E5960. Escala $2 \mathrm{~mm}$.

Figura 126 - Morfotipos de escamas encontrados na Bacia do Paraná, segundo RICHTER, et al. (1985).

Figura 127 - Fragmento de dentário de Palaeonisciformes. GP/2E-3761. A) Vista lingual (interna). B) Vista labial (externa) Escala 10mm. C) Vista de corte transversal do dente anterior incompleto com detalhe para a cavidade pulpar; D e E) Detalhe da parte superior do dente completo, destacando o capuz apical e as costelas, F) Detalhe dos "tubérculos". Escala de C a F: $2 \mathrm{~mm}$.

Figura 128 - Parte superior de caixa craniana de peixe ósseo encontrada no Afloramento 11 (GP/2E-6929). Escala 5mm.

Figura 129 - Escamas cosmóides atuais de celacanto (PARKER, 1990). Escala 1mm.

Figura 130 - Escamas de Actinistia. A) Exemplar da Formação Tatuí, Escala 2 mm. GP/2E-

5965. B) Exemplar 1 da base arenosa do Membro Taquaral, GP/2E-5966. Escala 1mm. C) Exemplar 2 da base arenosa do Membro Taquaral, GP/2E-5967. Escala 0,6mm. D) Exemplar 3 da base arenosa do Membro Taquaral, GP/2E-5968. Escala 0,6mm.

Figura 131 - Características de dentes labirintodontes. A) detalhe da dentina (MOY-THOMAS \& MILES, 1971) e B) morfologia externa (RICHTER, 2004).

Figura 132 - Possível dente labirintodonte (GP/2E-6309). Escala $2 \mathrm{~mm}$.

Figura 133 - Osso de vertebrado não identificado (GP/2E-6457), possivel osso longo de

Sarcopterygii. Escala $1 \mathrm{~mm}$.

Figura 134 - Dente labirintodonte descoberto no Afloramento 1 (GP/2E-3762). A) face lingual, B) face labial, C e D) vistas laterais, E) vista inferior da base. Escalas 10mm. 
Figura 135 - Fragmento mandibular de labirintodonte (GP/2E-5971). A) face interna, B) face

externa. Escala $10 \mathrm{~mm}$.

Figura 136 - Vista em planta com ossos orientados em diferentes posições. Escala $2 \mathrm{~mm}$.

Figura 137 - Vista em perfil com um dente de Palaeonisciformes orientado concordantemente

ao acamamento. Escala $1 \mathrm{~mm}$.

Figura 138 - Vista em planta de acumulação de escamas de Palaeonisciformes. Única evidência de associação encontrada no Afloramento 1 . Escala $1 \mathrm{~cm}$.

Figura 139 - Escamas de peixes ósseos que sofreram abrasão, arredondamento e desgaste da superfície. Escala $0,5 \mathrm{~cm}$.

Figura 140 - Vista em planta destacando dentes de paleoniscideos em diferentes posições.

Escala $1 \mathrm{~mm}$.

Figura 141 - Vista em perfil mostrando ossos e dentes concordantes e oblíquos. Escala $2 \mathrm{~mm}$.

Figura 142 - Maior exemplar de Xenacanthidae indeterminado, fragmentado, encontrado no Afloramento 3. Escala $1 \mathrm{~mm}$.

Figura 143 - Dente de Petalodonte (GP/2E-5921B) encontrado no Afloramento 3, muito desgastado pela abrasão, expondo todo o sistema de dentina tubular. Escala $1 \mathrm{~mm}$.

Figura 144 - Dente Palaeonisciformes sem desgaste com estrutura superficial intacta. Escala: $1 \mathrm{~mm}$.

Figura 145 - Dentes de Taquaralodus próximos de um dente menor fragmentado de

Palaeonisciformes. Escala 2mm.

Figura 146 - Amostra proveniente da base do Membro Taquaral no ponto C do Afloramento 12 com inúmeras escamas de tamanho variado acumuladas sem orientação em planta. Escala $1 \mathrm{~cm}$.

Figura 147 - Região com densidade de empacotamento diferenciado. Escala $2 \mathrm{~mm}$.

Figura 148 - Vista em planta de amostra proveniente do Afloramento 5. Escala 2mm.

Figura 149 - Vista em perfil de amostra proveniente do Afloramento 5. Escala $2 \mathrm{~mm}$.

Figura 150 - Comparação da base e topo da Camada da base da Formação Irati no Afloramento 1

Figura 151 - Amostra proveniente do Afloramento 1 exibindo camadas mais finas entre as mais grossas. Escala $2 \mathrm{~cm}$.

Figura 152 - Exemplar de Clarkecaris encontrado em Rio Claro. A) GP/1E-5691. B) GP/1E5689; C) GP/1E-5692; D) GP/1E-5693; E) GP/1E-5690a, Escala: 5 mm.

Figura 153 - Reconstituição de Clarkecaris (BRITO et al. 2000). Escala 4mm.

Figura 154 - Crustáceo indeterminado. A) GP/1T-6173A parte e B) GP/1T-6173B contraparte.

C) Exemplar GP/1T-6174. Escala 10mm.

Figura 155 - A) Escama Palaeonisciformes (GP/2E-6222a); B) Contraparte da escam de A) (GP/2E-6222b) com evidência de ornamentação na superfície e articulação "peg-and-socket" na lateral superior. B) Escama (GP/2E-6225) com articulação "peg-and-socket" em destaque como uma "ponta" na extremidade da escama. D) Escama de Palaeonisciformes (GP/2E-6223).

Escalas para escamas de 2mm E) Maxila de Palaeonisciformes (GP/2E-6231), Escala 4mm.

Figura 156 - A) Escama de Actinistia Parte (GP/2E-5969a); B) Escama de Actinistia contraparte (GP/2E-5969b). Escalas 2mm. C) Escama Actinistia parte (GP/2E-6233a) e D) contraparte (GP/2E-6233b). Escala 10mm. E) Detalhe da zona de articulação e das linhas de crescimento do exemplar GP/2E-6233d. Escala $2 \mathrm{~mm}$.

Figura 157 - Restos organicos fósseis dispersos provenientes do Afloramento 5, Próximo do Rio Passa Cinco no município de Rio Claro. Escala $10 \mathrm{~mm}$.

Figura 158 - Fragmento de crustáceo encontrado no Afloramento 1. Possíveis somitos. Escala $2 \mathrm{~mm}$.

Figura 159 - Acumulação pontual de escamas e partes ósseas encontradas no Afloramento 1. 


\section{INDÍCE DE TABELAS}

Tabela 1 - Quadro litoestratigráfico do Permiano da Bacia do Paraná no centro-leste do Estado de São Paulo, destacando as unidades relevantes para o trabalho (baseado em CPRM, 2006 e MILANI et al. 2007).

Tabela 2 - Evidências de assinaturas tafonômicas que podem ser observadas e comparadas nas acumulações de vertebrados (Adaptado de BEHRENSMEYER, 1991).

Tabela 3 - Características principais dos gêneros mais representativos de dentição cladodonte. Adaptada de DUFFIN \& GINTER (2006) acrescentando dados anatômicos observados em outros trabalhos (WILLIAMS, 1985; GINTER \& IVANOV, 1992; DUFFIN et al. 1996; GINTER et al. 2002; GINTER, 2002; e IVANOV, 2005)

Tabela 4 - Tabela comparativa dos Afloramentos estudados para tafonomia.

Tabela 5 - Tabelas de idades atribuídas ao permo-triassico da Bacia do Paraná comparando com outras localidades 


\section{ÍNDICE}

1.1 Apresentação...

MATERIAL E MÉTODOS.

Trabalhos de Campo.

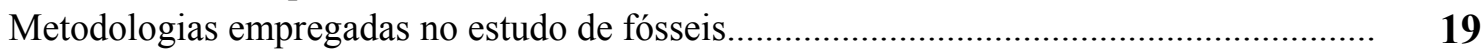

Preparação de amostras.

Metodologia empregada no estudo tafonômico.

Metodologia aplicada a tafonomia de vertebrados.

Definição geral das fácies observadas nos afloramentos estudados.

\section{PALEONTOLOGIA DA FORMAÇÃO TATUÍ.}

Icnofósseis.

Dentes cladodontes.

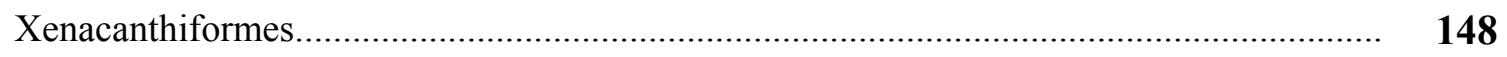

Holocephali.

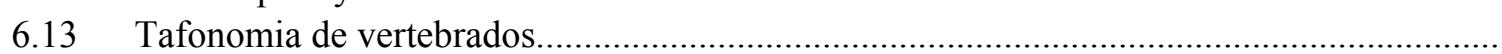

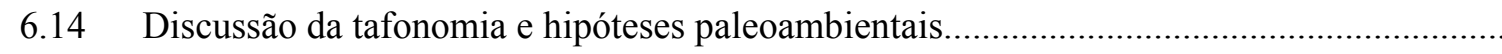


7.5 Outros fósseis.

7.7 Discussão sobre as assinaturas tafonômicas....................................................................... 258

7.7 Discussão sobre os estudos com o siltito Taquaral................................................................. 260

8 CONSIDERAÇÕES SOBRE A IDADE DAS UNIDADES DE ESTUDO....................... 261

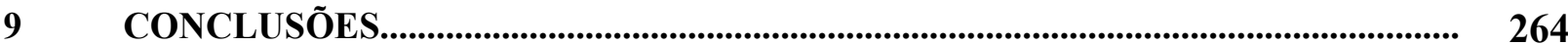

10 REFERÊNCIAS BIBLIOGRÁFICAS................................................................... 270

ANEXOS: Lista de espécimes $\quad 288$ 


\section{INTRODUÇÃO}

\subsection{Apresentação}

A região centro-leste do Estado de São Paulo, entre Leme e Capivari (Fig. 1), expõe praticamente toda a seção neopaleozóica-mesozóica, começando com o Supergrupo Tubarão (Grupo Itararé e Formação Tatuí), passando pelo Grupo Passa Dois (formações Irati e Corumbataí) e terminando com o Grupo São Bento (formações Pirambóia, Botucatu e Serra Geral) (MILANI et al., 2007).

As unidades ocorrem em grande extensão no centro-leste do estado e na região do Alto Estrutural de Pitanga entre Piracicaba e Ipeúna (Fig.1).

A Formação Tatuí, exclusiva do Estado de São Paulo, é formada por sucessão de siltitos e arenitos finos bem selecionados. Entre estas camadas ocorrem níveis conglomeráticos de origem flúvio-deltaica (STEVAUX et al. 1986; ASSINE et al. 2003). A Formação Tatuí é correlata, cronologicamente, às formações Rio Bonito e Palermo, na Região Sul do Brasil.

O topo da Formação Tatuí, em contato com o Membro Taquaral, unidade basal da Formação Irati, no centro-leste do Estado de São Paulo, é representado por fácies variadas que podem ser sílticas, conglomeráticas ou areníticas.

O Membro Taquaral se inicia nesta região por arenitos conglomeráticos, comumente ricos em restos de peixes. Esta litologia exibe contato abrupto com os folhelhos cinza-esverdeados, ainda do Membro Taquaral, com fósseis de crustáceos e peixes.

ASSINE et al (2003) detalharam o conjunto "topo Tatuí - base Taquaral" em termos de estratigrafia de sequência, separando o evento final Tatuí, com caracteríticas regressivas, dos eventos da base do Membro Taquaral, com estruturas de "lag" residual sob ação de correntes de certo grau de energia. Também CHAHUD (2007), a partir de estudos paleontológicos e sedimentológicos a considerou base do Membro Taquaral.

O conhecimento paleontológico da Formação Tatuí é bastante precário. Inclui descrições de crustáceos e apenas citações bibliográficas de fósseis vegetais, conchostráceos e outros microfósseis (acritarcos e foraminíferos aglutinantes) (MEZZALIRA, 1959, FÚLFARO et al. 1984, CABRAL Jr. et al. 1988, MEZZALIRA \& MARTINS NETO, 1992). Em nenhum trabalho foram realizados estudos adequados dos fósseis nas fácies do topo da formação. 


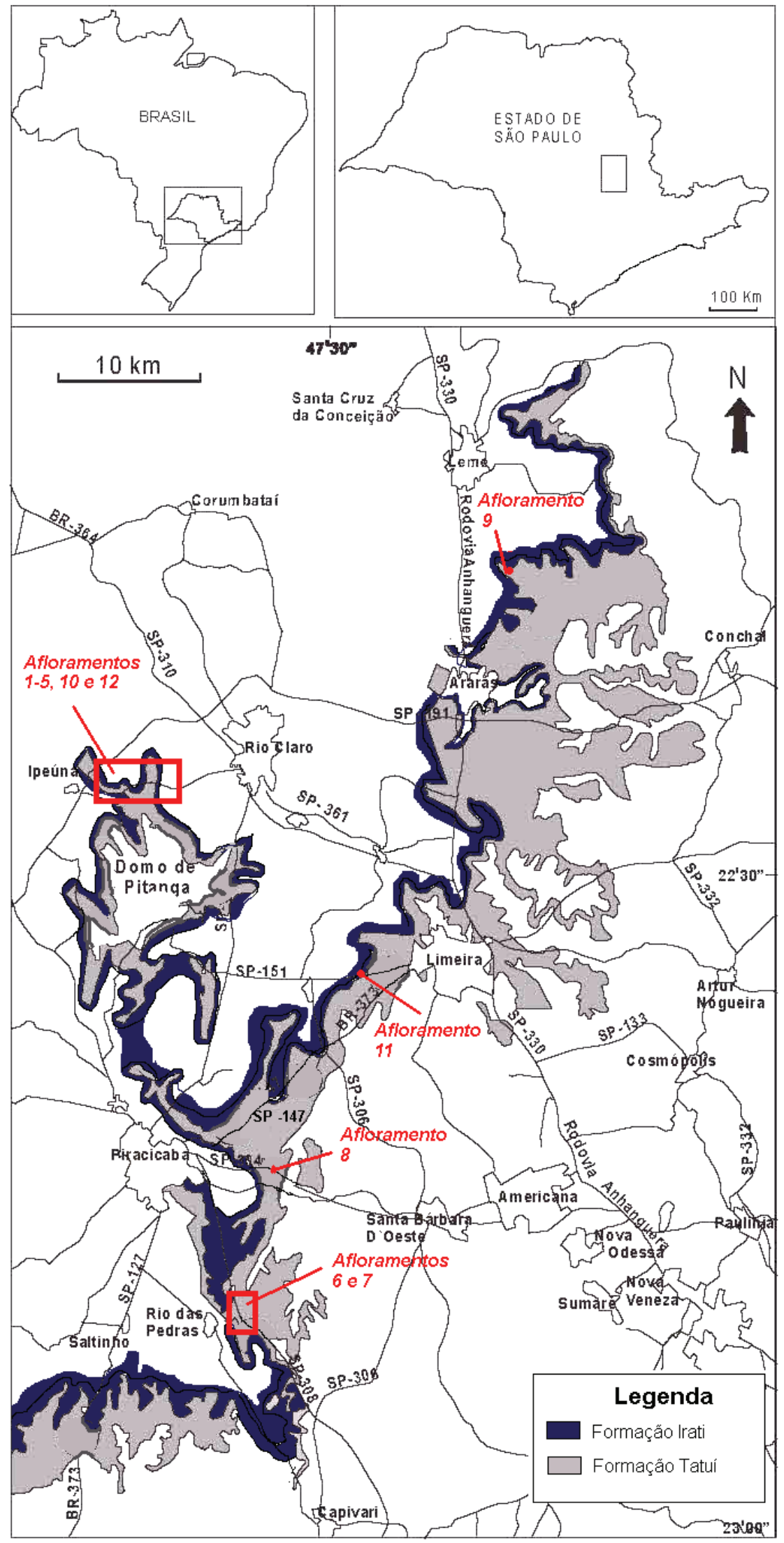

Figura 1 - Distribuição das formações Tatuí e Irati no centro-leste do estado de São Paulo com todos os afloramentos estudados e as principais vias de acesso (modificado de ASSINE et al., 2003). 
Ao contrário da Formação Tatuí, os fósseis do Membro Taquaral, foram discutidos pormenorizadamente os crustáceos por MEZZALIRA (1952) e os vertebrados por CHAHUD (2007), CHAHUD \& PETRI (2008a, 2008b, 2010) CHAHUD et al. (2010).

Os peixes fósseis das formações Tatuí e Irati vem sendo objeto de estudo nos últimos anos e revelaram surpreendente diversidade taxonômica e biológica (CHAHUD \& FAIRCHILD, 2003a; 2003b; 2006a; 2006b; CHAHUD, 2003b; 2007; CHAHUD \& PETRI, 2008a; 2008b; 2010a; 2010b), com documentações paleontológicas e tafonômicas, fornecendo subsídios não somente para entender melhor suas relações paleoecológicas, mas também testar hipóteses paleoambientais e paleogeográficas.

\subsection{Objetivos}

A pesquisa teve por objetivo a investigação da Formação Tatuí e do Membro Taquaral da Formação Irati (Tabela 1) na região centro-leste do Estado de São Paulo, porém com maior ênfase ao contato entre as duas unidades litoestratigráficas.

Há grande variação sedimentológica e paleontológica entre os depósitos do topo da Formação Tatuí em relação aos depósitos arenosos da base e dos folhelhos sílticos do Membro Taquaral. Os trabalhos incluem estudos paleontológicos e geológicos e para isso foram consideradas:

a) Revisão do conteúdo paleontológico das formações, incluindo táxons conhecidos.

b) Coleta de fósseis em afloramentos já conhecidos, nas diferentes unidades entre as cidades de Leme e Rio das Pedras, com o objetivo de ampliar o conhecimento paleontológico.

c) Assinaturas tafonômicas (bioestratinômicas e diagenéticas) como subsídios para estudos paleoecológicos e sedimentológicos das concentrações em cada afloramento.

d) Ampliação dos conhecimentos das paleofaunas preservadas (diversidade, interrelações entre taxa) das formações Tatuí e Irati, principalmente nas áreas de contato entre as formações. 
e) Análise de ocorrências locais da Formação Tatuí e a relação de contato da Formação Tatuí com a Formação Irati, em pontos da região centro-leste do Estado de São Paulo.

Tabela 1 - Quadro litoestratigráfico do Permiano da Bacia do Paraná no centro-leste do Estado de São Paulo, destacando as unidades relevantes para o trabalho (baseado em CPRM, 2006 e MILANI et al. 2007).

\begin{tabular}{ccc}
\multicolumn{2}{c}{ Litoestratigrafia do Permiano da Bacia do Paraná na área de estudo } \\
Formação Corumbataí \\
Grupo Passa \\
Dois & Formação & Membro Assistência \\
& Irati & Membro Taquaral \\
Grupo Guatá & Formação Tatuí \\
\hline
\end{tabular}

\section{Grupo Itararé}

\section{MATERIAL E MÉTODOS}

\subsection{Trabalhos de Campo}

Os trabalhos de campo incluiram a coleta de fósseis e amostras fossilíferas em afloramentos das formações Tatuí e Irati já selecionados. Foram realizados levantamentos de dados litológicos, tafonômicos, sedimentológicos, tectônicos e estratigráficos locais.

Durante a pesquisa, foram investigados afloramentos com rochas que representam diferentes ambientes e processos deposicionais para testar hipóteses paleogeográficas e paleoambientais referentes à Formação Tatuí e as camadas situadas entre as duas formações, Tatuí e Irati. Foram observadas rochas supostamente fluviais da região do alto estrutural de Pitanga, onde se localiza a maior parte dos afloramentos, e da região ao sul de Piracicaba, supostamente mais afastada da área fonte dos clastos grossos dos conglomerados.

Entre 50 e 300 amostras (dependendo da disponibilidade do afloramento) de mão foram coletadas em cinco afloramentos, além de amostragens onde não foram encontrados fósseis. Esta amostragem se destinou a estudos de fósseis, levantamentos tafonômicos e sedimentológicos, tanto macroscópico como petrográfico. 


\subsection{Metodologias empregadas no estudo de fósseis}

Para invertebrados e icnofósseis foram utilizadas técnicas próprias de descrição e de classificação sistemática de novas espécies (CARVALHO \& FERNANDES, 2000; FERNANDES, 2000).

O material estudado da paleoictiofauna constitui-se de escamas, espinhos, vértebras, dentes, ossos e, eventualmente, coprólitos. Alguns destes fósseis puderam ser identificados até o nível de gênero ou de espécie. Os fósseis foram estudados sob aspectos paleobiológicos e taxonômicos de modo a permitir inferências gerais relativamente seguras sobre o modo de vida, habitat (p. ex., águas doces vs. salgadas), bioestratigrafia, biocronologia ou influência tectônica na preservação ou distribuição paleogeográfica dos fósseis.

Os fósseis, quando possível, foram removidos das amostras trazidas do campo por métodos mecânicos, utilizando-se ferramentas odontológicas, na maioria dos casos, e métodos químicos quando necessários. Em alguns casos foram confeccionadas lâminas delgadas (petrográficas) para observar estruturas internas. Os fósseis foram registrados e analisados em fotografias, imagens digitais e fotomicrografias (MEV e microscopia óptica).

A verificação e obtenção de imagens da maior parte dos fósseis foram realizadas através de estereomicroscópio Zeiss, modelo SV6, com câmera digital, JVC acoplada a um microcomputador PC e software AxioVision. Estas técnicas foram utilizadas em função do alto poder de resolução e da ampliação das imagens do esteromicroscópio.

Também foram obtidas imagens digitais a partir de um Omega Megascan ACCU 6000 Scanner, uma máquina fotográfica analógica SONY 3CCD e processadas em um analisador de imagem da LEICA do Laboratório de Petrografia Sedimentar do Instituto de Geociências da Universidade de São Paulo (IGc-USP). Foram usados softwares como Corel Draw, MGI Photo Suíte para o tratamento de imagens e figuras.

Todos os espécimes ilustrados estão registrados e depositados na coleção fóssil do Laboratório de Paleontologia Sistemática (LPS) do IGc-USP.

\subsection{Preparação de amostras}

A metodologia desenvolvida na preparação das amostras constituiu-se da preparação mecânica, com uso de agulhas, estiletes, pinças, martelos e serras na remoção dos fósseis encontrados em arenitos. 
Esta preparação visou separar o material paleontológico muito cimentado ao sedimento em matrizes arenosas ou argilosas dependendo da situação.

Desagregação de material e peneiramento (peneira de $0,06 \mathrm{~mm}$ ) para estudos micropaleontológicos.

Confecção de lâminas petrográficas para a análise sedimentológica e microestrutura de fósseis.

Todos os trabalhos de preparação dos materiais coletados em campo são realizados nos Laboratório de Paleobiologia e no Laboratório de Micropaleontologia Setembrino Petri do Departamento de Geologia Sedimentar e Ambiental do Instituto de Geociências da Universidade de São Paulo. Os melhores fósseis, localizados através do microscópio estereoscópio, foram registrados em imagens digitais com os equipamentos do Laboratório de Sedimentologia Petrográfica do IGc/USP.

\subsection{Metodologia empregada no estudo tafonômico}

A análise tafonômica dos troncos vegetais, bivalves, artrópodes e restos de peixes devem levar em conta os estados de desarticulação, desgaste e dispersão dos fósseis em questão. Tal análise baseou-se no tratamento qualitativo e quantitativo de variáveis tafonômicas como abrasão, transporte, quebras, articulação e disposição dos fósseis no afloramento conforme abordagem de BEHRENSMEYER \& KIDWELL (1985), ALLISON \& BRIGGS (1991), HOLZ \& SIMÕES (2002), BEHRENSMEYER, (1982), BENTON (1997) e outros.

Uma vez estabelecidas as características tafonômicas e o contexto sedimentar das concentrações fossilíferas, passou-se à reconstituição da história tafonômica (bioestratinômica e diagenética) para a interpretação de questões sedimentológicas (modos de deposição e influencia tectônica) e paleobiológicas (paleoecológicas, principalmente).

\subsection{Metodologia aplicada a tafonomia de vertebrados}

Metodologia para o estudos tafonomicos dos vertebrados das camadas arenosas da base do Membro Taquaral é aqui descrita

O corpo vertebrado é composto de grande número de partes biomineralizadas (ossos) que se desprendem e desarticulam facilmente, quando expostos. Durante os períodos bioestratinômico e diagenético, os restos sofrem modificações física, química e biológica, criando diversas assinaturas tafonômicas. 
Técnicas aplicadas ao estudo das assinaturas tafonômicas em vertebrados aquáticos e terrestres foram desenvolvidas e aplicadas por diversos pesquisadores (VOORHIES， 1969; MARTILL \& HARPER， 1990; BEHRENSMEYER 1991; MANCUSO, 2003).

BEHRENSMEYER (1991) estudou a acumulação de vertebrados continentais e sistematizou a coleta e o tratamento de evidências de assinaturas tafonômicas. As sugestões de Behrensmeyer foram adaptadas para a análise das concentrações esqueléticas de vertebrados encontradas na base da Formação Irati (Tabela 2).

Tabela 2 - Evidências de assinaturas tafonômicas que podem ser observadas e comparadas nas acumulações de vertebrados (Adaptado de BEHRENSMEYER, 1991).

\begin{tabular}{|l|c|}
\hline \multicolumn{1}{|c|}{ Variáveis } & Possíveis manifestações no sítio paleontológico \\
\hline Dados do sítio & $1 \mathrm{~m}^{2} ; 100 \mathrm{~m}^{2} ; 1000 \mathrm{~m}^{2}$. \\
Área da acumulação & $0,1 / \mathrm{cm}^{2} ; 1 / \mathrm{cm}^{2} ; 10 / \mathrm{cm}^{2} ; 100 / \mathrm{cm}^{2}$. \\
Densidade espacial dos fósseis & Grau de empacotamento (alto, fraco ou disperso). \\
Arranjo espacial & Ao acaso; orientação preferencial. \\
Em planta & Paralelas ao acamamento; discordantes. \\
Em perfil & Isolados; agregados. \\
Agregados & $1,10,100,1000$ \\
\hline $\begin{array}{l}\text { Dados da Assembléia } \\
\text { Número de táxons }\end{array}$ & Prticulação \\
Aeleção & Partes articuladas; desarticuladas, porém associadas; isoladas. \\
\hline $\begin{array}{l}\text { Modificação dos ossos } \\
\text { Quebra }\end{array}$ & Dispersas e não selecionadas; selecionadas. \\
Abrasão/polimento & Osso inteiro; quebrado. \\
\hline
\end{tabular}

\subsection{Parâmetros importantes para estudos tafonômicos}

\section{Área da acumulação e densidade espacial}

A área da acumulação é o calculo da área total efetivamente estudada no afloramento, expressa em $\mathrm{m}^{2}$.

A densidade espacial é o número de fósseis em relação à área da acumulação determinada $\left(\mathrm{N} / \mathrm{m}^{2}\right)$. Relacionado a este dado, o empacotamento pode ser denso ou fraco dependendo de como os bioclastos se apresentam dentro da matriz, se dispersos ou se tocando. KIDWELL \& HOLLAND (1991) apresentaram três graus de empacotamento fóssil (Fig. 2):

Concentrações densamente empacotadas são aquelas suportadas por bioclastos com muito contato físico. Os fósseis estão presentes com mínima cimentação nos interstícios. Acumulações deste tipo podem representar mortandade em massa ou baixa taxa de sedimentação, permitindo acúmulo de material ósseo. 
Concentrações fracamente empacotadas são suportadas pela matriz com pouco ou nenhum contato entre os bioclastos.

Concentrações dispersas são suportadas pela matriz e os fósseis estão esparsamente distribuídos, não havendo o contato entre as partes.

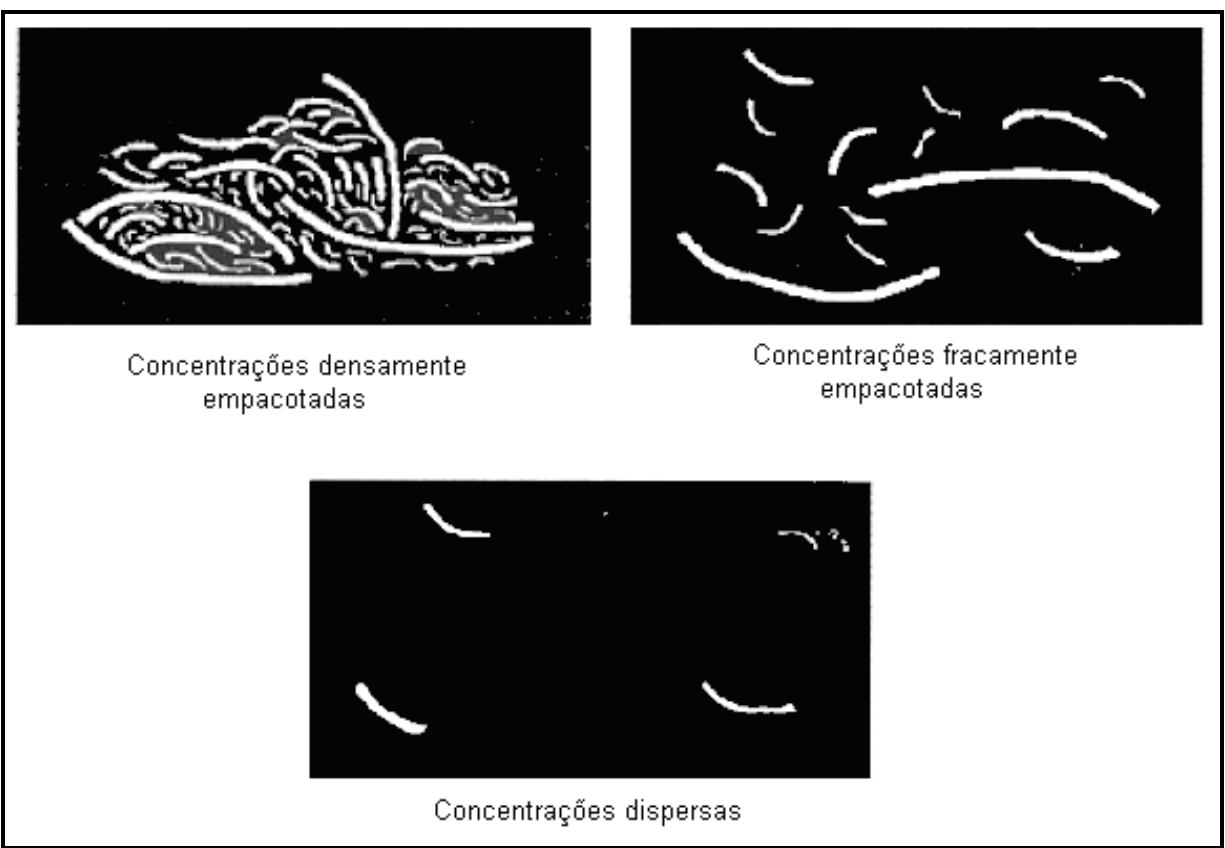

Figura 2 - Diferentes graus de empacotamento dos bioclastos (KIDWELL \& HOLLAND, 1991).

\section{Arranjo Espacial}

O arranjo espacial expressa a disposição da assembléia fóssil no estrato sedimentar (BEHRENSMEYER, 1991) e abrange: orientação em planta, orientação em perfil (paralela ou discordante em relação ao acamamento) e a natureza da acumulação do material fóssil (em agregados ou isolados).

O estudo da orientação dos bioclastos em planta (ou azimutal) pode fornecer dados da dinâmica deposicional, como o sentido de fluxo e paleocorrentes. Fósseis alongados, como espinhos, ossos longos e dentes de vertebrados, são bons indicadores para este estudo, pois facilmente se orientam concordantes ao fluxo (VOORHIES, 1969). Ondas e fluxo oscilatório podem reorientar diversos fósseis segundo um eixo preferencial, mas com dois sentidos opostos (orientação bimodal).

Existe ainda a distribuição dispersa ou polimodal, sem orientação dos bioclastos. Neste caso o fluxo pode ter sido insuficiente para movimentar os bioclastos ou justamente o contrário, muito turbulento. 
A orientação dos bioclastos, em perfil ou corte, pode ser concordante, perpendicular ou oblíqua em relação ao acamamento. Ese dado também fornece informações sobre a paleocorrente e regime de fluxo.

Agregados fósseis podem resultar da ação de organismos coletores ou carniceiros, em meio terrestre ou lacustre (ARRIBAS \& PALMQVIST, 1998; BRAIN,1980), ou de variações na geometria do depósito que favoreçam determinadas áreas de deposição.

\section{Número de táxons ou morfotáxons}

O número de táxons em uma assembléia caracteriza a biodiversidade fóssil dentro de uma fácies ou unidade sedimentar. Tal número de espécies não tem caráter paleocológico, apenas descritivo.

A composição taxonômica de uma assembléia pode ser monotípica, formada por um único tipo de material ósseo, ou politípica, quando formada por vários tipos de materiais ósseos. A assembléia fóssil também pode ser poliespecífíca, formada por espécies diferentes, ou monoespecífica, formada por uma única espécie.

Composições poliespecíficas e politípicas são resultado do baixo transporte sem seleção de tamanho ou parte óssea.

\section{Articulação de partes esqueléticas}

A presença de partes articuladas permite caracterizar e interpretar o tempo de exposição e deposição.

Animais encontrados articulados e completos caracterizam eventos de pouca exposição. Partes ósseas desarticuladas são evidências de exposição aos processos hidrodinâmicos e intempéricos antes do seu soterramento final (BADGLEY, 1986a; 1986b; BEHRENSMEYER, 1978; BEHRENSMEYER, 1982, MARTILL \& HARPER, 1990, MANCUSO, 2003).

\section{Seleção}

A seleção por tamanho é uma feição sedimentológica muito significativa para entender a formação de assembléias fossilíferas (KIDWELL \& HOLLAND, 1991). Acumulações de fósseis de boa seleção representam pequena variação no tamanho da maior parte dos bioclastos. Concentrações pouco ou não selecionadas são aquelas que possuem três ou mais classes granulométricas distintas, enquanto a seleção ótima 
representa uma composição em que praticamente todos os fósseis possuem o mesmo tamanho. As acumulações bimodais são concentrações com bioclastos bem selecionados em relação à moda primária, porém apresentando uma segunda moda distinta. $\mathrm{O}$ aspecto geral seria de dois padrões de tamanho fóssil.

A seleção de restos esqueléticos resulta do transporte hidráulico, atividade biológica e condições ecológicas e ambientais. Processos diagenéticos também podem afetar a seleção de uma concentração fossilífera com a eliminação de bioclastos quimicamente instáveis, enriquecendo a proporção de restos esqueléticos quimicamente estáveis.

\section{Modificação Óssea}

O corpo vertebrado é composto de grande número de ossos que podem se desprender após a morte do animal, e ser transportados por água e/ou por necrófagos. Até o seu soterramento final os ossos podem sofrer grandes modificações e alterações.

A análise tafonômica de escamas e dentes baseou-se no tratamento qualitativo de variáveis tafonômicas relacionadas à modificação óssea, tais como: quebras e abrasão (BEHRENSMEYER, 1991; BEHRENSMEYER \& KIDWELL, 1985; HOLZ, 1998).

As quebras naturais dos elementos esqueléticos podem auxiliar a identificar elementos que sofreram transporte, esmagamento, atividades predatórias ou exposição subaérea (BEHRENSMEYER, 1978; CHAHUD, 2001; 2003a; 2003b; 2007; MANCUSO, 2003). Os critérios utilizados para a determinação da origem das quebras de fósseis são:

a) Ausência de quebra ou parte óssea completa;

b) Parte fóssil com 95\% quebrado ou mais da composição original, considerouse quebrado ou alguma quebra;

c) Material com menos de $95 \%$ de sua totalidade, fragmentado.

Outro processo de modificação óssea é a abrasão dos fósseis, que envolve o polimento da superfície e o arredondamento, em alguns casos a esfericidade, do material.

BENTON (1997) discriminou cinco estágios de abrasão (Fig. 3) aplicáveis em dentes de tubarões paleozóicos do tipo cladodonte, orodonte e diplodonte: Estágio 0: dente fóssil sem alteração das cúspides ou da superfície; Estágios 1 e 2: modificações por desgaste e arredondamento crescente, mais facilmente observadas nas cúspides; 
Estágio 3: desaparecimento das cúspides menores; e Estágio 4: desaparecimento total das cúspides.

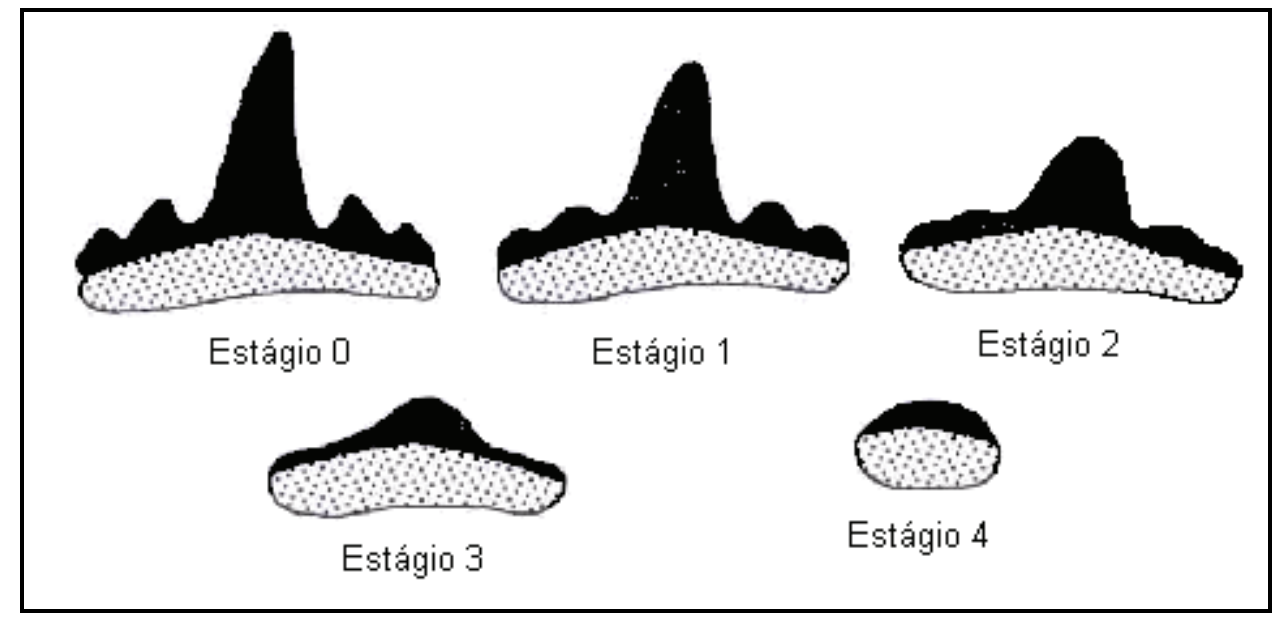

Figura 3 - Estágios de desgaste de dente de Chondrichthyes (BENTON, 1997).

IRMIS \& ELLIOTT (2006) estudaram tafonomicamente dentes de Chondrichthyes atuais para tentar obter respostas sobre processos de acumulações antigas. Mesmo sabendo que existiam limitações como número de amostras e diferenças ambientais, estes autores comentaram que o efeito de abrasão em dentes é continuo quando marcado pelo arredondamento das extremidades das cúspides e pontas da base, exposição da dentina interna e polimento da superfície, critérios usados pelos autores para diferenciar abrasão de dissolução.

Para este trabalho os estudos de IRMIS \& ELLIOTT (2006) são importantíssimos, pois seus testes simularam um ambiente marinho proximal dominado por ondas com dentes de Chondrichthyes recentes. Pode-se assim inferir se os dentes fosseis aqui pesquisados tiveram retrabalhamento contínuo e que poderiam ser facilmente transportados por ondas de tempestade para outras regiões.

\section{TRABALHOS PRÉVIOS SOBRE AS UNIDADES E ÁREA ESTUDADAS}

A análise bibliográfica de trabalhos prévios foi realizada através de leitura crítica de artigos paleontológicos e geológicos referentes às Formações Tatuí e Irati no Estado de São Paulo e correspondentes em outras localidades, enfatizando a história e a contribuição científica dos diversos autores. Também foi realizada busca de dados na rede mundial de computadores $(\mathrm{WWW}=$ World Wide $\mathrm{Web}$ ) no que diz respeito a 
obtenção de informações sobre a paleofauna estudada, unidades litológicas e técnicas para o tratamento de amostras.

\subsection{Evolução tectono-sedimentar da Bacia do Paraná}

Na região centro-leste do Estado de São Paulo, entre as cidades de Piracicaba e Rio Claro, ocorre uma estrutura tectônica conhecida como Alto Estrutural de Pitanga e nela localiza-se a maior concentração de afloramentos do Paleozóico do estado. Trata-se de um anticlinal en echelon, que expõe praticamente toda a seção NeopaleozóicaMesozóica da borda leste da Bacia do Paraná (SOARES \& LANDIM, 1973; RICCOMINI, 1992a, 1992b).

SOARES (1974) e SOARES et al. (1974) estudaram o Alto estrutural de Pitanga o descreveram como levemente assimétrico, com mergulhos que variam de 12 a 2 graus e um fechamento de quase $100 \mathrm{~m}$ próximo da curva de $550 \mathrm{~m}$. Observaram que o sistema de falhas dos rios Passa Cinco - Cabeças, centro leste de São Paulo, tem direção dominante $\mathrm{N} 45^{\circ} \mathrm{W}$. Em falha entre Rio das Pedras - Piracicaba - Ipeúna (SOARES, 1974) obteve $\mathrm{N} 10-20^{\circ} \mathrm{W}$.

A influência do magmatismo na gênese das estruturas encontradas no Alto estrutural de Pitanga manifestou-se apenas por sobrelevação de camadas por esforços tectônicos que atuaram de modo vertical durante o Eocretáceo, a partir do vulcanismo Serra Geral (SIQUEIRA, 2007).

De acordo com SOARES (1974) os falhamentos na borda leste da Bacia do Paraná seriam predominantemente verticais ou subverticais. No caso do Alto estrutural de Pitanga o mergulho de uma falha tem $88^{\circ}$, com um rejeito vertical de $70 \mathrm{~m}$ e um horizontal de $2,5 \mathrm{~m}$.

Segundo SAAD et al. (1979) a evolução tecto-sedimentar no Estado de São Paulo do Grupo Tubarão permitiria o reconhecimento de 5 fases deposicionais distintas, A, B, C, D e E, sendo que a fase E representa a Formação Tatuí.

De acordo com SOUZA FILHO (1983), camadas permianas do Alto estrutural de Pitanga foram afetadas por grande número de falhas. As camadas mais jovens que o Permiano não foram afetados por esta falha indicando uma fase diastrófica restrita ao Permiano, reativada posteriormente no Juro-Cretáceo, com novas falhas relacionadas ao magmatismo da Formação Serra Geral.

RICCOMINI (1992a, 1992b) reconheceu seis fases tectônicas no período entre o final do Paleozóico e o Quaternário na região de pesquisa do presente trabalho. A 
primeira foram eventos sísmicos sinsedimentares durante o Permo-Triássico, que causaram liquefação dos depósitos da Formação Corumbataí e injeção de diques clásticos. A segunda, terceira e quartas fases foram eventos ligados ao tectonismo e magmatismo da Formação Serra Geral, que formaram diques e sills do Eocretáceo, que afetando depósitos do Permiano e Eomesozóico. As duas últimas fases foram manifestações neotectônicas (quaternárias) no vale do Rio Passa Cinco. RICCOMINI (1995) considerou o Alto estrutural do Pitnga como uma dobra escalonada.

MORALES et al. (1997) descreveram falhamentos em depósitos relacionados à Formação Tatuí em um afloramento na rodovia SP-147, entre Piracicaba e Limeira. Nessa estrada, além das camadas sílticas, da Formação Tatuí, são comuns depósitos da Fácies Ibicatu e coberturas cenozóicas que não foram afetadas pelos falhamentos. Este tectonismo foi considerado atuante durante o início deposicional da Formação Tatuí e pode ter favorecido o surgimento dos depósitos grossos, pois foram gerados dobramentos e antiformais que modelaram o relevo da época criando alto estruturais.

\subsection{Contexto geológico das unidades de estudo}

\subsubsection{Trabalhos pioneiros sobre a Formação Tatuí}

A análise de trabalhos pioneiros servirá para observar a evolução da pesquisa cientifica das unidades de estudo e também na "reativação" de temas esquecidos para a formulação de hipóteses futuras.

O nome Tatuí ("Tatuhy") foi formalmente proposto por WASHBURNE (1930) a rochas permo-carboníferas. A unidade foi descrita como pós-glacial, discordante no topo, que marcaria a mudança de água doce para marinha.

BARBOSA \& ALMEIDA (1949a; b) propuseram uma subdivisão do Grupo Tubarão (Supergrupo atualmente) no Estado de São Paulo nas formações Itu (basal), Capivari, Gramadinho, Tietê e Itapetininga, esta última dividida em membros Tupi, Tatuí e Taquaral.

ALMEIDA \& BARBOSA (1953) caracterizaram o Membro Tatuí da sua Formação Itapetininga como de constituição arenosa, estratificação plano-paralela, de coloração verde com tons avermelhados e com algumas camadas de calcários. Interpretaram o ambiente de deposição como marinho de águas rasas e mornas com deposição lenta, em fundo lodoso de plataforma estável, sem evidência de clastos de 
origem glacial. No topo, os autores anotaram a presença de camadas e lentes de sílex e, a oeste da quadrícula de Piracicaba, a presença de um fino conglomerado contendo seixos de sílex.

BARBOSA \& GOMES (1958) mantiveram o termo Membro Tatuí, mas excluíram o Membro Taquaral da Formação Itapetininga. Consideraram composta apenas de rochas sedimentares de cor verde, com espessura entre 30 e $50 \mathrm{~m}$.

PETRI (1964) revalidou o termo Formação Tatuí e considerou as rochas esverdeadas como de origem continental pós-glacial. ROCHA-CAMPOS (1967), definiu os limites pós-glaciais no contato entre o Grupo Itararé e a Formação Tatuí.

\subsubsection{Conceitos estratigráficos da Formação Tatuí no centro leste de São Paulo}

Este item tem por objetivo expor o conhecimento da literatura sobre a estratigrafia da Formação Tatuí a comparações com o Grupo Guatá da Região Sul do Brasil para auxilio na formulação de hipóteses.

Os primeiros estudos estratigráficos envolvendo a Formação Tatuí sempre tiveram características gerais. A Formação Tatuí tem sido correlacionada ao Grupo Guatá, nos estados sulinos, bem preservado e passivel de divisão, enquanto a Formação Tatuí é de caracteriação difícil e subdivisão polêmica em São Paulo.

Os estudos estratigráficos da Formação Tatuí se iniciaram com o trabalho de SOARES (1972). Segundo este autor, tanto a base quanto o topo da unidade seriam separados por descontinuidades. Para SOARES (1972) as litologias da unidade saio monótonas, caracterizada por siltitos, que predominam em $90 \%$ da seção, juntamente com finas camadas de calcário, sílex e arenitos.

A unidade é formada por dois pacotes separados por cores dominantes. O inferior é constituído de siltitos marrom-arroxeados escuros (mas por vezes brancos), com acamamento fino a espesso, raramente laminado. As camadas de calcário e de sílex variam de poucos milímetros até $30 \mathrm{~cm}$ de espessura. Os arenitos, normalmente muito finos ou sílticos, exibem estratificação plano-paralela. O segundo pacote é constituído de siltitos cinza-esverdeados e amarelo-esverdeados. Em sua base observam-se lentes de arenitos médios ou grossos, subarredondados, com estratificação cruzada acanalada e ondulações associadas a arenitos finos com estratificação plano-paralela. Ocorrem camadas de seixos de sílex, angulosos ou arredondados, com tamanho médio de cinco centímetros. 
O limite entre os dois pacotes é marcado por um diastema, designado L2 por SOARES (1972). Dentro do pacote superior, SOARES (1972) identificou uma desconformidade, L3, que separa duas fácies: a primeira de siltitos argilosos maciços sem arenitos intercalados, e a segunda de lamitos cinza esverdeados, intercalados por arenitos médios, arredondados, bem selecionados, com marcas onduladas, moldes de conchas e fragmentos de ossos.

O limite L4 marca a brusca mudança litológica com os folhelhos da Formação Irati. Em algumas localidades associa-se a esta superfície, feições erosivas e concentrações de até $15 \mathrm{~cm}$ de espessura de arenitos conglomeráticos contendo seixos arredondados e subangulares de silex. Em outras loclidades não existe este conglomerado, mas uma camada arenosa centimétrica contendo grânulos, fragmentos de ossos e dentes. Na estrada de Araras para Ibicatu, o conglomerado atinge seis metros de espessura (descrito como cunha clástica de "Imbicatu" [sic]).

SOARES \& LANDIM (1973) colocaram a Formação Tatuí na mesma posição estratigráfica do Grupo Guatá representado em São Paulo somente pela porção superior da Formação Rio Bonito e toda a Formação Palermo. Conclusão parecida foi adotada por SCHNEIDER et al. (1974) correlacionando a Formação Tatuí ao Membro Paraguaçu da Formação Rio Bonito mais a Formação Palermo. Segundo SOARES \& LANDIM (1973), a Formação Tatuí no flanco nordeste da bacia, em São Paulo, tem espessura reduzida (inferior a $30 \mathrm{~m}$ ) representada por sua base com apenas ocorrência local dos siltitos do topo.

PETRI \& FULFARO (1983) descreveram a Formação Tatuí como composta de siltitos e arenitos micáceos, calcíferos e com pirita, intercalações de calcários, folhelhos e camadas conglomeráticas com fósseis de vertebrados. PETRI \& FÚLFARO (1983), por outro lado, alegaram que a Formação Rio Bonito estaria ausente no Estado de São Paulo e que a Formação Tatuí corresponderia à Formação Palermo. Pouco depois, FÚLFARO et al. (1984) propuzeram a Formação Tietê que seria equivalente à Formação Rio Bonito e a Formação Tatuí, à Formação Palermo.

CASTRO et al. (1993a) consideraram difícil mapear o Grupo Guatá no Estado de São Paulo e validaram o nome Formação Tatuí, que dividiram em três ciclos transgressivos e regressivos. O primeiro seria pós-glacial e marinha posterior ao Grupo Itararé e o último evento transgressivo máximo, anterior aos depósitos do Membro Taquaral. CASTRO et al. (1993a; b) consideraram o contato na base da Formação Tatuí, discordante e no topo, poderia ocorrer um pavimento transgressivo de arenitos 
com fragmentos fosfáticos (ossos, dentes, escamas e coprólitos) em contato com a Formação Irati.

PERINOTTO \& FÚLFARO (1993) consideraram as formações Tatuí e Palermo equivalentes litológicos e caracterizaram oito fácies: F1: fácies de pelitos, bioturbados ou não; F2: fácies de arenito I, com estratificação cruzada do tipo "hummocky", associada a F1; F3: fácies de arenito II, turbiditos oscilatórios; F4: fácies de arenito III, arenitos em sand waves; F5: fácies de arenito IV, arenito conglomerático a conglomerado silexítico; F6: fácies de arenito V, arenito com estratificação cruzada de baixo ângulo; F7: fácies arenito VI, com granodecrescência ascendente e estratificações cruzadas; e F8: fácies carbonática (bancos e lentes associados a F1).

PIRES \& PETRI (1993) estudaram a estratigrafia da Bacia do Paraná em São Paulo e consideraram o máximo transgressivo no topo da Formação Tatuí, segundo um sistema de mar alto com baixa taxa de sedimentação durante a deposição do Membro Taquaral.

GIMENEZ \& CHANG (1997) estudaram os afloramentos do km 150 e 152,5 da Rodovia do Açúcar (SP-308) e a seção tipo de Ibicatu ("Imbicatu” de SOARES, 1972) com objetivo de estudar a diagênese dos depósitos de arenitos da Formação Tatuí. Caracterizaram a eodiagênese, mesodiagênese e a telodiagênese concluindo que a composição dos arenitos da Formação Tatuí teriam sido modificados por diversos processos diagenéticos, caracterizados por dissolução de minerais instáveis, substituição de grãos do arcabouço por cimento carbonático, argilo-minerais e albitização de feldspatos.

MOCHIZUKI (2001) considerou a Formação Tatuí equivalente as unidades encontradas no Grupo Guatá. Segundo esta autora a Formação Rio Bonito, em São Paulo, representaria dois sistemas deposicionais. A primeira formada por arenitos finos a sílticos, acastanhados (raramente esbranquiçados), bioturbados. A segunda caracterizada por siltitos esverdeados, nódulos silicosos esbranquiçados e bancos de arenitos finos com intercalações carbonáticas.

A Formação Palermo no Estado de São Paulo seria composta por siltitos argilosos na base, no meio por arenitos finos maciços, bioturbados ou com estratificação "hummocky" e no topo por arenitos finos a muito finos com estratificação cruzada apresentando uma intercalação de clastos e lâminas de carvão.

FERNANDES (2004) analiou sete afloramentos da região de Rio Claro e Ipeúna, além do afloramento clássico da cunha clástica de Ibicatu ou Fácies Ibicatu 
(SOARES, 1972). Correlacionou a camada arenosa conglomerática entre as formações Tatuí e Irati da região de Paraisolândia às rochas de Ibicatu.

\subsubsection{Propostas paleoambientais para os estudos da Formação Tatuí}

Os primeiros trabalhos sugerindo paleoambientes foram poucos e não tratavam desse assunto como prioridade. Os primeiros, de ALMEIDA \& BARBOSA (1953) e BARBOSA \& GOMES (1958), atribuíram as rochas da Formação Tatuí uma origem marinha rasa a partir da presença de espículas de esponjas. PETRI (1964) contestou esta interpretação, argumentando que os fósseis de espongiários citados não constituíam evidência conclusiva de paleoambiente marinho.

STEVAUX et al. (1983) estudaram marcas onduladas simétricas do "Membro Tupi da Formação Itapetininga" (BARBOSA \& ALMEIDA, 1949), equivalente ao topo do Grupo Itararé e consideraram o ambiente deposicional marinho em um corpo d'água que variava de 0,36-4,64 metros e com ondas oscilatórias de 0,22-1,57m de altura.

PETRI \& FULFARO (1983) admitiram que a Formação Tatuí teria caráter não marinho. Os depósitos teriam se formados em lagunas ou lagoas de salinidade variável em planície costeira e uma pequena abertura para o mar aberto na parte sul da bacia do Paraná.

FULFARO et al. (1984) consideraram que a Fácies Ibicatu (SOARES, 1972) teria se depositado em um "fan delta", resultado de soerguimento desta área marginal da bacia. Segundo, estes autores, teriam ocorrido duas épocas de formação de deltas. A primeira teria formado o complexo deltaico de orientação $\mathrm{SE} / \mathrm{NW}$ na região de Itapetininga e o segundo, presente no topo da Formação Tatuí, com a formação dos deltas, entre Leme e Araras (Ibicatu)

STEVAUX et al. (1986) estudaram quatro seções faciológicas na Formação Tatuí. A primeira é a cunha clástica de Ibicatu, que se localiza entre Araras e Leme, onde ocorria uma exposição de cerca de seis metros de conglomerado (com seixos de sílex de 1 a $2 \mathrm{~cm}$ ) e lenhos, ambos orientados no sentido W, WSW e WNW, formando um leque, que os autores associaram a um sistema deltaico. O sistema conglomerático com seixos e lenhos indica fluxo de alta densidade, causado por levantamento da área marginal da bacia. Recobrindo esta seção, ocorrem camadas de folhelho cinza do Membro Taquaral. A segunda seção situa-se no Córrego do Veado em Limeira (SP151), com sedimentos do topo da Formação Tatuí. Nesta localidade observaram um pacote de 6 metros de arenitos conglomeráticos com seixos de 1 a $2 \mathrm{~cm}$ de sílex 
correlacionados com os depósitos entre Leme e Araras, porém com evidencias de correntes de marés, baseados em estratificação sigmóide, apesar de nem sempre este tipo de estratificação significar atividade de marés. As terceira e quarta seções localizam-se na Rodovia do Açúcar (Km 150 e 152,5) e são caracterizadas por siltitos da Formação Tatuí. No Km 150 ocorre o contato com a Formação Irati marcado por argilitos cinzas.

ASSINE et al. (1999) consideraram a parte superior da Formação Tatuí no centro-leste de São Paulo, um trato de sistemas de mar alto, caracterizado pela progradação de sistemas aluviais costeiros, sobre uma plataforma marinha dominada por ondas com evidência de marés, estes sistemas aluvionais pertenceriam a cunha clástica de Ibicatu. Sugeriram que a fonte dos sedimentos estaria ao norte com as paleocorrentes dirigidas para o sul.

Mais tarde ASSINE et al. (2003) separaram os níveis conglomeráticos ricos em clastos de sílex da Formação Tatuí no centro-leste de São Paulo em dois níveis distintos. O primeiro é observado entre os municípios de Leme e Araras (conhecidos como Fácies Ibicatu), consideradas leques aluviais costeiros que posteriormente teriam sido sobrepostos por rochas da Formação Irati. O segundo nível, superior, seriam camadas de arenitos conglomeráticos resultadas de um trato de sistemas de mar alto caracterizado pela progradação e retrabalhamento dos depósitos da Fácies Ibicatu sobre uma plataforma marinha dominada por marés, recoberta pelos folhelhos do Membro Taquaral. Este segundo nível de conglomerados seriam depósitos residuais, "Lags", transgressivos que constituiriam o início da deposição do Membro Taquaral e sem ligação com a Fácies Ibicatu de Leme e Araras. Em suas palavras:

"Por fim, é importante enfatizar que os níveis de conglomerados que ocorrem como depósitos residuais transgressivos no contato entre as formações Tatuí e Irati (L4 de SOARES, 1972), são estratigraficamente distintos dos conglomerados e arenitos grossos com clastos de sílex que ocorrem inseridos na parte superior da Formação Tatui e que informalmente são referidos como "Fácies Ibicatu". A fim de evitar impropriedades e falhas na comunicação geológica, propõe-se reservar o nome Ibicatu apenas para as fácies de arenitos grossos e conglomerados silexiticos pertencentes à parte superior da Formação Tatui, não se utilizando tal denominação para os conglomerados associados às superficies transgressivas que caracterizam o limite entre as duas unidades litoestratigraficas." 
Julga-se a hipótese de ASSINE et al. (2003) mais adequada e foi a partir dela que o trabalho se desenvolveu.

\subsubsection{Trabalhos pioneiros sobre a Formação Irati}

Rochas equivalentes à Formação Irati foram primeiramente registradas no Estado do Paraná por WHITE (1908), como parte de um pacote espesso de "xisto" preto que se estendia de São Paulo ao Paraná. Este pacote era constituído de camadas com nódulos de sílex, calcários impuros e dolomitos. Posteriormente, OLIVEIRA (1940) foi o primeiro a utilizar a denominação Formação Irati de modo formal para o pacote de rochas descritas por White.

ALMEIDA \& BARBOSA (1953) caracterizaram o Membro Taquaral, composto de folhelhos cinza esverdeados escuros, e o Membro Assistência, de calcários dolomíticos e pelitos subordinados. No entanto, os dois membros não pertenceriam à mesma formação. Para os autores, o Membro Taquaral representava o topo da Formação Itapetininga, termo hoje em desuso.

A atual classificação estratigráfica da Formação Irati em dois membros, Taquaral (basal) e Assistência (topo), foi proposta por BARBOSA \& GOMES (1958).

FÚLFARO (1970), em estudos geológicos na região de Angatuba, considerou o contato entre a Formação Tatuí e o Grupo Passa Dois, gradacional, não estando presente a camada arenosa conglomerática na base do Taquaral. A unidade Irati na região de Angatuba é representada por folhelhos escuros e "fétidos" com intercalações dolomíticas.

A espessura da Formação Irati para AMARAL (1971) varia em toda bacia do Paraná ente 20 e 40 metros. A definição geral da unidade para o Estado de São Paulo seria um banco cálcario dolomítico na base e tendo acima deste nível, intercalações de calcário dolomítico e folhelho pirobetuminoso. A ausência do banco calcário seria conseqüência de profundidades de deposição maiores. Para AMARAL (1971) o Membro Taquaral não pertenceria a Formação Irati.

\subsubsection{Trabalhos estratigráficos e sedimentológicos sobre a Formação Irati}

Os membros Taquaral e Assistência da Formação Irati passaram a ser mais aceitos a partir dos anos de 1970 (MEZZALIRA, 1971). 
Segundo HACHIRO (1991) a Formação Irati assentaria, em concordância, sobre a Formação Tatuí e os arenitos da base do Membro Taquaral seriam correlacionáveis à fácies Ibicatu.

HACHIRO et al. (1993) sugeriram a promoção da Formação Irati à condição de subgrupo e o dividiram em duas formações: Taquaral e Assistência. Esta divisão não foi seguida por muitos pesquisadores posteriores (Milani et al. 2007).

A "Formação Taquaral" (Membro Taquaral neste trabalho) não possui subdivisões claras. Segundo HACHIRO et al (1993) o Irati inicia-se com as rochas da "Formação Taquaral” sobre a Formação Tatui, em São Paulo, representando um período transgressivo após a progradação dos "conglomerados Ibicatu" do topo da Formação Tatuí. Eles dividiram a "Formação Assistência" (Membro Assistência neste trabalho) em dois membros: "Membro Morro do Alto" (inferior) e "Membro Ipeúna" (superior).

O "Membro Morro do Alto" inicia-se com a fácies basal Camadas de Folhelhos Pirobetuminosos, a mais euxínica da unidade Irati, seguida das Camadas Evaporíticas constituídas por intercalações de folhelhos e evaporitos; acima estão os folhelhos pirobetuminosos intercalados por carbonatos dos Ritmitos Inferiores e no topo do Membro Morro do Alto, Camada Laje Azul, de folhelhos ricos em restos de peixes e pelotilhas de glauconita.

A fácies basal do "Membro Ipeúna" é caracterizada pelas Camadas Bairrinho (Fácies Bairrinho de MEZZALIRA 1971), constituídas por dolomito. Acima ocorrem os Ritmitos Delgados Regulares e no topo os Ritmitos Superiores, representados pela variação folhelhos e carbonatos, em camadas que gradualmente aumentam de espessura.

HACHIRO \& COIMBRA (1993) estudaram os ciclos regressivos e transgressivos das seqüências Irati e admitiram 2,7-3,5 milhões de anos como tempo de deposição da unidade. A deposição do Taquaral, com 30 metros de espessura, pela litologia poderia variar de 0,7 - 1,5 milhões de anos em um único evento.

CASTRO (1993) considerou apenas dois ciclos de carbonatos-folhelhos para o Membro Assistência baseado na interpretação de dois eventos, regressivos e transgressivos. O Estado de São Paulo ocorreria num ambiente mais raso e costeiro enquanto a região Sul um ambiente mais distal da bacia com diferentes variações deposicionais.

HACHIRO (1997), em sua tese de doutorado, estudou toda a extensão do Irati e a subdividiu em oito fácies sedimentares, duas no Taquaral e seis no Assistência. A unidade Taquaral é diferenciada por não possuir betume em seus folhelhos ao contrário 
da unidade Assistência, com folhelhos betuminosos com intercalações carbonáticas. Considerou local e subordinada a camada conglomerática da base do Taquaral, variando em espessura (de $0,1 \mathrm{~m}$ a $1 \mathrm{~m}$ ) e também na sua composição, mais arenosa ou mais conglomerática, sempre com granodecrescência ascendente. Ao sul do Arco de Ponta Grossa, HACHIRO (1997) comentou que a "Formação" Assistência também conporta subdivisões estratigráficas, porém as diferenças não são muito claras.

\subsubsection{Estudos paleoambientais realizados na Formação Irati}

Um dos principais objetivos deste item é a caracterização do paleoambiente da unidade litoestratigráfica estudadas. Tornou-se necessário levantamento dos trabalhos relacionados com o tema para fornecer subsídeos às conclusões obtidas.

Desde os primeiros trabalhos de WHITE (1908) e WASHBURNE (1930) o Irati foi alvo de estudos paleoambientais baseados em fósseis e na sedimentação.

Para AMARAL (1971), o betume dos folhelhos pirobetuminosos seria singenético. O sílex também teria origem singenética, resultado da dissolução e reprecipitação a partir de espículas de espongiários. O paleoambiente da Formação Irati seria de clima quente e pouco chuvoso no inicio passando a chuvoso e frio, alternando com épocas quentes e secas. $\mathrm{O}$ pH do corpo d'água durante a deposição seria alcalino, em torno de 8 , o Eh em torno de $-0,3$. O autor também sugeriu possível conexão marinha em lugar desconhecido. $\mathrm{O}$ ambiente redutor seria predominante na bacia durante a deposição da Formação Irati com algumas zonas de oxigenação, tanto paleogeográfica como no tempo geológico. Nas regiões oxidantes teriam se depositado sedimentos similares ao das unidades sobrejacentes.

GEOVANI et al. (1974), baseando-se em isótopos, consideraram paleoambiente de água doce gerador de deposição da Formação Irati. Os indícios de águas salinas seriam diagenéticos.

DELLAZZANA (1976) admitiu sazonalidade a partir de anéis de crescimento em lenhos fósseis, porém segundo ALVES \& GUERRA-SOMMER (2005) os anéis de crescimento encontrados em lenhos não são necessariamente evidência de sazonalidade podendo ser problema genético.

MUSSA (1986b), baseada em eustelos de lenhos fósseis, deduziu que a vegetação encontrada no Membro Assistência era adaptada a paleoambientes mais áridos e de águas salobras. Ela chamou a atenção sobre lenhos silicificados, envolvendo restos de betume. 
PETRI \& FÚLFARO (1983) sugeriram que a deposição da Formação Irati teria ocorrido em um grande corpo de água ou mais lagos ou mares internos (lago-mar).

Segundo OELOFSEN \& ARAÚJO (1983) a deposição dos sedimentos da Formação Irati teria ocorrido em uma baia rasa envolvendo parte da América do Sul e a África do Sul. Os folhelhos negros pirobetuminosos do sul do Brasil e África depositados em águas mais profundas e os calcários e dolomitos, dos Estados de São Paulo, Mato Grosso e Goiás, em águas mais rasas

HACHIRO (1991 e 1997) e HACHIRO \& COIMBRA (1991a;1991b) reconheceram duas fases transgressiva e regressiva e cinco sucessões, uma no Membro Taquaral e quatro no Membro Assistência.

AFONSO et al. (1992 e 1994) em estudo geoquímico do óleo e folhelhos da Formação Irati, concluiram que os folhelhos possuíam baixo índice de maturidade, a matéria orgânica de origem microbiana e foi depositada em ambiente lacustre.

ARAÚJO-BARBERENA (1993) concluiu, a partir de análise bibliográfica, que o paleoambiente da Formação Irati seria constituído de um mar, restrito, normalmente calmo, de baixa salinidade e de profundidade variável, mas relativamente raso, habitado por diversas populações adaptadas aos diferentes paleoambientes.

Apesar do sistema deposicional ter sido geralmente em ambientes calmos, LAVINA et al. (1991) a partir de estudos sedimentológicos no Rio Grande do Sul observaram grande mortalidade de mesossaurídeos associados a depósitos sedimentares de alta energia. Os autores concluíram que tempestades causaram mortandade em massa dos répteis. Estas tempestades foram observadas nas Camadas Bairrinho do Estado de São Paulo e em Santa Rosa de Viterbo por HACHIRO (1991 e 1997) e HACHIRO \& COIMBRA (1992).

MEDEIROS (1993) considerou a Formação Irati constituída por transgressão marinha máxima do Permiano da Bacia do Paraná. Na fase final da deposição teria havido a perda das ligações diretas com o oceano, iniciando a desertificação e posterior secagem da bacia, registradas nas formações sobrepostas.

SANTOS-NETO \& CERQUEIRA (1993) estudaram a geoquímica do topo do Irati e consideram que a partir das camadas dolomíticas calcíferas, os depósitos seriam de origem marinha rasa com alta salinidade e altas taxas de evaporação. A presença de glauconita e o estudo das razões isotópicas da fração carbonática $\left(\delta^{13} \mathrm{C}\right.$ entre $-1,95$ a $1,16 \%$ e $\delta^{1} 80$ entre $-5,65$ a $-4,27 \%$ ) indicariam ambiente marinho durante a deposição dos bancos dolomitos. Os autores ainda citam a presença de algas Chrysophyta, por 
eles consideradas marinhas. A simples presença dessas algas não são indicadores de meio marinho, pois são observadas Chrysophyta em lagoas salinas ou salitradas do Pantanal (SANTOS et al. 2004) e também em água doce (BICUDO \& MENEZES, 2006).

Segundo FAURE \& COLE (1999) analisando isótopos estáveis em matéria orgânica, pirita e camadas de carbonato, dentro das formações Whitehill e Irati, concluíram que os sedimentos foram depositados em água doce para água salgada, localmente evaporítica e provavelmente lacustre. Concluíram ainda que não existe evidência que sugira mistura de águas marinhas e meteóricas, ou matéria orgânica marinha e terrestre nestas unidades e nas subjacentes.

Um motivo para a falta de águas de origem marinha estaria no desenvolvimento de um "cinturão" tectônico no Eopermiano no Oeste do Gondwana e que o contato com o paleoceano Panthalassa foi anterior aos depósitos das formações Palermo e Príncipe Albert (África) portanto ambos seriam não marinhos. Segundo LAVINA et al. (1991), se houve um contato com o oceano aberto este teria ocorrido na região ao sul da Serra de La Ventana. Esta água oceânica seria esporádica, pois a salinidade era baixa.

Segundo ARAÚJO et al. (2004) durante a deposição das camadas calcárias da Formação Irati, a água não apresentaria estratificação, alternando momentos de alta e baixa oxigenação, marcados por fases de águas mais rasas ou tempestades esporádicas.

LISBOA (2006), a partir de análises químicas, comparou o óleo e matéria orgânica presente nos folhelhos da Formação Irati em São Paulo, concluindo que a matéria orgânica teria origem marinha hipersalina com uma discreta participação continental.

\subsection{Estudos paleontológicos do Grupo Guatá e da Formação Irati}

O objetivo deste item é citar trabalhos que tratam de fósseis não observados ou estudados no presente trabalho. As informações estratigráficas e paleontológicas destes fósseis serão discutidas quando se discorrer sobre as hipóteses paleoambientais.

Foi dada preferência a fósseis encontrados nos equivalentes da Formação Tatuí no Grupo Guatá (Formações Rio Bonito e Palermo), fósseis do Membro Taquaral e de difícil posição estratigráfica na Formação Irati. 


\subsubsection{Palinologia}

Estudos prévios palinológicos e micropaleontológicos das formações Tatuí e Irati não foram muitos e com poucas ilustrações.

Os trabalhos mais freqüentes na Bacia do Paraná, estão relacionados ao Grupo Itararé (MEZZALIRA, 1989), porém nos últimos 35 anos, diversos trabalhos foram desenvolvidos nos Grupo Guatá e Formação Irati, sempre visando idades, correlações estratigráficas das unidades e paleoambientes.

CORREAA DA SILVA et al. (1984) reconheceram em carvões do topo do Itararé e na Formação Rio Bonito, Gimnospermas, Pteridófitas e raros microfósseis do tipo Botryococcus.

MARQUES-TOIGO et al. (1984) estudaram depósitos de carvão da Formação Rio Bonito, tendo em vista o predomínio de pteridófitas nesta unidade, dada a grande quantidade de esporos, concluiu que o clima seria úmido.

Trabalhos de DELLAZZANA (1976) e ARAÚJO-BARBERENA (1993), na Região Sul do Brasil, visando a paleoecologia e paleoambiente da Formação Irati ressaltaram aumento da proporção de grãos de polens monossacados, bissacados e estriados de gimnospermas e decréscimo na quantidade de esporos, indicativo de evolução para ambiente seco a semi-árido.

LAGES (2004) observou nos membros Taquaral e Assistência uma grande diversidade de esporos e pólens. Os pólens encontrados no Membro Taquaral incluem os gêneros de palinomorfos: Alisporites, Lueckisporites, Striatopodocarpites, Vittatina, Punctatisporites e Cirratriradites.

\subsubsection{Acritarcos e algas}

Os Acritarcos são um grupo polifilético de seres vivos com afinidades incertas. Atualmente são considerados como cistos de algas fotossintéticas, microscópicas (CRUZ, 2000). Nas unidades em estudo no Estado de São Paulo, foram poucos os trabalhos que descrevem estes fósseis.

CABRAL Jr. et al (1988) citaram em testemunhos de sondagens, acritarcos no topo da Formação Tatuí, porém não ilustraram ou descreveram.

CAZZULO-KLEIPZIG et al. (1989) reconheceram acritarcos no topo da Formação Palermo e base da Formação Irati, nos Estados de Santa Catarina e Rio Grande do Sul. 
MARASCO et al. (1993) mencionaram a presença do acritarco Micrhystridium em lente conglomerática do contato Tatuí-Irati, base do Irati, na região dos municípios de Itapetininga e Morro do Alto no sul do Estado de São Paulo. No contato entre as Formações Palermo e Irati da região sul, ARAÚJO-BARBERENA (1993) relatou a presença de um horizonte de acritarcos, provavelmente o mesmo citado por MARASCO et al. (1993) em São Paulo. A autora sugeriu que estes níveis tivessem sido depositados sob influência marinha e marcariam o máximo transgressivo e o fato da comunidade ser abundante e monoespecífica o ambiente deveria ter sido restrito, típico de lago-mar. Foram observados outros Micrhystridium, Veryhachium, Tasmanites e Deusilites no folhelho do Membro Taquaral em sondagem de São Mateus do Sul (CARDOSO, 2010).

O acritarco Micrhystridium, citado nos trabalhos da região sul (CARDOSO, 2010) e também no de MARASCO et al. (1993), é um habitante de origem marinha rasa que pode ser associado a variação de salinidade por causa da influência continental (GRICE et al. 2005). Veryhachium, Deusilites e Tasmanites também ocorrem em salinidade variável (SOUZA \& CALLEGARI, 2004, MARTÍNEZ et al. 2008).

QUADROS (2002) analisou amostras de poços provenientes de Santa Catarina e Mato Grosso que continham camadas dos grupos Itararé e Guatá. Os fósseis do acritarco Dictyotidium foram encontrados na Formação Rio Bonito enquanto Michrystridium foi encontrado no topo da Formação Palermo. Apesar de QUADROS (2002) ter interpretado como ambiente marinho raso para as duas formações a partir dos fósseis. Dictyotidium não é um fóssil confiável, pois pode estar associado a unidades com forte influência continental e até mesmo algas de água doce, Botryococcus (AMENÁBAR et al. 2006). QUADROS (2002) também citou a presença de polens e esporos nestes sedimentos.

LAGES (2004) observou acritarcos tanto no Membro Taquaral quanto no Membro Assistência em material de testemunho de sondagem. O material estava muito fragmentado com quebras que impediu a indentificação. Lages também observou a alga Botryococcus nas duas unidades.

\subsubsection{Foraminíferos aglutinantes}

Na Formação Tatuí foram citados por FÚLFARO et al. (1984) três gêneros de foraminíferos aglutinantes: Erlandia, Ammodiscus, Hyperamina registrados em camadas síltico-arenosas entre os municípios de Guarizinho e Itaporanga. STEVAUX et al. (1986), citando FÚLFARO et al. (1984), consideraram a presença dos mesmos 
foraminíferos no Afloramento do Córrego do Veado, porém não foram localizados ou observados por outros autores mais recentes (MOCHIZUKI, 2001; ASSINE et al. 2003) no mesmo afloramento.

CABRAL Jr. et al. (1988) citaram foraminíferos no topo da Formação Tatuí em testestemunhos de sondagem do estado de São Paulo, em contato com o Membro Taquaral.

CAMPANHA (1985) registrou o gênero Ammodiscus e Sorosphaera na Formação Irati em um testemunho coletado no município de Marília. CAMPANHA \& ZAINE (1989) citaram a presença de Fusulinina nas camadas Bairrinho do Membro Assistência no centro leste do Estado de São Paulo.

O material de CAMPANHA (1985) e CAMPANHA \& ZAINE (1989) encontrados em testemunhos da Paulipetro estão perdidos (CAMPANHA, 2007, comunicação verbal). A ocorrência de Foraminíferos não foi mais confirmada em trabalhos mais recentes no centro-leste do Estado (HACHIRO, 1991; CALÇA, 2008).

A presença de poucos gêneros de foraminíferos e em determinados pontos da bacia pode ser indicador de ambientes extremos (LUGER, 1988) que tiveram pouca duração no registro geológico tendendo sempre a condições de água doce ou de hipersalinidade muito elevada, alem de oxigenação variada.

\subsubsection{Espículas de espongiários}

BARBOSA \& ALMEIDA (1949a) e ALMEIDA \& BARBOSA (1953) foram os primeiros a observar espículas no Supergrupo Tubarão que seriam poliaxiais no "Membro" Tatuí (aqui ainda era considerada parte da Formação Itapetininga). A presença de espículas poliaxiais não é um indicador paleoambiental confiável, por isso os autores tiveram dúvidas na classificação do paleoambiente.

AMARAL (1971) revelou variedade de espículas monoaxiais de Demospongia na Formação Irati, podendo pertencer às ordens Haploscerida, Poecilosclerida ou Epipolapsida. No Membro Taquaral (considerado topo do Grupo Tubarão, Formação Itapetininga) as espículas são raras, as camadas de folhelhos argilosos abaixo do banco dolomítico do Membro Assistência encontrados na pedreira Maluf, exibiram a maior abundância e diversidade e nas camadas calcárias as espículas voltam a ser incomuns. As ordens citadas por AMARAL (1971) não são indicadoras paleoambientais, pois podem ser encontradas em águas doces e salinas. 


\subsubsection{Moluscos do Grupo Guatá e Formação Irati}

Os moluscos, apesar das conchas duras e resistentes a transporte e ocorrerem em diversos ambientes, não são encontrados com freqüência no Grupo Guatá (exceção de Taió, São Sepé e Guiratinga) e na Formação Irati.

Durante muito tempo alguns crustáceos foram confundidos com bivalves. VIEIRA et al. (1991) observaram que os moluscos descritos em trabalhos pioneiros da Formação Irati na região centro-oeste do Brasil, eram crustáceos do tipo Liocaris.

YOCHELSON \& ROCHA-CAMPOS (1966) identificaram o gastrópode Warthia na base da Formação Rio Bonito. Este gastrópode foi comparado com formas encontradas na Austrália e América do Norte, indicando diferenças morfológicas com as espécies australianas e norte-americanas. Em depósitos que são encontrados está associada com raras camadas de siltitos que contém folhas de Gangamopteris e Glossopteris.

GORDON Jr. (1947) citou bivalves na Formação Palermo da região sul do Brasil, mas sem classificação taxonômica e segundo PERINOTTO (1992) em má, preservação.

ROCHA-CAMPOS (1970) descreveu diversos fósseis de moluscos da região de Taió, Formação Rio Bonito. Entre os bivalves estão Myonia tayoensis (Reed), Schizodus occidentalis, Heteropecten catharinae, Myonia (?) costata, Stutchburia brasiliensis, Schizodus occidentalis, Solenomorpha? sp. e Oriocrassatella itajaiensis, junto com gastrópode, Warthia catarinensis. Heteropecten é o gênero dominante na fauna, o que indica que a maior parte da comunidade fóssil tinha modo de vida vágil com alguns elementos da infauna e epifauna. Os fósseis não são encontrados em posição de vida e foram depositados em ambiente de alta energia. ROCHA-CAMPOS (1970) observou que existe tendência a posicionar a malacofauna de Taió em águas mais frias e salobras, porém tal dado não seria possível de se caracterizar com segurança devido o retrabalhamento dos fósseis.

ROCHA-CAMPOS \& SIMÕES (1993) descreveram o bivalve Australomya sinuosa na assembléia de Taió, reconhecido também no Eopermiano da Austrália. A presença desta espécie reforça a interpretação da fauna de Taió como gondvânica e não endêmica da Bacia do Paraná. Segundo os autores, o fóssil seria escavador intermediário.

SIMOES (1992 e 2000) e SIMOES \& ROCHA-CAMPOS (1993) descreveram a fauna de bivalves de São Sepé no Rio Grande do Sul e Guiratinga, Estado do Mato 
Grosso. Segundo os autores, São Sepé corresponderia a uma assembléia pouco diversificada, composta de nove espécies pertencentes a três famílias. A família dominante é Megadesmidae, incluindo Astartila clossi, Megadesmus bortoluzzii, Jacquesia guataensis, Myonia riograndensis e Pyramus cf. P. cowperesioides. Outra espécie comum é Stutchburia sepeensis da Família Permophoridae. A Família Edmondiidae (Edsondia sp.) é de ocorrência esporádica. A assembleia de Guiratinga, por sua vez, é monoespecifica, sendo composta por Guiratingia mendesi (PETRI \& FULFARO, 1966).

As afinidades paleobiogeográficas da malacofauna de São Sepé são tipicamente gondvânicas, apresentando composição genérica similar à das assembleias de bivalves marinhos do Neopaleozóico da Austrália (Astartila, Megadesmus, Myonia e Stutchburia) e da Bacia do Paraná (Supergrupo Tubarão e Grupo Passa Dois).

Stutchburia sepeensis e Myonia riograndensis estão mais relacionadas à fauna de Taió (ROCHA-CAMPOS, 1970). Segundo SIMÕES (1992) Pyramus cf. P. cowperesioides e Jacquesia possuem relações filogenéticas com fósseis do topo do Grupo Passa Dois (formações Teresina e Corumbatai), da borda leste da Bacia do Paraná.

A análise da morfologia funcional dos bivalves de São Sepé e Guiratinga mostra que as duas assembléias são dominadas por formas escavadoras rasas. Em São Sepé, ocorrem ainda elementos escavadores intermediários e da semi-infauna. A tafonomia desta comunidade indica que a deposição ocorreu durante evento episódico.

Algumas descobertas pontuais foram realizadas revelando, diferentes fósseis, que não foram registrados em outras oportunidades. Entre estes se destacam os moluscos citados em trabalhos de sedimentologia e estratigrafia na Formação Tatuí. SOARES (1972) citou a existência de moldes de possíveis bivalves na Formação Tatuí, mas nenhum foi ilustrado. Outra ocorrência não formal encontra-se na monografia de MOCHIZUKI (2001) que registra a existência de bivalves em afloramento da rodovia Limeira-Piracicaba.

Bivalves, muito raros, também foram encontrados em finas camadas calcárias que se intercalam com os folhelhos próximos ao topo do Membro Taquaral (KAZUBEK \& SIMOES, 2002, 2003a).

A espécie Maackia iratiensis ainda é duvidosa e necessita de maiores estudos. Reconhecida primeiramente a partir de uma única valva preservada em folhelho escuro, provavelmente topo do Membro Taquaral ou base do Membro Assistência, proveniente 
de um furo de sondagem, é um dos fósseis mais raros da Formação Irati. Segundo KAZUBEK \& SIMÕES (2002) o material está mal preservado e apresenta poucas estruturas que possam definir a espécie com clareza.

Diversas camadas delgadas com grande quantidade de bivalves de $5 \mathrm{~mm}$ de comprimento médio, que pelas características sedimentares e estratigráficas podem ser consideradas como topo do membro Taquaral, foram descobertas no Estado do Paraná (KAZUBEK \& SIMOES, 2003a e 2003b; ROHN et al, 2003, LAGES, 2004).

\subsubsection{Artrópodes não observados no presente estudo}

Além dos Malacostraca encontrados nas unidades aqui estudadas, outros artrópodes foram observados em outros locais do Grupo Guatá e Formação Irati da Bacia do Paraná. Entre estes estão ostracodes e insetos.

Os ostracodes são normalmente microscópicos, com o corpo lateralmente comprimido, envolvido por uma carapaça calcária bivalve articulada dorsalmente. A carapaça é facilmente fossilizada, o que os torna um dos artrópodes melhor documentados. Nas unidades estudadas apenas foram encontrados na Formação Irati, onde o gênero Bairdia é o único registrado por CAMPANHA (1985), em testemunhos provenientes do município de Marília.

CABRAL Jr. et al. (1988) analisaram testemunhos de sondagem de regiões do Estado de São Paulo, onde não afloram a Formação Tatuí e o Grupo Itararé. Observaram supostos ostracodes marinhos em siltitos do topo da Formação Tatuí, nenhum ilustrado ou analisado com detalhes.

Os insetos descritos na literatura são todos atribuídos ao Membro Assistência, foram encontrados na Região Sul e no Estado de São Paulo (PINTO 1972a, 1972b, 1987a, 1987b, 1990; PINTO \& ORNELLAS, 1978; e RÖSLER et al. 1981 e MARTINS-NETO, 2005)

\subsubsection{Invertebrados incomuns citados na literatura}

Alguns grupos de invertebrados foram objetos de pouca investigação ou receberam breves citações.

A Formação Tatuí não revelou até o momento nenhum fóssil de braquiópodes, porém na Formação Palermo foi encontrada uma comunidade de lingulídeos no Estado do Rio Grande do Sul. HOLZ et al. (1998) estudaram, tafonômicamente esta assembléia que seria correlacionável à São Sepé (SIMÕES, 1992), base da Formação Palermo. Os 
lingulídeos com tamanho entre 9 e $15 \mathrm{~mm}$, não estão em posição de vida, desarticulados e sem sinais de abrasão. Estes autores concluíram que houve rápido soterramento resultante de tempestade.

Apenas uma única ocorrência de braquiópode lingulídeo foi citada por CAMPANHA (1985) no Membro Assistência, na região de Marília, SP, em testemunho de sondagem.

BOARDMAN (2006) comenta a existência de equinodermos em níveis similares aos de moluscos descritos por ROCHA CAMPOS (1970) na Formação Rio Bonito no município de Taió. Tais fósseis, ainda não descrito, evidenciaria a única ocorrência desse grupo no Grupo Guatá.

\section{4 ÁREA DE ESTUdo}

\subsection{Localização dos afloramentos}

Os afloramentos utilizados na presente pesquisa se referem à fácies de topo da Formação Tatuí e do Membro Taquaral da Formação Irati. Ao todo foram estudados 12 afloramentos, nas cidades de Leme, Rio Claro, Ipeúna, Piracicaba, Rio das Pedras e Limeira. Os afloramentos são:

Afloramento 1: Santa Maria 1

Afloramento 2: Santa Maria 2

Afloramento 3: Rio da Cabeça, Divisa de Rio Claro com Ipeúna

Afloramento 4: Ponte sobre o Rio Passa Cinco

Afloramento 5: Próximo ao Rio Passa Cinco

Afloramento 6: Rodovia do Açúcar Km 150

Afloramento 7: Rodovia do Açúcar Km 152,5

Afloramento 8: Rodovia SP-304 entre Piracicaba e Santa Barbara d'Oeste

Afloramento 9: Ibicatu (seção tipo)

Afloramento 10: Rodovia Irineu Penteado

Afloramento 11: Córrego do Veado

Afloramento 12: Fazenda Ponte Nova

\subsection{Definição geral das fácies observadas nos afloramentos estudados}

Fácies arenosa basal da Formação Tatuí ( fácies Tab)

Esta fácies foi observada com segurança apenas no afloramento 12 (Fazenda Ponte Nova). Caracteriza-se por uma camada de arenito muito fino, de coloração branco 
amarelada e boa seleção granulométrica. Estratificações cruzadas tabulares e tangenciais, localmente intercaladas por Estratificações plano-paralelas ou lâminas ligeiramente onduladas.

A fácies é basal da presente pesquisa, porém não é a fácies basal da Formação Tatuí, não observada no presente trabalho.

Fácies síltico-arenosa da Formação Tatuí (fácies Tsa)

Observada nos afloramentos 7, 8, 9, 11 e 12. Sua composição é basicamente de síltitos de coloração branco-amarelada, com algumas porções mais arenosas, podendo ter ondulações ou laminações cruzadas subordinadas. Conchostráceos, outros crustáceos ou vertebrados desarticulados podem ocorrer.

Fácies arenitos grossos ou conglomeráticos da Formação Tatuí (fácies Tag)

Observada nos afloramentos 7, 9, 11 e 12 é caracterizada por corpos arenosos de grande porte, chegando a quase $1,5 \mathrm{~m}$ de espessura, constituídos de arenito grosso mal selecionado a conglomerático e conglomerados suportados ou não pela matriz. Os clastos são predominantemente arredondados, alguns angulosos. Sua granulometria varia de grânulos, seixos ou um pouco maiores, observados no afloramento 9, 11 e 12 .

Ocorrem estratificações cruzadas de grande porte, além de estratificações sigmóides na parte superior. Nos afloramentos 7, 11 e 12 ocorre também como intercalações de corpos arenosos com estratificação "flaser" ou pequenos conglomerados na fácies siltica-arenosa.No afloramento 8 , pequenas camadas de poucos centímetros intercaladas a fácies siltica poderiam ser associadas a esta fácies.

Os fósseis encontrados são lenhos no afloramento 9 ou icnofósseis no afloramento 7 .

Fácies arenitos finos da Formação Tatuí (fácies Taf)

Uma das fácies mais comuns na presente pesquisa, observada nos afloramentos 1-6, 10 e 12, consiste de arenito fino a muito fino, bem selecionado, de coloração clara esbranquiçada a amarelada, comumente com pintas ou manchas mais escuras, em torno de nódulos de pirita intemperizados.

Ocorre estratificação "hummocky" de grande porte (métrico), menos nos afloramento 5, 10 e 12 onde é maciço ou finamente laminado. No Afloramento 1 ocorrem os dois tipos, a parte maciça, com icnofósseis no topo e a com estratificaões cruzadas na base.

É geralmente afossilífero, exceto pela presença de icnofósseis tubulares no Afloramento 1 e escamas e dentes muito dispersos no Afloramento 5. 
Fácies arenitos com ictiofósseis do Membro Taquaral (fácies Iai)

Aa fácies de maior importância paleontológica pela sua diversidade e abundancia foi observada nos afloramentos $1-5$ e 12

Nos Afloramentos 1 a 4, esta fácies é constituída de arenito fino a médio, conglomerático, de tonalidade cinza clara a média nas porções mais grossas e cinza mais escura nas porções mais finas. Nesses afloramentos com granodecrescência ascendente e estratificação cruzada irregular em sets centimétricos. No Afloramento 5 a abundância de fósseis é maior, mas difere na cor associada a boa seleção granulométrica.

Os fósseis são exclusivamente de vertebrados aquáticos, peixes e anfíbios, fragmentados e desarticulados.

Fácies folhelho síltico-argiloso do Membro Taquaral (fácies Isa)

Ocorre nos afloramentos 1-3, 5-6, 8, 10 e 12. É a unidade mais homogênea da sucessão estudada, apresentando praticamente as mesmas características em toda a regiâo. É uma rocha síltico - argilosa de coloração cinza-escura (quando não alterada), com laminação plano-paralela. Pode ser chamada de folhelho embora nem sempre apresente fissilidade ao se quebrar. Os fósseis são restos de peixes (escamas, dentes) e crustáceos, em fragmentos ou inteiros, raros e muito dispersos.

\subsection{Localização geral}

Os afloramentos 1-3 se localizam dentro do Sítio Santa Maria (Figs. 4 e 5), às margens do Rio da Cabeça, localizado na divisa entre os municípios de Rio Claro e Ipeúna; outros dois, afloramentos 4-6 e 12, ficam em uma região agrária nas proximidades do Rio Passa Cinco (Fig.4 e 5).

Amostras de afloramentos com fósseis, além dos aparentemente, afossilíferos foram coletadas para estudos paleontológicos, estratigráficos e de correlação. Localizam-se em rodovias na região do Alto estrutural de Pitanga e entre os municípios de Leme e Rio das Pedras. Entre eles os afloramentos 6, 7, 8 e 11, que se localizam entre os municípios de Santa Barbara D’Oeste, Piracicaba, Limeira e Rio das Pedras (Fig. 6 e 7B). ). Foi investigado o antigo afloramento da Fácies Ibicatu (afloramento 9) (Fg.7A), nas proximidades de Leme. 
于

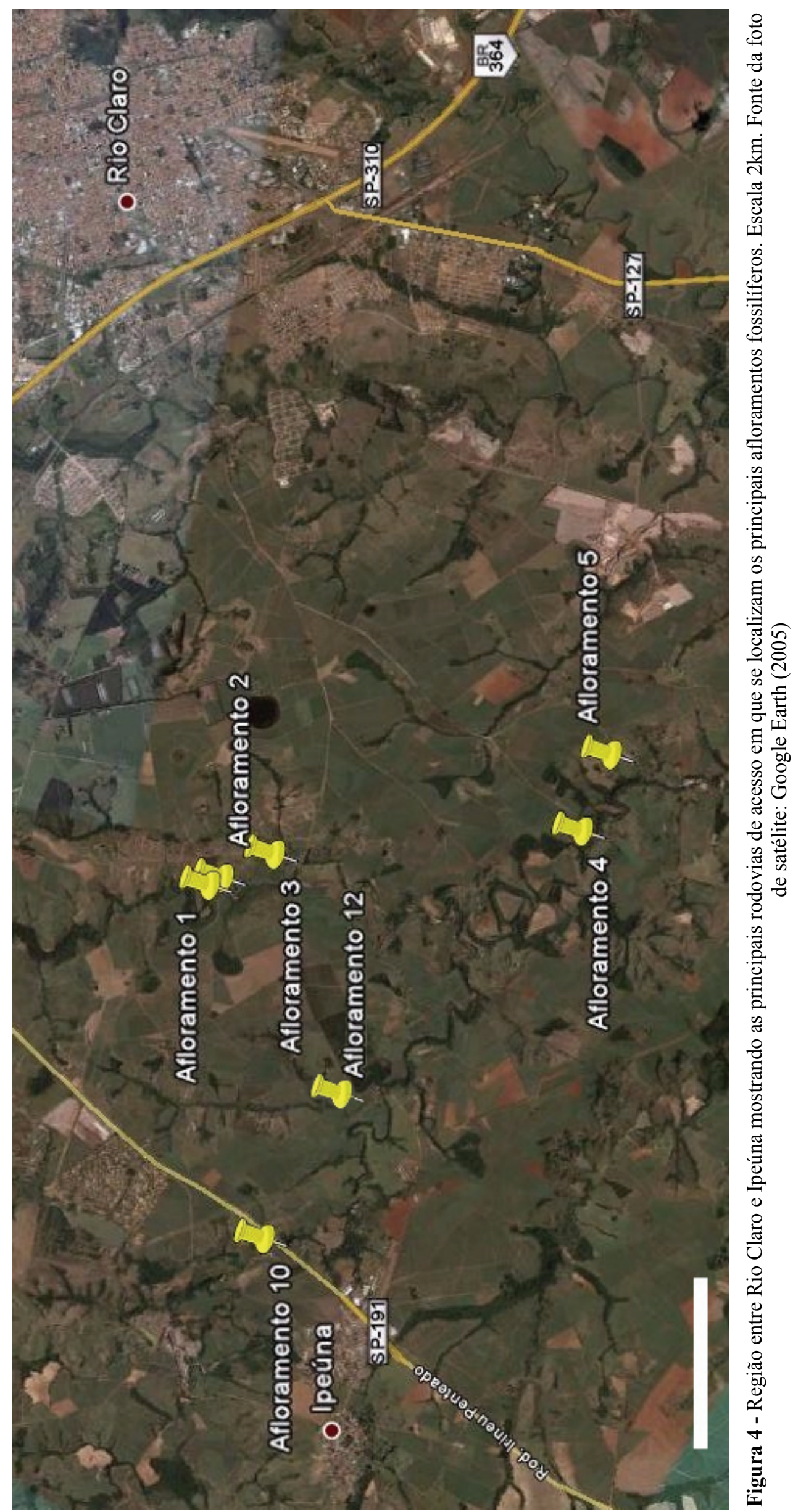




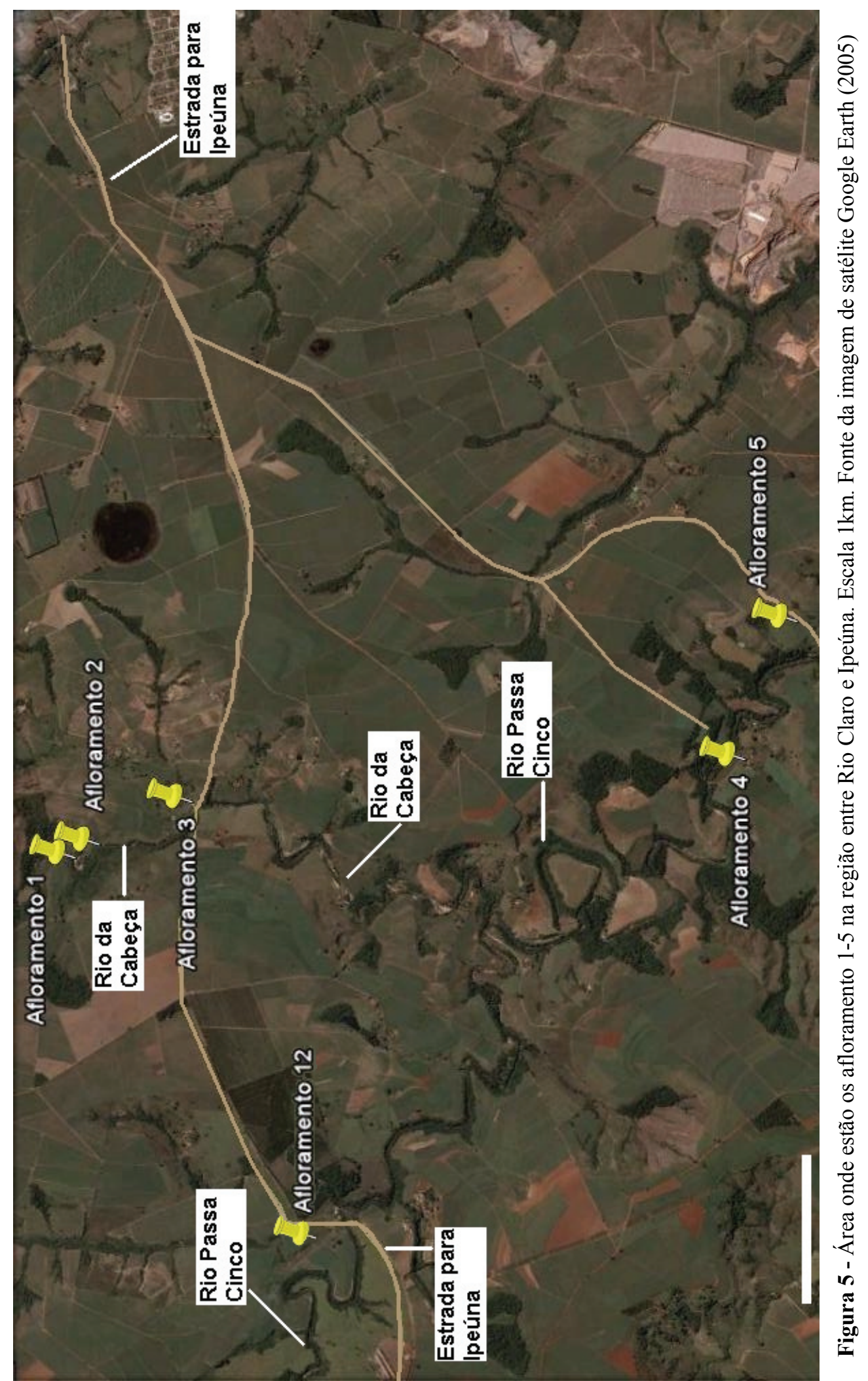




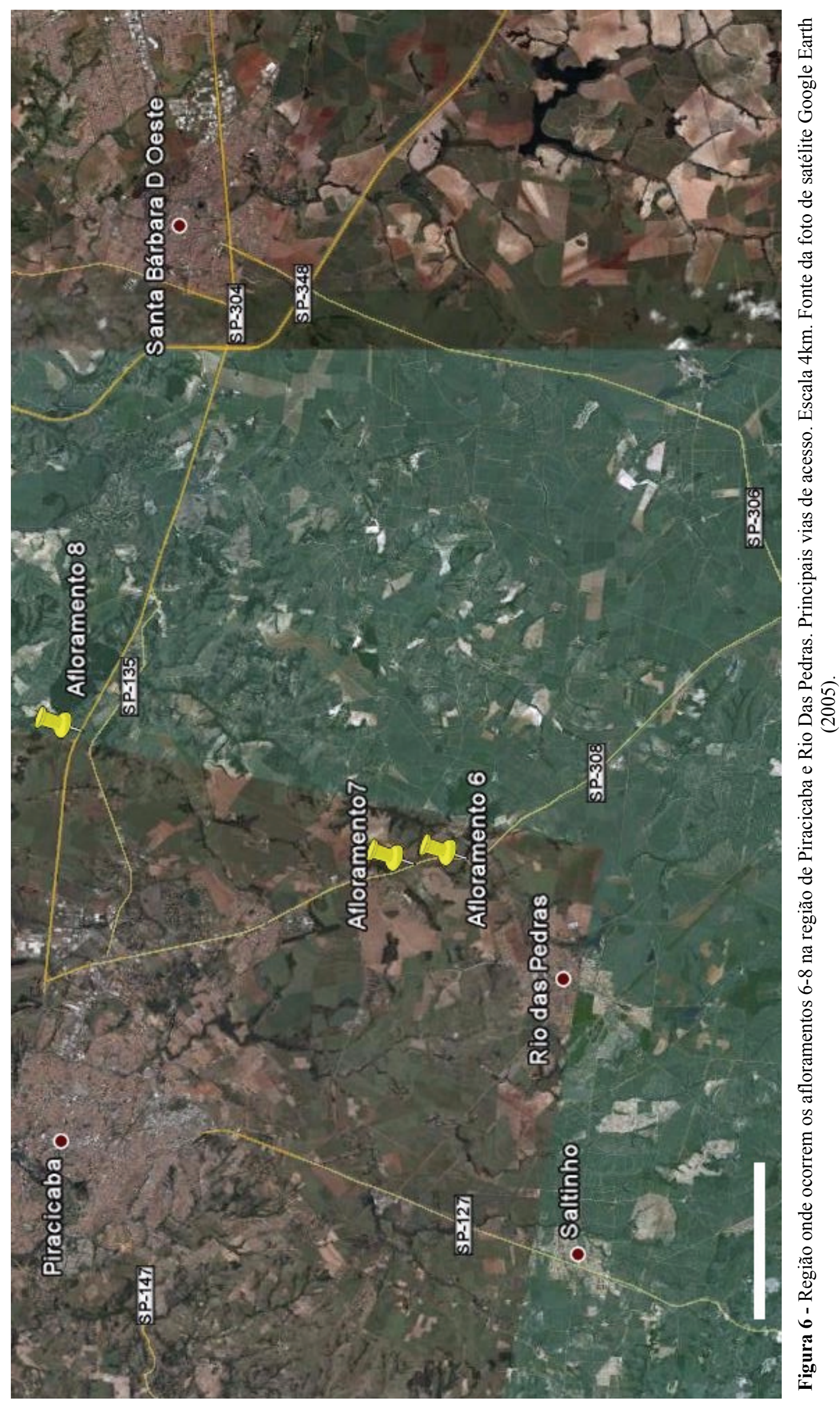



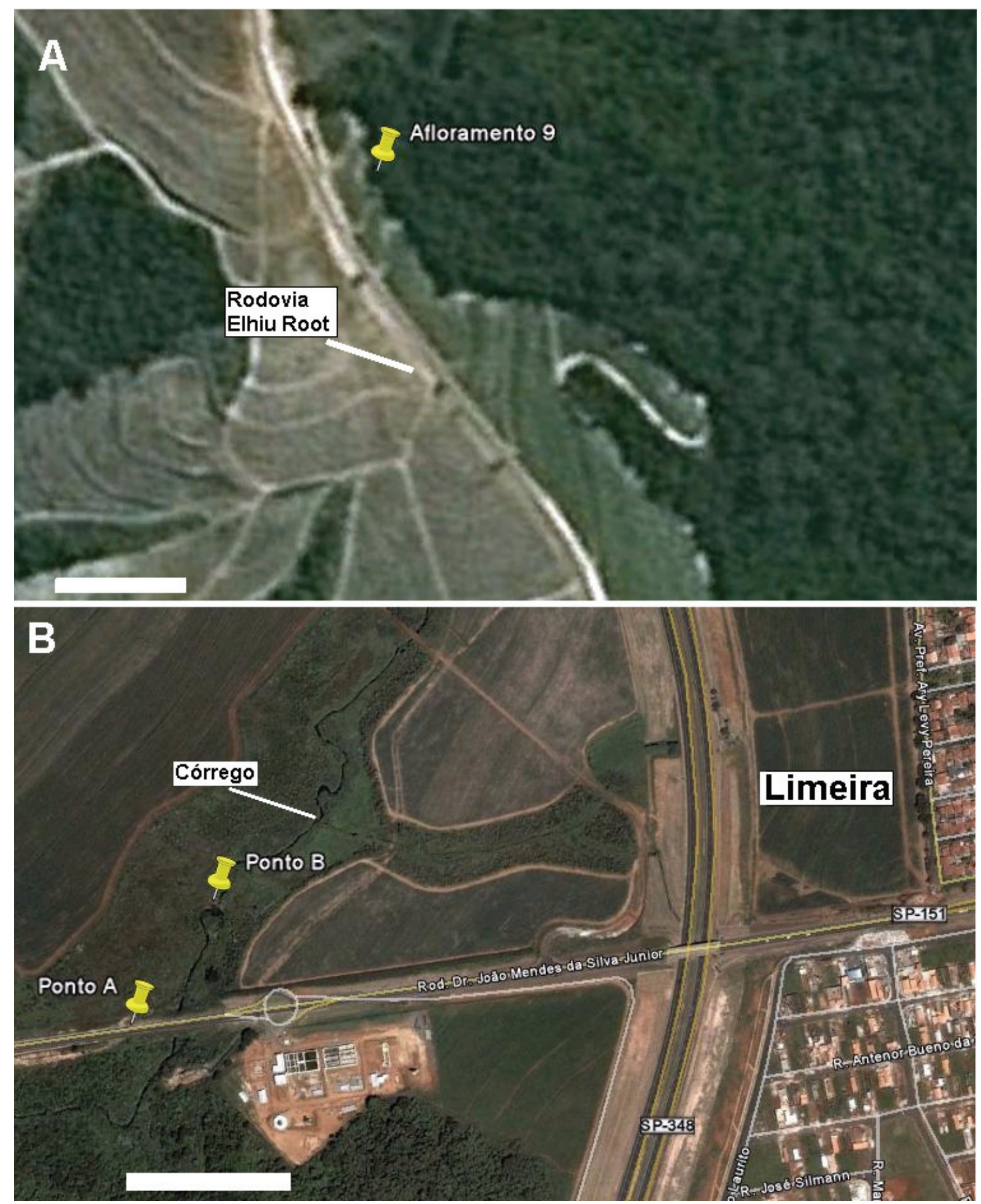

Figura 7- A) Localização do Afloramento 9 na Reodovia Elhiu Root nos arredores de Araras e Leme. Escala 100m. B) Localização do Afloramento 11, Córrego do Veado. Escala 200m. Fonte da foto de satélite Google Earth (2005). 


\subsection{Descrição de afloramentos}

\subsubsection{Afloramento 1: Sitio Santa Maria 1}

O afloramento situa-se no interior do Sitio Santa Maria, localizado próximo da divisa das cidades de Ipeúna e Rio Claro, na margem sul do Rio da Cabeça em coordenadas UTM: 23K 227055/7517325.

No afloramento foi possível diferenciar quatro camadas sedimentares, três se dispondo em forma de laje e a quarta, acima da lage, em corte (Figs.8 e 9).

\section{Afloramento 1 \\ Sítio Santa Maria 1}

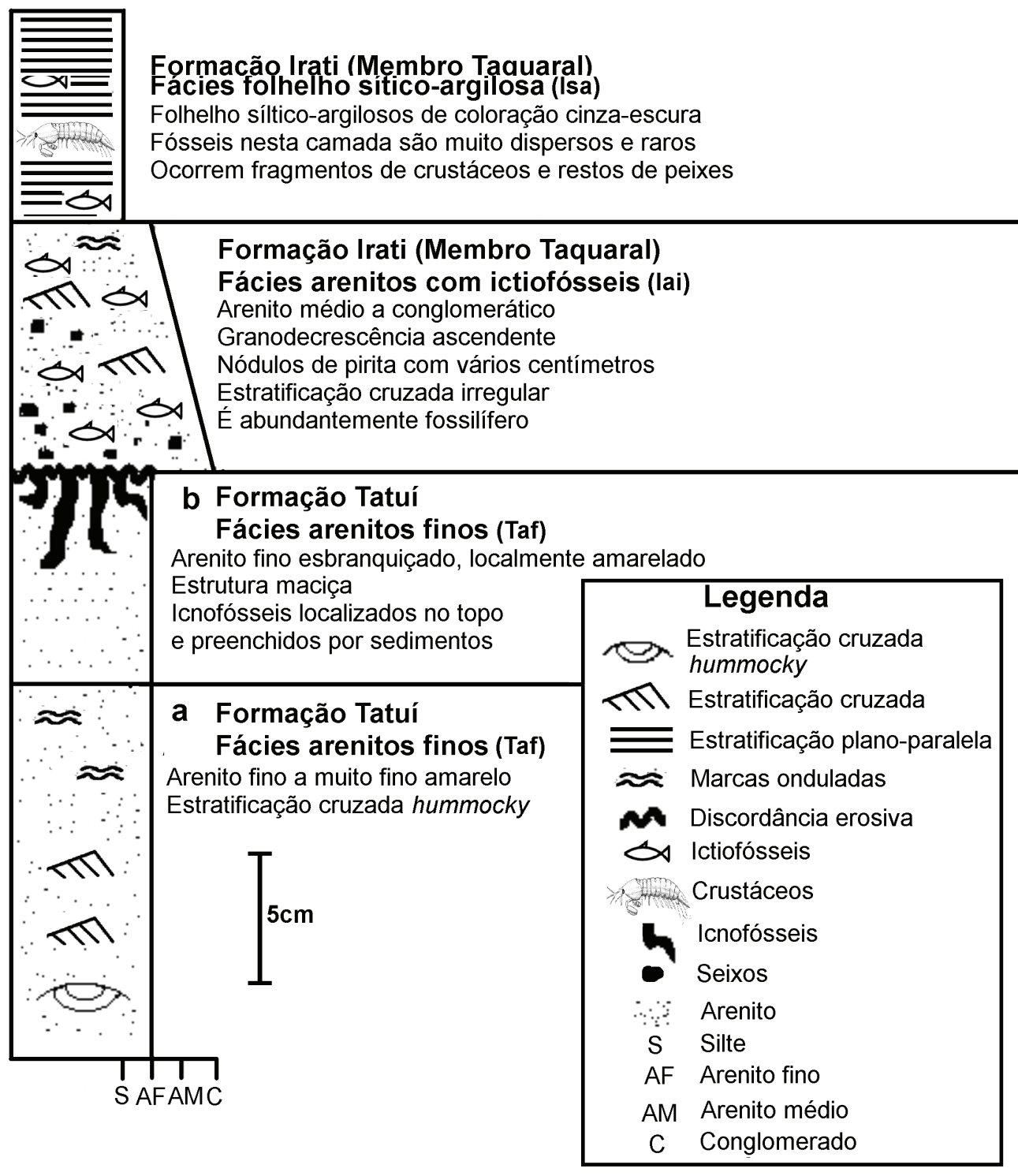

Figura 8 - Seção estratigráfica do Afloramento 1. 
Fácies Taf (a): constitui-se de uma camada suborizontal de arenito fino a muito fino, seleção granulométrica boa e coloração amarela esbranquiçada. Está diretamente em contato com o Rio da Cabeça, por isso em épocas de chuvas ela fica submersa, porém no dia em que foi medida, estava emersa $25 \mathrm{~cm}$ (no ano de 2005) da espessura total.

As estruturas sedimentares são caracterizadas por estratificação cruzada simples de grande porte e do tipo "hummocky", 0,5 m de tamanho, típico de depósitos de tempestades. No topo aparecem pequenas marcas onduladas paralelas, aparentemente simétricas, com cristas orientadas N20E e amplitude menor que $0,5 \mathrm{~cm}$. Foi observada, também, nodulação incipiente dando um aspecto de pequenas "pintas" ou manchas em núcleos maiores.

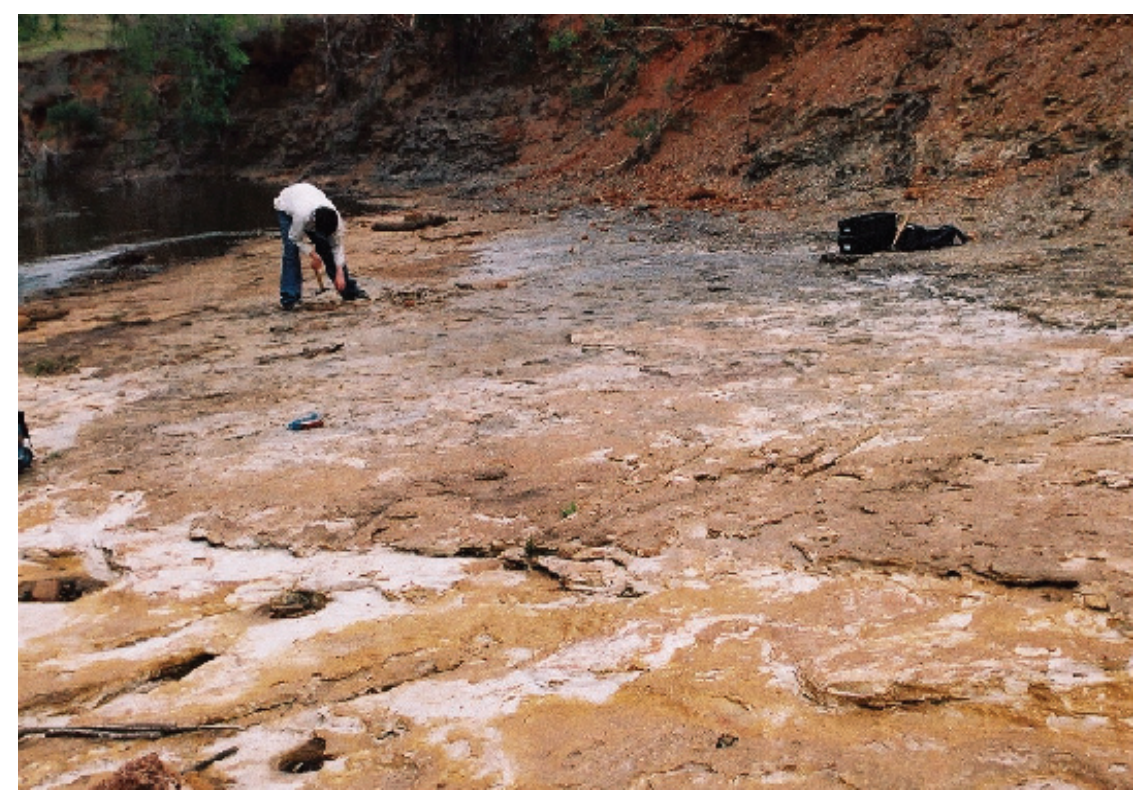

Figura 9 - Foto do Afloramento 1. No chão a fácies Iai do Membro Taquaral.

Fácies Taf (b): Camada suborizontal caracterizada por arenitos muito finos de coloração esbranquiçada, localmente amarelada clara (alteração de nódulos de pirita?) e de aproximadamente oito centímetros de espessura. Estruturas variando de finamente laminada a maciça e ótima seleção granulométrica.

A característica mais importante da camada é a existência de icnofósseis tubulares irregulares, localizados no topo, preenchidos por sedimentos mais grossos acinzentados, com bioclastos da camada sobrejacente. O comprimento desses tubos chega a quatro centímetros, o que equivale à metade da espessura total da camada.

O contato com a camada subjacente é concordante e gradual, o contato com a camada superior é marcado por uma discordância erosiva (Fig. 10). 


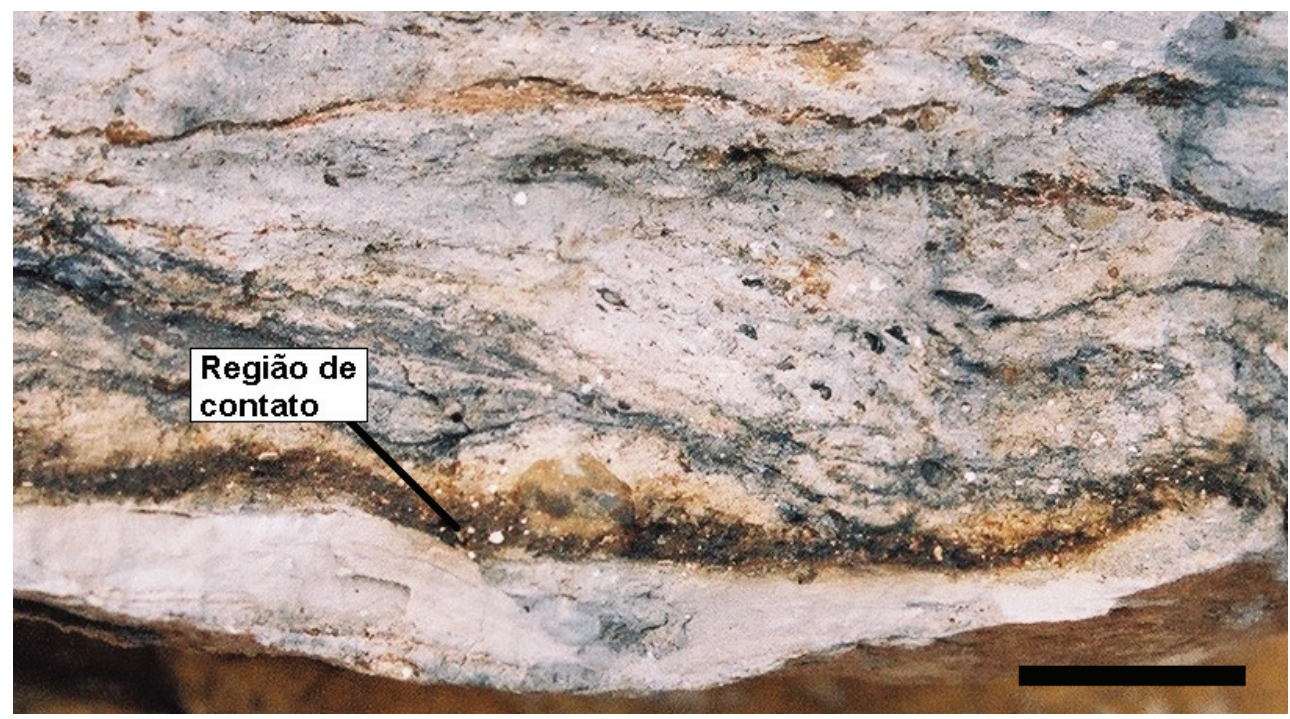

Figura 10 - Afloramento 1 região inferior da fácies Iai do Membro Taquaral, preservando o contato erosivo com a camada subjacente da fácies Taf da Formação Tatuí. Escala 20mm.

Fácies Iai: a exposição, em área, do afloramento é de, aproximadamente, $160 \mathrm{~m}^{2}$ $(\sim 8 \mathrm{X} 20 \mathrm{~m})$ em planta e $9,5 \mathrm{~cm}$ de espessura. O formato do pavimento segue o contorno das camadas subjacentes e a cor varia de cinza clara a média (em granulometrias mais grossas) a partes mais escuras (nas porções mais finas).

É constituída de arenitos finos a médios conglomeráticos, com grânulos, pequenos calhaus na base, granodecrescência ascendente até atingir a camada sílticoargilosa no topo (fácies Isa), embora de forma não gradual. Os clastos podem ser de origem biogênica, coprólitos, dentes e escamas.

Apresenta estratificação cruzada irregular com sentido da corrente variado, sem preferências. Clara granodecrescência ascendente com contato abrupto com a camada sobrejacente, síltica-argilosa (Figs. 10). É possível também observar camadas milimétricas sílticas cinza-escuras intercalando-se aos arenitos finos. Ocorrem nódulos de pirita, de esféricos a ovais, de diversos tamanhos, alguns com vários centímetros.

Fácies Isa: pacote homogêneo, plano, de rocha síltico - argilosa de coloração cinza-escura, quando fresca. É a maior área exposta do afloramento com $4 \mathrm{~m}$ de espessura. Estratificação plano-paralela horizontal e contínua (folhelho) sem deformações por atividade tectônica. Ocorrem pequenos nódulos de pirita de poucos milímetros, dispersos no sedimento.

Seus fósseis são muito dispersos e raros, escamas, dentes de peixes e fragmentos de crustáceos. 


\subsubsection{Afloramento 2: Sítio Santa Maria 2}

Este afloramento é muito próximo do primeiro e é parcialmente recoberto por grandes blocos rolados de diabásio e de camadas de calcário pertencentes ao Membro Assistência. Localizado a, aproximadamente, 100 metros do Afloramento 1 (UTM: 23K 227050/7517669), mede 30 metros de comprimento em corte nas margens do Rio da Cabeça. Ao contrario do Afloramento 1, o Membro Taquaral está bastante alterado no contato e não forma parede. As três fácies são observadas, sendo a última parcialmente coberta (Figs. 11 e 12).

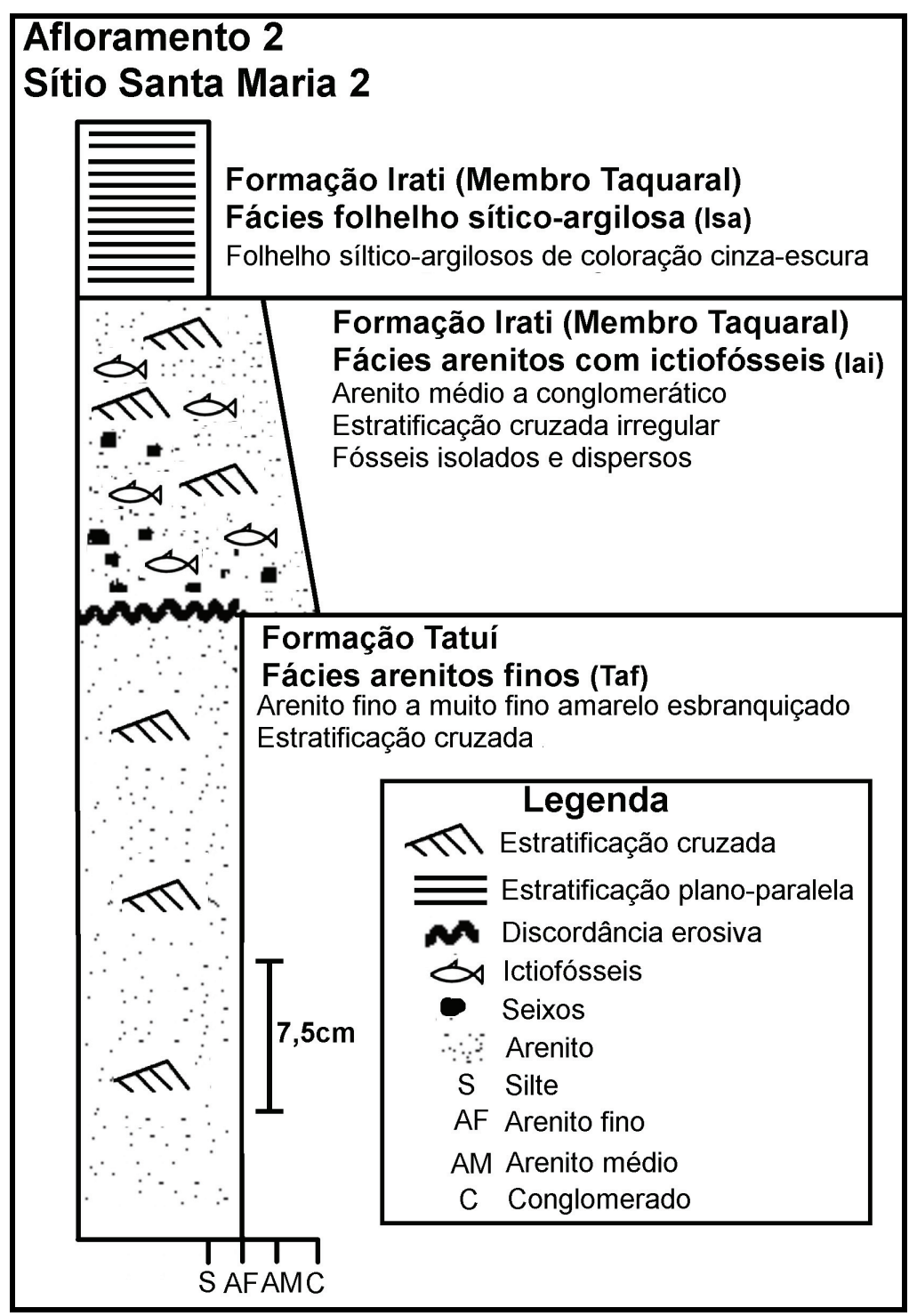

Figura 11 - Seção estratigráfica do Afloramento 2. 


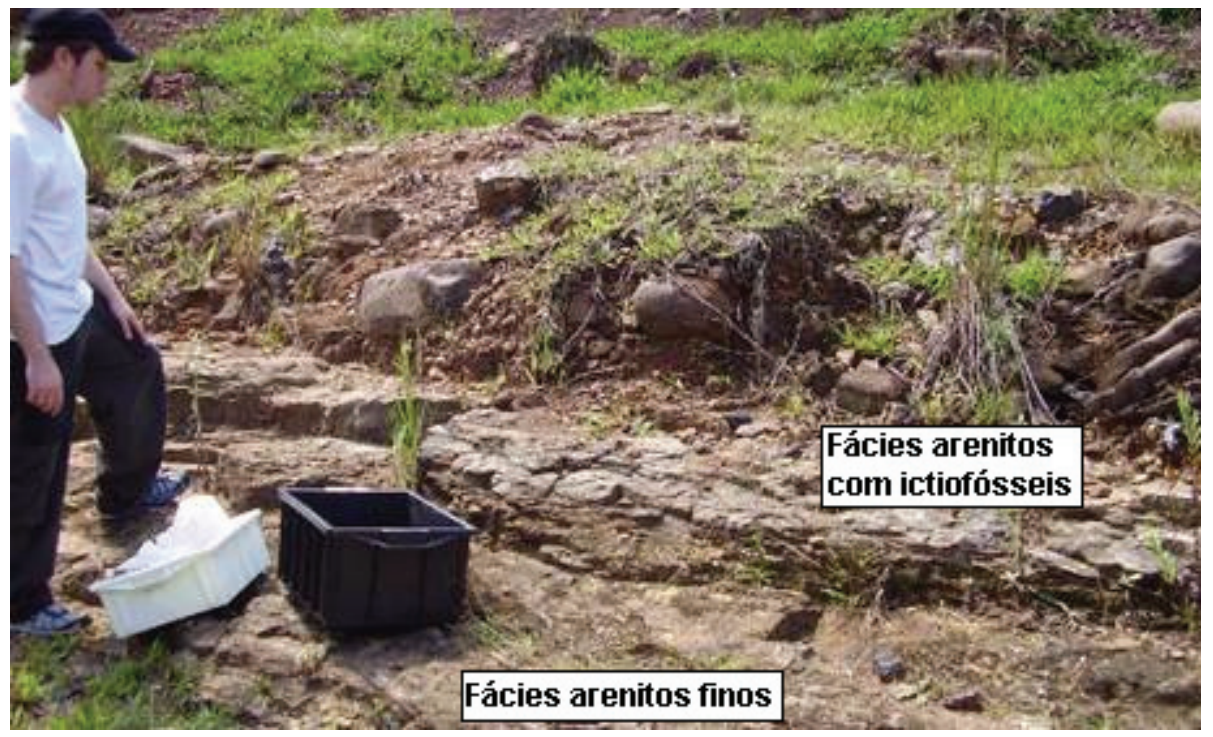

Figura 12 - Afloramento 2. Sítio Santa Maria 2. Degrau representando a fácies Iai. Acima blocos rolados de diabásio e de calcários do Membro Assistência.

Fácies Taf: caracteriza-se por arenito fino a muito fino, bem selecionado e de coloração amarelada para esbranquiçada.

As estratificações cruzadas "hummocky" do afloramento 1, não foram aqui observadas, mas estruturas menores podem ser eventualmente correlacionadas. A área de exposição não ultrapassa um metro de espessura.

Como no Afloramento 1, parece ser afossilífera. Não foram observadas estruturas de icnofósseis.

O contato com a camada sobrejacente é marcado por uma discordância erosiva. Esta fácies é equivalente à fácies Taf (a) do Afloramento 1, a fácies (b) não foi observada. A camada é representativa do mesmo evento e a ausência da fácies (b) estaria relacionada a processos erosivos.

Fácies Iai: constituída de arenitos finos a médios, conglomeráticos com grande quantidade de fósseis. A exposição no afloramento não é muito representativa, se comparada com o Afloramento 1, pois está em forma de um pequeno degrau (Fig. 12) que separa as rochas da Formação Tatuí dos folhelhos intemperizados do Membro Taquaral. O formato é tabular, a cor varia de cinza clara a média (em granulometrias mais grossas) a partes mais escuras (nas porções mais finas). A estratificação cruzada é irregular, com muitas ondulações, com sentido variado da corrente, sem preferência. A granodecrescência ascendente observada não é tão evidente quanto a do Afloramento 1, mas é possível diferenciar a base, mais grossa, do topo, mais fino. A espessura da camada é maior e alcança 15 centímetros, praticamente sem variação por todo o corte. 
Fácies Isa: Nesse afloramento os siltitos argilosos do Membro Taquaral estão muito alterados, mas é possível confirmar, sua presença em cortes, um pouco acima do afloramento, indicando que a sua espessura se mantém aproximadamente a mesma do afloramento 1.

\subsubsection{Afloramento 3: Rio da Cabeça, divisa de Rio Claro com Ipeúna}

Este afloramento, de quatro metros de comprimento, se localiza na entrada do Sitio Santa Maria, exatamente na divisa entre os municípios de Ipeúna e Rio Claro (UTM: 23K 227300/7517325). Situa-se na margem sul de um córrego afluente do Rio da Cabeça, em que se observam três fácies de estruturas e litologias diferenciadas (Figs. 13 e 14).

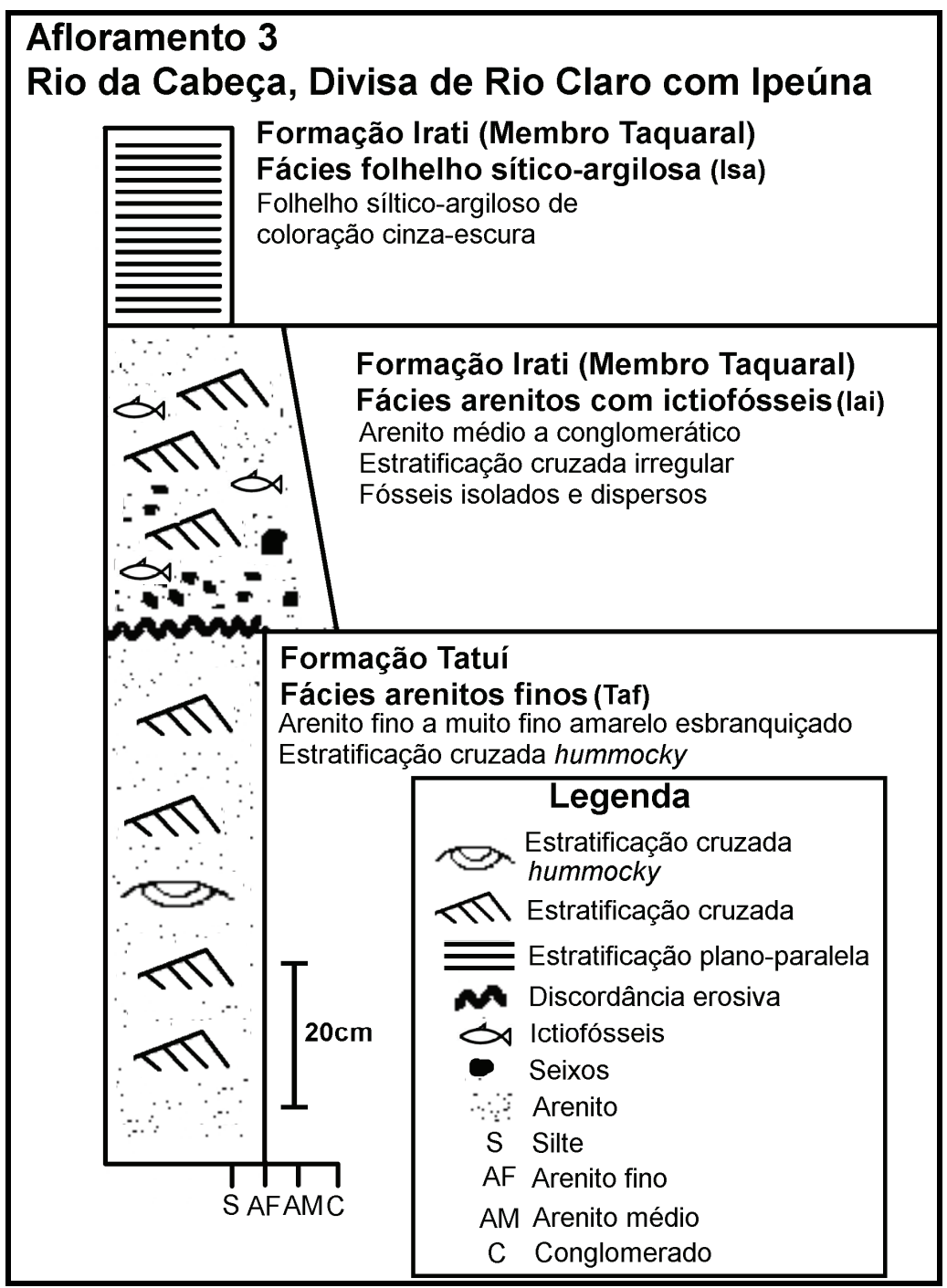

Figura 13 - Seção estratigráfica do Afloramento 3.

Fácies Taf: caracteriza-se por arenito fino a muito fino, bem selecionado e de coloração amarelada para esbranquiçada. Uma parte é submersa no afluente do Rio da 
Cabeça e outra emersa. Estratificações cruzadas do tipo "hummocky" de grande porte (1 $\mathrm{m}$ de tamanho), observada em um único ponto.

Aparentemente afossilífera, exibe algumas nodulações de coloração avermelhada como pintas ou manchas. $\mathrm{O}$ contato com a camada sobrejacente é marcado por uma discordância erosiva.

Fácies Iai: camada tabular com mergulho de 10 graus e $43 \mathrm{~cm}$ de espessura. Caracteriza-se por arenitos finos a médios, conglomeráticos.

Os clastos podem ser de origem biológica como coprólitos (bioclastos) ou de sílex e quartzo. A granulometria varia de grânulos a calhaus, estes últimos observados apenas na base. Granodecrescência ascendente, inclusive dos clastos que desaparecem a medida que se sobe na estratigrafia. A estratificação, como no Afloramento 1, é irregular com diversos sentidos de corrente. Foram constatadas estratificações cruzadas na base e no topo com mais de $10 \mathrm{~cm}$, dando falsa impressão de camadas diferenciadas. Verifica-se variações de cores no tom acinzentado, mais claros em porções mais grossas e escuras nas mais finas.

Contém grande diversidade de escamas, dentes e partes ósseas dispersas por toda a espessura do afloramento.

Como ocorre no Afloramento 1, o contato com a camada subjacente é marcado por discordância erosiva. Parte do afloramento está silicificada, atribuída a atividade ígnea, visto a presença de diabásio “in-situ”, porém os fósseis não foram afetados.

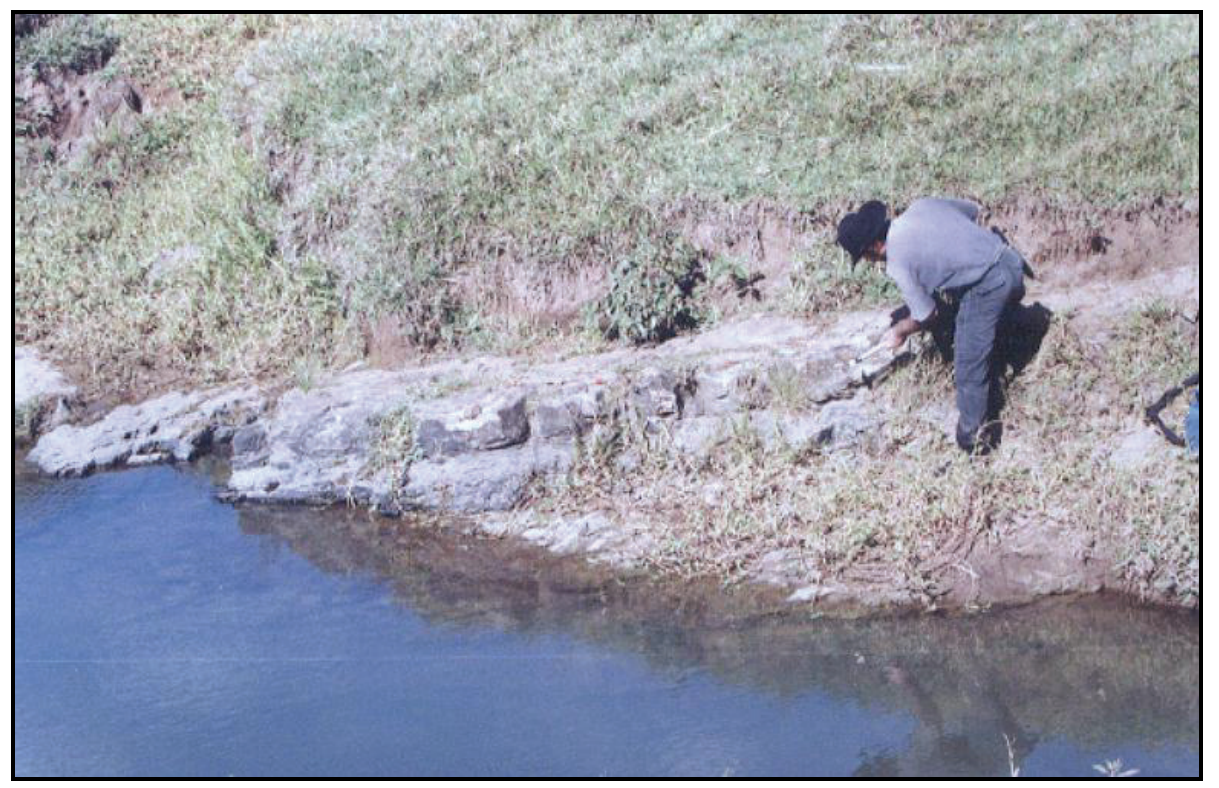

Figura 14 - Afloramento 3 na divisa de Rio Claro com Ipeúna. Destaque para a fácies Iai de coloração acinzentada. 
Fácies Isa: composta de rochas síltico - argilosas de coloração cinza-escura, com alguma calcita secundária e laminação plano-paralela. Aparentemente é afossilífera, porém a rocha está muito alterada o que pode ter destruído todo o material fóssil. A camada é muito parecida com a encontrada no Afloramento 1 e pertenceria ao folhelho síltico do Membro Taquaral.

Como as fácies se equivalem às do afloramento $1 \mathrm{e} 2$, pode-se considerar este terceiro afloramento uma extensão de ambos e deve ter feito parte do mesmo sistema deposicional. As poucas diferenças são a espessura da camada da base da Formação Irati e a ausência da fácies Taf (b) que pode ter sido totalmente erodida.

\subsubsection{Afloramento 4: Ponte sobre o Rio Passa Cinco}

O afloramento localiza-se no lado leste de uma ponte sobre o Rio Passa Cinco, dentro do município de Rio Claro, em coordenadas UTM: 23K 227500/751345. O afloramento é cortado pelo Rio Passa Cinco. Na margem noroeste é representado por um corte, enquanto na margem sudeste parte dele está parcialmente submerso. Em ambos foi possível observar duas camadas (Fig. 15 -17).

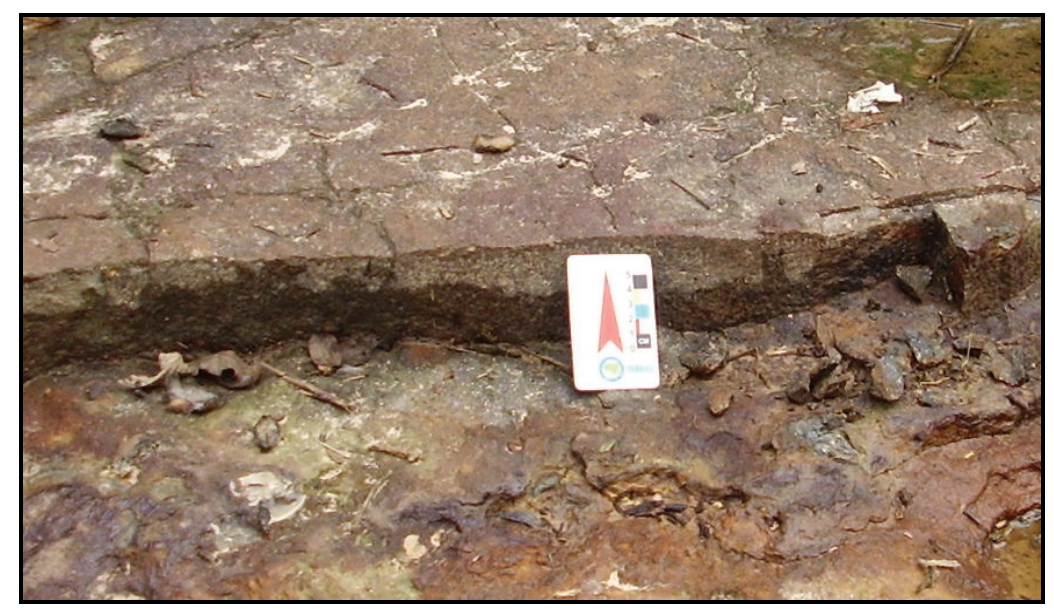

Figura 15 - Afloramento 4: contato da fácies Taf (inferior) com a fácies Iai (superior).

Fácies Taf: Representa praticamente todo o afloramento, constituído de arenitos finos, amarelados, bem selecionados, aparentemente afossilíferos, com estratificação cruzada de tamanho métrico e presença de estratificações cruzadas "hummocky", de 1 a $2 \mathrm{~m}$ de tamanho.

Fácies Iai: Arenito conglomerático cinza claro a médio com porções mais escuras, com clastos silexíticos de vários centímetros de tamanho. A espessura da camada é de $8 \mathrm{~cm}$, com estratificação cruzada irregular e granodecrescência ascendente. 


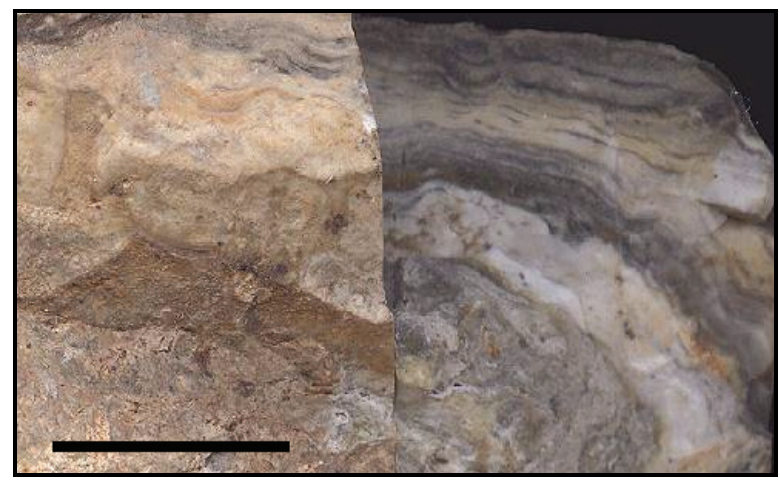

Figura 16 - Amostra de rocha silicificada do Afloramento 4. Escala $1 \mathrm{~cm}$.

Apesar da semelhança com as camadas que representam a base da Formação Irati nos afloramentos 1 - 3, este é muito mal selecionado, com quantidade maior de calhaus.

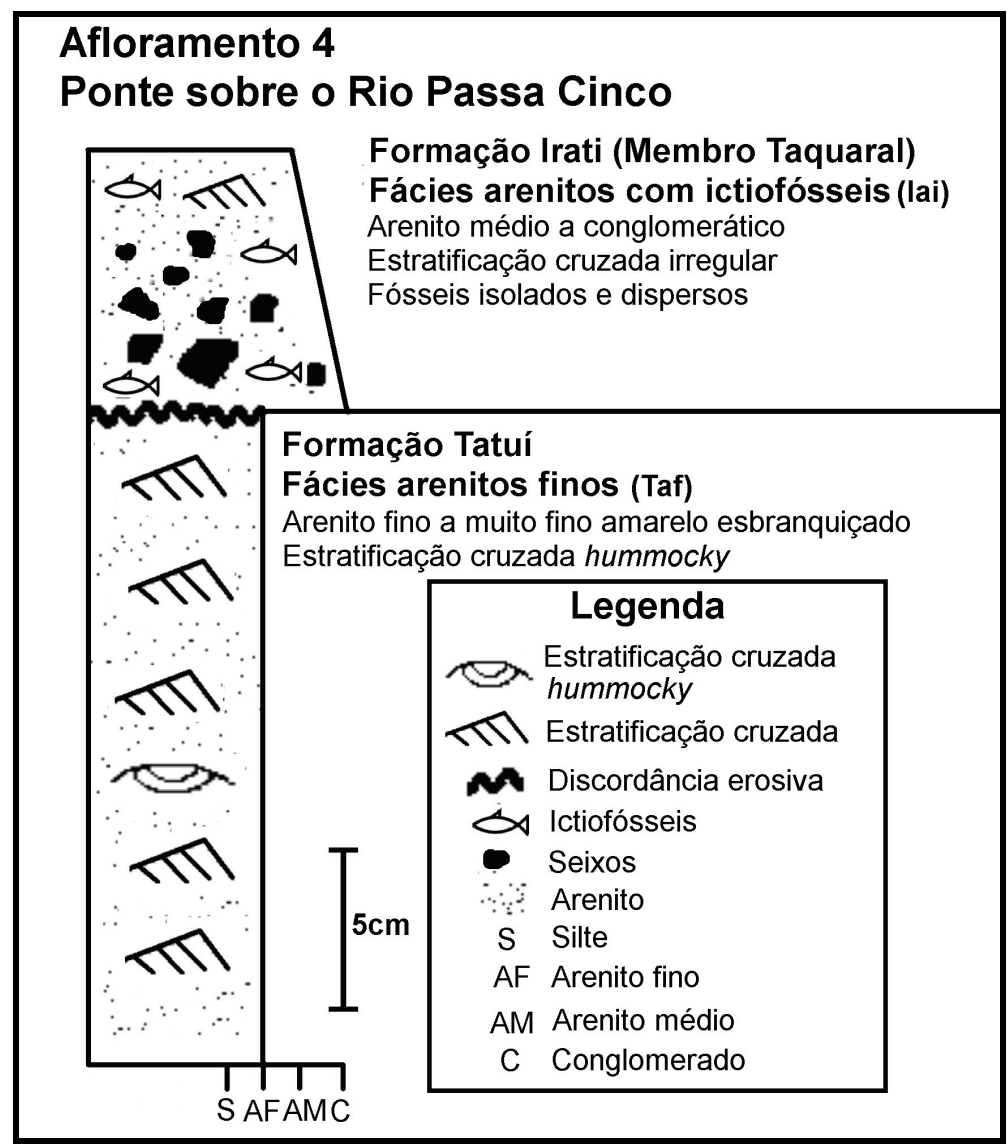

Figura 17 - Seção estratigráfica do Afloramento 4.

Foram observados indícios de silicificação causada por diques ou sills de diabásio presentes em diversos afloramentos das proximidades (Fig. 16). 
Também aqui a fácies é fossilífera, com diversidade de escamas, dentes e partes ósseas de vários peixes. Esta camada, como nos afloramentos anteriores, pode ser considerada pertencente à base da Formação Irati.

\subsubsection{Afloramento 5: Próximo ao Rio Passa Cinco}

O afloramento, dividido em duas partes, está localizado em uma estrada de terra quase paralela ao Rio Passa Cinco, dentro do município de Rio Claro, em coordenadas UTM: 23K 228537/7512610.

A primeira parte, Ponto A, é constituída de dois cortes pequenos que não superam dois metros de comprimento total (Figs. 18 e 19), porém são observadas três camadas sedimentares distintas representativas do topo da Formação Tatuí e da base do Membro Taquaral.

O Ponto B, continuação inferior do Afloramento 5, está localizado no chão, às margens de um pequeno córrego, afluente do Rio Passa Cinco, aproximadamente 260 metros do Ponto A e mais próximo do Rio Passa Cinco (Figs. 18 e 19).

A área exposta, muito pequena, situa-se ao redor do córrego e não supera $1 \mathrm{~m}$ de exposição em ambos os lados. Foram observadas duas camadas sedimentares, todas pertencentes à Formação Tatuí:

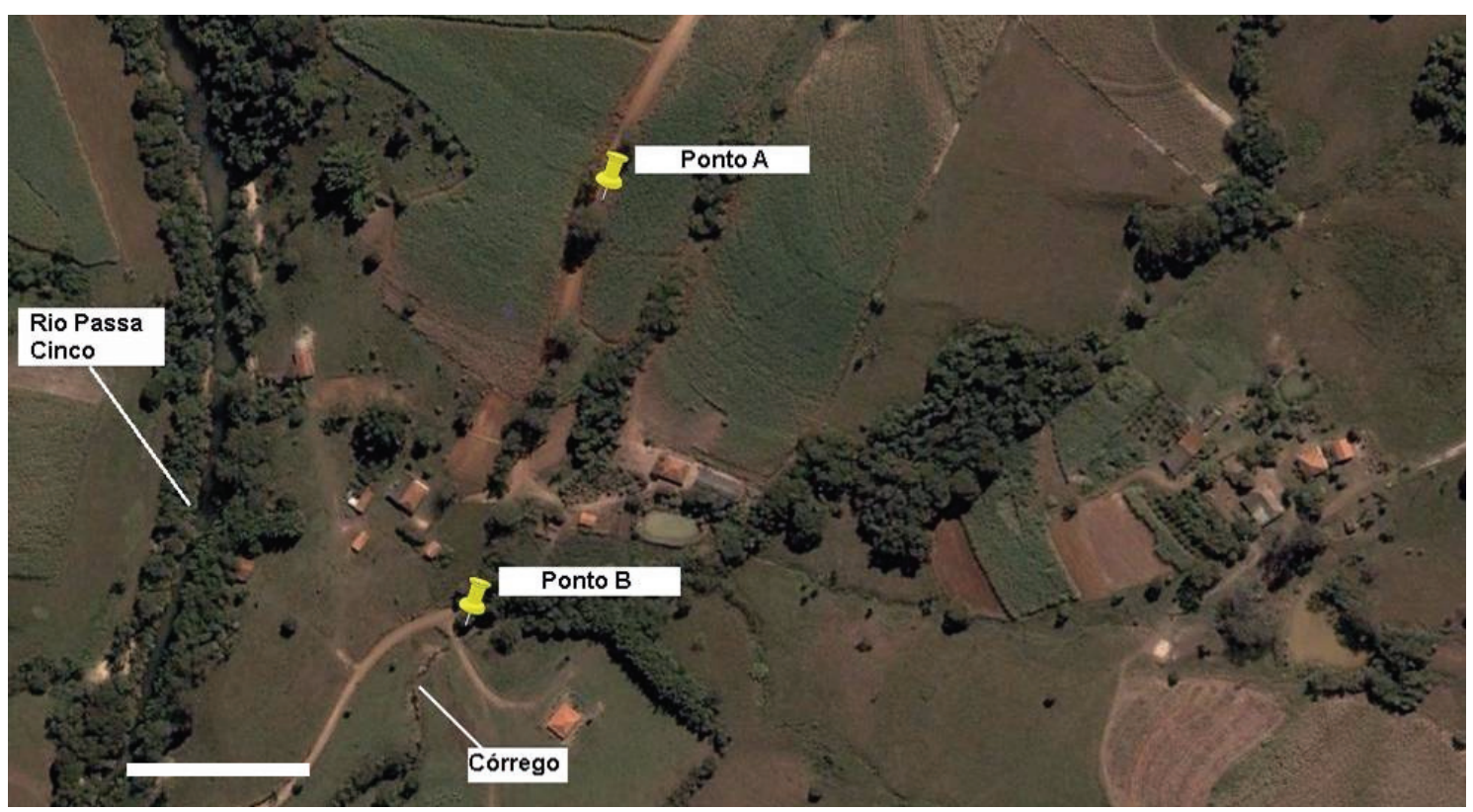

Figura 18 - Localização dos Pontos A e B do Afloramento 5. Escala 100m. Fonte da imagem de Satélite Google Earth (2005). 


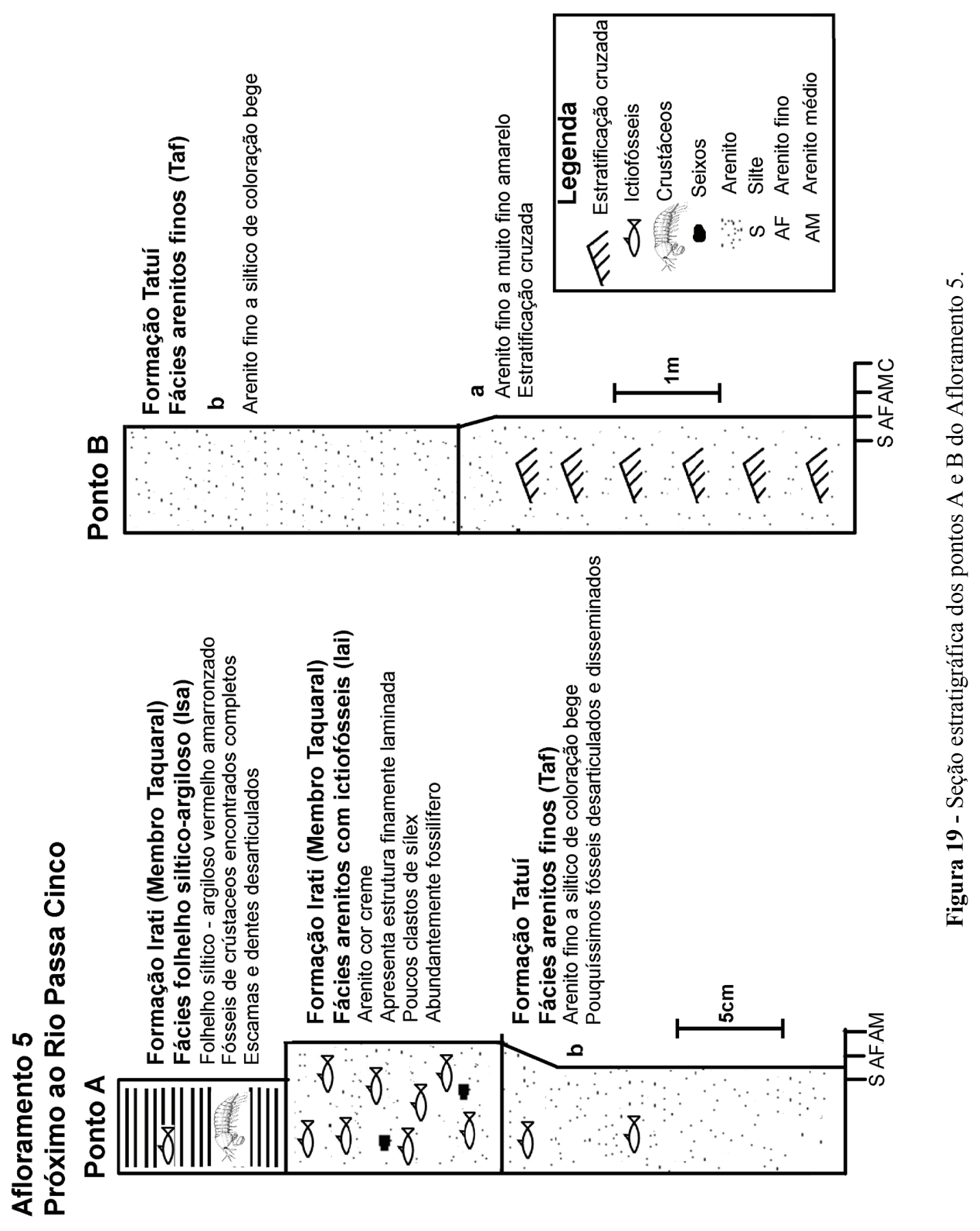




\section{Ponto A}

Fácies Taf: arenito fino a muito fino de coloração bege esbranquiçada, ótima seleção granulométrica e sem estruturas evidentes.

Esta camada possui pouquíssimos fósseis, muito disseminados, apenas possíveis de serem vistos em amostra pouco alterada. Aparentemente representa um pacote de grande espessura, mas devido a alteração, não foi possível delimita-la.

Fácies Iai: composta de arenitos finos a médios, de cor creme, com, aproximadamente, oito centímetros de espessura, laminação fina ondulada, por vezes maciça, e boa seleção granulométrica. São observados poucos seixos de sílex angulosos, disseminados no sedimento.

É o afloramento com a maior quantidade de bioclastos, porém todos fragmentados e desgastados.

O contato com a camada subjacente é gradual, caracterizado por ligeiro aumento da granulometria e aparecimento de grande quantidade de fósseis. O contato com a camada sobrejacente é abrupto, com súbito aparecimento de camadas síltico-argilosas

Ocorrem intercalações de finas lentes (próximas ou menores de $1 \mathrm{~cm}$ ), sílticas ou de arenitos finos finmente laminados ou ondulados com as mais grossas de arenitos com ictiofósseis (Fig. 20).

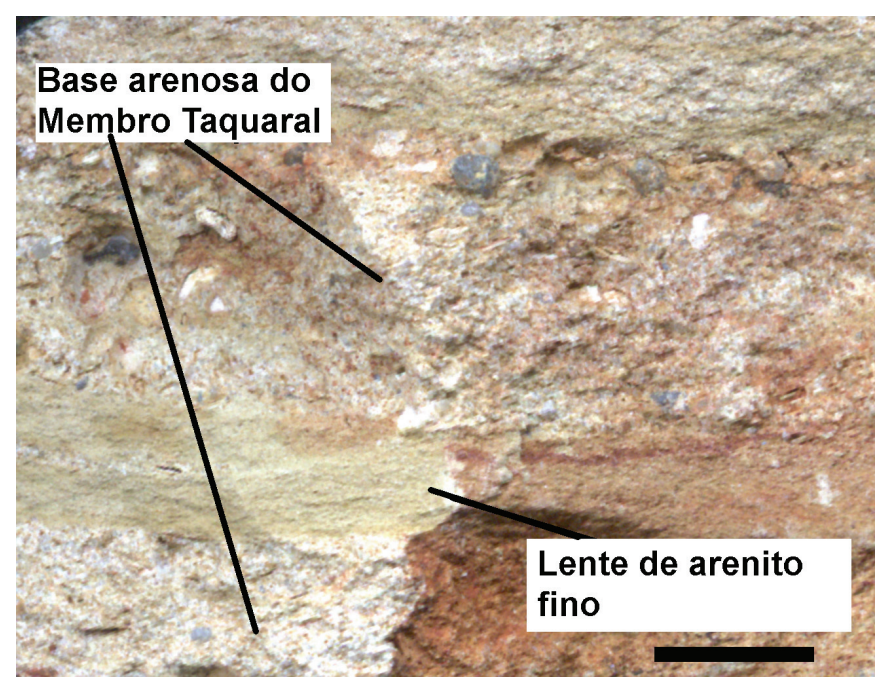

Figura 20 - Camada de arenito fino intercalando uma camada da base do Membro Taquaral da Formação Irati. Escala $1 \mathrm{~cm}$.

Fácies Isa: Folhelho síltico - argiloso de coloração vermelha amarronzada. Os fósseis não são abundantes, porém bem preservados, principalmente os da espécie Clarkecaris, exclusivo do Membro Taquaral, tendo sido possível obter diversos 
exemplares completos, além de escamas, dentes de paleoniscídeos e Actinistia desarticulados e dispersos.

Este afloramento, por não exibir contatos discordantes entre as litologias Tatuí e Irati se diferencia dos afloramentos até aqui descritos. Por outro lado sucessões de litologias típicas do Membro Taquaral estão presentes nas camadas B e C.

Alguns metros acima da camada do Membro Taquaral, ainda na estrada, foi possível ver um pequeno depósito de sílex formado pelo contato com o diabásio. $\mathrm{O}$ depósito está alterado para solo (terra roxa) e não foi possível a observação do Membro Assistência em contato com o Membro Taquaral, sugerindo que ambos foram separados pela rocha intrusiva ou que esta ainda tenha cortado o próprio Taquaral, pois ocorre menos de 10 metros de espessura do membro basal da Formação Irati na estrada.

\section{Ponto B}

Fácies Taf (a): Arenito fino a muito fino, seleção granulométrica boa e coloração amarela esbranquiçada. A espessura desta camada é desconhecida, pois avança para dentro do córrego próximo. Caracteriza-se por estratificação cruzada simples e localmente, plano-paralela. A camada é aparentemente afossilífera e pelas características sedimentológicas pode ser correlacionada à fácies Taf (a) do Afloramento 1 e as que ocorrem em outros pontos.

Fácies Taf (b): é correlata à porção inferior da fácies basal do Ponto A e possui a mesma característica sedimentológica, porém não foram observados fósseis. Apesar da coloração bege este litossoma é similar em composição e estrutura à fácies Taf (b) do Afloramento 1.

\subsubsection{Afloramento 6: Rodovia do Açúcar, Km 150}

Corte de estrada em ambos os lados da pista (coordenadas UTM: 23K 235667 / 7473790). Boa parte do afloramento está alterada e coberto por grama alta, contudo foram caracterizadas duas camadas distintas (Figs. 21 e 22). 


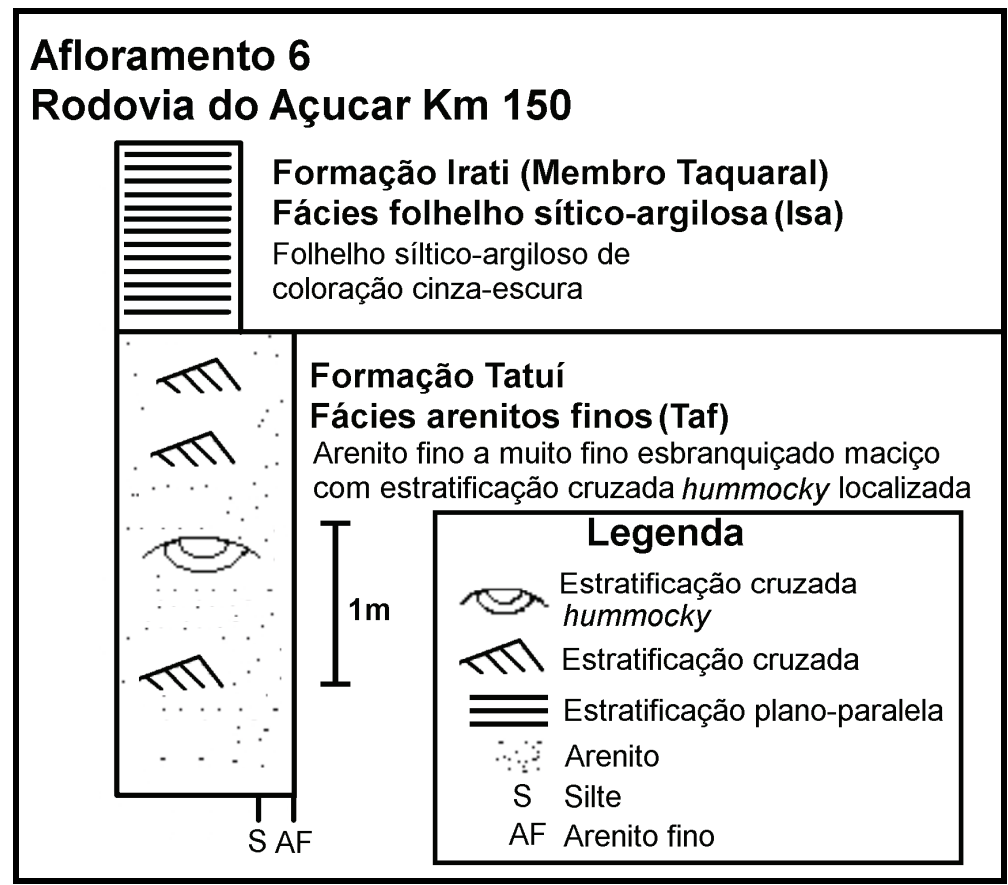

Figura 21 - Seção estratigráfica do Afloramento 6.

Fácies Taf: arenito fino a muito fino amarelo esbranquiçado, maciço, com porções pontuais apresentando estratificação cruzada "hummocky" (0,5 m de tamanho), A espessura total não supera dois metros e foi possível caracterizar nodulação incipiente.

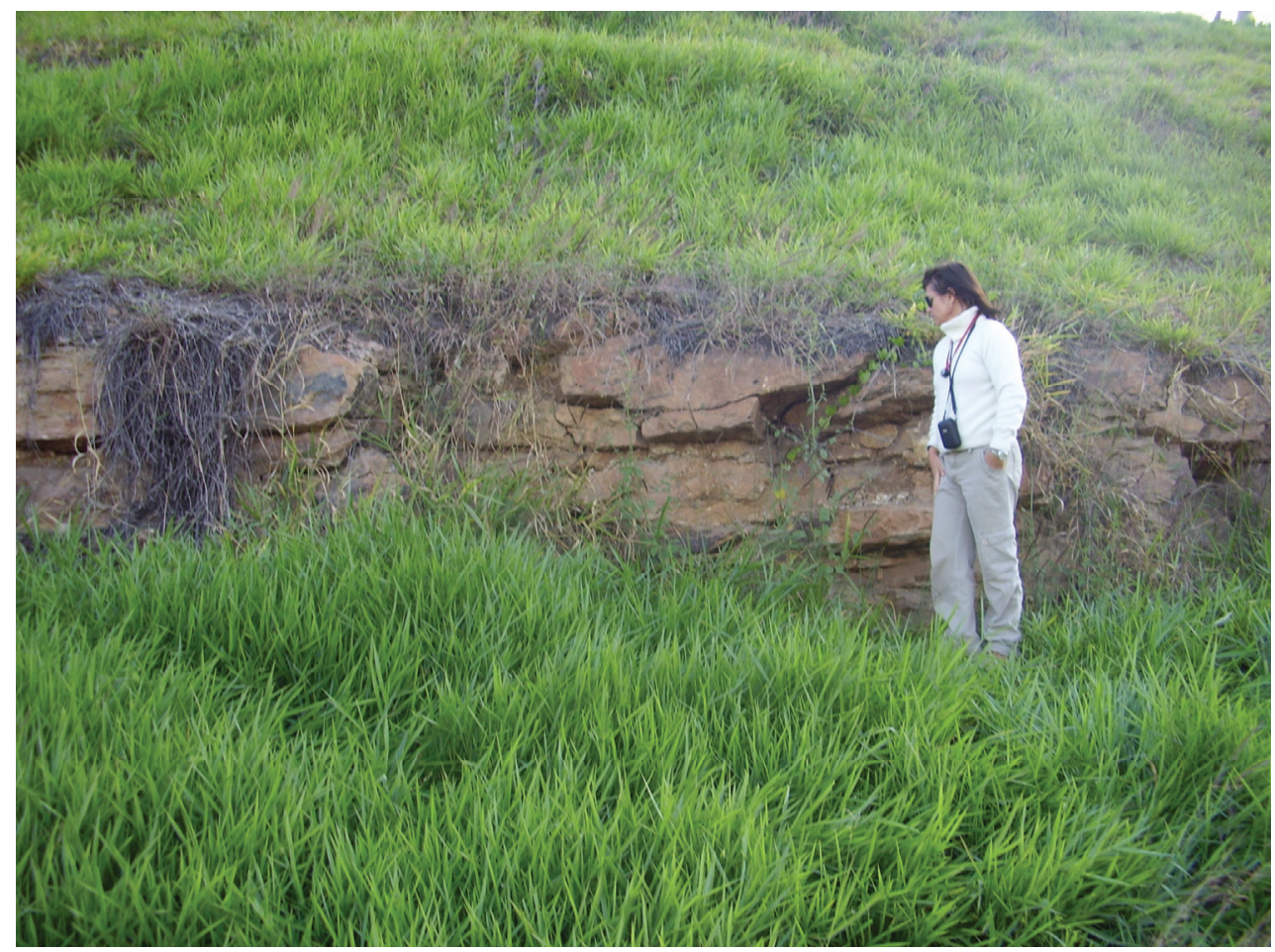

Figura 22 - Fácies basal arenosa da Formação Tatuí encontrada no Afloramento 6. Destaque para a fácies Taf. 
Fácies Isa: é a parte superior do afloramento, composto exclusivamente de um folhelho cinza síltico - argiloso muito alterado.

Este afloramento é conhecido na literatura, por estudos de STEVAUX et al. (1986), quando compararam quatro seções faciológicas pertencentes a Formação Tatuí.

Ele é aparentemente afossilífero nas duas camadas. Não foi encontrada a fácies Iai, base do Membro Taquaral referida em outros afloramentos (CHAHUD \& PETRI, 2010), por isso o objetivo para a sua inclusão é estratigráfico, para correlação com os da região de Rio Claro e demonstrar que não é em todos os lugares que existe a fácies Iai.

\subsubsection{Afloramento 7: Rodovia do Açúcar, Km 152,5}

Como o Afloramento 6, está localizado na Rodovia do Açúcar (Fig. 23-25), em corte de estrada em ambos os lados da pista, porém mais ao norte, com coordenadas UTM: 23K 235438 / 7475357. Este afloramento já era conhecido da literatura a partir de trabalhos sedimentológicos (STEVAUX et al. (1986); ASSINE et al. 2003).

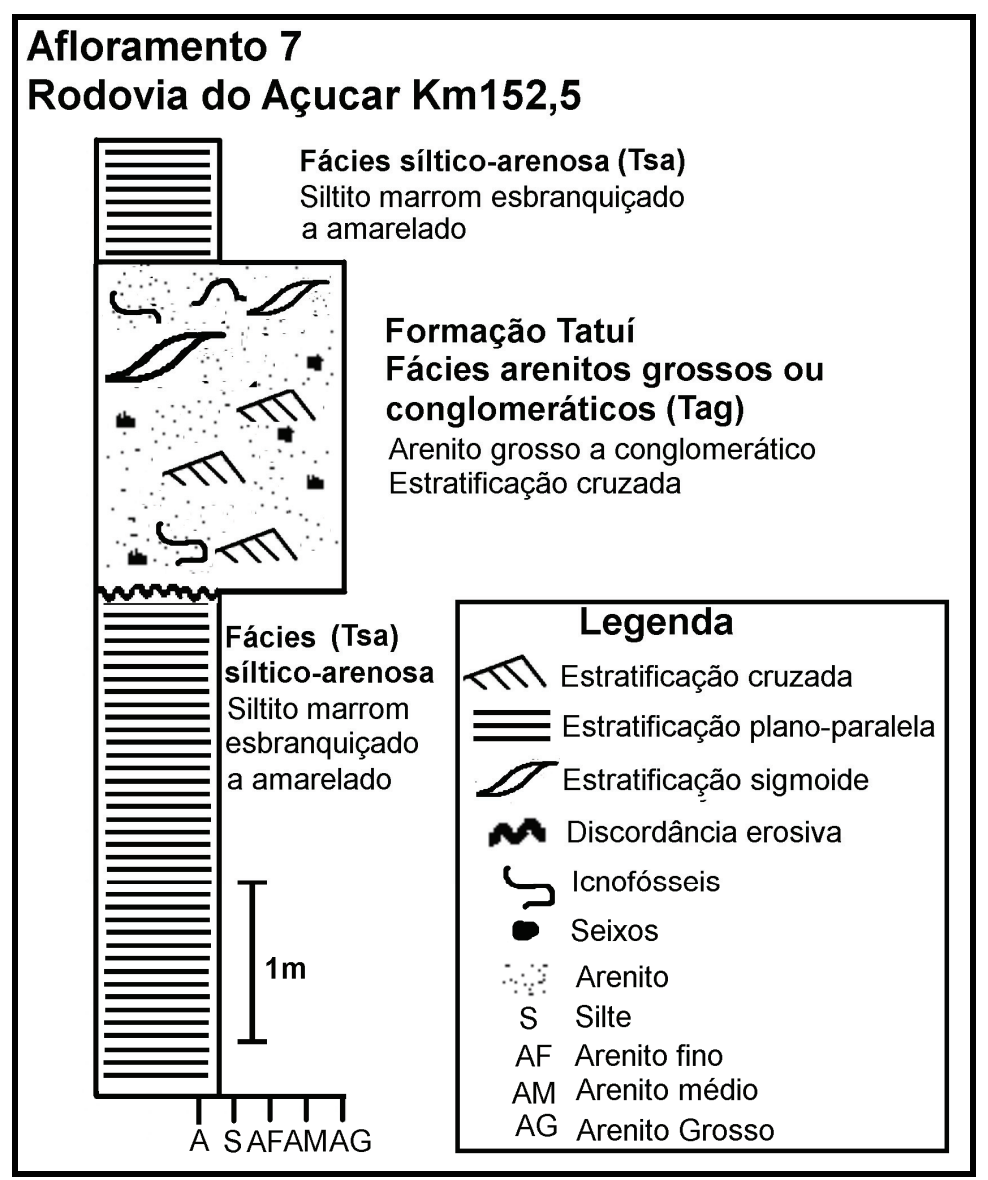

Figura 23 - Seção estratigráfica do Afloramento 7. 
Fácies Tsa (base e topo): dois pacotes espessos de siltitos de coloração esbranquiçada e amarronzada (Figs. 23 e 24), chegando a ficar amarela ou esverdeada, bastante alteradas. É a maior área exposta do afloramento, com cinco metros de espessura abaixo da fácies Tag e um pouco mais de 50 centímetros na parte acima da fácias arenitos grossos. Ela é fina com estratificação plano-paralela horizontal e contínua sem deformações por atividade tectônica.

Análises em campo e em laboratório não detectaram fósseis. Não foi observada matéria orgânica amorfa, razão porque ela foi considerada afossilífera.

$\mathrm{Na}$ parte basal é possível identificar delgadas camadas de arenito fino com pequenas laminações cruzadas e ondulações intercalando-se às camadas sílticas. No topo foram observados pequenos nódulos arredondados dentro da camada síltica, que neste ponto chega a ter granulometria argilosa subordinada.

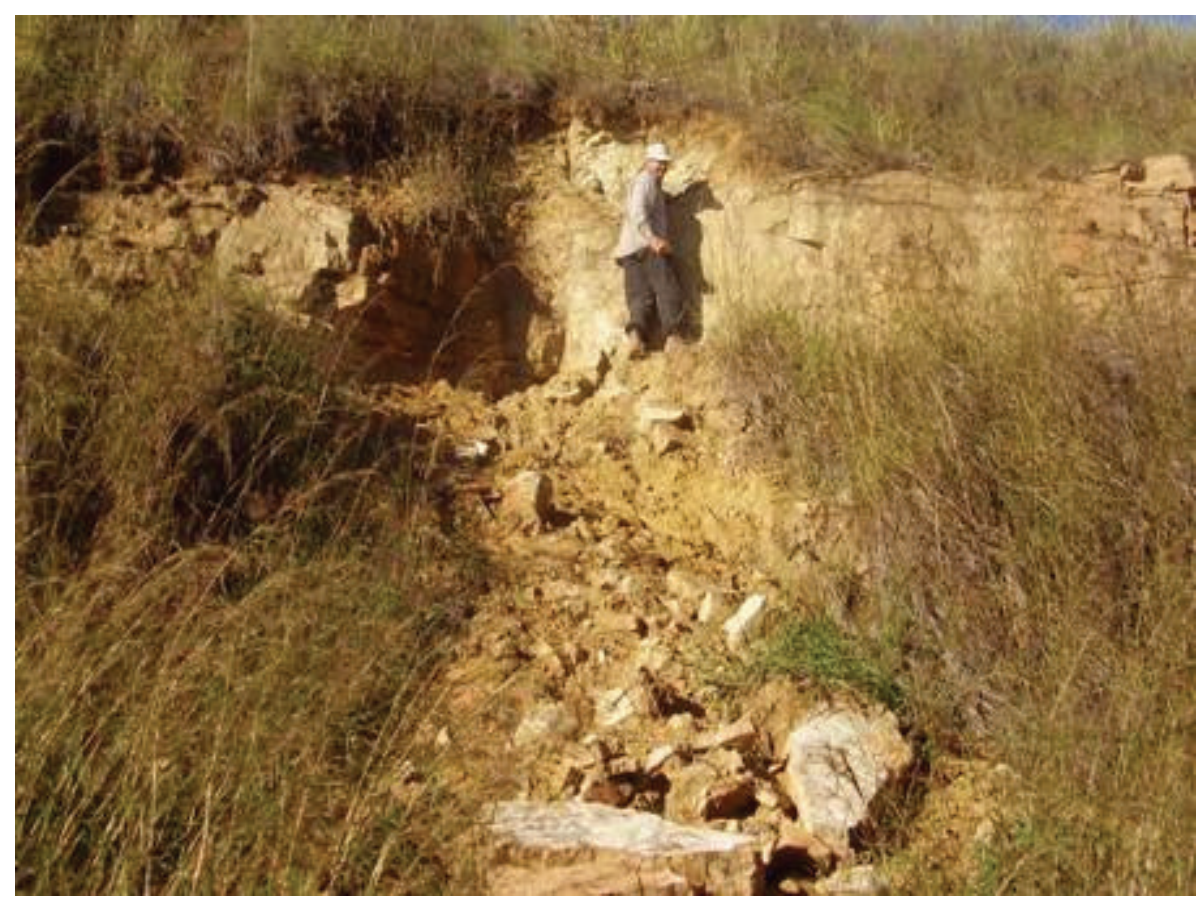

Figura 24 - Afloramento 7. Km 152,5 da Rodovia do Açúcar. Destaque para os blocos rolados pertencentes a Fácies arenosa na porção superior do afloramento.

Fácies Tag: um corpo arenoso tabular que intercala a camada síltica predominantemente no afloramento. Constituído principalmente de um arenito grosso com níveis conglomeráticos ou mal selecionados (Fig. 25). Os clastos angulosos normalmente são do tamanho de grânulos, com alguns seixos de quartzo, rochas escuras e feldspatos. Também são encontradas, no contato inferior da camada, fragmentos de rochas sílticas retiradas da camada inferior. 


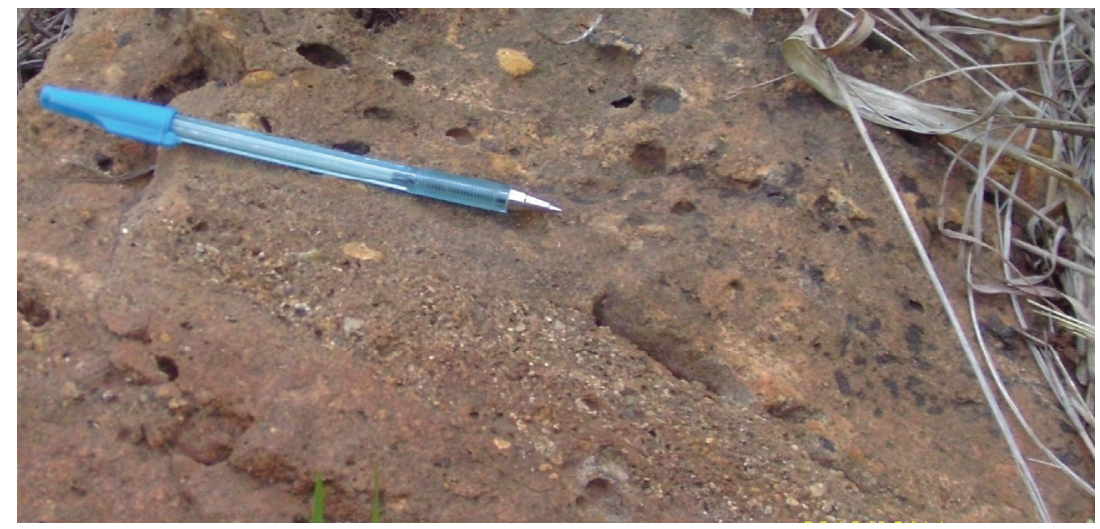

Figura 25 - Camada conglomerática encontrada intercalando camadas mais finas.

Estratificações cruzadas, de pequeno porte, são observadas em todo o corpo arenoso, sendo mais evidentes na base, em contato com a camada síltica. As estratificações cruzadas indicam rumos $\mathrm{N}$ para $\mathrm{S}$. No topo são observadas grandes estratificações sigmóides que modelam todo o pacote sedimentar.

Foram observados icnofósseis como pistas, desenvolvidas por algum tipo de invertebrado na porção superior e próxima da inferior da fácies arenosa. Não há orientação preferencial para as pistas (Fig. 26).

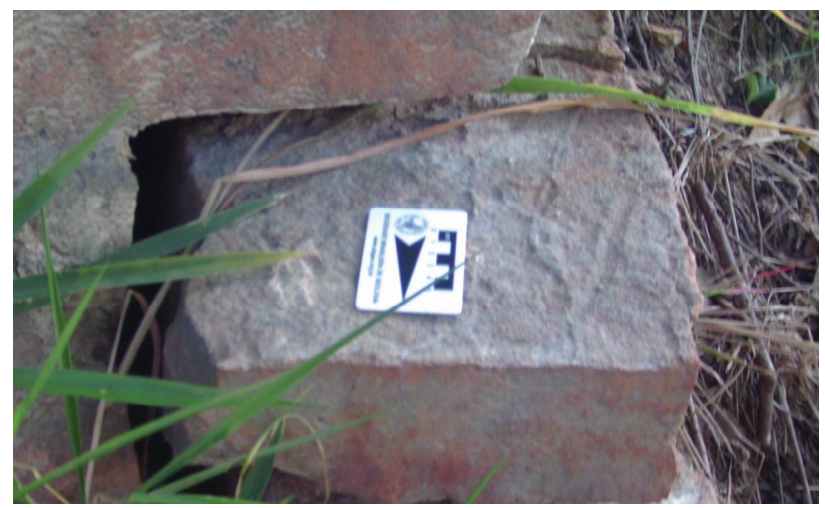

Figura 26- Icnofósseis observados próximos da base da fácies arenosa.

\subsubsection{Afloramento 8: Rodovia SP-304, Km, 151, entre Piracicaba e Santa Bárbara D'Oeste.}

Este afloramento está próximo dos Afloramentos 6, 7 e 11 e de litologias similares aos localizados na Rodovia do Açúcar e Córrego do Veado. Aparece em grande corte de estrada, UTM: 23K 238437 / 7484266. A alteração se acentuou nos últimos anos, porém foram observadas e confirmadas estruturas vistas nos anos anteriores e acrescentadas maiores informações a respeito (Fig. 27). Foram observadas duas facies: 
Fácies Tsa: Rocha síltica, de coloração esbranquiçada e amarronzada muito alterada. É a maior área exposta do afloramento, ocupando mais de cinco metros da pista da rodovia, até o contato com a camada sobrejacente.

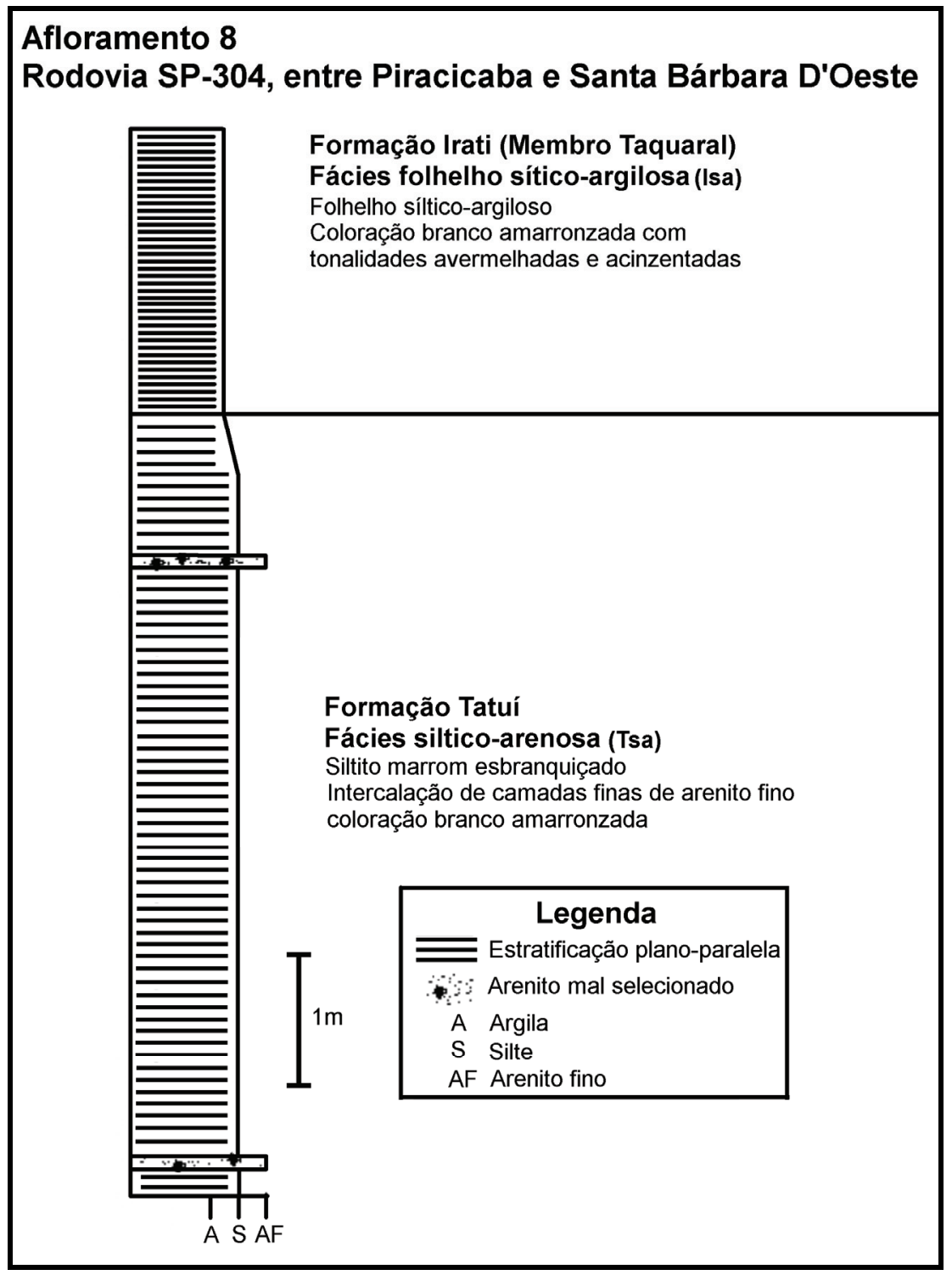

Figura 27 - Seção estratigráfica do Afloramento 8.

Caracterizada por fina estratificação plano-paralela horizontal e duas camadas irregulares de arenitos finos de coloração similar, de $5 \mathrm{~cm}$ de espessura, com seixos de sílex de tamanho centimétrico. Não foram observados fósseis.

ASSINE et al. (2003) interpretaram a camada síltica como típicas da Formação Tatuí, incluindo não só esta exposição, mas também uma sequência de afloramentos pela rodovia.

O contato com a camada sobrejacente sugerido por ASSINE et al (2003) é marcado por um depósito residual (primeira camada fina de material arenoso mal 
selecionado) não foi observado em campo no contato, mas aproximadamente 50 centimetros abaixo, dentro da Formação Tatuí. Aparentemente o contato é gradual e marcado por diminuição da granulometria de silte para argila.

A segunda camada arenosa foi observada no trabalho de campo realizado no ano de 2005 e está a mais de dois metros abaixo do contato com a unidade sobrejacente (Fig. 27).

Fácies Isa: observada quase no topo do afloramento constituí-se do folhelho síltico argiloso de coloração branco amarronzada com tonalidades avermelhadas escuras e porções cinzas.

Não é fácil a sua identificação por causa da alteração, mas possui características similares às observadas no Afloramento 6, identificado como folhelho do Membro Taquaral. A camada é aparentemente afossilífera, mas a ausência de fósseis foi causada pela alteração.

\subsubsection{Afloramento 9: Ibicatu}

O antigo afloramento Ibicatu estava localizado entre os municípios de Leme e Araras (fig. 29). Seu acesso era pela rodovia Elhiu Root, saída de Araras em direção a Leme, em coordenadas UTM: 23K 266711/7537355, $16 \mathrm{~km}$ do centro de Araras. O corte de estrada constituía a seção tipo da cunha clástica de Ibicatu, definida por SOARES (1972). O afloramento foi visitado e citado por FÚLFARO et al. (1984), STEVAUX et al. (1986), MOCHIZUKI (2001), ASSINE et al. (2003) e FERNANDES (2004), hoje ele está destruído (Fig. 29) com pedaços da cunha clástica e fragmentos fósseis espalhados pelo chão.

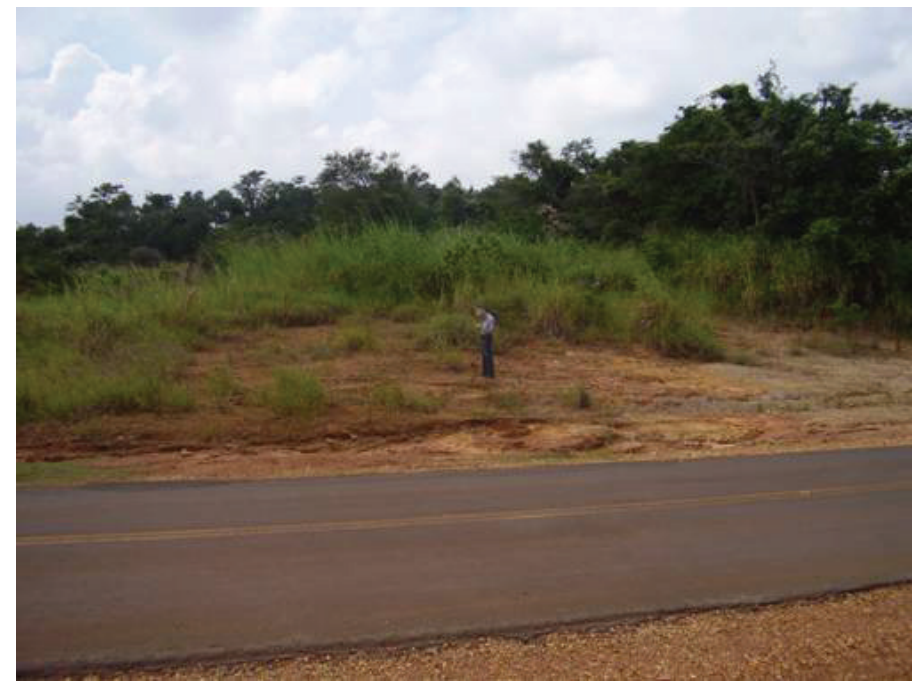

Figura 28- Estrada Elhiu Root onde estaria localizado o afloramento 9, seção tipo da cunha clástica de Ibicatu. 
Não foi possível detalhar a estratigrafia, porém foi possível diferenciar dois tipos de litologias. Através de um caminhamento pelo que restou do afloramento.

Fácies Tsa: constituída por uma camada suborizontal de siltitos com porções de arenito muito fino, seleção granulométrica boa e coloração amarela esbranquiçada. Aparece na área do afloramento estendendo-se pelo menos até $2 \mathrm{~km}$ para o norte, seguindo a estrada. A estratificação observada é predominantemente plano-paralela com trechos maciços. Diabásio aparece cortando a unidade em vários pontos.

Pelas características sedimentológicas esta fácies seria equivalente a fácies Tsa encontrada nos afloramentos 7, 8, 11 e 12 .

Fácies Tag: apesar de fragmentadas muitas informações foram obtidas. Em amostras coletadas foi possível observar que se trata de um conglomerado (clastos arredondados) variando para brechas (com clastos angulosos) de seixos de sílex de um a três centímetros de tamanho. Seixos de formas variáveis, arredondados, alongados e angulosos (Fig. 29) e na maior parte das amostras, os clastos são suportados pela matriz.

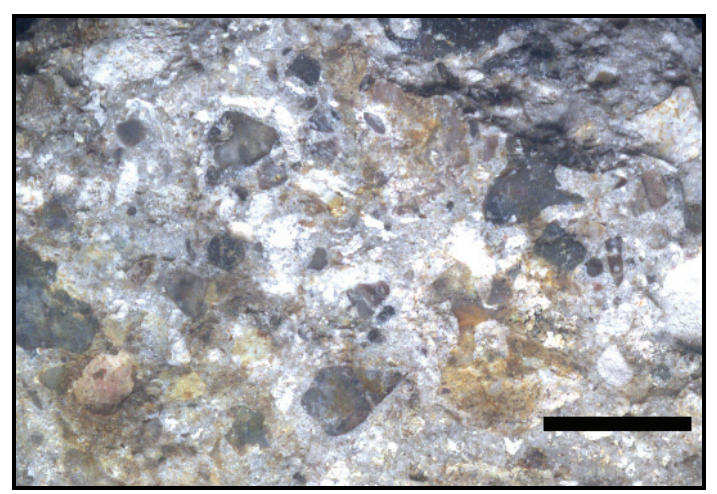

Figura 29 - Amostra da Fácies conglomerática. Escala 10mm.

Grande quantidade de fósseis, todos vegetais, alguns de grande porte, lenhos que alcançam quase um metro, caracteriza este afloramento

O contato com a unidade basal é erosiva. Em um ponto foi observado um grande tronco em contato com a unidade basal. Não foi possível medir ou observar claramente estruturas sedimentares, uma vez que apenas fragmentos da camada puderam ser analisados, mas foi possível caracterizar uma orientação de alguns clastos.

O grande lenho observado era quase perpendicular a estrada que tem direção NNW-SSE, caracterizando sentido E-W para o tronco. Outro tronco, muito desgastado, foi encontrado com o mesmo sentido. Apesar de ambos estarem in-situ tal dado é insuficiente para determinar a direção da corrente. Pesquisas anteriores revelaram que o sentido é para o S ou variável (STEVAUX et al. 1986; FERNANDES, 2004). 
Fácies Isa ?: não foi possível registrar, com segurança, a camada representativa do Membro Taquaral, observada por outros autores. Apenas foram vistas camadas finas síltico argilosas, róseas (Taquaral alterado) em pontos mais altos da estrada Elhiu Root que poderiam ser associadas a esta unidade.

\subsubsection{Afloramento 10: Rodovia Irineu Penteado}

Este afloramento está às margens do Rio Passa Cinco (Figs. 30 e 31) tendo sido observado dos dois lados de sua margem. Está localizado no município de Ipeúna, a menos de $3 \mathrm{~km}$ da cidade, abaixo de uma ponte que faz parte da Rodovia Irineu Penteado, em coordenadas UTM: 23K 222411/7516987. Foi estudado por MOCHIZUKI (2001) e não foi mais visitado nos anos seguintes, até esta pesquisa.

O afloramento se desenvolve parcialmente no chão e em corte, constituído por duas litologias distintas (Figs. 30):

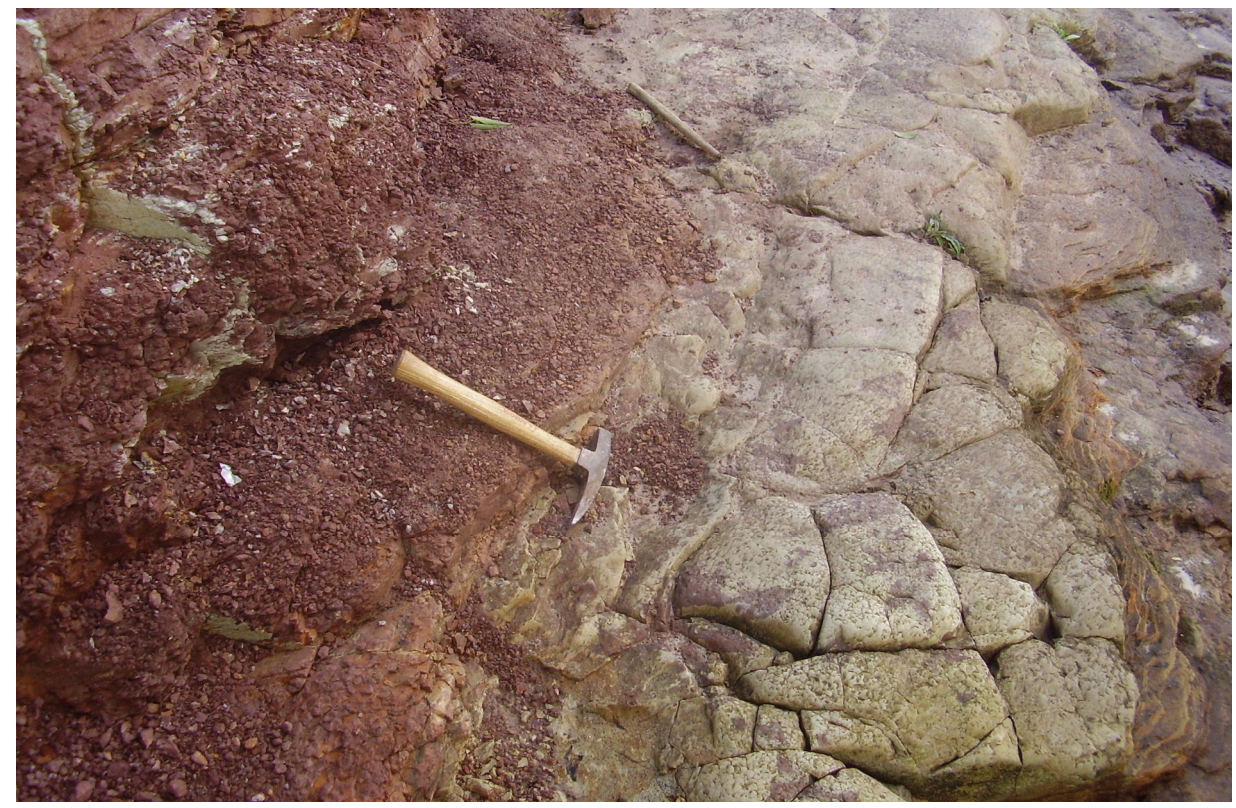

Figura 30 - Contato entre as unidades de topo e base do Afloramento da Rodovia Irineu Penteado. Martelo marca o contato. 


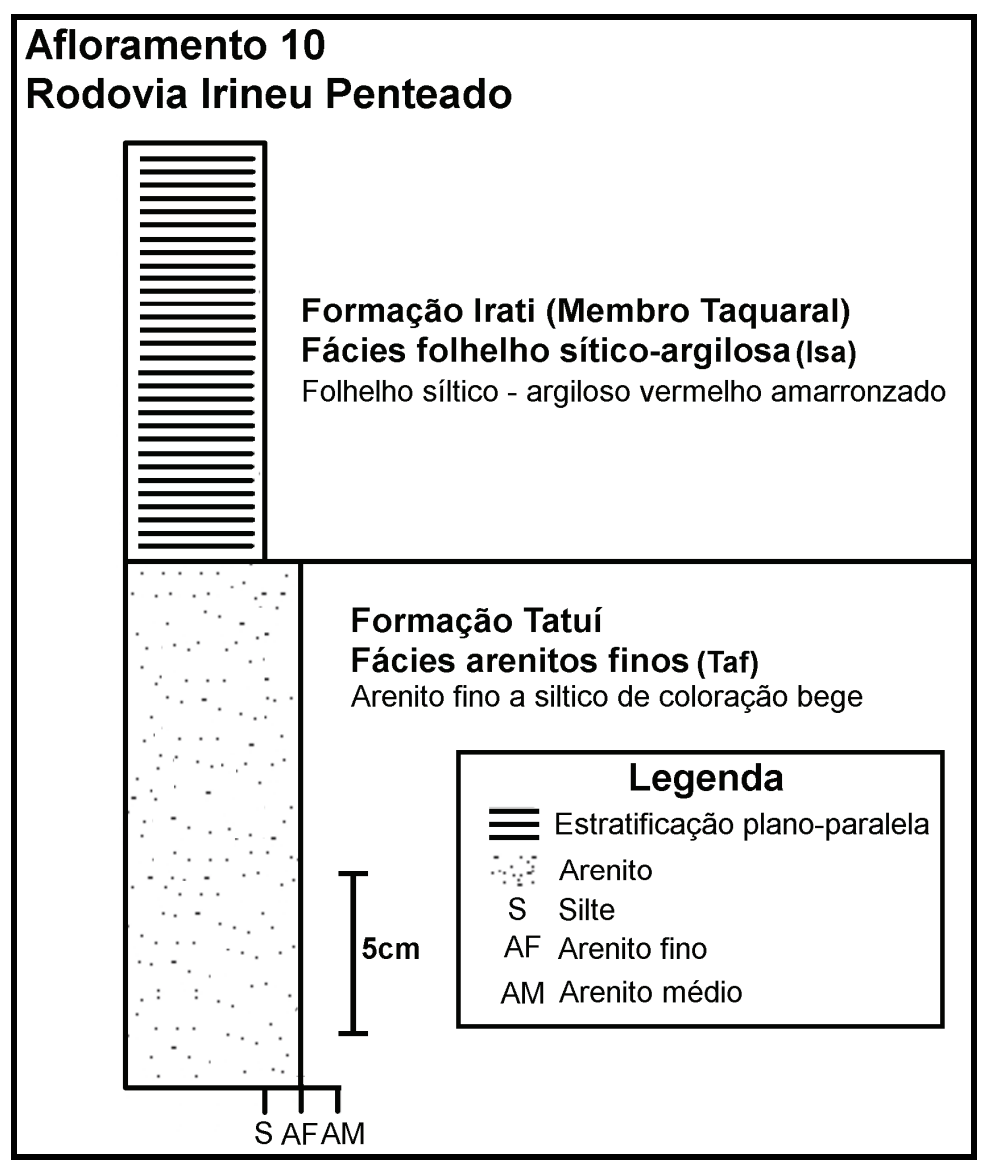

Figura 31 - Seção estratigráfica do Afloramento 10.

Fácies Taf: aflora no chão (Fig. 30), constituída por arenito fino a muito fino de coloração bege esbranquiçada e ótima seleção granulométrica. A camada é em, geral, maciça, com algumas áreas apresentando tênue laminação plana - paralela ou estratificação cruzada. Localmente a granulometria do arenito aumenta, porém esta variação é irregular e não ultrapassa a de um arenito fino.

Ocorrem vários níveis em que o arenito foi silicificado por atividade ígnea do Cretáceo, pois em partes do afloramento ocorrem blocos de diabásio que aparentemnete afetou a rocha e pode ter sido o causador da cor avermelhada da camada do topo.

Não foi observado fóssil, porém a camada é idêntica à observada no afloramento 5 , onde ocorrem escamas de peixes.

Fácies Isa: é caracterizada por folhelho síltico - argiloso de coloração avermelhada (figs. 30 e 31) com partes esbraquiçadas. Fósseis não foram observados, mas é possível associá-lo ao Membro Taquaral.

O corte, entre 1 e 2 metros de espessura, é formado por rocha síltico-argilosa, com laminação plano-paralela, às vezes incipiente, quando, então tem aspecto maciço. 
O contato com a fácies Taf é brusco passando imediatamente do silte para o arenito fino.

A camada é granulometricamente comparável a dos folhelhos sílticos do Membro Taquaral do Afloramento 5, porém é mais avermelhada, por intemperismo e aparentemente é afossilífera.

\subsubsection{Afloramento 11: Córrego do Veado}

O Afloramento do Córrego do Veado está localizado na Rodovia LimeiraIracemápolis (SP-151) na saída de Limeira, em coordenadas: 23K 0246657/7501835. Localiza-se na beira da estrada e às margens do córrego (Figs 32 - 34).

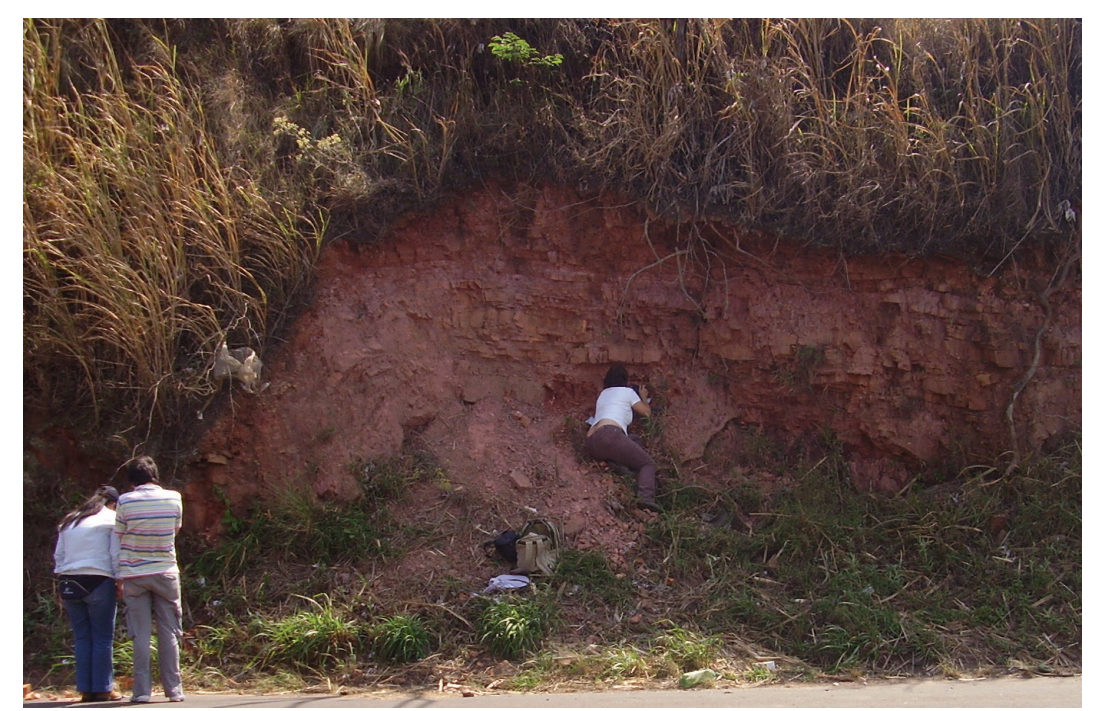

Figura 32 - Ponto A do afloramento 11, Córrego do Veado. Próximo da Rodovia entre Limeira e Iracemápolis.

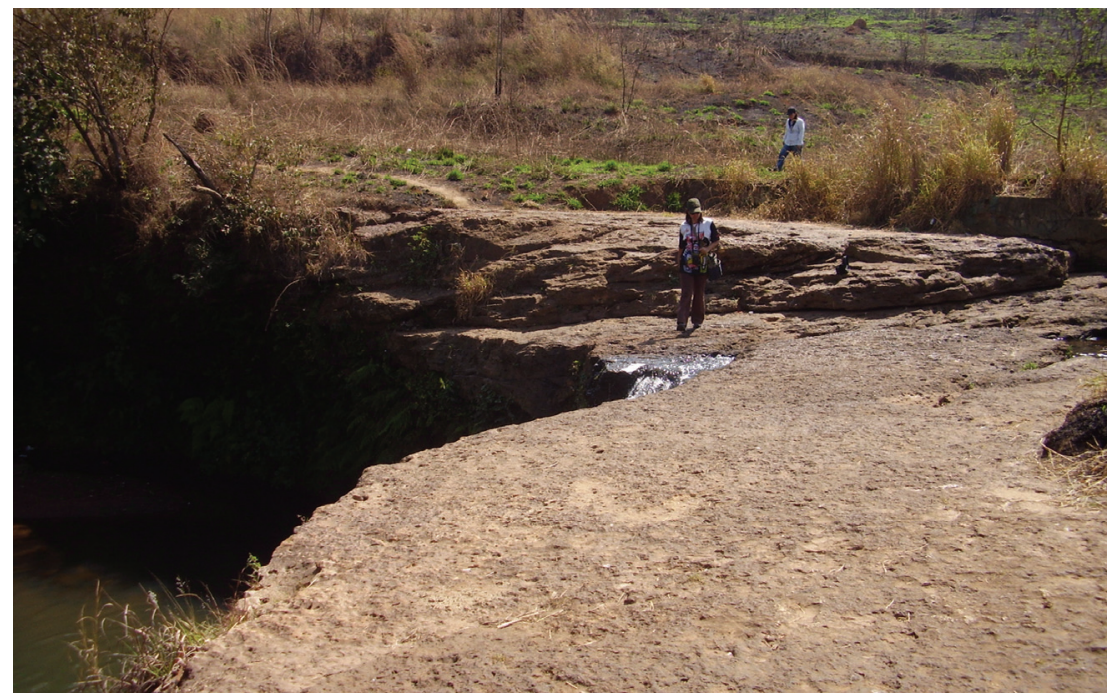

Figura 33 - Ponto B do afloramento 11. Córrego do Veado. 


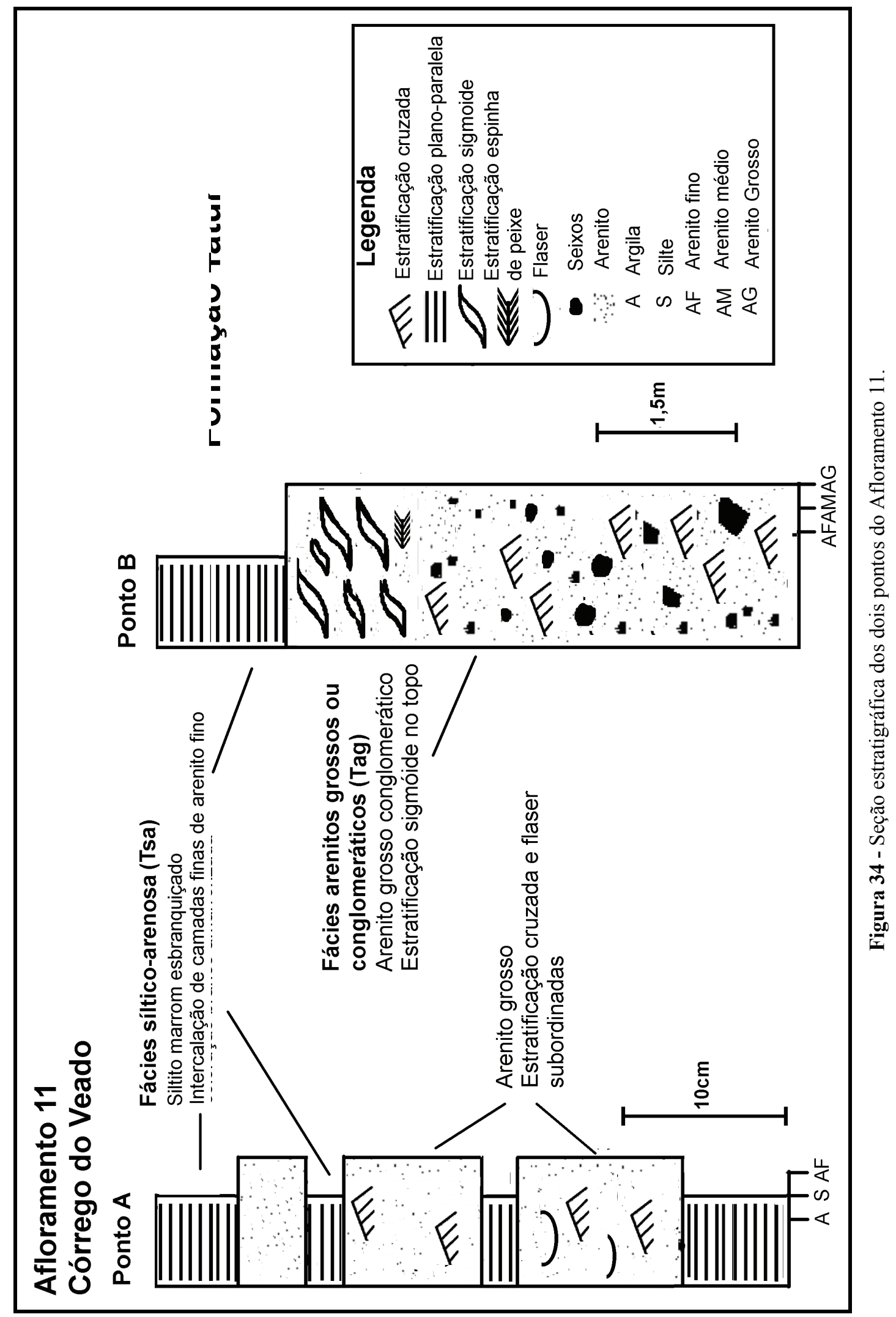


O afloramento é constituído predominantemente de rochas da Formação Tatuí dividida em quatro fácies. Está dividido em pontos A, do topo da unidade, representado por um corte de estrada e o ponto $\mathrm{B}$, localizado em uma pequena cachoeira às margens do córrego, onde afloram as rochas basais.

Segundo STEVAUX et al. (1986), MOCHIZUKI (2001) e ASSINE et al. (2003) ocorrem, no topo, rochas do Membro Taquaral, porém tais rochas não foram estudadas, dando ênfase as fácies da Formação Tatuí. Ao contrário do que foi citado por ASSINE et al. (2003), não foi observada a fácies basal arenosa do Membro Taquaral.

Fácies Tag: Observado apenas no Ponto B, é um grande corpo arenoso de aproximadamente $5 \mathrm{~m}$ de espessura. Constituído de arenito grosso mal selecionado a conglomerático. Os clastos em geral variam de 1 a $5 \mathrm{~cm}$, porém com alguns maiores, predominantemente arredondados (fig. 35) com alguns angulosos.

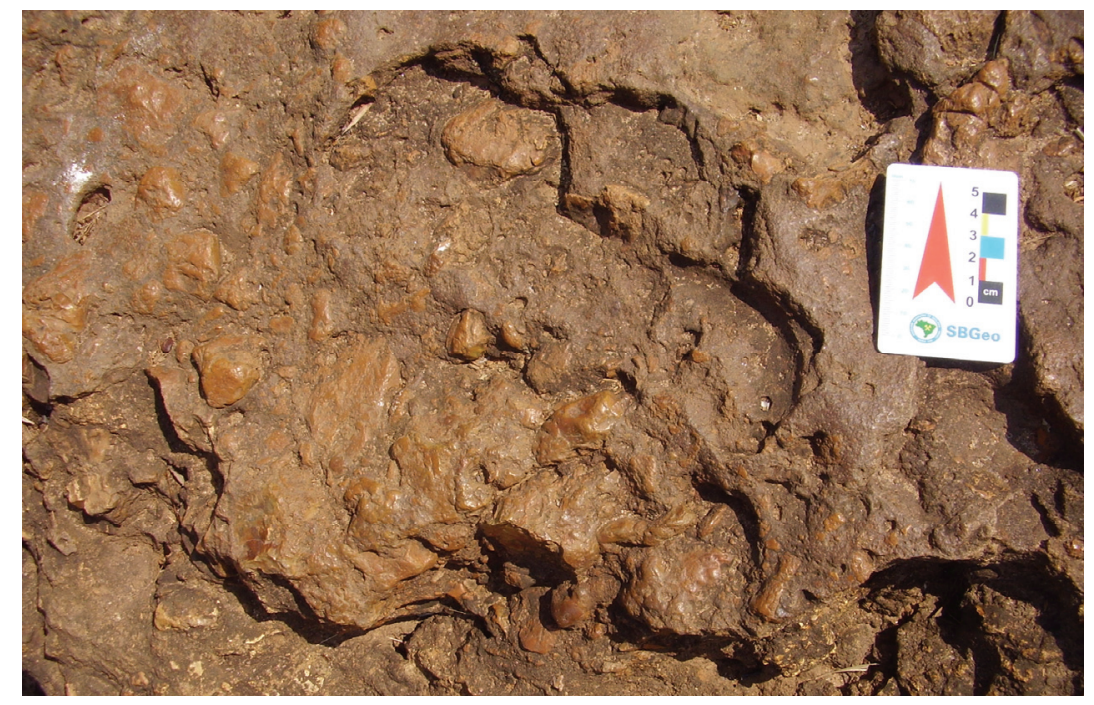

Figura 35 - Conglomerado silexítico do Ponto B.

No topo foram observadas estratificações cruzadas sigmóides e, subordinadamente, estratificação espinha de peixe. Sua espessura não ultrapassa $1 \mathrm{~m}$ (fig.36).

Abaixo desta fácies, uma rocha mais fina, foi observada porém não foi possível estudá-la pelo estado do afloramento e dificuldade de acesso.

No Ponto A a fácies é composta de camadas de arenitos finos a médios, silicificados, maciços ou com estratificação cruzada subordinada e estratificação “flaser" em camadas maiores. 


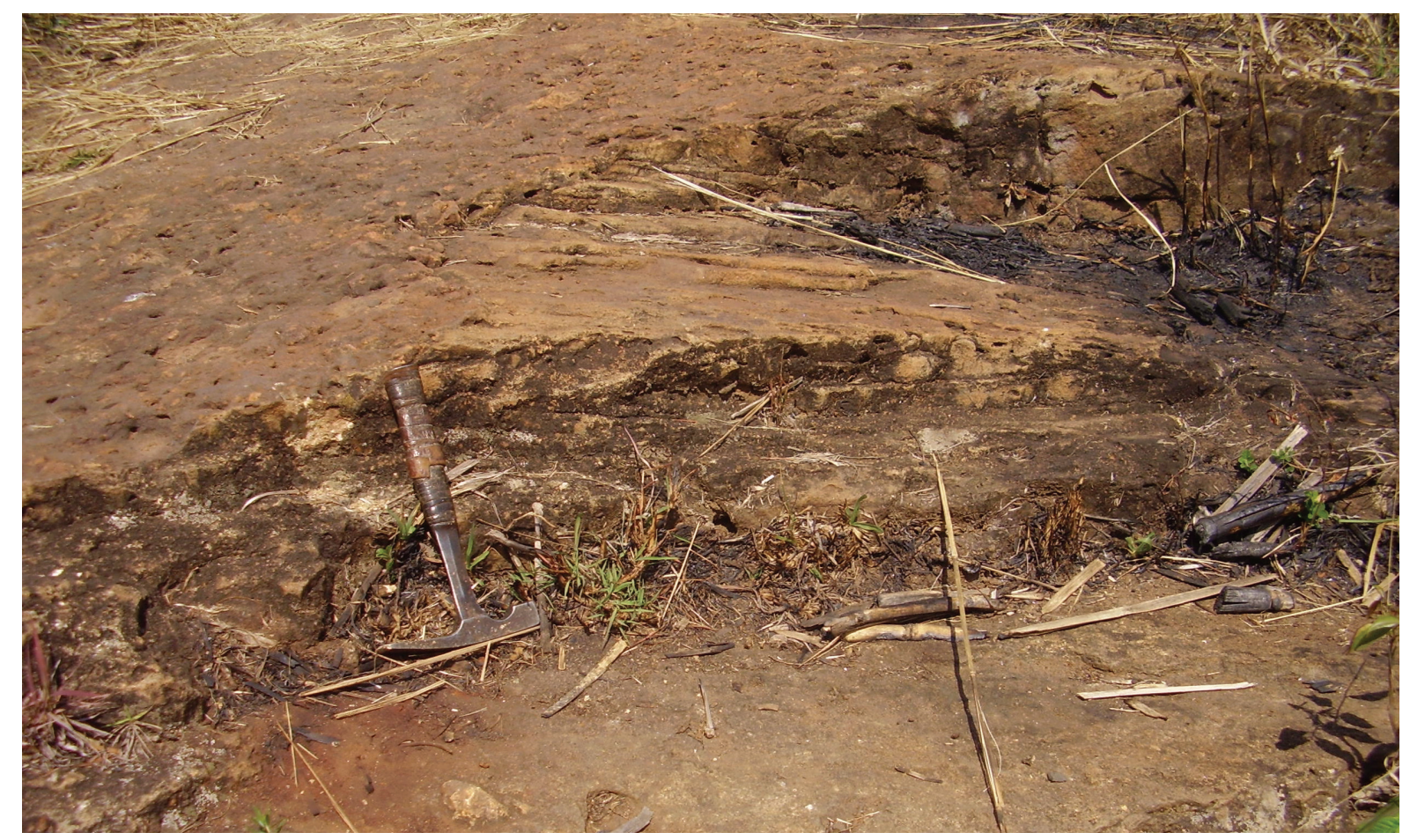

Figura 36 - Estratificações cruzadas sigmoides e estratificação espinha de peixe no Ponto B. Ponto também ilustrado por STEVAUX et al. (1986) e MOCHIZUKI (2001)

Estas camadas ocorrem como intercalações dentro da fácies síltica-arenosa no Ponto A e sua espessura gradualmente diminui nas camadas superiores. A maior observada tinha $10 \mathrm{~cm}$ de espessura e localizava-se acima de um grande pacote sílticoarenoso.

Fácies Tsa: Caracterizada por uma rocha síltica, de coloração marrom esbranquiçada e pontualmente amarelada, com intercalações de camadas de arenito muito fino. Esta fácies é a predominante no Ponto A e ocorre acima da fácies Tag no ponto B.

Caracteriza-se por uma fina laminação plano-paralela horizontal e algumas ondulações nas camadas mais arenosas. Não foram observados fósseis.

\subsubsection{Afloramento 12: Fazenda Ponte Nova}

A Fazenda Ponte Nova (UTM: 23K 0224255/7516138) apresenta uma sucessão de três afloramentos, pontos A-C. Os pontos (Figs. 37-40) estão muito próximos entre si, entre A e B é de $120 \mathrm{~m}$ e a de B e C, $87 \mathrm{~m}$ com uma variação topográfica de, no máximo, $4 \mathrm{~m}$ entre os pontos A (Fig. 38) e C (Fig. 39).

A Formação Tatuí e a unidade predominante nos três pontos, com quatro fácies distintas. No ponto $\mathrm{C}$ aparecem rochas da Formação Irati, representada por rochas do Membro Taquaral, compostas de duas fácies, arenosa e folhelho síltica (Fig.40). 


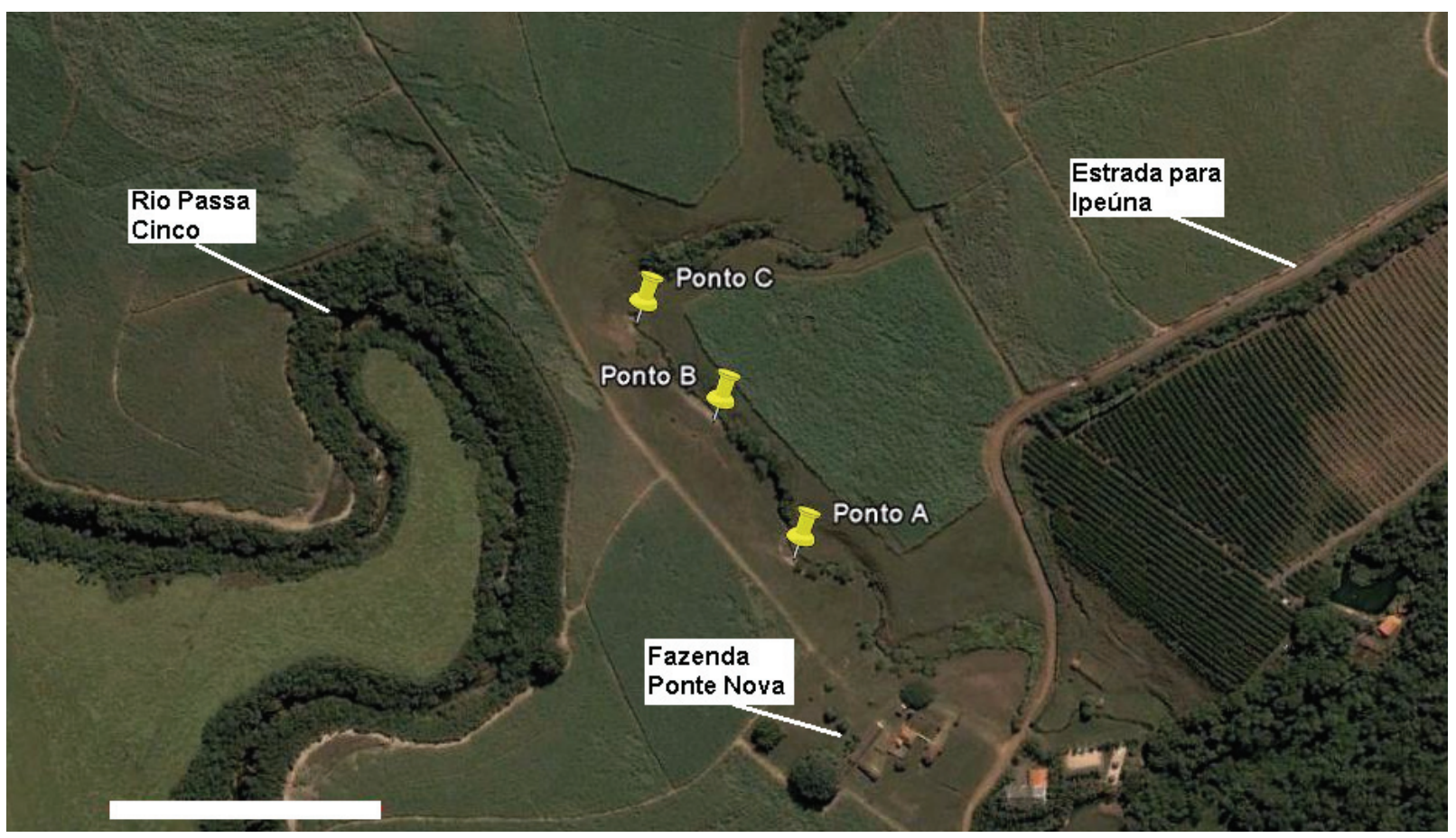

Figura 37 - Pontos A, B e C do Afloramento 12. Escala 200m. Fonte Google Earth 2005.

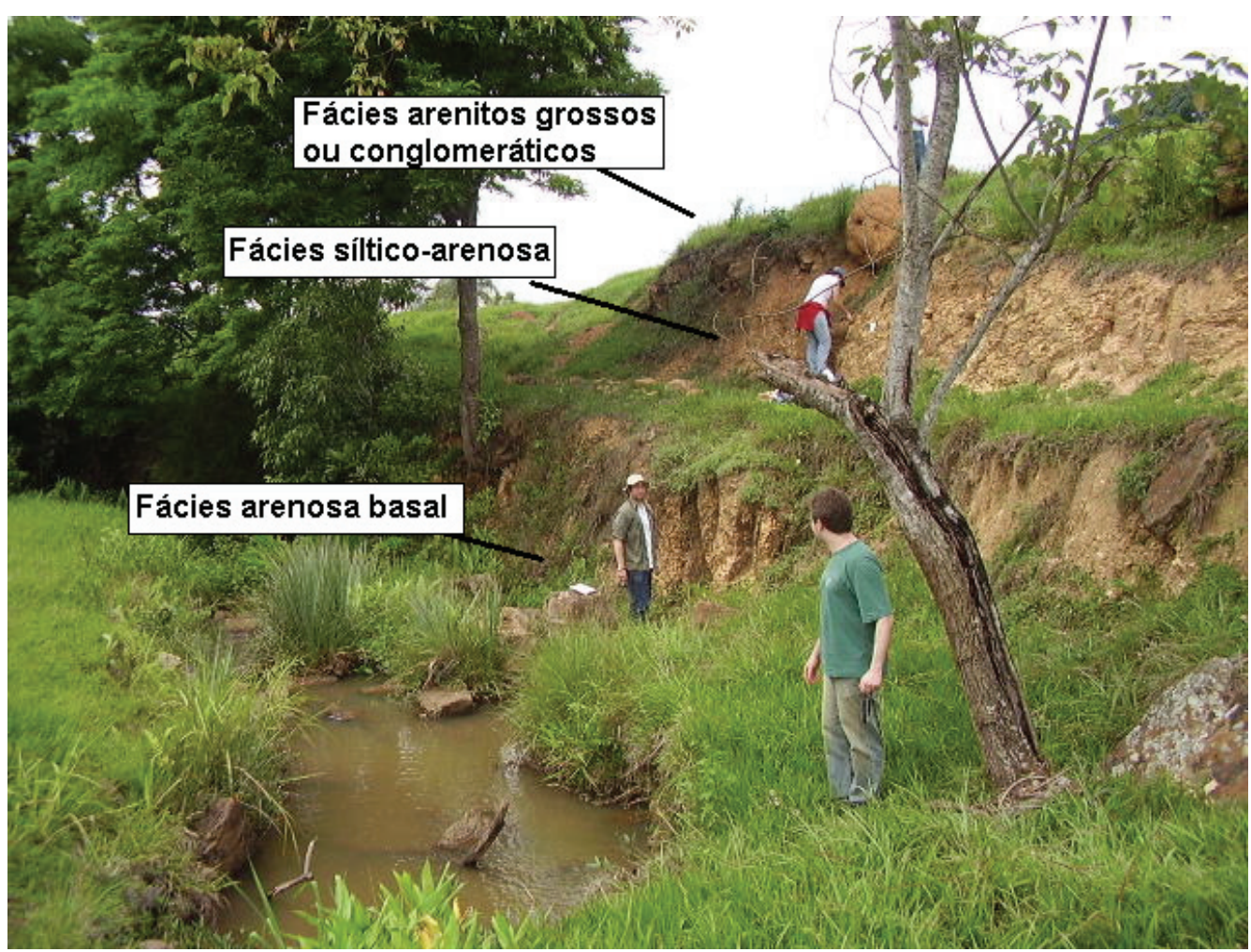

Figura 38 - Ponto A do Afloramento da Fazenda Ponte Nova. 
$\stackrel{\infty}{\sim}$

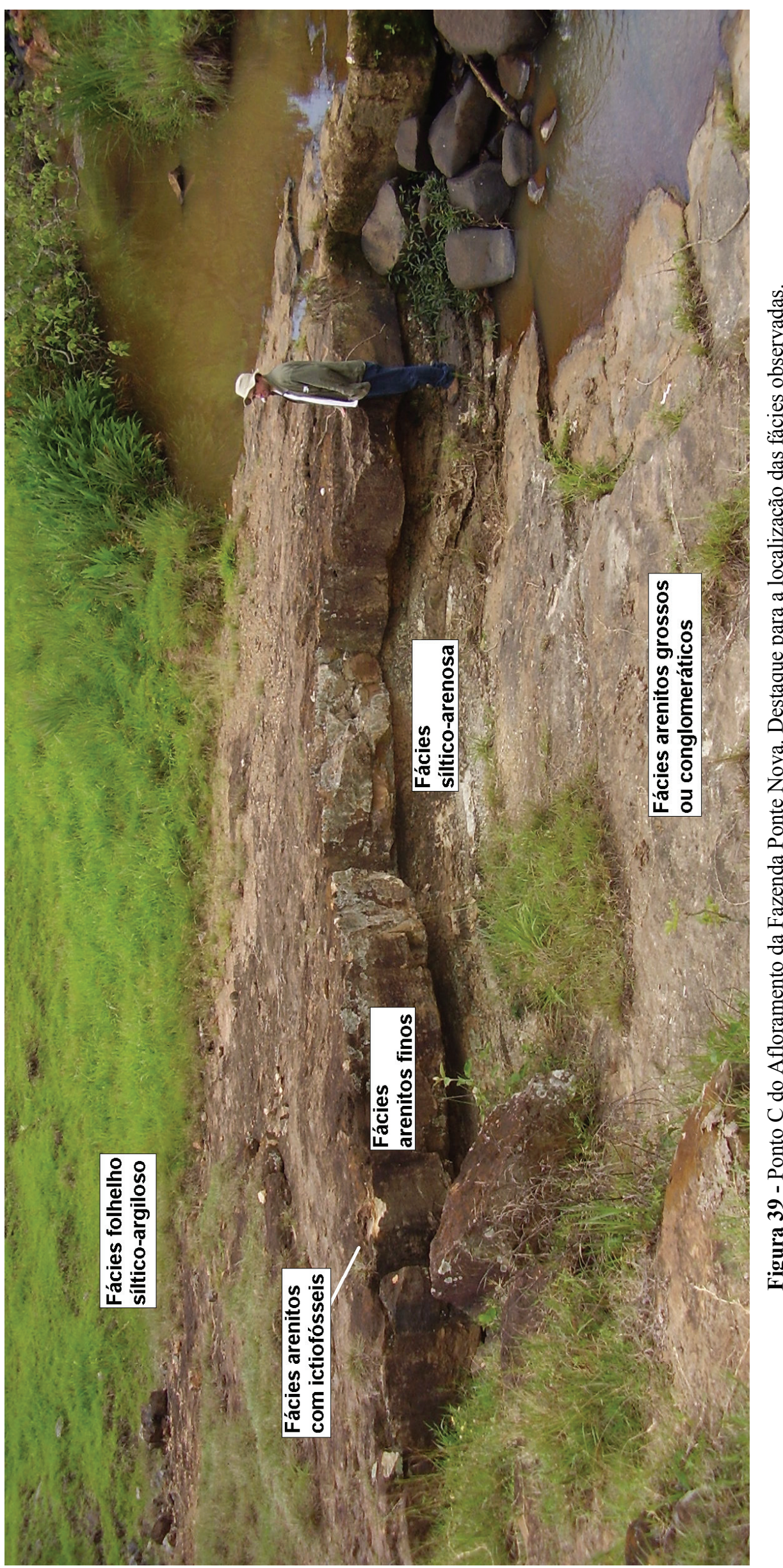




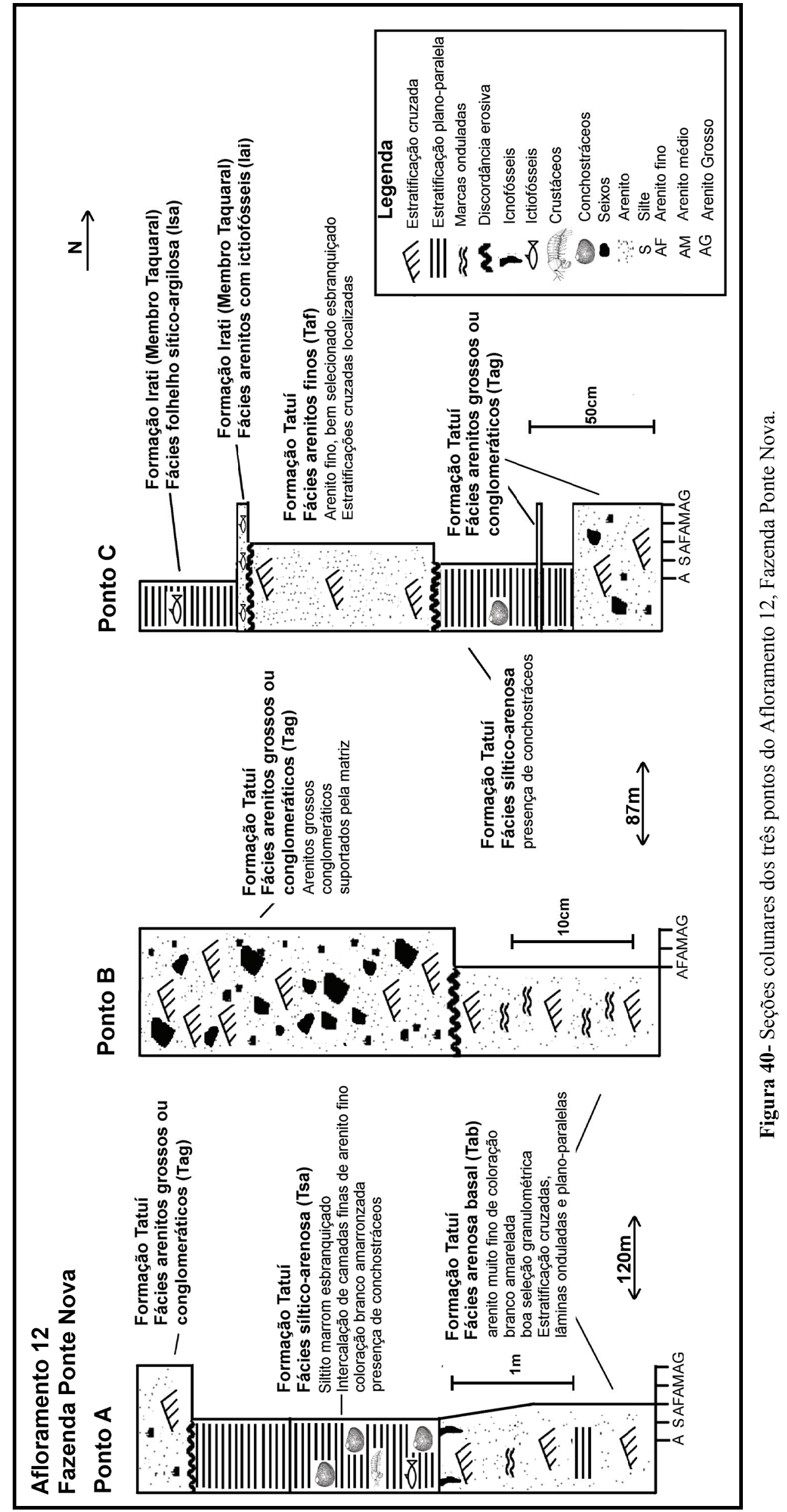


Fácies Tab: caracterizada por uma camada de arenito muito fino, de coloração branco amarelada (Fig. 41), com boa seleção granulométrica. A espessura exposta ultrapassa $2 \mathrm{~m}$, sendo que $1,75 \mathrm{~m}$ aflora acima de um córrego. $\mathrm{O}$ termo basal refere-se ao afloramento e não a base da Formação Tatuí.

Caracteriza-se por estratificações cruzadas tabulares e tangenciais, localmente intercalada por laminações plano-paralelas ou ligeiramente onduladas, principalmente próximas ao topo. No topo foram encontrados icnofósseis tubulares simples, sem ramificações.

No ponto A, o contato com a fácies Tsa é gradual, por diminuição de granulometria para síltico. No ponto B falta a fácies Tsa e o contato entre a fácies Tab e a fácies Tag é brusco.

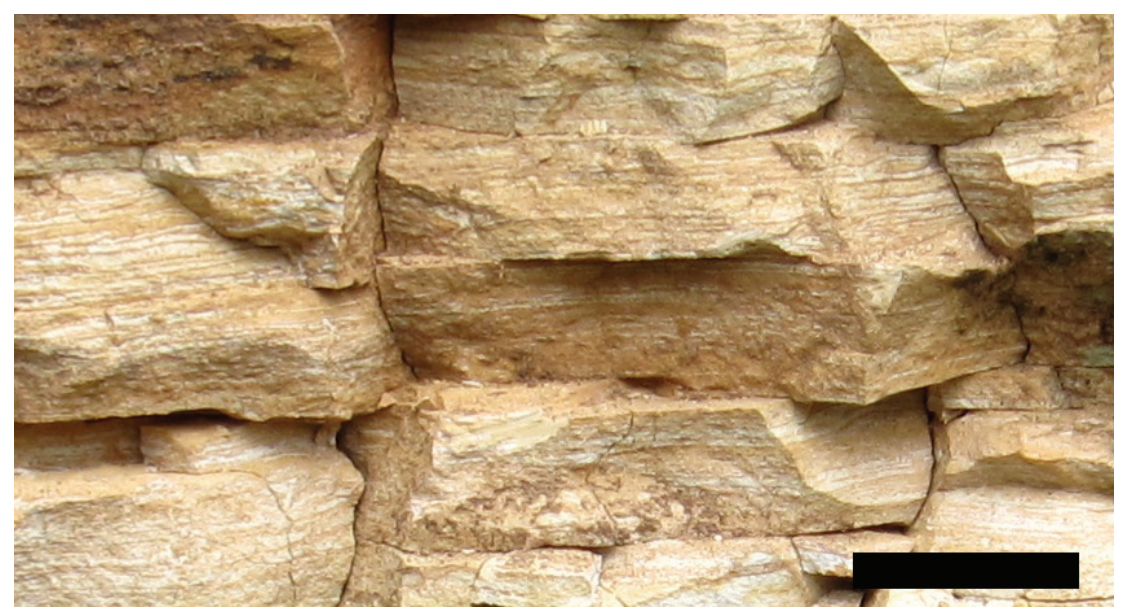

Figura 41 - Estratificação da camada basal do Ponto A, Afloramento 12. Escala 4cm.

Fácies Tsa: esta fácies é composta basicamente de síltitos de coloração brancoamarelada, com algumas porções mais arenosas(Fig. 42). A espessura no Ponto A é próxima de $2 \mathrm{~m}$, sendo que a $1,21 \mathrm{~m}$ ocorrem intercalações de camadas abundantemente fossilíferas.

Os fósseis mais comuns são conchostráceos formando "coquinas", além de fragmentos de artrópodes (prováveis crustáceos) e raros ictiofósseis.

Apesar da quantidade de vegetação atual ao redor do afloramento, foi possível caracterizar contato brusco de diastema entre a fácies siltico-arenosa e a fácies Tag.

No Ponto C esta fácies ocorre acima da fácies Tag, com um microconglomerado de dois centímetros de espessura, esbranquiçado e com poucos seixos escuros, próximo da base. Este microconglomerado exibe as mesmas características sedimentológicas do conglomerado da fácies conglomerática, podendo ser considerado como fácies recorrente (Fig. 43). 


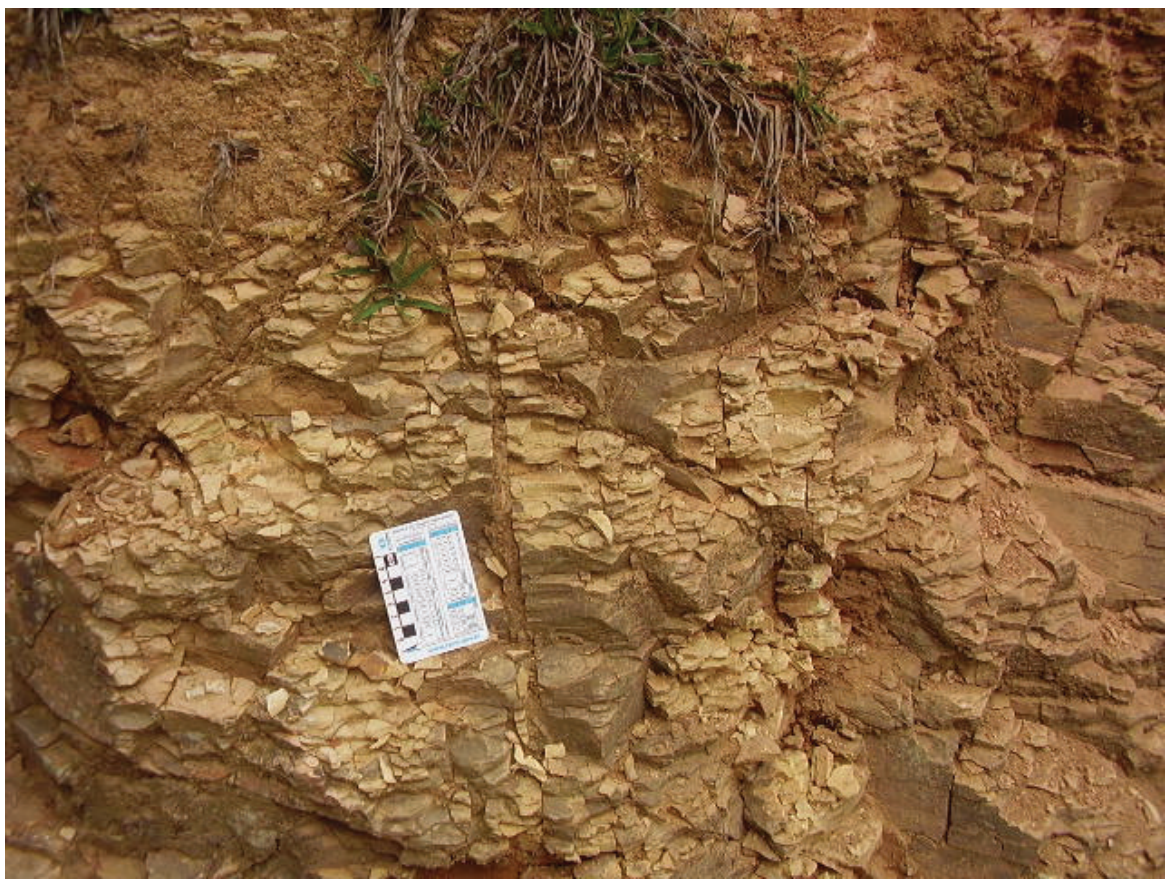

Figura 42 - Detalhe da fácies Tsa observada no Ponto A.

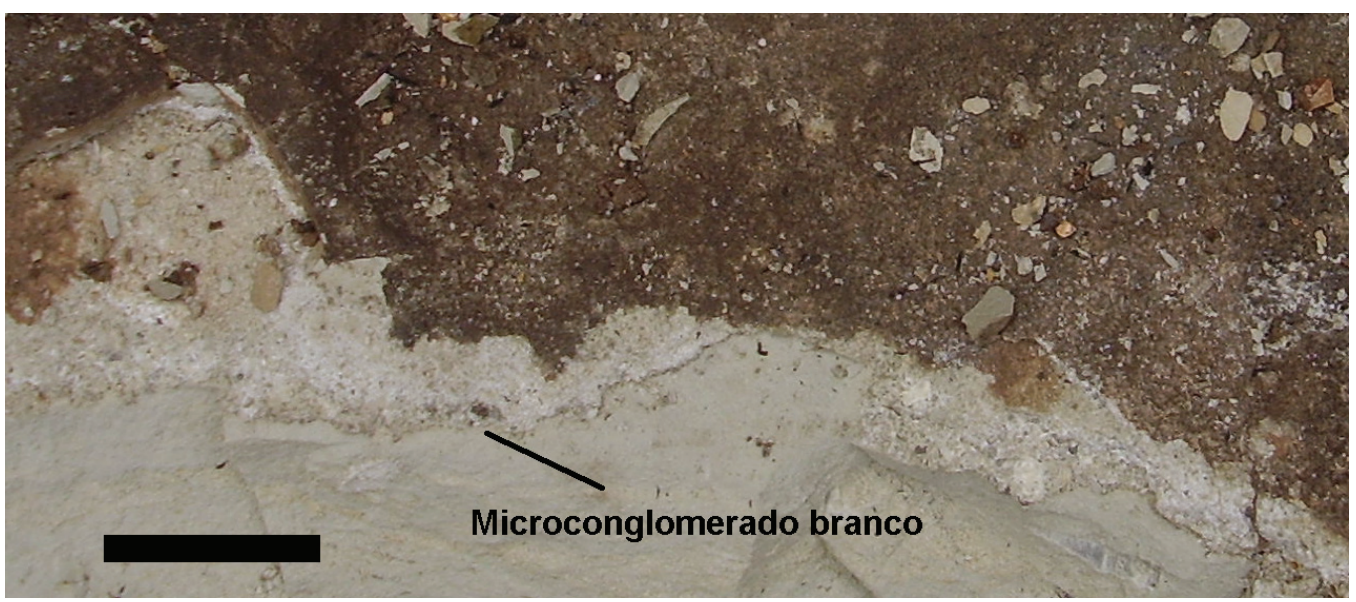

Figura 43 - Área de exposição do microconglomerado visto em planta dentro da camada 2. Escala $2 \mathrm{~cm}$.

A espessura total da fácies Tsa do Ponto C é de $56 \mathrm{~cm}$ (até a pequena fácies conglomerática são $15 \mathrm{~cm})$. Conchostráceos foram observados, porém não foi possível localizar com exatidão onde estava a camada com os fósseis

No Ponto $\mathrm{C}$ o contato com a fácies conglomerática, é brusco e com a sobrejacente, fácies Taf, ocorre discordância erosiva.

Fácies Tag: corpo arenoso de grande porte, chegando a quase $1,5 \mathrm{~m}$ de espessura, constituída de arenito grosso mal selecionado a conglomerático. Neste ponto os clastos são predominantemente arredondados com alguns angulosos. Sua granulometria não ultrapassa a de seixos.

No Ponto $\mathrm{B}$, as estratificações cruzadas de vários centímetros de espessura, podem ser observadas a distancia. Neste ponto, a camada, com aproximadamente três 
metros de espessura, tem características de um conglomerado com clastos de sílex suportados pela matriz, de tamanhos que variam de um a, aproximadamente, 10 centímetros. Os clastos são, normalmente, arredondados, alguns alongados e, ocasionalmente, angulosos.

Não foi possível observar claramente rumos preferenciais das estruturas observadas, não só por causa do intemperismo, mas também pela presença de blocos removidos por processos atuais.

Fácies Taf: Está fácies, verificada apenas no Ponto C, caracteriza-se por arenito fino, bem selecionado e de coloração esbranquiçada onde não foi alterado. Estratificações cruzadas foram observadas, mas predomina esrutura maciça.

Aparentemente representa um corpo tabular levemente inclinada (3-5 graus de mergulho), provavelmente por eventos tectônicos que afetaram a região, posteriores à sua deposição. Sua espessura é de aproximadamente $60 \mathrm{~cm}$. Não foram evidenciados fósseis.

Fácies Iai: Esta fácies, observada apenas no Ponto C, representa a base arenosa do Membro Taquaral (CHAHUD \& PETRI, 2008a; 2008b; 2010) com espessura média de $12 \mathrm{~cm}$. Na Fazenda Ponte Nova, a fácies é constituída por arenito conglomerático, com clastos variando de 1 a $10 \mathrm{~cm}$ de comprimento, intercalações de camadas argilosas acinzentadas e algumas lentes de arenitos grossos bem selecionados. Contém dentes e escamas de peixes em abundância, semelhantes aos observados por CHAHUD \& PETRI (2008a; 2008b; 2010) e CHAHUD et al. (2010), além de pirita disseminada

O contato com a fácies subjacente é marcado por uma discordância erosiva.

Fácies Isa: Camada síltica-argilosa do Membro Taquaral, sempre constituída de um pacote homogêneo, de rocha síltico - argilosa cinza-escura, quando fresca. É a maior área exposta do afloramento, com mais de $8 \mathrm{~m}$ de espessura. Laminação planoparalela horizontal e contínua (folhelho) sem deformações por atividade tectônica.

Boa parte da fácies esta encoberta pela vegetação estando presente só em alguns pequenos afloramentos. O topo está em contato brusco com o diabásio do magmatismo Serra Geral.

\subsection{Discussão litoestratigráfica dos afloramentos}

Seis fácies foram observadas nos afloramentos estudados, quatro da Formação Tatuí e duas pertencentes ao Membro Taquaral da Formação Irati. 
Das fácies pertencentes à Formação Tatuí, apenas a fácies Tab do Afloramento 12 não possui equivalente em outros pontos. A fácies é sugestiva da fácies superior da porção basal da Formação Tatuí, definida por SOARES (1972), que separou a Formação Tatuí em pacote inferior e superior. Em outras localidades a fácies é formada por arenitos, normalmente muito finos ou sílticos, com estratificação plano-paralela.

ASSINE et al. (2003) observaram essa fácies em municípios próximos do Domo do Pitanga, e a consideraram como constituinte das camadas basais da Formação Tatuí, antes do evento Ibicatu, proposto por SOARES (1972). Estes autores perceberam a mesma situação deposicional, agora observada na Fazenda Ponte Nova, em contato direto com os depósitos grossos da fácies Tag ou com a fácies Tsa.

A fácies siltico-arenosa é a predominante na Formação Tatuí e pode fazer contato direto com a Formação Irati, como observado no afloramento 8, porém esta relacionada com a fácies Tag Esta fácies pode ocorrer acima, abaixo ou como intercalações mais grossas dentro da fácies siltico-arenosa.

A fácies Tag está relacionada às camadas Ibicatu de SOARES (1972), baseada na composição sedimentológica. São constituintes de corpos arenosos ou conglomeráticos de grande importância como datum estratigráfico da Formação Tatuí no Estado de São Paulo.

Esta fácies pode ocorrer a poucos metros abaixo do contato com a Formação Irati, como observado no afloramento 12, logo abaixo de depósitos areníticos da Formação Tatuí ou mesmo com a camada síltica da Formação Tatuí como vista nos afloramentos 7, 11 e 12 e em municípios próximos de Rio Claro e Ipeúna (ASSINE et al. 2003), mas em alguns locais o contato com a Formação Irati é direto como no afloramento 9, seção tipo de Ibicatu, segundo STEVAUX et al. (1986).

No afloramento 7 e 11, ocorrem estruturas de marés, como estratificação sigmóide e espinha de peixe. Estas estruturas não ocorrem em outros afloramentos, sugerindo diferenças paleoambientais.

A fácies Taf ocorre de duas maneiras, como arenitos finos a muito finos com grandes estratificações cruzadas e estratificações "hummocky" ou como maciça ou com laminações e estratificações cruzadas localizadas e, raras, com fósseis no topo. Observando os afloramentos 1-6 e 12, a fácies com grandes estruturas é mais comum, porém quando ocorrem ambas, a fácies maciça é sempre estratigraficamente a superior. Tal diferença pode estar relacionada a mudanças no nível do corpo d'água do Mar Palermo. 
O Membro Taquaral é o mais fácil de ser reconhecido em campo pelas suas duas fácies. A fácies Iai, considerada camada basal do Membro Taquaral (HACHIRO, 1997, RICCOMINI et al. 1997; ASSINE et al. 2003; CHAHUD et al. 2010) normalmente exibe granodecrescência ascendente, observada em quase todos os afloramentos (exceto afloramento 5) e grande quantidade de vertebrados. O Afloramento 5 de menor granulometria, maior fragmentação dos fósseis e melhor seleção. Estas diferenças pode ser o resultado de um ambiente deposicional diferenciado dos demais.

Não é incomum encontrar camadas sílticas escuras intercalandas nesta fácies, as quais são similares a fácies Isa sobrejacente

SOARES (1972) considerou tais camadas como de topo da Formação Tatui relacionadas à Fácies Ibicatu, porém ASSINE et al. (2003) e CHAHUD \& PETRI (2010) observaram que ela é distintas da Fácies Ibicatu e não deveriam ser correlacionadas.

A fácies Isa é a unidade mais homogênea da sucessão, apresentando praticamente as mesmas características em toda a região: rocha síltico - argilosa de coloração cinza-escura (quando não alterada, caso dos afloramentos 5, 8 e 10), com laminação plano-paralela. Pode ser considerada folhelho embora nem sempre apresente fissilidade ao se quebrar.

O conteúdo fossilifero é variável, tendo sido observados fósseis nos afloramentos do Sitio Santa Maria (Afloramento 1-3) e no Afloramento 5. Os fósseis são restos de peixes (escamas, dentes) e crustáceos, normalmente fragmentados ou inteiros e dispersos nos sedimentos, portanto difíceis de serem recuperados.

Atividade tectônica foi observada nos afloramentos do Alto estrutural de Pitanga (afloramentos 1-5, 10 e 12) e nos afloramentos da Rodovia do Açúcar (afloramentos 6 e 7) com ação do magmatismo que ocasionou desde pequenas fraturas e falhas até a deformação, afloramentos 3 e 12 com leve inclinação das camadas, e silicificação nas rochas arenosas da Formação Irati, do afloramento 4, e nas sílticas do afloramento 5.

\section{PALEONTOLOGIA DA FORMAÇÃO TATUÍ}

O estudo de fósseis da Formação Tatuí constitui uma das maiores contribuições deste trabalho por causa da escassez de dados na literatura. A discussão destes fósseis e a localização de suas posições estratigráficas são importantes nas considerações paleoambientais da unidade 


\subsection{Icnofósseis}

\subsubsection{Icnofósseis encontrados no Afloramento 12}

Icnólitos foram os únicos fósseis observados na fácies Tab do Ponto $\mathrm{A}$ da Fazenda Ponte Nova (Figs. 44A-B). Eles se situam no topo desta fácies, imediatamente abaixo da fácies Tsa.

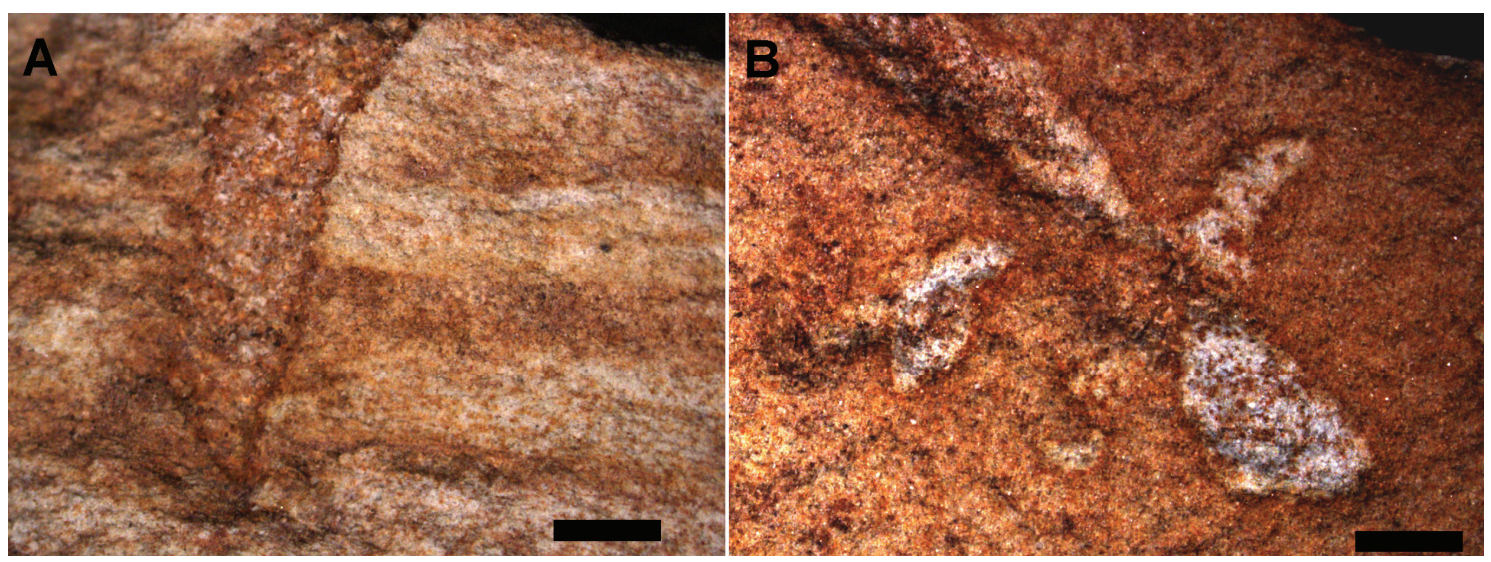

Figura 44 - A) Vista em perfil do icnofóssil encontrado na fácies 1, GP/7E-352. B) Vista em planta de icnofóssil encontrado na fácies 1. Escala $2 \mathrm{~mm}$.

Constituem-se em escavações simples irregulares, cônicas, em arenito fino. Em perfil cortam perpendicularmente as camadas e em planta possuem aberturas irregulares, variando de ovais a alongadas.

São vários os icnofósseis que poderiam ser associados a este exemplar, com base neste tipo de escavação. O icnogênero Conichnus tem formato cônico, como o exemplar descrito (Fig 44A e 44B) e sua superfície, em planta é também alongada. Este icnogênero difere do exemplar em questão pelo preenchimento do tubo em forma de chevron, diagnóstico deste icnogênero.

Cylindrichnus possui formato em perfil semelhante, porém não é perpendicular à camada e a parede superior é formada de camadas concêntricas.

O icnogênero Ophiomorpha tem a forma de escavações simples, formando redes verticais, similares aos icnofósseis observados. Difere na parte superior, pelas pelotas arredondadas, ovais ou discóides ausentes no icnofóssil estudado.

Os icnólitos do tipo Skolithos são estruturas tubulares simples verticais e alongadas, porém são muito regulares, diferindo do exemplar observado.

O icnogênero Arenicolites aparentemente é o que mais se assemelha ao exemplar da Fazenda Ponte Nova. Desenvolve-se em arenitos laminados ou estratificados com formato simples ou em "U”" e sempre perpendicular à estratificação. 
Em relação ao estudo paleoambiental, nenhum dos icnogêneros comparados é um indicador paleoambiental confiável, podendo ser atribuído a organismos de águas rasas, doce ou salgada, e até terrestres. O mais provável é que tenha se desenvolvido em águas rasas bastante oxigenadas.

\subsubsection{Icnofósseis do Afloramento 7}

O Afloramento do Km 152,5 da Rodovia do Açúcar exibe pistas na fácies arenosa. (Fig. 45). Os fósseis estão localizados no topo e próximo da base do corpo de arenito grosso mal selecionado, que se intercala à camada síltica do afloramento.

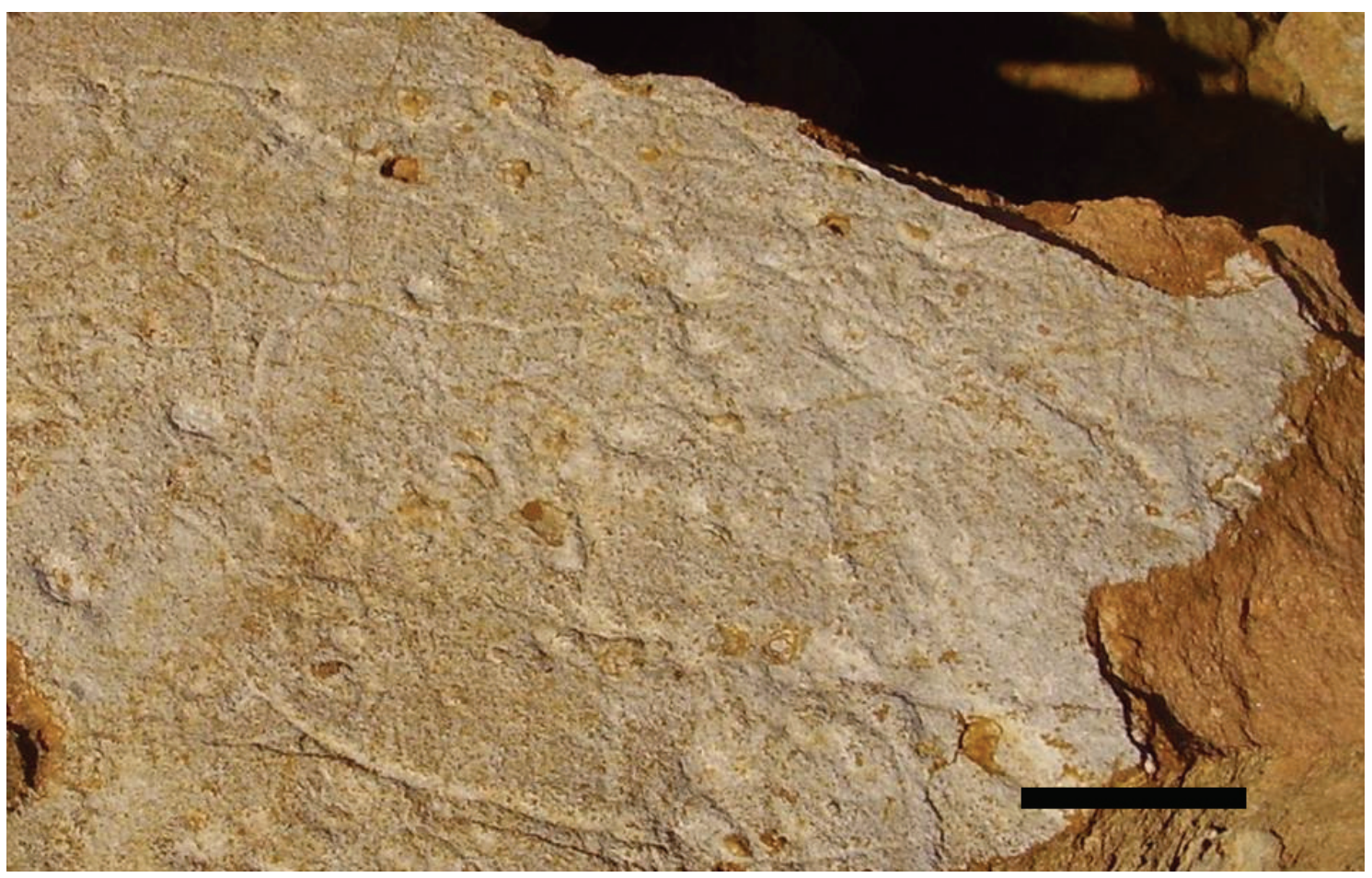

Figura 45 - Icnofósseis encontrados no Km152,5 da Rodovia do Açucar. Escala 4cm.

Os fósseis encontrados são escavações horizontais ligeiramente inclinadas. As ramificações são simples e pouco são encurvados. O espaçamento é regular em torno de $5 \mathrm{~mm}$ de largura entre as paredes.

Os exemplares observados não apresentam marcas de espinhos ou patas, com traçado liso e não exibem ornamentações. Estão preservados em hiporrelevo e epirrelevo, este mais comum.

Nenhum icnólito possui direção preferencial e alguns cortam perpendicularmente ou obliquamente outros. 
As pistas observadas no Afloramento do Km 152,5 da Rodovia do Açúcar são de difícil interpretação são comparáveis a quatro icnogenêros conhecidos do Subgrupo Guatá: Gordia Helminthopsis, Palaeophicus e Planolites.

O gênero Gordia é semelhante por ser uma trilha tipicamente vermiforme,longa, delgada, lisa, de largura uniforme ao longo de toda a trajetória, por vezes, recurvada e com entrecruzamento entre os icnólitos. Não foi observado o padrão meandrante, alguns bastante retilíneos e outros fragmentados.

Comparado com esse icnogênero não foram observadas grandes diferenças, porém segundo FERNANDES et al. (2002) Gordia tem por hábito a mudança de nível estratigráfico. Esta característica não foi verificada nos exemplares aqui descritos e sim uma pequena obliqüidade. Gordia se distribui do Proterozóico até os dias atuais e sempre atribuídos à atividade de pastagem de organismos vermiforme (possivelmente anelídeos).

O icnogênero Helminthopsis é semelhante à Gordia, sendo facilmente confundido, pois também é um escavador horizontal irregular, com pouco curvamento, sem direção preferencial. Como em Gordia e nos exemplares descritos, o preenchimento é maciço. O icnofóssil da Formação Tatuí exibe cruzamentos e espaçamentos regulares, características não observadas em Helminthopsis.

O gênero Palaeophicus possui características similares às do fóssil descrito, pelas escavações intraestratais retas a levemente curvas, ligeiramente onduladas e de superfícies lisas. São dispostos horizontalmente, com preenchimento da litologia similar a rocha matriz. Como em Gordia, Palaeophicus possui características muito semelhantes aos fosseis observados na Formação Tatuí, sem diferenças significativas.

Inicialmente o gênero Planolites foi o principal candidato a ser o icnofossil encontrado no Km 152,5 da Rodovia do Açúcar por exibir escavações horizontais a oblíquas, raramente ramificadas e se preservarem em epirrelevo e hiporrelevo, porém diferem no preenchimento diferente da matriz e pelas larguras variadas.

Tanto Palaeophicus como Planolites são atribuídos a seres vermiformes de corpo mole.

A comparação com os icnofósseis referidos na literatura levou a incluir os icnólitos da camada arenosa grossa do Km 152,5 ao icnogênero Palaeophicus, similar ao da Formação Furnas (FERNANDES et al. 2002) e da Formação Palermo (NETTO, 2000) 
Tanto Gordia, Helminthopsis e Planolites são de ampla distribuição, comuns na icnofacies Cruziana, Mermia e Nereites. Os Palaeophicus são típicos da icnofácies Cruziana. Tendo em vista caráter cosmopolita destes icnofósseis, não é possível atribuir o paleoambiente. Seriam necessários outros icnofósseis ou outro icnogênero mais específico.

\subsubsection{Icnofósseis do Afloramento 1}

Diversas perfurações biogênicas ocorrem no afloramento 1 do Sítio Santa Maria, logo abaixo do Membro Taquaral. Os icnólitos possuem forma alongada assimétrica, com variações de largura, comprimento e ramificações (Fig. 46) ou aparecerem isolados. Desenvolveram no arenito esbranquiçado do topo da Formação Tatuí, no Afloramento 1 do Sítio Santa Maria e os maiores alcançam $4 \mathrm{~cm}$ de comprimento.

Em geral, não foi vista nenhuma inclinação ou direcionamento preferencial dos icnofósseis, mas a maioria estava inclinada entre 10 e 80 graus, em alguns casos os ângulos são muito pequenos quase paralelos à camada sobrejacente. Fator importante é a disposição irregular da camada, da base da Formação Irati

A partir do tubo principal é possível observar prolongamentos laterais irregulares, sem forma definida (Fig. 46C), alguns com poucos milímetros, outros maiores, 1 ou mais centímetros. Estas estruturas podem exibir prolongamentos secundários também irregulares. Em alguns casos ocorriam icnofósseis paralelos e inclinados, seguindo rumos determinados pelas correntes que formaram o depósito da camada sobrejacente (Fig. 46C e 46D).

As extremidades dos tubos aparentemente são irregulares (Fig. 46A e 46B) com maior ou menor achatamento, porém pode ser aparente por causa do caráter incompleto das extremidades.

O preenchimento dos icnólitos pelas camadas sobrejacentes contendo comumente ictiofósseis, é uma característica comum. Os fósseis maiores que preenchem estas estruturas são escamas, sem direção preferencial. 

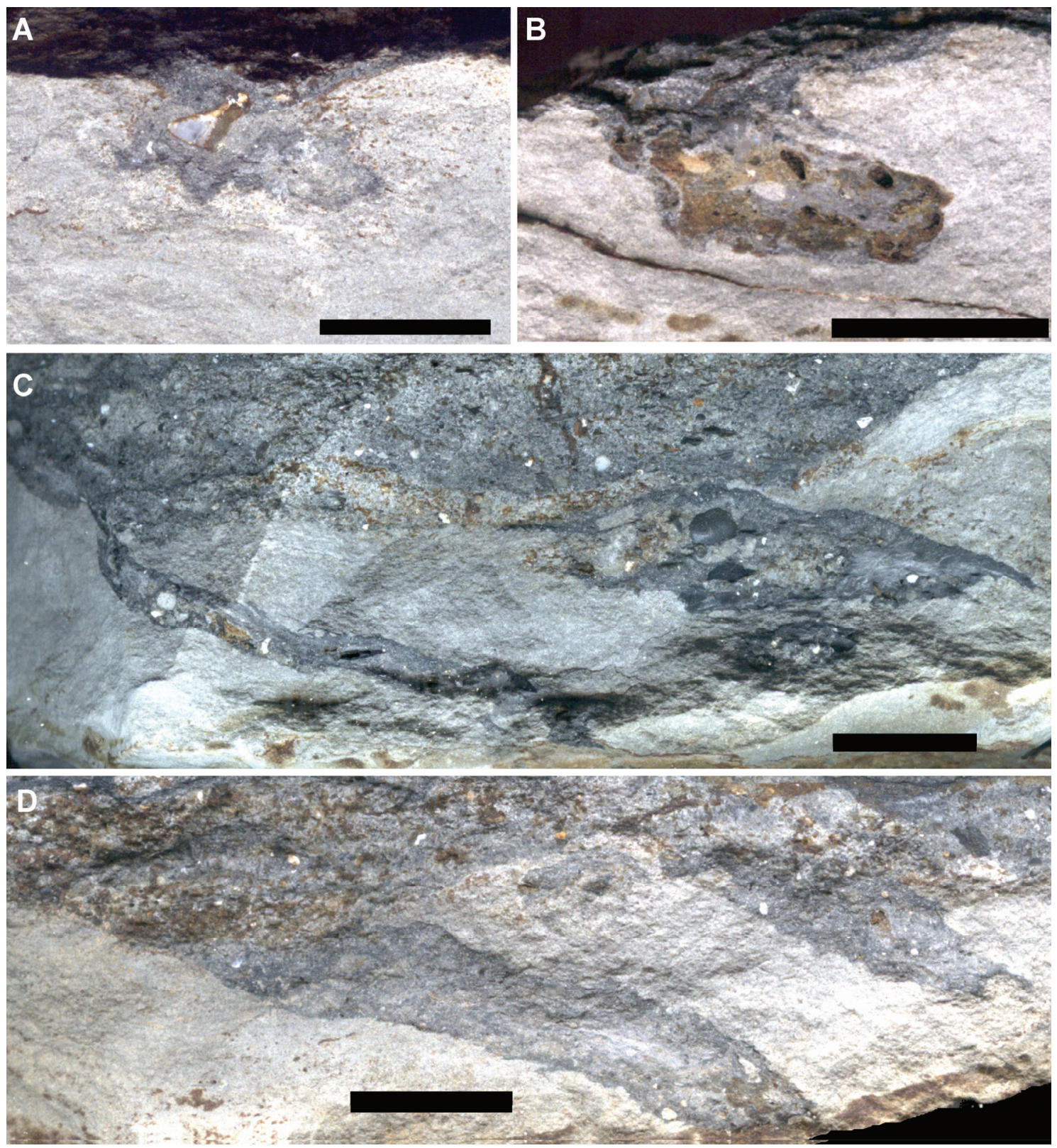

Figura 46 - Icnofósseis encontrados no Afloramento do Sítio Santa Maria. A e B) exemplares com preenchimentos contendo ictiólitos (GP7E/349b e GP7E/351a). C-D) Icnofósseis orientados (GP7E/350a e GP7E/349a). Escala 10mm.

Discussão - Os icnólitos do Sítio Santa Maria são raros e em nenhum outro ponto foram encontradas estruturas deste tipo em camadas do topo da Formação Tatuí, no centro-leste do Estado de São Paulo. Nenhum dos icnólitos descritos por NETTO (2000) e FERNANDES et al. (2002), das formações Rio Bonito e Palermo exibem características semelhantes aos do Sitio Santa Maria, embora alguns são comparáveis em certos aspectos, mas com marcantes diferenças.

O icnogênero Skolithos é semelhante no comprimento, em média maior que a largura, porém são estruturas simples e verticais diferindo do icnofóssil observado. 
O icnogênero Arenicolites, como os exemplares observados, constitui-se de tubos encurvados que se desenvolvem em arenitos finos, porém seu desenvolvimento é bastante característico, em forma de "U" e suas paredes são regulares e perpendiculares ao acamamento. Segundo NETTO (2000) estas estruturas também podem ter a forma de um funil, diferindo dos exemplares aqui encontrados.

A estrutura de repouso Conichnus lembra as menores formas de icnólitos encontrados e também por ser normalmente estruturas isoladas, porém a forma cônica e perpendicular de Conichnus elimina a possibilidade do icnofóssil do Sitio Santa Maria representar este icnogênero.

Cylindrichnus são estruturas cônicas encurvadas com alguns exemplares menores, porém Cylindrichnus possui estruturas internas, diferindo deste icnofóssil encontrado.

O icnogênero Ophiomorpha, reconhecido nas formações Rio Bonito e Palermo (NETTO, 2000), são semelhantes por possuir um sistema de escavações tridimensionais, simples ou complexas, contendo túneis cilíndricos verticais e horizontais, com ramificações dicotômicas e diâmetros variáveis, formando ângulos agudos. Contudo a estrutura interna característica, as paredes bem delineadas e a presença de pelotas de sedimento aglutinado ao longo da escavação, diferem do icnólito observado. Os exemplares do Sítio Santa Maria também possuem paredes irregulares, mas sem estrutura definida.

O icnogênero Thalassinoides possui ramificações de terceira ordem, porém em Thalassinoides, as ramificações de primeira e segunda ordens possuem o mesmo tamanho enquanto nos fósseis do Sítio Santa Maria ocorre um tubo principal seguido de ramificações menores.

O icnólito não tem nenhuma estrutura que lembrasse estruturas de escape, pois não há associação com a laminação ao redor ou da camada sobrejacente.

O icnogênero Psilonichnus, comum no mesozóico e cenozóico, foi o icnofóssil que mais se aproximou da descrição da icnólito do Sitio Santa Maria. Segundo NESBITT \& CAMPBELL (2006) o gênero Psilonichnus se constitui de uma cavidade vertical cilíndrica simples em forma de Y com as hastes filiais comuns no topo e de 3 a $5 \mathrm{~cm}$ de comprimento, mas alguns tubos poderiam chegar a $2 \mathrm{~m}$. FÜRSICH (1981), FREY et al. (1984) e GINGRAS et al. (2000) observaram algumas espécies do icnogênero Psilonichnus que podem apresentar forma de $\mathrm{J}$, como observado em Psilonichnus tubiformis e Psilonichnus upsilon, podendo ter o tubo principal inclinado. 
As duas características podem ser vistas em alguns exemplares do Sitio Santa Maria (Figs. 46B e 46C)

As diferenças de Psilonichnus e a forma aqui descrita estão na origem, pois este icnogênero estaria associado com crustáceos decápodos, mais comuns no Mesozóico e Cenozóico, além de que as estrutura em forma de $\mathrm{Y}$ e $\mathrm{J}$ não estão perfeitas nos exemplares do Sitio Santa Maria. O mais provável é que o icnofóssil encontrado pertença a outro gênero de características similares a Psilonichnus.

Psilonichnus também é uma icnofácies de origem costeira marginal, na zona praial de dunas para terrestre ou com influência fluvial (NESBITT \& CAMPBELL, 2006), o que estaria de acordo com a evolução da camada sobrejacente, base arenosa do Membro Taquaral da Formação Irati (CHAHUD, 2007).

Ainda são necessários maiores dados e exemplares mais completos, mas provavelmente o icnolito deva ter uma origem similar aos encontrados na icnofácies Psilonichnus e sua formação dever-se-ia aos crustáceos que viveram durante a deposição da Formação Tatuí e base da Formação Irati (MEZZALIRA \& MARTINS NETO, 1992).

Os fósseis inclinados orientados seriam o resultado de correntes durante a deposição da camada sobrejacente. Tais estruturas poderiam ser o resultante da fuga de seus construtores devido a nova sedimentação acima.

\subsection{Paleoflora}

A Formação Tatuí tem como únicas ocorrências na literatura de vegetais carbonizados citados por FÚLFARO et al. (1984) em arenitos médios a grossos avermelhados, no Km 169 da rodovia Itapetininga - Capão Bonito e de caules silicificados na Fácies Ibicatu.

O Afloramento 9, seção tipo da Fácies Ibicatu, entre os municípios de Leme e Araras no centro leste do Estado de São Paulo, já era conhecido por possuir caules fósseis (FULFARO et al. 1984), porém nenhum trabalho os descreveram ou ilustraram. Os fósseis da fácies Ibicatu são os maiores do presente estudo, sendo observados caules métricos. Alguns fósseis foram coletados e pertencem a Espermatófitas (Gimnospermas ou Pteridospermas) e Pteridófitas. 


\subsubsection{Pteridófitas}

\section{Ordem PSARONIALES Corsin, 1955}

Gênero Tietea (?)

Figs. $47-51$

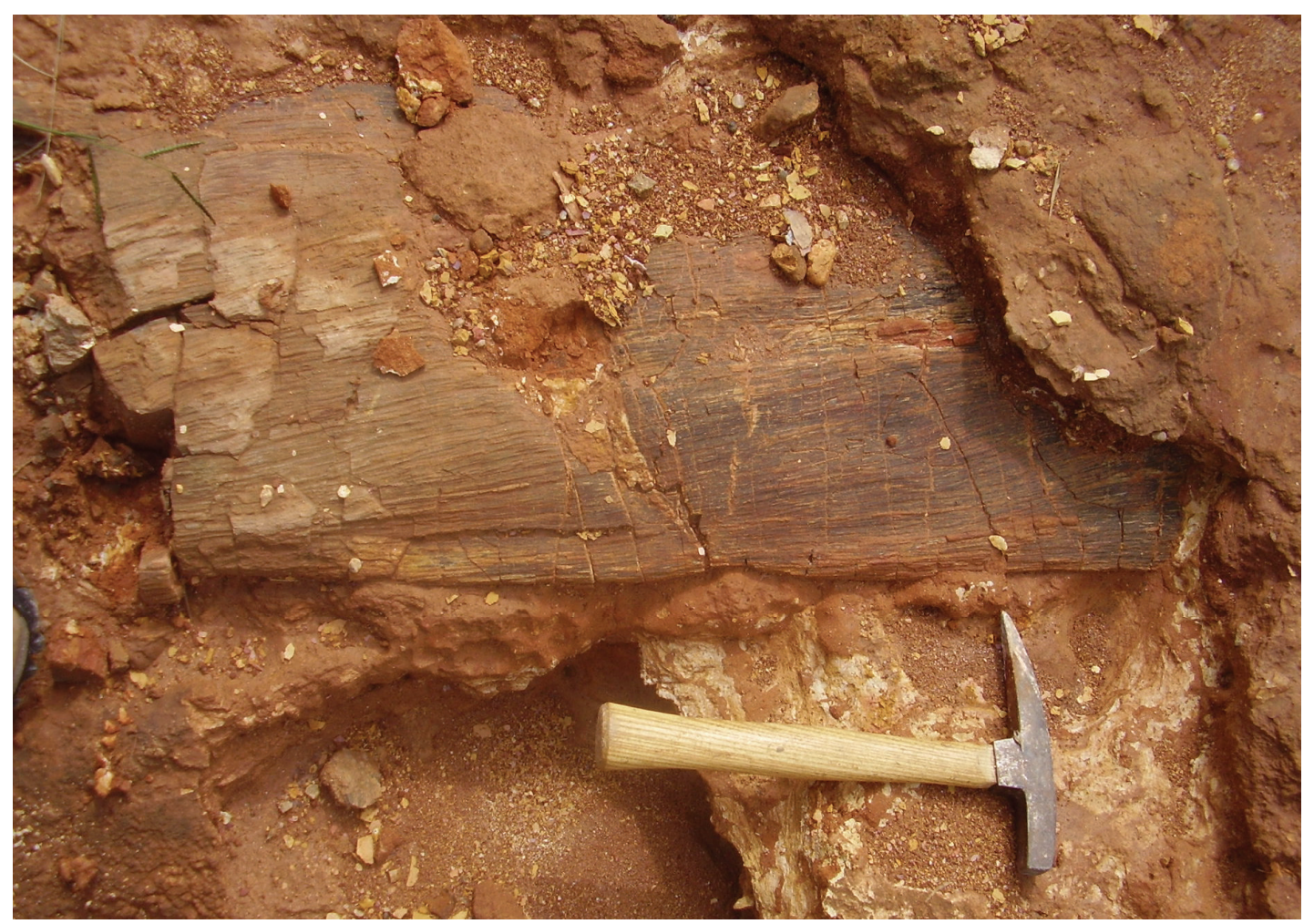

Figura 47 - Fóssil na base da camada Ibicatu, Fácies Tag.

Material - fragmentos de caules (GP/3E - 9183, GP/3E - 9184, GP/3E - 9185)

Localização - Afloramento 9, Fácies Ibicatu entre os municípios de Leme e Araras. Rodovia Elhiu Root, em coordenadas UTM: 23K 266711/7537355, 16 km NE do centro de Araras.

Características gerais - Os exemplares analisados estão deformados e permineralizados por sílica. Em todas as amostras coletadas foram preservadas somente parte do estelo e o manto radicular. A parte central do estelo, quando preservada, exibe muitas estruturas irregulares, sem orientação evidente

Os exemplares coletados estavam fragmentados, porém em campo foram observados espécimes com vários centímetros (Fig. 47) permitindo avaliação de caules muito alongados. A coloração de todos os fosseis varia de marrom escuro a claro e partes internas esbranquiçadas.

A espessura do manto radicular varia de $1 \mathrm{~cm}$ a $1,5 \mathrm{~cm}$. As radículas exibem alinhamento constante por toda a superfície. Transversalmente, são em geral, bastante 
alongadas, algumas ovais. Em um exemplar as radículas são quase circulares em contato com o estelo (Fig. 48).

O manto radicular possui diâmetro máximo de $4 \mathrm{~mm}$ nas maiores, mas raramente ultrapassam $2 \mathrm{~mm}$. No estelo as radículas são muito maiores que as observadas no manto radicular, com diâmetros máximos que variando de 4,0 $\mathrm{mm}-9,0$ $\mathrm{mm}$.

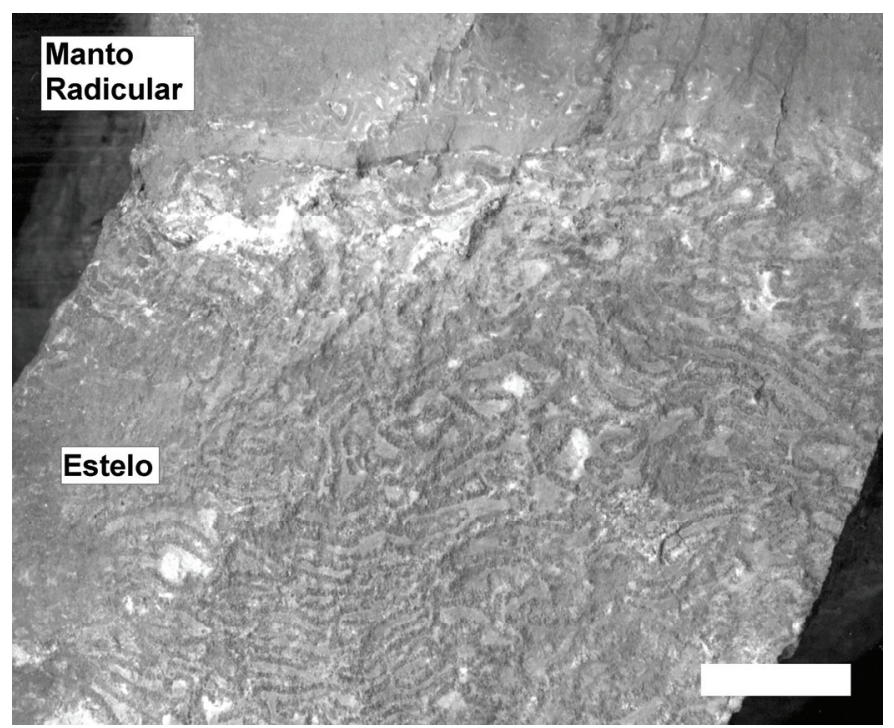

Figura 48 - Exemplar coletado na Facies Ibicatu do Afloramento 9 (GP/3E - 9183). Escala 1cm.

Todas as radículas e meristelos possuem anéis esclerenquimáticos contornando suas estruturas. A espessura é variável com $0,5 \mathrm{~mm}$ no estelo e inferiores a $0,1 \mathrm{~mm}$ nas encontradas no manto radicular (Fig. 48). O contorno raramente é interrompido nos espécimes analisados.

Os meristelos (Fig. 49) variam em tamanho e em formato, sendo irregulares e formando desenhos alongados ou em forma de letras E, U ou C. Não há uma concentração específica dos meristelos.

Em geral as radículas do estelo estão em contato com o manto radicular, não o atravessam, porém é possível observar algumas com o término tendendo a penetrar no manto radicular. 


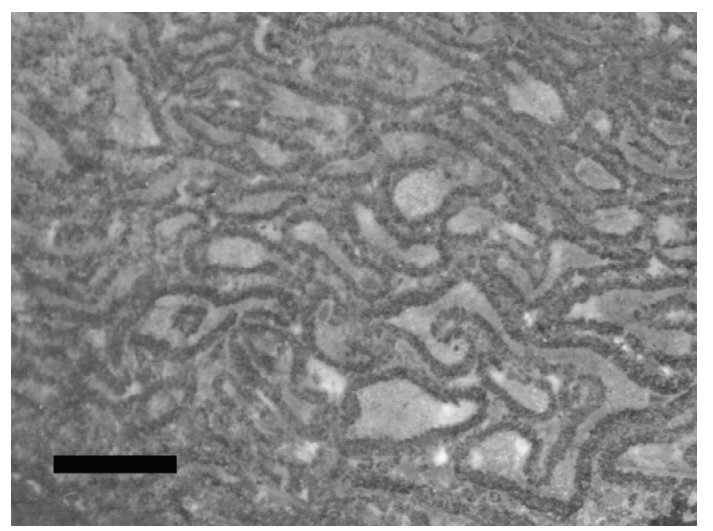

Figura 49 - Detalhes dos meristelos com contorno escleremquimático (GP/3E - 9183). Escala 5mm.

Longitudinalmente (Fig. 50) foi observada que em alguns momentos a continuação do traqueídeo é interrompido.

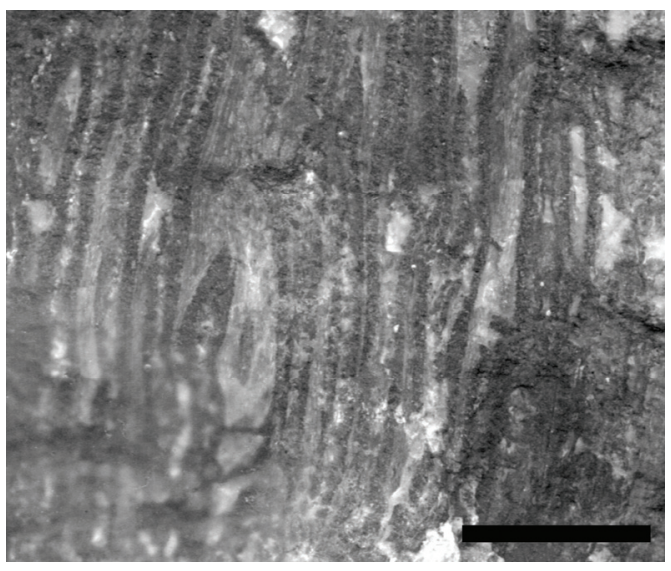

Figura 50 - Vista longitudinal do exemplar coletado na Facies Ibicatu do Afloramento 9 (GP/3E 9184).. Escala $1 \mathrm{~cm}$.

Discussão - observa-se maiores semelhanças com espécimes do gênero Tietea pelo formato dos meristelos, similares aespécimes descritos por DERBY (1915) e TAVARES (2007) e ausência de organização dos meristelos na partte central do estelo, ao contrario de Psaronius com meristelos bem definidos e organizados.

Esta característica, no entanto, não seria suficiente para identificar o gênero, pois segundo TAVARES (2007) os gêneros Tietea (SOLMS-LAUBACH, 1913) e Tuvichapteris (HERBST,1987) não possuem organização dos meristelos na parte central do estelo e a diferença estaria no número de frondes que emergem do caule, não preservada nos exemplares aqui presentes. Segundo a autora esta característica também é variável, pois há variação durante o crescimento da planta, por isso estes gêneros deverão futuramente ser melhor avaliados.

Concluí-se portanto que o gênero Tietea parece ser apropriado, sendo mais antigo ele teria prioridade, no caso de se chegar a sinonímia com Tuvichapteris. 
Os fósseis analisados estão muito deformados, mas um exemplar chamou atenção por apresentar o manto radicular muito espesso, penetrando dentro do estelo (Fig. 51). Talvez tal anomalia deva ter ocorrido em vida, causada, por algum fator ambiental.

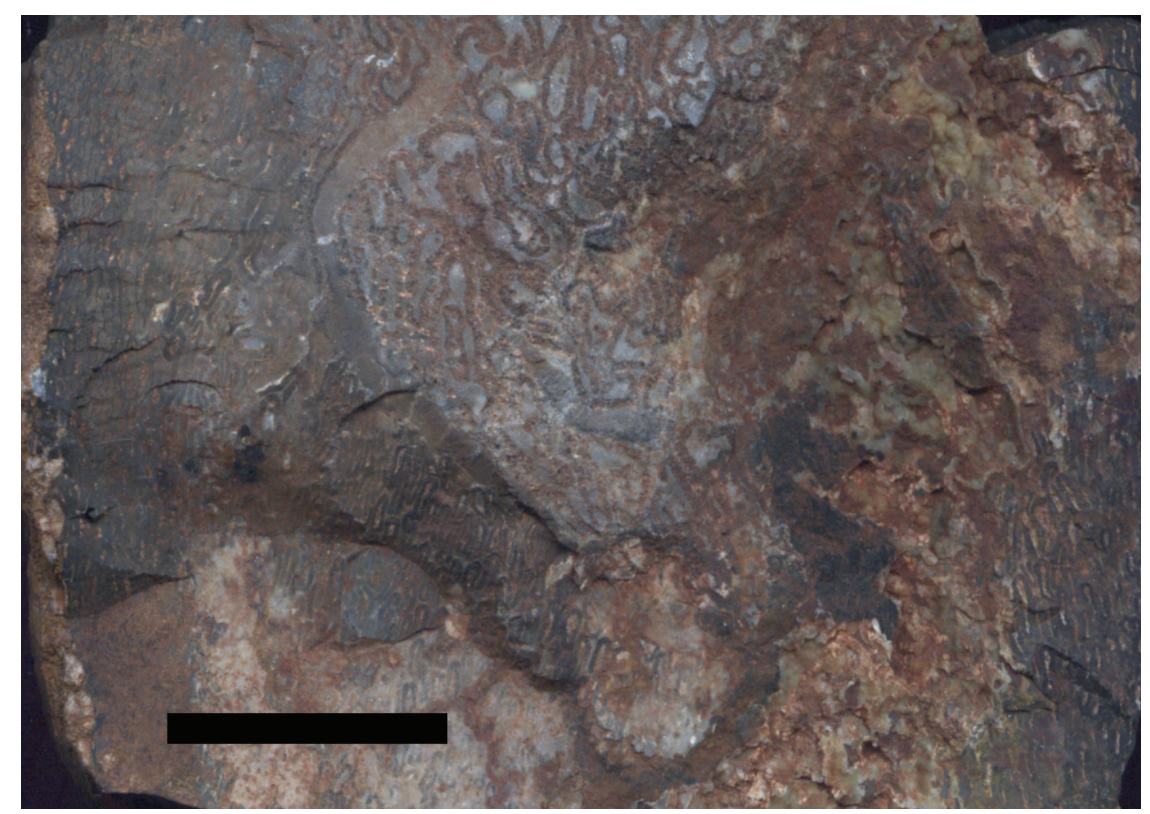

Figura 51 - Exemplar com manto radicular penetrando dentro do estelo (GP/3E - 9184). Escala $2 \mathrm{~cm}$.

As estruturas e morfologia observadas em vista longitudinal, são similares às descritas por DERBY (1915) em um exemplar de Tietea singularis do Neopermiano do Estado de São Paulo. As estruturas descontínuas e irregulares, citadas por DERBY (1915), são notadas nos exemplares da fácies Ibicatu, reforçando a hipótese de que pertençam ao gênero Tietea.

\subsubsection{Espermatófitos}

Além das pteridófitas, lenhos menores atribuídos a Gimnospermas ou a Pteridospermas foram encontrados no mesmo afloramento, além do tamanho menor, estes são aparentemente mais raros que as pteridófitas.

\section{Superdivisão: SPERMATOPHYTA \\ Divisão Incertae sedis}

Figs. 52-55 


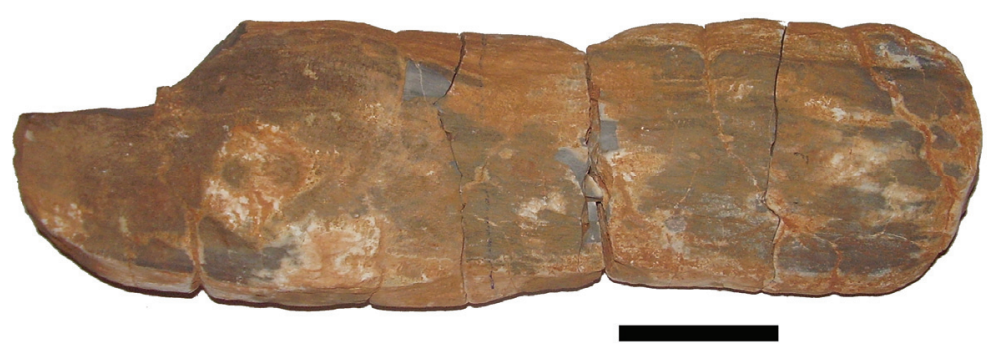

Figura 52 - Lenho fóssil coletado na Fácies Ibicatu do Afloramento 9(GP/3E - 9185). Escala $5 \mathrm{~cm}$.

Material - Fragmentos de caules (GP/3E - 9185, GP/3E - 9186)

Localização - Afloramento 9, Fácies Ibicatu entre os municípios de Leme e Araras. Rodovia Elhiu Root, em coordenadas UTM: 23K 266711/7537355, 16 km NE do centro de Araras.

Características gerais - Os caules encontrados são do tipo gimnospérmico cilíndricos com deformação causada por compactação (Fig. 53). Nos exemplares analisados a medula é pequena, comparada ao tamanho do exemplar, alongada e irregular.

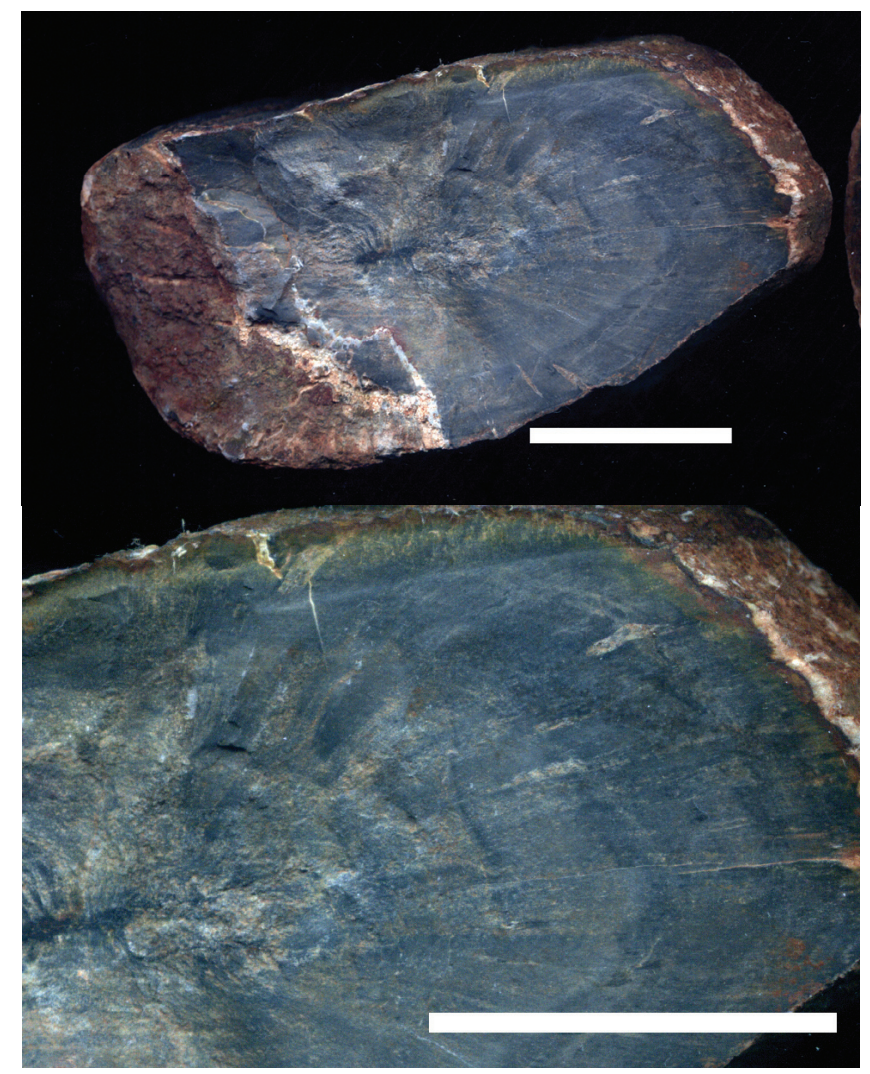

Figura 53 - Acima, corte transversal do exemplar GP/3E - 9185 mostrando o aspecto raiado e a pequena medula. Abaixo detalhe do mesmo exemplar. Escala $2 \mathrm{~cm}$. 
Os raios que partem da medula são unisseriados e chegam até próximo da parte externa. Foram observados falsos anéis de crescimento e concentrações de células maiores, lembrando anéis interrompidos.

Em lâmina delgada foi possível observar que estes anéis não continham células verdadeiras (fig. 54), por vezes são apenas manchas escuras, e a medula não apresenta orientação celular. Possíveis anéis incompletos (fig.55) são observados próximos da medula (fig. 56), mas ficam restritos a este ponto

O formato da medula e proporções é similar às descritas por MUSSA (1982; 1986a; 1986b), porém a classificação em gênero e espécie seria arriscada, devido à deformação dos fósseis pela diagênese.

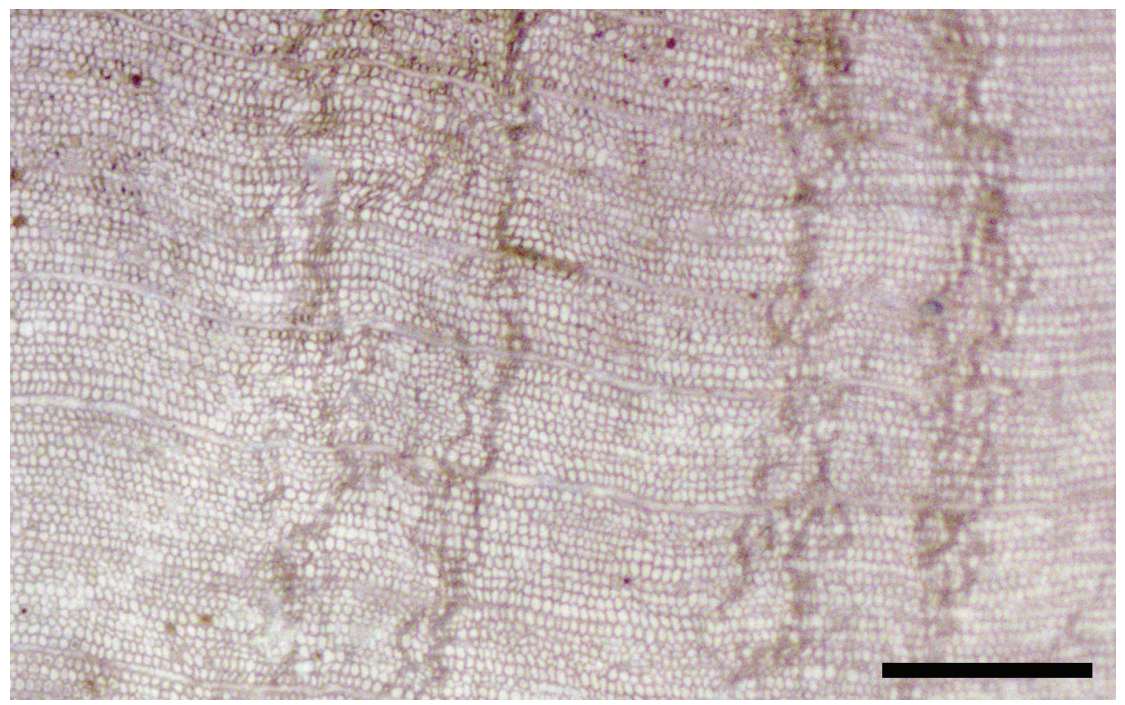

Figura 54 - Detalhe de falsos anéis em lâmina delgada. Escala 0,2mm.

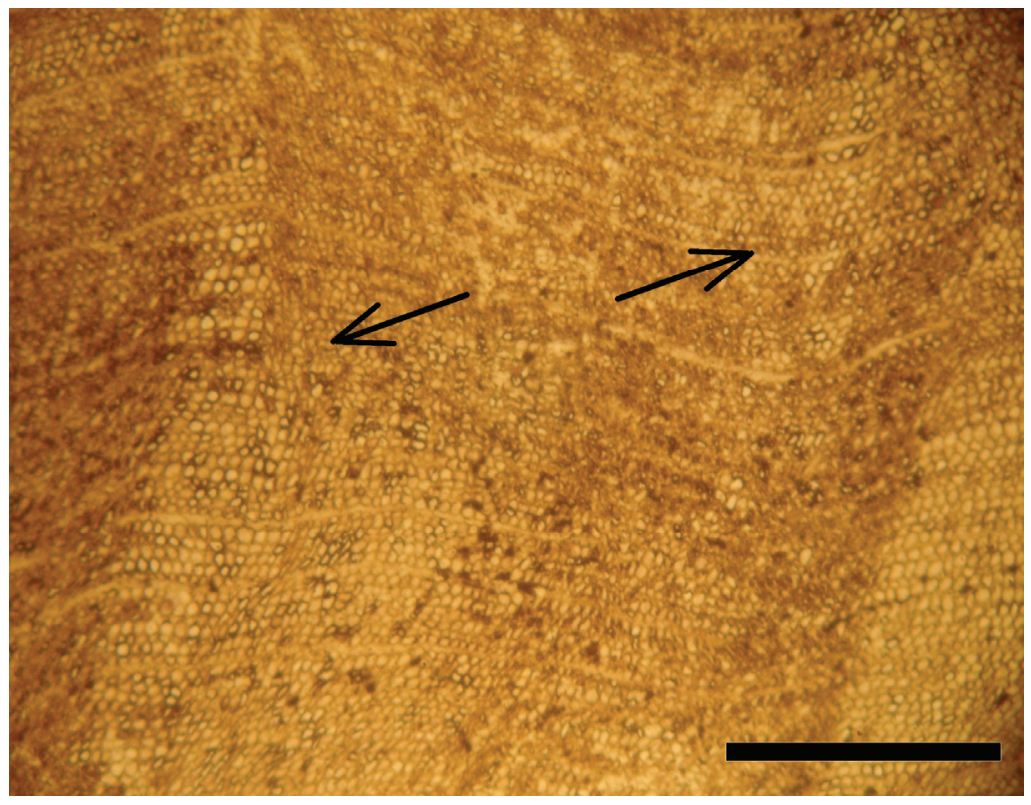

Figura 55 - Anéis interrompidos em região próxima da medula. Escala 0,2mm. 


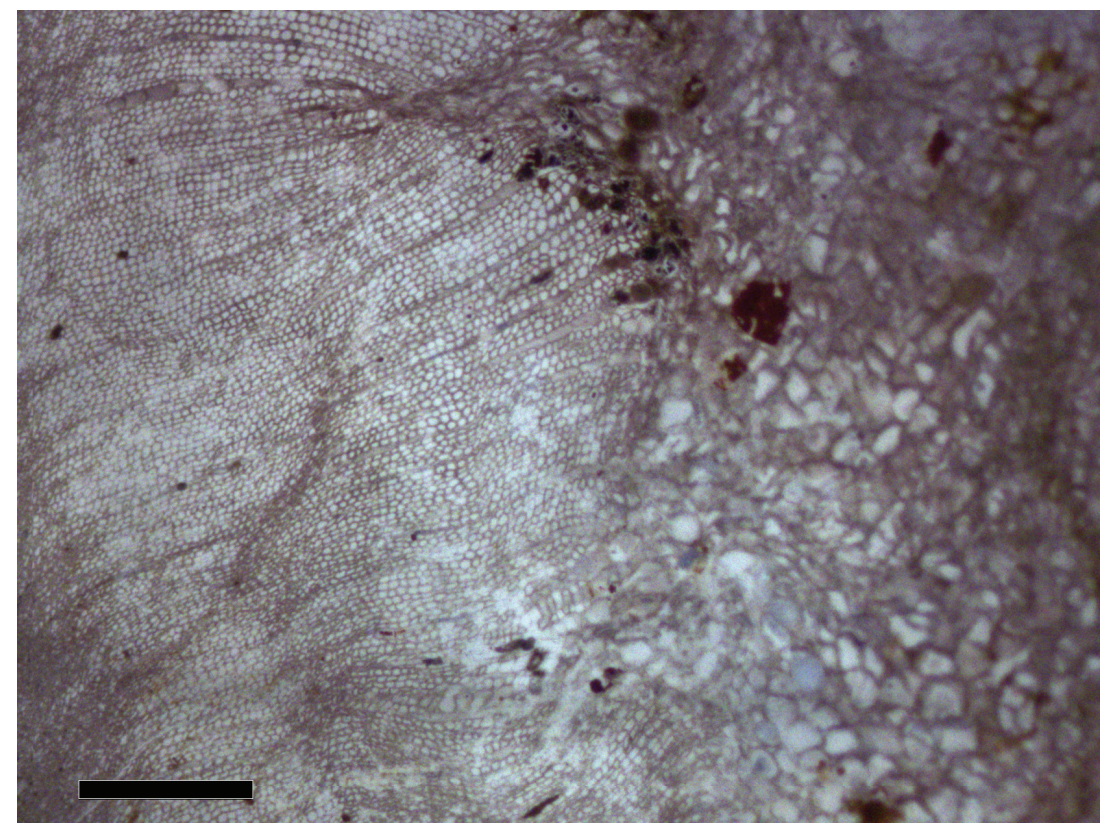

Figura 56 - Região de borda da medula, destacando as celulas maiores não orientadas em lâmina delgada $\mathrm{GP} / 3 \mathrm{E}-9186$. Escala 0,2mm.

\subsubsection{Comentários sobre a tafonomia dos lenhos}

Os fósseis foram encontrados em um conglomerado de clastos de tamanhos variando de cinco milímetros a três centímetros. Os clastos são alongados, arredondados e angulosos.

Foram medidas direções E-W em dois caules. Esta observação também foi feita por STEVAUX et al. (1986) e FERNANDES (2004), apesar de ter observado sentido de corrente N-S concluíram que os depósitos seriam unidirecionais.

Nenhum fóssil foi encontrado em posição de vida, mas em posições geradas por transporte. Observando o fóssil encontrado na base da camada (Fig. 47), é possível inferir que eram vegetais de grande porte e a energia que os carregou era muito alta. Contudo não foi possível inferir a distância de transporte, mas observando também a textura da rocha e a quantidade de grãos angulosos, é sugestiva a existência de um evento único ou de curta duração que pouco retrabalhou os fósseis e aparentemente estaria próximo da rocha fonte.

A estrutura interna dos fósseis foi modificada pela digênese (Fig. 57). A principal característica diagenética observada foi a compressão dos fósseis, pelo peso do aporte sedimentar que o cobriu, gerando aumento aparente da largura dos fósseis e deformações internas. 
As deformações observadas nas pteridófitas incluem o espessamento do manto radicular e o aumento da desorganização do estelo, causando variação no formato do meristelo e das radículas nas bordas, em contato com o manto radicular. Nos espermatófitos ocorreu a formação de falsos anéis de crescimento e do formato oval em corte transversal de alguns lenhos.

O manto radicular do fóssil da Fig. 57 aparece quase retilíneo com pequenas inclinações, ao invés de estar curvo, em ambos os lados do exemplar, praticamente comprimindo a estrutura interna do meristelo e o deformando.

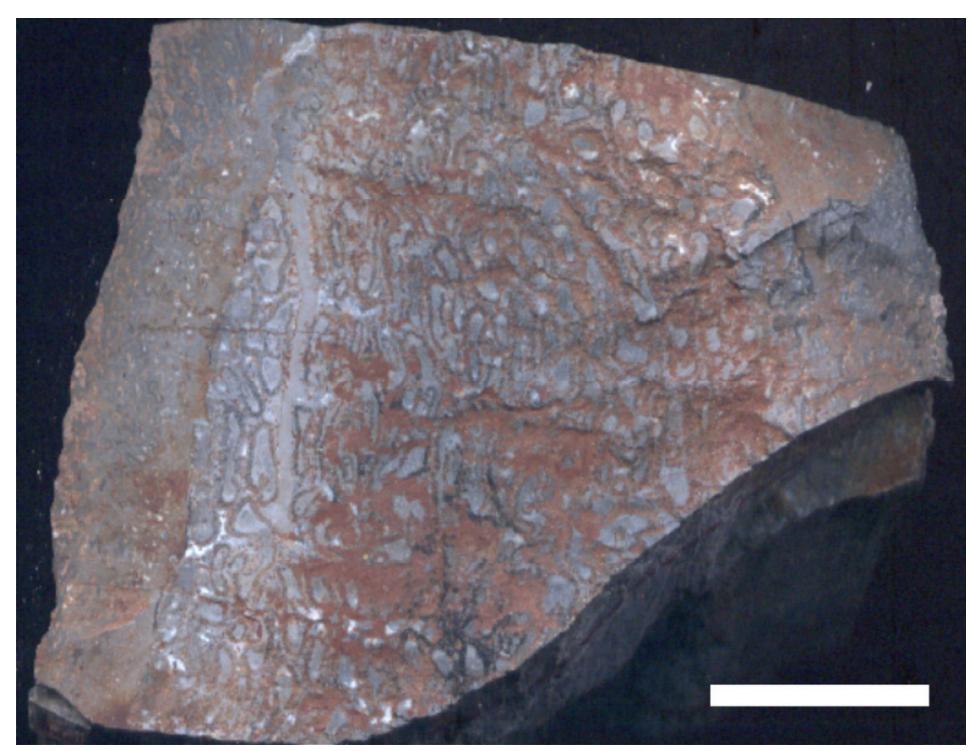

Figura 57 - Exemplar deformado pela diagenêse distorcendo o manto radicular do lado esquerdo e direito, comprimindo-o (GP/3E - 9184). Escala $2 \mathrm{~cm}$.

\subsection{Artrópodes}

\subsubsection{Conchostráceos}

Conchostráceos são crustáceos de carapaças bivalves de pequeno porte. A constituição da carapaça (ou concha) é quitinosa ou calco-quitinosa.

Apesar de serem constituídos de cabeça, tronco e anatomia interna complexa, estas raramente são preservadas no registro fóssil, sobrando apenas a carapaça (ou concha) bivalve. Ao contrário de outros artrópodes com ecdise (ou muda), os conchostráceos não trocam as valvas, exibindo crescimento bandado concêntrico, periódico, formando linhas de crescimento.

O contorno das valvas pode ser circular, subcircular, oval ou subquadrada. A charneira pode ser reta ou curva, e o umbo pode se situar numa posição subcentral ou entre este e a região extrema anterior. 
Filo ARTHROPODA Latreille, 1829

Superclasse CRUSTACEA Brünnich, 1772

Classe BRANCHIOPODA Latreille, 1817

Ordem DIPLOSTRACA Gerstaecker, 1866 (CONCHOSTRACA Parafilético)

Subordem Indeterminada

(Figs. 58 e 59)

Material - coquinas e espécimes isolados e dispersos na rocha (GP/1E-6196, GP/1E-6197, GP/1E-6198, GP/1E-6199, GP/1E-6200, GP/1E-6201, GP/1E-6202, GP/1E-6203, GP/1E-6204).

Localização - Afloramento 12 Fazenda Ponte Nova, Pontos A e C.

Estratigrafia - Próximo ao topo da Formação Tatuí.

Descrição - os espécimes estão preservados como impressões da carapaça com poucas características morfológicas externas preservadas. Em alguns casos, o umbo é facilmente observado. Raramente, a presença das linhas de crescimento é evidenciada, sem, contudo, ser viável a discriminação entre cada uma delas. Nos espécimes analisados, não há espessura detectável, nem concavidade ou convexidade.

Em poucas amostras foram observadas impressões de conchostráceos completos, dispostos com suas valvas fechadas. Alguns exemplares maiores e/ou mais completos apresentaram em suas bordas parte do bandamento e duas ou três linhas de crescimento, que auxiliaram na discussão.

Tomados em conjunto, poucos exemplares apresentaram a valva totalmente preservada. Diante disso, o esforço amostral, para o efeito de análises biométricas e estatísticas, reuniu 66 espécimes (considerados mais íntegros). Em nenhum caso foi possível medir o ângulo de crescimento da valva, devido, conforme supracitado, à ausência de linhas de crescimento completas. Os espécimes com a carapaça completa são ligeiramente ovais. Valvas com altura variando entre 0,98 e $3,54 \mathrm{~mm}$ e comprimento entre 1,25 e $5,57 \mathrm{~mm}$. Exemplares fragmentados também foram observados em abundância.

Discussão - Atualmente os conchostráceos são considerados parafiléticos incluído em Diplostraca (SCHMINKE, 1981; MARTIN \& THE CLASH-CLARK, 1995; OLESEN, et al. 1996; OLESEN, 1998).

Entre os exemplares em melhor estado de preservação, foi possível verificar que as valvas são geralmente ovais, com contorno arredondado (Fig. 58A-C), semelhantes 
aos atribuídos aos gêneros descritos na Formação Rio do Rasto Cyzicus e Asmussia (BRITO et al. 2000; FERREIRA DE OLIVEIRA, 2007). Outros mais alongados, poderiam ser atribuídos ao gênero Euestheria. Entre os fragmentados ocorrem alguns com carapaça com partes retilíneas, lembrando possíveis formas de Hemicycloleaia.

Contudo, deve-se ressaltar que é necessário proceder com cautela na tentativa de identificação taxonômica, baseada somente no formato da carapaça e/ou na ínfima ornamentação das linhas de crescimento. É importante salientar que muitos dos caracteres taxonômicos dispõem-se nas partes moles e apêndices, raramente preservados nos fósseis (CHEN \& HUDSON, 1991). Além disso, KOBAYASHI (1954) já havia alertado para o polimorfismo entre os conchostráceos. De acordo com o autor, estas características populacionais podem ser atribuídas a vários fatores, como mutações, dimorfismo sexual, variações de caráter ontogenético e fenótipo diferenciado de parcelas de populações que se isolam. Algumas dessas premissas foram corroboradas por FERREIRA DE OLIVEIRA (2007) por meio da verificação da alteração na forma e ornamentação das valvas, em diferentes estágios ontogenéticos e/ou paleoautoecológicos (especialmente vinculados à reprodução).

Os conchostráceos são típicos de ambientes não marinhos, adaptados a condições estabelecidas em pequenos corpos de água doce a oligohalinos, rasos, com menos de um metro de profundidade (FERREIRA DE OLIVEIRA (2007). O pH da água é um fator importante pois varia do pouco acido ou neutro $(\mathrm{pH}=6,0-7,0)$ ao alcalino $(\mathrm{pH}=9,7)$, não tolerando águas muito ácidas. Conchostráceos atuais podem sobreviver em temperatura variando entre $1^{\circ}$ e $41^{\circ} \mathrm{C}$, a maioria com ótimos populacionais a temperaturas entre $20^{\circ}$ e $30^{\circ} \mathrm{C}$. A temperatura e a disponibilidade de luz e alimento são fatores limitantes para desenvolvimento e reprodução de várias espécies.

A mais antiga citação provém da Formação Rio Bonito, Permiano da Bacia do Paraná, do afloramento Bainha em Criciúma por BERNARDES DE OLIVEIRA (1977).

SAAD (1977) observou, na Formação Palermo do Estado do Paraná, um nível rico em conchostráceos próximo do contato com a Formação Irati. A estratigrafia neste trabalho não estava bem definida, mas a descrição geológica é muito similar às de rochas atribuídas à Formação Palermo, nos estados da Região Sul, ou a Formação Tatuí, no Estado de São Paulo.

Na Formação Tatuí ocorrem citações de MEZZALIRA (1959) e apenas é conhecido o gênero, Cyzicus, descrito por MEZZALIRA \& MARTINS NETO (1992). 
Este fóssil foi encontrado em um antigo afloramento que situava a $2 \mathrm{~km}$ do Afloramento 8 da presente pesquisa, porém neste ponto nenhum fóssil foi encontrado.

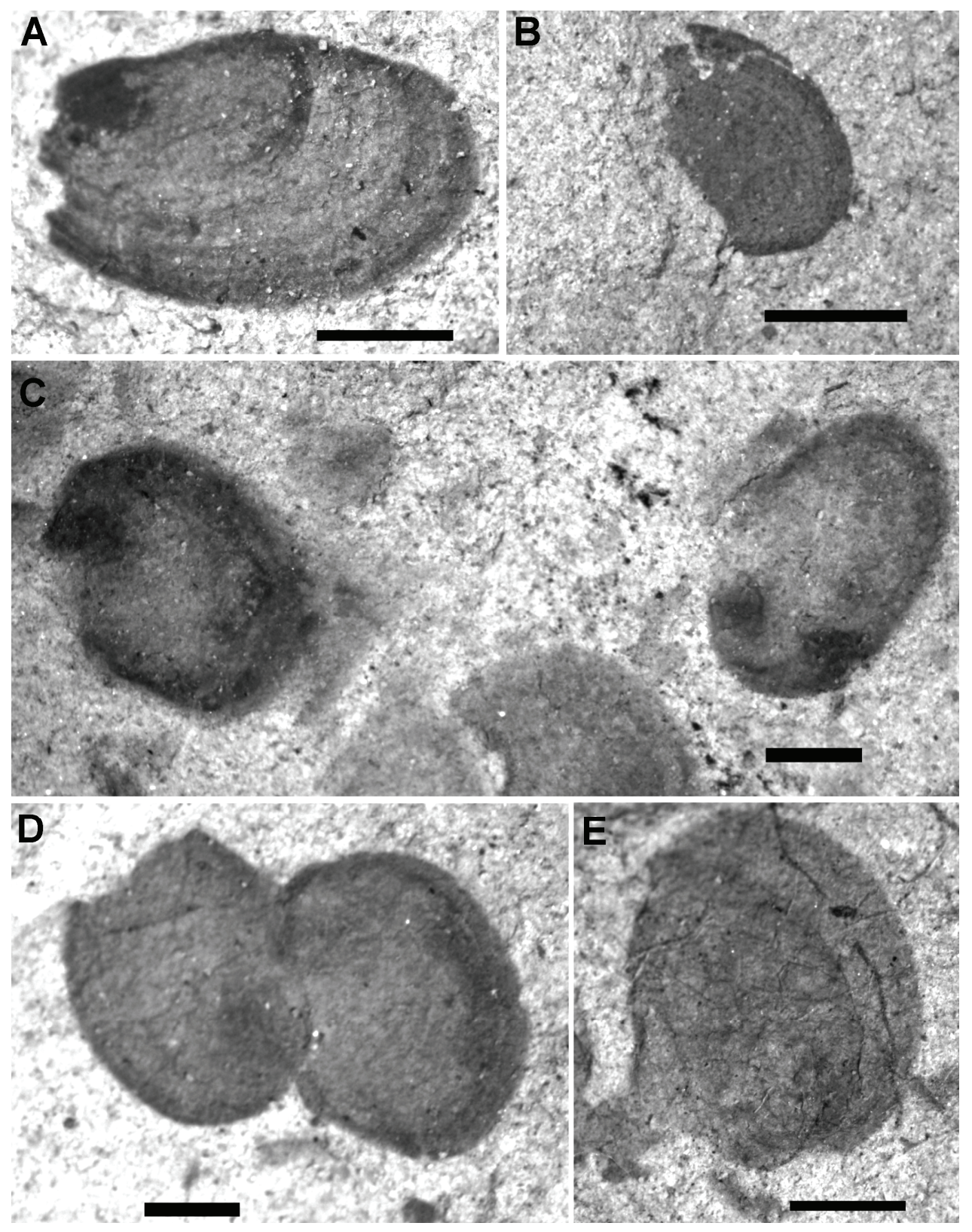

Figura 58 - Conchostráceos provenientes do Ponto A do Afloramento 12. A-B) Conchostráceos de carapaça incompleta (A) GP/1E-6203; B) GP/1E-6197). C) Conchostráceos com possíveis resíduos de matéria orgânica no interior da concha (GP/1E-6201). D) Conchostráceo de valva desarticulada (GP/1E6199). E) conchostráceo de valva deslocada (GP/1E-6200). Escala $1 \mathrm{~mm}$.

\subsubsection{Estudo tafonômico de conchostráceos}

Os fósseis de conchostráceos do afloramento 12 são encontrados numa faixa de $1,21 \mathrm{~m}$ de espessura, dentro da camada síltica intermediária dos pontos $\mathrm{A}$ e $\mathrm{C}$ do afloramento 12 da Fazenda Ponte Nova. 
Tanto no Ponto A quanto no Ponto C, conchotráceos sempre aparecem em siltitos finos com laminação plano-paralela, típicos de depósitos de decantação ou de ausência de tração.

Os fósseis estão bastante compactados e ocasionalmente aparecem como impressões simples de conchas. Ocorrem como assembléias aparentemente monotípicas, porém não há segurança de ser monoespecífica ou poliespecífica.

Os exemplares analisados são constituídos de carapaças isoladas ou valvas fechadas, pois alguns espécimes apresentavam as duas valvas separadas, estando próximas ou até ligeiramente deslocada uma em relação à outra (Fig. 58D-E). Alguns apresentaram resíduos de matéria orgânica sem forma definida no interior de suas conchas, caracterizados por manchas escuras (Fig. 58C).

A gama de tamanho de indivíduos e a mistura de carapaças de indivíduos de tamanho e preservação diferentes indicariam diversas idades ontogenéticas, dimorfismo sexual e/ou polimorfismo, conforme suposto por Kobayashi (1954) para conchostráceos fósseis e vivos. Também há a possibilidade do viés tafonômico inferido por eventos de mortandade em épocas distintas, estabelecendo mistura temporal e/ou espacial.

Estes fósseis ocorrem em camadas intercaladas, com muitos indivíduos formando coquinas (shell beds) localizadas. A concentração fóssil varia lateralmente e verticalmente (Figs. 58A-D, 59A-B) na seção com fósseis fortemente empacotados (Fig. 59A) e dispersos (Figs. 59C-D) em várias direções.

Associados aos conchostráceos são observados fragmentos de crustáceos ou artrópodes indeterminados e escamas de Palaeonisciformes (tratados mais adiante). Esta associação com peixes e artrópodes indicaria que os ambientes deposicionais onde viviam não eram corpos d'água temporários ou sazonais.

O mais provável, de acordo com os dados obtidos, é que a composição da água ou sua oxigenação poderia ter sido modificada de tempos em tempos levando os conchostráceos a morte em quantidade variada, uma vez que não há perturbação sedimentar. Tais eventos podem estar relacionados a sutil aumento de salinidade ou diminuição do oxigênio.

Outro fator de mudança ambiental seria de $\mathrm{pH}$ neutro ou alcalino para ácido levando inúmeros indivíduos à morte. Contudo se isto ocorreu, foi por curta duração não destruindo completamente as valvas. 

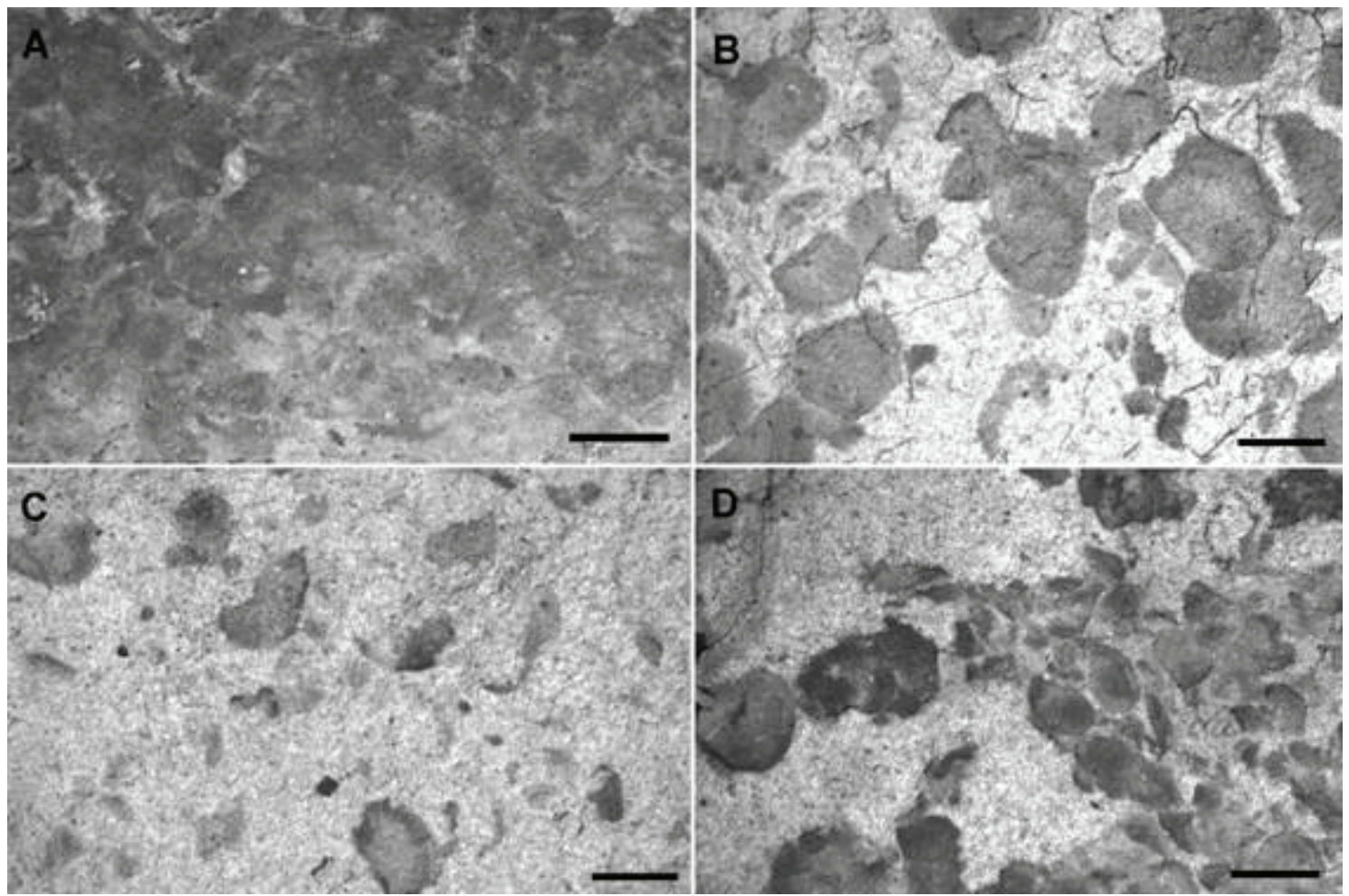

Figura 59 - Acumulações de conchostráceos no Ponto A. A) Vista em planta de uma assembléia fortemente empacotada de conchostráceos (GP/1E-6198). B) Vista em planta de uma assembléia mediamente empacotada (GP/1E-6196). C) Vista em planta de uma assembléia fracamente empacotada (GP/1E-6204). D) Vista em planta de uma assembléia que passa lateralmente de fortemente empacotada para fracamente empacotada (GP/1E-6200). Escala $2 \mathrm{~mm}$.

\subsubsection{Subclasse Malacostraca}

Os malacostraceos constituem $3 / 4$ das espécies de crustáceos modernos. A subclasse é bastante diversificada e seus fósseis, registrados desde o Cambriano, são de grande interesse para a paleontologia e estratigrafia.

Segundo (BRITO et al., 2000) os Malacostracea podem ser divididos em quatro ordens: Pericarida, Syncarida, Hoplocarida e Eucarida, sendo que a primeira é de maior importância para o presente estudo na Formação Tatú́.

Os Isópodes, incluído em Pericarida, são morfologicamente diversificados e de grande interesse para a presente pesquisa. Habitam ambientes de água doce e salgada. São caracterizados por possuírem geralmente um único par de maxilípedes (raramente dois ou três) e mandíbulas com um processo articulado entre os dentes. A carapaça é pequena ou reduzida, não está fundida com os segmentos torácicos. Na maioria das espécies os segmentos basais das patas exibem placas achatadas (oostegitos) que abrigam uma bolsa ventral (marsúpio) para chocar os ovos (MARTIN \& DAVIS, 2001) 


\subsubsection{Crustáceos da Formação Tatuí}

Os primeiros registros de crustáceos da Formação Tatuí datam do final do século XX por MEZZALIRA \& MARTINS NETO (1992). Estes autores descreveram dois novos gêneros de isópodes, Pseudopalaega e Protourda, provenientes da Formação Tatuí na rodovia Americana-Piracicaba, no município de Piracicaba (Fig. 60). São as únicas ocorrências conhecidas de Malacostraca associados com peixes e conchostráceos.

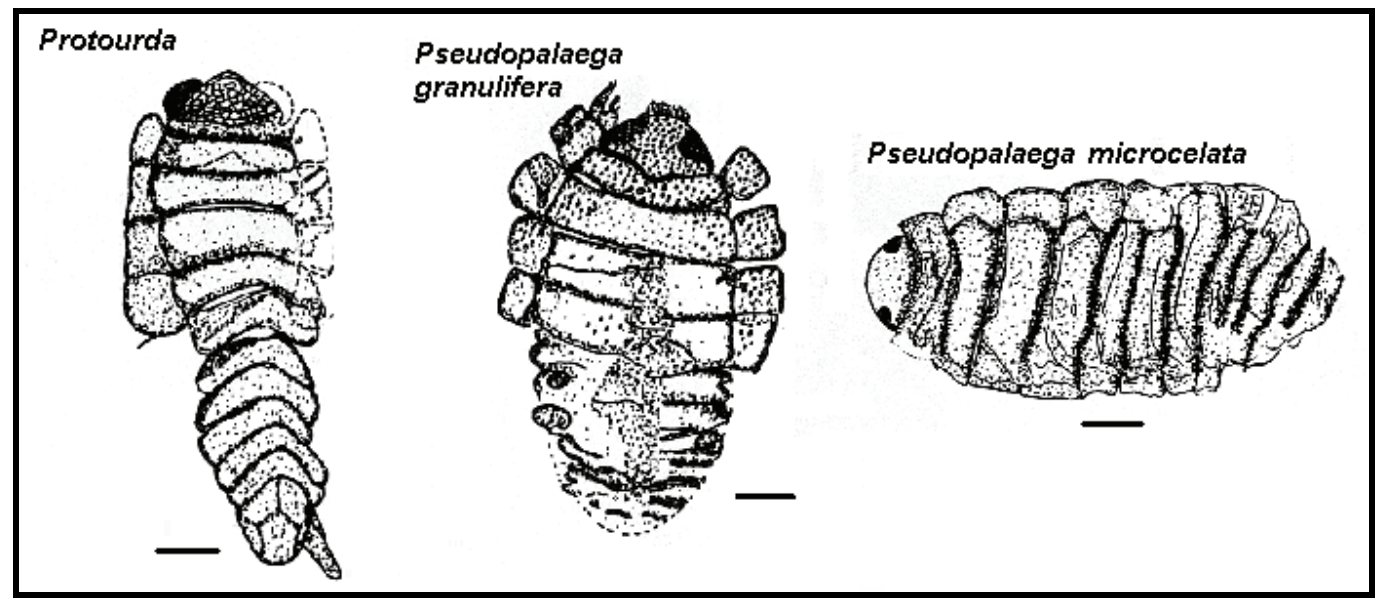

Figura 60 - Desenhos esquemáticos de vários crustáceos identificados na Formação Tatuí por MEZZALIRA \& MARTINS NETO (1992) (Protourda, Pseudopalaega granulifera e Pseudopalaega microcelata). Escala $1 \mathrm{~mm}$.

Até o momento nenhum malacostraca foi observado, porém alguns fósseis constituídos de quitina e preservação similar ao dos conchostráceos estão em associação com os mesmos no Afloramento 12, porém sua identificação como crustáceo é duvidosa. São reconhecidos pelo formato irregular ou ornamentações pontiagudas e onduladas (Fig. 61)

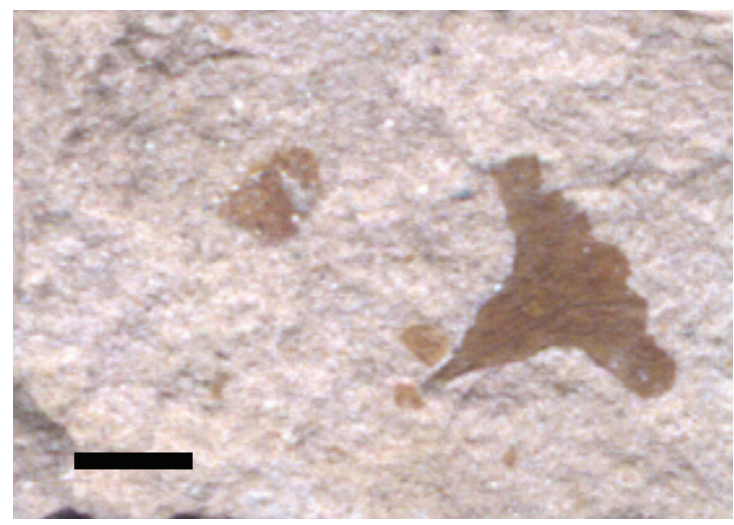

Figura 61 - Fragmento de artrópode não identificável da Formação Tatuí do Afloramento 12 (GP/1E6205). Escala $12 \mathrm{~mm}$. 


\subsection{Paleovertebrados}

Os vertebrados encontrados na Formação Tatuí são restritos a determinados níveis próximos ao topo da unidade. Na literatura é comum encontrar citações de dentes e escamas, mas nenhuma foi ilustrada (RAGONHA,1978 e MOCHIZUKI, 2001).

Todos os fósseis encontrados são de Osteichthyes, cujas definições e métodos de identificação serão detalhados no capítulo relacionado a base da Formação Irati, onde são mais diversificados e abundantes.

A única identificação na literatura foi feita por SILVA SANTOS (1991) a partir de restos de Actinopterygii do tipo Platysomoidea em folhelho cinza da Formação Tatuí na estrada Piracicaba - Americana, porém nunca foi ilustrado. O fóssil foi encontrado em associação com os crustáceos descritos por MEZZALIRA \& MARTINS NETO (1992).

Entre os fósseis da Formação Tatuí observados no presente estudo apenas os afloramentos 5 (Afloramento com ocorrências de Clarkecaris) e 12 (Afloramento da Fazenda Ponte Nova), possuem fósseis de escamas e dentes de peixes.

Os fósseis da Formação Tatuí no afloramento 5 ocorrem apenas no topo da unidade, em contato com a base da Formação Irati. Os fósseis são isolados, dispersos e estão em uma camada bege de arenito fino bem selecionado.

Normalmente são dentes e escamas mal preservados de Palaeonisciformes (Fig. 62) atribuídos a varias partes do corpo do animal. Ocasionalmente são observados possíveis ossos e escamas de Sarcopterygii Coelacanthimorpha, detalhados no item específico do grupo mais adiante.

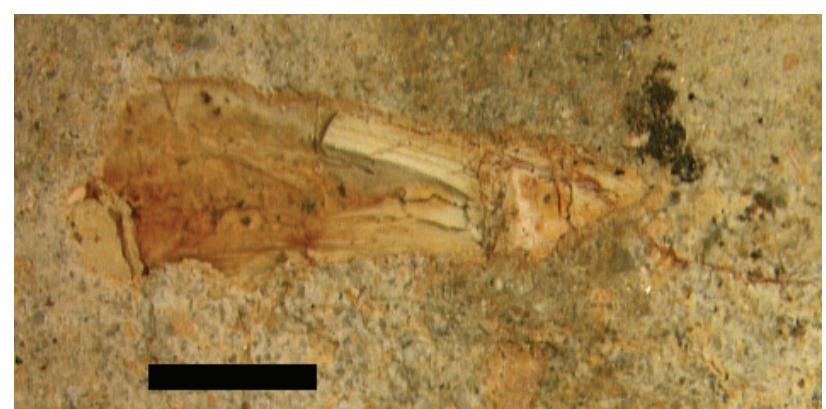

Figura 62 - Dente fragmentado de Palaeonisciformes, proveniente do topo da Formação Tatuí no Afloramento 5. Escala 2mm.

Como o contato Tatuí-Irati no Afloramento 5 é gradual e representado por intercalações de camadas da Formação Tatuí na base do Membro Taquaral, tais peixes podem não ser necessariamente associados a Formação Tatuí, mas sim a uma transição Tatuí- Irati. 
Associados aos conchostraceos da Fácies síltica arenosa do Afloramento 12 ocorrem ictiofósseis. Foi encontrado um exemplar de escama paleoniscóide com mais de $10 \mathrm{~mm}$ de comprimento (Fig. 63). Trata-se um molde externo em relevo negativo. Devido ao modo de preservação foram revelados detalhes surpreendentes de sua morfologia. O formato original da escama era romboédrica com toda a superfície de imbricação e costelas longitudinais superficiais preservadas. $\mathrm{Na}$ face superior foi possível até mesmo registrar a pequena marca da articulação "peg-and-socket".

Comparado com fósseis descritos por CHAHUD (2007) e CHAHUD \& PETRI (2008b), conclui-se que tal fóssil não sofreu retrabalhamento, tendo sido depositado logo após a desarticulação do corpo do peixe. Esta escama deveria pertencer a um dos maiores Palaeonisciformes que habitaram a região, comparável em tamanho, aos fosseis de grandes paleoniscoides do Membro Taquaral, unidade sobrejacente (CHAHUD \& PETRI 2008b).

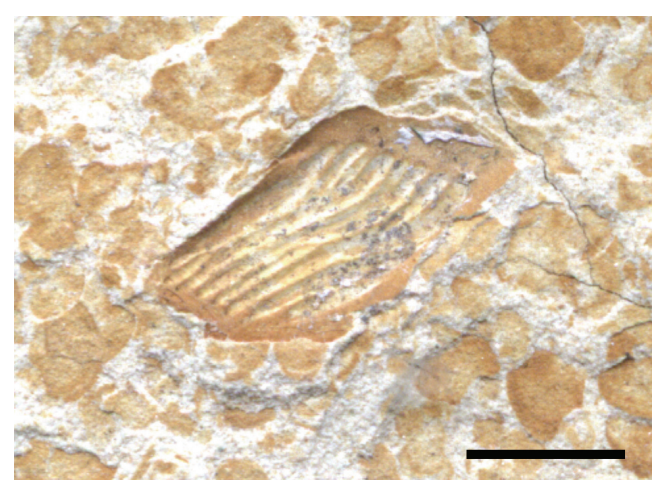

Figura 63 - Escama de Palaeonisciformes, associada aos conchostráceos, encontrado no Afloramento 12 (GP/2E-6585). Escala 5mm.

\subsection{Hipóteses paleoambientais referentes à Formação Tatuí}

A partir dos dados levantados em afloramentos e do estudo dos fósseis até agora descobertos e identificados, foi possível deduzir dois contextos paleoambientais para a Formação Tatuí.

O mais evidente está relacionado com a Fácies Ibicatu da região de Araras e Leme, Afloramento 9, em que são encontrados caules de pteridófitas e espermatófitas de grande porte. Depósitos de alta energia provavelmente associados a canais contínuos e os vegetais teriam sido transportados durante grandes enxurradas, como às que ocorrem em tempos atuais na Região Sudeste do Brasil. Depósitos semelhantes também foram observados nos afloramentos 7, 11 e 12, que possuem fácies de constituição sedimentológica similar, porém sem a presença de restos fósseis. 
Esta fácies representaria depósitos de domínio de água doce em que o paleoambiente era dominado por sistema de rios de alta energia que poderiam ter formado depósitos deltaicos como sugeriu STEVAUX et al. (1986). Estes rios poderiam ter empurrado o grande corpo d'água, responsável pelos depósitos das formações Rio Bonito e Palermo, para regiões mais ao sul.

Esta hipótese é viável, pois rios controlando a posição da linha de costa são observados em tempos atuais. Um exemplo são as relações do Rio São Franscisco e outros rios menores que se dirigem diretamente para o oceano. Os sedimentos trazidos pelos rios barram as suas desembocaduras e as correntes costeiras provocam os deslocamentos dos rios a jusante da corrente costeira, crescendo o continente para o sul (BACOCCOLI, 1971; GAMA Jr. 1976).

O recuo do grande corpo d'água para regiões ao sul da bacia, também, poderia ser resultado de mudanças ocasionais do nível do Mar Palermo. Tais mudanças foram observadas por PERINOTTO (1992) e ZACHARIAS \& ASSINE (2005) que relataram variações dos níveis dos corpos d' água durante a deposição das formações Rio Bonito e Palermo, que poderiam afetar os depósitos da Formação Tatuí em São Paulo.

Com o recuo do Mar Palermo foram isoladas lagoas e lagunas na linha de costa, tornando-se, com o tempo, dulceaquícolas, permitindo a existência de conchostráceos. Tais lagoas poderiam ter tido sua composição química modificada sazonalmente, levando diversos conchostráceos a morte, formando coquinas.

Em uma segunda mudança paleoambiental os depósitos tempestíticos ou de decantação sucederam os de água doce.

Os depósitos tempestíticos seriam representados por arenitos finos com estratificação cruzada de grande porte e hummockies que podem ser observados nos afloramentos do Sitio Santa Maria (Afloramentos 1, 2 e 3), Afloramento 4 (Ponte sobre o Rio Passa Cinco), Afloramento 6 (Km 150 da Rodovia do Açúcar) e no ponto C do Afloramento 12 (Fazenda Ponte Nova).

Os depósitos de decantação são siltitos ou arenitos muito finos, encontrados em contato com a Formação Irati. Estes depósitos foram observados no Afloramento 5 (Próximo ao Rio Passa Cinco, ocorrência de Clarkecaris), Afloramento 8 (Rodovia SP304, Km, 151, entre Piracicaba e Santa Bárbara D’Oeste) e Afloramento 10 (Rodovia Irineu Penteado). Em todos estes casos ocorre o contato direto com a Formação Irati.

Observações nos afloramentos com depósitos tempestiticos conduziram à interpretação de que se trata de um corpo de água de grande extensão, sugerido pelo 
tamanho métrico das estruturas observadas. Tal corpo seria relacionado aos depósitos da Formação Palermo (PERINOTTO, 1992), sugerindo que os grandes rios atuantes na região não eram mais importantes no controle da linha da costa ou pelo aumento do nível do corpo d'água. Este evento é posterior ao dos rios, como observado no Ponto C do Afloramento 12, onde o corpo arenoso grosso, correlacionado à Fácies Ibicatu, é subjacente ao de arenitos finos com estratificação cruzada em contato com a Formação Irati. Esta hipótese reforça a proposta de ASSINE et al. (2003), que separa os depósitos da Fácies Ibicatu dos arenitos da base da Irati.

Os Afloramentos representados por depósitos de decantação (afloramentos 5, 8 e 10) foram formados provavelmente afastados da linha de costa e da ação de ondas e teriam se formado na mesma época dos depósitos tempestíticos.

Contudo durante um período as enxurradas que afetaram os depósitos da fácies Ibicatu, ainda se manifestariam como camadas arenosas grossas ou conglomeráticas, de diferentes espessuras nas fácies siltico-arenosas dos Afloramentos 8, $11 \mathrm{e} 12$, sugerindo que a influência de rios e de enxurradas não havia parado imediatamente, mas teria sido gradual. No afloramento 11 ocorrem ainda estratificações flaser nestes pequenos corpos arenosos. Tanto neste afloramento quanto no afloramento 7 ( $\mathrm{Km} \mathrm{152,5}$ da Rodovia do Açúcar) ocorrem estratificações sigmóides e "espinha de peixe",modificando o topo da fácies Ibicatu nestes afloramentos, sugerindo a presença de marés.

A influência dos depósitos de marés aparentemente é mais presente nos depósitos ao sul, pois o topo da fácies Ibicatu do afloramento da Fazenda Ponte Nova não apresenta estratificações sigmóides, sendo caracterizado pelos depósitos de enxurradas, observados no Ponto $\mathrm{C}$ deste afloramento. Segundo levantamentos históricos do afloramento 9, seção tipo da fácies Ibicatu, não foram observadas estratificações sigmóides ou evidencias de marés (STEVAUX et al. 1986; MOCHIZUKI, 2001; ASSINE et al. 2003; FERNANDES, 2004)

O topo da Formação Tatuí é caracterizado por uma regressão, registrada principalmente nos afloramentos onde ocorrem os depósitos tempestíticos em contato arenoso brusco com a Formação Irati, marcado por uma discordância erosiva. O Afloramento 1 foi o que melhor representou essa regressão, com as grandes estruturas de tempestade gradualmente substituídas por marcas onduladas e, em seguida, um arenito maciço com icnofósseis. Estes, únicos na região, estariam possivelmente relacionados com a icnofácies Psilonichnus, praial aérea, indicando o recuo total do grande corpo de água naquele ponto. 
Na região centro-leste de São Paulo este grande corpo d'água, que resultou nos depósitos do topo da Formação Tatuí, não fornece informações sobre salinidade, por causa da total ausência de fósseis indicadores de água doce ou salgada. Contudo em depósitos correlatos no sul do Estado de São Paulo e da Formação Palermo na Região Sul foram observados acritarcos (Michrystridium) no contato Palermo (Tatuí em São Paulo) e Irati (CAZZULO-KLEIPZIG et al. 1989; PERINOTTO, 1992; ARAÚJOBARBERENA,1993; MARASCO et al.,1993). Estas observações sugerem salinidade para o corpo d'água, mas não necessariamente marinho como sugeriram alguns destes autores. Pelo menos o ambiente não foi salino o suficiente para a colonização de corais, cefalópodes e outros seres vivos marinhos e também não teria sido de água doce para suportar conchostráceos e carófitas.

A presença de acritarcos não deve ser considerada indicadora marinha e sim da presença de salinidade mínima, pois acritarcos ocorrem logo que é injetada alguma água salina no ambiente. Um exemplo significativo ocorreu na fase "Yoldia Sea", referente a evolução do Mar Báltico, que representou uma fase de salinidade entre duas dulceaquícolas e de confinamento do Mar Báltico, que durou apenas 200 anos, no final do Pleistoceno. Nesta fase foi encontrado um único gênero de acritarco junto com algas de água doce (BRENNER, 2005), similar ao que ocorre na Formação Palermo e Formação Tatuí, contudo o ambiente do Mar Báltico era controlado pelo degelo glacial o que não ocorreu nessa época, na Bacia do Paraná.

Os foraminíferos aglutinantes, citados por FÚLFARO et al. (1984), estariam na base da Formação Tatuí e não no topo. Tais fósseis poderiam estar associados aos moluscos (SIMÕES, 1992) e braquiópodes (HOLZ et al.1998) descritos em São Sepé, Rio Grande do Sul, base da Formação Palermo, ou relacionados às ultimas transgressões marinhas da Formação Rio Bonito (ZACHARIAS \& ASSINE, 2005). Se esta interpretação estiver correta, poder-se-ia afirmar que, anteriormente ao "domínio da água doce", os depósitos da base da Formação Tatuí teriam sido formados em paleoambiente salino passando gradualmente a dulciaquícola. Em visita ao Afloramento do Córrego do Veado, tais foraminíferos (citados por STEVAUX et al. 1986) não foram encontrados nas camadas silticas e na Fácies Ibicatu. Provavelmente estariam abaixo da fácies Tag e seriam correlatos à fácies basal do Afloramento da Fazenda Ponte Nova, de ambiente costeiro. 


\section{PALEONTOLOGIA DA FÁCIES ARENOSA DO MEMBRO TAQUARAL}

\subsection{Apresentação}

A Fácies arenosa da base do Membro Taquaral (fácies Iai) é conhecida desde os tempos de WASHBURNE (1930), porém sua posição estratigráfica sempre foi motivo de discussão, principalmente nas décadas de 1970 e 1980.

Alguns pesquisadores como AMARAL (1971) não consideraram o Membro Taquaral pertencente à Formação Irati, que seria restrito ao Membro Assistência. Apesar disso, já na época de AMARAL (1971), o termo Membro Taquaral já era bastante aceito.

SOARES (1972) considerava esta fácies como topo da Formação Tatuí e a correlacionou com os "Conglomerados Imbicatu" (Fácies Ibicatu em terminologia posterior). Foi aceito por outros pesquisadores da época e mais recentes com GAMA Jr. et al. (1982) e CABRAL Jr. et al. (1988). Esta posição estratigráfica não foi aceita por todos, RAGONHA (1978) a colocou na Formação Irati.

Na década de 1990 e nos primeiros anos do século XXI, a unidade voltou a ser alvo de estudos sedimentológicos e estratigráficos que discordavam das observações de SOARES (1972). Os primeiros trabalhos foram de HACHIRO (1997), o qual, pela evolução estratigráfica, considerou a unidade como parte da evolução da Formação Irati.

RICCOMINI et al. (1997) vai além e descreveu um afloramento em que foi possível observar a unidade dentro dos siltitos do Membro Taquaral na região de Rio Claro, reforçando a hipótese de HACHIRO (1997). Posteriormente ASSINE et al. (1999; 2003) caracterizaram a unidade como um depósito residual pertencente a Formação Irati, reforçada por CHAHUD (2007) a partir de estudos paleontológicos.

Segundo HACHIRO (1997) e CHAHUD (2007), a fácies arenosa do Membro Taquaral (fácies Iai) é mais comum no centro leste de São Paulo do que no sul do estado e no Paraná (LAGES, 2004) podendo ter dois litossomas. A primeira, mais comum, consiste de quartzo - arenitos conglomeráticos de espessura de poucos centímetros $(5-100 \mathrm{~cm})$, constituídos basicamente de grânulos e seixos de sílex em matriz arenosa variando de média a fina. Os grânulos e seixos variam de angulosos a arredondados e podem exibir contatos entre si ou não. $\mathrm{O}$ acamamento é característicamente lenticular com estratificação cruzada regular ou ondulações. Ocorre 
grande quantidade de paleoictiofósseis em diferentes tamanhos e estados de preservação. Esta composição sedimentológica foi observada nos afloramentos 1-4 e 12

O segundo litossoma é constituído de arenitos finos, bem selecionados, com poucos clastos. Geralmente são maciços, mas podem apresentar laminação planoparalela levemente ondulada e descontínua. Os clastos são muito pequenos $(<1 \mathrm{~cm}$ de comprimento) e angulosos, constituídos normalmente de grãos de quartzo e fragmentos de rocha de coloração escura. Os ictiólitos, presentes nesta litologia, estão muito fragmentados e só foram observados no Afloramento 5.

No centro-leste de São Paulo foram observados apenas vertebrados fósseis nesta Fácies, sendo a mais fossilífera do presente estudo e, até o momento, a mais importante pela grande diversidade de grupos e espécies.

\subsection{Estudos paleoictiológicos e de tetrápodes basais}

Em classificações antigas os peixes constituíam uma superclasse, Pisces, abrangendo as classes Osteichthyes e Chondrichthyes, excluindo a Agnatha. Atualmente são considerados "peixe" todos os vertebrados dotados de notocorda e crânio (RICHTER et al. 2004). O termo "peixe" ainda é bastante utilizado em trabalhos científicos, porém alguns pesquisadores (MAISEY, 1994) não o consideram válido, por causa da relação filogenética de peixes com e sem mandíbula.

Os Ágnatos (parafiléticos), peixes sem mandíbulas, são os mais primitivos conhecidos e incluem as Superclasses Myxinomorphi, Petromyzontomorphi, Conodonta, Pteraspidomorphi, Anaspida, Thelodonti e Osteostracomorphi (NELSON, 2006).

Os Gnathostomata compreendem as classes Chondrichthyes, Actinopterygii e Sarcopterygii (NELSON, 2006), estas duas últimas compõem os peixes ósseos, Osteichthyes. De Sarcopterygii teriam surgido os tetrápodes.

A classificação adotada nesta tese é baseada nos estudos ictiológicos de NELSON (2006). A seguir são citados apenas os vertebrados permianos observados na Bacia do Paraná:

Filo Chordata

Subfilo Craniata (Cambriano - Recente) Superclasse Gnathostomata (Siluriano - Recente) Classe Acanthodii (Siluriano - Permiano) Classe Chondrichthyes (Siluriano-Recente) Subclasse incertae sedis 
Ordem Orodontiformes $\uparrow$ (Devoniano - Permiano)*

Subclasse Elasmobranchii (Devoniano - Recente)

Infraclasse Euselachii

Incertae Ordinis - dentes cladodontes $\uparrow$ (Devoniano -

Triássico) e espinhos indeterminados de Euselachii $\dagger$

Ordem Ctenacanthiformes $\uparrow$ (Devoniano - Triássico)

Ordem Xenacanthiformes $\uparrow$ (Devoniano - Triássico)

Subclasse Holocephali (Devoniano - Recente)

Ordem Petalodontiformes $\uparrow$ (Carbonífero - Permiano) ${ }^{* *}$

Classe Actinopterygii (Siluriano - Recente)

Subclass Chondrostei (Siluriano - Recente)

Ordem Palaeonisciformes (Parafilética) $\uparrow$ (Siluriano -

Cretáceo)

Classe Sarcopterygii (Devoniano - Recente)

Subclasse Coelacanthimorpha (Actinistia) (Devoniano -

Recente)

Subclasse Osteolepimorpha $\uparrow$ (Devoniano - Permiano)

(† extinto)

* Orodontiformes é aceito como Elasmobranchii (ZANGERL, 1981) ou Holocephali

(NELSON, 2006) por isso foi considerado no presente estudo como indeterminado. GROGAN \& LUND (2000; 2004) sugerem a nova subclasse Euchondrocephali, considerada sinônima de Holocephali para NELSON (2006)

** Petalodontiformes é aceito também como Elasmobranchii (STAHL, 1999) e como um Chondrichthyes basal (JANVIER, 1996).

O conhecimento dos principais grupos, anatomia, habitats e histórico evolutivo auxiliam na interpretação da origem dos depósitos em que se encontram. Este capítulo apresenta as características gerais dos grupos vertebrados relevantes para pesquisas na base do Membro Taquaral da Formação Irati.

\subsection{Classe Chondrichthyes}

Os Chondrichthyes constituem um dos grupos de vertebrados de maior sucesso evolutivo. Os fósseis mais antigos deste grupo foram encontrados em rochas silurianas da Europa. Mas foi durante o Devoniano e o Neopaleozóico que ocorreu sua maior diversificação evolutiva e ecológica, levando este grupo a ocupar diversos nichos ecológicos em praticamente todos os continentes e oceanos (LONG, 1993).

Os Chondrichthyes são caracterizados pelo esqueleto interno revestido basicamente de cartilagem de calcificação prismática (por isso são conhecidos como peixes cartilaginosos), pele revestida por escamas placóides, boca ventral, narinas não 
comunicantes com a boca e intestino com válvula espiral. A respiração é feita através de brânquias presas a bolsas branquiais em que cada uma comunica-se com o meio externo por uma fenda (RICHTER et al. 2004).

A composição cartilaginosa do esqueleto prejudica as chances de preservação de seus restos. Por isso, seu registro é escasso e normalmente os fósseis encontrados não são completos, restringindo-se apenas a espinhos, escamas placóides e dentes. A cartilagem, no entanto, trouxe vantagens para esse grupo, uma vez que é leve e flexível, resultando em maior agilidade e tornando-os mais eficientes como predadores.

O grupo é composto das subclasses Elasmobranchii e Holocephali, ambas com representantes fósseis e atuais.

\subsubsection{Escamas placóides}

Escamas de Chondrichthyes (escamas placóides) não são raras no registro fóssil, mas são pouco estudadas quando comparadas a espinhos e dentes. Sua importância é maior no entendimento da evolução dos primeiros Chondrichthyes durante o Eopaleozóico (TURNER \& MILLER, 2005). O estudo de formas neopaleozóicas e recentes é complexo, pois as escamas de diversos grupos são semelhantes, o que dificulta sua diferenciação taxonômica.

A escama placóide é constituída de uma camada de odontode, caracterizando a coroa, conectada perpendicularmente a uma estrutura de tecido ósseo, que forma a base. O odontode é a unidade básica de dentes e escamas. É caracterizado por uma cavidade interna de tecido mole, contendo freqüentemente vasos sanguíneos, coberto por uma camada de dentina e capeada por um tecido hipermineralizado (por exemplo, esmalte ou enamelóide) (TURNER \& MILLER, 2005).

Um exemplo são as diversas escamas de Chondrichthyes descritas por DIAZSARAVIA (2001) do Carbonífero da Argentina. A identificação é incerta e foram classificadas inicialmente como escamas de Ctenacanthiformes e Hybodontiformes.

\section{Possível escama encontrada no Membro Taquaral}

Ordem incertae sedis

Gênero Petrodus (?)

Fig. 64 
Material - GP/2E-5935A. Dentículo isolado.

Localidade - Sítio Santa Maria, município de Rio Claro.

Distribuição geográfica e estratigráfica - Permiano Membro Taquaral da Formação Irati no Estado de São Paulo.

Descrição: O exemplar (fig. 64) representa a coroa de um dentículo dérmico parcialmente desgastado, incrustado na rocha e com a base e parte da superfície perdida. A superfície do dentículo revela inúmeras costelas longitudinais que se bifurcam, tornando-se mais estreitas próximas da base. $\mathrm{O}$ topo aparentemente é liso e plano. $\mathrm{O}$ fóssil tem 2,5mm de comprimento máximo e 1,4mm de altura.

Discussão: Pouco foi preservado do exemplar por isso a classificação como Petrodus é incerta. A coroa com cristas convergindo na parte superior é semelhante aos descritos por ELLIOTT et al. (2004) do Carbonífero da América do Norte e alguns de CIONE et al. (2010) do Permiano da Argentina.

Os dentículos dérmicos associados do gênero Petrodus são comuns no Neopaleozóico, mas não haviam sido observados em rochas da Bacia do Paraná. Segundo ZANGERL (1981), ELLIOTT et al. (2004) e CIONE et al. (2010) sua afinidade taxonômica é discutível, podendo ser associados aos Elasmobrânquios ou à Holocephali.

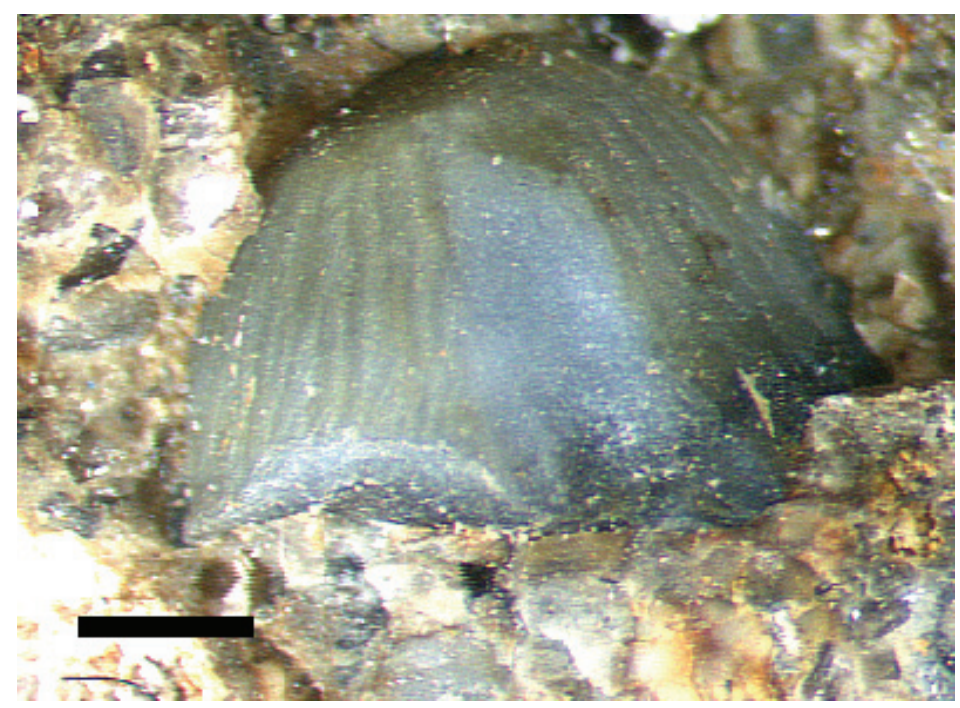

Figura 64 - Petrodus (?) GP/2E-5935a. Escala 0,5mm.

\subsection{Dentição de Chondrichthyes Paleozóicos}

Os dentes de tubarões paleozóicos têm variadas formas de cúspides e base.

Recentemente TURNER \& MILLER (2005) separaram os diferentes tipos de dentes em 
quatro grupos para os Elasmobranchi: cladodonte, diplodonte, hibodonte (Fig. 65) e simmorideo.

\section{Dentes Cladodontes}

(1)

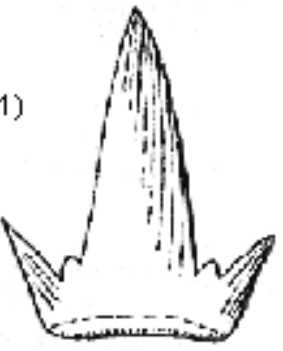

Cladoselache

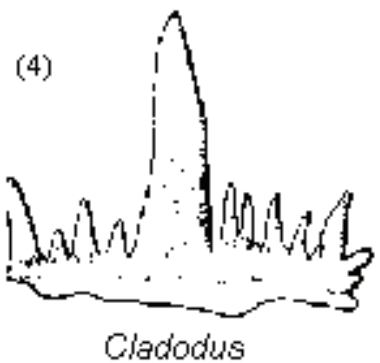

(2)

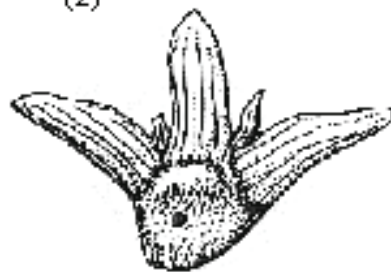

Phoebodus
(3)

(4)

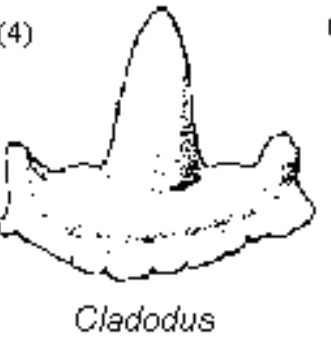

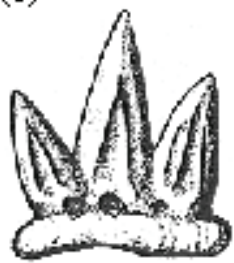

Bandringa

(5)

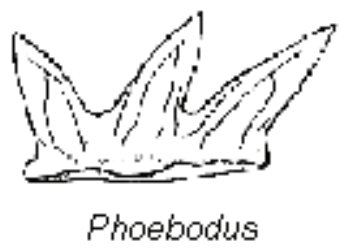

Phoebodus

\section{Dentes Hibodontes}

(2)

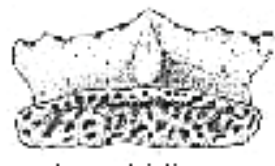

(2)

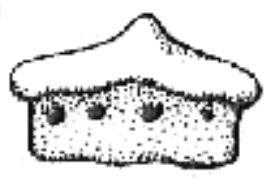

Onichoselache

Dentes Diplodontes

(1)

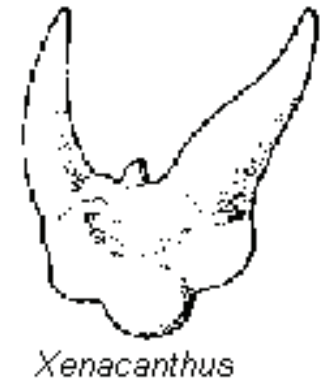

(6)

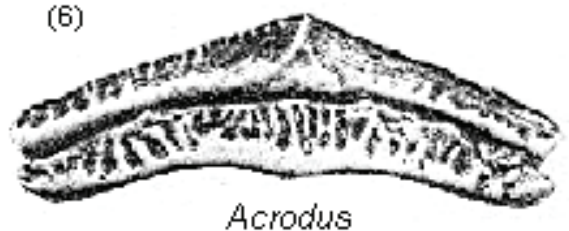

(1)

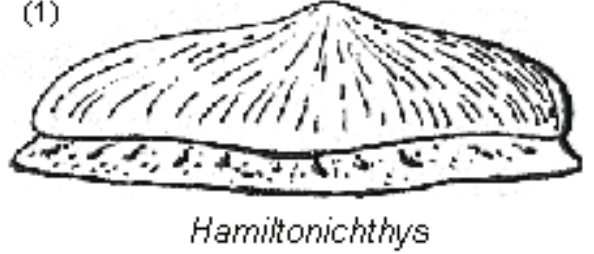

(1)

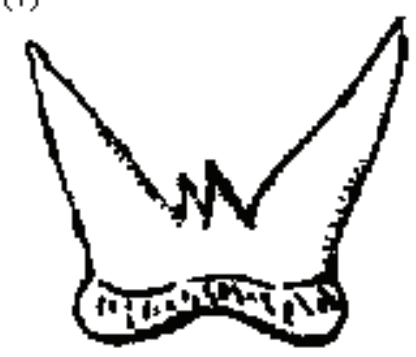

Diplodoselache

Figura 65 - Variedade de dentes cladodontes, hibodontes e diplodontes (1. JANVIER, 1996; 2. LONG, 1993; 3. BAIRD, 1978; 4. MOY-THOMAS \& MILES, 1971; 5. LONG, 1995; 6. JOHNSON, 1981). 
Os dentes cladodontes são caracterizados por uma grande base com uma coroa alta composta de uma cúspide central maior e de laterais menores, posicionadas próximas da margem labial (MOY-THOMAS \& MILES, 1971, RAGONHA, 1978, RICHTER, 1985).

Os dentes simmorideos e cladodontes são muito parecidos, mas o primeiro é mais comum no Devoniano. Os dentes diplodontes (Fig. 65) são identificados por duas grandes cúspides laterais divergentes. São características comuns e diagnósticas da ordem Xenacanthiformes e de alguns tubarões primitivos do Devoniano, como Antarctilamna da Antártida.

Os dentes do tipo hibodonte apresentam a base lateralmente alongada com a parte central da coroa mais elevada que as extremidades (Fig. 65), formando uma cúspide mediana central inclinada em relação à base. O comprimento longitudinal é muito maior que a largura, a parte superior da coroa é marcada por uma crista oclusal mediana ou submediana, no qual podem partir costelas oblíquas secundárias que se ramificam para os lados (JOHNSON, 1981).

Os dentes hibodontes são comuns em três grupos de peixes no Paleozóico, Hybodontiformes, Protacrodontiformes e Orodontiformes.

GINTER et al. (2002) chamaram a atenção para a separação dos dentes de Protacrodontiformes e Orodontiformes, muito semelhantes e de difícil diferenciação. Os protacrodontes possuem cúspides com contato entre si, com substituição parcial da ortodentina por osteodentina e dentina tubular. A base normalmente com extensão lingual curta e a coroa possui uma crista muito forte.

Os Hybodontiformes do Paleozóico normalmente não apresentam costelas ou finas cristas nas cúpides. O gênero Acrodus (JOHNSON, 1981) é um dos poucos que possuem esta característica. São os que mais se assemelham aos Orodontiformes, diferindo apenas na base, que em Acrodus é menor, côncava em sua parte inferior central, e na disposição da cúspide principal muito rebaixada (JOHNSON, op. cit).

Outro tipo de dentição comum em Chondrichthyes é a dentição bradiodonte, placas dentárias romboédricas maciças compostas de dentina tubular e trabecular. Este tipo de dentição é observada nos Chondrichthyes da subclasse Holocephali, que será discutida mais adiante. 


\subsection{Dentes cladodontes}

Os dentes tipo cladodonte são conhecidos desde o século XIX e sempre foram associados a Chondrichthyes primitivos. Basicamente os cladodontes (Figs. 66 e Tabela 3) são caracterizados por uma base de dente larga com maior desenvolvimento na face lingual, uma cúspide central grande e um número variável de cúspides laterais. Em corte transversal, as cúspides variam de circulares a ligeiramente ovaladas (por vezes em forma de D).

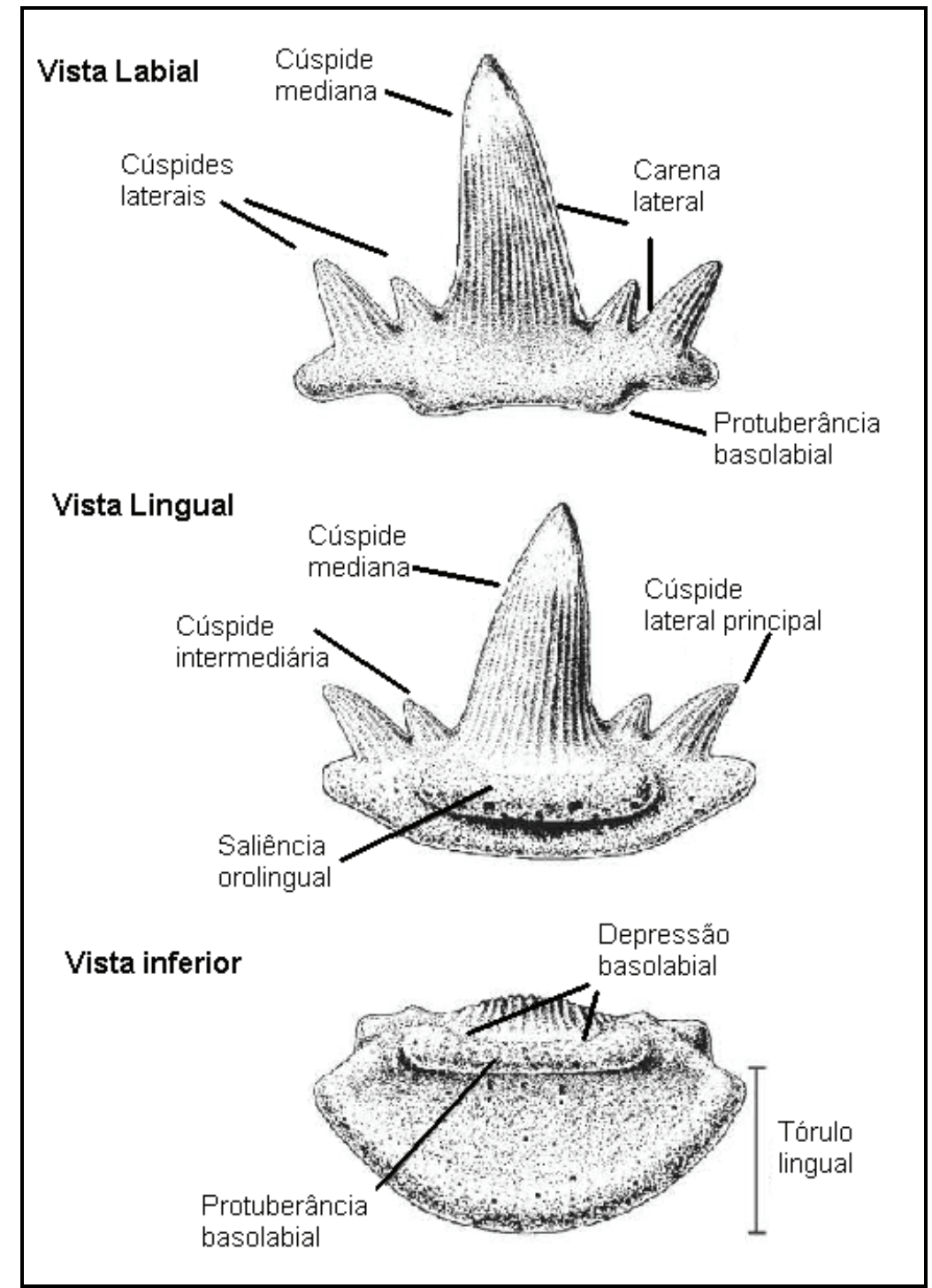

Figura 66 - Esquema de dente Cladodonte proposto por DUFFIN \& GINTER (2006).

Esta descrição generalista resultou na atribuição ao gênero Cladodus, no século $\mathrm{XX}$, de grande número de formas que seriam mais propriamente colocadas em gêneros diferentes (ZANGERL, 1981, LONG, 1995). A revisão de DUFFIN \& GINTER (2006), restringiu o gênero Cladodus a apenas seis espécies. Outros exemplares, antes atribuídos a Cladodus, pertenceriam a outros grupos de Ctenacanthiformes. 
DUFFIN \& GINTER (2006) compilaram 48 espécies atribuídas ao gênero Cladodus no final do século XIX, número aumentado para mais de 70 no inicio do século XXI. Para a diagnose corrigida deste gênero, estes autores consideraram características comuns às mencionadas nas espécies por eles validadas. DUFFIN \& GINTER (2006) descreveram e organizaram os gêneros de vários tubarões com dentição cladodonte. Separaram características morfológicas importantes para diferenciação de diversos gêneros. Consultando outros trabalhos (WILLIAMS, 1985; GINTER \& IVANOV, 1992; DUFFIN et al. 1996; GINTER et al. 2002; GINTER, 2002; GINTER et al. 2005; IVANOV, 2005), foi possível acrescentar na tabela proposta por DUFFIN \& GINTER (2006), os gêneros Denaea, Heslerodus e Phoebodus, muito comuns em depósitos do Neopaleozóico (Tabela 3).

A análise de dentes cladodontes realizadas por GINTER et al. (2005) e DUFFIN \& GINTER (2006) ainda deve ser considerada em andamento, pois foram poucos os fósseis permianos analisados e poucos os fósseis gondwânicos estudados, resumindo a formas devonianas (TURNER, 1982; TURNER \& YOUNG. 1987).

O gênero Phoebodus foi alvo de investigação dentre os que estudaram tubarões Ctenacanthiformes e Xeanacanthiformes, pois está associado aos Xeanacanthiformes por causa da dentição semelhante. Ao contrário de outros cladodontes, foram estudados formas gondwanicas da Austrália e África, porém todas restritas ao Devoniano e Eocarbonífero (TURNER, 1982; TURNER \& YOUNG. 1987; TURNER e YOUNGQUIST, 1995; GINTER et al. 2002).

Os Phoebodus estão entre os Chondrichthyes mais antigos. LIAO et al. (2007) descreveram dentes e dentículos dérmicos de Chondrichthyes do Givetiano (Devoniano) pertencentes a Phoebodus fastigatus. Os fósseis foram encontrados em carbonatos associados a fósseis marinhos: trilobitas, briozoários e foraminíferos. 
తิ

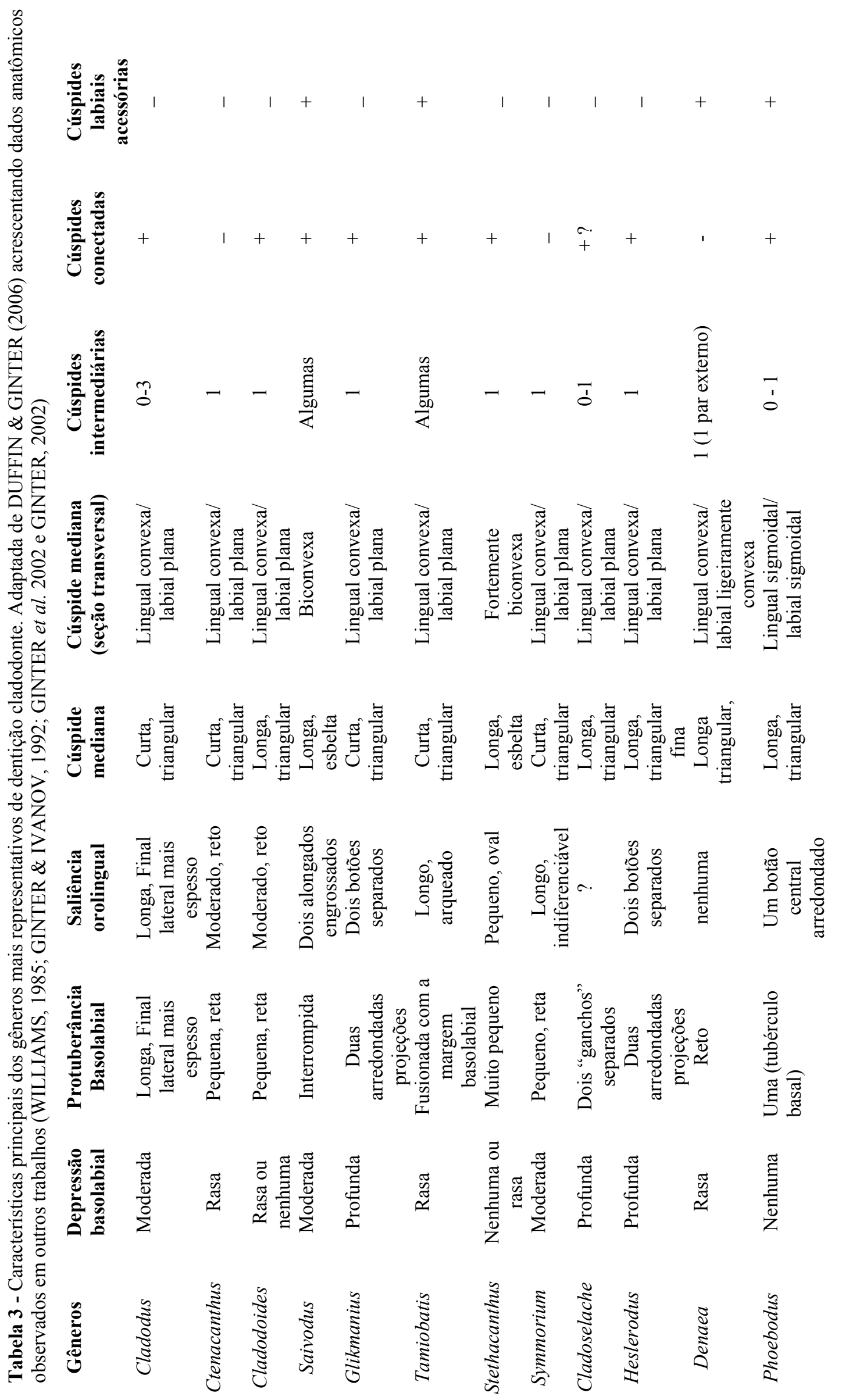




\subsubsection{Revisão dos Cladodontes sul-americanos}

“Cladodus” parauariensis descrito por SILVA SANTOS (1967) foi o primeiro fóssil de um dente cladodonte formalmente descrito na América do Sul. A espécie, baseada em um único dente, é proveniente da Formação Itaituba, Eopensilvaniano, da Bacia do Amazonas (MATSUDA et al. 2004). O fóssil foi encontrado associado a braquiópodes, cefalópodes, gastrópodes e bivalves indicando ambiente deposicional marinho.

SILVA SANTOS (1967) o comparou a vários gêneros que possuem dentição tipo cladodonte como Cladodus, Denaea, Symmorium, Ctenacanthus e Goodrichia concluindo que o fóssil apresentava maior semelhança com dentes atribuídos a Cladodus do Carbonífero da Grã Bretanha e Estados Unidos, como C. gomphoides, $C$. intercostatus (= C. elegans para DUFFIN \& GINTER, 2006) e C. bellifer, atribuindo-o, portanto, ao gênero Cladodus. A partir das revisões de dentes cladodontes de GINTER et al. (2005) e DUFFIN \& GINTER (2006) "Cladodus" parauariensis pode ser comparável não a Cladodus, mas a Glikmanius, devido à presença do botão preservado na região orolingual e pelas protuberâncias basolabiais.

Na mesma Formação Itaituba, foi descrito por DUFFIN et al. (1996), outro exemplar, atribuído com reservas, ao gênero Denaea, do Carbonífero, baseado em características morfológicas externas. O fóssil é um dente fragmentado em uma das laterais, com desgaste em toda a superfície.

DUFFIN et al. (1996) também descreveram, na mesma formação, um dente muito fragmentado, classificando-o, com reservas, ao gênero (?)Triodus, discutindo e rejeitando a possibilidade de ser Phoebodus, baseados em GINTER \& IVANOV (1992). Estudos posteriores evidenciaram, contudo, característica como o botão apical citados pelos mesmos autores DUFFIN et al. (1996), que pode ser encontrado no gênero Phoebodus. O exemplar também mostra abrasão, além de fraturas (base quase destruída e apenas um fragmento preservado das cúspides) o que dificulta a classificação genérica.

BARCELLOS (1975) descreveu outro cladodonte sul americano na Bacia do Paraná, proveniente da Fácies Budó, Permiano do Grupo Itararé do Rio Grande do Sul. BARCELLOS (1975) atribuiu, com reservas, ao gênero Cladodus, embora a própria autora tenha notado semelhanças com Danaea. Realmente parece ser mais apropriada a referência ao gênero Danaea, tendo em vista comparações com formas descritas deste 
gênero em outras localidades do mundo (DUFFIN et al. 1996, IVANOV, 2005, WILLIAMS, 1985).

O único cladodonte do Neopermiano brasileiro, citado na literatura científica, é proveniente da Formação Corumbataí do Estado de São Paulo. O fóssil, fragmentado, foi ilustrado por WÜRDIG-MACIEL (1975). A autora não detalhou suas características anatômicas, mas é possível observar, na ilustração publicada, semelhanças com o dente descrito por SILVA SANTOS (1967) da Formação Itaituba tais como uma das laterais maior e com uma cúspide intermediária a mais que a outra.

Há apenas mais um trabalho sobre cladodontes na América do Sul. Trata-se de um fóssil, muito fragmentado, proveniente da Formação Copacabana, Eopermiano, Bacia Madre de Dios (AZCUY et al., 2007) da Bolívia, descrito por MERINO-RODO \& JANVIER (1986). Estes autores sugeriram o gênero Cladodus em comparação com Cladodus mirabilis, porém a característica diagnóstica do gênero proposta por GINTER et al. (2005) não foi observada podendo, por isso, ser atribuído também a Glikmanius, Tamiobatis ou Denaea.

\subsubsection{Descrição de cladodontes da base do Membro Taquaral}

Classe CHONDRICHTHYES Huxley, 1880 Subclasse ELASMOBRANCHII Bonaparte, 1838

Ordem incertae sedis

Figs. 67-69

Material - GP/2E-5918, dente quase completo separado da matriz rochosa, com algumas quebras e fraturas na coroa (Fig.67), GP/2E-5919, dente completo (Fig.68), GP/2E-6306, dente fragmentado (Fig. 69)

Localização - Afloramento 1: Sítio Santa Maria 1, divisa dos municípios de Rio Claro e Ipeúna, SP.

Estratigrafia - Camada de arenito conglomerático da base do Membro Taquaral, Formação Irati.

Descrição - o dente GP/2E-5918 (Fig.67) possui coroa alta localizada na região labial da base, composta de três cúspides cônicas curvas, sendo a mediana muito maior que as demais.

A cúspide principal tem 4,4 $\mathrm{mm}$ de largura e 4,6 $\mathrm{mm}$ de altura. A base e a coroa têm 10,6 mm de comprimento. As cúspides menores são de tamanhos similares com, aproximadamente, $2 \mathrm{~mm}$ de altura e $0,8 \mathrm{~mm}$ de largura. 
A maior cúspide não está posicionada no centro da coroa, mas deslocada lateralmente. A maior distância de uma lateral ao centro da cúspide principal é 7,4 mm. Todas as cúspides curvam-se em sentido lingual e são ornamentadas por costelas que partem da base e aparentemente percorrem toda a superfície sem ramificações ou bifurcações. As laterais das cúspides exibem pequena inclinação lateral (provavelmente em direção à região posterior do dente). Existe uma tênue crista longitudinal (bordo cortante) que percorre as três cúspides e separa a face labial da lingual. A parte inferior da coroa, em contato com a base, apresenta curvatura côncava, mais acentuada abaixo da cúspide principal.

As cúspides estão em contato direto, sem espaço entre elas. Em vista transversal todas tem forma oval, sendo mais comprimida no sentido labial-lingual e alongada no sentido anterior-posterior.
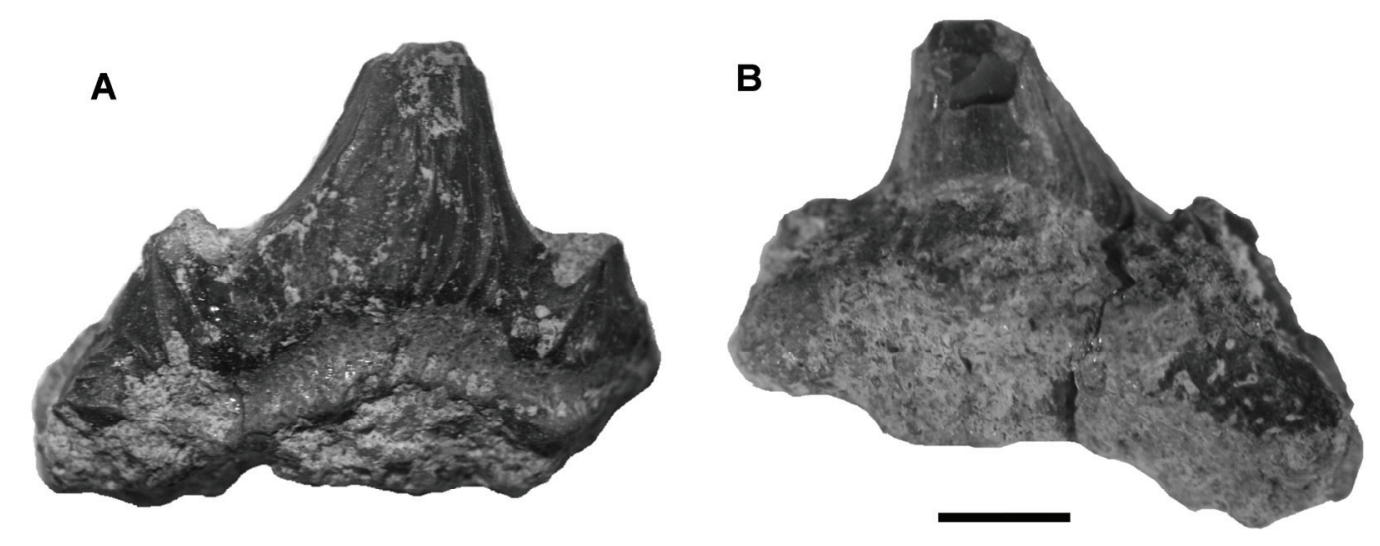

Figura 67 - Cladodonte GP/2E-5918 encontrado na base da Formação Irati. A) vista labial; B) vista lingual. Escala $2 \mathrm{~mm}$.

A base é pouco espessa com um prolongamento maior na face lingual do que na labial. Tem forma alongada e irregular, com uma das laterais maior do que a outra. A base acompanha o comprimento da coroa, sem extensões laterais na parte anterior e posterior, sendo côncava na parte inferior e convexa na parte superior.

Observam-se alguns foramens irregulares, mas nenhuma evidência de tubérculo basal ou de qualquer tipo de proeminência articulatória.

O espécime é pequeno e frágil, mas sem sinais de abrasão e as quebras se limitam apenas aos ápices das cúspides. Por causa de sua fragilidade não foi possível preparar melhor o material e observar sua face lingual. 
O exemplar GP/2E-5919 (Fig.68) é um cladodonte de coroa muito alta, posicionada na região labial da base. É caracterizado por uma única cúspide cônica curva, disposta na região centro-labial.

A cúspide é muito alongada, comparada às do exemplar GP/2E-5918, com altura (11 mm) maior que a da coroa $(9,0 \mathrm{~mm})$. Costelas superficiais são comuns em toda a coroa, com algumas bifurcações próximas do contato com a base. Tais costelas aparecem na base da cúspide e desaparecem na sua região central. A cúspide possui inclinação para uma das laterais, alem de pequena curvatura para a face lingual.

A coroa exibe crista longitudinal proeminente, separando a face labial da lingual na cúspide, muito mais evidente do que em GP/2E-5918. A parte inferior da coroa, em contato com a base, é lisa e plana, sem concavidades ou convexidades.

A base é pouco espessa, com extensões nas duas laterais, tornando-a mais alongada $(10,9 \mathrm{~mm})$ do que a coroa $(9,0 \mathrm{~mm})$. O formato é retangular, acompanhando o formato transversal da área da coroa. A largura máxima da base é de $6,2 \mathrm{~mm}$ e a da coroa 3,2 $\mathrm{mm}$. O prolongamento da face lingual da base, de 3,0 $\mathrm{mm}$ de largura da coroa ocorre até a margem.
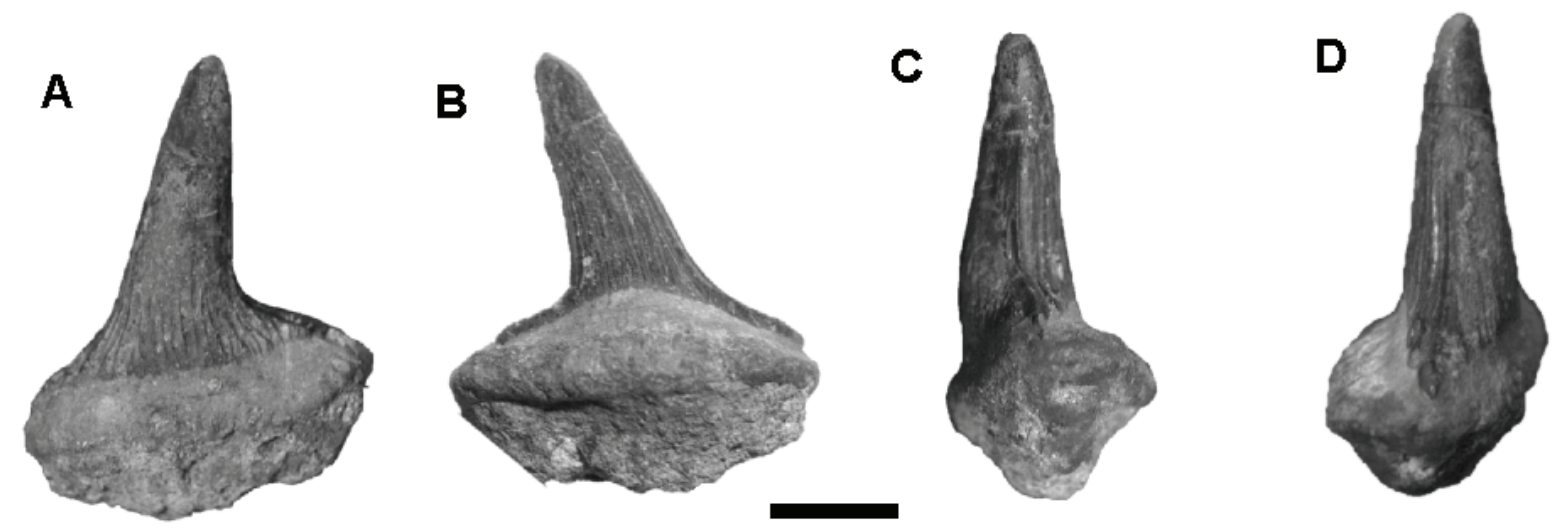

Figura 68 - Cladodonte GP/2E-5919 do Membro Taquaral. A) vista labial; B) vista lingual; C e D) vistas laterais. Escala $2 \mathrm{~mm}$.

$\mathrm{Na}$ base ocorrem alguns foramens irregulares na parte inferior e sulcos na região lingual superior. O exemplar não está desgastado, porém apresenta uma pequena fratura na cúspide. O material arenoso incrustado na parte inferior da base impediu observação desta parte do dente e a fragilidade do material dificulta o processo de preparação do espécime. 
O terceiro dente cladodonte aqui descrito, identificado como GP/2E-6306 (Fig. 69), é o menor dos exemplares encontrados até o momento e o que está em pior estado de preservação. A coroa, apesar de fragmentada, é robusta, posicionada na região labial central da base. Possui duas pequenas cúspides laterais, uma delas está quebrada.

Embora o espécime esteja incompleto, a porção preservada da cúspide mede 1,3 $\mathrm{mm}$ de altura. Costelas ou cristas verticais aparecem na cúspide e em toda a superfície da coroa, com algumas poucas costelas bifurcadas próximas do contato com a base. A cúspide possui uma pequena curvatura para a face lingual, porém não foi possível observar se existe alguma inclinação para as laterais devido a fragmentação.

A coroa exibe uma fina crista longitudinal que se estende pelas laterais da cúspide e separa a face labial da lingual do dente, semelhante a do espécime GP/2E5918.. A parte inferior da coroa, em contato com a base, é lisa e plana, sem concavidades ou convexidades como em GP/2E-5919.

A base é pouco espessa e menor que a coroa. Existe um prolongamento da face lingual da base de $0,9 \mathrm{~mm}$ de largura da coroa até a margem. Ocorrem foramens irregulares na parte inferior e sulcos na região lingual superior. Na base não foram preservados botões apicais ou saliências na face lingual e nem curvaturas na face labial inferior.
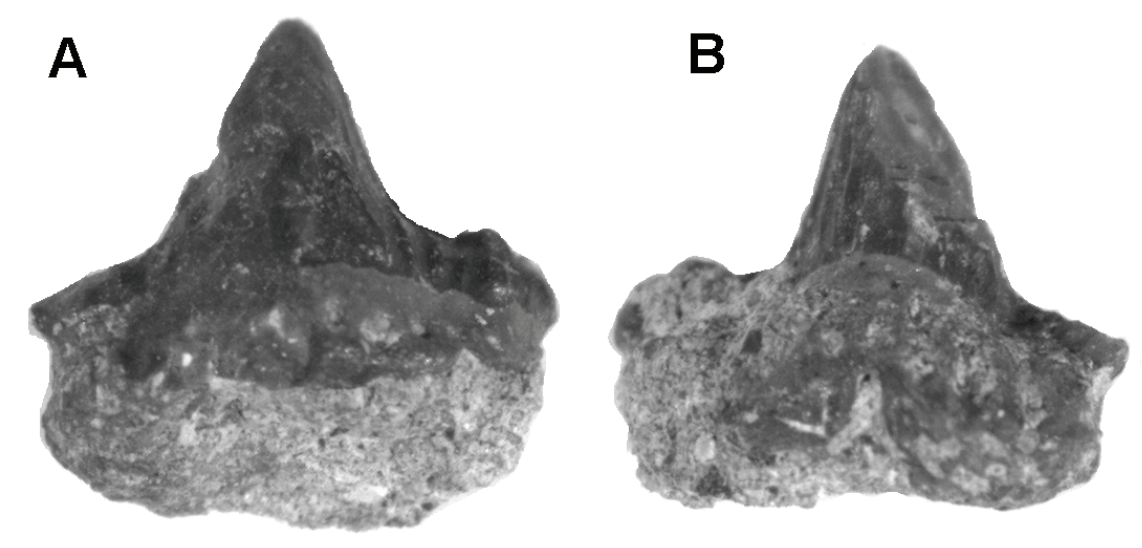

Figura 69 - Cladodonte GP/2E-6306 do Membro Taquaral. A) Vista Labial; B) Vista Lingual. Escala $2 \mathrm{~mm}$.

Discussão: Dentes cladodontes no Neopaleozóico da Bacia do Paraná são raros e o estado de preservação normalmente não é bom. 
Das três formas de cladodontes encontrados na base do Membro Taquaral, o exemplar GP/2E-5918 é semelhante a dois tipos de cladodontes previamente encontrados no Brasil: A) “Cladodus” parauariensis do Neocarbonífero da Bacia do Amazonas (SILVA SANTOS, 1967), em relação ao formato das cúspides e ornamentação por costelas, mas difere desta espécie pelo menor número de cúspides (a espécie amazônica tem cinco), formato da base mais alongada em um dos lados, e a ausência de um minúsculo botão apical na face lingual. B) GP/2E-5918 exibe similaridade com o cladodonte da Formação Corumbataí (WÜRDIG MACIEL, 1975) como o tamanho e ornamentação das cúspides, mas difere na posição e número de cúspides, quatro no fóssil da Formação Corumbataí, sendo uma cúspide principal e três secundárias e a base é plana e sem curvaturas.

GP/2E-5918 têm uma coroa muito parecida com as espécies do Neocarbonífero do hemisfério norte, Glikmanius occidentalis, Cladodus marginatus, Cladodus mirabilis, Cobelodus e Synechodus (DUFFIN \& GINTER, 2006; GINTER et al. 2005, GINTER \& MAISEY, 2007, IVANOV, 2005, LEIDY. 1859). A semelhança está no formato, disposição das cúspides e curvatura da base. No entanto GP/2E-5918 não possui estrias observadas em G. occidentalis, C. marginatus e C. mirabilis. Também é muito parecido com dentes cladodontes atribuídos ao Ctenacanthiformes Tamiobatis, Devoniano dos Estados Unidos (WILLIAMS, 1998, 2001). Os dentes cladodontes de Tamiobatis possuem cúspides robustas, mas a base em Tamiobatis é plana e sem curvaturas basolabiais (WILLIAMS, 1998).

A base é muito similar a dos dentes de tubarões pertencentes ao gênero Heslerodus, Pensilvaniano dos Estados Unidados, por causa da profunda depressão basolabial, porém em Heslerodus a coroa é diferenciada com cúspides laterais muito grandes (GINTER, 2002).

O cladodonte GP/2E-5918 é muito semelhante a espécies do gênero Glikmanius por causa da depressão basolabial profunda, porém serão necessários exemplares melhor preservados para uma identificação definitiva.

Ao contrário dos dentes descritos no Hemisfério Norte, o espécime GP/2E-5918 apresenta assimetria lateral, incomum em dentes de outras localidades, apenas conhecida no exemplar de WÜRDIG MACIEL (1975) da Formação Corumbataí.

O espécime GP/2E-6306 possui uma base muito semelhante a do exemplar $\mathrm{GP} / 2 \mathrm{E}-5919$, porém a coroa é semelhante a do exemplar GP/2E-5918, com cúspides laterais robustas. A coroa de GP/2E-6306 é semelhante a Glikmanius occidentalis e 
“Cladodus" parauariensis, porém não foi possível constatar uma concavidade na face labial ou botões na base.

Os gêneros cladodontes Tamiobati, Ctenacanthus e Cladodoides por terem bases retas e pouco ornamentadas são os que mais se aproximam de GP/2E-6306, porém sua coroa difere em tamanho e número de cúspides. Saivodus ainda possui cúspides laterais muito pequenas e base reta como em GP/2E-6306, porém a ornamentação da face superior lingual o diferencia.

O cladodonte GP/2E-5919 difere de todos os dentes cladodontes descritos no Brasil, no formato da base e cúspide. Em relação aos cladodontes do hemisfério norte, GP/2E-5919 possui uma cúspide similar a Glikmanius myachkovensis e Glikmanius occidentalis, por causa da cúspide alongada, porém ela não é robusta e sem as cúspides secundárias e de botões apicais na projeção lingual.

Cúspides alongadas também são comuns nos gêneros paleozóicos Akmonistion, Saivodus, Stethacanthus e Cladoselache (COATES \& SEQUEIRA, 2001, DUFFIN \& GINTER, 2006), porém estes gêneros diferem na base, com projeções basolabiais e ornamentações, na presença de cúspides secundárias (ou acessórias), na ornamentação da projeção lingual e presença de botões ou saliências.

O gênero Cladodoides aparentemente é muito similar ao espécime GP/2E-5919 por ter uma longa cúspide mediana triangular e uma base com pequena ou nenhuma projeção basolabial ou ornamentação na projeção lingual, porém no exemplar aqui descrito as cúspides secundárias estão ausentes.

GP/2E-5919 é semelhante a dentes neocarboníferos atribuídos a Cladodus sp. de Queen Shale da Formação Lecompton de Nebraska (EUA) (CASE, 1982). Os espécimes norte-americanos desta unidade também possuem uma única cúspide, maior em altura do que o comprimento da base, porém a crista longitudinal e as costelas são menos proeminentes. Segundo a nova classificação proposta por DUFFIN \& GINTER (2006), o espécime de Nebraska, ilustrado por CASE (1982), não deve ser incluído no gênero Cladodus, representando um gênero a parte.

A ornamentação da cúspide do exemplar GP/2E-5919 do Membro Taquaral é muito similar a de Cladodus bellifer do Mississipiano da Formação Burlington de Iowa (DUFFIN \& GINTER, 2006), porém a base difere no formato e ornamentação.

O cladodonte GP/2E-5919 aparentemente representa uma espécie ou gênero diferente dos demais. 


\subsection{Euselachii}

Os Euselachii são um grupo de tubarões de corpo fusiforme reconhecido por duas nadadeiras dorsais precedidas por um espinho. As nadadeiras pareadas e o lóbulo inferior são raiados. Uma nadadeira anal está presente.

Seu maior desenvolvimento foi durante o Neopaleozóico e acredita-se que os Neoselachii evoluíram deste ramo.

Inclusos dentro dos Euselachii está a ordem Ctenacanthiformes surgidos no Devoniano e chegando até o Triássico.

A identificação de Ctenacanthiformes é baseada principalmente em espinhos. Em revisão crítica de espinhos, MAISEY $(1981,1982,1984)$ discutiu as identificações taxonômicas de espinhos de Euselachii e demonstrou enganos prévios nas classificações de diversas espécies. Redescreveu os gêneros Ctenacanthus, Bythiacanthus, Amelacanthus, Eunemacanthus, Sphenacanthus e Wodnika, mostrando as características dos espinhos de cada um (Fig. 70) (MAISEY, 1982).

Acondylacanthus (Fig. 71), Bythiacanthus e Amelacanthus já foram considerados Ctenacanthiformes (ZANGERL, 1981), porém hoje são gêneros incertae sedis. Muitos dos exemplares são apenas espinhos e, por isso, sua classificação não é segura (MAISEY, 1982, 1984).

O gênero Goodrichthys do Eocarbonífero da Escócia (ZANGERL, 1981) pode ser considerado sinônimo de algumas espécies de Bythiacanthus (MAISEY, 1982).

O gênero triássico Pyknotylacanthus possui um espinho com ornamentação em tubérculos semelhante aos encontrados em Bythiacanthus e Glymmatacanthus (sinônimo de Bythiacanthus, segundo MAISEY, 1982) do Carbonífero dos Estados Unidos. MUTTER \& RIEBER (2005) observaram características primitivas em Pyknotylacanthus e consideraram um gênero incerto dentro dos Ctenacanthiformes. MUTTER \& RIEBER (op. cit.) ainda estudaram exemplares de "Cosmacanthus" humboldtensis, classificando-os, provisoriamente, como indivíduos juvenis de Pyknotylacanthus. Outros gêneros como Carinacanthus e Acronemus, ambos do Triássico, tem também classificação incerta.

A classificação de Wodnika também gera discussão e atualmente faz parte da ordem Hybodontiformes. 


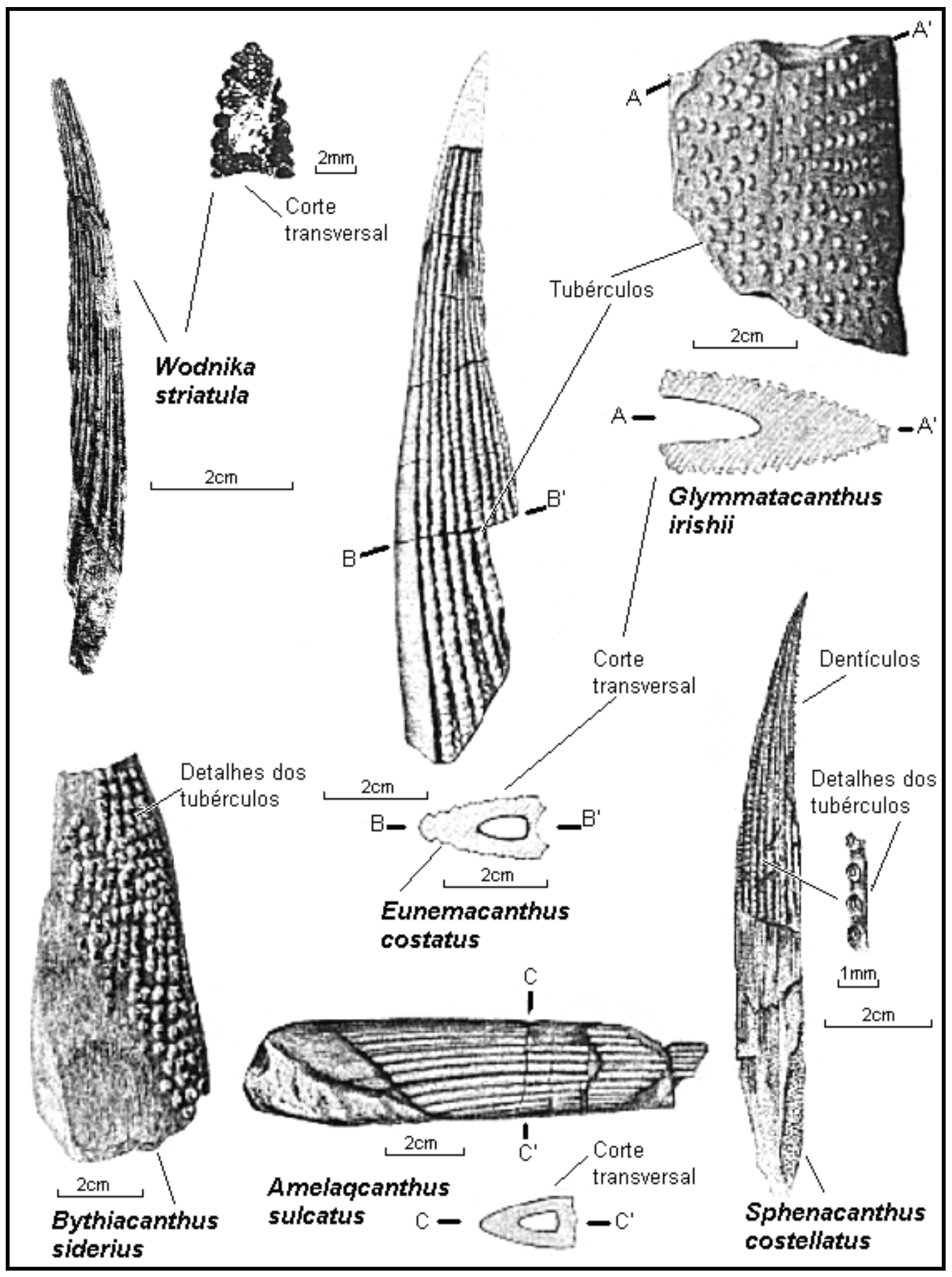

Figura 70 - Características de diversos espinhos de Euselachii (MAISEY,1982). 


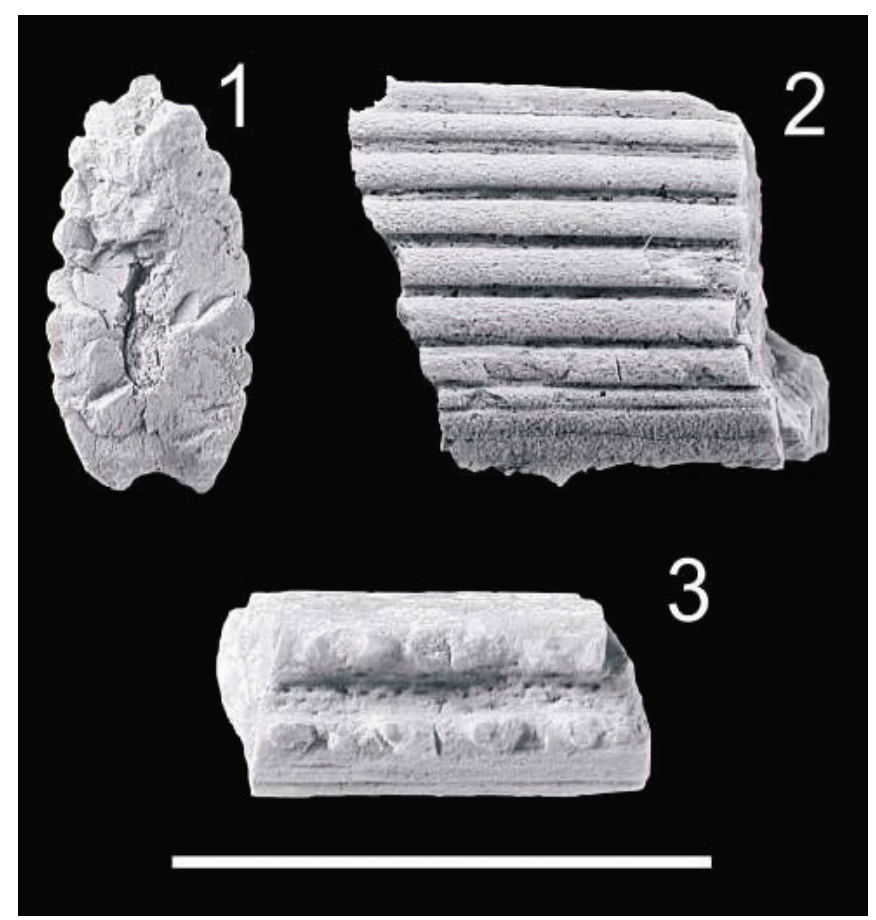

Figura 71 - Fragmento de espinho de Acondylacanthus da Formação Minturn, Neocarbonífero da América do Norte (ITANO et al. 2003). 1) Corte transversal; 2) Vista lateral esquerda; 3) Vista inferior. Escala: $10 \mathrm{~mm}$.

\subsubsection{Estudos paleoambientais envolvendo Ctenacanthiformes}

Nas pesquisas pioneiras sobre o grupo, os tubarões Ctenacanthiformes eram considerados marinhos. Segundo BAIRD (1978), no entanto, análise mais detalhada revelou que em vários casos, estes tubarões deviam ter habitado água doce ou de baixa salinidade. BAIRD (1978) comentou a ocorrência do gênero Ctenacanthus em ambiente lacustre nos depósitos permo-carboníferos da Escócia e registra a existência do gênero Bandringa em ambientes de água doce nos Estados Unidos.

Apesar das citações de BAIRD (1978) os gêneros Ctenacanthus e Bandringa, são mais comumente associados com faunas marinhas do Carbonífero (ZANGERL, 1981)

DICK (1998) observou que espinhos atribuídos ao gênero Sphenacanthus são encontrados juntos a xenacantídeos dos gêneros Triodus e Xenacanthus, bem como a outros animais de águas continentais. Por isso, ele considerou Sphenacanthus como um tubarão de água doce. MAISEY (1982), mais cauteloso, aceita que Sphenacanthus possa ter habitado águas menos salinas, mas não o coloca claramente em águas doces.

Provavelmente os Ctenacanthiformes representem um grupo variado de animais que habitaram diferentes ambientes e não devem ser considerados indicadores paleoambientais confiáveis. 


\subsubsection{Ctenacanthiformes da base do Membro Taquaral da Formação Irati}

Classe CHONDRICHTHYES Huxley, 1880

Subclasse ELASMOBRANCHII Bonaparte, 1838

Infraclasse EUSELACHII Hay, 1902

Ordem CTENACANTHIFORMES Zangerl, 1981

Familia SPHENACANTHIDAE Maisey, 1982

Gênero Sphenacanthus Agassiz 1837

Sphenacanthus sanpauloensis, sp. nov.

Figs. 72 e 74

Material - Espinhos GP/2T-204 (Fig. 72 e 73) e GP/2E-6583 (Fig. 74)

Localização - Afloramento 1: Sítio Santa Maria 1

Estratigrafia - Base arenosa do Membro Taquaral, Formação Irati.

Holótipo: (GP/2T-204) espinho de nadadeira dorsal incrustado em arenito fino

(Figs. 72 e 73).

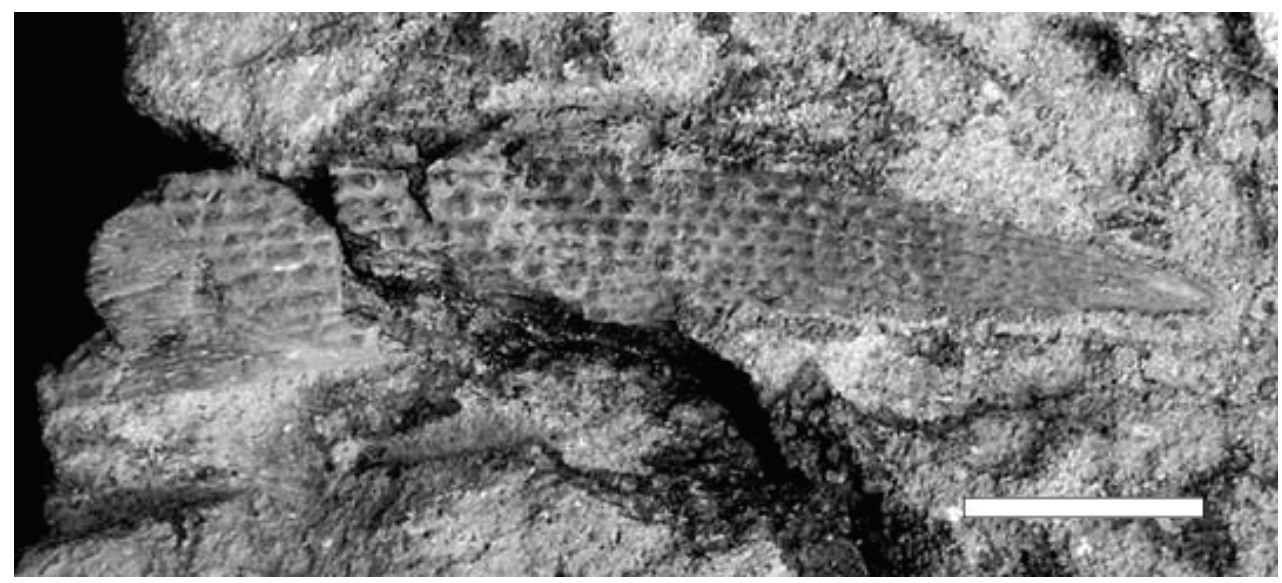

Figura 72 - Espinho GP/2T-204 de Sphenacanthus sanpauloensis, encontrado na Base da Formação Irati. Escala 10mm.

Diagnose: Espinho de nadadeiras dorsais com faces laterais ornamentadas por costelas longitudinais paralelas, com espaços intercostais. Afina-se da base para o ápice, com pequena curvatura convexa na margem anterior. Bifurcação das costelas maiores perto da zona de imbricação. Tubérculos, ornamentando as costelas, bem espaçados entre si, com distância do espaçamento superior a três vezes o seu diâmetro. A margem anterior é ornamentada por uma fileira de tubérculos. A seção transversal com formato de triângulo isósceles, com os lados maiores arqueados e a base reta sem concavidades. A cavidade pulpar tem o formato geral do espinho, ocupando a região posterior. Presença de dentículos em espinhos maiores, nas margens laterais posteriores, próximo ao ápice. 
Descrição do exemplar GP/2T-204 - O exemplar consiste de um espinho da nadadeira dorsal parcialmente incrustada na matriz rochosa. Boa parte do espinho está exposta, porém como a peça é frágil não foi possível retirá-la da amostra. Por isso os estudos foram restritos a região exposta.

O espinho mede $88 \mathrm{~mm}$ de comprimento, do qual 20,1 $\mathrm{mm}$ correspondem à região de articulação. A distância máxima entre a margem anterior e posterior (largura), medida na região da articulação, é de $15 \mathrm{~mm}$ e a espessura medida na base é de 7,0 $\mathrm{mm}$.

Apesar de fraturada na região central, a peça revela claramente uma ligeira convexidade da face anterior do espinho e se mostra reta na face posterior.

O espinho é ornamentado por 10 costelas longitudinais baixas, ornamentadas por tubérculos, que convergem em direção ao ápice. Todas apresentam uma seqüência de tubérculos (Fig. 73A e 73B) de tamanho igual ou maior que a largura da costela. Os tubérculos são em geral cilíndricos, com a parte superior circular ou oval, por vezes arredondados ou com aspecto intumescido. Cada tubérculo é disposto um após o outro, com espaçamento igual ou duas vezes maior que seu diâmetro máximo. $\mathrm{O}$ diâmetro varia de 0,5 a 1mm, sendo maiores nas costelas próximas à margem anterior do espinho, onde o espaçamento entre eles também é maior.
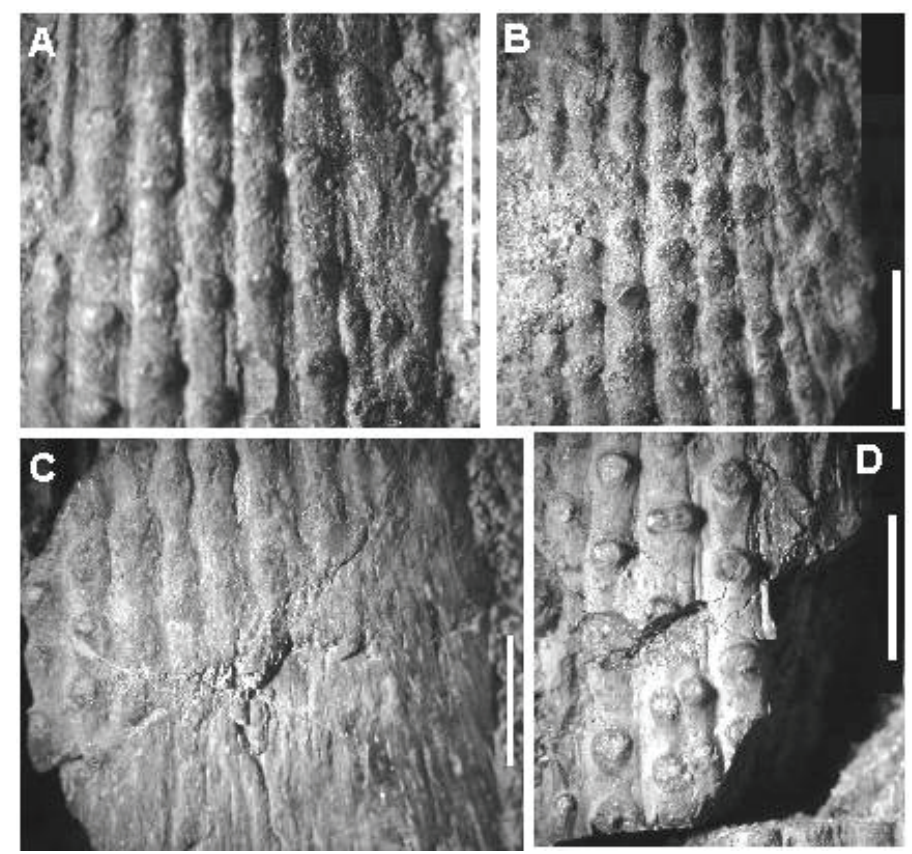

Figura 73 - Espinho GP/2T-204 de Sphenacanthus sanpauloensis. A) região mediana superior; B) Região mediana inferior; C) Região de imbricação; D) costela bifurcada. Escala: $5 \mathrm{~mm}$.

As costelas não se unem ao longo do espinho, permanecendo separadas por um pequeno espaçamento intercostal igual ou um pouco maior que a metade da largura da costela. Cada costela percorre toda a face livre do espinho, sendo que a maior exposta 
possui $35 \mathrm{~mm}$ de comprimento. A largura varia de $1 \mathrm{~mm}$, na face anterior, e menos que 0,5mm na posterior. Uma única costela apresentou bifurcação (Fig. 73D) (no sentido distal-proximal) próxima da zona de articulação.

Próxima da base, as faces laterais quase se unem anteriormente. Assim, a face anterior é muito estreita, arredondada e ornamentada por uma única fileira de tubérculos, que separa as duas faces laterais. A borda posterior é mais larga $(6,1 \mathrm{~mm}$ de largura) e, embora muito alterada, mostra-se mais lisa (sem ornamentação) do que a anterior.

A região de inserção do espinho não apresenta ornamentação positiva. Contudo, ocorrem muitas estriações (Fig. 73C). O contato entre esta região e a face livre do espinho tem formato sigmóide. Forma um ângulo de $53^{\circ}$ em relação a parte ornamentada na borda posterior do espinho.

Descrição do espécime GP/2E- 6583 - O espécime (Fig. 74) é um espinho fragmentado em 3 partes, todas com quebras significativas e abrasão. A maior, basal, revelou o maior número de informações sobre a superfície do espinho, porém não foi preservada a região de articulação. A de topo, menor, tem pequenos dentículos nas laterais posteriores. Em todas ocorrem pequenas incrustações de rocha.

Apesar de inúmeras quebras, as partes proximal e mediana exibem uma ligeira convexidade na parte anterior do espinho e uma concavidade na face posterior.

O comprimento da parte proximal do espinho é de 42,05mm, 13,86mm de largura, sentido anterior-posterior, e 7,49mm de espessura máxima medida na parte posterior. A parte mediana correspondente à região central do espinho, possui $24,26 \mathrm{~mm}$ de comprimento, 9,67mm de largura, sentido anterior-posterior, e $8,15 \mathrm{~mm}$ de espessura medida na região central da peça. $O$ fragmento correspondente ao topo inclui parte do ápice do espinho e é a menor dos três, com 17,89mm de comprimento, 7,06mm de largura, sentido anterior-posterior, e $5,22 \mathrm{~mm}$ de espessura. Este exemplar é ornamentadas por oito costelas observadas na parte maior basal, três destas convergem em uma única na peça da região mediana e poucas ocorrem no fragmento de topo, caracterizando um topo mais liso. 


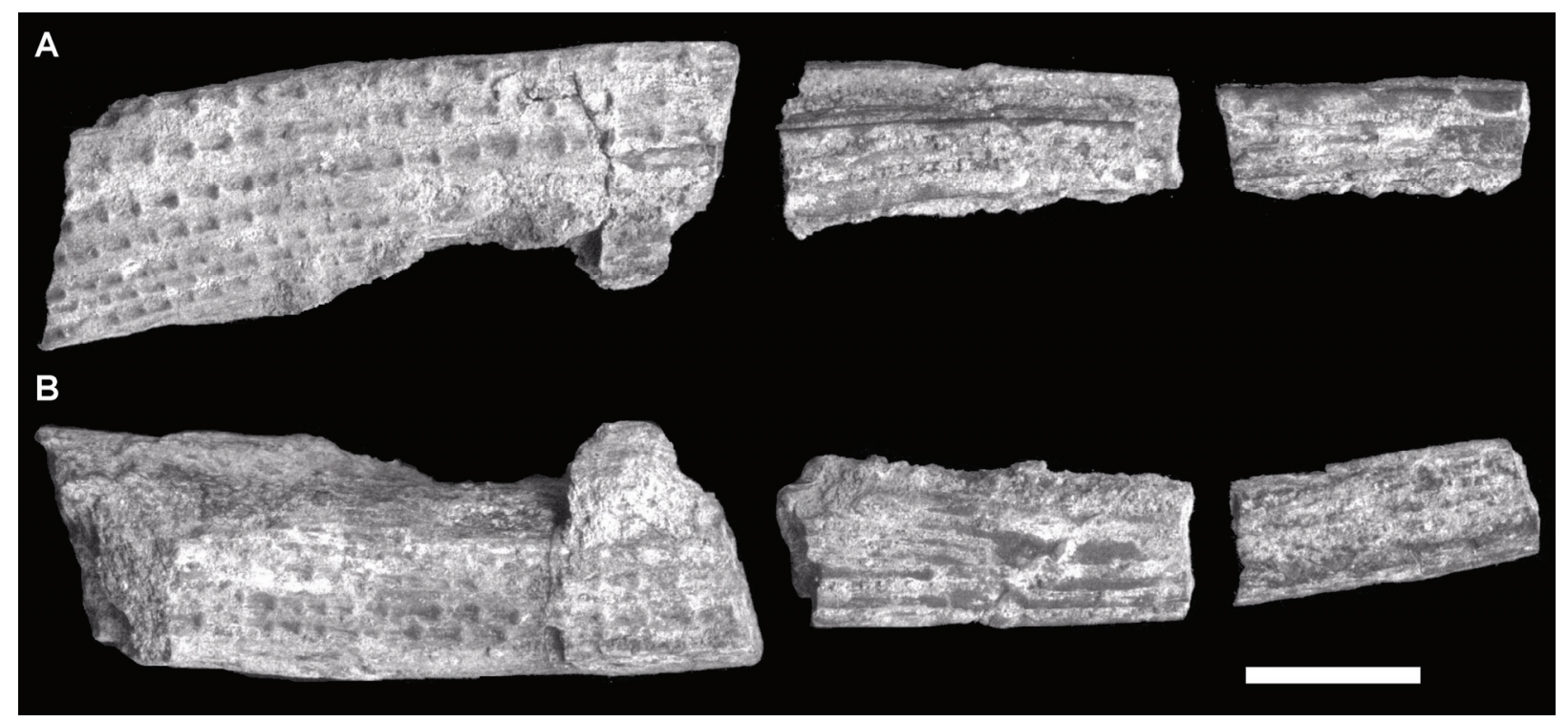

Figura 74 - Exemplar de Sphenacanthus sanpauloensis GP/2E-6583. A-B) faces laterais direita e esquerda. Escala $10 \mathrm{~mm}$.

As costelas, na peça correspondente à parte mediana do espinho, são lisas e quase sem espaçamentos intercostais. $O$ fragmento da região proximal apresenta costelas ornamentadas por tubérculos e espaçamento intercostal, além de duas bifurcações. A largura média das costelas é de $0,8 \mathrm{~mm}$ e varia muito pouco na superfície lateral correspondente à região basal do espinho.

Os tubérculos são de tamanhos iguais ou maiores que a largura da costela. São, em geral, cilíndricos, com a parte superior circular ou oval, por vezes arredondadas, com aspecto intumescido ou pontiagudo. Os tubérculos são dispostos um após o outro com tamanho variável, $0,9 \mathrm{~mm}$ entre os maiores e 0,5 os menores, próximos da região posterior. $\mathrm{O}$ espaçamento entre eles também varia de $2,7 \mathrm{~mm}$, distância máxima, e $1,7 \mathrm{~mm}$, mínima, na região posterior. A distância entre os tubérculos é próxima de três vezes o seu diâmetro.

Os espaçamentos intercostais também são variáveis, maior na peça que corresponde a região proximal do espinho com $0,9 \mathrm{~mm}$ na parte posterior e $1,8 \mathrm{~mm}$ na anterior. A peça mediana possui $1,4 \mathrm{~mm}$ de espaçamento intercostal.

A seção transversal está deformada em boa parte do espinho e por isso não foi possível analisar a cavidade pulpar, mas foi possível observar que ela tem forma triangular na peça de topo. No mesmo ponto foi possível medir o ângulo entre as faces laterais alcançando $45^{\circ}$.

Discussão - Espinhos de nadadeiras dorsais que possuam costelas longitudinais ornamentadas por tubérculos são características típicas de tubarões Ctenacanthiformes 
(MAISEY, 1981, 1982). O tamanho do espécime e o ângulo de inserção permitem interpretá-lo como um espinho da nadadeira dorsal de um animal adulto.

Segundo a classificação de Ctenacanthiformes proposta por MAISEY (1981, 1982, 1984), as seguintes características identificam os espinhos descritos ao gênero Sphenacanthus: espaçamento intercostal, bifurcação de costelas (apesar de ser apenas uma única ocorrência) e ornamentação por tubérculos bem espaçados entre si.

Em relação às outras duas espécies brasileiras de Ctenacanthiformes descritas (SILVA SANTOS, 1946, 1947), Sphenacanthus sampauloensis é similar na ornamentação e número de costelas a Ctenacanthus gondwanus, proveniente da Formação Rio Bonito de Santa Catarina. No entanto, é maior e apresenta ornamentação em toda a superfície lateral do espinho e não só em uma parte. Em relação a Ctenacanthus maranhensis, encontrado na Formação Pedra do Fogo do Maranhão, $S$. sampauloensis difere no formato e separação dos tubérculos, bem como no espaçamento intercostal, maiores na espécie paulista. A única semelhança está no comprimento total dos espinhos, atribuídos em ambos os casos, a animais adultos.

A atribuição dos tubarões descritos por SILVA SANTOS $(1946,1947)$ ao gênero Ctenacanthus foi questionada por MAISEY (1984), que sugeriu afinidades com Sphenacanthus para C. gondwanus e com Sphenacanthus ou Wodnika para $C$. maranhensis.

A presença de tubérculos acima, na superfície lateral do espinho, distingue Sphenacanthus sanpauloensis de Sphenacanthidae não tuberculados como $S$. aequistriatus e $S$. hybodoides. E de espécies parcial ou totalmente tuberculadas como $S$. serrulatus, S. costellatus e Bythiacanthus. (ITANO et al. 2003) em que variam a disposição ou número de tubérculos.

RAGONHA (1978) descreveu um espinho tão parecido com o espinho ora descrito que os dois certamente devem pertencer à mesma espécie. Contudo, Ragonha preferiu atribuir seu espinho a um exemplar infantil de C. maranhensis. Ele especulou, ainda, que o espaçamento e disposição dos tubérculos se modificariam durante o desenvolvimento até se assemelharem aos indivíduos encontrados na Formação Pedra do Fogo. Os exemplares aqui descritos demonstram justamente o contrário, ou seja, que a ornamentação básica dos espinhos infantis se mantém nos adultos. 
Sphenacanthus sp.

Fig. 75

Material - (GP/2E-6582) espinho fragmentado (Fig. 75).

Localização - Afloramento 1, Sitio Santa Maria 1.

Estratigrafia - Base da fácies arenosa do Membro Taquaral da Formação Irati. Eopermiano da Bacia do Paraná.

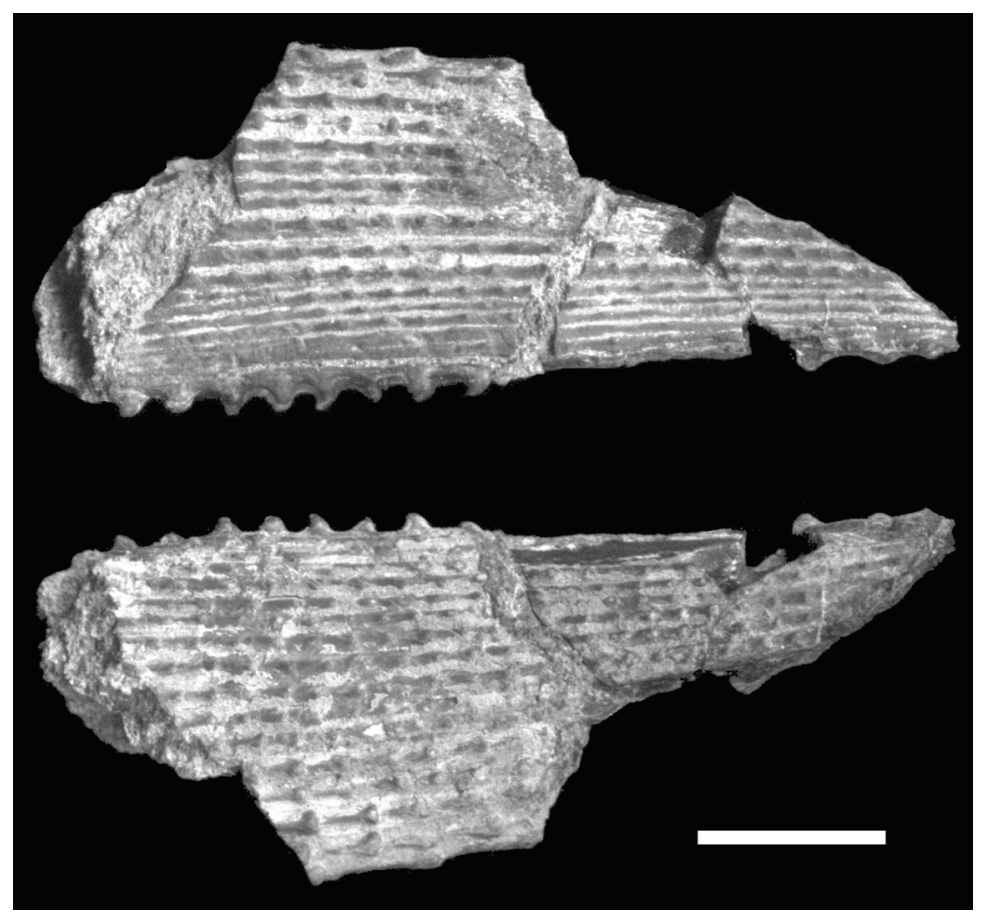

Figura 75- - Exemplar de Sphenacanthus sp. GP/2E-6582. A-B) faces laterais direita e esquerda. Escala $10 \mathrm{~mm}$.

Descrição: O exemplar é um espinho fragmentado da nadadeira dorsal e com uma fratura preenchida por sedimentos em sua porção superior. É possível observar leve deslocamento causado por esta fratura.

O fragmento do espinho mede 49,8 $\mathrm{mm}$ de comprimento, a distância máxima entre a margem anterior e posterior (largura) é de 19,5 $\mathrm{mm}$ e a espessura é de $6,3 \mathrm{~mm}$.

Apesar de fragmentada, a peça revela claramente ligeira inclinação da face anterior e reta na face posterior.

O espinho é ornamentado por 18 costelas longitudinais baixas e finas, a maior apenas $0,88 \mathrm{~mm}$ de largura, a maioria ornamentada por tubérculos, que diminuem de tamanho e intensidade, a medida que se dirigem para a parte superior do espinho. $\mathrm{Na}$ região posterior, os tubérculos vão desaparecendo, tornando as costelas lisas. 
Os tubérculos possuem tamanho próximo da largura da costela em que se localizam. O maior $0,8 \mathrm{~mm}$, mas a maioria não ultrapassa $0,5 \mathrm{~mm}$, havendo tubérculos com duas vezes o tamanho de outros. Em geral são cilíndricos, com a parte superior circular ou oval, por vezes arredondados ou com aspecto intumescido, mas nunca pontiagudos. Cada tubérculo se dispõe um após o outro, com espaçamento duas vezes maior que seu diâmetro, em torno de $2,3 \mathrm{~mm}$.

Ocorrem quatro bifurcações nas costelas localizadas em lugares variados na lateral do espinho. O espaçamento intercostal observado é irregular e variado, nas costelas maiores $0,7 \mathrm{~mm}$ e nas menores é inferior a $0,5 \mathrm{~mm}$. Próximo da região posterior, o espaçamento é mínimo, chegando a se encostarem e se unirem.

A região posterior do espinho é de aspecto pectinado, com a presença de duas fileiras laterais de dentículos pontiagudos (quando não desgastados). Todos são voltados para a região inferior do espinho e são paralelos entre si. O tamanho de cada um é de 1,3mm de comprimento máximo, sentido superior-inferior do espinho, e um espaçamento praticamente constante de $2,0 \mathrm{~mm}$.

Uma costela longitudinal ornamentada por tubérculos separa a região frontal em duas faces laterais.

Em corte transversal, o triangulo isósceles apresenta-se deformado e não foi possível análise da cavidade pulpar.

Discussão: $O$ espaçamento intercostal, entre os tubérculos e a presença de poucas costelas com bifurcações simples são características que permitem associar o presente exemplar ao gênero Sphenacanthus (MAISEY, 1981; 1982; 1984). Esta característica distinguem estes, dos espinhos com costelas longitudinais lisas, como Amelacanthus, Acondylacanthus e Hybodus (MAISEY,1981, 1982,; ITANO et al. 2003; ELLIOTT et al. 2004). A forma e o tamanho dos tubérculos no espécime aqui estudado, são diferentes dos tubérculos em espinhos atribuídos aos gêneros Ctenacanthus, Glymmatacanthus e Eunemacanthus (MAISEY,1981, 1982, 1984).

Embora a ornamentação dos espinhos dos gêneros Bythiacanthus e Wodnika sejam semelhante ao observado, são distribuídos diferentemente em Bythiacanthus (ITANO et al. 2003) e mais amplamente espaçados em Wodnika (MAISEY,1982).

Em relação às três únicas espécies brasileiras de ctenacantídeos tuberculados descritas até agora, Sphenacanthus gondwanus, do Eopermiano da Formação Rio Bonito de Santa Catarina, "Ctenacanthus" maranhensis do Eopermiano da Formação Pedra do fogo do Maranhão, (SILVA SANTOS, 1946, 1947, MAISEY, 1984) e 
Sphenacanthus sanpauloensis do Eopermiano da base da Formação Irati (CHAHUD et al. 2010), o presente exemplar apresenta similaridades e diferenças em relação às espécies supracitadas. Em relação ao número de costelas, difere das três espécies brasileiras por possuir mais de 15 costelas distintas, enquanto as outras possuem, em média, 11 (12 em Sphenacanthus gondwanus). Ao contrário de Sphenacanthus sanpauloensis e "Ctenacanthus" maranhensis o exemplar não é todo tuberculado, apresentando costelas sem ornamentação por tubérculos. O espaçamento intercostal e entre os tubérculos é maior que nas duas espécies referidas.

A presença de costelas lisas foi observada também em Sphenacanthus gondwanus e em S. costelatus, do Mississipiano da Escócia. S. gondwanus possui dentículos laterais muito pequenos se comparados com o presente exemplar. O número de costelas é muito pequeno e a quantidade de tubérculos onde ocorre o aspecto pectinado é muito menor (menor que 6).

É possível que o novo exemplar seja derivado da espécie Sphenacanthus gondwanus presente em depósitos mais antigos da Bacia do Paraná evoluindo desde então como uma espécie endêmica.

\title{
6.6.3 Outros Euselachii da base do Membro Taqural
}

\author{
Familia Indeterminada \\ Gênero Amelacanthus Maisey (1982) \\ Amelacanthus sp. \\ Figs. 76 e 77
}

Material: GP/2E- 6461, GP/2E-6584A, GP/2E-6584B e GP/2E-6579; espinhos incompletos (Figs. 76 e 77).

Localização: Afloramento 1, Sitio Santa Maria 1, no município de Rio Claro para GP/2E- 6461, GP/2E-6584A, GP/2E-6584B e Afloramento 12, Fazenda Ponte Nova para GP/2E-6579 .

Estratigrafia: Base da fácies arenosa do Membro Taquaral da Formação Irati. Eopermiano da Bacia do Paraná.

Diagnose genérica: Elasmobrânquio reconhecido por espinhos, de nadadeiras dorsais, alongados e ligeiramente recurvadas para trás; margem anterior aguda, mas arredondada; laterais posteriores divergentes quase achatadas, seção transversal subtriangular; parede posterior côncava ou plana, por vezes com uma pequena elevação mediana; costelas largas e lisas, superficialmente com encaixes intercostais estreitos; 
costelas com camada de enamelóide, exibindo linhas de crescimento; bifurcações primárias de costelas ocorrem na margem anterior e nas margens póstero - laterais da região apical, sendo pequenas, pouco curvadas e arredondadas ou com pequenos dentículos.

Descrição do espécime GP/2E- 6461: O espécime é a parte proximal de um espinho de nadadeira dorsal, ainda com a zona de articulação preservada, incrustada na matriz arenosa. Aparentemente o espinho se afina para a região distal, porém como pouco de sua área está preservada, esta observação não é segura.

O espinho todo mede $35,10 \mathrm{~mm}$ de comprimento, do qual praticamente metade corresponde à região de articulação (Fig. 76A). A distância máxima entre a margem anterior e posterior (largura), medida na região da articulação, é de 11,6 mm e a espessura medida na base é de 4,2 $\mathrm{mm}$.

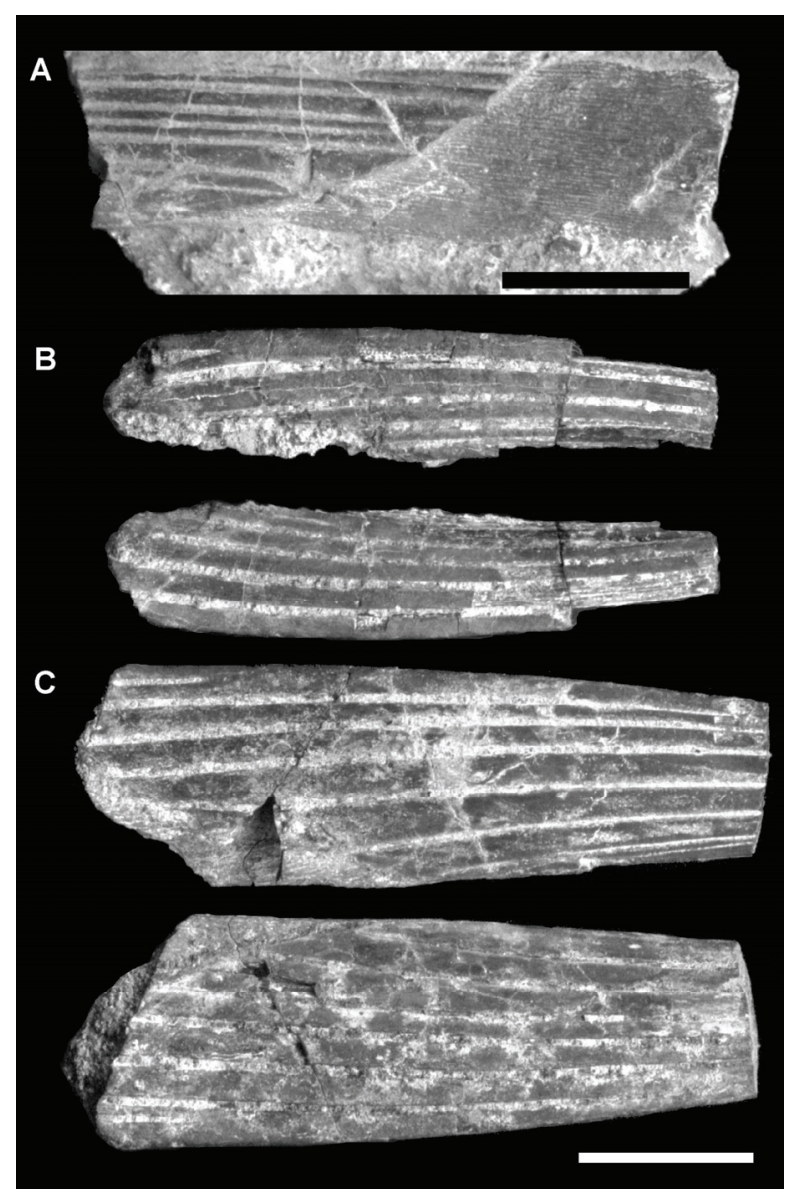

Figura 76 - Espinhos de Amelacanthus encontrados na base da Formação Irati. A) Exemplar GP/2E6461; B-C) Exemplar GP/2E-6584. B) (GP/2E-6584A) parte centro distal de espinho; C) (GP/2E-6584B) parte centro proximal. Escalas $10 \mathrm{~mm}$. 
O espinho é ornamentado por nove costelas longitudinais baixas e lisas na zona de inserção. As costelas não se unem ao longo do espinho, permanecendo separadas por pequeno espaçamento intercostal, constante, de $0,6 \mathrm{~mm}$ de largura. Cada costela percorre toda a face livre do espinho (região que exclui a zona de articulação), a maior exposta, com 22,5mm de comprimento. A largura máxima é de $2 \mathrm{~mm}$, observada em uma costela na região centro-lateral posterior, porém são observadas costelas com menos de $1 \mathrm{~mm}$. Uma única costela apresentou bifurcação (no sentido distal-proximal) próxima à zona de articulação. Não foram observados dentículos laterais na face posterior e a anterior possui uma costela que separa as duas faces laterais do espinho.

A região de articulação exibe finas estrias em toda a superfície e o contato com a zona livre do espinho é de formato sigmoidal, formando ângulo, na face posterior, de $20^{\circ}$.

A seção transversal tem a forma de triangulo isóscele e o ângulo formado entre as faces laterais na face anterior é inferior a $10^{\circ}$. O comprimento da face posterior é igual ao da espessura do espinho $(\sim 4 \mathrm{~mm})$, o que representa quase $1 / 3$ do tamanho das laterais (aproximadamente $11 \mathrm{~mm}$ para cada lateral). Assim, a face anterior é muito estreita e a posterior é ligeiramente côncava.

A cavidade pulpar está alterada, porém foi possível observar a forma oval localizada na região posterior do espinho. O comprimento máximo é de $5 \mathrm{~mm}$.

Descrição do exemplar GP/2E-6584 (Figs. 76B e 76C): O espécime representa duas partes fragmentadas de um espinho da nadadeira dorsal. A primeira parte representa a região próxima do ápice (região distal) enquanto a segunda estaria próxima da região de inserção (região proximal).

A parte distal do espinho tem $35,0 \mathrm{~mm}$ de comprimento, 7,5 $\mathrm{mm}$ de largura, que corresponde à distância entre a margem anterior e posterior, e 4,83mm de espessura, equivalente da largura da face posterior. A parte inferior (proximal) é maior, com $38,2 \mathrm{~mm}$ de comprimento, $13,5 \mathrm{~mm}$ de largura e $6,2 \mathrm{~mm}$ de espessura máxima, medida na parte frontal. Nesta parte foi possível observar uma curvatura convexa na área frontal e côncava na face posterior do espinho. Não foi possível caracterizar, com segurança, o ângulo entre as faces, formado com a parte frontal, mas é possível observar que as faces são divergentes.

O fragmento distal (Fig. 76B) possui quatro costelas lisas em cada lateral e uma costela separando as faces laterais. A primeira costela lateral frontal, mais espessa, tem $2,23 \mathrm{~mm}$ e as duas últimas costelas distais tem em torno de $1 \mathrm{~mm}$. Ocorre uma única 
bifurcação entre a costela que divide as faces laterais e a primeira costela anterior na parte inferior do espinho.

O fragmento proximal (Fig. 76C) possui seis costelas lisas em cada lateral e uma frontal que divide as faces laterais, sendo que duas com largura de 2,6mm, a primeira frontal lateral e a antepenúltima na parte posterior. Há três bifurcações sempre nas partes extremas da peça.

Tanto na peça distal como na proximal as costelas permanecem separadas por um pequeno espaçamento intercostal muito menor que a largura das costelas e praticamente constante por toda a superfície, ao redor de $0,6 \mathrm{~mm}$.

A parte proximal possui bordas lisas e sem ornamentações, porém a distal revelou que a parte posterior do espinho é pectinada, pois foi observado um único dentículo desgastado de $1,97 \mathrm{~mm}$ de comprimento e $0,96 \mathrm{~mm}$ de largura. Não está claro se o dentículo está voltado para cima ou para baixo no espinho.

Como a seção transversal não esta completa a cavidade pulpar foi observada apenas no fragmento da parte superior e na parte posterior do espinho. Tem formato oval com comprimento máximo de $1,3 \mathrm{~mm}$ na extremidade.

Ainda foi possível observar o ângulo entre as faces laterais do espinho, em torno de $28^{\circ}$, medido no fragmento da parte inferior.

Descrição do exemplar GP/2E-6579 - O espécime (Fig. 77) é um espinho da nadadeira dorsal com poucas incrustações da matriz rochosa, com quase toda parte preservada exposta. Representa boa parte da região central com apenas ausência da região de articulação e o ápice.

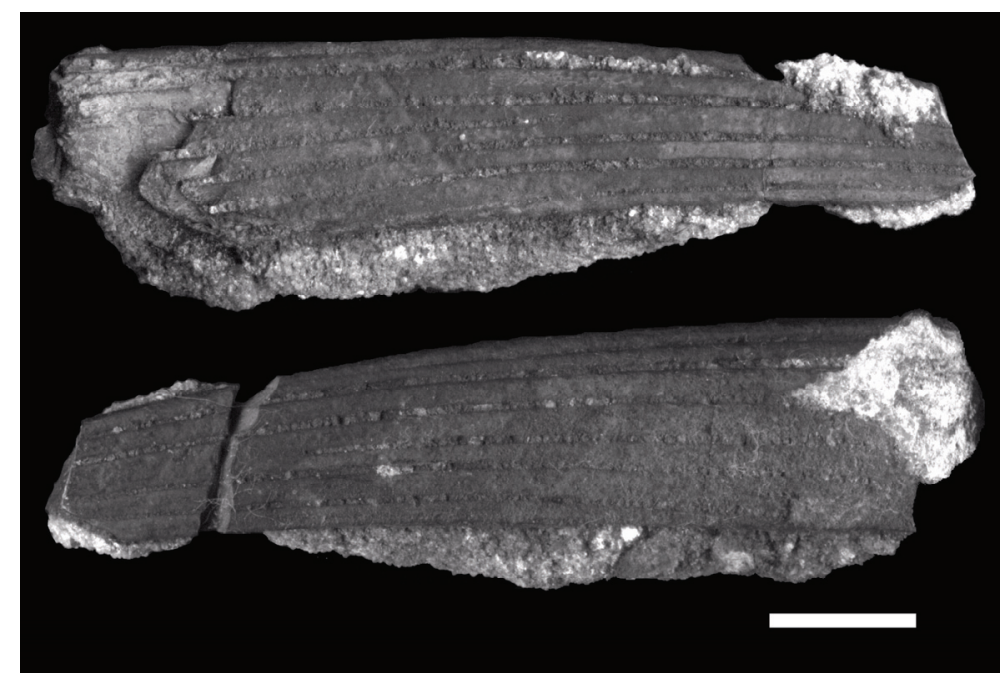

Figura 77 - Faces laterais do espécime GP/2E-6579 de Hybodontiformes. Escala 10mm. 
O espinho mede 64,1 $\mathrm{mm}$ de comprimento, a distância entre a margem anterior e posterior (largura) é de 15,0 $\mathrm{mm}$ e a espessura medida na base é de 9,5 $\mathrm{mm}$.

O espinho é ornamentado por sete costelas longitudinais lisas e largas, em relação ao espaçamento intercostal. A maior largura entre as costelas está na segunda lateral frontal com $2,7 \mathrm{~mm}$ e o espaçamento intercostal é constante, $0,6 \mathrm{~mm}$ em todo o comprimento do espinho. Há três bifurcações nas costelas em pontos variados do exemplar. Um deles na região central de uma das laterais.

O exemplar revela claramente uma ligeira convexidade da face anterior do espinho e uma concavidade na parte posterior. Não foram observados sinais de dentículos laterais ou qualquer tubérculo em nenhuma das costelas longitudinais. As faces laterais são divergentes com um ângulo de $30^{\circ}$ na parte frontal do espinho.

Em seção transversal foi constatado um triangulo isósceles com as faces laterais próximas de duas vezes a medida da base do triangulo. Infelizmente não foi possível fazer o estudo da cavidade pulpar por causa da alteração e grande concentração de sedimentos preenchendo-o deformando o formato original, contudo foi possível constatar que a cavidade pulpar se localiza na região posterior do espinho.

Discussão: Observando as costelas lisas e largas dos espécimes analisados, é seguro afirmar que não pertencem a gêneros tuberculados de elasmobrânquios paleozóicos como Bythiacanthus, Eunemacanthus, Wodnika e Ctenacanthus (MAISEY, 1981,1982 e 1984)

O gênero Sphenacanthus, apesar de possuir espécies com tubérculos, algumas espécies não são tuberculadas, como Sphenacanthus hybodoides (MAISEY, 1982), porém a largura das costelas é muito fina, diferente das observadas nos exemplares descritos aqui.

Elasmobrânquios de espinhos com costelas lisas, comuns no Permiano, são atribuídos ao gênero Acondylacanthus e à Ordem Hybodontiformes. O primeiro difere no corte transversal de formato oval e não triangular (ITANO et al. 2003), já os espinhos atribuídos aos hibodontes possuem costelas finas e bem espaçadas se comparadas com os exemplares aqui descritos.

O gênero Amelacanthus pode ser aplicado aos aqui estudados, pois apresentam características diagnósticas típicas deste gênero. A mais importante são as costelas largas e lisas, com encaixes intercostais estreitos e bifurcação primária. Também é possível observar uma ligeira curvatura e a seção transversal tem aspecto triangular, com a parede posterior achatada. 
O gênero Amelacanthus foi atribuído a espécies do Mississipiano da Irlanda do Norte (MAISEY, 1982; 1984) e Pensilvaniano da America do Norte (ELLIOTT, et al. 2004), sendo, até então, os mais recentes atribuídos a este gênero.

Comparando os presentes espécimes com fósseis de Amelacanthus sulcatus, do Mississipiano da Irlanda do Norte, os espinhos se assemelham pela seção transversal com formato triangular e as laterais duas vezes maiores que a face posterior, além das faces laterais divergentes a partir da extremidade anterior, formando um ângulo de 30 graus. A. sulcatus tem número de costelas muito maior, 15 para cada lateral, enquanto varia de 6-9 nos exemplares aqui estudados, além da costela anterior mais larga.

Amelacanthus laevis, do Mississipiano da Irlanada do Norte possui a seção transversal semelhante ao dos exemplares aqui descritos, contudo com muito mais costelas, 24 em cada lateral e a presença de pequenas costelas terminais na parte posterior. Amelacanthus plicatus difere em todos os aspectos dos exemplares observados, com seção transversal em forma de triangulo eqüilátero sem uma costela anterior separando as faces laterais e sim diversas costelas que se inósculam (tem contato entre si).

De todas as quatro espécies, estudadas por MAISEY (1982; 1984), Amelacanthus pustulatus é a mais parecida com os exemplares do Eopermiano brasileiro. Posssui costelas laterais largas e o espaço intercostal muito estreito, como nos exemplares estudados. O número de costelas entre 9-10 e a bifurcação primaria são observadas nos exemplares da base da Formação Irati, porém em A. pustulatus é restrita à face anterior. Outra diferença é que em A. pustulatus podem ocorrer pequenos tubérculos, não observados aqui.

O espécime do Pensilvaniano do Arizona, Amelacanthus sp., descrito por ELLIOTT et al. (2004) estava fragmentado, mas foi possível observar semelhanças como o grande espaçamento das costelas e pequeno espaço intercostal.

Gênero Iratiacanthus gen. nov.

Iratiacanthus santamariaensis

Figs. 78 e 79 


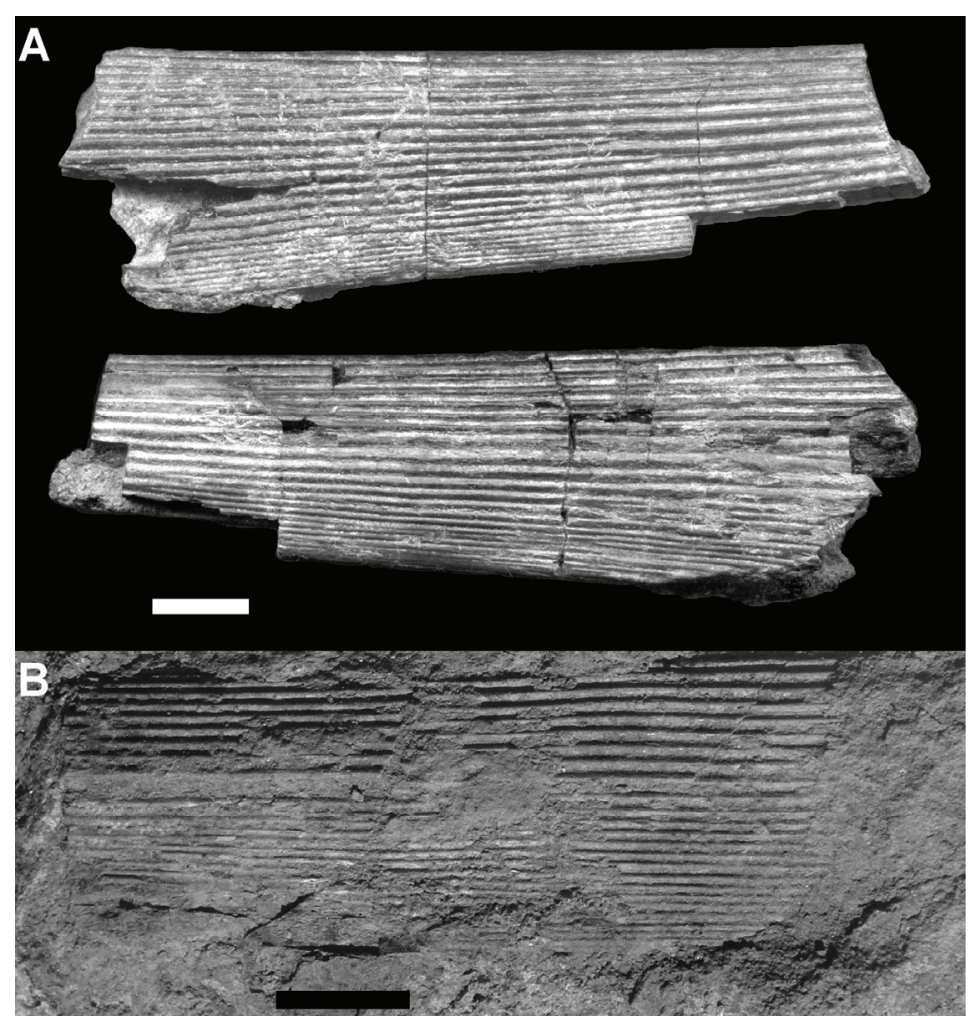

Figura 78 - Espécimes de Iratiacanthus santamariaensis. A) faces laterais do espécime GP/2E-6455; B) face lateral do espécime GP/2E-6462. Escala 10mm.

Material: GP/2E-6455 (Fig. 78A e 79) e GP/2E-6462 (Fig. 78B), espinhos incompletos.

Localização: Afloramento 1, Sitio Santa Maria 1.

Estratigrafia: Base da fácies arenosa do Membro Taquaral da Formação Irati. Eopermiano da Bacia do Paraná.

Etnologia: Gênero referente à Formação Irati e espécie referente ao Sitio Santa Maria onde foi inicialmente encontrado.

Diagnose: Elasmobrânquio reconhecido por espinhos de nadadeiras dorsais, alongados, que se afinam sem curvatura para o ápice; margem anterior arredondada, faces laterais divergentes próximas da região frontal, formando ângulo obtuso entre as faces, tornando-se gradualmente paralelas na região mediana, caracterizando, em seção transversal, a forma de $\mathrm{U}$; parede posterior plana ou com pequena concavidade, costelas lisas e finas com espaçamentos intercostais com metade da largura da costela; bifurcação primária terminando na região mediana do espinho; As larguras das costelas e do espaçamento intercostal diminuem da região anterior para a posterior do espinho. 

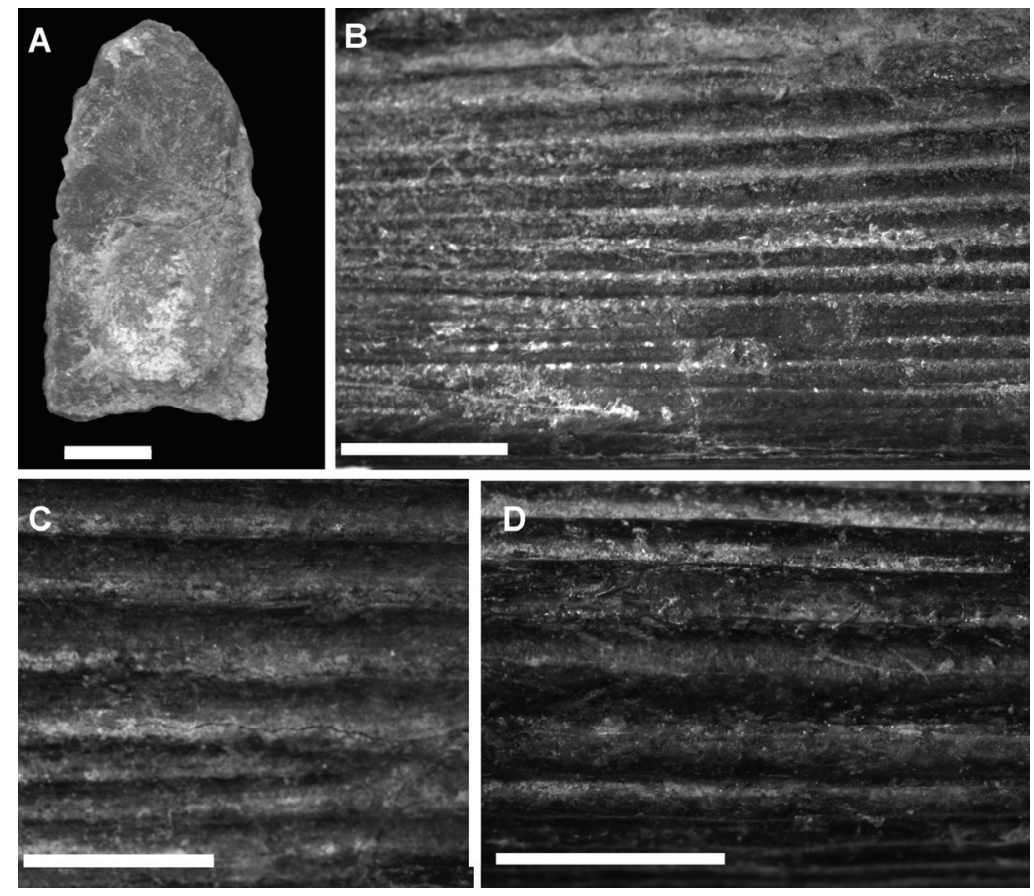

Figura 79 - Detalhe do exemplar GP/2E-6455 de Iratiacanthus santamariaensis. A) Seção transversal; B)

Diminuição gradual da largura das costelas do sentido anterior (superior na imagem) para posterior (Inferior na imagem). C) Bifurcação de costela; D) Costela frontal na parte central da imagem que separa as faces laterais do espécime. Escalas $5 \mathrm{~mm}$.

Descrição do exemplar GP/2E-6455: (Fig. 78A e 79) o espécime representa a parte mediana do espinho da nadadeira dorsal. Não foram observadas as regiões de articulação ou imbricação e nem do ápice. O espinho se afina da região inferior para a superior, tendo inclinação maior na face anterior do que na posterior, não foram observadas curvaturas.

O espinho mede 90,96 mm de comprimento máximo. A largura máxima entre a margem anterior e posterior é de $26,4 \mathrm{~mm}$ e $15,7 \mathrm{~mm}$ a mínima; a espessura máxima de $12,6 \mathrm{~mm}$.

O espinho é ornamentado por 22 costelas longitudinais baixas, lisas e contínuas (Fig.78A e Figs79B e 79C) da região inferior para a superior do espinho em toda a sua superfície. As larguras das costelas diminuem, gradualmente, da face anterior para a posterior, a partir da largura máxima de $1,84 \mathrm{~mm}$ da costela frontal para menos de $1 \mathrm{~mm}$ nas costelas posteriores.

As costelas não se unem ao longo do espinho, permanecendo separadas por um pequeno espaçamento intercostal igual ou um pouco maior que a metade da largura da costela. O espaçamento intercostal é de $0,7 \mathrm{~mm}$ entre as costelas maiores e menor que $0,3 \mathrm{~mm}$ entre as costelas menores da região posterior. Observaram-se costelas 
terminando na região central do espinho e bifurcações (Fig. 79C), cinco, em vários pontos das laterais do espécime.

A seção transversal possui a forma de U invertido ( $($ ) (Fig. 79A), com o ângulo maior entre as faces de $52^{\circ}$, obtida em ambos os lados, excluindo possível deformação diagenética. A face posterior é côncava, porém com a parte central sem proeminências.

A cavidade pulpar tem formato oval, com 1,94mm de comprimento máximo no sentido anterior- posterior e $7,3 \mathrm{~mm}$ de largura, localizada na região posterior do espinho. As medições da cavidade pulpar foram feitas na região mediana do espécime.

Descrição do exemplar GP/2E-6462: (Fig. 78B) o exemplar é a parte fragmentada de um espinho da nadadeira dorsal de elasmobrânquio fortemente incrustado na matriz arenosa. Não foram observados a região de articulação e o ápice. O espinho se afina discretamente da região inferior para a superior e não foram observadas curvaturas.

O espinho mede 82,9 mm de comprimento máximo. A distância entre a margem anterior e posterior (largura) é de 28,2 $\mathrm{mm}$ a máxima, e 21,0mm a mínima e a espessura $12,8 \mathrm{~mm}$.

O espinho é ornamentado por 28 costelas longitudinais baixas, lisas e contínuas, da região inferior para a superior do espinho, em toda a sua superfície. A largura das costelas é variada, sendo $1,4 \mathrm{~mm}$ de largura máxima obtida na costela frontal. Medições menores que um milímetro ocorrem nas costelas da região posterior, com aumento gradual e contínuo no tamanho das costelas, no sentido posterior para o anterior.

O espaçamento intercostal é de $0,8 \mathrm{~mm}$ entre as costelas maiores e $0,3 \mathrm{~mm}$ nas menores da região posterior. O espaçamento intercostal é próximo da metade da largura das costelas maiores e de um terço das costelas menores.

A seção transversal com forma de $U$ invertido $(\cap)$, o ângulo maior entre as faces em torno de $50^{\circ} \mathrm{em}$ ambos os lados rapidamente passando a paralela entre as faces. A face posterior é côncava, porém com a parte central sem proeminências. A cavidade pulpar não foi preservada.

Discussão: A grande espessura do espinho e as finíssimas costelas próximas das margens posteriores (Fig. 79B) diferem de espinhos de qualquer outro gênero conhecido de elasmobrânquio paleozóico, caracterizando assim um novo gênero aqui denominado Iratiacanthus, aparentemente endêmico da Bacia do Paraná.

O espinho difere dos gêneros permo-carboníferos Sphenacanthus, Ctenacanthus, Eunemacanthus e Bythiacanthus pela ausência de ornamentação por tubérculos nas 
costelas longitudinais e mantendo por toda a superfície costelas lisas com diminuição da largura.

Não é possível associar Iratiacanthus com os gêneros de costelas lisas Acondylacanthus, Amelacanthus e Hybodontiformes

O gênero Acondylacanthus possui costelas longitudinais lisas e finas com espaçamento intercostal entre as costelas maiores como em Iratiacanthus, porém em corte transversal em forma elíptica ou subtriangular em Acondylacanthus difere de Iratiacanthus que possui forma de U.

Comparando com Acondylacanthus nuperus, do Pensilvaniano do Colorado (ITANO et al. 2003), além das diferenças citadas, Iratiacanthus possui gradual diminuição do espaçamento das costelas, não observada na espécie do hemisfério norte.

Alguns espinhos de Hybodontiformes do Paleozóico e Mesozóico possuem finas costelas ou estrias, porém o espaçamento entre elas e a seção transversal diferem dos exemplares de Iratiacanthus da Formação Irati.

Entre os Sphenacanthus que possuem costelas lisas, $S$. hybodoides e $S$. aequistriatus, ambos do Carbonífero da Grã-Bretanha, tem na sua região anterior a disposição das costelas diferente, sendo mais finas e com menor espaçamento no exemplar da Formação Irati. O número de costelas e disposição também difere de Wodnika striatula que apesar de ter formato similar ao exemplar estudado difere pela disposição, espaçamento maior e menor número de costelas nas laterais.

A seção transversal, em forma de U invertido, é similar a de Sphenacanthus marshi, porém a presença de pequenos tubérculos nas margens laterais, a disposição das costelas e o espaçamento intercostal são distintos dos espécimes analisados.

Amelacanthus é o que mais se assemelha a Iratiacanthus, como o grande número de costelas, acima de 15, espessuras finas e espaçamento intercostal, porém comparando com as espécies atribuídas aquele gênero é possível observar diferenças anatômicas significativas.

Comparando com Amelacanthus sulcatus, do Mississipiano da Irlanda do Norte, seu comprimento anterior-posterior é duas vezes maior que a espessura da face posterior, semelhante aos exemplares aqui estudados, porém tem menos costelas em cada lateral, máximo 15, e apresentam costelas também na borda lateral posterior, além de que os exemplares aqui descritos são achatados na região posterior ou ligeiramente côncavos e as costelas são mais finas do que em A. sulcatus. 
A bifurcação primária das costelas e o grande número de costelas finas são observados na espécie do Mississipiano de Armagh, Irlanda do Norte, Amelacanthus laevis, com 24 costelas em cada lateral. A curvatura do espinho, porém, é muito acentuada nos exemplares de A. leavis. Em relação à Amelacanthus pustulatus, a nova espécie difere por ter costelas laterais finas e número muito maior.

Amelacanthus plicatus, do Mississipiano da Irlanda, também possui grande numero de costelas, 20 em cada lateral, porém não existe a costela que separa as faces laterais na região anterior e em seção transversal. A. plicatus tem o aspecto de um triangulo isósceles, em corte transversal, com pequeno arredondamento no vértice superior, diferentemente dos exemplares aqui descritos que possui forma de $U$ e um grande arredondamento na face frontal.

Iratiacanthus santamariaensis tem aparentemente relação filogenética com Amelacanthus e Sphenacanthus do Carbonífero da America do Norte e Grã-Bretanha, gêneros com maior quantidade de características morfológicas similares, o que indicaria origem mais antiga para os Chondrichthyes da Bacia do Paraná e que teriam se diversificado isoladamente desde o fim do Carbonífero.

\subsection{Xenacanthiformes}

Os primeiros fósseis de Xenacanthiformes foram descobertos na Europa, no decorrer da década de 1830. Naquela época todos os exemplares provinham das minas de carvão, sendo que na Republica Tcheca (região da Boêmia) apareceram os primeiros restos articulados.

Os mais antigos fósseis são do Devoniano (TURNER, 1982; YOUNG, 1982; TURNER et al, 2005), porém foi no Carbonífero que se tornaram comuns e desapareceram no Neotriássico.

Os tubarões xenacantos eram peixes grandes, com espécie alcançando $5 \mathrm{~m}$ de comprimento, de corpo fino e alongado, facilmente distinguíveis de outros grupos de elasmobrânquios. A maior parte habitava rios e lagos de água doce, porém algumas, principalmente no Eocarbonífero, preferiam salinidades maiores como estuários e ambientes costeiros (PRICE, 1948, BAIRD, 1978, PARRISH, 1978, JANVIER, 1996, JOHNSON, 2005a, 2005b). Não é incomum encontrar dentes e espinhos de espécies de água doce retrabalhadas em depósitos marinhos costeiros, de alta energia ou de origem deltaica (MOY-THOMAS \& MILES, 1971; LONG, 1995; NELSON, 2006). 
No inicio acreditava-se que os Xenacanthiformes possuíam pele lisa, sem escamas placóides ou qualquer outra proteção, contudo espécies pertencentesà família Diplodoselachidae (SOLER-GIJÓN, 1997a) revelaram dentículos dérmicos e escamas placóides, algumas de tamanho aproximado de $1 \mathrm{~mm}$.

Os dentes e espinhos, por serem mais comumente preservados, são os principais modos de identificação deste grupo. Para o estudo de dentes existem diversas características genéricas para todos os Xenacanthiformes (JANVIER, 1996, HAMPE, 2003).

Os dentes são do tipo diplodonte, duas cúspides principais (fig. 80). A base é larga e geralmente oval ou circular (algumas losangulares ou triangulares), enquanto sua porção superior é sempre convexa, exibindo no centro, uma proeminência conhecida como botão apical ou botão coronal. De tamanho e formas variadas, esta estrutura pode ocorrer isolada das cúspides principais ou entre elas. Contudo, não chega até o bordo lingual. A superfície inferior pode ser côncava ou plana (em raros casos convexa) e apresenta poucos foramens nutritivos dispostos aleatoriamente em sua superfície. $\mathrm{Na}$ face labial inferior ocorre uma saliência proeminente denominada tubérculo basal, caracterizado pela ponta externa arredondada e a superfície articular côncava.

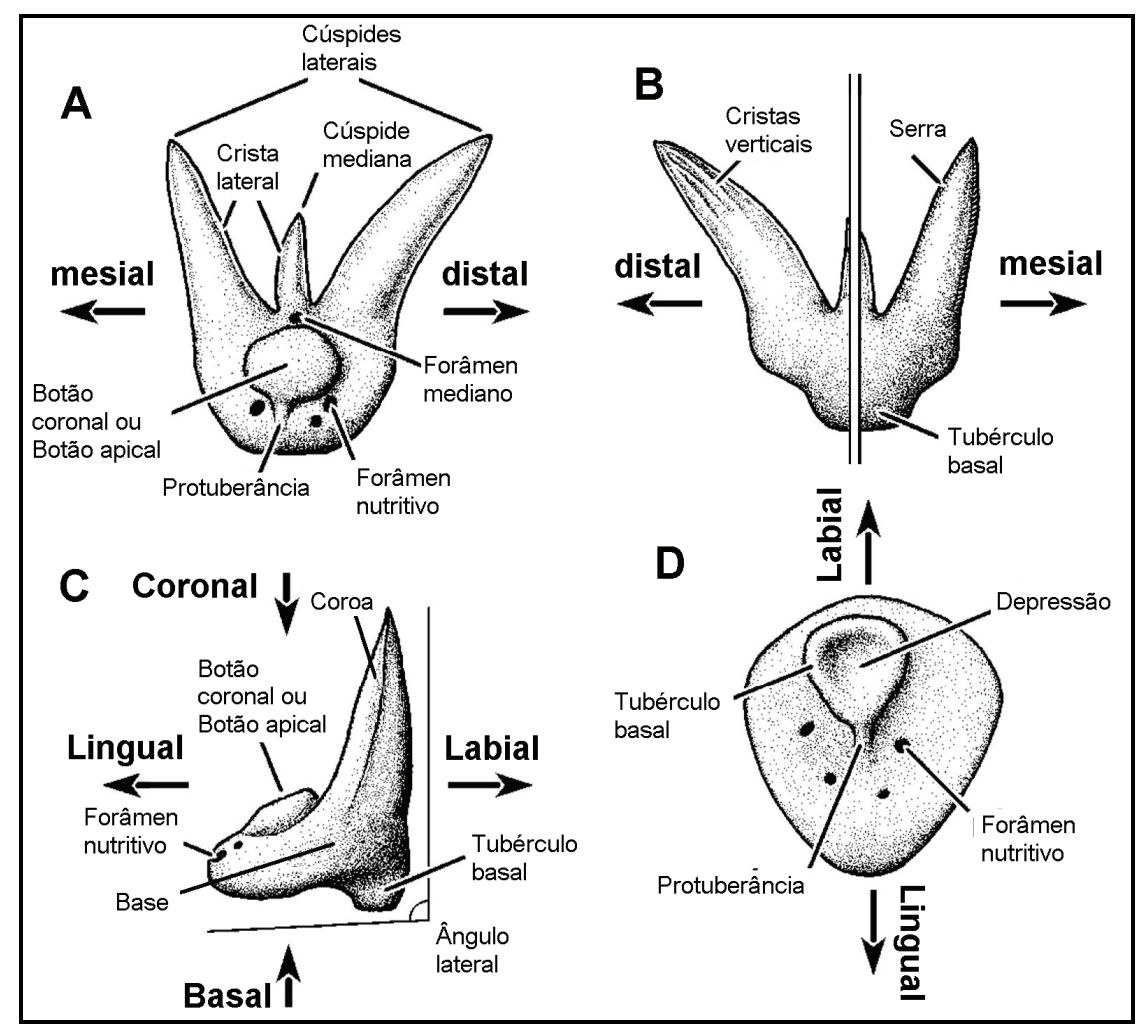

Figura 80 - Esquema de dente de Xenacanthiformes, adaptado de HAMPE (2003). A) Vista lingual; B) Vista labial; C) Vista lateral; D) Vista basal. 
A coroa geralmente é tricuspidada, com todas as cúspides situadas no bordo labial. As duas cúspides principais divergem entre si, dando o caráter diplodonte, e no centro ocorrem uma ou duas cúspides menores com 1/5 a 1/3 do tamanho das maiores.

As cúspides principais são cônicas com cristas (cristas longitudinais ou costelas), lisas ou estriadas. Os dentes ainda podem apresentar variações morfológicas de acordo com o estágio ontogênico e posicionamento na boca do animal.

Os espinhos encontrados podem ser associados à nadadeira dorsal, livres na região dorsal ou ser cefálicos. O espinho cefálico, localizado logo atrás do crânio ou na região dorsal (SOLER - GIJÓN, 1997b), é alongado, afinando-se gradualmente, possui estrias e duas fileiras de farpas na borda distal.

No Brasil SILVA SANTOS \& SALGADO (1970), RAGONHA (1984) e TOLEDO et al. (2005) pesquisaram alguns espinhos cefálicos do Permo-carbonífero brasileiro. Observaram que em diversas espécies, os espinhos cefálicos são retos ou ligeiramente encurvados e as duas fileiras diminutas de farpas não são necessariamente opostas.

HAMPE (2003) separou os Xenacanthiformes em apenas duas famílias; Diplodoselachidae e Xenacanthidae. A família Orthacanthidae, com apenas o gênero Orthacanthus (HEYLER \& POPLIN, 1989) e a família Lebachacanthidae, com Lebachacanthus (SOLER-GIJÓN, 1997A, 1997B, 2000) foram incluídas por HAMPE (2003) nos Diplodoselachidae.

\subsubsection{Família Diplodoselachidae}

A família Diplodoselachidae compõe o mais primitivo grupo de Xenacanthiformes. Caracteriza-se pelo espinho dorsal e não cefálico e a nadadeira caudal, inequilobada e não dificerca, chegando a ser heterocerca em alguns casos.

Atualmente os gêneros atribuídos a esta família são: Diplodoselache (Fig. 81A e 81B), Dicentrodus (Fig. 81C), Lebachacanthus, Orthacanthus (Fig. 81D e E), Hagenoselache, Reginaselachi (TURNER \& BURROW, 2011), Anodontacanthus (este representado apenas por espinhos) e Wurdigneria, este endêmico da Bacia do Paraná (Fig.81F). 


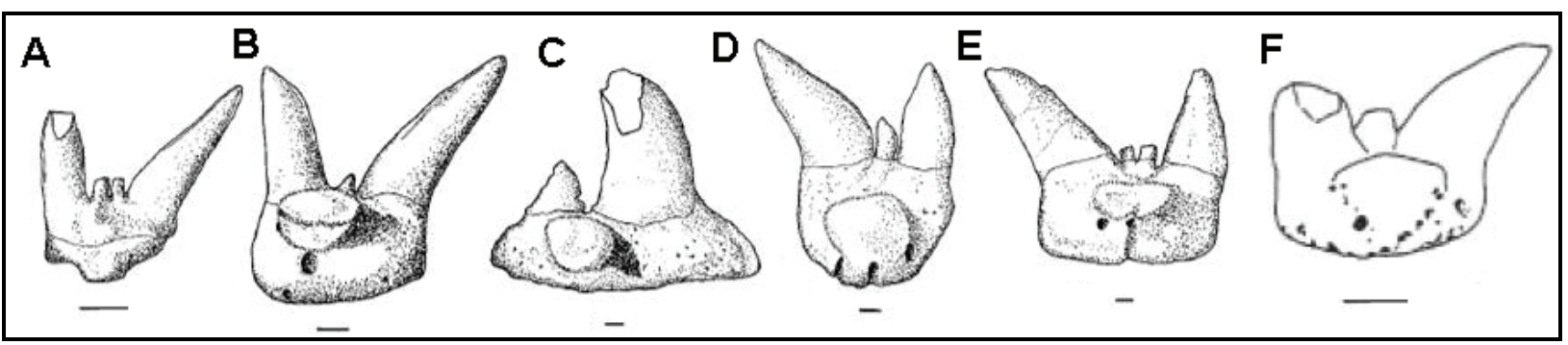

Figura 81 - Dentes de Diplodoselachidae. A) Diplodoselache woodi; B) Diplodoselache parvulus; C) Dicentrodus bicuspidatus; D - E) Orthacanthus gibbosus; F) Wurdigneria obliterata. A) Vista labial; BF) Vista lingual. Escala $1 \mathrm{~mm}$ (HAMPE, 2003, A-E; RICHTER, 2005, apenas F).

\subsubsection{Família Xenacanthidae}

A família Xenacanthidae é caracterizada por dentes tricúspides, não serrilhados. Cúspides com uma crista vertical, a base com um tubérculo basal e uma depressão na parte inferior. O espinho dorsal está inserido no neurocrânio com uma fileira de dentículos em cada lateral. Nadadeira caudal pseudo-dificerca (lóbulo epicaudal aumentado, alongado no eixo longitudinal).

Atualmente são considerados Xeanacanthidae os gêneros Xenacanthus (Fig. 82 A,B,C), Triodus (Fig. 82 D), Plicatodus e Barbclabornia (Fig. 82E).

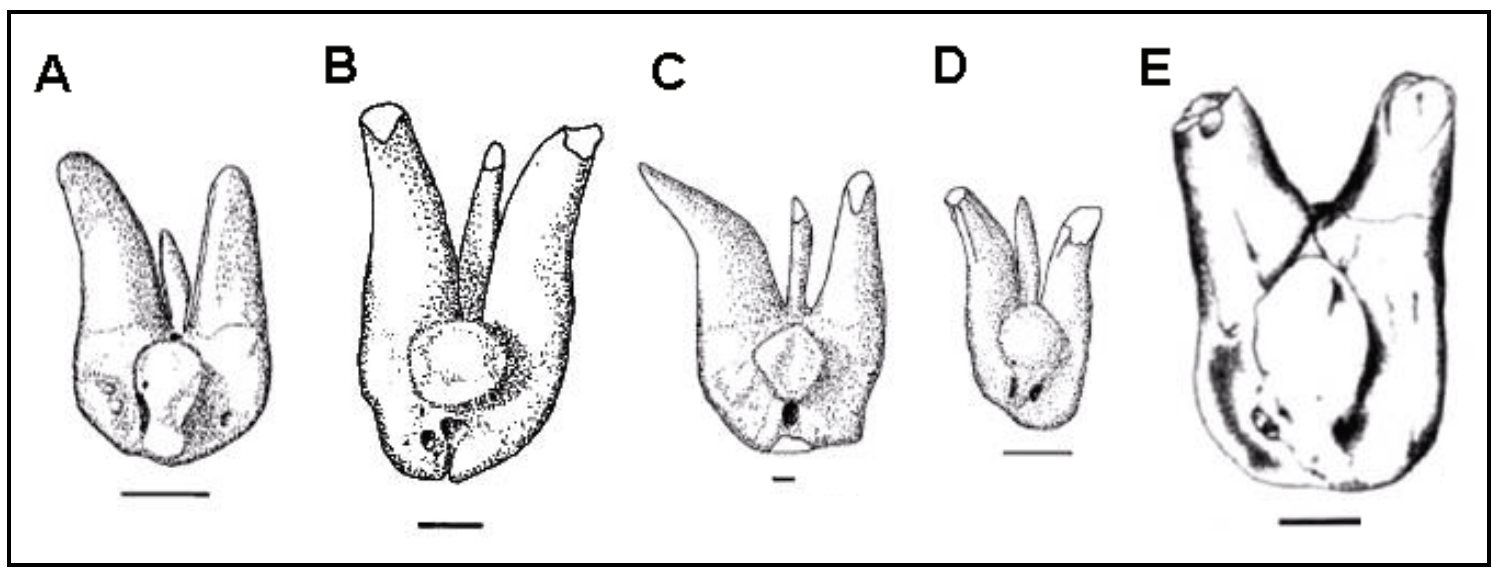

Figura 82 -Dentes de Xenacanthidae. A) Xenacanthus elegans B) Xenacanthus tenuis; C) Xenacanthus laevissimus; D) Triodus serratus; E) Barbclabornia luedersensis. Todos em vista lingual. Escalas: 1 mm (HAMPE, 2003, A-D; JOHNSON, 2003, E).

Alguns gêneros comuns na literatura científica perderam sua validade. HAMPE (2003) observou que o gênero Pleuracanthus foi primeiramente associado a um inseto e o gênero Expleuracanthus é equivalente a espécies de Xenacanthus ou Triodus.

HAMPE (op. cit.) chamou atenção para o gênero Bransonella que costuma ser associado à Xeanacanthiformes. Segundo o autor, existem características que não são 
comuns a outros xenacantos e por isso o gênero não deve ser considerado como pertencente à ordem.

O gênero Antarctilamna é interpretado atualmente como um "elo" de ligação entre os Ctenacanthiformes e Xenacanthiformes por apresentar características comuns a ambos os grupos, como a dentição diplodonte (YOUNG, 1982; JANVIER, 1996). HAMPE \& LONG (1999), HAMPE (2003) e TURNER \& BURROW (2011) não o incluíram na ordem Xenacanthiformes, baseados em estudos detalhados da caixa craniana e espinho dorsal. Para TURNER \& BURROW (2011) Phoebodus, como Antarctilamna, teria evoluído paralelamente aos primeiros Xenacanthiformes.

\subsubsection{Estudo paleoambiental de tubarões Xenacanthiformes}

Os Xenacanthiformes por se associarem normalmente a camadas de carvão e a fósseis de origem continental (vegetais, répteis e anfíbios) foram considerados exclusivamente de água doce (RAGONHA, 1984; JOHNSON, 1999; 2005a; 2005b; HAMPE, 2003), porém constatou-se a existências de espécies que habitavam ambientes costeiros ou de salinidade variável.

Nos últimos 20 anos do século XX estes fósseis foram alvo de estudos paleoambientais, principalmente com formas do Carbonífero da Europa e América do Norte. O maior número de formas eurialinas como Dicentrodus, Diplodoselache e Orthacanthus, todos Diplodoselachidae, ocorrem em depósitos marinhos costeiros, estuarinos, deltaicos e lagunares (HAMPE, 2003; JOHNSON, 2003; HAMPE et al 2006).

A maior parte dos Xenacanthidae é representada pelos gêneros Triodus e Xenacanthus, normalmente retrabalhados em depósitos costeiros, sem evidências que habitavam estes ambientes. Dentes atribuídos ao gênero de Triodus, por serem muito abundantes na Europa são encontrados em depósitos de paleoambientes incertos, necessitando maiores estudos para se chegar a exata posição paleoambiental.

Até hoje não foi encontrado Xenacanthiformes associado com animais exclusivamente marinhos ou em depósitos marinhos profundos e sim citações de camadas com fósseis eurialinos, como acritarcos, ostracodes, bivalves e alguns braquiópodes (Lingula ou Orbiculoidea), então é possível presumir que não viviam em mar aberto.

Muitos trabalhos que associam Xenacanthiformes a meio eurialino apenas apresentaram como evidência a presença de fósseis nos sedimento, não levando em 
conta processos tafonômicos, ocorrências ou não de fósseis marinhos ou, em alguns casos, a própria sedimentação estudada (SOLER-GIJON, 1997a; 1997b; 2000; HAMPE, 2003; JOHNSON, 2003; HAMPE et al 2006), por isso muitos devem ser revisados do ponto de vista paleoambiental.

\title{
6.7.4 Xenacanthiformes encontrados na base da Formação Irati
}

\author{
Subclasse ELASMOBRANCHII Bonaparte, 1838 \\ Ordem XENACANTHIFORMES Berg, 1940 \\ Família DIPLODOSELACHIDAE \\ Taquaralodus gen. nov.
}

Distribuições Geográficas e Estratigráficas - Formação Pedra do Fogo do

Estado do Maranhão e base do Membro Taquaral da Formação Irati do Estado de São Paulo, ambos do Permiano.

Holótipo - 442-P, DGM - DNPM, dente incompleto da Formação Pedra do Fogo, 6km ao sul de Pastos Bons.

Etimologia - Dente do Taquaral, referindo-se a unidade em que foram encontrados em maior abundância.

Diagnose (emendada de SILVA SANTOS, 1946 e RAGONHA, 1978) - Os dentes possuem coroa tricuspidada, com duas cúspides laterais maiores, desiguais, e uma intermediária, muito pequena (ou ausente), dispostas aproximadamente no mesmo plano do bordo labial da base e sempre inclinadas para a face lingual. A cúspide maior ocupa mais ou menos a metade do bordo labial, e se eleva sempre perpendicularmente à base, a segunda cúspide se dispõe na lateral labial do dente, a intermediária é sempre menor que a segunda e se dispõe obliquamente entre as duas cúspides. As cúspides são ovais em corte transversal, não apresentam superfície serrilhada e podem ter cristas irregulares. A base, de forma alongada ou circular, apresenta a face lingual voltada para baixo e um pequeno botão apical de forma elíptica na parte superior. A face labial exibe uma pequena saliência alongada, conhecida como tubérculo basal, abaixo da cúspide principal. A superfície inferior da base é sempre plana.

\section{Sinonímias}

\section{Taquaralodus albuquerquei (SILVA SANTOS 1946)}

Figs. $83-89$

Pleuracanthus albuquerquei Silva Santos 1946

Taquaranthus albuquerquei Ragonha 1978 (nomen nudum)

Xenacanthus albuquerquei Richter 1985 


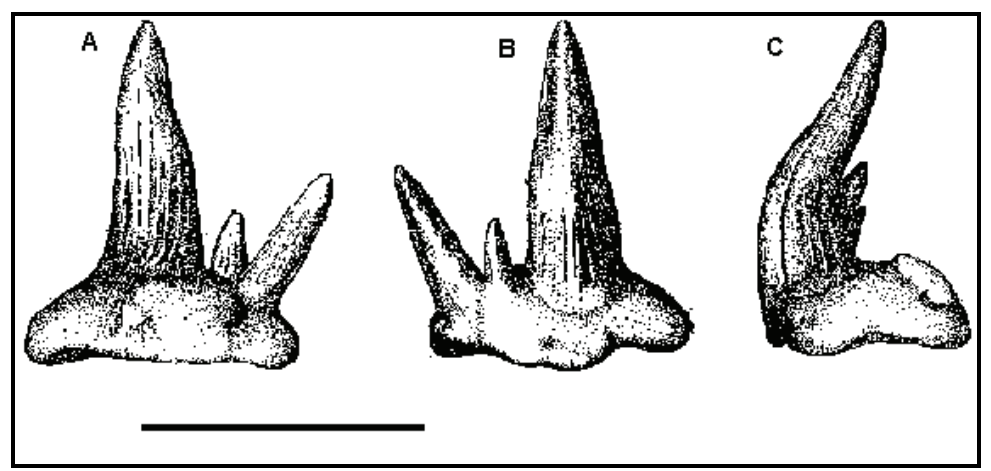

Figura 83 - Esquema de dente de Taquaralodus (RAGONHA, 1978). A) vista lingual, B) vista labial, C) vista lateral. Escala $10 \mathrm{~mm}$.

Material - GP/2T-210 (Fig. 88A-88D), GP/2T-211 (Fig 84-86A-D), GP/2T-212 (Fig. 86E-H) . GP/2T-213 (Fig. 88E-88F), GP/2T-214 (Fig. 89), GP/2E-6580 (Fig 87G87L), GP/2E-6581 (Fig. 87A-87F). Dentes isolados em vários estados de preservação.

Localização - Afloramento 1 Sitio Santa Maria 1 (GP/2T-210, GP/2T-211, GP/2T-212, GP/2T-213 e GP/2T-214) e Afloramento 12 Fazenda Ponnte Nova (GP/2E-6580 e GP/2E-6581)

Distribuições Geográficas e Estratigráficas - a mesma do gênero.

Diagnose específica - gênero monoespecífico.

Descrição - os exemplares encontrados de Taquaralodus podem apresentar três, duas ou uma única cúspide. O exemplar GP/2T-211, por causa de quebras, apenas preservou as partes inferiores das cúspides. A coroa apresenta duas cúspides principais divergentes e uma intermediária, dispostas no bordo labial da base. Em vista transversal, as cúspides maiores são ovais e a menor circular.

A partir da parte preservada das cúspides, confirmou-se o tamanho diferenciado entre as cúspides. A maior ocupa mais da metade do bordo labial e aparentemente eleva-se verticalmente. A segunda tem 1/3 do diâmetro máximo da cúspide maior e está localizada em uma das laterais. A menor, intermediária em posição, está posicionada labialmente às demais e tem diâmetro $1 / 9$ do diâmetro da cúspide principal (Fig. 84, $85 \mathrm{~A}$ e $85 \mathrm{~B})$. 


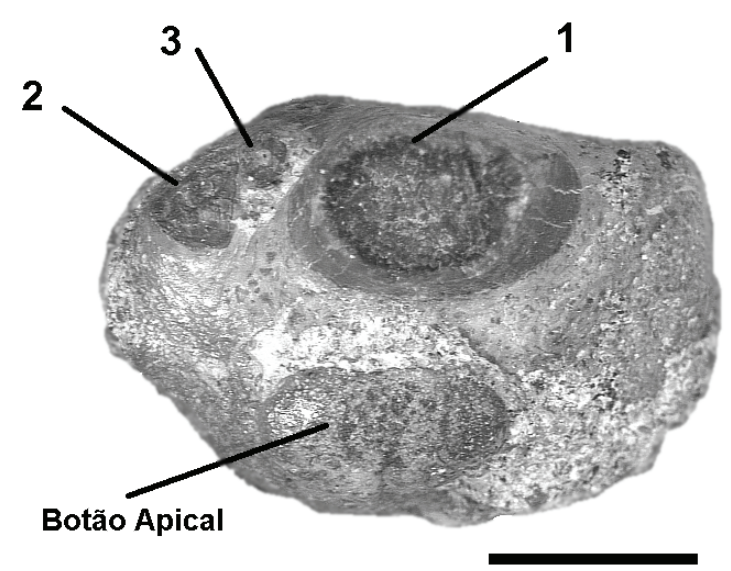

Figura 84 - Dente de Taquaralodus indicando características morfológicas. 1) Cúspide principal,. 2) Cúspide secundária. 3) cúspide intermediária. Escala. 4mm.

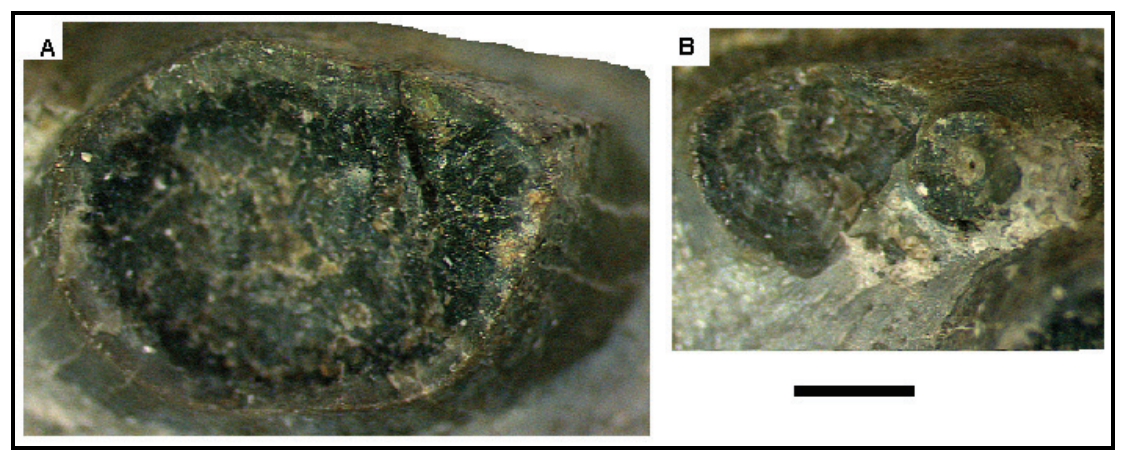

Figura 85 - Detalhe das cúspides do exemplar tricuspidado de Taquaralodus albuquerquei (GP/2T-211). A) cúspide principal maior. B) cúspide lateral secundária e cúspide intermediária menor. Exemplar $1 \mathrm{~mm}$.

O segundo exemplar tricuspidado GP/2E-6581 manteve parte da cúspide principal e as outras duas cúspides. Como em GP/2T-211 as duas maiores cúspides estão dispostas no bordo labial, sendo que a maior ocupa mais da metade do bordo labial e ocorre uma pequena cúspide entre elas. A segunda cúspide é inclinada para a lateral do dente e tem tamanho um pouco maior que $1 / 3$ do diâmetro da maior e a cúspide intermediária tem $1 / 5$ do diâmetro da principal.

$\mathrm{Na}$ parte preservada da cúspide principal em GP/2T-211 e em GP/2E-6581, a face labial é lisa e a lingual com cristas muito finas, como nos exemplares observados por SILVA SANTOS (1946) e RAGONHA (1978). As ornamentações das cristas são paralelas, partindo da base da cúspide, mas são irregulares na forma, comprimento e orientação. A distância entre elas também é variada.

A base é alongada e irregular com a superfície inferior levemente côncava. $\mathrm{O}$ bordo labial exibe uma protuberância, o tubérculo basal, enquanto na região lingual observa-se um prolongamento para baixo. No bordo lingual da parte superior existe uma proeminência elíptica, o botão apical, separada das cúspides. 
O exemplar bicuspidado (GP/2T-212) é similar aos tricuspidados e difere apenas na ausência da cúspide intermediária (Figs. 86E e 86F). A coroa possui duas cúspides de tamanhos diferentes, dispostas no mesmo plano do bordo labial da base. Como nos exemplares anteriores, o diâmetro da cúspide menor é de pouco mais de $1 / 3$ da maior.

O exemplar (GP/2E-6580) representa um espécime unicuspidado que apenas possui a cúspide principal maior, porém percebe-se protuberâncias no bordo labial onde se localizaria a segunda cúspide principal (Fig. $87 \mathrm{G}$ e $87 \mathrm{H}$ ).
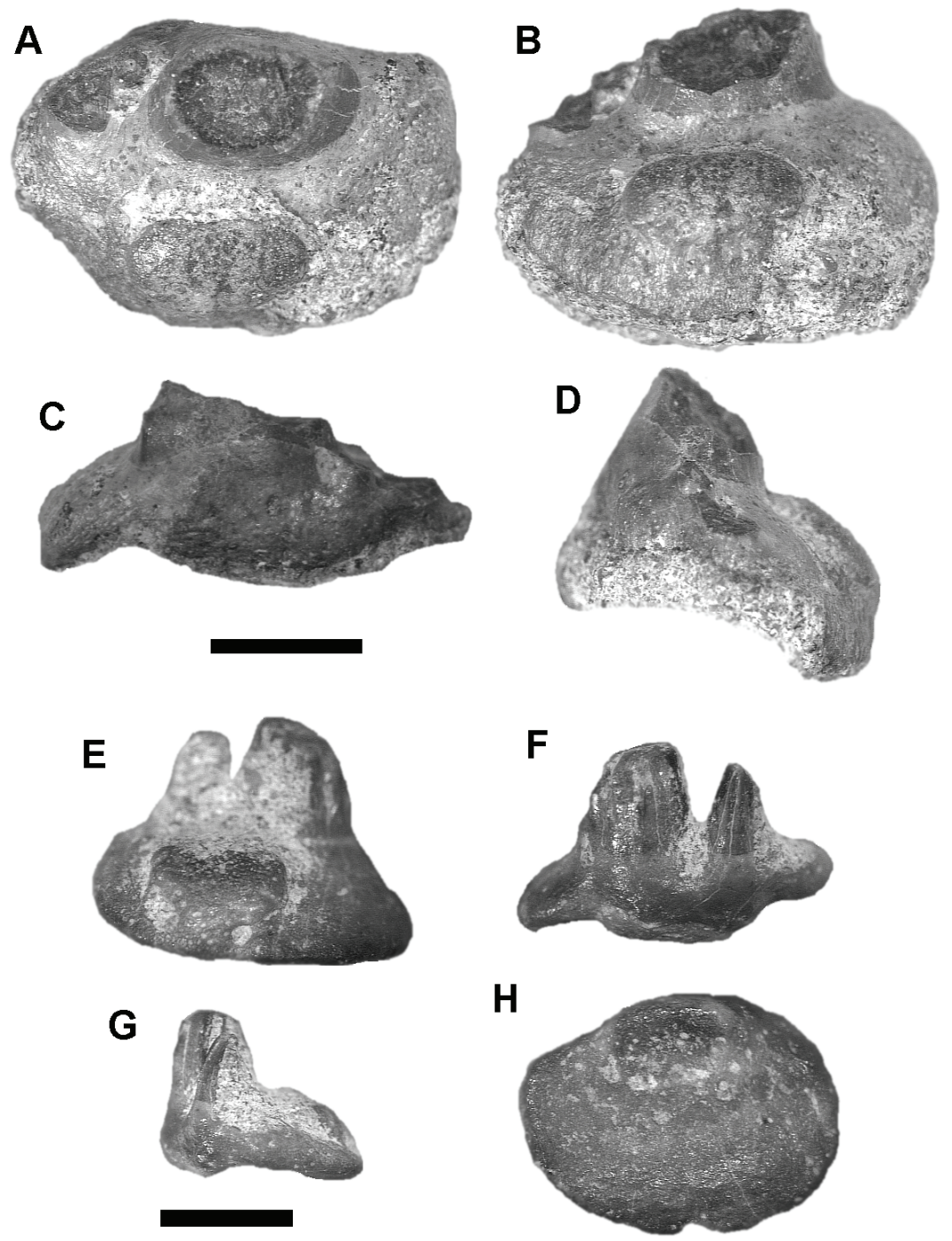

Figura 86 - Dentes de Taquaralodus albuquerquei encontrados no Afloramento 1, Sítio Santa Maria. Dente tricuspidado A) vista superior. B) vista lingual. C) vista labial. D) vista lateral.(GP/2T-211) Escala 4mm. Dente bicuspidado E) vista lingual. F) vista labial. G) vista lateral. H) vista inferior. (GP/2T212). Escala $2 \mathrm{~mm}$. 

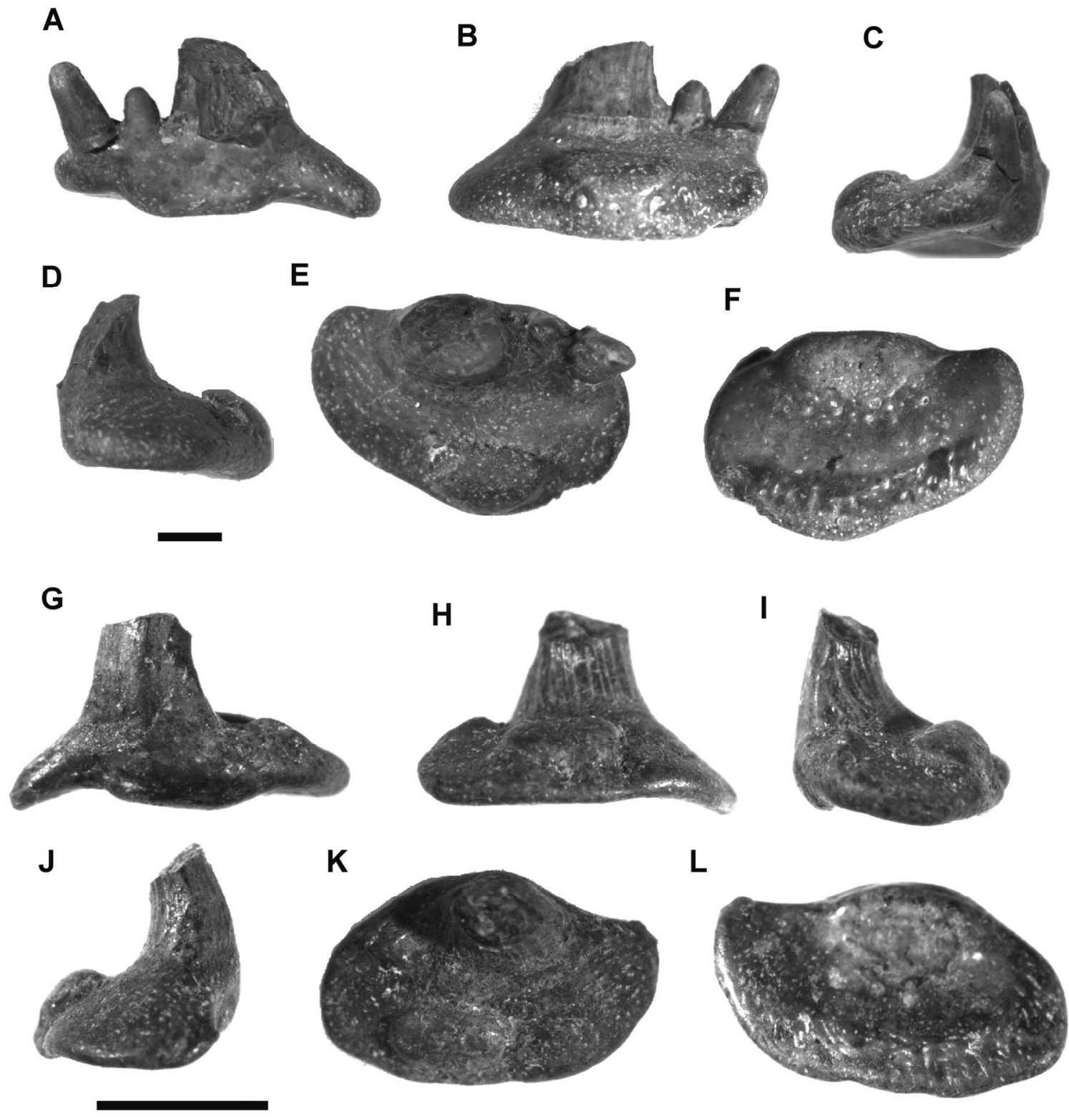

Figura 87 - Dentes de Taquaralodus albuquerquei encontrados no Afloramento 12, Fazenda Ponte Nova A-F) Exemplar GP/2E-6581 . A) vista labial, B) vista lingual. C-D) vistas laterais, E) vista oclusal, F) vista inferior. Escala 2mm. G-L) Exemplar GP/2E-6580. G) vista labial, H) vista lingual. I-J) vistas laterais, K) vista oclusal, L) vista inferior. Escala $5 \mathrm{~mm}$.

A cúspide ocupa a região centro-lateral do bordo labial, com cristas muito finas que partem paralelas à base e se tornam irregulares à medida que se dirigem ao topo da cúspide, tanto na face labial quanto na lingual, porem na face labial são quase imperceptíveis.

A base é alongada com um prolongamento lateral para uma das laterais, e quase plana, com a superfície inferior levemente côncava próxima do tubérculo basal. A região do botão apical preservou o botão apical alongado e ocorrem foramens na face inferior e superior da base. 
O exemplar (GP/2T-210) representa um espécime unicuspidado (Fig. 88A-88D). Cristas finas irregulares percorrem toda a superfície das cúspides, tanto na face lingual como na labial. A base é subcircular, com um prolongamento lateral em relação à coroa. Como em GP/2T-211, possui no bordo labial inferior, um alongado tubérculo basal, enquanto na face inferior da parte lingual ocorre um prolongamento para baixo. A parte superior exibe um pequeno botão apical elíptico. Tanto na face inferior da base como na superior foram observados pequenos foramens.

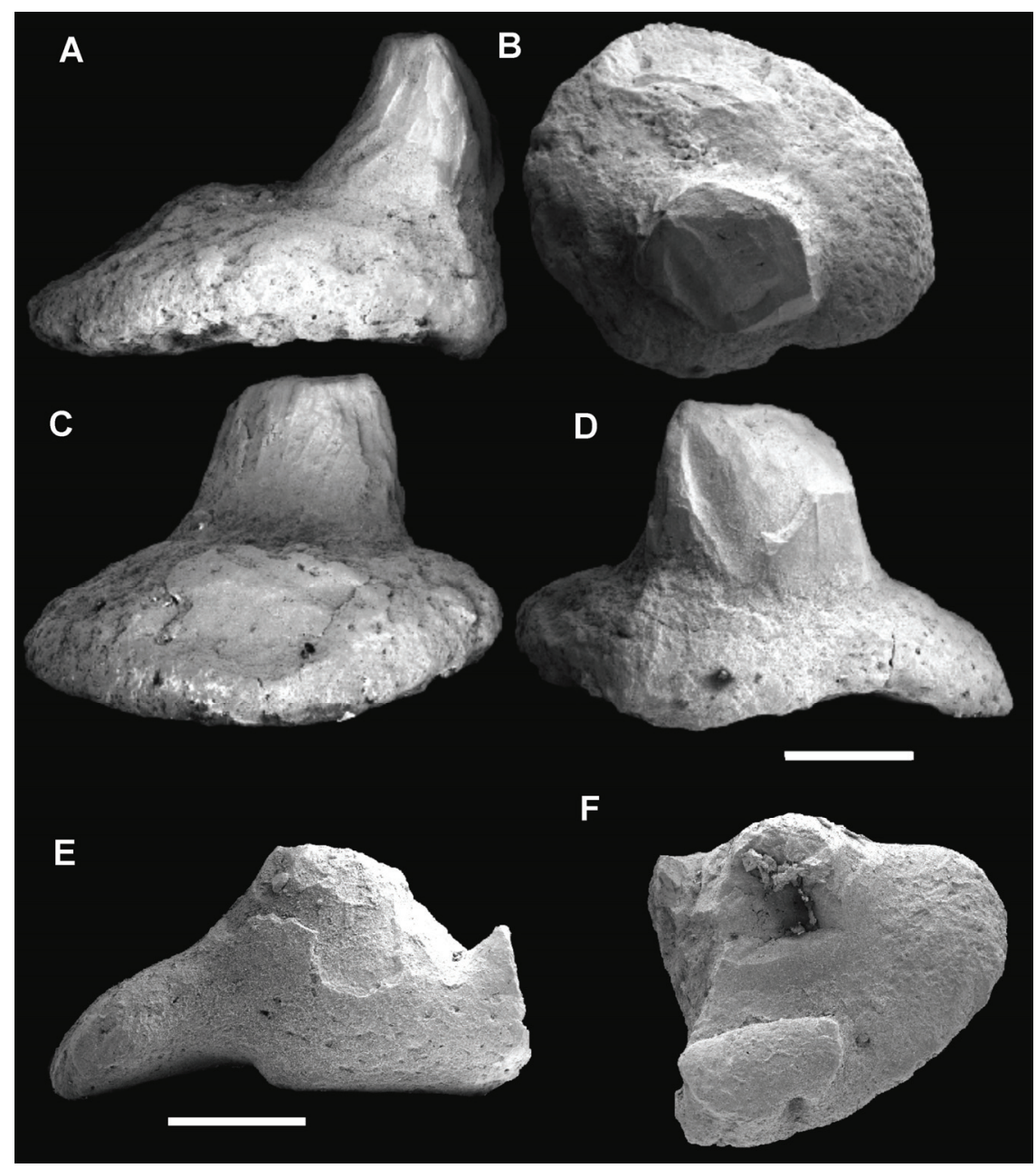

Figura 88 - Montagem de fotografias em MEV de Taquaralodus albuquerquei. Exemplar unicuspidado GP/2T-210. A) vista lateral. B) vista superior. C) vista lingual. D) vista labial. GP/2T-210. Exemplar GP/2T-213. E) Face labial incompleta com destaque a cúspide maior fragmentada; F) Vista oclusal com destaque ao botão apical na parte inferior. Escalas: $2 \mathrm{~mm}$.

A cúspide do espécime GP/2T-210 ocupa a região central do bordo labial, com cristas muito finas que partem paralelas à base e se tornam irregulares à medida que se dirigem ao topo da cúspide, tanto na face labial quanto na lingual. A base é circular e quase plana com a superfície inferior levemente côncava próxima do tubérculo basal. A 
região do botão apical está quebrada, mas ainda preserva fragmentos do botão apical. Ocorrem foramens na face inferior e superior da base.

O comprimento máximo da base do exemplar tricuspidado GP/2T-211 é de $10,3 \mathrm{~mm}$ e a largura, $7,1 \mathrm{~mm}$. O botão apical tem $4,2 \mathrm{~mm}$ de comprimento e $2,4 \mathrm{~mm}$ de largura. Em corte a cúspide principal tem forma oval, 4,7mm por 3,1mm; a cúspide secundária, $1,6 \mathrm{~mm}$ por $1 \mathrm{~mm}$, e a intermediária, $0,5 \mathrm{~mm}$ por $0,4 \mathrm{~mm}$.

O comprimento da base do exemplar (GP/2E-6580) é de 10,0mm e a largura, $6,1 \mathrm{~mm}$. O botão apical tem $3,7 \mathrm{~mm}$ de comprimento e 2,5mm de largura. Em corte a cúspide principal tem forma oval, $3,8 \mathrm{~mm}$ por 2,3mm; a cúspide secundária, $1,5 \mathrm{~mm}$ por $1 \mathrm{~mm}$, e a intermediária, $0,8 \mathrm{~mm}$ por $0,4 \mathrm{~mm}$.

A base do exemplar bicuspidado (GP/2T-212) tem 4,4mm de comprimento e $3,2 \mathrm{~mm}$ de largura. A cúspide maior (incompleta) tem $1,6 \mathrm{~mm}$ de altura e $1,9 \mathrm{~mm}$ de diâmetro. A cúspide menor tem, aproximadamente, $0,9 \mathrm{~mm}$ de diâmetro e $1 \mathrm{~mm}$ de altura. O botão apical tem $1 \mathrm{~mm}$ de comprimento máximo.

O exemplar unicuspidado (GP/2T-210) é o segundo maior, com comprimento máximo da base de $7,7 \mathrm{~mm}$ e a largura $7,4 \mathrm{~mm}$. A cúspide tem $3,7 \mathrm{~mm}$ de diâmetro máximo e $2,8 \mathrm{~mm}$ de mínimo.

O exemplar unicuspidado (GP/2E-6580) (Fig. 86G-Fig.86L) tem o comprimento da base de $9,5 \mathrm{~mm}$ e a largura $5,5 \mathrm{~mm}$. A cúspide tem $3 \mathrm{~mm}$ de diâmetro máximo e 2,8mm de mínimo

Outros fósseis incompletos auxiliaram na descrição da espécie. No exemplar GP/2T-213 (Fig. 88E-88F), não ocorrem estrias ou finas costelas longitudinais na base, tubérculo basal achatado e alongado (Fig. 88E) e o botão apical reduzido (comparado com outros Xenacanthiformes) de formato trapezóide (Fig. 88F). Este exemplar, incompleto, possui a base alongada como nos exemplares tricuspidado (GP/2T-211) e bicuspidados (GP/2T-212), alem de parte da segunda cúspide preservada. Ocorrem foramens na região lingual em contato direto com o botão apical.

O exemplar incompleto GP/2T-214 (Figs. 89A-89F) possui características morfológicas que o aproximam de um exemplar unicuspidado, como a base subcircular e a cúspide postada na região central, porém não se tem certeza se é um exemplar de uma única cúspide dada sua quebra lateral. O tubérculo basal (Fig. 89D) é bem proeminente se comparado com os exemplares de mais cúspides e o botão apical tem a forma hexagonal, enquanto os outros exemplares possuem forma trapezoidal ou elíptica. 

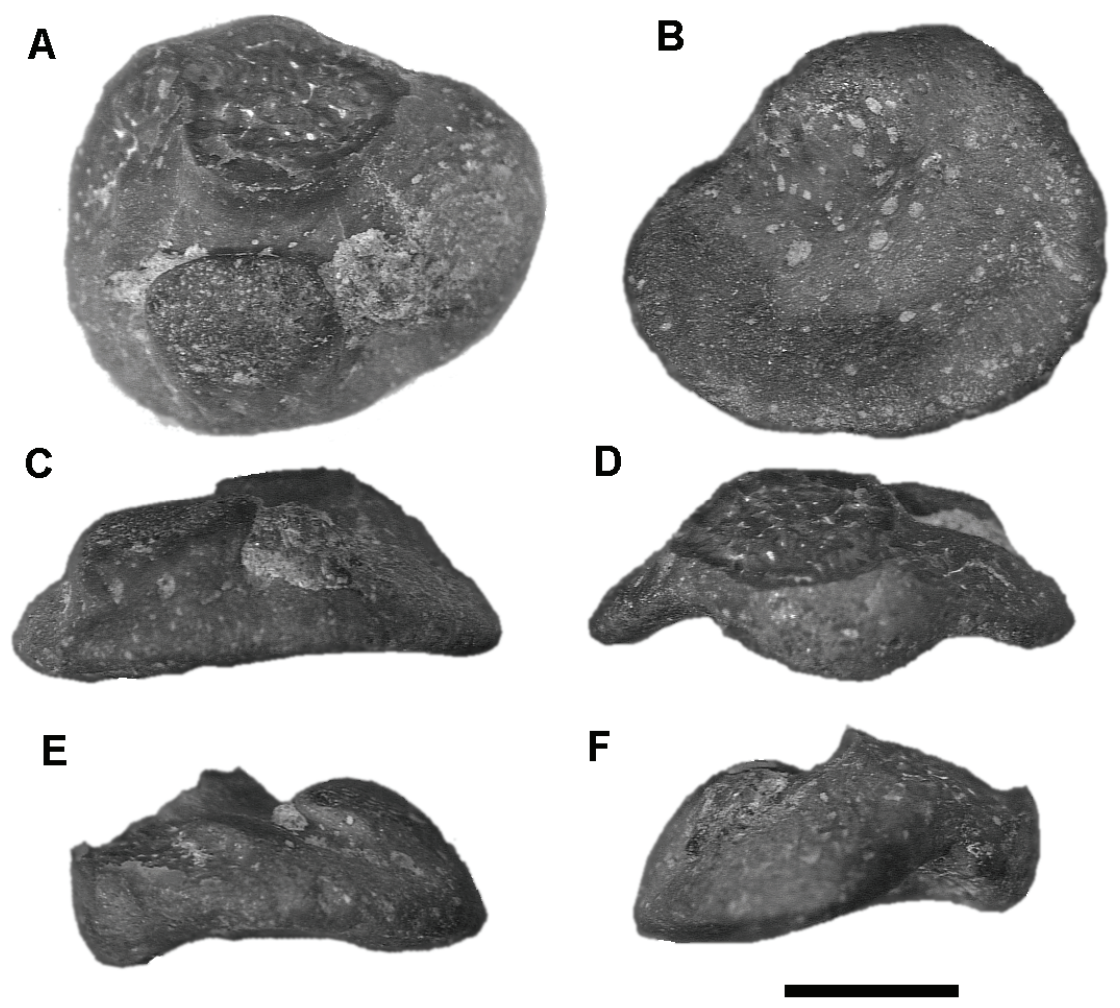

Figura 89 - Taquaralodus albuquerquei exemplar GP/2E - 6314. A) Vista superior. B) Vista inferior. C) Vista lingual-lateral. D) Vista Labial. E-F) Vista lateral. Escala $2 \mathrm{~mm}$.

Discussão - Em geral os dentes dos Xenacanthiformes têm as seguintes características: base alongada ou circular e prolongada para a região lingual; quando possuem mais de uma cúspide, duas são principais e sempre situadas na borda labial, com leve curvatura para a face lingual. Entre as duas cúspides laterais pode existir uma intermediária, sempre de tamanho menor. No bordo lingual ocorre o botão apical e no bordo labial da base, o tubérculo basal (DAVIS, 1892, RAGONHA, 1984, LONG, 1995; JANVIER, 1996; HAMPE, 2003).

Dentes idênticos foram observados em exemplares descritos por SILVA SANTOS (1946) na Formação Pedra do Fogo no Estado do Maranhão, identificados originalmente ao gênero "Pleuracanthus" e assim batizado como "Pleuracanthus" albuquerquei. RAGONHA (1978) observou que a cúspide lateral muito maior, evidente em todos os exemplares com duas ou tres cúpsides, era incomum nos gêneros conhecidos de Xenacanthiformes, o que foi determinante para a criação do gênero Taquaranthus (nomem nudum), que, infelizmente, nunca foi formalmente publicado. A denominação Taquaranthus para este gênero, proposto por Ragonha (1978) é mal 
aplicada, pois seu significado, "espinho do Taquaral", relaciona-se a espinhos que não foram encontrados até o momento.

Posteriormente RICHTER (1985) considerou a espécie "Pleuracanthus" como sinônimo de Xenacanthus. Atualmente "Pleuracanthus" é atribuído a gênero de Coleópteros, não sendo mais usado para Xenacanthiformes e Expleuracanthus, derivado, é considerado como sinônimo de Xenacanthus ou Triodus (HAMPE, 2003).

A espécie aqui descrita mostra várias semelhanças com espécies de Xenacanthidae, como as cúspides sem bordo cortante ou serrilhado e cristas finas nas cúspides. O botão apical pequeno e sem contato com as cúspides é observado em algumas espécies de Xenacanthiformes do Devoniano, porém é rara em dentes de gêneros permo-carboníferos, como Wurdigneria, Orthacanthus, Triodus, Reginoselache e "Pseudoxenacanthiformes", Bransonella (RAGONHA, 1978; 1984; HAMPE, 2003; JOHNSON, 2005a; 2005b; RICHTER, 2005; TURNER \& BURROW, 2011).

Variação no tamanho das cúspides não é incomum em Xenacanthiformes, podendo ser observada em Diplodoselachidae e em Xenacanthidae (WÜRDIGMACIEL, 1975; JOHNSON, 1980, RAGONHA, 1984; HAMPE, 2003), porém esta diferença não é muito acentuada como em Taquaralodus.

Os outros Xenacanthiformes descritos no Brasil são neopermianos, da Bacia do Paraná, mais novas do que a Formação Irati, Formação Corumbataí em São Paulo (RAGONHA, 1984) e Formação Teresina no Rio Grande do Sul (WÜRDIG-MACIEL, 1975; RICHTER, 2005). Suas dentições são muito semelhantes, diferindo em poucos caracteres. Algumas espécies, da Bacia do Paraná da região Sul, como Wurdigneria obliterata (Formação Teresina) e Xenacanthus pricei (Formação Irati, Membro Assistência), possuem cúspides laterais de tamanhos desiguais, mas a desigualdade é mínima comparada à das cúspides dos exemplares de Taquaralodus albuquerquei da Formação Irati. Outra característica que chama atenção é o tamanho muito grande do botão apical destas espécies de Xenacanthiformes, ocupando quase toda a parte lingual e às vezes fazendo contato direto com as cúspides, enquanto em Taquaralodus o botão apical é pequeno, como em Dicentrodus.

O botão apical pequeno e dentes com três cúspides também podem ser encontrados em tubarões do Devoniano e Mississipiano, ocorrendo também em alguns dentes cladodontes e em Phoebodontidae (HAMPE, 2003; GINTER et al. 2005). Estes grupos são diferenciados, entretanto, pela posição central da cúspide principal e a falta de tubérculo basal característico de Xenacanthiformes. 
Entre todos os Xenacanthiformes observados, o que é morfologicamente mais próximo de Taquaralodus é o Diplodoselachidae Dicentrodus. HAMPE et al. (2006) foram os primeiros a comparar a nova espécie (ainda como "Pleuracanthus" albuquerquei) com Dicentrodus destacando a cúspide lateral proeminente que seria uma característica só encontrada em Dicentrodus. A outra semelhança é o pequeno botão apical, porém em Dicentrodus é arredondado ou triangular e não alongado e não é comum uma terceira cúspide em Dicentrodus, como em Taquaralodus.

HAMPE (2003) e HAMPE et al. (2006) sugeriram o gênero Triodus baseados nas cristas das cúspides e no botão apical, porém o botão apical é alongado e não circular, ao contrário do que estes autores discutiram, comparando com espécies de Triodus, e as cristas muito finas e irregulares (Fig. 5A) também diferem deste gênero.

A sugestão de um novo gênero, Taquaralodus, como proposto inicialmente por RAGONHA (1978) ao sugerir Taquaranthus, é válido por causa das características morfológicas externas do botão apical, tamanho e ornamentação das cúspides diferente de qualquer outro gênero de Xenacanthiformes.

A ausência da cúspide intermediária e, por vezes, também, de uma segunda cúspide, pode estar relacionada à posição na boca e/ou à idade relativa dos dentes na boca do animal, como sugerido originalmente por SILVA SANTOS (1946), para o material da Formação Pedra do Fogo. Se for idade relativa, os dentes tricuspidados representariam os mais desenvolvidos, e os unicuspidados mais novos dentro de uma série ontogenética, como observados em Orodus (CHAHUD, 2007) e em outros Xenacanthiformes (HAMPE, 2003, HAMPE et al. 2006). Esta hipótese é reforçada pelo exemplar unicuspidado GP/2E-6580, dotado de base alongada e uma pequena protuberância na região onde estaria a segunda cúspide.

A presença de ornamentação (costelas ou cristas) em ambas as faces, labial e lingual, dos dentes bicuspidados e unicuspidados e apenas na face lingual do dente tricuspidado, talvez reflita o desgaste por uso, reforçando a hipótese de idade ontogenética dos dentes, uma vez que os dentes unicuspidados e bicuspidados seriam mais novos.

A quebra de cúspides nos exemplares, provavelmente está relacionada ao transporte ou à quebra e perda durante sua utilização pelo animal. Se a quebra aconteceu durante transporte, isto deve ter ocorrido durante curto período, apenas o suficiente para quebrar a cúspide, pois as bases dos dentes estudados exibem pouco desgaste. 
Família XENACANTHIDAE Fritsch, 1889

Xenacanthus sp.

Fig. 90

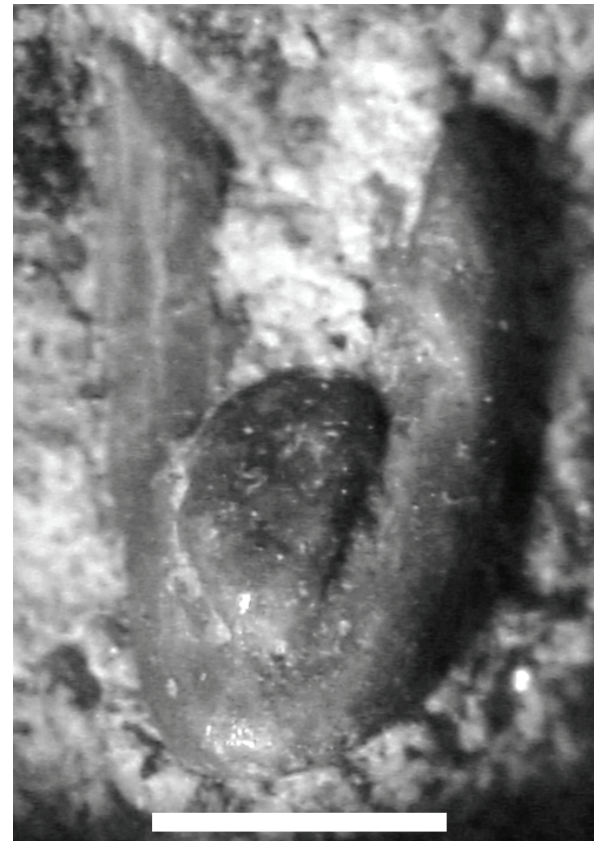

Figura 90 - Dente de Xenacanthus sp. (GP/2T-215). Escala 1mm.

Material - GP/2T-215. Dente isolado fixo na matriz (Fig. 89).

Localização - Afloramento 1 Sítio Santa Maria 1

Descrição - O dente apresenta muitos traços de abrasão por toda a sua superfície, mas de modo homogêneo, com todas as bordas laterais e as cúspides arredondadas. Possui duas cúspides laterais que se destacam, desenvolvendo-se paralelamente entre si, voltadas para a face labial da base.

A base é triangular e pouco espessa, com grande botão apical ocupando todo o espaçamento entre as cúspides e a região centro-labial. Entre o botão apical e a borda da base ocorrem pequenos foramens nutritivos. A altura da cúspide maior é 1,6 $\mathrm{mm}$ e da menor $1,5 \mathrm{~mm}$ e a base possui 1,3 $\mathrm{mm}$ de largura. O botão apical tem $0,6 \mathrm{~mm}$ de largura e 0,9 mm de comprimento, medido na distância lingual-labial. As cúspides localizam-se mais ou menos na mesma região da face labial e não há cúspide mediana; são ligeiramente arredondadas em corte transversal, com um pequeno achatamento lábiolingual. Apesar da abrasão, são originalmente lisas, a menor com algumas fraturas. $\mathrm{O}$ ângulo lateral entre a coroa e a base é superior a $130^{\circ}$.

Discussão - As cúspides lisas, aproximadamente circulares em vista transversal, o grande botão apical e os foramens nutritivos próximos da base, são características diagnósticas do gênero Xenacanthus (HAMPE, 2003). Como apenas um exemplar foi 
coletado com as características aqui descritas, não foi possível à identificação em nível específico.

As cúspides paralelas entre si e com grande ângulo para a face labial ( $>$ que $120^{\circ}$ ) em relação à base, são características encontradas em três espécies do gênero Xenacanthus do Hemisfério Norte; X. laevissimus, X. elegans e X. tenuis. Porém, o exemplar estudado difere por não possuir cúspide intermediária e nem arqueamento nas cúspides maiores, comuns nas espécies do Hemisfério Norte.

Entre as espécies brasileiras, a que mais se assemelha é Xenacanthus pricei (WÜRDIG - MACIEL, 1975) do topo da Formação Irati do Rio Grande do Sul. A diferença entre ambas refere-se ao tamanho entre as cúspides principais divergentes, maior em $X$. pricei, além da ausência de cristas muito finas nas cúspides, que ocorrem na face superior de $X$. pricei (WÜRDIG - MACIEL, 1975).

\section{Gênero incertae sedis}

Figs. 91-93

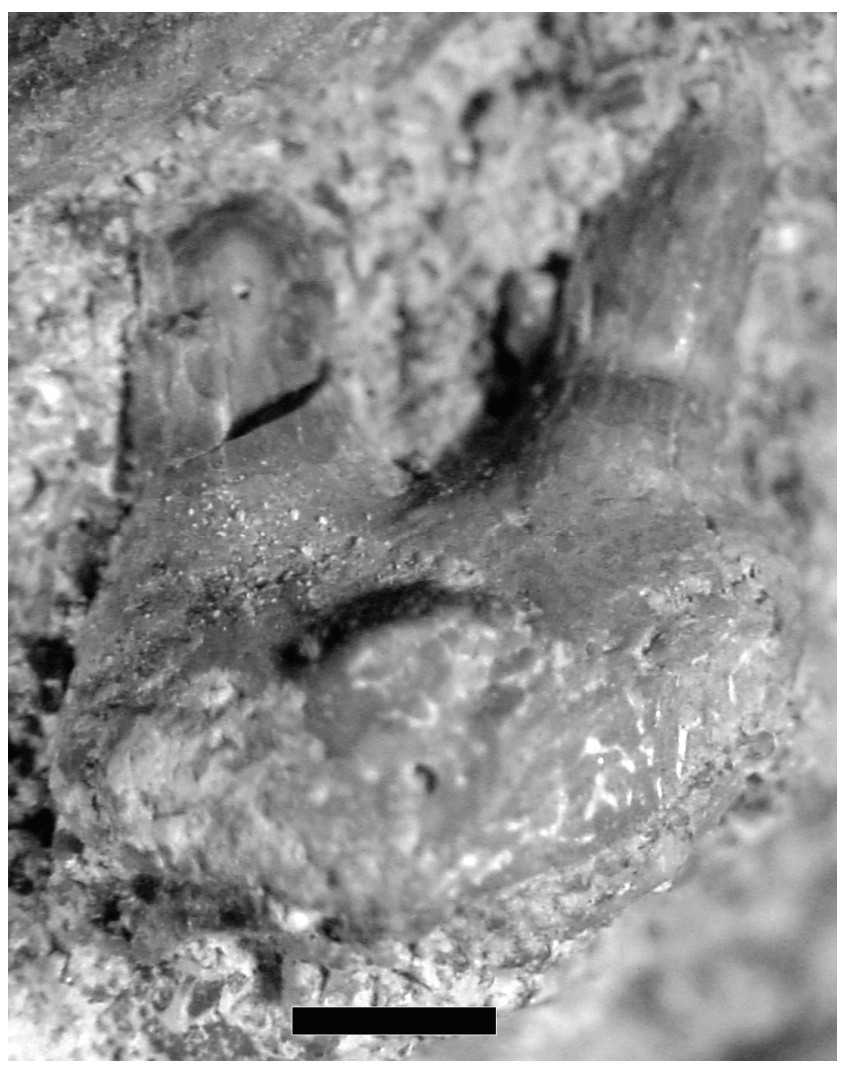

Figura 91 - Exemplar GP/2T-216 de Xenacanthidae preso a matriz rochosa. Escala $1 \mathrm{~mm}$.

Material - GP/2T-216 (Fig. 91), GP/2E-6456 (Fig. 92) e GP/2T-217 (Fig. 93).

Dentes fragmentados. 
Localização - Afloramento 1 para GP/2T-216 e GP/2T-217 Sítio Santa Maria 1 e GP/2E-6456 para o Afloramneto 3 Rio da Cabeça.

Descrição de GP/2T-216- (Fig. 91) Coroa consistindo de duas cúspides divergentes, sendo que uma delas muito inclinada, de tamanhos similares $(1 \mathrm{~mm}$ de largura na parte mais espessa). Não existe evidência de que tenha havido uma cúspide intermediária. Apesar de fragmentadas, é possível inferir que as cúspides são alongadas. Observam-se estriações (possíveis cristas desgastadas) em uma das cúspides e não ocorre serrilhamento de nenhum tipo. A base é pouco espessa, com a face lingual voltada para baixo. Apesar do estado de preservação, é possível observar foramens nutritivos, um muito próximo do botão apical. O botão apical, também apresenta quebras, é pequeno, totalmente isolado das cúspides, posicionado na face lingual. A base tem 3,4 $\mathrm{mm}$ de comprimento anteroposterior e 4,3 $\mathrm{mm}$ de altura. A cúspide maior mede, aproximadamente, 2,1 $\mathrm{mm}$ de altura e 0,9 $\mathrm{mm}$ de diâmetro. A cúspide menor tem, aproximadamente, $0,9 \mathrm{~mm}$ de diâmetro e 1,9 $\mathrm{mm}$ de altura. $\mathrm{O}$ botão apical tem $1 \mathrm{~mm}$ de comprimento máximo.

Descrição de GP/2E-6456. - (Fig. 92) dente composto por duas cúspides laterais principais e vestígios de cúspide intermediária, todas em contato direto. As cúspides principais estão fragmentadas, mas é possível observar que são arredondadas em corte transversal. A cúspide intermediária, menor em diâmetro, também está fragmentada e possui aproximadamente metade do diâmetro das maiores. Todas as cúspides estão localizadas na face labial.

A base apresenta quebras pequenas, mas é possível observar o formato arredondado ou quadrangular. Ocorrem foramens nutritivos na parte superior lingual, próximos do botão apical, nas laterais e face inferior. Não foi observada depressão significativa na face inferior da base. O tubérculo basal está muito desgastado e incrustações prejudicaram a análise.

O botão apical é circular, não tem contato com as cúspides os quais estão posicionadas na face lingual da base.

A base tem $1,0 \mathrm{~mm}$ de comprimento tanto anterior - posterior quanto na distancia labial - lingual. A cúspide maior tem $0,8 \mathrm{~mm}$ de altura. $\mathrm{O}$ botão apical possui, aproximadamente, $0,5 \mathrm{~mm}$ de comprimento máximo. 


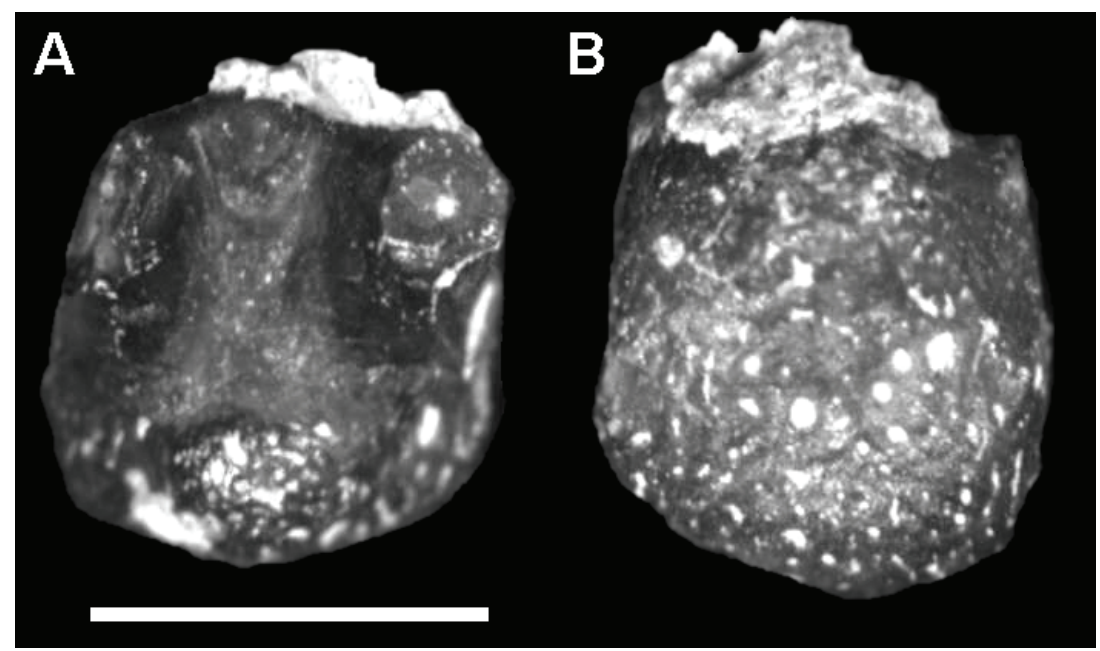

Figura 92 - Exemplar GP/2E-6456 de Xenacanthidae indeterminado do Afloramento 3. A) Vista oclusal; B) Vista inferior. Escala $1 \mathrm{~mm}$.

Descrição de GP/2T-217 - (Fig. 93) dente composto por duas cúspides laterais de tamanhos ligeiramente diferentes, a maior com 0,9 $\mathrm{mm}$ de diâmetro e a menor com 0,7 mm. Uma cúspide intermediária, situada entre as maiores, tem menos da metade do diâmetro da maior, em contato direto com as laterais das cúspides maiores, e localizada obliquamente na face labial. Uma das laterais da base está preservada, sendo possível inferir que tem o formato arredondado. Ocorrem foramens nutritivos na parte superior lingual, próximos do botão apical e na região central na face inferior, onde verificou-se uma pequena depressão. A ausência do tubérculo basal talvez deva a uma quebra de formato arredondado na borda labial.

O botão apical tem contato com as cúspides, porém não chega a se posicionar na face labial e fica restrito à região central e parte da região lingual da base.

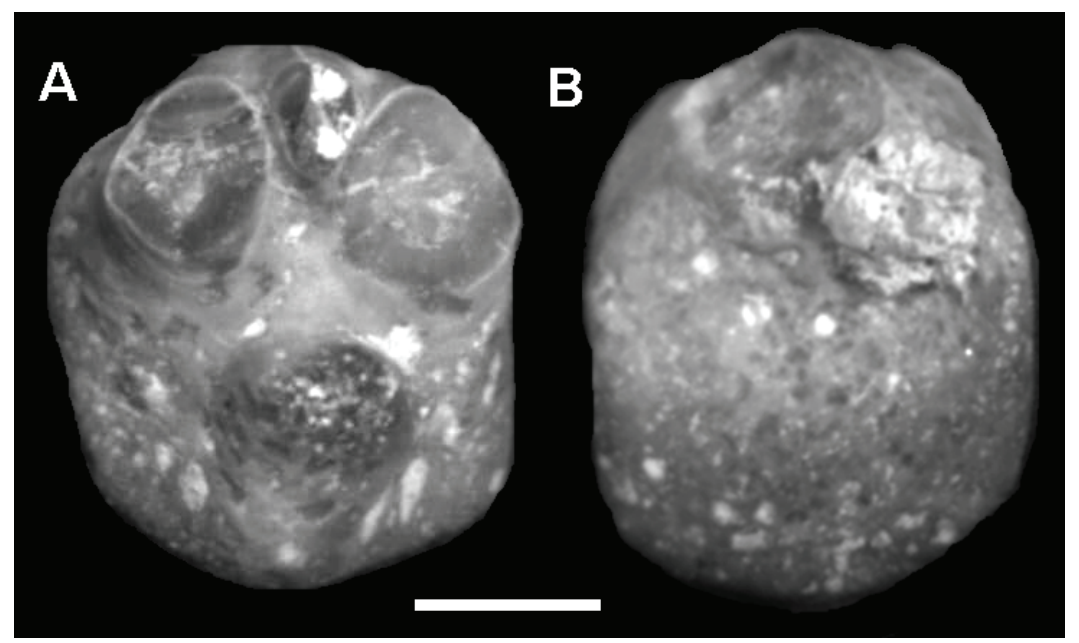

Figura 93 - Exemplar GP/2T-217 de Xenacanthidae indeterminado do Afloramento 1. A) Vista oclusal; B) Vista inferior. Escala $1 \mathrm{~mm}$. 
Discussão: Os dois exemplares aparentemente pertencem à mesma espécie, pois as bases e o botão apical são muito semelhantes. A falta da cúspide intermediária no GP/2T-216 seria sugestiva de dentição heterodonte.

A classificação dos exemplares é incerta por serem os únicos e por estarem mal preservados, porém é possível sugerir afinidades e diferenças com alguns gêneros de Xenacanthiformes.

Os exemplares podem ser associados com segurança dentro dos Xenacanthidae, pelas cúspides circulares e sem evidências de bordos cortantes ou serrilhados, características distintas em Diplodoselache, Dicentrodus, Lebachacanthus, Orthacanthus e Hagenoselache (HAMPE, 2003; JOHNSON, 1999; 2003 HAMPE et al. 2006). A classificação em gênero conhecido ou novo é discutível, pois seria necessária análise de mais exemplares com as cúspides melhor conservadas.

A divergência das cúspides é comum em espécies de Orthacanthus e em Wurdgneria, porém em GP/2T-216, a ornamentação das cúspides, o botão apical e a base, diferem, em tamanho e forma, dos gêneros citados acima.

A ornamentação por cristas longitudinais irregulares por toda a superfície, evidentes no GP/2T-216 e pouco claras no exemplares GP/2E-6456 e GP/2T-217, exclui a possibilidade de associação ao gênero Xenacanthus, aproximando-os dos fósseis de Plicatodus e Triodus (HAMPE, 2003)

Barbclabornia (JOHNSON, 2003) é um gênero bicuspidado, assemelhando-se ao exemplar GP/2T-216, porém a base mais espessa e o grande botão apical o separa dos aqui descritos.

A morfologia dos dentes com duas cúspides de grande porte e tamanhos semelhantes o diferencia da espécie Taquaralodus albuquerquei, o Xenacanthiformes mais comum da unidade, no que diz respeito à morfologia das cúspides e do botão apical. Os exemplares aqui descritos diferem de Xenacanthus sp., aqui mencionado, pela grande diferença do botão apical, forma da base e disposição das cúspides.

\subsubsection{Discussão paleoambiental e paleogeográfica dos Xenacanthiformes da base do Membro Taquaral}

Taquaralodus e os outros Xenacanthiformes existentes na base do Membro Taquaral foram encontrados em depósitos de alta energia e alguns muito desgastados e fragmentados. Este tipo de ambiente deposicional prejudica qualquer interpretação segura paleoambiental, porém é possível inferir algumas hipóteses. 
A base do Membro Taquaral da Formação Irati pode ser interpretada como de salinidades variáveis, mais doce (MUSSA et al. 1980) ou com certa salinidade e influencia continental (CHAHUD, 2007).

Taquaralodus é muito mais abundante que qualquer outro Xenacanthiformes da Formação Irati. RAGONHA (1978) o observou em depósitos arenosos dos municípios de Itapetininga e Assistência, CHAHUD (2003b; 2007) o reconheceu em depósitos entre Rio Claro e Ipeúna, todos no Estado de São Paulo. A única ocorrência fora do Estado de São Paulo é da Formação Pedra do Fogo no Estado do Maranhão, onde SILVA SANTOS (1946) descreveu os primeiros achados, também em depósitos de alta energia.

Os exemplares encontrados são dentes de diferentes tipos de preservação (Figs. 94 e 95), tamanho e ontogenia.

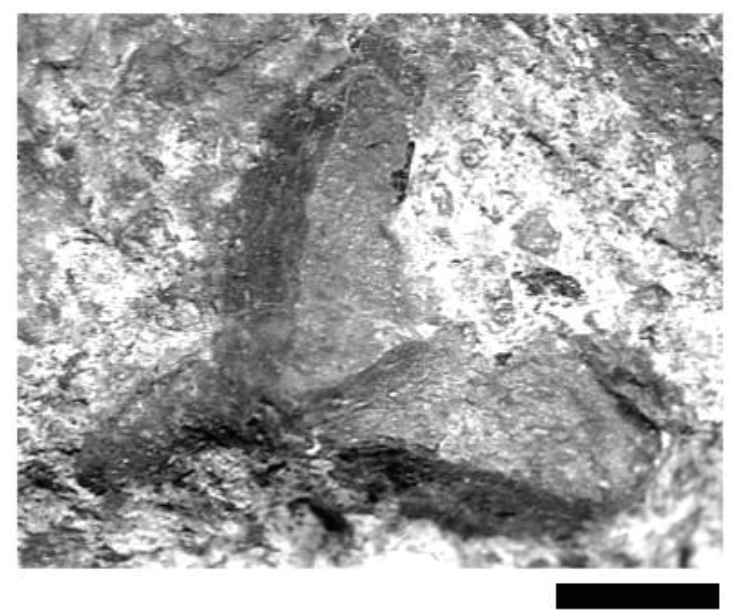

Figura 94 - Dente de Taquaralodus com a cúspide preservada na rocha. GP/2E-3753. Escala 2mm.

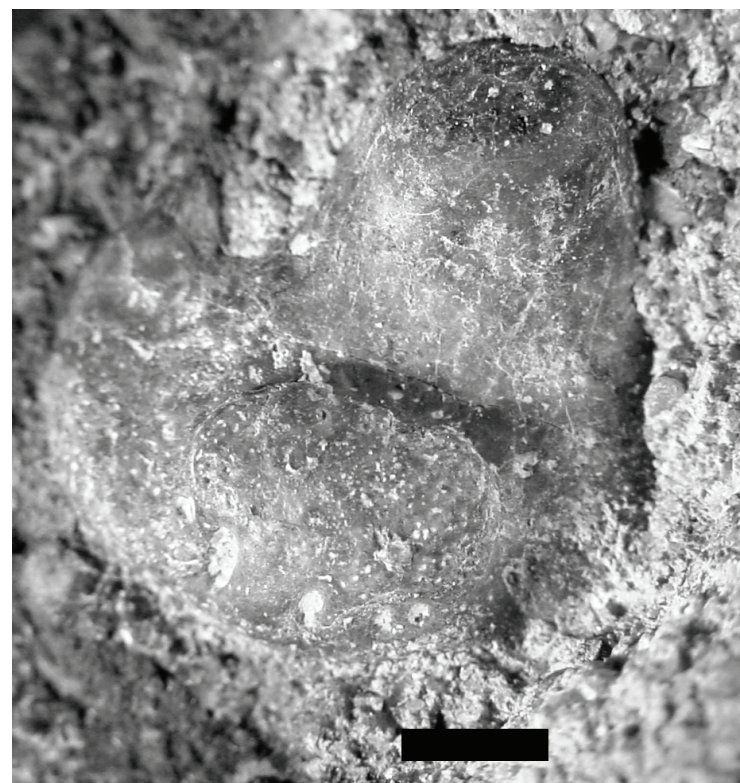

Figura 95 - Dente de Taquaralodus muito desgastado preso a rocha. GP/2E-6251. Escala 2mm. 
Os outros Xenacanthiformes são raríssimos, observados pela primeira vez e exclusivos dos aforamentos 1 e 3, distantes, menos de um quilômetro entre si no Sítio Santa Maria. No afloramento 3, de maior espessura, não havia fósseis de Taquaralodus e foi encontrado o Exemplar 2 de Xenacanthidae incertae sedis, além de outros dois exemplares muito fragmentados reconhecidos apenas pelas impressões das cúspides e o botão apical.

É possível que os Xenacanthidae sejam alóctones, transportados a partir de sistemas fluviais. A justificativa para isso estaria no alto desgaste, fragmentação e raridade. Taquaralodus teria sido autóctone ou parautóctone com base na abundância e na variedade de formas encontradas.

A interpretação paleoambiental de um sistema fluvial alimentando o sistema não pode ser mais baseada a partir de Taquaralodus como inferido inicialmente por CHAHUD (2007), mas por outros Xenacanthidae, além do retrabalhamento dos depósitos por ondas.

\subsection{Holocephali}

Muitos Chondrichthyes antigos são representados por grandes placas dentárias isoladas que seriam destinadas à trituração. Os dentes dos holocéfalos (Bradiodonte) são maciços compostos de dentina tubular e trabecular intersticial. Os peixes com esta dentição se caracterizam por lenta substituição dentária.

Junto com os Elasmobranchii, Holocephali representa a outra subclasse de Chondrichthyes. Surgiram no Devoniano (DARRAS et al. 2008) e foram abundantes e diversificados durante todo o paleozóico com grande riqueza de ordens e espécies. Atualmente são representados apenas pelas Quimeras, peixes cartilaginosos que hoje habitam as profundezas oceânicas.

Os Holocephali exibem grande diversidade morfológica, em particular pelo desenvolvimento de apêndices na cabeça destinados a corte (atrativo sexual), como o clasper frontal existente no individuo masculino de quimeras.

A Subclasse é caracterizada pelo escápulo-coracóide próximo do neurocrânio, osso hióide e arcos branquiais aglomerados no espaço restrito entre arco mandibular e cintura escapular, embaixo do neurocrânio, separado da região occipital.

A classificação é motivo de discussão, pois alguns grupos não são fáceis de definir sua posição filogenética. 
Para NELSON (2006) os Holocephali podem ser divididos em duas grandes superordens Paraselachimorpha e Holocephalimorpha.

Os Paraselachimorpha são Holocephali com dentição semelhante a dos seláquios, o palato-quadrado é fusionado ao neurocrânio em algumas formas e não em outras. Presença de crescimento contínuo de escamas cúbicas em alguns tipos (NELSON, 2006). Estão inclusos nesta superordem as ordens Orodontiformes, Petalodontiformes, Helodontiformes, Iniopterygiformes, Eugeneodontiformes e Debeeriiformes.

Os Orodontiformes, Eugeneodontiformes e Petalodontiformes possuem características que os aproximam de Elasmobranchii, por isso ZANGERL (1981), JANVIER (1996) e STAHL (1999) os excluem de Holocephali.

Os Holocephalimorpha são caracterizados por uma dentição constituída de placas dentárias permanentes destinadas à trituração, palato - quadrado fusionado ao neurocrânio (holostílica); espinho de nadadeira dorsal normalmente presente. Muitos fósseis, infelizmente, são conhecidos por dentes isolados e boa parte das características não foi preservada (NELSON, 2006).

Fazem parte dos Holocephalimorpha as ordens Psammodontiformes, Copodontiformes, Squalorajiformes, Chondrenchelyiformes, Menaspiformes, Cochliodontiformes e Chimaeriformes.

\subsubsection{Ordem Petalodontiformes}

Os petalodontes são um grupo importante de Chondrichthyes do Carbonífero e Permiano. Seus fósseis são encontrados normalmente em depósitos marinhos.

Apesar de ser um Chondrichthyes comum no registro fóssil, poucos são os exemplares que permitiram análise anatômica mais detalhada da morfologia corporal, pois muitas espécies são conhecidas exclusivamente a partir de dentes isolados.

Os dentes de Petalodonte são comprimidos no sentido lábio-lingual. A coroa alongada transversalmente, via de regra, é limitada por uma crista que pode ser imbricada ou lingualmente proeminente. A coroa normalmente forma uma extremidade cortante afiada, mas dentes sem bordas cortantes são comuns.

A base normalmente tem o comprimento da coroa, porém sua morfologia é variada conforme o gênero, podendo ser reduzida em espessura ou com vários prolongamentos alongados. 
A organização da dentição é conhecida de poucos exemplares como em Janassa, Belantsea, Petalorhynchus, Megactenopetalus e Climaxodus (Fig. 96). O que se percebeu foi que os dentes são organizados em sucessão com substituição lingual-labial, como em seláquios e eusseláquios. Segundo ZANGERL (1981) há muita variação entre os dentes atribuídos ao grupo e é incerta que tal característica seja comum em todos os gêneros. Alguns petalodontes apresentam coroas multicuspidadas como observadas em Pristodontídeos.

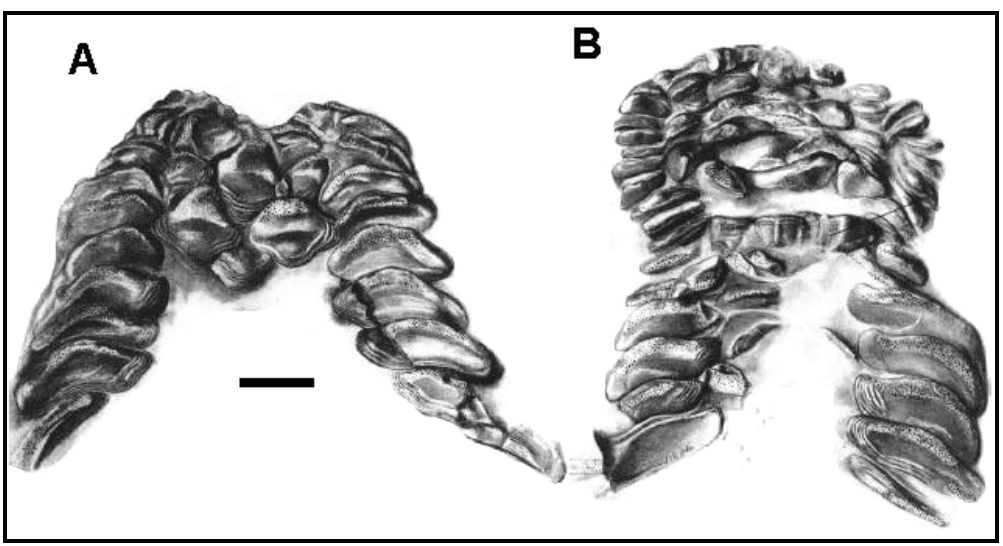

Figura 96 - Disposição dentária em Climaxodus. A) Arcada superior; B) Arcada inferior (WOODWARD, 1919). Escala 10mm.

A forma corporal dos petalodontes é pouco conhecida. Algumas interpretações baseadas em dois fósseis que preservaram partes da suas estruturas. Inicialmente, baseado em um exemplar do gênero Janassa, os petalodontes foram interpretados como semelhante a raias, porém a preservação em perfil de um exemplar de Belantsea do Carbonífero de Bear Gulch, EUA (LUND, 1989) caracterizou um peixe robusto com grandes nadadeiras.

\subsubsection{Posição filogenética de Petalodontiformes}

A classificação de Petalodontiformes é polêmica, sendo constantemente revisada nos últimos 30 anos. Um dos fatores que geraram diversas opiniões sobre a posição sistemática está na falta de informações morfológicas corporais e também na grande variação dentária nos diversos gêneros (ZANGERL, 1981).

Atualmente os Petalodontiformes constituem uma ordem de Chondrichthyes constituída de quatro famílias do Neopaleozóico; Belantseidae, Janassidae, Petalodontidae e Pristodontidae. Só a classificação em superordem e classe é incerta.

Inicialmente com base na dentição e por apresentarem características bradiodonte em muitos gêneros, como dentes durófagos, foram classificados como 
Holocephalimorpha (MOY-THOMAS \& MILES, 1971). Essa posição é aceita por diversos pesquisadores (LUND, 1989, LONG, 1995, LUND \& GROGAN, 1997).

Outra linha de pesquisadores considera os Petalodontiformes como Elasmobranchii. Esta idéia é baseada na disposição e formação dos dentes na mandíbula do animal e posição das brânquias observada apenas em Janassa (ZANGERL, 1981, STAHL, 1999, ROB III, 2003).

JANVIER (1996), observando as características morfológicas e dentárias, sugere que os Petalodontiformes sejam considerados Chondrichthyes basais e intermediários entre Elasmobranchii e Holocephali. Como Janvier, GROGAN \& LUND (2000; 2004) consideraram Petalodontiformes em uma classe a parte, Euchondrocephali, próxima de formas basais de Chondrichthyes.

NELSON (2006) colocou os Petalodontiformes na Superordem Paraselachimorpha dentro da Subclasse Holocephali. NELSON (op cit) baseou-se no estudo feito por LUND \& GROGAN (1997), STAHL (1999) e GROGAN \& LUND (2000; 2004). Para NELSON (2006) a Subclasse Euchondrocephali GROGAN \& LUND (2000) seria sinônima de Holocephali, esta classificação foi adotada neste trabalho.

\subsubsection{Petalodontiformes e Holocephalimorpha da Base da Formação Irati}

A principio os Petalodontiformes do Membro Taquaral tinham sido identificados apenas como pertencentes à espécie Itapyrodus punctatus (RAGONHA, 1978; CHAHUD, 2003b).

Subclasse HOLOCEPHALI Bonaparte, 1832-41

Ordem PETALODONTIFORMES Zangerl, 1981

Família PETALODONTIDAE Newberry e Worthen, 1866

Itapyrodus punctatus Silva Santos 1990

Figs. 97-103

Espécie tipo - Itapyrodus punctatus Silva Santos 1990

Distribuições Geográficas e Estratigráficas - Apenas Eopermiano da Formação Pedra do Fogo do Maranhão e base da Formação Irati do Estado de São Paulo.

Diagnose genérica (SILVA SANTOS, 1990) - Elasmobranchii conhecido somente pelos dentes. Dentição com heterodontia, distinguindo-se dentes sinfisianos e dentes póstero-laterais para trituração. Dentes em séries, justapostos entre si, não formando placas dentárias. Todos os dentes com a coroa lisa. Dentes sinfisianos com a 
coroa alta, alongada e comprimida no sentido transversal, e levemente inclinada para a face interna (lingual). Margem superior da coroa inteira com os extremos bem distintos: o do lado próximo da sínfise com o contorno arredondado e o oposto pontiagudo e algo inclinado para baixo. Dentes para trituração com a coroa baixa, moderadamente convexa ou quase plana. Base de fixação (raiz) baixa, de superfície lisa e côncava. Bordas laterais da base de fixação com fortes sulcos e saliências. Coroa formada de uma dentina tubular, sem esmalte e ausência de tecido trabecular diferenciada na base de fixação.

Diagnose específica- gênero supostamente monoespecífico.

Características gerais dos dentes sinfisianos - Os dentes sinfisianos possuem coroa alta, alongada longitudinalmente (sentido anterior - posterior, entre as laterais), mas comprimida transversalmente (sentido labial - lingual), formando uma crista longitudinal aguda com inclinação para a face lingual. A relação de largura das faces lingual - labial varia, sendo que a face lingual pode ser maior ou menor, dependendo da região que o dente ocupava na boca do animal. O ângulo formado entre as faces é um dos principais critérios para distinguir dentes sinfisianos, pois é sempre um ângulo agudo.

Uma extremidade lateral da coroa é arredondada, por vezes pontiaguda, voltada para baixo e outra angulosa, cuja superfície pode apresentar uma pequena concavidade ou ser plana. A face labial normalmente é convexa, enquanto a lingual apresenta certa concavidade. Porém, em raros casos, ambas podem ser côncavas ou convexas.

A base é bilobada, com a mesma largura da coroa com uma concavidade central na face inferior. Em poucos exemplares o caráter côncavo e bilobado está ausente e a base é plana.

Características gerais dos dentes póstero - laterais - Os dentes póstero laterais são identificáveis pela coroa baixa e larga, com uma superfície convexa ou aplainada na face labial e ligeiramente côncava na lingual. A face lingual nestes dentes sempre é muito menor que a labial (metade do tamanho). O ângulo formado entre as faces labial e lingual é, em geral, obtuso, porém exemplares com estas faces em ângulo reto não são incomuns.

A margem superior da coroa exibe pequena curvatura, porém não forma uma crista longitudinal. As extremidades laterais da coroa são diferenciadas: em um lado arredondada e outro, angulosa ou reto, sem inclinação. 


\section{Descrição dos principais exemplares}

\section{Dentes sinfisianos}

Material -GP/2T-206 (Fig. 97A-97F). GP/2T-207 (Fig. 97G-97L). GP/2T-208 (Fig. 98A-98F). Dentes completos.

\section{Localização - Afloramento 1, Sitio Santa Maria 1}

Descrição de GP/2T-206 (Figs. 97A-97F) O dente possui uma coroa comprimida voltada para a face lingual e uma crista desgastada no topo, disposta diagonalmente entre as laterais. A face labial é plana até próxima da base de articulação, onde apresenta uma pequena convexidade. A face lingual é menor que a labial e com uma concavidade na região central. Em vista transversal o dente tem o formato de "A" irregular, estando encurvado em um dos lados. A base articulatória é lisa e bilobada e disposta longitudinalmente. O lobo na face labial é aproximadamente 1,5 vezes maior que o da face lingual. O comprimento máximo é de $6.3 \mathrm{~mm}$; a altura medida na face labial é $5,1 \mathrm{~mm}$, e na face lingual é menor, $4,2 \mathrm{~mm}$. A crista mede $5,9 \mathrm{~mm}$ de comprimento, a região articulatória tem $4,6 \mathrm{~mm}$ e a largura é de $3,6 \mathrm{~mm}$.

Ainda nas faces labial e lingual, a porção anterior exibe uma ponta arredondada e um encurvamento para baixo, enquanto a posterior é reta e angulosa.

A parte superior da coroa exibe duas pequenas convexidades, a primeira alongada nas regiões central e posterior, e a outra mais acentuada na face anterior do dente. Em ambas as faces puderam ser observadas concavidades, abaixo da ponta arredondada na face anterior e na parte central superior da coroa, na face posterior.

O espécime está muito desgastado, deixando bem evidente o aspecto pontuado da superfície de todas as faces.

Descrição de GP/2T-207 (Figs. 97G-97K) O exemplar é quase idêntico ao primeiro, porém muito mais desgastado, com acentuado arredondamento das laterais. A única diferença em relação ao primeiro está na crista que em GP/2T-207 é muito mais proeminente, com destacado caráter cortante não serrilhado.

O dente é o maior exemplar desta espécie encontrado até agora no país, com comprimento máximo de 20,4mm, altura da face labial de $16,5 \mathrm{~mm}$ e altura da face lingual de 13,4mm. O comprimento da crista é de $14,2 \mathrm{~mm}$, a região articulatória da base tem comprimento menor que a coroa, com 11,6mm, e a largura é de 7,1 $\mathrm{mm}$.

$\mathrm{O}$ aspecto pontuado ocorre em toda a superfície, revelando detalhes da dentina tubular. Nas faces lingual e labial os pontos são circulares, ovais ou irregulares (em 
forma de oito), prováveis ramificações superficiais da dentina tubular. Em vista transversal é possível constatar os tubos alongados de dentina tubular.

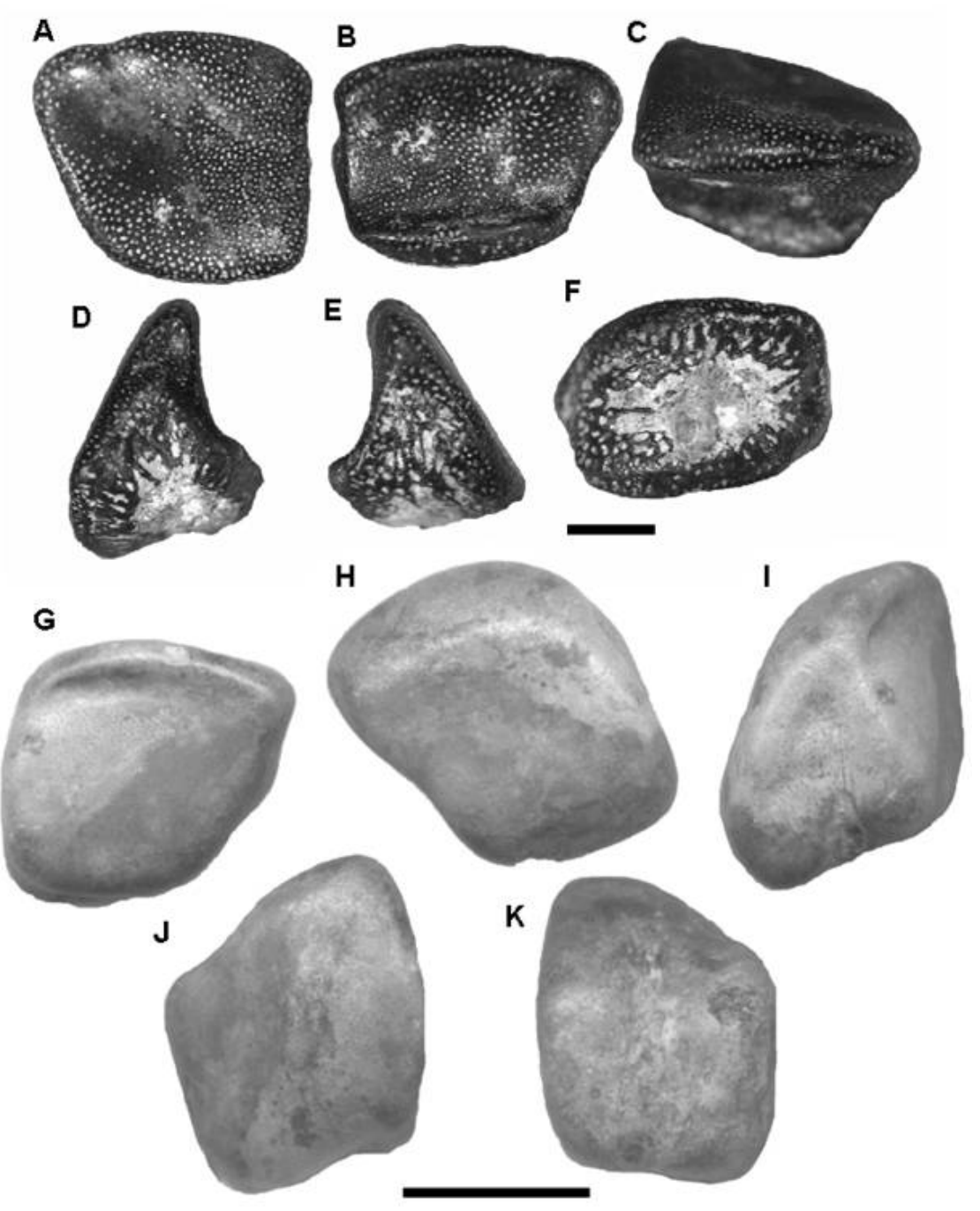

Figura 97 - Dentes sinfisianos de Itapyrodus punctatus. Espécime GP/2T-206: A) Vista labial; B) Vista lingual; C) Vista oclusal; D) e E) Vistas laterais; F) Vista inferior. Escala 2mm. Espécime GP/2T-207: G) Vista lingual; H) Vista labial; I) Vista lateral; J) Vista oclusal; L) Vista inferior. Escala 10mm.

Descrição de GP/2T-208 (Figs. 98A-98F) Este exemplar difere dos outros pelas faces labial e lingual retas, sem curvaturas nem concavidades centrais. A coroa é comprimida em sentido lingual-labial e a crista na parte superior está disposta quase longitudinalmente no sentido anterior - posterior. Apresenta também uma convexidade um pouco mais acentuada na região posterior do dente.

Em vistas anterior e posterior o exemplar possui formato de triângulo isóscele. $\mathrm{Na}$ região de articulação, a base apresenta saliências, sendo na face lingual mais proeminente, o que serviu para diferenciar as faces. 
O comprimento máximo é igual ao da crista, $8,4 \mathrm{~mm}$ e a altura é igual nas faces labial e lingual, 6,4 $\mathrm{mm}$. A região articulatória tem 7,0 $\mathrm{mm}$ de comprimento e 5,1 $\mathrm{mm}$ de largura.

Neste exemplar, como nos anteriores, o desgaste revelou o aspecto pontuado da dentina tubular em todas as faces.
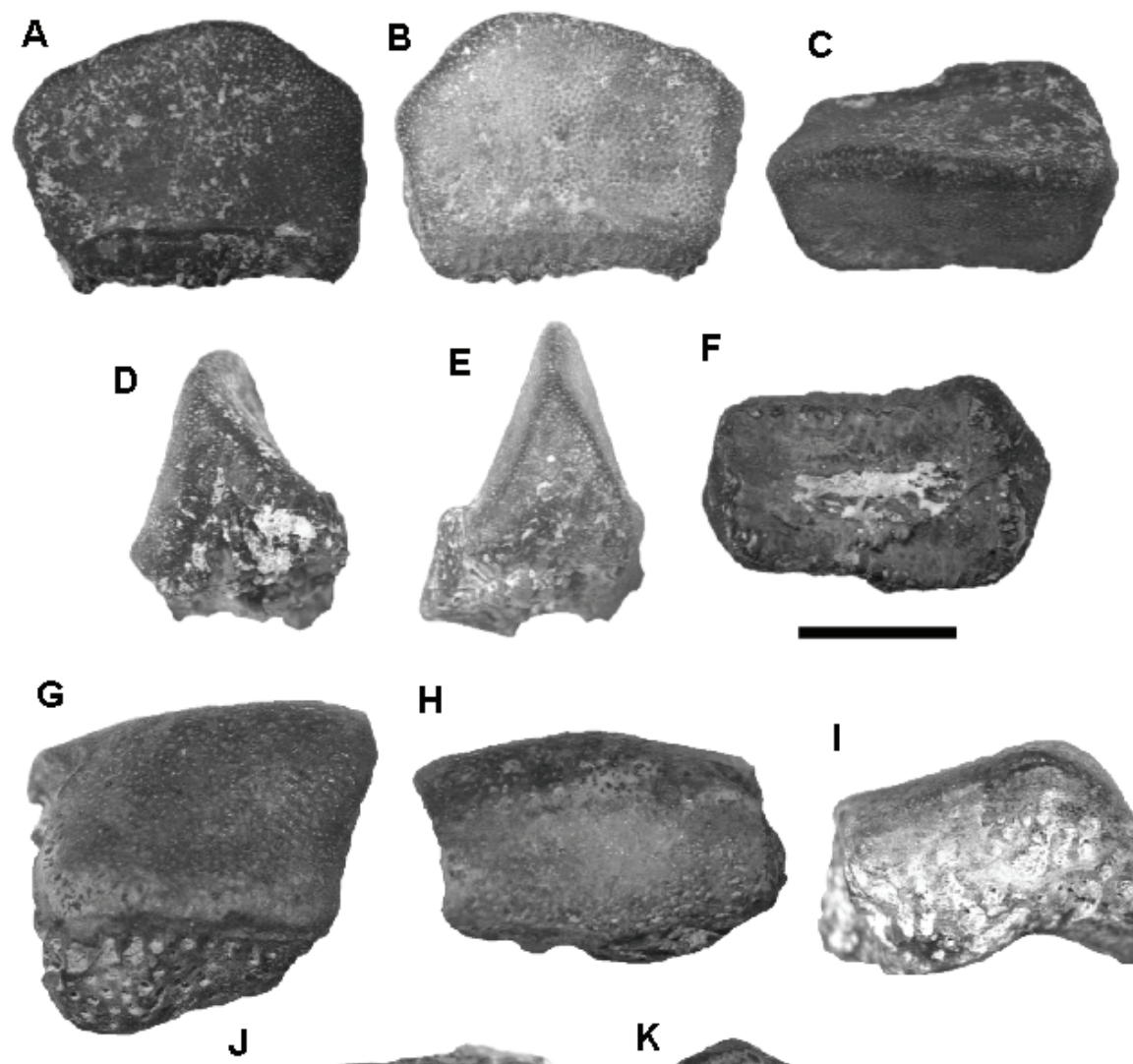

H
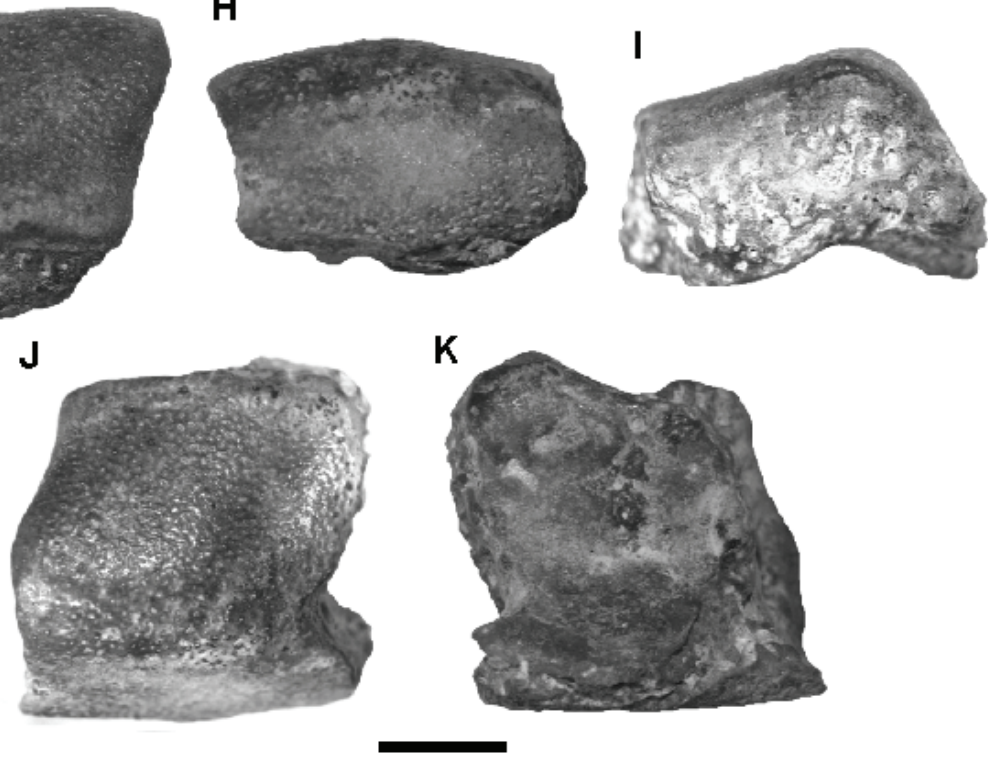

Figura 98 - Dentes de Itapyrodus punctatus. Sinfisiano espécime 3 (GP/2T-208): A) Vista lingual; B) Vista labial; C) Vista oclusal; D) e E) Vistas laterais; F) Vista inferior. Póstero-lateral (GP/2T-209): G) Vista labial; H) Vista lingual; I) Vista lateral; J) Vista oclusal; K) Vista inferior. Escala 2mm.

\section{Dentes póstero-laterais}

Material - GP/2T-209. (Figs. 98G-98K), GP/2E-6290 (Fig.99), GP/2E-6304, (Fig. 100). Dentes completos.

Localização - Afloramento 1, Sitio Santa Maria 1 
Descrição de GP/2T-209 (Figs. 98G-98K) - Coroa aberta, formando um ângulo de $92^{\circ}$ entres as faces lingual e labial. Não possui crista na parte superior.

A face labial tem a forma de um paralelogramo disforme, com um lado maior, com uma pequena convexidade central. A lingual é plana, menor em altura e maior em comprimento.

$\mathrm{Na}$ parte superior da lateral anterior, uma ponta se estende anteriormente, enquanto na posterior ocorre uma pequena concavidade na região equivalente do dente.

A base de articulação é simples (sem lobos), côncava e se caracteriza pela presença de saliências ósseas que expõem a estrutura alongada da dentina tubular e a estrutura irregular da dentina trabecular.

O comprimento é de $10,3 \mathrm{~mm}$, a altura; $6,5 \mathrm{~mm}$, e a largura; $10,5 \mathrm{~mm}$. A face labial tem $7,1 \mathrm{~mm}$ de largura e $8,6 \mathrm{~mm}$ de comprimento, enquanto a lingual tem $6,5 \mathrm{~mm}$ de largura e 9,5mm de comprimento. A largura da região articulatória é de 3,5mm.

Descrição de GP/2E-6290 - (Fig. 99A-99D) neste exemplar a coroa forma um ângulo de $90^{\circ}$ entre a face labial e a face lingual, logo abaixo de uma crista cortante voltada para a face lingual.

A face labial tem a forma de um trapézio, com um lado maior. Ambas as bordas laterais são retas, com alguma irregularidade. A labial é plana, menor em altura e maior em comprimento, com muito desgaste. A face lingual apresenta uma pequena concavidade central.

$\mathrm{Na}$ parte superior da face lateral anterior uma ponta se estende anteriormente, enquanto na posterior o prolongamento é menor. Em ambos os lados são observadas pequenas concavidades centrais.

A base de articulação é plana, com exceção de próximo à parte lingual onde ocorre uma pequena concavidade. Na superfície da base é possível observar a presença de saliências ósseas e crenulações.

O comprimento máximo do dente é de $13,7 \mathrm{~mm}$, a altura; $5 \mathrm{~mm}$, e a largura; 12 $\mathrm{mm}$. A face labial tem $8 \mathrm{~mm}$ no sentido labial-lingual e $12 \mathrm{~mm}$ de comprimento entre as laterais, enquanto a lingual tem $12 \mathrm{~mm}$ e $5 \mathrm{~mm}$ de altura. 
A
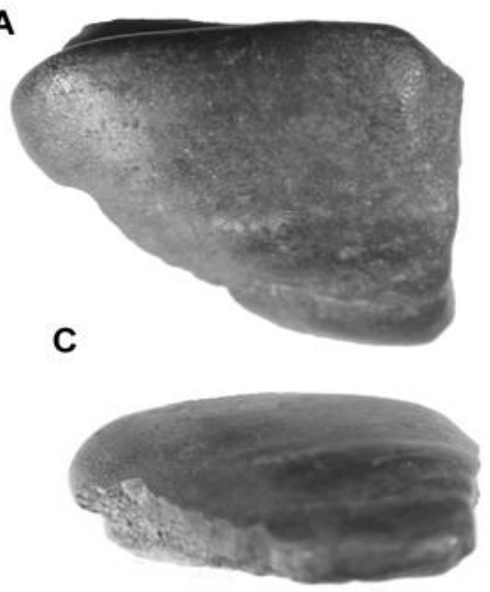

B
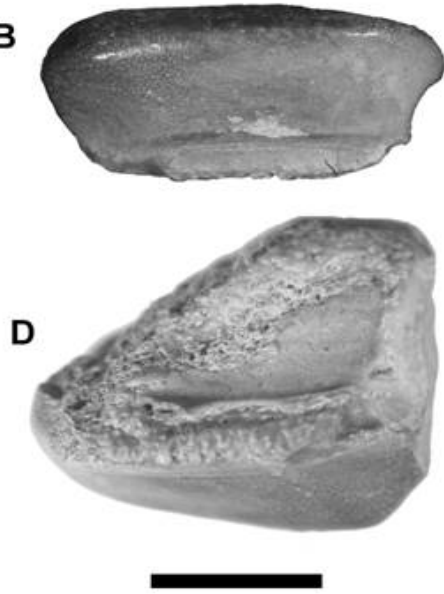

Figura 99 - Exemplar 2 de dente póstero-lateral (GP/2E-6290). A) Vista labial - oclusal; B) Vista lingual; C) Vista labial; D) Vista inferior. Escala $5 \mathrm{~mm}$.

Descrição de GP/2E-6304 (Fig. 100A-100D) O terceiro exemplar de dente póstero-lateral é menor que os dois primeiros. A face labial e lingual exibem um ângulo pouco menor que $90^{\circ}$, resultando em uma crista voltada para a face lingual.

Base reta, com irregularidades e crenulações, menor que a largura da coroa, sentido anterior-posterior, com $4 \mathrm{~mm}$ na base e $5 \mathrm{~mm}$ na coroa, esta caracterizada pelo comprimento da crista.

A face labial tem a forma de um trapézio, com um dos lados maior e uma das pontas arredondada e a outra pontiaguda.

As bordas laterais são diferenciadas, convexa no lado maior e quase reto com uma pequena curvatura próxima da extremidade lingual.

A face labial exibe forte concavidade próxima da crista e ligeira convexidade na extremidade distal. A face lingual apresenta uma pequena concavidade central. A diferença de tamanho entre as faces, labial e lingual, é muito acentuada, a face lingual com $4 \mathrm{~mm}$ de altura e a face labial, $9 \mathrm{~mm}$. 


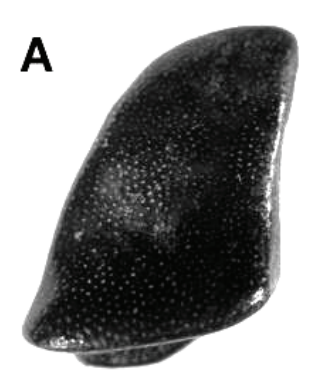

C

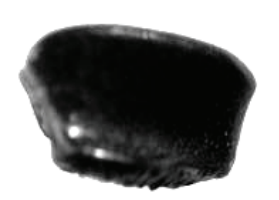

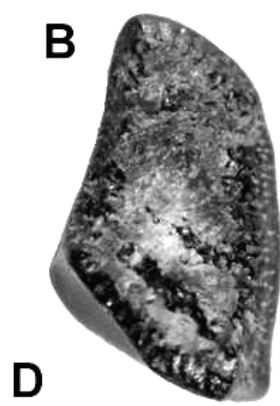

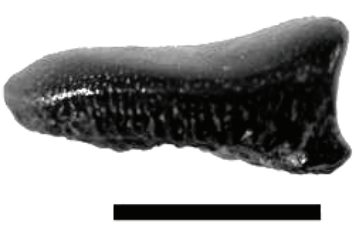

Figura 100 - Exemplar (GP/2E-6304) de dente póstero-lateral. A) Vista labial - oclusal; B) Vista inferior; C) Vista lingual; D) Vista lateral. Escala $2 \mathrm{~mm}$.

\section{Outros dentes de Itapyrodus punctatus}

Dentro da espécie Itapyrodus punctatus ocorrem dentes que apresentam características tanto sinfisianas como de póstero-lateral. Duas delas foram observadas no presente estudo

Descrição de GP/2E-6258 (Fig. 101A-101E) O dente possui uma coroa mais alta que um dente posterior convencional, porém mais baixa que um sinfisiano típico. Como nos dentes sinfisianos este dente é voltado para a face lingual, com uma crista desgastada no topo, separando a face lingual da labial, disposta diagonalmente entre as laterais. O ângulo entre as faces labial e lingual é de $90^{\circ}$ como em dentes póstero-lateral.

A face labial é plana, com um prolongamento em uma das laterais, formando um pequeno triangulo irregular em uma extremidade, com o vértice arredondado próximo da base. Próximo desse prolongamento ocorre um pequeno arqueamento. A face lingual é menor que a labial, $8 \mathrm{~mm}$ de altura contra $11 \mathrm{~mm}$. Apresenta concavidade central, que separa o todo da base do dente. Em vista lateral o dente tem o formato de triangulo aberto curvo e com um dos lados menor.

A base articulatória é irregular, com crenulações como no dente látero-posterior e muito grande no sentido labial - lingual, com $14 \mathrm{~mm}$ de comprimento e pequeno no sentido anterior posterior, com $5 \mathrm{~mm}$, a máxima medida na região lingual e $2 \mathrm{~mm}$ na região em que ocorre o prolongamento lingual.

Ainda nas faces labial e lingual, a porção anterior exibe uma ponta arredondada, enquanto a posterior é reta e angulosa. A crista mede $7 \mathrm{~mm}$ de comprimento. 
O espécime está muito desgastado, deixando bem evidente o aspecto pontuado da superfície de todas as faces.
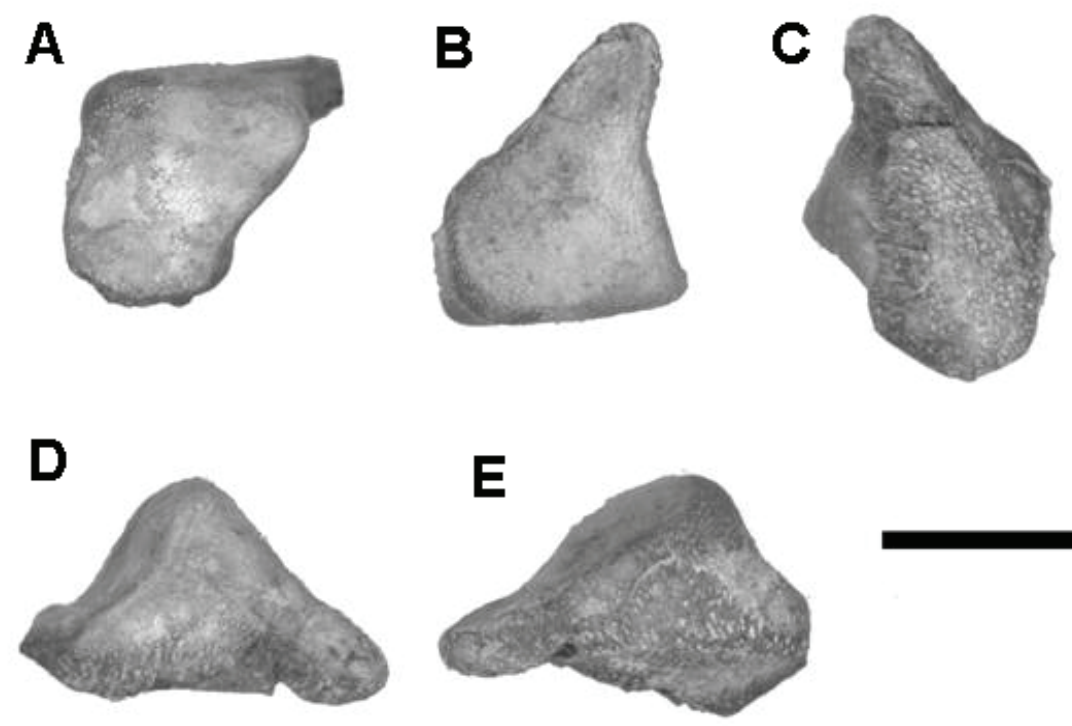

Figura 101 - Dente incomum de Itapyrodus punctatus (GP/2E-6258). A) Vista lingual; B) Vista labial oclusal; C) Vista inferior; D) e E) Vistas laterais. Escala 10mm

Descrição de GP/2E-5925 (Fig. 102) Este exemplar está incrustado fortemente em sedimento arenoso fino. Possui $5 \mathrm{~mm}$ de comprimento e desgaste por toda a superfície.

A coroa é mais baixa que um dente sinfisiano, porém tanto o lado labial quanto lingual são semelhantes na forma, sendo a lateral labial um pouco maior. Como nos póstero-laterais, o ângulo entre a face labial e lingual é próxima de $90^{\circ}$.

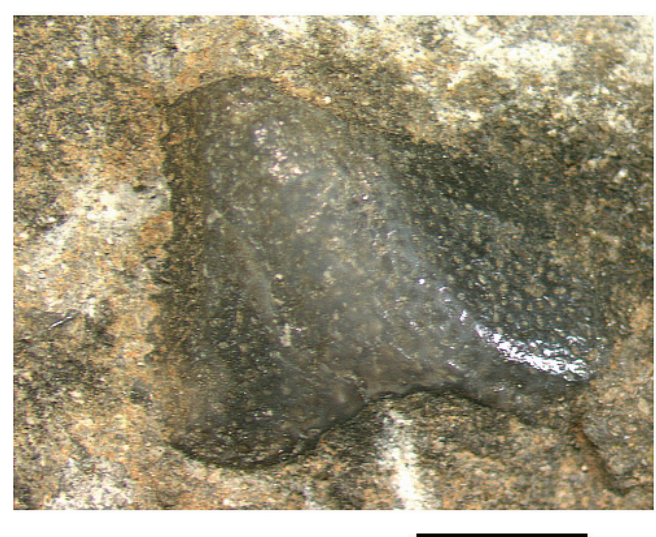

Figura 102 - Dente sinfisiano de Itapyrodus punctatus (GP/2E-5925) ainda na rocha. Escala $2 \mathrm{~mm}$. 
Discussão - Os espécimes GP/2T-206 e GP/2T-207 sinfisianos, espécime GP/2E-5925 intermediário e o espécime GP/2E-6290 póstero-lateral são idênticos aos estudados por RAGONHA (1978) e SILVA SANTOS (1990), podendo ser associados, com segurança, a espécie Itapyrodus punctatus, reconhecida na Formação Pedra do Fogo e base da Formação Irati.

É possível observar nos exemplares descritos acima, que a margem posterior de um se ajustaria a margem anterior de um dente semelhante (não igual), formando uma seqüência contínua, com variações mínimas. Isso pode ser comprovado comparando os exemplares dos dentes sinfisianos. As diferenças registradas no exemplar GP/2T-208 sugerem que este dente ocuparia uma posição diferente, provavelmente frontal, na boca do animal.

Os dentes intermediários seriam dentes sifisianos laterais e ocupariam a região entre os dentes sinfisianos frontais e póstero-laterais, mantendo características comuns dos dois grupos de dentes.

Não existem, na área de contato entre os dentes, quebras laterais que pudessem sugerir fusão entre eles. Evidentemente, estes dentes eram individuais e justapostos, mas não formavam um pavimento típico de placas dentárias. Como observado por SILVA SANTOS (1990) todos os dentes aparentemente estavam na parte direita ou esquerda da mandíbula ou maxila, não havendo de fato uma sequencia sagital, como em outros gêneros de Petalodontiformes, como por exemplo, Janassa.

Segundo SILVA SANTOS (1990), a classificação de Itapyrodus punctatus dentro de Petalodontiformes é segura, pois os dentes se assemelham muito com os dentes de Chomatodus, Climaxodus e algumas variedades dentro do gênero Petalodus, no que diz respeito, principalmente, à forma, morfologia das faces labial-lingual e coroa alta nos dentes sinfisianos.

A sequencia completa dos dentes não foi verificada na Formação Pedra do Fogo por SILVA SANTOS (1990). No presente estudo foi considerada a existência de um dente realmente frontal, GP/2T-208, e de outros que caracterizariam uma sequencia ininterrupta entre os sinfisianos e os póstero-laterais, inclusive dentes intermediários GP/2E-5925 e GP/2E-6258, e foi observada a mudança gradual na dentição, como ocorre em Climaxodus (WOODWARD, 1919).

Climaxodus e Chomatodus, apesar de terem sequencia dentária similar, exibem formatos diferentes no comprimento e na ornamentação da parte superior da coroa (WOODWARD, 1919; ZANGERL, 1981). Climaxodus também não apresenta dentes 
exclusivos para trituração como em Itapyrodus e sim um dente maior e mais alongado na parte lateral da mandíbula.

SILVA SANTOS (1990) apenas ilustrou um dente póstero-lateral, que seria um equivalente do exemplar GP/2E-6290. Os exemplares de dentes pôster-laterais GP/2T209 e GP/2E-6304 do presente estudo revelam que o dente descrito por SILVA SANTOS (1990) e o exemplar GP/2E-6290 provavelmente deveriam ter sido intermediários entre GP/2T-209 e GP/2E-6304, sendo que GP/2E-6304 seria o ultimo dente da sequencia e o que apresentou mais características de dentes destinado a trituração e que GP/2T-209 seria o primeiro ainda com a coroa pouco mais alta.

A comparação com Climaxodus é válida, pois a sequência de dentes na boca de Itapyrodus punctatus deveria ser idêntica, principalmente em relação aos dentes postero-laterais e que como sugeriu SILVA SANTOS (1990), apenas teriam a fileira esquerda e direita. Uma característica que reforçaria esta hipótese e a grande face labial alongada. Esta característica também é sugerida para outros Holocephali como Lagarodus e Psammodus, com uma ou mais placas destinadas a trituração, em cada lado da região posterior da mandíbula (ELLIOTT, et. al. 2004; LEBEDEV, 2008).

MOY-THOMAS \& MILES (1971), ZANGERL (1981), LONG (1995) e JANVIER (1996) colocaram os petalodontes como animais típicos de ambientes costeiros e de águas rasas do Neopaleozóico. No Brasil os Petalodontiformes ocorrem associados não a fósseis marinhos, mas sim, em algumas localidades, a animais de águas doces e de baixa salinidade (xenacantídeos) e continentais (anfíbios) (RAGONHA, 1978, SILVA SANTOS, 1990, SANTOS, 1994; TOLEDO, 2001; CHAHUD, 2007; CHAHUD \& FAIRCHILD, 2003a; 2005). Talvez os petalodontes brasileiros representem uma linhagem que desenvolveu tolerância a ambientes menos salinos nas bacias intracratônicas brasileiras durante o Permiano.

A área de abrangência geográfica de Itapyrodus punctatus é uma das maiores entre os vertebrados paleozóicos brasileiros, com exemplares encontrados no nordeste e sudeste. Sua origem é controversa eventualmente de depósitos eopermianos de outras bacias gondwânicas.

A única outra localidade na America do Sul com fósseis de Petalodontiformes, provém de depósitos marinhos da Formação Copacabana da Bolívia (MERINO-RODO \& JANVIER, 1986; JANVIER, 1996), porém o gênero observado é Megactenopetalus, uma forma diferente das observadas nas Bacias do Parnaíba e Paraná, por isso ainda não se pode ter certeza sobre a origem dos petalodontes brasileiros. 


\subsubsection{Variações incomuns de dentes de Petalodontiformes encontrados}

\section{Itapyrodus sp. (?)}

Figs. 103 e 104

Material - GP/2E-6307 (Fig. 103). GP/2E-6308 (Fig. 104). Dentes isolados.

\section{Localização - Afloramento 1, Sitio Santa Maria 1}

Descrição de (GP/2E-6307) (Figs. 103A-103D) O dente possui uma coroa comprimida, voltada para face lingual e uma crista no topo, disposta no sentido anterior-posterior do dente. A face labial é plana e inclinada e a face lingual apresenta uma concavidade forte que se inicia na parte central da coroa, dando um aspecto de "L" em vista lateral, apenas na região lingual.

A

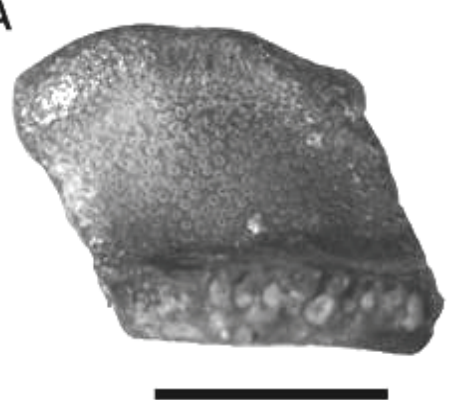

C

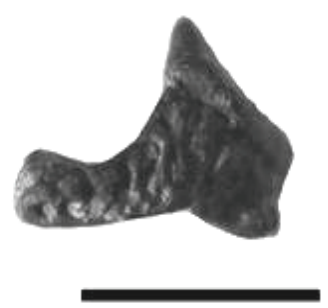

B
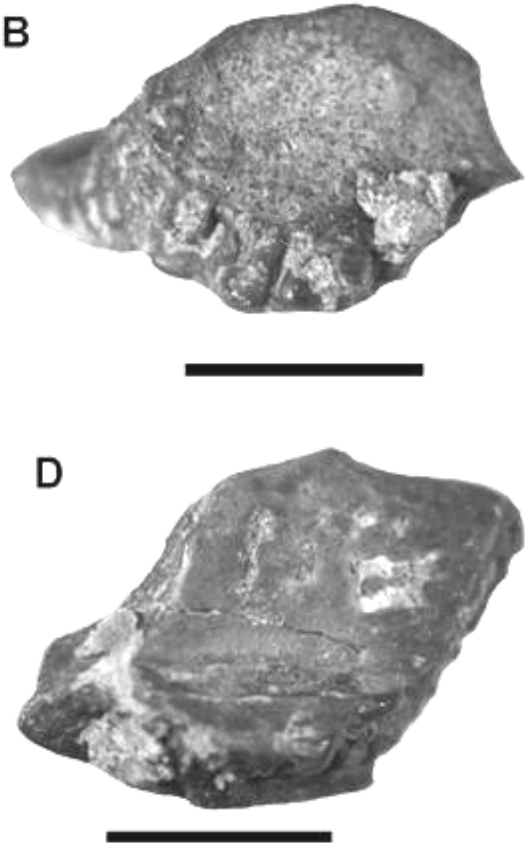

Figura 103 - Espécime incomum de Itapyrodus (GP/2E-6307). A) Vista lingual; B) Vista labial; C) Vista lateral; D) Vistas inferior. Escala 2mm.

A face lingual é muito maior que a face labial, com $5 \mathrm{~mm}$ de largura (sentido labial-lingual) contra $3 \mathrm{~mm}$ obtido na face labial.

A base tem a forma de um paralelogramo, em vista inferior é lisa e plana, com exceção da região lingual, onde ocorrem crenulações. O comprimento máximo é de 8 $\mathrm{mm}$, medido diagonalmente, pois tanto o comprimento da borda na face labial quanto na lingual é de $4 \mathrm{~mm}$. 
A coroa é inclinada para uma das laterais e a altura medida é de $4 \mathrm{~mm}$. O topo da coroa é convexo, mais acentuado em uma das laterais. A crista mede $5 \mathrm{~mm}$ de comprimento. Ambas faces laterais (faces anterior e posterior) são retas, planas e inclinadas no mesmo modo.

O espécime está desgastado, deixando bem evidente o aspecto pontuado da superfície em todas as faces.

Descrição de (GP/2E-6308) (Figs. 104A-104D) como no exemplar GP/2E-6307 a face lingual é muito maior que a face labial, com $4 \mathrm{~mm}$ de comprimento no sentido labial-lingual e $2 \mathrm{~mm}$ medido na face labial.

O dente possui coroa robusta, comparada com GP/2E-6307, voltada para a face lingual, o topo arredondado com uma crista, disposta no sentido anterior-posterior na face lingual. A face labial é plana e inclinada lingualmente e a lingual apresenta uma concavidade forte que se inicia na parte central da coroa e é mais acentuada próxima da borda lingual.
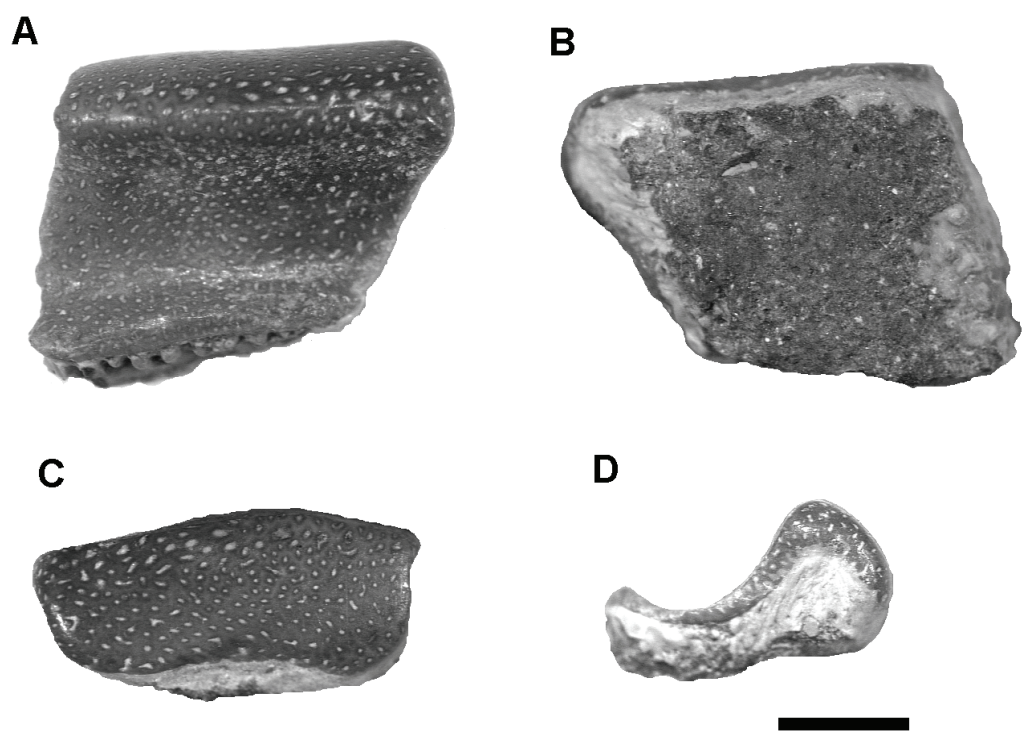

Figura 104 - Espécime incomum de Itapyrodus GP/2E-6308. A) Vista lingual; B) Vista inferior; C) Vista labial; D) Vistas lateral. Escala $2 \mathrm{~mm}$.

A base em vista inferior é lisa e plana, com exceção de algumas irregularidades mais evidentes na borda lingual. O comprimento máximo é de 7,5 mm, medido diagonalmente, com a borda labial de $5,5 \mathrm{~mm}$ e a lingual $4 \mathrm{~mm}$.

A coroa é inclinada para uma das laterais a altura medida é de $4 \mathrm{~mm}$. O topo da coroa é arredondado com convexidade mais acentuada na parte central. A crista é pouco mais de $5 \mathrm{~mm}$ de comprimento. 
Ambas faces laterais (faces anterior e posterior) são retas e planas, porém na posterior existe uma inclinação maior com relação a margem lingual.

Discussão - $\mathrm{O}$ aspecto pontuado e a disposição da coroa alta caracterizam típicos dentes sinfisianos de Itapyrodus, podendo ser incluído, com segurança, neste gênero, porém diferentemente da espécie I. punctatus, a face labial é muito menor que a face lingual. A crista pronunciada nos exemplares revela que são frontais ou próximos da parte frontal da mandíbula ou maxila, porém os dentes mais delgados que em $I$. punctatus, sugerem diferente tipo de alimentação.

O gênero Itapyrodus provavelmente não era monoespecífico e talvez em fase de isolamento teria se diversificado para formas especializadas para determinados ambientes e alimentação.

\subsubsection{Holocephali indeterminados}

$\mathrm{Na}$ base do Membro Taquaral ocorrem alguns dentes bradiodontes de características variadas.

O exemplar GP/2E-6263 (Fig. 105) é dente de coroa muito baixa, semelhante aos gêneros de Holocephali: Platyxystrodus, Chomatodus, Lagarodus e Psammodus. Tanto o exemplar como os gêneros citados acima possuem a base crenulada e a coroa muito fina, alem de uma morfologia externa em forma de trapézio ou retângulo.

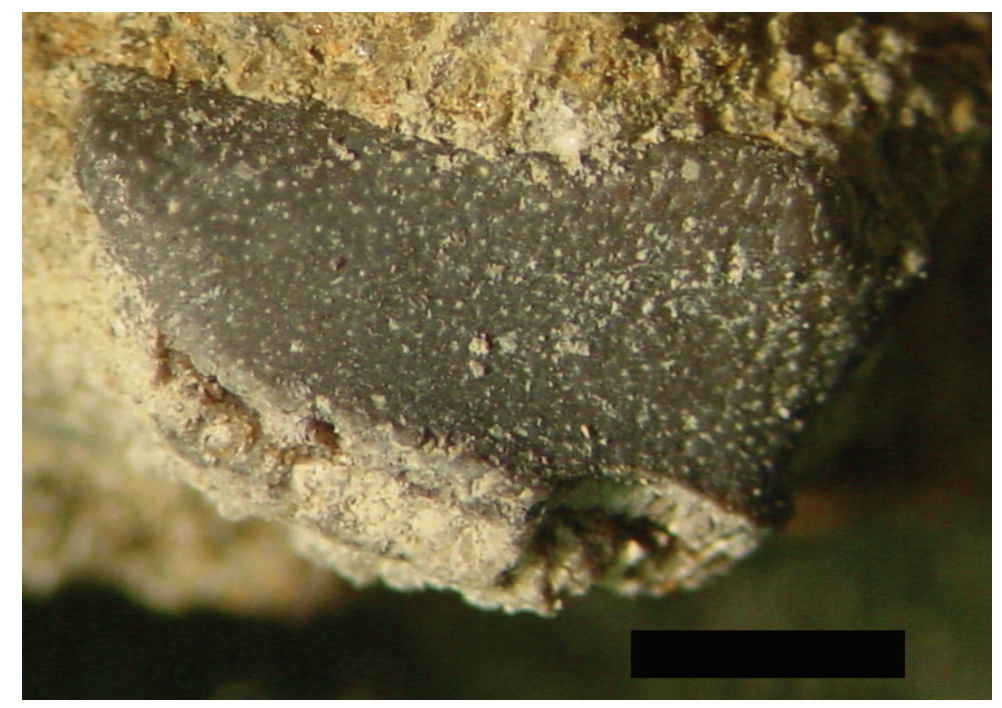

Figura 105 - Holocephali indeterminado (GP/2E-6263). Escala 2mm.

O exemplar GP/2E-6432 (Fig. 106) tem coroa baixa e alongada, mas um pouco mais alta que o exemplar anterior. É semelhante a placas dentárias associadas ao gênero, porém como o fóssil é fragil e não foi possível a retirada da amostra, não foi descartada a possibilidade de ser um póstero-lateral de Itapyrodus. 


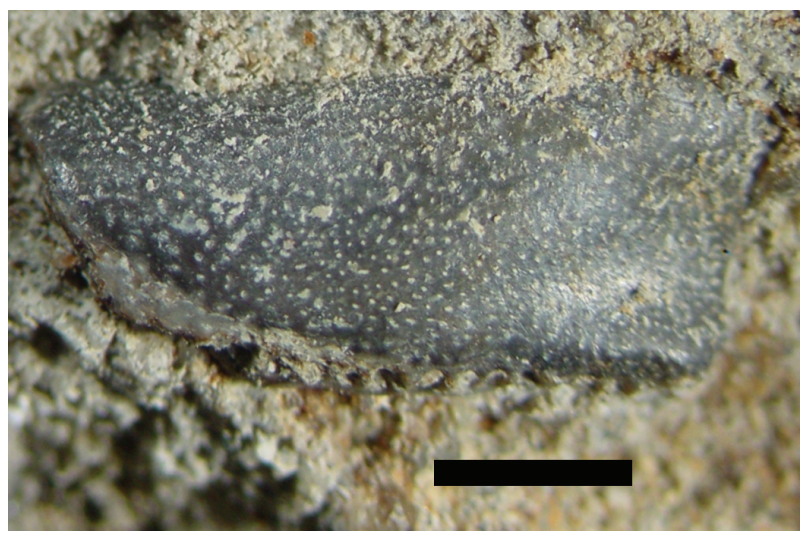

Figura 106 - Holocephali indeterminado (GP/2E-6432). Escala 2mm.

\subsection{Chondrichthyes Indeterminados}

\subsubsection{Orodontiformes}

Os Orodontiformes formaram um grupo de Chondrichthyes de classificação sistemática incerta. NELSON (2006) classifica-os como Paraselachimorpha dentro de Holocephali, contudo (ZANGERL, 1981; GINTER et al. 2010) os consideram como Elasmobranchii primitivos. Em ambos os casos há aceitação científica por isso este grupo será tratado como uma ordem a parte neste trabalho.

A maior parte das espécies é definida por dentes isolados, porém raros exemplares, com conservação de outras características anatômicas, foram descritos no Carbonífero dos EUA.

Segundo ZANGERL (1981), a família Orodontidae contém os gêneros Orodus e Campodus.

Campodus é baseado apenas em dentes e não é descartada a possibilidade de ser um Eugeneodontida, por causa do ajuste entre os dentes na mandíbula.

Orodus (Fig. 107), mais representativo dessa família, foi inicialmente descrito a partir de dentes isolados encontrados no Carbonífero de Bristol, Inglaterra. É um Chondrichthyes de forma alongada, comparável a algumas enguias. A cabeça é ligeiramente achatada ou rombuda e as nadadeiras são pequenas em relação ao tamanho do corpo. A superfície corporal está coberta por uma armadura relativamente grossa de dentículos dérmicos. Os dentículos variam em formato, sendo mais achatados no dorso e flancos. A caixa craniana é pouco calcificada e a cartilagem de Meckel é curta e expandida dorso ventralmente. A nadadeira peitoral é unisserial axial.

O gênero Orodus é reconhecido através de dentes grandes com grande variação individual e ontogenética, caracterizando heterodontia. Os dentes formam um 
pavimento de dentes sinfisianos, com os maiores localizados na frente (externamente) e os menores atrás (internamente). Os dentes são relativamente robustos, coroa com uma crista longitudinal não cortante na extremidade superior e cristas (costelas) verticais ou oblíquas por toda a superfície da coroa.

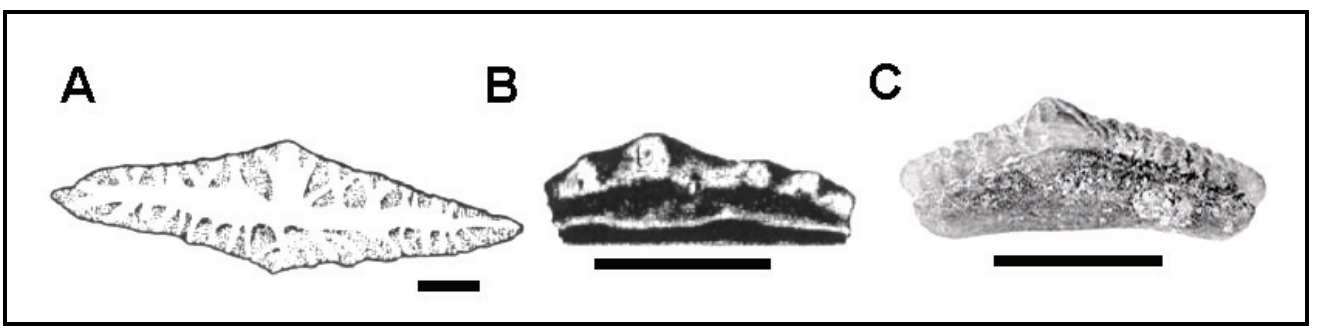

Figura 107 - Dentes de Orodus do Carbonífero dos EUA. A) Vista oclusal de O. ramosus. Escala: $10 \mathrm{~mm}$ (MOY-THOMAS \& MILES, 1971); B) Vista labial de O. micropterygius. Escala: 5 mm (ZANGERL, 1981); C) Vista lingual de Orodus sp. Escala $1 \mathrm{~mm}$ (ELLIOTT et al. 2004).

O primeiro esqueleto articulado de Orodus provém dos Folhelhos negros do Carbonífero de Indiana (ZANGERL \& RICHARDSON, 1963). Fóssil de grandes proporções, para os tubarões da época, com, aproximadamente, $3 \mathrm{~m}$ de comprimento. Segundo ZANGERL, (1981) seus dentes são muito pequenos se comparados com Orodus ramosus, da Europa, por isto este autor ficou em dúvida se seria uma característica desta espécie ou do gênero, pois $O$. ramosus baseado em dentes, seria um tubarão com mais de 12 ou 15 metros de comprimento, contudo não confirmado por nenhum resto ou vestígio em depósitos contendo esta espécie.

O problema com descrições apenas de dentes de Orodus reside na grande variação (Fig. 108), que sugere que muitas espécies novas possam ser sinônimas. Segundo ZANGERL (1981) para uma espécie ser caracterizada como tal se além dos dentes, forem encontrado boa parte do corpo preservada.

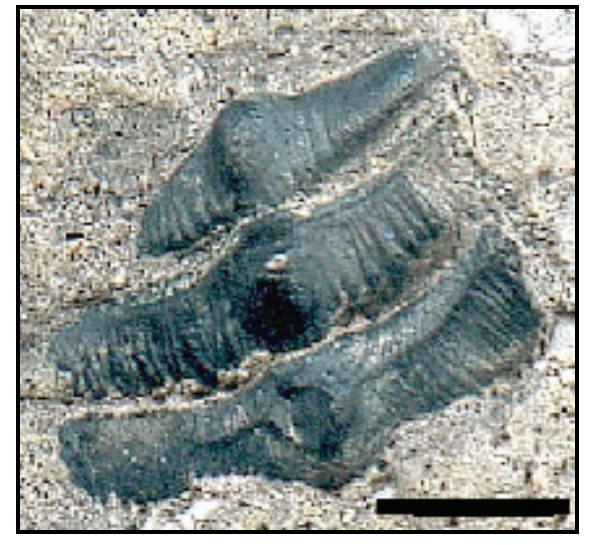

Figura 108 - Variação ontogenética de dentes ainda articulados de Orodontiformes. Escala 5mm (WPS, 2002). 
O habitat dos Orodontiformes também é incerto, pois diversos exemplares estão associados a diversas faunas do Paleozóico. Espécies norte-americanas são mais comuns em ambiente marinho, por vezes marinho profundo (ZANGERL \& RICHARDSON, 1963).

\subsubsection{Orodontiformes da base da Formação Irati}

Ordem ORODONTIFORMES Zangerl, 1981

Família ORODONTIDAE de Koninck, 1878

Gênero Orodus Agassiz, 1838

\section{Diagnose genérica}

Dentes de comprimento muito maior que a largura. A base é mais espessa que a coroa e extensão maior na face lingual. A coroa é baixa com a parte central mais elevada que as extremidades. Possui uma cúspide transversal central inclinada para a face lingual e uma crista longitudinal média que separa a face lingual da labial, de onde partem costelas verticais ou oblíquas, de cima para baixo, que se ramificam para as laterais.

Espécie tipo do gênero: Orodus cinctus Agassiz, 1838

Orodus ipeunaensis sp. nov.

Figs. 109 - 110

Derivação do nome - Homenagem ao município de Ipeúna, interior do Estado de São Paulo, onde foram encontrados os primeiros exemplares da espécie.

Holótipo (GP/2T-205) (Fig. 109) dente completo apresentando desgaste por toda sua superfície.

\section{Localização - Afloramento 1, Sitio Santa Maria 1}

Estratigrafia: Camada de arenito conglomerático da base do Membro Taquaral, Formação Irati.

Diagnose - Dentes de base espessa e comprimento semelhante ao da coroa. Coroa baixa, com a parte central mais elevada que as extremidades, formando uma cúspide principal central voltada para a face lingual. Uma crista longitudinal mediana percorre toda a coroa e separa as faces lingual e labial, sem uma borda cortante. Costelas oblíquas partindo da crista superior, de cima para baixo, e se ramificam a partir da região central da coroa. Cúspides secundárias laterais localizadas na face labial da 
coroa, eqüidistantes da cúspide mediana. Base com grande prolongamento na face lingual.

Material - GP/2T-205. (Fig. 109) GP/2E-5933. (Fig. 110) Dente isolado completo.

Descrição do exemplar GP/2T-205 - É um dente de coroa baixa e comprimento pouco maior que duas vezes a altura. Apresenta cinco cúspides eqüidistantes entre si na borda labial da coroa, uma cúspide principal, localizada na região central da coroa, com duas cúspides secundárias, lateralmente. As cúspides partem perpendicularmente da base, apresentam extremidade arredondada e se curvam ligeiramente para a face lingual, com pequena inclinação para a lateral posterior.

A cúspide principal exibe pequena quebra na face lingual no centro da coroa.

Uma crista longitudinal percorre todo o comprimento da coroa, passando por todas as cúspides. Na cúspide principal ocorre também uma pequena crista transversal visível apenas na face lingual. As cúspides centro-laterais se localizam simetricamente em torno da principal e têm tamanho similar. Apresentam pequenas variações, possívelmente como resultado de desgaste em vida ou de abrasão hidráulica "posmortem". As cúspides laterais são as menores e estão localizadas nas bordas anterior e posterior da coroa, em contato com a base.
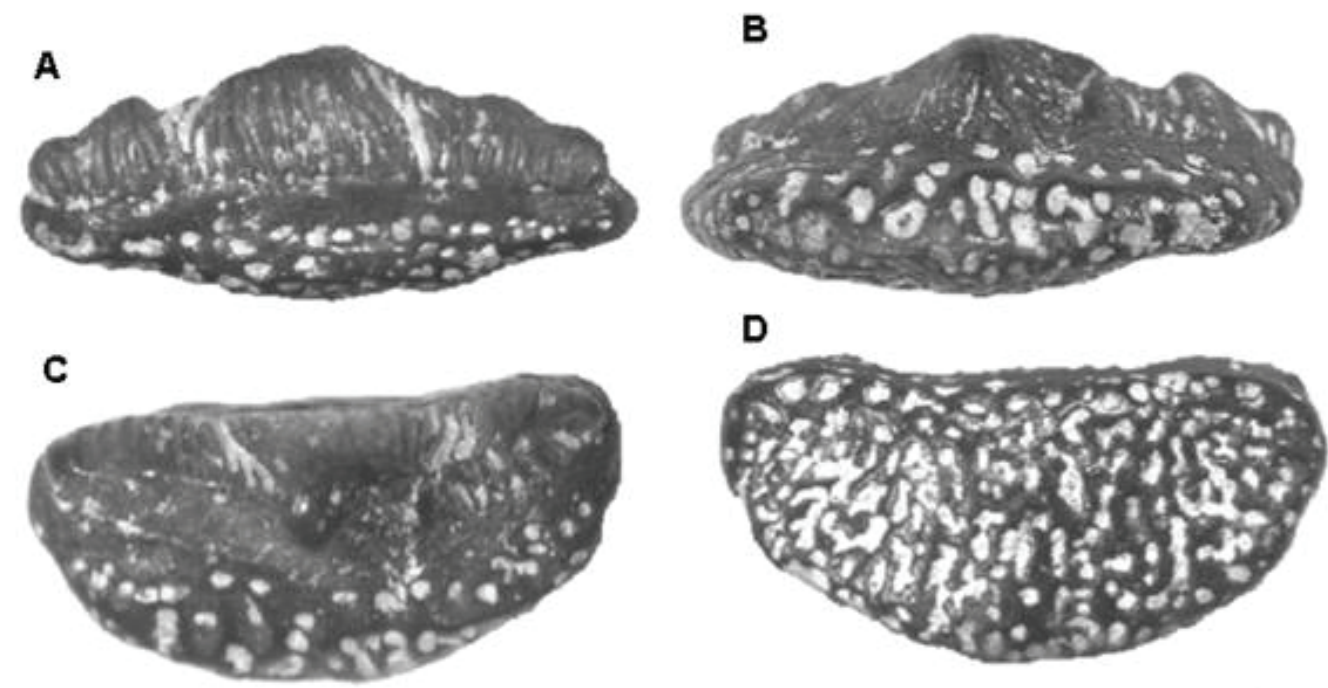

Figura 109 - Dente de Orodus ipeunaensis GP/2T-205: A)Vista labial; B) Vista lingual; C) Vista oclusal; D) Vista Inferior. Escala: $3 \mathrm{~mm}$.

Observam-se dezenas de finas cristas (mais de 40) que partem perpendicularmente da parte superior da coroa (crista) até alcançarem o contato com a base. Em vários locais ocorrem bifurcações simples próximas da base. É possível que a 
crista transversal localizada na cúspide central seja uma costela mais espessa, como ocorre em alguns dentes hibodontes. O número de costelas é semelhante nas duas faces do dente, porém são mais fortes e proeminentes na face labial.

O contato entre a base e a coroa é brusco, marcado apenas pelo surgimento de costelas na porção basal da coroa e pela presença de um sulco horizontal contínuo que percorre a superfície.

A base é ovalada, mas assimétrica, com o formato de uma letra " $D$ ". É convexa na parte lingual superior com uma pequena concavidade na parte inferior. $\mathrm{O}$ desgaste expôs muito da dentina trabecular irregular e orifícios simétricos e alongados possivelmente de dentina tubular.

A coroa tem 10,2 mm de comprimento, e a base, 10,4mm. Esta diferença se deve a um pequeno prolongamento basal observado nas laterais. A largura máxima da base é de $5,4 \mathrm{~mm}$, sendo que $3,7 \mathrm{~mm}$ se referem ao prolongamento na face lingual a partir da coroa.

A altura da cúspide principal é de 3,1mm. As cúspides secundárias centro laterais possuem alturas diferentes, a maior com $1,8 \mathrm{~mm}$, e a menor com $1,5 \mathrm{~mm}$. A altura máxima da base é de 2,2 $\mathrm{mm}$ registrado no centro da face lingual.

Descrição do exemplar GP/2E-5933 - O espécime possui coroa com três cúspides ornamentadas por finas cristas irregulares espaçadas entre si. As cúspides estão posicionadas assimetricamente na borda labial da coroa; todas partem perpendicularmente da base, apresentam extremidades arredondadas com pequena curvatura para a face lingual e outras para as laterais.

A

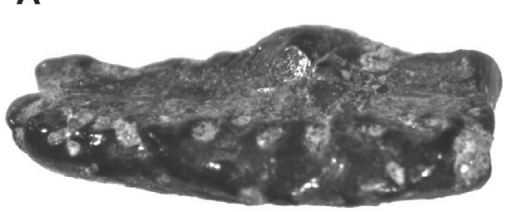

C

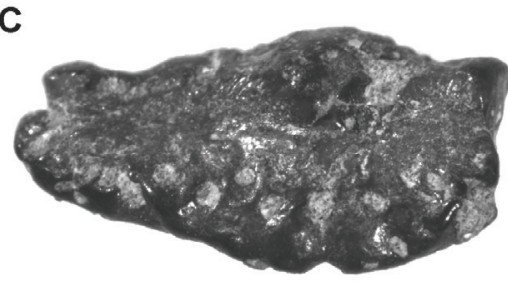

B

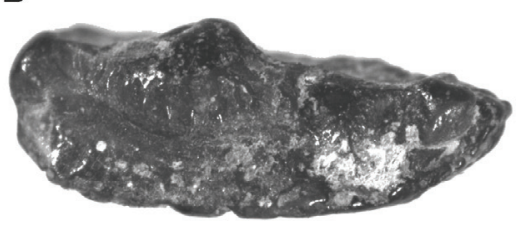

D

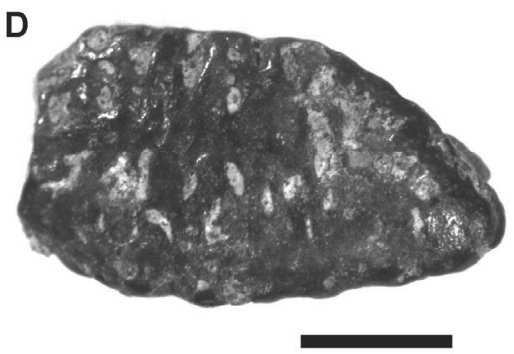

Figura 110 - Dente de Orodus ipeunaensis. GP/2E-5933. A) vista lingual, B) vista labial, C) vista superior labial, D) vista inferior. Escala $2 \mathrm{~mm}$. 
A cúspide principal, localizada em uma das laterais, está desgastada, apresentando poucas cristas transversais finas com bifurcações na face lingual e 11 pequenas cristas transversais sem bifurcação na parte labial. As cúspides secundárias lisas, localizam-se nas extremidades laterais e têm forma e tamanhos diferentes, a menor, muito próxima da principal enquanto a outra, fica distante $2,0 \mathrm{~mm}$.

Uma crista longitudinal percorre todo o comprimento da coroa, observada em todas as cúspides.

A face lingual, na base, é lisa e prolongada no sentido contrário ao da coroa.A base tem formato oval assimétrico, com extensões laterais em apenas um dos lados e convexidade nas partes lingual e labial, mais acentuada abaixo da cúspide principal. Contém foramens irregulares e desgaste, expondo parte da dentina.

A coroa tem $6,1 \mathrm{~mm}$ de comprimento no topo e $6,2 \mathrm{~mm}$ na parte inferior. A largura máxima da base é de 3,4mm, destes, 2,9mm referem-se ao prolongamento na face lingual. A altura máxima do dente, a partir da cúspide principal, é de 4,6mm da altura total, sendo que $1,2 \mathrm{~mm}$ pertencem a coroa. As cúspides secundárias tem em torno de $1,0 \mathrm{~mm}$ de altura.

Discussão - As características da coroa e da base do novo exemplar são diagnósticas de dentes hibodontes, atribuídos aos Orodontiformes.

O espécime se assemelha a diversas espécies de Orodontiformes de varias localidades. As espécies $O$. cinctus, O. greggi, e O. ornatus, todas do Carbonífero norteamericano (MOY-THOMAS \& MILES, 1971; WÜRDIG -MACIEL, 1975, ZANGERL, 1981), possuem coroas muito semelhantes no que diz respeito à ornamentação e inclinação da cúspide principal para a face lingual. Difere dessas espécies pelo comprimento mais curto da base na região lingual e no número de cúspides secundárias.

Orodus ramosus do Carbonífero da America do Norte e Europa (MOYTHOMAS \& MILES, 1971) chama a atenção por possuir uma crista longitudinal simples e uma cúspide principal mediana semelhante à do Exemplar GP/2T-205. A ornamentação por costelas e a crista transversal nas cúspides são muito parecidas na forma e estilo de ornamentação, porém a base é muito menor que a coroa e pouco espessa.

Orodontiformes aparentemente foi uma ordem rara no Brasil. RAGONHA (1978) não encontrou nenhum dente nos afloramentos de Assistência e Itapetininga. 
Estudos realizados na Bacia do Parnaíba, Formação Pedra do Fogo (SILVA SANTOS, 1947 e 1990) e Formação Corumbataí, Bacia do Paraná (MARANHÃO, 1995 e TOLEDO, 2001) não mencionam este grupo.

O dente da única espécie brasileira Orodus milleri da Formação Teresina do Rio Grande do Sul (WÜRDIG -MACIEL, 1975) tem a base larga, similar aos espécimes da base da Formação Irati. Esta espécie difere do exemplar aqui descrito por possuir coroa com duas cúspides do lado esquerdo e três do lado direito. As costelas também são muito mais proeminentes e espessas em $O$. milleri.

A base larga em Orodontiformes sul americanos talvez seja uma característica típica destes animais do Gondwana, pois espécies da América do Norte e Orodus sp. do Carbonífero da Bélgica (DELSATE et al. 2003) exibe base estreita e fina.

O exemplar GP/2E-5933 possui características semelhantes às observadas em $O$. ipeunaensis, como o grande prolongamento da base lingual, número de cúspides e a inclinação da cúspide principal para a face lingual, porém a assimetria das cúspides difere bastante de O. ipeunaensis. Segundo ZANGERL (1981), há grande variação dentária em diversas espécies do gênero Orodus e por isso o exemplar talvez seja imaturo ou de uma posição diferente dentro da boca do animal.

Apesar de ZANGERL (1981) sugerir a não classificação de novas espécies a partir de dentes, por causa de variações morfológicas entre os dentes, este exemplar é único em suas características em comparação com outros da Europa e América do Norte, além de também diferir do exemplar brasileiro, Orodus milleri da Formação Estrada Nova. Outro fator importante é que este exemplar representa o fóssil mais antigo de Orodus do Brasil.

\subsubsection{Orodontiformes incertae sedis}

Outro exemplar (GP/2E-3751) (Fig. 111) coletado de um possível Orodontiformes possui muitas quebras.

A região oclusal da coroa está fragmentada, mas ainda é possível identificar diversos caracteres, dentre os quais três cúspides, sendo a central muito maior que as laterais. As cúspides, como no Exemplar GP/2T-205, aparentemente são eqüidistantes entre si.

A má conservação da coroa impediu a observação de cúspides secundárias. No topo de uma das cúspides foi observada uma pequena extensão da crista longitudinal. 
A base tem forma oval irregular como uma letra " $\mathrm{D}$ ", com lado labial reto. Possui inúmeros foramens circulares e fortes sulcos transversais na face inferior, salientados pelo desgaste.

A coroa mesmo incompleta, tem 13,8 mm de comprimento e a base, 15,2 mm. A largura máxima da base é de $10,4 \mathrm{~mm}$, sendo que $4,6 \mathrm{~mm}$ se referem ao prolongamento da face lingual até a coroa.

A altura do dente é de $7,0 \mathrm{~mm}$, sendo que $3,5 \mathrm{~mm}$ correspondem à parte preservada da cúspide principal. As cúspides secundárias têm, aproximadamente, $1 \mathrm{~mm}$ de diâmetro máximo. A altura máxima da base é de $4,2 \mathrm{~mm}$, registrado no centro da face lingual

O desgaste é evidente no exemplar, mas as quebras na coroa provavelmente ocorreram durante a coleta.

Observando a morfologia da base e da coroa fragmentada, foi possível inferir que o fóssil tinha característica de um dente hibodonte como O. ipeunaensis, porém o fóssil infelizmente não preservou feições diagnósticas desta espécie.

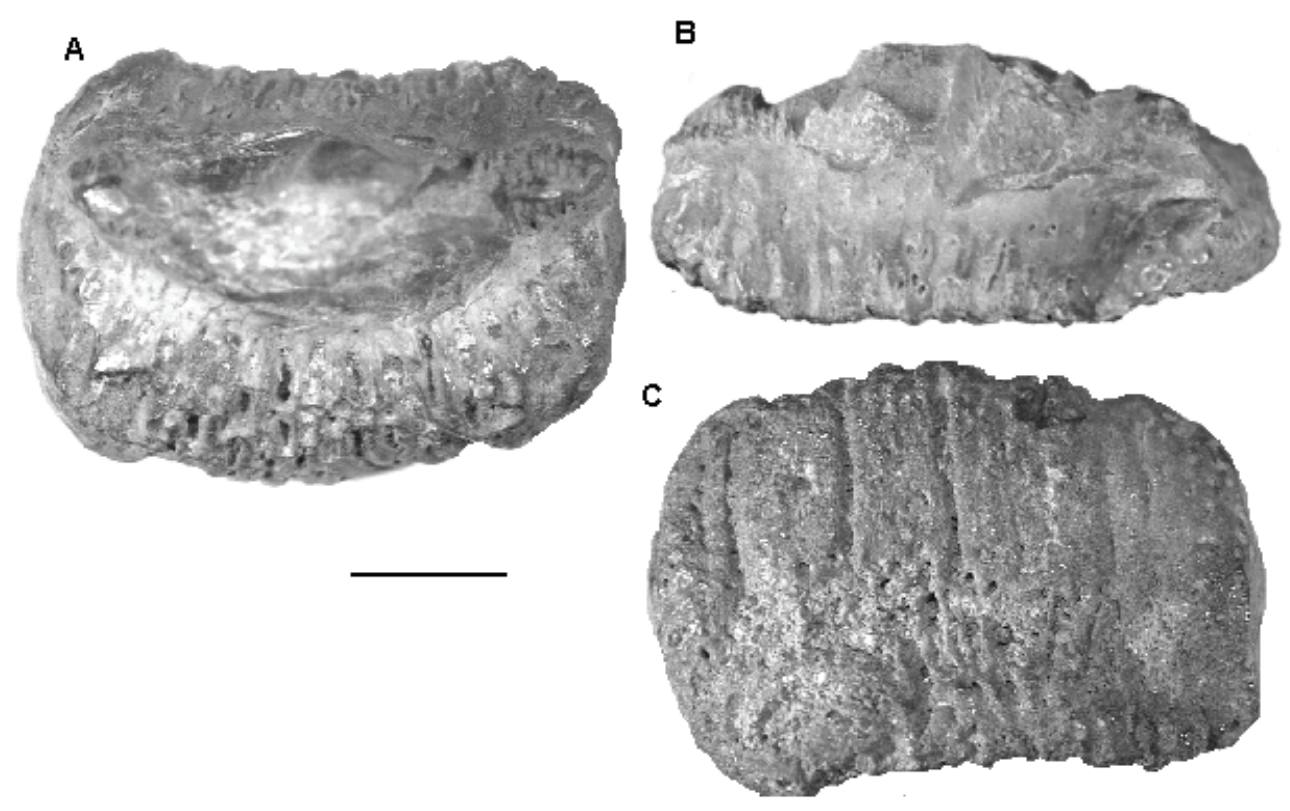

Figura 111 - Dente de Orodontiformes indeterminado GP/2E-3751. A) vista lingual, B) vista labial, C) vista inferior. Escala $4 \mathrm{~mm}$.

\subsubsection{Ordem indeterminada}

Material - GP/2E-5929 (Fig. 112A -112C) e GP/2E-6459 (Fig. 112D - 112F). Dentes isolados completos.

Localização - Afloramento 1 Sítio Santa Maria 1, município de Rio Claro. 
Distribuição Geográfica e Estratigráfica - Permiano do Membro Taquaral da Formação Irati no Estado de São Paulo.

Descrição - o exemplar GP/2E-5929 é um dente completo, aparentemente pouco desgastado, com formato de "A" (Fig. 112A, 112B). A base é bilobada e côncava com pequena saliência reta transversal, provavelmente relacionada ao sistema articulatório (Fig.112A).

A
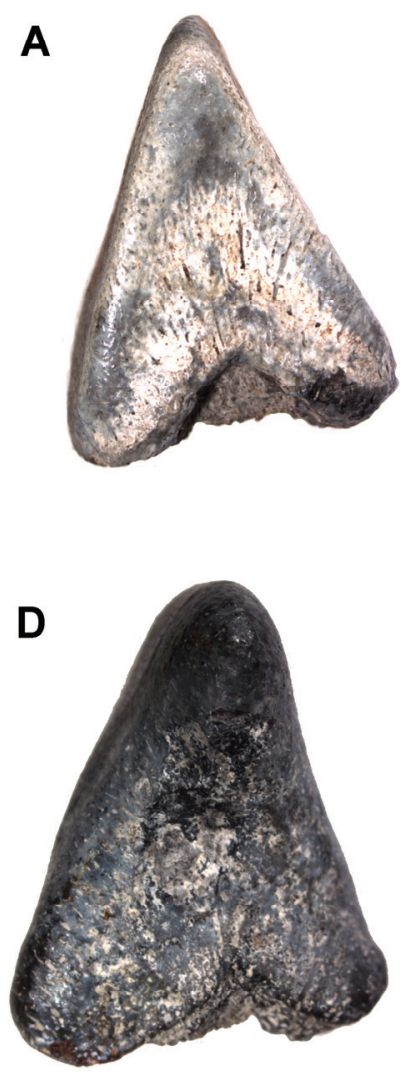

B

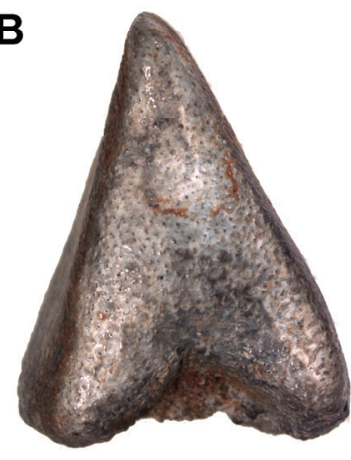

$\mathbf{E}$

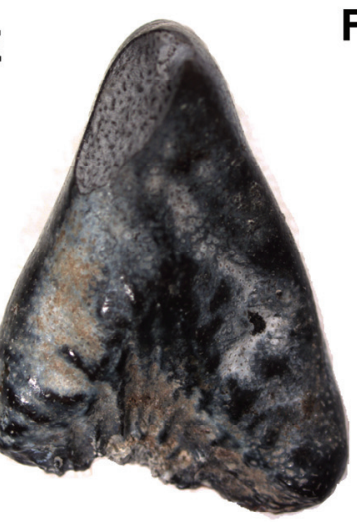

C

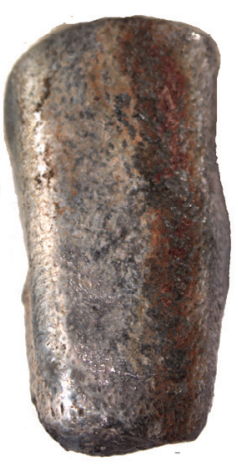

$\mathbf{F}$

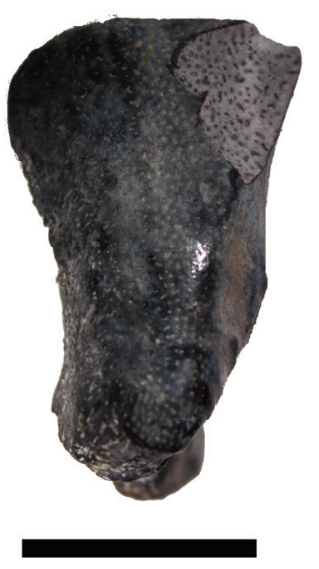

Figura 112 - Dentes de Chondrichthyes indeterminados Exemplar GP/2E-5929. A) vista labial. B) vista lingual. C) vista lateral. Exemplar GP/2E-6459. D) vista labial. E) vista lingual. F) vista lateral. Escala $8 \mathrm{~mm}$.

A coroa é muito alta, marcada, no topo, por uma crista longitudinal, voltada para trás. Esta crista é alongada e curva, obliqua no sentido anterior - posterior do dente, na face superior, com pequena inclinação para a face lingual em uma das extremidades. Percorre toda a coroa, ultrapassando seus limites para formar uma pequena protuberância pontiaguda na face lingual do dente. 
A face labial possui uma concavidade central expondo o sistema de dentina tubular que parte da base em direção ao topo da coroa (Fig. 112A). Na face lingual a dentina tubular é discreta e evidenciada por um sistema pontuado (Fig. 112B).

As faces laterais são aplainadas, retangulares muito similares entre si (Fig.112C). Podem ser diferenciadas pela inclinação da crista, voltada para uma das laterais. Estas faces formam um ângulo de $40^{\circ}$, com vértice na parte superior do dente.

É um exemplar grande comparado aos outros dentes de Chondrichthyes coletados, com 14,5mm de altura, $10,5 \mathrm{~mm}$ de largura da base e a crista mede $7,0 \mathrm{~mm}$ de comprimento.

O exemplar GP/2E-6459 (Fig 112 D - 112F) é semelhante, porém um pouco maior: $16,3 \mathrm{~mm}$ de altura, $13 \mathrm{~mm}$ de largura medida na base e a crista mede $10,0 \mathrm{~mm}$ de comprimento. Como no exemplar GP/2E-5929 tem forma de "A". Uma das laterais é menor que a outra, contudo esta diferença é mais acentuada em GP/2E-6459. O espécime é marcado principalmente pelo achatamento muito maior da base e concavidade mais acentuada do que em GP/2E-5929.

Discussão - Os dois dentes são os únicos a apresentar as características morfológicas descritas entre todos os encontrados na base da Formação Irati. A presença de uma crista longitudinal na parte superior terminando em uma protuberância pontiaguda é similar aos dentes sinfisianos de Itapyrodus punctatus (CHAHUD et al. 2010), contudo a sua disposição é diferente e destinada a outro tipo de alimentação.

$\mathrm{O}$ achatamento apenas da base e zona de articulação de GP/2E-6459 são conclusivos para que este dente seja de fase ontogenética diferente da de GP/2E-5929. Ambos deveriam pertencer a uma sequencia em espiral de substituição dentária semelhante a observada em elasmobrânquios, contudo seriam necessários outros dentes para melhor análise.

\subsection{Actinopterygii (Palaeonisciformes)}

Os Actinopterygii representam a classe dominante de peixes incluindo formas de água doce e marinhas. Os representantes são caracterizados por nadadeiras suportadas por "raios" ou lepidotríquias, esqueleto interno tipicamente calcificado e aberturas branquiais protegidas por um opérculo ósseo.

Os Palaeonisciformes (NELSON, 2006) formam um grupo parafilético de actinopterígeos do Paleozóico. Segundo RICHTER et al. (2004), são representativos de sete famílias, com parentesco duvidoso, de grande sucesso. O grupo continuou durante 
o Mesozóico com poucos representantes até o Cretáceo (FIGUEIREDO \& GALLO, 2006a; 2006b).

Praticamente todos os Palaeonisciformes apresentavam um padrão básico de desenvolvimento, com grandes bocas e olhos colocados na face anterior do crânio e escamas ganóides rígidas e primitivas com baixa diversidade e baixa variação morfológica. As nadadeiras aparentemente seguiam o mesmo padrão, tanto anal quanto dorsal, esta única de bases longas e a cauda heterocerca.

Os dentes consistem basicamente de uma fuste de formato cônico, com um capuz apical no ápice (Fig. 103). A superfície da fuste pode ser lisa ou ornamentada por costelas ou pequenos tubérculos. São constituídos, internamente, por ortodentina com uma camada de esmalte envolta (ganoína de colar). Em geral, o capuz apical é maciço e composto de um material resistente, acrodina (um enamelóide).

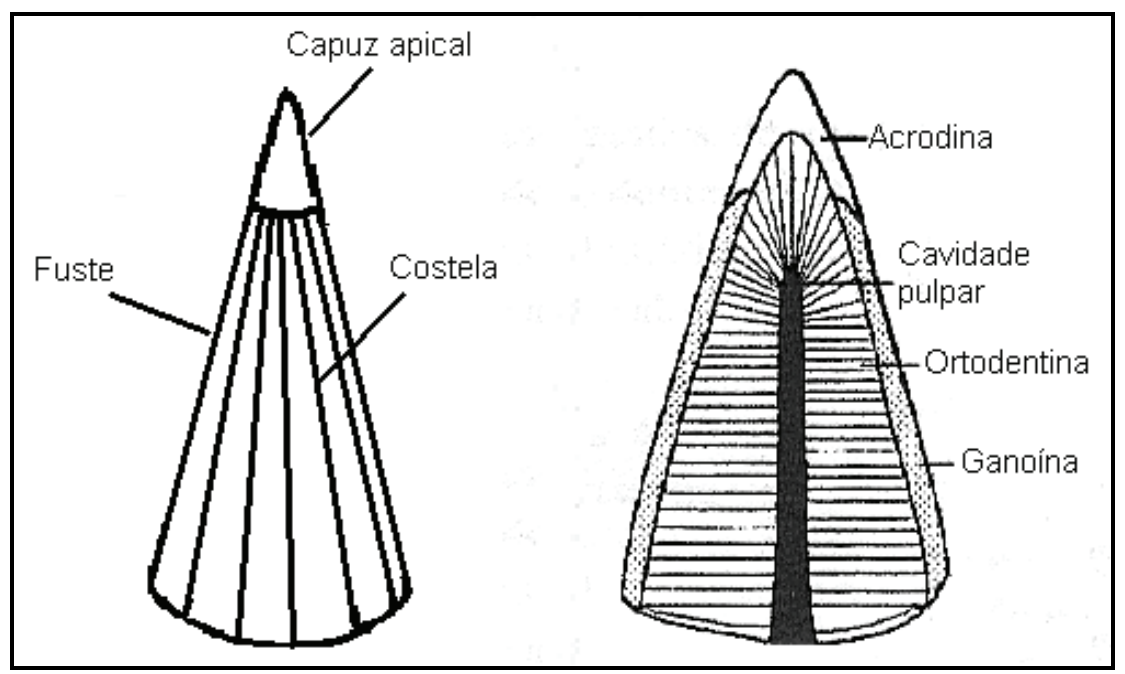

Figura 113 - Características gerais de um dente Palaeonisciformes (RICHTER et al. 2004).

As escamas (Fig. 114) nos Palaeonisciformes são do tipo ganóide, com formato romboédrico, constituição rígida e sistema articulatório “peg-and-socket”. Apresentam uma camada basal de osso lamelar celular, uma camada de dentina (ortodentina) e uma cobertura de esmalte de origem ectodérmica (ganoína).

Apesar da abundância de Palaeonisciformes, a identificação de espécies somente é possível em exemplares completos ou semicompletos, dada a baixa variação morfológica externa entre os diversos gêneros. RICHTER et al. (1985) sugeriram uma associação de diversas escamas a determinados gêneros neopaleozóicos. Os mais antigos peixes desse grupo, do Eopaleozóico, também foram diferenciados com base em escamas (LONG, 1993, 1995). 
WÜRDIG-MACIEL (1975) e RICHTER (1980) ressaltaram a grande variedade morfológica interna e externa de dos dentes Palaeonisciformes no Grupo Passa Dois do Rio Grande do Sul. Sabendo que não poderiam classificar os dentes em espécies, desenvolveram uma classificação artificial com finalidades bioestratigráficas, na qual foram levados em conta caracteres diagnósticos e básicos, como, por exemplo, a curvatura ou não dos dentes e a presença de costelas no capuz apical ou na fuste.

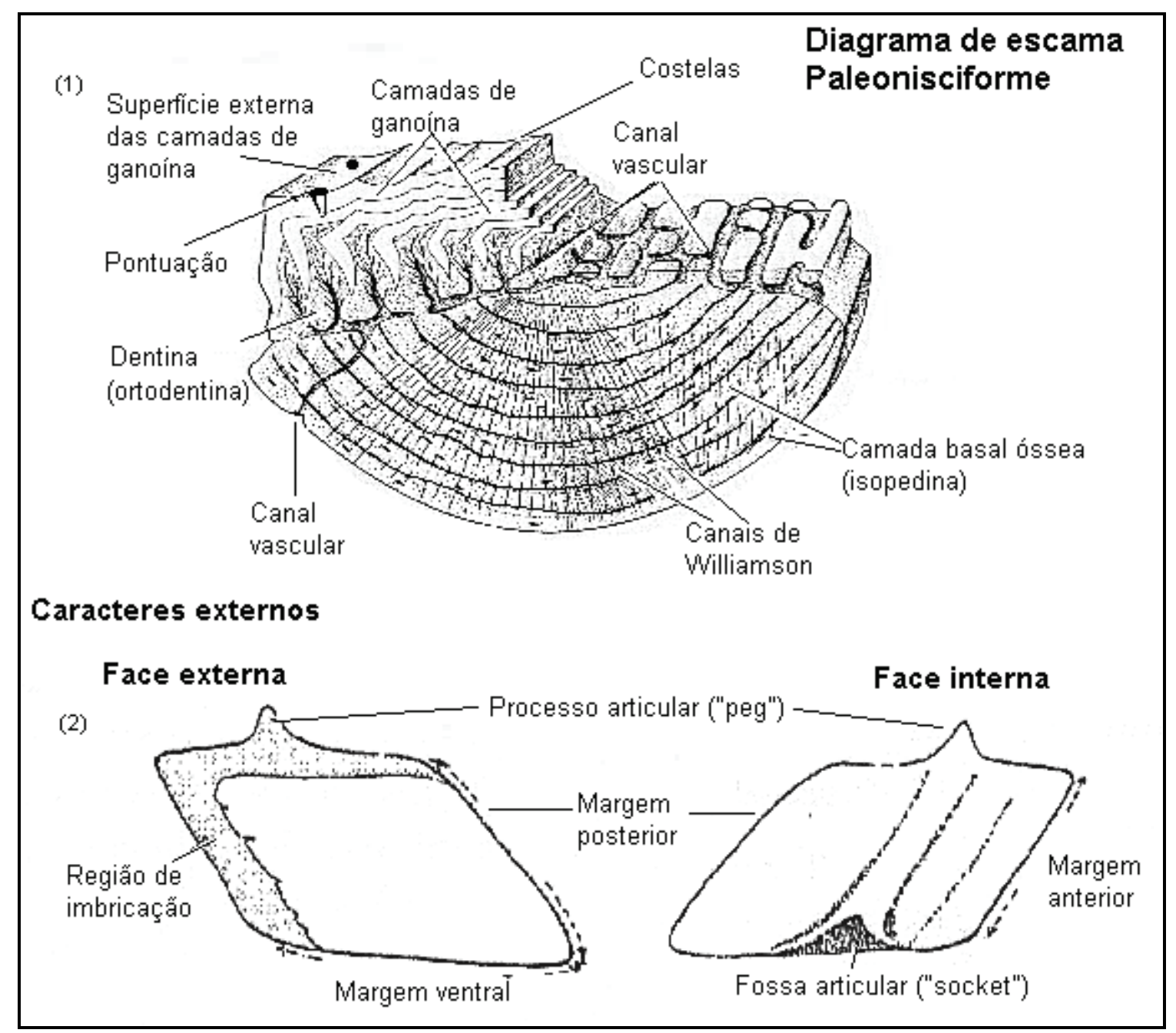

Figura 114 - Características gerais de um escama de Palaeonisciformes (1. MOY-THOMAS \& MILES, 1971; 2. RICHTER et al. 2004).

\subsubsection{Origem de Actinopterygii do Paleozóico brasileiro}

Os Actinopterygii têm origem antiga dentro do Paleozóico brasileiro. São encontrados fósseis de escamas e dentes nas bacias do Amazonas, Parnaíba e Paraná, nesta última encontrados exemplares completos. 
As mais antigas escamas no Brasil foram identificadas e descritas por JANVIER \& MELO $(1987,1988,1992)$ do Neodevoniano da Bacia do Amazonas. Estes fósseis estão associados com acantódios em depósitos deltaicos e marinhos.

RICHTER et al. (1999) descreveram dentes de Palaeonisciformes da Formação Itaituba, Neocarbonífero da Bacia do Amazonas, similares aos descritos por WÜRDIGMACIEL (1975) do Neopermiano do Estado do Rio Grande do Sul.

$\mathrm{Na}$ Bacia do Paraná conhece-se ictiólitos apenas nas unidades do Neocarbonífero e do Permiano. Dos trabalhos que visaram identificação de fósseis destacam-se BRYANT (1929) e BARCELLOS (1975) que observaram escamas e dentes de idade Permo-carbonífera no Grupo Itararé de São Paulo e Rio Grande do Sul, respectivamente.

A Formação Rio do Sul do Grupo Itararé de idade Eopermiano do Estado de Santa Catarina, é a unidade que apresentou os melhores exemplares, com espécimes completos da espécie Roslerichthys riomafrensis (HAMEL, 2005) e outras espécies inéditas.

\subsubsection{Actinopterygii encontrados no Paleozóico do Estado de São Paulo}

Os Palaeonisciformes são os fósseis mais comuns e os mais citados em trabalhos científicos. Um dos primeiros trabalhos foi de FLORENCE (1907), que observou escamas e dentes isolados da Formação Corumbataí.

Os mais antigos fósseis publicados de Palaeonisciformes no Estado de São Paulo foram descritas por BRYANT (1929). Constituem-se de escamas de Acrolepidae dispersas em um sedimento identificado como tilito do Neocarbonífero do Grupo Itararé. Os fósseis de BRYANT (1929) são os únicos no Brasil associados a tilitos e a um clima mais frio. Esse dado é significativo, pois antes da glaciação, que afetou a Bacia do Paraná no Carbonífero, não foi comprovada a presença de peixes no Devoniano na bacia.

BARBOSA \& ALMEIDA (1949a) citaram Elonichthys sp. no Grupo Itararé da região de Monte Mor. Na mesma unidade LIMA et al. (1976) destacaram a presença de escamas em concreções provenientes da base do Subgrupo Itararé associadas a foraminíferos aglutinantes, grãos de pólen e braquiópodes inarticulados, nas proximidades de Araçoiaba da Serra.

A Formação Tatuí contém fósseis de Palaeonisciformes em grande quantidade, porém os estudos são raros. SILVA SANTOS (1991) descreveu restos parcialmente 
articulado de um possível Platysomoidea em um folhelho cinza da Formação Tatuí na estrada Piracicaba - Americana. O fóssil foi encontrado em associação com crustáceos descritos por MEZZALIRA \& MARTINS NETO (1992).

RAGONHA (1978) e MOCHIZUKI (2001) chamaram atenção para a abundância de escamas e dentes de Palaeonisciformes nas formações Tatuí e Irati, mas não descreveram ou identificaram este material.

Na base da Formação Irati MARASCO et al. (1993), CHAHUD \& FAIRCHILD (2003a) e CHAHUD (2003b) registraram escamas, coprólitos, dentes e partes ósseas dispersas nas regiões de Rio Claro e Itapetininga, sempre associados a Tetrapoda, Sarcopterygii e Chondrichthyes.

O Membro Assistência é muito pobre em restos de peixes no Estado de São Paulo. RAGONHA (1985) descreveu o melhor espécime da formação, uma impressão de peixe em folhelho negro do Membro Assistência de uma pedreira no município de Rio Claro. O exemplar apresenta claras afinidades com a família Acrolepidae; ele sugeriu, ainda, mas com restrições, que os Palaeonisciformes deveriam ter habitado água doce durante o Permiano e teriam invadido os mares no Triássico. Desta mesma formação, CAMPANHA (1985) citou sem descrições ou ilustrações em testemunho de sondagem proveniente de um poço na região de Marília, partes ósseas, dentes e escamas de Palaeonisciformes associadas a braquiópodes lingulídeos e foraminíferos aglutinantes. CHAHUD \& FAIRCHILD (2003a) descreveram escamas e dentes de Palaeonisciformes no folhelho cinza do Membro Taquaral na região de Rio Claro.

Escamas e dentes de peixe ocorrem em toda a extensão da Formação Corumbataí (MARANHÃO, 1995), mas apenas dois trabalhos foram realizados com fósseis completos de Palaeonisciformes da Formação Corumbataí. DUNKLE \& SCHAEFFER (1956) descreveram um espécime completo da familia Acrolepidae, designado Tholonotus braziliensis, proveniente de uma pedreira no município de Conchas. O peixe é fusiforme com escamas romboédricas, um crânio que corresponde a um quarto do comprimento total do corpo, grandes olhos e cauda heterocerca. Os ossos do crânio eram rígidos e recobertos por várias camadas de ganoína, as escamas estão articuladas e nem sempre são lisas.

FIGUEIREDO \& CARVALHO (2004) publicaram o segundo peixe completo da Formação Corumbataí, que teria sido coletado na cidade de Angatuba por Josué Camargo Mendes em 1964, Angatubichthys mendesi. Trata-se de um peixe fusiforme, com região cefálica curta e alta, e escamas romboédricas lisas. 


\subsubsection{Palaeonisciformes encontrados na Base do Membro Taquaral}

Os restos de Palaeonisciformes são os mais abundantes em toda a coleção de fósseis estudados. O material coletado consiste de escamas, dentes isolados e partes ósseas.

Superclasse OSTEICHTHYES Huxley, 1880
Classe ACTINOPTERYGII Cope, 1887
Ordem "PALAEONISCIFORMES" (parafilético)
Família incertae sedis
Figs. $115-128$

Localização - Afloramentos 1 - 5 e 12 entre os municípios de Rio Claro e Ipeuna

\section{Características gerais dos dentes encontrados}

Os dentes de Palaeonisciformes são bem característicos e variam muito na forma e tamanho. Externamente, apresentam poucas características, como capuz apical e fuste de formato cônico. A fuste pode ser costelada, lisa ou coberta por tubérculos.

Características internas observadas em seção transversal de dentes incluem uma cavidade pulpar geralmente circular e mais clara, uma espessa camada de ortodentina e uma fina camada externa, conhecida como ganoína de colar (Fig. 115D). Em seção longitudinal, a cavidade pulpar, ocupa o espaço central que vai da base ao topo, porém não ocupa o espaço interno do capuz apical (Fig. 115B).

O capuz apical é maciço, sem ornamentação, e se destaca no dente pela coloração geralmente mais clara que a fuste.

\section{Características gerais das escamas encontradas}

As escamas de Palaeonisciformes constituem a maior parte de todo o material coletado e são encontradas de todos os modos de preservação e em todos os afloramentos. As bem preservadas são romboédricas e losangulares em vista superior. Internamente, diversas camadas de isopedina são distribuídas umas sobre as outras concordantemente, acompanhando o formato original da escama tanto transversalmente quanto longitudinalmente (Fig.115A e 115C).

$\mathrm{Na}$ face superior (coroa), camadas de ganoína podem ocorrer como costelas ou como uma capa lisa, com poucas ondulações e pontuações (poros). Vários exemplares exibem estruturas ramificadas de ortodentina entre as camadas de ganoína. Em geral as escamas encontradas possuem margens lisas, ou desgastadas, sem a articulação preservada. 
A
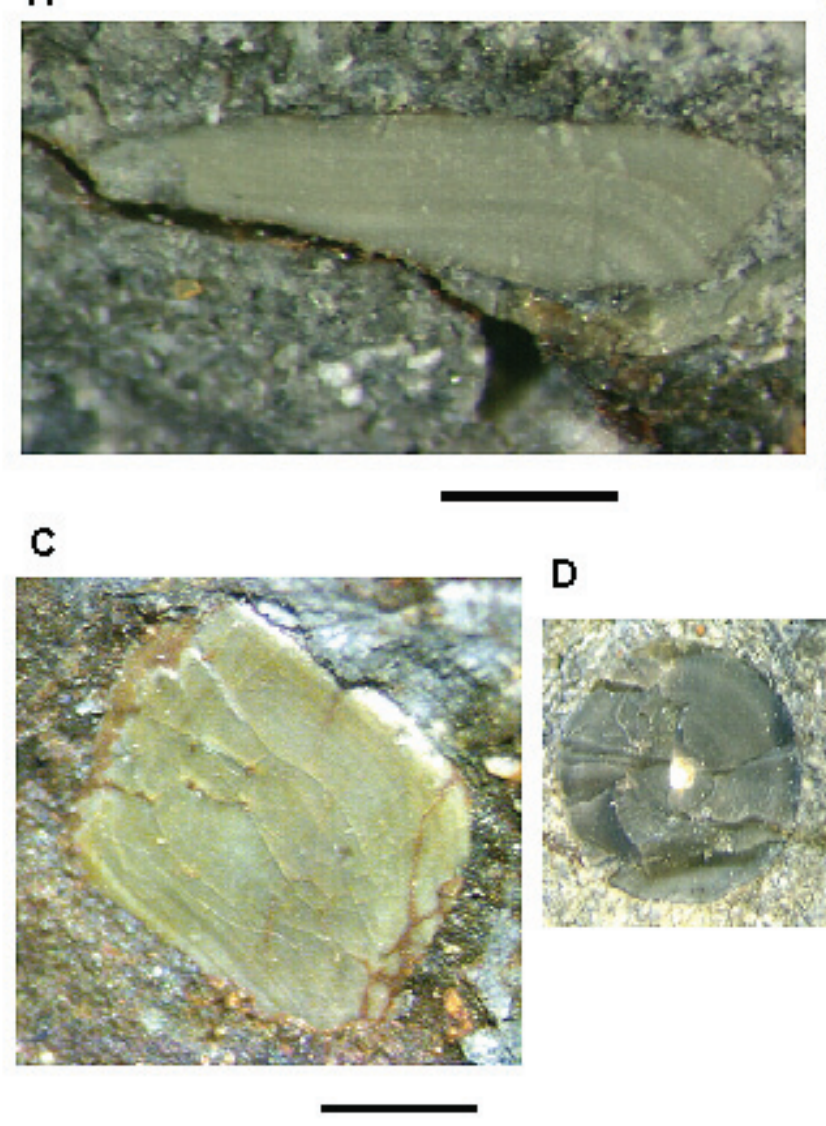

B

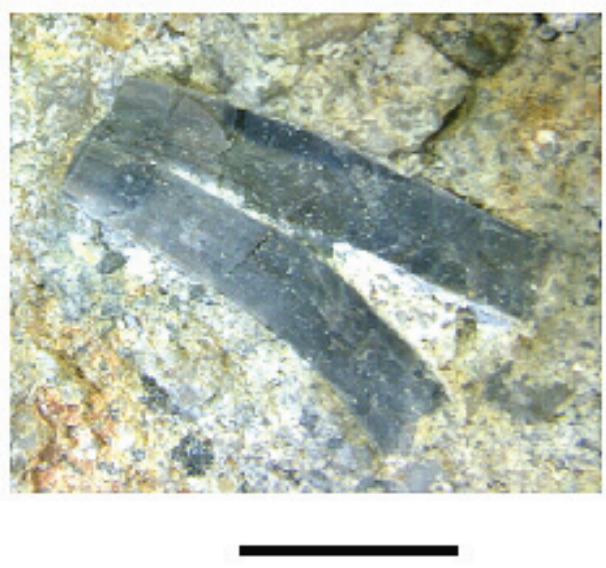

D

Figura 115 - Características internas de dentes e escamas de Palaeonisciformes. A) corte longitudinal de escama (GP/2E-5939). B) corte longitudinal de dente (GP/2E-5936). C) corte oblíquo (quase transversal) de escama (GP/2E-5940). D) cortes transversais de dentes (GP/2E-5937 e GP/2E-5938). Escalas $1 \mathrm{~mm}$.

\section{Descrição de espécimes}

\section{Ictiodontes de fuste lisa}

Material - GP/2E-5941 (Fig. 116A), GP/2E-5942 (Fig. 116B), GP/2E-5943 (Fig. 116C). Dentes.

Descrição - Dente alongado, cônico, com fuste lisa, sem ornamentação e de coloração mais clara (Fig. 116 A, 116B e 116C) nos exemplares bem preservados. A fuste normalmente não é robusta e em alguns exemplares a superfície está desgastada. É o menor dos tipos de dentes estudados, variando em comprimento entre 0,5 e 1,0 milímetro. Os dentes mais comuns são retos, porém existem formas curvas, raras e apenas vistas em arenito conglomerático, nos afloramentos 1 a 3. 

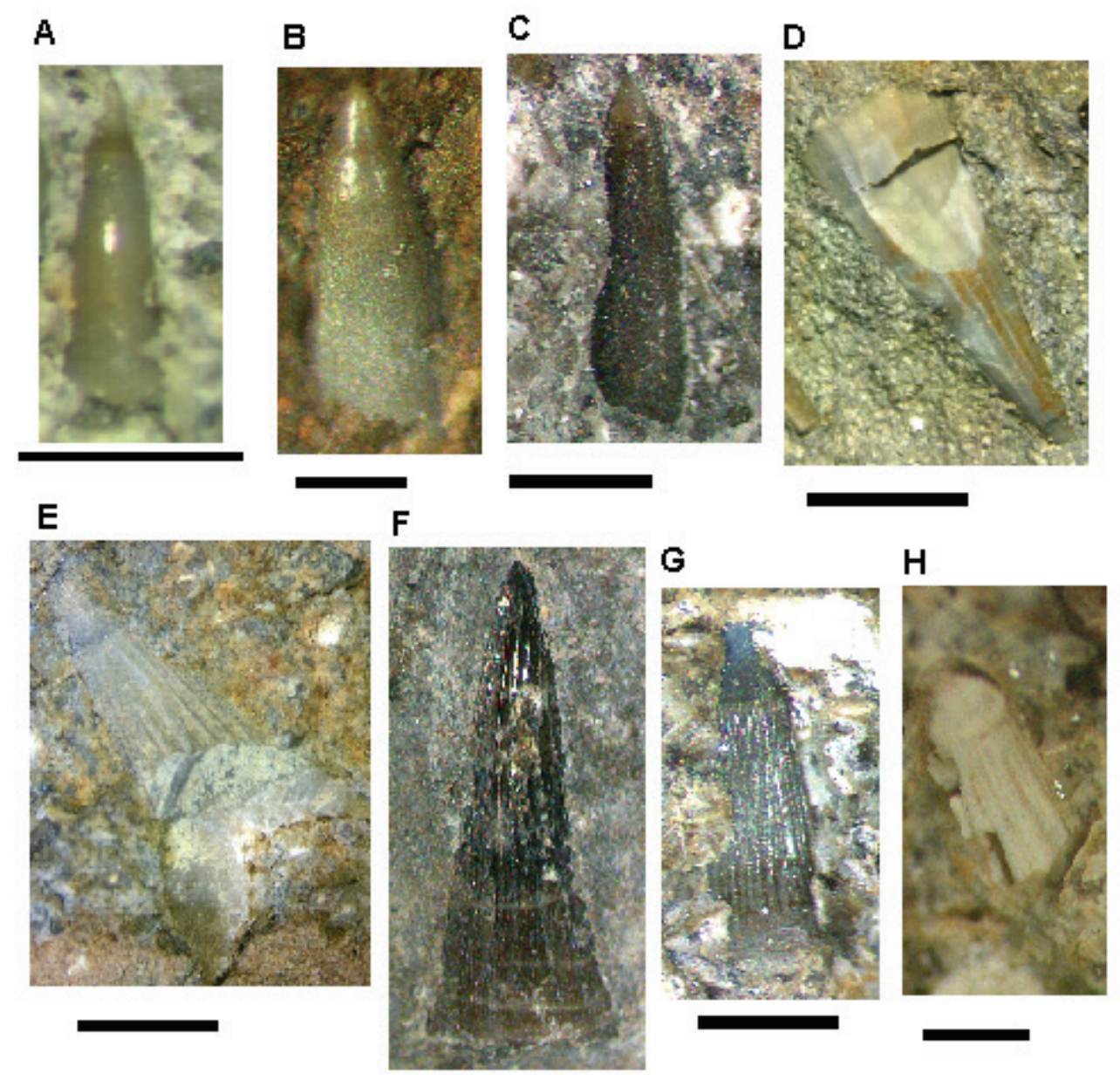

Figura 116 - Dentes de Palaeonisciformes. A-C) dentes retos lisos dos afloramento 1, 3 e 4, respectivamente (GP/2E-5941, GP/2E-5942, GP/2E-5943). D-H) dentes retos costelados dos afloramentos 1 (GP/2E-5944, GP/2E-5945) e 3-5 (GP/2E-5946, GP/2E-5935B, GP/2E-5947), em seqüência. Escala $1 \mathrm{~mm}$.

\section{Ictiodontes retos de fuste costelada}

Material - GP/2E-5935 (Fig. 116D), GP/2E-5944 (Fig. 116E), GP/2E-5945 (Fig. 116F), GP/2E-5946 (Fig. 116G), GP/2E-5947 (Fig. 116H) e GP/2E-5948 (Fig. 117A). Dentes.

Descrição - Os dentes são alongados, cônicos e com a fuste ornamentada por costelas (Fig. 116D, E, F, G e H e Fig. 117A). O capuz apical, quando presente, é liso e maciço. As costelas normalmente são homogêneas da base até o capuz apical, porém em um exemplar, GP/2E-5948 do Afloramento 1 (Fig. 117A), as costelas são mais proeminentes na base e vão se afinando, tornando-se menos nítidas próximo ao capuz apical. A fuste em geral é alongada, formando um cone de ângulo agudo, em alguns exemplares é robusta. São dentes pequenos, com comprimento inferior a dois 
milímetros. Este morfotipo foi um dos poucos fósseis que puderam ser identificados no Afloramento 4, apesar de quebrados.

A

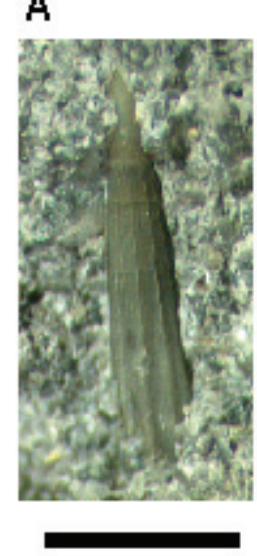

D

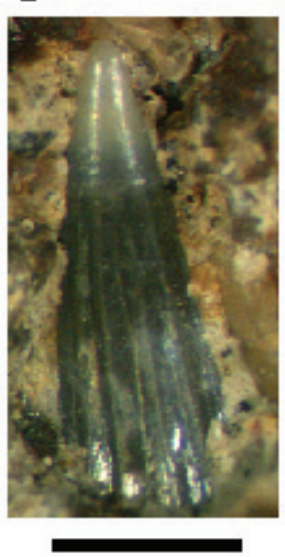

B

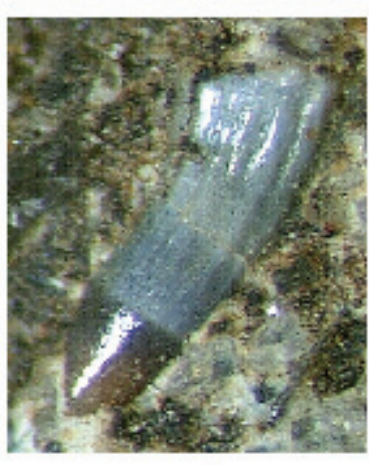

E
C
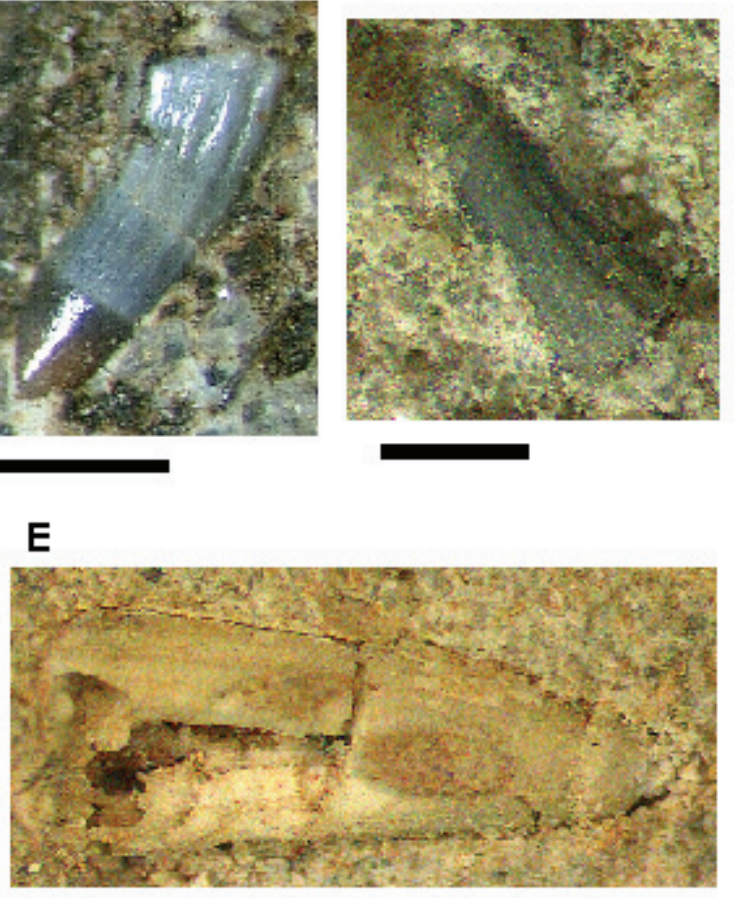

Figura 117 - Dentes de Palaeonisciformes. A) dente reto costelado do afloramento 1(GP/2E-5948). B D) dentes curvos costelados dos afloramentos 1 (GP/2E-5949, GP/2E-5950, GP/2E-5951) e 5 E) (GP/2E5952). Escalas $1 \mathrm{~mm}$.

\section{Ictiodontes curvos ou sigmoidais de fuste costelada}

Material - GP/2E-5949 (Figs. 117B), GP/2E-5950 (Figs. 117C), GP/2E-5951

(Figs. 117D) e GP/2E-5952 (Figs. 117E). Dentes.

Descrição - De todos os dentes de Palaeonisciformes, esta é a variedade mais comum, sendo abundante em todos os afloramentos. Os dentes são alongados e curvos ou com forma sigmóide. O caráter sigmóide só se revela na base do dente e apenas em indivíduos maiores e bem preservados. A fuste normalmente não é robsuta é ornamentada por costelas (Figs. 117B, C, D e E). Na maioria dos dentes o diâmetro da base equivale a 1/5 do comprimento do dente. O capuz apical é variado em tamanho, liso, alongado e mais claro que a fuste. O comprimento varia entre 2 e $30 \mathrm{~mm}$. 
Discussão - A maioria dos dentes Palaeonisciformes da base da Formação Irati é idêntica aos estudados por WÜRDIG - MACIEL, (1975) e RICHTER et al. (1985) na Formação Teresina, Grupo Passa Dois do Rio Grande do Sul. Nos trabalhos citados acima os dentes foram separados em 10 categorias morfológicas, com base na ornamentação e curvatura, I-1 a I-10 (RICHTER et al. 1985). A classificação (Fig. 118) infelizmente só tem valor em unidades de deposição lenta, pois a análise é prejudicada em depósitos de alta energia com dentes quebrados. Por exemplo, a fragmentação de dentes sigmoidais poderia gerar fragmentos que seriam identificados erroneamente como apenas curvos.

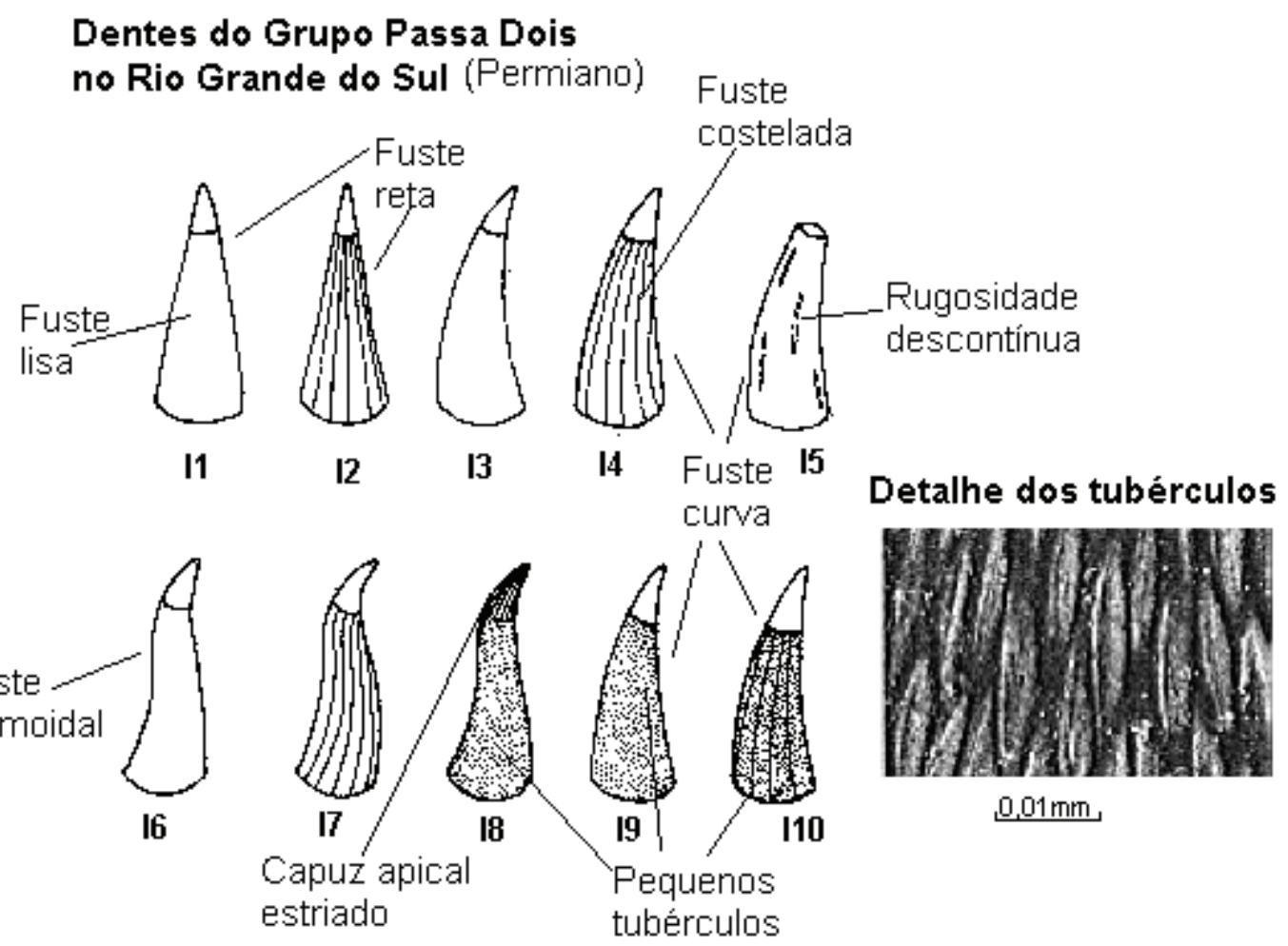

Figura 118 - Características de dentes de Palaeonisciformes encontrados na Formação Teresina do Rio Grande do Sul (RICHTER, 1980 e RICHTER et al. 1985).

No presente estudo, ao contrário dos exemplares da região Sul que praticamente não exibem indícios de abrasão, os fósseis da base da Formação Irati sofreram desgaste superficial e quebras, o que dificulta a diferenciação, especialmente, entre dentes sigmóides e curvos (I-3 e I-4 são indistinguíveis de I-6 e I-7, respectivamente) e também a constatação de micro-tubérculos na fuste (I-3 e I-4 semelhantes a I-9 e I-10), limitando a comparação (Fig. 118). 
Apesar do diferente grau de preservação, apenas dois tipos de ictiodontes descritos por RICHTER et al (1985), I-5 e I-8, não foram observados nos da Formação Irati. Por outro lado, dois tipos foram encontrados no presente trabalho diferentes dos encontrados no Neopermiano da região Sul, os grandes dentes curvos e costelados, com mais de um centímetro, e um dente costelado apenas na base.

Os dentes menores que $1 \mathrm{~mm}$ são semelhantes aos exemplares descritos no Neopermiano da região Sul e em outras partes da Bacia do Paraná (como os da Formação Corumbataí, MARANHÃO, 1995), porém os de tamanho centimétrico (Fig. 119) se assemelham ao dente descrito na fácies Budó (Grupo Itararé) do Rio Grande do Sul (BARCELLOS, 1975) e a dentes da Formação Pedra do Fogo (COX \& HUTCHINSON, 1991). Estes grandes dentes aparentemente pertenceram aos maiores Palaeonisciformes que habitaram a região.

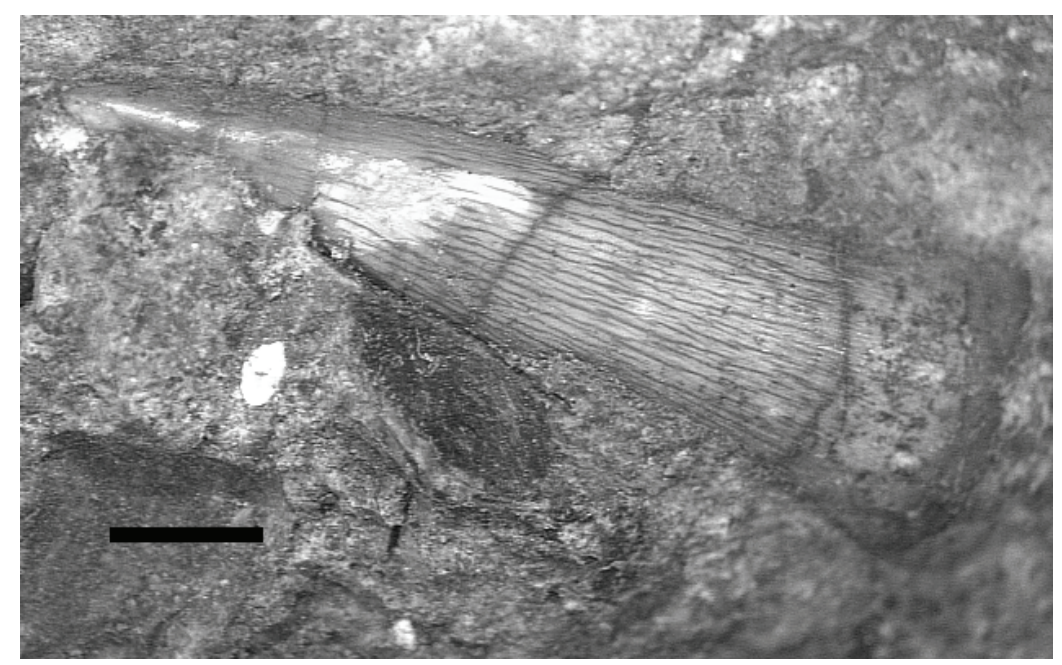

Figura 119 - Ictiodonte Palaeonisciformes curvo de grande porte. GP/2E-5973. Barra de escala 2mm.

\section{Formas incomuns}

Algumas formas de Palaeonisciformes possuem características morfológicas externas variadas no formato da fuste, inclinação, espessura de costelas e robustez do dente. Algumas dessas formas serão expostas neste subitem.

O exemplar GP/2E-6412 (Fig. 120) exibe a região inferior da fuste com uma largura muito maior que o resto do dente. O espécime é curvo apenas em sua parte inferior, próximo da inserção com a mandíbula. Apresenta espessas costelas que se afinam próximo do ápice. $\mathrm{O}$ capuz apical com menos de $0,5 \mathrm{~mm}$ é pequeno e liso. 


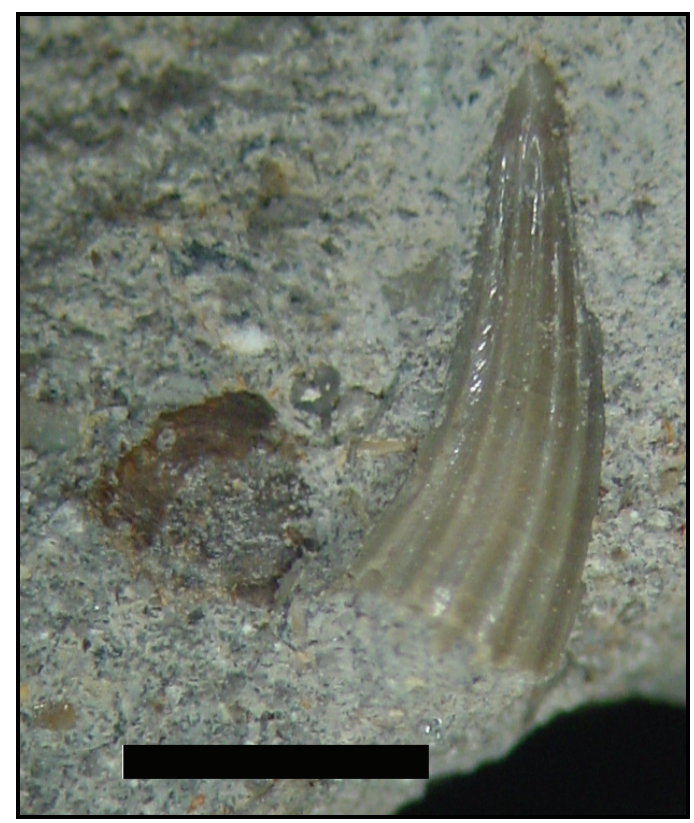

Figura 120 - Dente de Palaeonisciformes curvo de base espessa GP/2E-6412. Escala 2mm.

Dentes muito finos e alongados são mais raros. Foram observados apenas dois exemplares. O exemplar GP/2E-6409 (Fig. 121B) é o maior observando-se a ausência de costelas, disposição reta e com capuz apical liso, apesar de parte da superfície estar desgastada. O comprimento total deste exemplar é de 3,5mm.

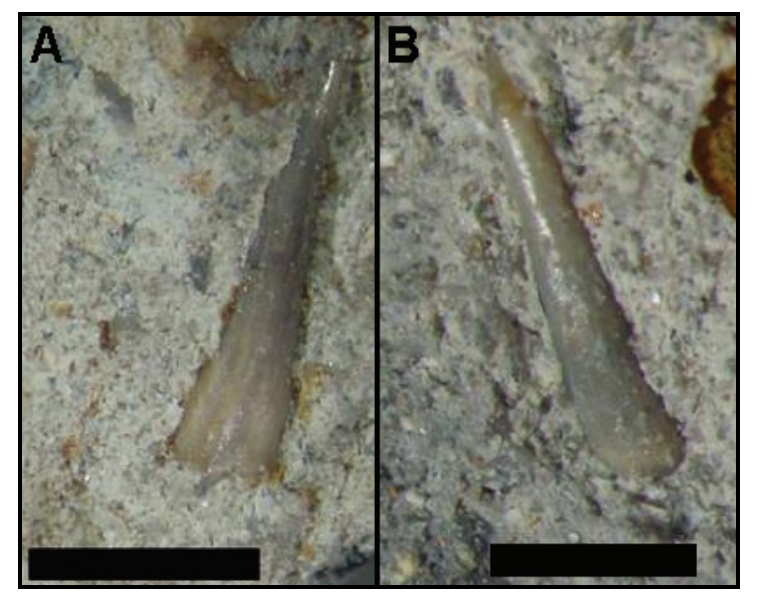

Figura 121 - Dentes retos muito alongados A) GP/2E-6450, escala 2mm; B) GP/2E-6409, escala 1mm.

O exemplar GP/2E-6450 (Fig. 121A) é um espécime com pouco mais de $2 \mathrm{~mm}$ de comprimento e possuindo as mesmas características do exemplar GP/2E-6409.

Além dos citados exemplares delgados, ocorrem dentes robustos, normalmente apresentando abrasão e, por isto, nem sempre são indicadores de variedades morfológicas válidas. 
Exemplares de porte centimétrico, curvos, de costelas muito finas, são comuns, em exemplares menores, estas costelas apresentam-se como linhas finas por toda a superfície.

O exemplar GP/2E-6389 (Fig. 122) de, aproximadamente, $2 \mathrm{~mm}$ de comprimento é curvo, com finas linhas em sua superfície. Na fuste também podem ser observadas linhas transversais ao dente.

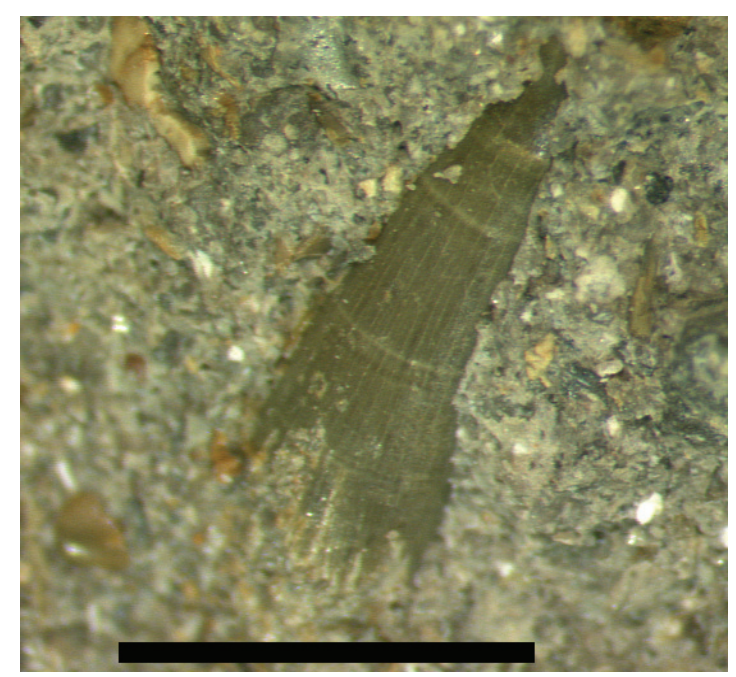

Figura 122 - Dente de Palaeonisciformes (GP/2E-6389) com finas linhas na superficie da cúspide. Escala $2 \mathrm{~mm}$.

\section{Descrição de escamas}

\section{Escamas lisas de superfície pontuada}

Material - GP/2E-5953, GP/2E-5954, GP/2E-5955, GP/2E-5956, GP/2E-5957, GP/2E-5958. Escamas (Fig.123A-F). Afloramentos 1-4. base do Membro Taquaral da Formação Irati

Descrição - As escamas pontuadas nem sempre estão inteiras, mas são facilmente reconhecidas. Esta variedade é caracterizada pela superfície externa de ganoína lisa ou levemente ondulada, com alguns sulcos que seguem o contorno original da escama. Ocorrem poros (pontos), que representam a abertura de canais vasculares formados na camada de dentina cortando as camadas de ganoína (Fig. 123D e 123E). Possuem forma rômbica, contorno liso sem o processo articulatório "peg and socket", porém com parte da zona de imbricação preservada. $\mathrm{O}$ tamanho varia muito, tanto em comprimento quanto em largura e espessura. 


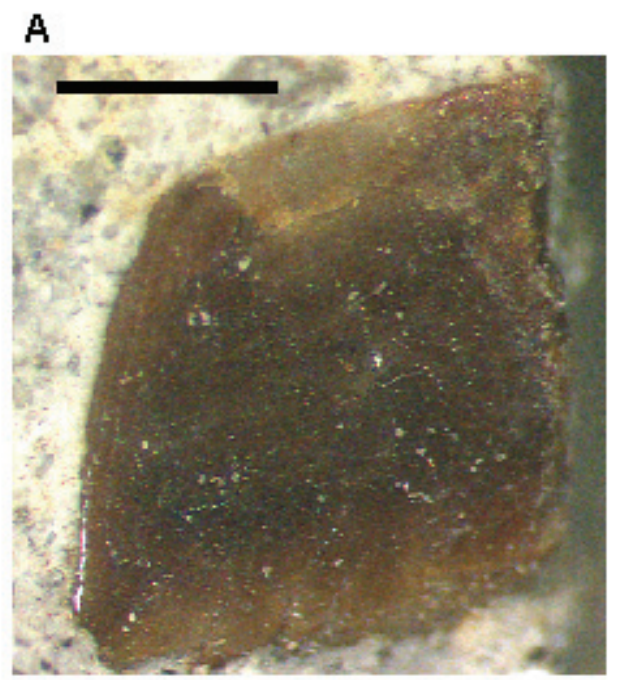

$\mathrm{C}$

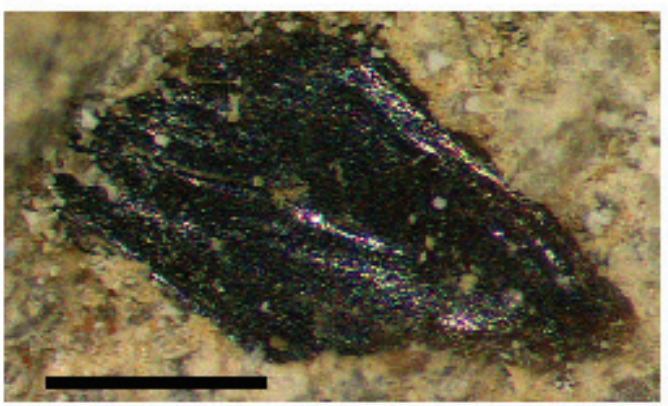

E

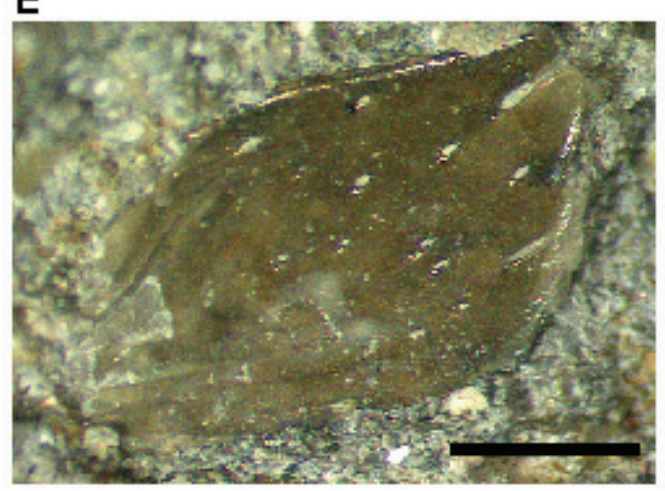

B

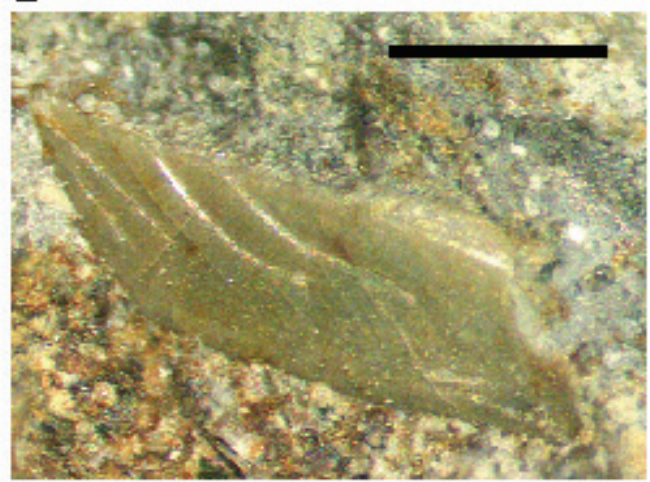

D

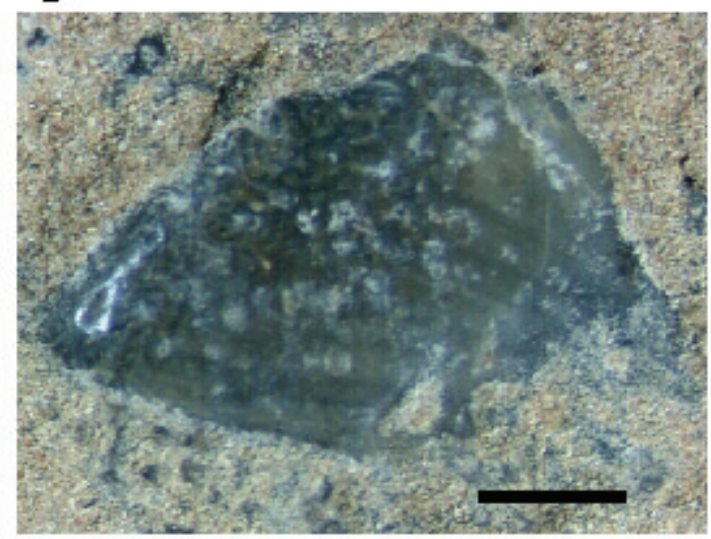

$\mathbf{F}$

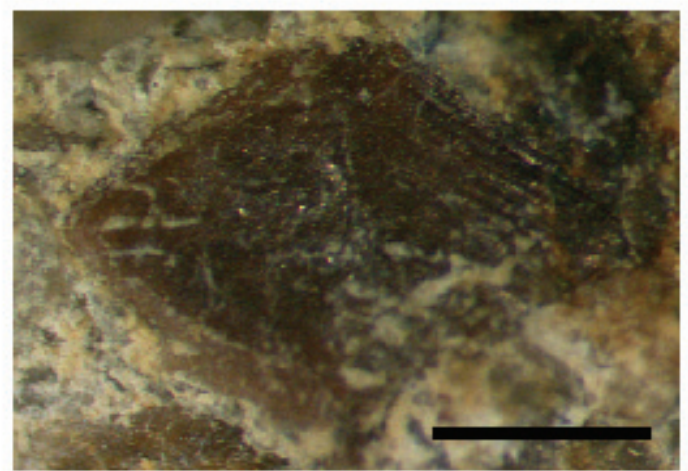

Figura 123 - Escamas lisas de Palaeonisciformes de superfície pontuada, encontradas nos afloramentos 1 e 3. GP/2E-5953, GP/2E-5954, GP/2E-5955, GP/2E-5956, GP/2E-5957, GP/2E-5958. Escala $1 \mathrm{~mm}$.

\section{Escama costelada}

Material - GP/2E-3757, GP/2E-3758, GP/2E-3759, GP/2E-3760, GP/2E-5959, GP/2E-5960, GP/2E-5961, GP/2E-5962, GP/2E-5963 e GP/2E-5964. Escamas isoladas (Figs. 124 e 125). 
A

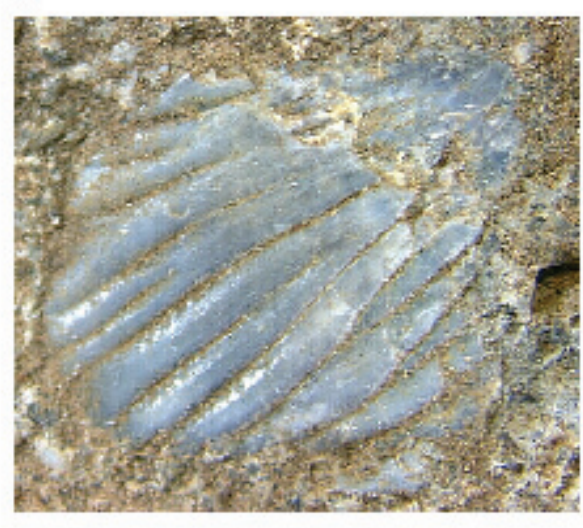

C

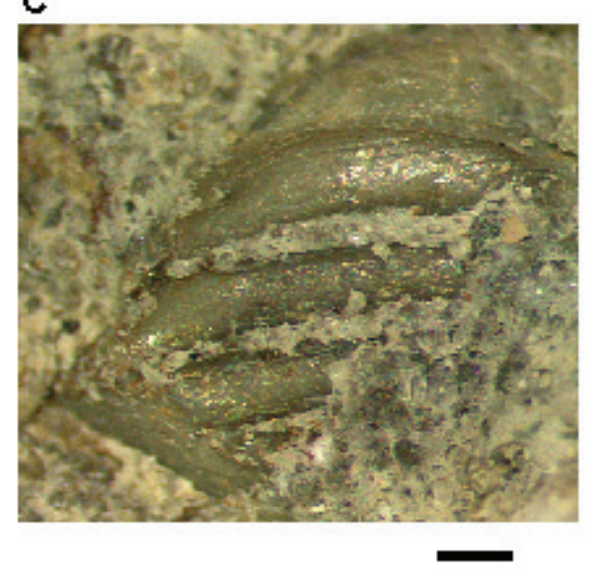

B

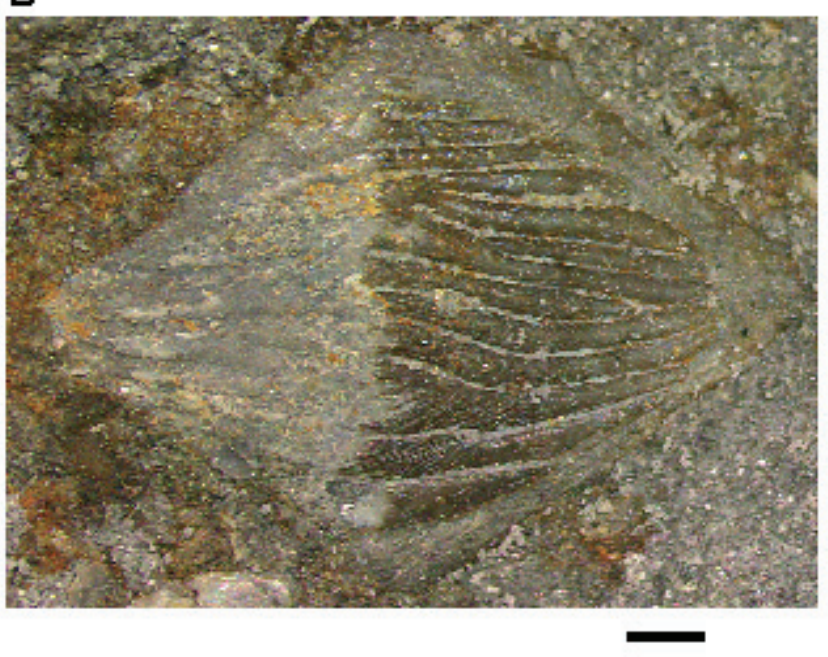

D

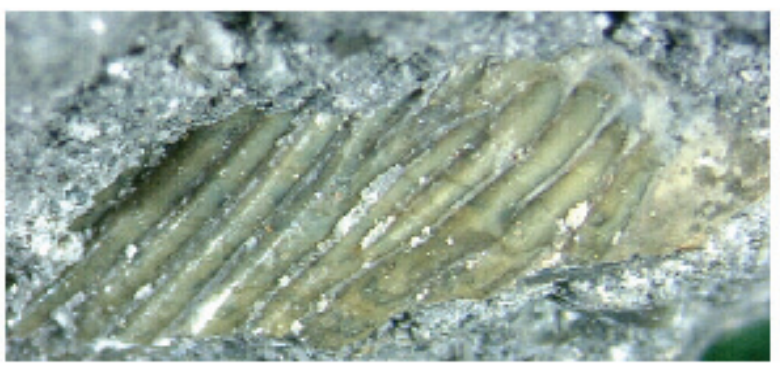

Figura 124 - Escamas costeladas de Palaeonisciformes do Afloramento 1. GP/2E-5961, GP/2E-5962, GP/2E-5963, GP/2E-5964. Escala $1 \mathrm{~mm}$.

Descrição - As escamas costeladas são as mais facilmente reconhecidas e também as mais abundantes. São caracterizadas pela superfície externa de ganoína com forma de diversas costelas longitudinais subparalelas a paralelas, que em alguns exemplares são sobrepostas.

As margens normalmente são lisas, porém em muitos exemplares ocorre um aspecto serrilhado na borda da escama (Fig. 124A), por causa da camada de ganoína que ultrapassa o limite da base articulatória (Fig. 124A, 124C e 124D). Em exemplares não serrilhados as costelas posicionam-se na parte central da escama

A morfologia da região de imbricação de todas as escamas deste grupo é pouco conhecida por causa do desgaste da maioria das escamas, mas é possível observar boa parte da margem correspondente da zona de imbricação, em exemplares maiores (Figs. $125 \mathrm{~A}-125 \mathrm{~F})$. É caracterizada por faces lisas e extremidades que podem ser arredondadas ou angulosas. $\mathrm{O}$ tamanho varia de 0,5 -15 $\mathrm{mm}$ de comprimento. 

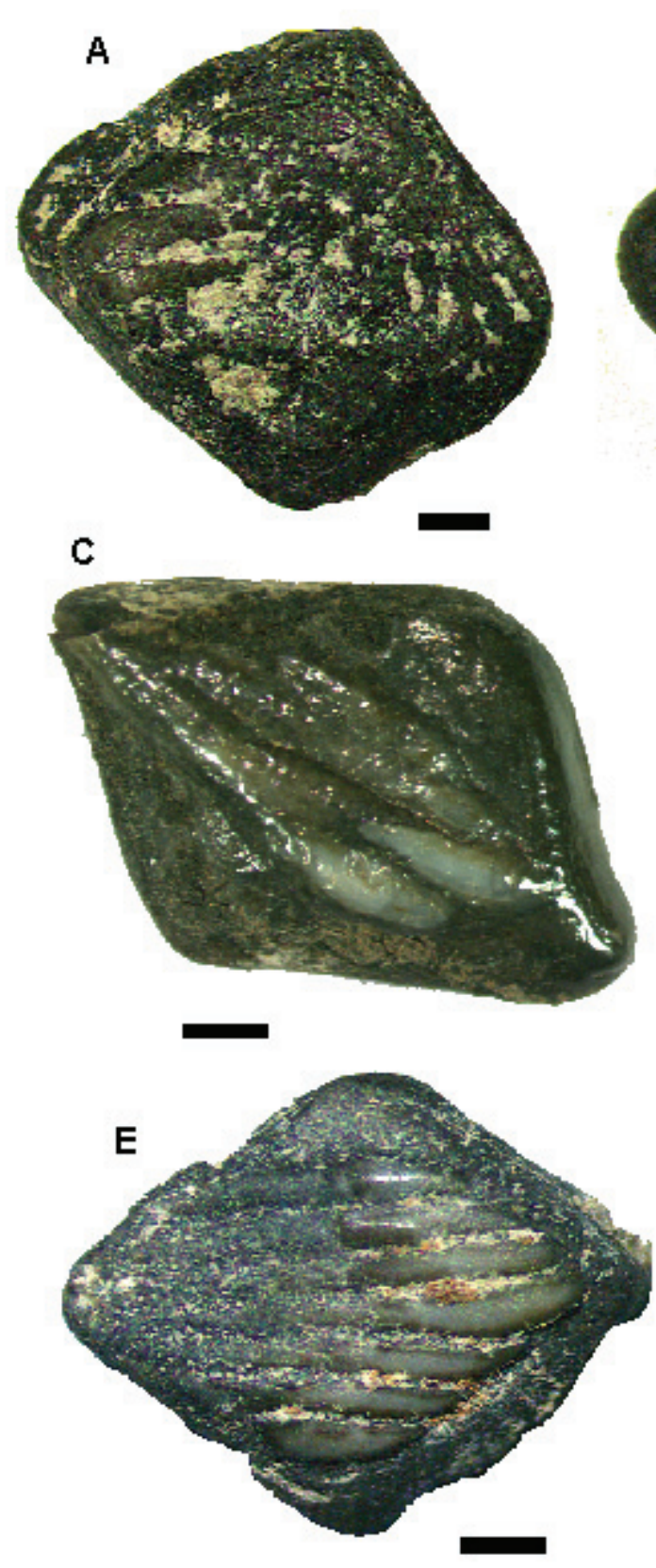
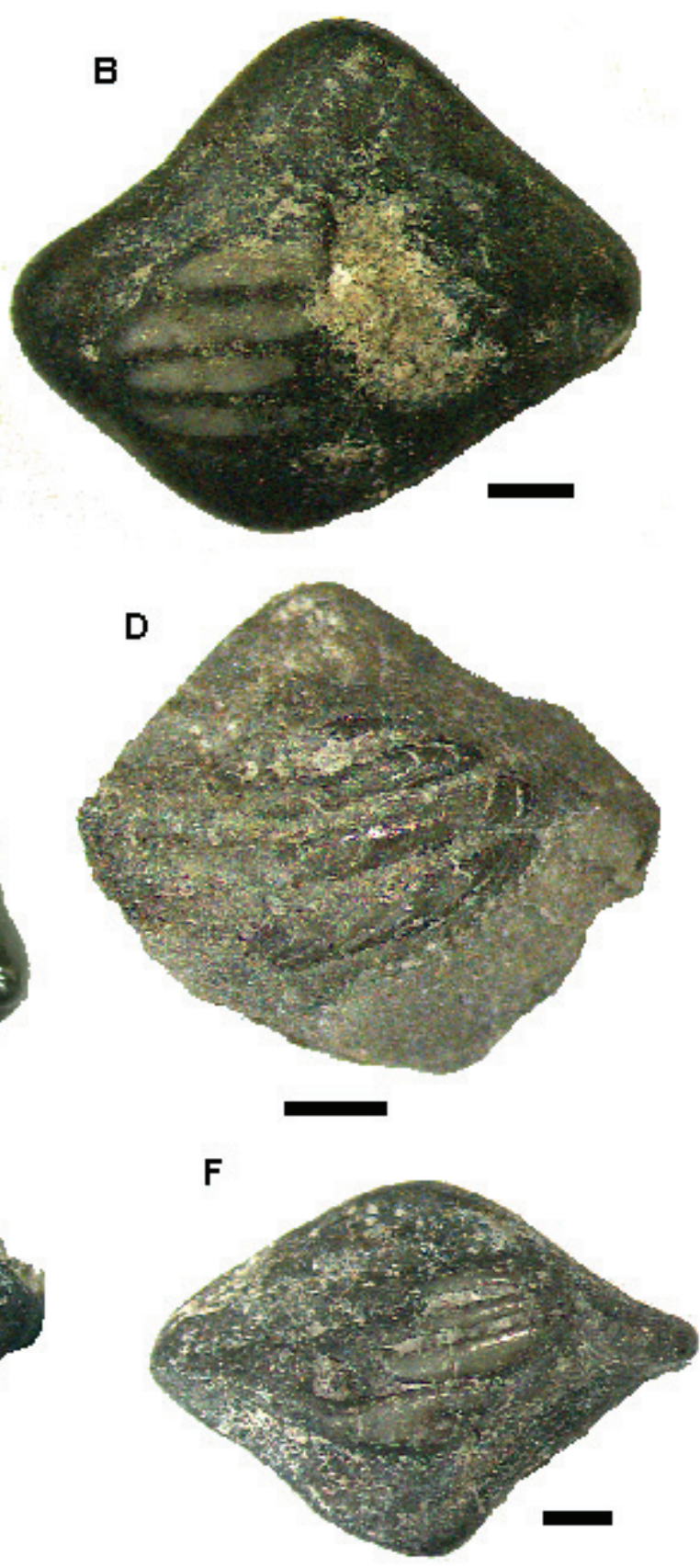

Figura 125 - Escamas costeladas de grande porte provenientes da matriz arenosa do Afloramento 1. GP/2E-3757, GP/2E-3758, GP/2E-3759, GP/2E-3760, GP/2E-5959, GP/2E-5960. Escala 2mm.

Discussão - RICHTER et al. (1985) foram as primeiras a descrever o formato geral de escamas encontradas na Bacia do Paraná no Rio Grande do Sul, identificando cinco tipos (P-1 a P - 5) (Fig. 126), correlacionando-as com reservas aos gêneros Acrolepis e Elonichthys. Como muitas escamas da base arenosa do Membro Taquaral estão desgastadas ou quebradas, elas foram classificadas em dois tipos bem diferenciados (escamas lisas com a superfície pontuada e escamas costeladas). 


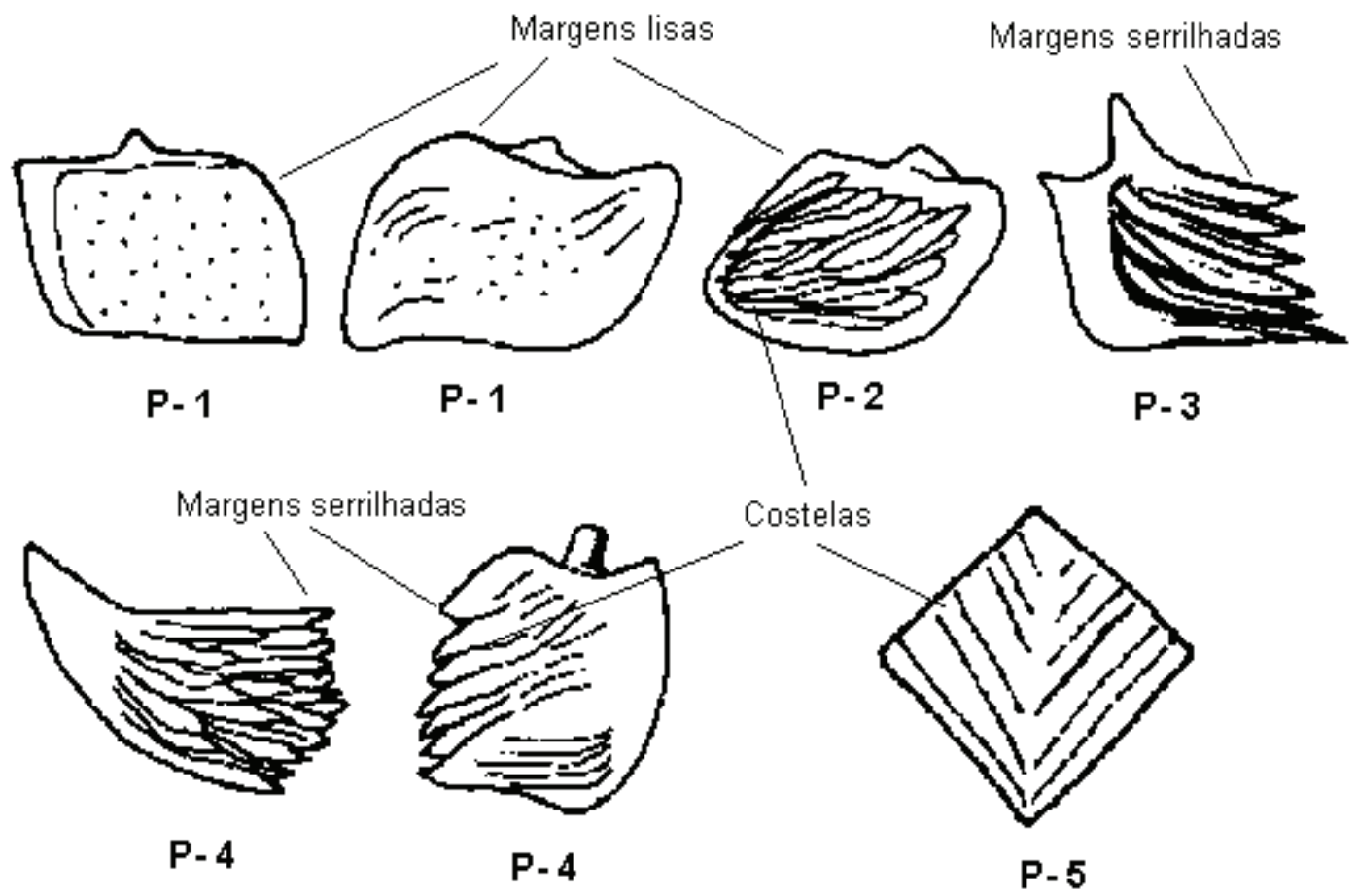

Figura 126 - Morfotipos de escamas encontrados na Bacia do Paraná, segundo RICHTER, et al. (1985).

A partir da classificação de RICHTER et al., (1985), as escamas lisas de superfície pontuada podem ser colocando-as como do tipo P - 1, enquanto as escamas costeladas podem ser associadas às do tipo $\mathrm{P}-2, \mathrm{P}-3, \mathrm{P}-4$ e $\mathrm{P}-5$.

As escamas estudadas possuem características externas muito semelhantes ao material mais antigo do Neocarbonífero do Grupo Itararé (BRYANT, 1929; BARCELLOS, 1975) bem como do material mai recente do Neopermiano e Triássico da Bacia do Paraná (HUSSAKOF, 1930; PEREZ \& MALABARBA, 2002), sugerindo pouca modificação dos Palaeonisciformes do Carbonífero ao Triássico na Bacia do Paraná.

Além de escamas rômbicas foram encontradas formas irregulares que podem ser associadas a diversos ossos dérmicos e escamas fulcrais. $\mathrm{O}$ formato destas partes ósseas e escamas variam de retangulares, estiradas ou alongadas. SCHULTZE \& BARDACK (1987) estudaram estas "formas" diferenciadas em espécies do gênero Elonichthys provenientes do hemisfério norte, considerando que muitas escamas retangulares ocorrem em partes das nadadeiras. A mesma observação foi feita por DUNKLE \& SCHAEFFER (1956) e RICHTER (2002) para espécimes completos da Bacia do Paraná. 


\section{Dentário}

Material - fragmento mandibular (GP/2T-201) (Fig. 127).

Localização - Afloramento 1, Sitio Santa Maria 1

Descrição - O fragmento mandibular (GP/2T-201) representa a porção anterior do dentário esquerdo de um paleonisciforme e mede 28,5 $\mathrm{mm}$ de comprimento e 17,0 mm de altura dorso - ventral (distância da base ao topo da parte óssea). Ainda contém dois dentes cônicos, curvos sigmoidais bem alongados, alcançando $11,1 \mathrm{~mm}$ de comprimento no dente maior (Figs. 127A-127D).

A face labial é plana e expõe estruturas internas complexas, como parte do canal mandibular da porção inferior. A face lingual apresenta uma convexidade central que termina em uma crista pronunciada (provável parte da gular extralateral) localizada na parte central da base óssea do dentário. A borda ventral é lisa, volumosa e com a margem basal arredondada.

Entre os dentes ocorrem pequenos "tubérculos" circulares de, aproximadamente, $1 \mathrm{~mm}$ de diâmetro, localizados lateralmente, mais comuns na face labial do dentário (Fig. 127B e 127F). Nestes tubérculos observa-se estrutura interna em forma concêntrica.

Em seção vertical, o dentário é triangular alongado, sendo maior na parte superior e estreito na região dorsal.

Os dentes estão separados entre si por 5,9 mm, inclinados para frente e voltados para a face lingual. Apresentam costelas longitudinais proeminentes. O capuz apical estava preservado em um dos dentes, mas acidentalmente foi quebrado durante o tratamento da amostra, possuía $1 \mathrm{~mm}$ de diâmetro, com sinais de desgaste (Fig. 127B e 127C). O dente incompleto é menor que o completo (diâmetro de 4,5 mm vs. 6,5 mm no dente inteiro), porém possui as mesmas características na fuste. Apresenta cavidade pulpar circular típica de Palaeonisciformes (Fig. 127A).

Discussão - O dentário apresenta características de alguns gêneros de Palaeonisciformes, como a presença de uma pequena gular extra lateral que é comum em fósseis de grandes Palaeonisciformes como Wendyichthys dicksoni e Cyranorhis bergeraci (LUND \& POPLIN, 1997), do Carbonífero de Montana, ambos com dentário maior que $1 \mathrm{~cm}$ de comprimento.

Os dentes cônicos curvos e levemente sigmoidais são semelhantes ao observado por BARCELLOS (1975) e sua disposição é idêntica aquela de vários grupos de Palaeonisciformes. Os "tubérculos" encontrados na face labial são provavelmente 
dentes menores quebrados entre os maiores, uma característica comum em Actinopterygii paleozóicos. Por exemplo, em Luederia kempi (SCHAEFFER \& DALQUEST, 1978), do Eopermiano do Texas, os dentes menores chegam a rodear os maiores, porém foram observados apenas na maxila. Brasilichthys macrognathus (COX \& HUTCHINSON, 1991), da Formação Pedra do Fogo do Maranhão, apresenta também estas características, tanto na maxila como no dentário. Como ambos são peixes de grande porte, o tamanho aparentemente influi na presença ou não destes pequenos dentes secundários.

Apesar dos caracteres tipicamente Palaeonisciformes, não foi possível atribuir o espécime a uma espécie conhecida ou mesmo a uma família. Mas com base no tamanho e espaçamento dos dentes, é possível especular sobre a localização do fragmento na mandíbula e o tamanho total do peixe, uma vez que a morfologia geral dos Palaeonisciformes pouco muda de um grupo para outro. Comparado com formas inteiras descritas no Brasil e em outras localidades do mundo (DUNKLE \& SCHAEFFER, 1956; LOWNEY, 1980; SCHULTZE \& BARDACK, 1987; COX \& HUTCHINSON, 1991; LUND \& POPLIN, 1997, 2002; POPLIN \& LUND, 2002; RICHTER, 2002), o fragmento parece representar a parte anterior do dentário de um peixe com meio metro de comprimento. O fragmento de dentário, portanto, provavelmente, pertenceu a um dos maiores Palaeonisciformes do Estado de São Paulo. 


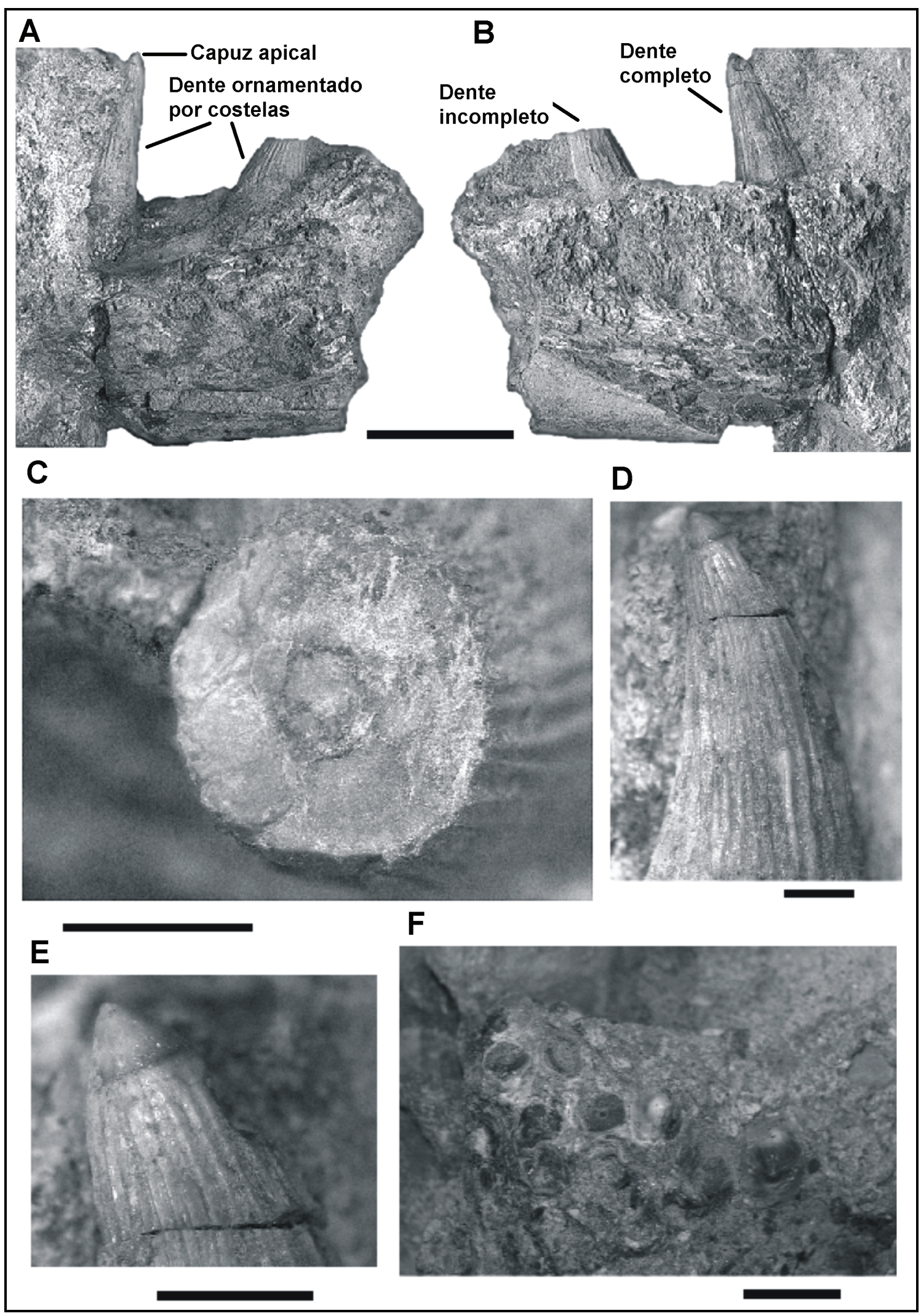

Figura 127 - Fragmento de dentário de Palaeonisciformes. GP/2T-201. A) Vista lingual (interna). B)

Vista labial (externa) Escala 10mm. C) Vista de corte transversal do dente anterior incompleto com detalhe para a cavidade pulpar; D e E) Detalhe da parte superior do dente completo, destacando o capuz apical e as costelas, F) Detalhe dos "tubérculos". Escala de C a F: 2mm. 


\section{Caixa craniana de Actinopterygii}

Entre os fósseis atribuídos aos peixes ósseos está a parte superior de caixa craniana, de pequenas dimensões (Fig. 128). Devido ao seu estado de preservação características como suturas não ficaram claramente preservadas e diversos processos articulatórios foram perdidos.

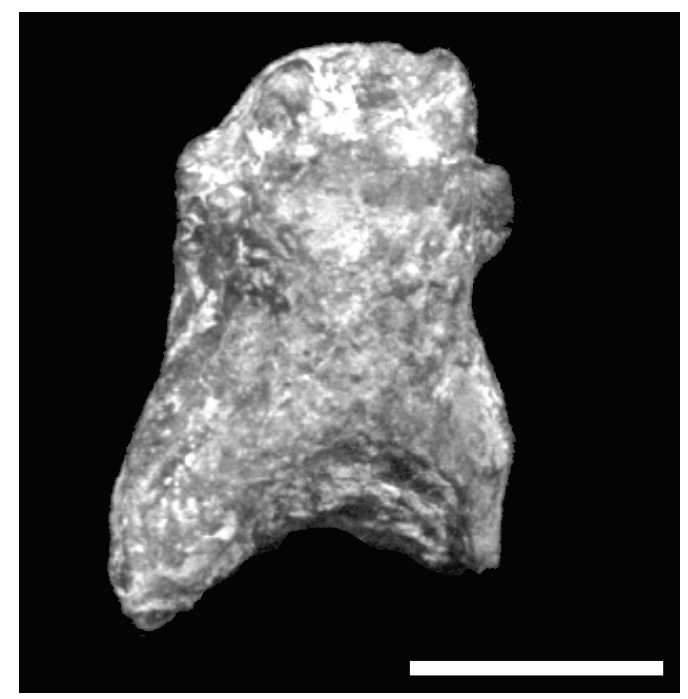

Figura 128 - Parte superior de caixa craniana de peixe ósseo encontrada no Afloramento 1 (GP/2E-6929). Escala $5 \mathrm{~mm}$.

Características Gerais - Comparando-a com outros Palaeonisciformes, esta caixa craniana difere de outros conhecidos, além de estar bastante alterada, por isso a comparação é limitada a características morfológicas externas.

O fóssil difere de outros grupos de vertebrados como Acanthodii, Chondrichthyes e Placodermi (BRAZEAU, 2009) na constituição e formato. Os peixes ósseos sarcopterígios e tetrapodes diferem, além do formato, também em articulações, por isso a comparação com Palaeonisciformes é a mais provável.

A região pós-rostral, até o inicio da região supraorbital mostra a frente arredondada, com duas pequenas protuberâncias voltadas para frente. Uma delas, um pouco desgastada. Comparando com o tamanho de outros Palaeonisciformes, é similar a Kalops monophrys, do calcário de Bear Gulch, Carbonífero dos EUA (POPLIN \& LUND, 2002), porém na espécie do hemisfério norte não ocorre protuberâncias.

As pequenas protuberâncias são observadas em fósseis de Palaeonisciformes como na Formação Lueders, Permiano do Texas (SCHAEFFER \& DALQUEST, 1978), contudo a região frontal é muito estreita e afinada. DALY (1973) observou saliências frontais em Tersomius, do Eopermiano de Oklahoma, mas neste gênero o pós-rostral não é arredondado. 
As cavidades supra-orbitais do exemplar são posicionadas lateralmente e ocupam mais da metade do comprimento total, $0,8 \mathrm{~mm}$. O processo pós-orbital é muito alongado enquanto o pré-orbital é bastante saliente próximo da região nasal. Os Tarrassidae possuem estas características para a região orbital (LUND \& POPLIN, 2002), no entanto o rostro afinado difere do exemplar encontrado.

O frontal dorsal é bastante largo ( $\sim 4 \mathrm{~mm})$ comparado com tarrasideos e a muitos palaeoniscóides, porém não é incomum como observado nas espécies Kalops diophrys do Carbonífero de Bear Gulch (POPLIN \& LUND, 2002) e Tersomius, do Eopermiano de Oklahoma DALY (1973). Como não foram preservadas suturas, não está descartada a hipótese de deformação diagenética.

As regiões supratemporal e póstemporal são muito alongadas em ambos os lados do espécime, formando uma concavidade na sua parte posterior. É a região mais desgastada e pouco pode-se dizer a respeito, mas assemelha-se pelo grande tamanho aos Tarrasidae (LUND \& POPLIN, 2002) de Bear Gulch. A falta de outras características cranianas e a ausência de articulações pós-temporais impede análise mais detalhada.

\subsection{Sarcopterygii}

Os peixes sarcopterígeos foram os vertebrados que originaram os celacantos, peixes pulmonados e todos os vertebrados terrestres. Na Era Paleozóica foi uma subclasse de grande potencial evolutivo evidenciado pela diversidade de forma e habitat. Compreende, ao todo, quatro infraclasses, mas apenas duas, Actinistia e Tetrapoda, apresentam representantes atuais.

Com exceção dos tetrápodes, os sarcopterígeos são caracterizados por nadadeiras pares lobadas com um único elemento de articulação, úmero ou o fêmur (RICHTER et al. 2004). As escamas são do tipo cosmóide, compostas por osso e cosmina, um tecido combinando dentina, esmalte e um sistema de poro-canais, que provavelmente funciona como órgão sensorial.

\subsubsection{Coelacanthimorpha (Actinistia)}

Os Actinistia, também conhecidos como celacantos, são representados através de várias espécies desde o Mesodevoniano até hoje. As características principais do grupo são o crânio que não possui um maxilar ósseo e o arranjo solto dos ossos (SCHAEFFER, 1952; FOREY, 1981). A mandíbula possui dentes destinados a predação. A cauda na maioria dos gêneros é dificerca, com um lobo epicordal. 
As escamas, em geral, tanto em espécies fósseis como atuais (Fig. 129), são arredondadas com fileiras diminutas radiais representando linhas de crescimento. $\mathrm{Na}$ parte posterior ocorrem pequenas costelas longitudinais de diferentes tamanhos, que podem ou não ser paralelas entre si (Fig. 129).

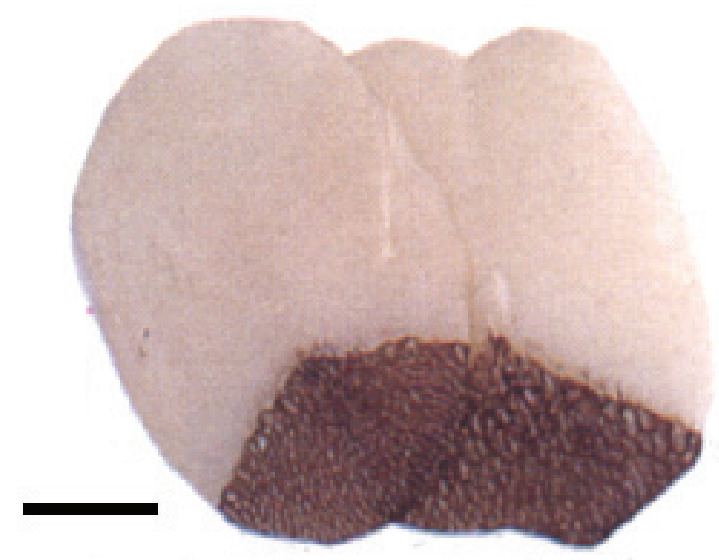

Figura 129 - Escamas cosmóides atuais de celacanto (PARKER, 1990). Escala 1mm.

Os celacantos não são bons indicadores paleoambientais, apesar da única espécie atual ser marinha, pois a falta de maiores estudos de exemplares paleozóicos impede uma resposta segura a esse respeito.

\subsubsection{Coelacanthimorpha no Paleozóico do Brasil}

O registro de Coelacanthimorpha Neopaleozóicos no Brasil são conhecidos através de escamas, pouco descritas e ilustradas embora ocorrendo em diversas unidades litoestratigráficas

O primeiro a observá-las foi BRYANT (1929) que descreveu uma escama de celacantídeo proveniente de uma rocha descrita como tilito do Grupo Itararé do Estado de São Paulo.

A segunda identificação também é proveniente do Grupo Itararé na Fácies Budó, do Estado do Rio Grande do Sul, BARCELLOS (1975) descreveu diversas formas que considerou pertencentes a uma única espécie.

Fósseis mais recentes incluem uma escama descrita por RICHTER, 1985, no topo da Formação Irati do Estado do Rio Grande do Sul. WÜRDIG - MACIEL (1975) e MARANHÃO (1995) mencionaram a presença de escamas na Formação Corumbataí, região de Piracicaba, no Estado de São Paulo.

Fosseis completos de celacantídeos, no Brasil, só ocorrem no Cretáceo da Chapada do Araripe, Formação Santana, Axelrodichthys e Mawsonia (MAISEY, 1991). 


\subsubsection{Descrição de espécimes da Formação Tatuí e na base do Membro Taquaral da Formação Irati}

Classe SARCOPTERYGII Romer, 1955

Subclasse ACTINISTIA Cope, 1871

Ordem COELACANTHIFORMES Berg, 1937

Família Incertae sedis

Fig. 130

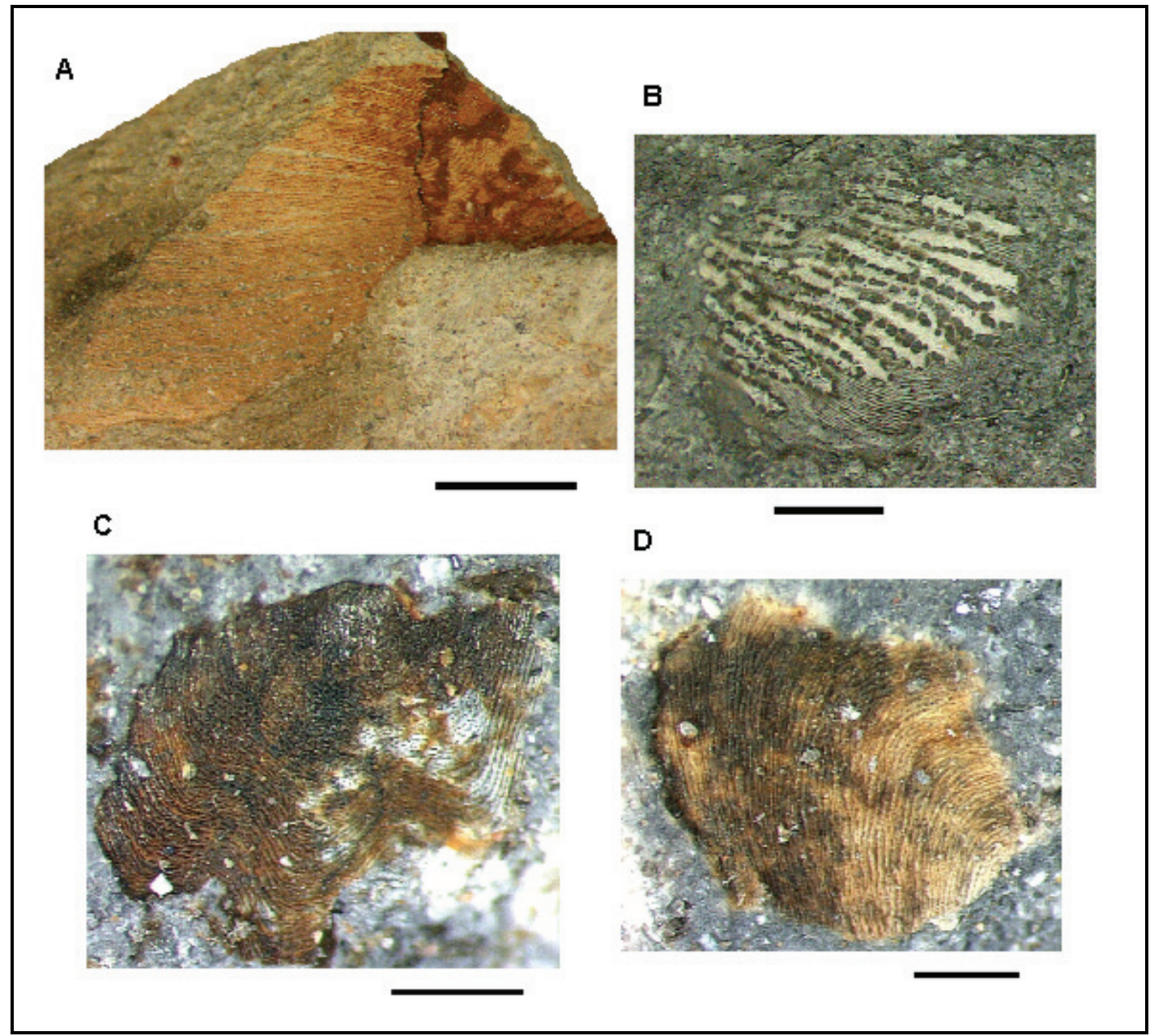

Figura 130 - Escamas de Actinistia. A) Exemplar da Formação Tatuí, Escala 2 mm. GP/2E-5965. B) Exemplar 1 da base arenosa do Membro Taquaral, GP/2E-5966. Escala 1mm. C) Exemplar 2 da base arenosa do Membro Taquaral, GP/2E-5967. Escala 0,6mm. D) Exemplar 3 da base arenosa do Membro Taquaral, GP/2E-5968. Escala 0,6mm.

\section{Escama do topo da Formação Tatuí}

Material - GP/2E-5965. Escama (Fig. 130A).

Localização - Afloramento 5 Proximo ao Rio Passa Cinco em Rio Claro

Descrição - O exemplar, incompleto, foi encontrado em arenito bege muito fino, maciço, bem selecionado. Representa a parte distal de uma escama com as linhas de crescimento e uma pequena parte da zona de imbricação bem preservada. 
As linhas de crescimento são finas, retas, separadas por pequenos espaços e divergentes nas regiões mais distais da estrutura. Próximo da região de articulação as linhas de crescimento estão unidas e ligeiramente encurvadas. A parte articulatória aparece fragmentada com apenas quatro pequenos fragmentos das costelas.

O comprimento máximo da escama é de $7,3 \mathrm{~mm}$ e a largura é de aproximadamente 5,0mm. A maior costela da zona de imbricação possui $1,0 \mathrm{~mm}$ de comprimento. A espessura da escama é muito fina, impossível de ser medida.

\section{Escamas da base do Membro Taquaral}

\section{Exemplar 1}

Material - GP/2E-5966. Parte proximal de escama (Fig. 130B).

Localização - Afloramento 1, Sitio Santa Maria 1, Município de Rio Claro.

Descrição - O espécime encontrado é uma escama muito fina, incompleta, de forma irregular. Apresenta pouquíssimas linhas de crescimento concêntricas na região livre da articulação e algumas dentro da própria zona de imbricação entre as costelas.

A zona articulatória ocupa a maior parte da área da escama e é marcada por costelas longitudinais, curtas e longas, que em alguns casos se sobrepõem até atingirem a margem posterior. As costelas apresentam pequenos "dentículos" laterais que chegam a tocar outras costelas.

O que restou da escama foi praticamente só sua zona de imbricação. Por isso, o tamanho é reduzido, com comprimento máximo de $3 \mathrm{~mm}$ e largura de 2,5mm.

\section{Exemplar 2}

Material - GP/2E-5967. Fragmento distal de uma escama (Fig. 130C).

Localização - Afloramento 1, Sitio Santa Maria 1, Município de Rio Claro.

Descrição - Representa a parte distal de uma escama, onde se observam apenas as linhas de crescimento. São muito finas, sem espaçamento entre elas e concêntricas, porém não circulares. O comprimento máximo do fragmento é de 2,3mm e a largura, $1,8 \mathrm{~mm}$.

\section{Exemplar 3}

Material - GP/2E-5968. Fragmento distal de escama (Fig.130D).

Localização - Afloramento 1, Sitio Santa Maria 1, Município de Rio Claro.

Descrição - O espécime é muito parecido com o exemplar 2 e como foram encontrados próximos, provavelmente fazem parte do mesmo indivíduo. Representa a parte distal, ornamentada por linhas de crescimento finas e concêntricas, sem espaçamento. O comprimento máximo do fragmento é de $2,1 \mathrm{~mm}$ e a largura, $1,8 \mathrm{~mm}$. 
Discussão - A grande semelhança entre as escamas descritas e as de celacantídeos atuais do Oceano Índico (Latimeria) justifica sua classificação dentro dos actinístios.

Os exemplares da base do Membro Taquaral e a escama encontrada na Formação Tatuí são muito semelhantes, no formato das linhas de crescimento e na zona articulatória, ao material descrito por BARCELLOS (1975) e BRYANT (1929) proveniente do Grupo Itararé, respectivamente, do Rio Grande do Sul e São Paulo.

BARCELLOS (1975) foi quem mais descreveu escamas de actinístios no Brasil. Entre seus exemplares, a zona de imbricação apresenta os mais variados tamanhos e formas, como costelas lisas e disposição diferenciada, lembrando o Exemplar 1 da base do Membro Taquaral.

A parte distal e as linhas de crescimento dos exemplares das duas unidades são morfologicamente idênticas. Contudo, o exemplar 1 da base da Formação irati apresenta zona de imbricação diferenciada dos outros exemplares, com costelas denteadas e linhas de crescimento ainda dentro da zona de imbricação. Esta diferença não representaria com segurança uma diferenciação de espécies, pois seriam necessários maior quantidade de exemplares para uma análise detalhada.

\subsubsection{Osteolepimorpha e Tetrápodes basais}

Além dos Coelacanthimorpha, os Sarcopterygii são constituídos pelas subclasses Tetrapoda, Rhizodontiformes, Osteolepimorpha, Dipnoi e Porolepimorpha, estas duas últimas podem representar um único grupo (NELSON, 2006).

Além dos tetrápodes, os Osteolepimorpha foram os únicos a alcançar o Neopaleozóico. Tiveram muito sucesso e diversidade no Devoniano, porém se extinguiram no Eopermiano.

Características principais de Osteolepimorpha são um único par externo de aberturas nasais e uma choana, ou narina palatal. Possuem nadadeiras peitorais compostas por ossos apendiculares longos, como úmero, ulna e rádio.

Os ossos do crânio são diferentes das dos Actinistia, assemelhando-se aos de peixes ósseos primitivos, com uma grande quantidade de ossos unidos e articulados.

Os representantes mais primitivos do grupo apresentavam escamas romboédricas espessas e todos os ossos dérmicos com uma camada de cosmina, embora em várias linhagens posteriores a cosmina continuou comum, mas as escamas ficaram mais finas e arredondadas. 
A dentição, tanto para os Ostelepimorpha quanto para os tetrápodes basais, é do tipo labirintodonte, grandes dentes de formato cônico com dentina em dobras complexas na cavidade pulpar (Fig. 131A e 131B). Externamente, os dentes apresentam inúmeras estrias longitudinais próximas da base que, aos poucos, diminuem até desaparecerem completamente, próximo do topo. Podem apresentar, ainda, uma pequena crista, mas nunca um capuz apical de acrodina.

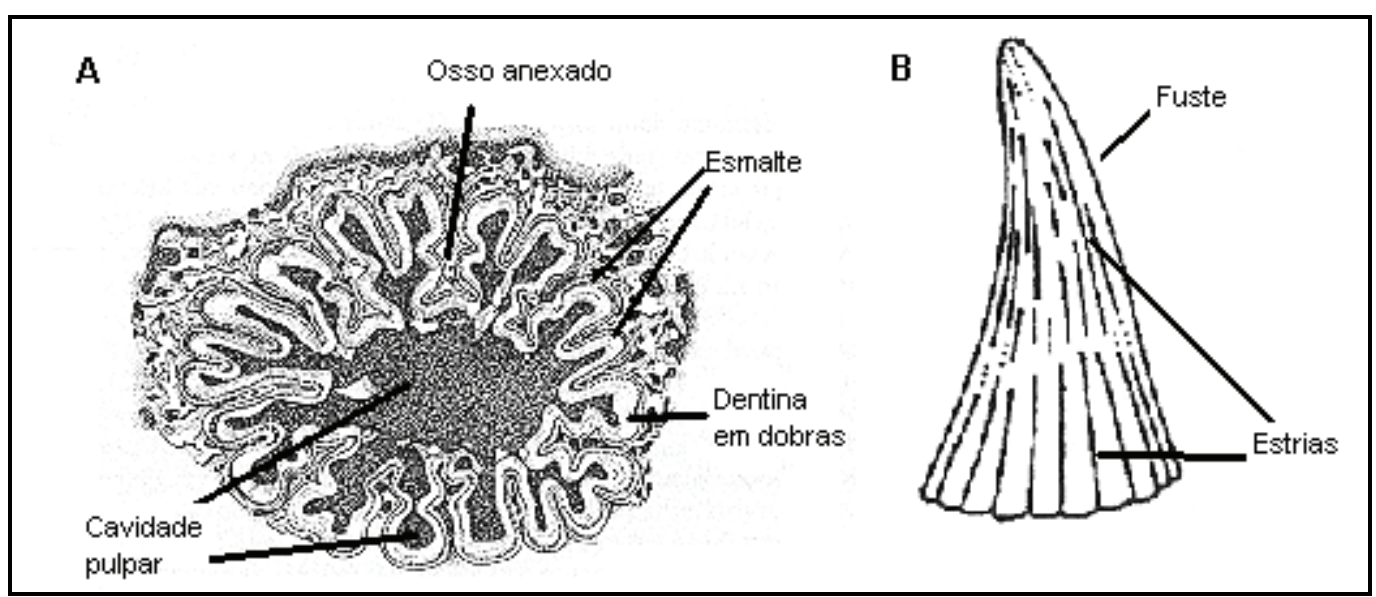

Figura 131 - Características de dentes labirintodontes. A) detalhe da dentina (MOY-THOMAS \& MILES, 1971) e B) morfologia externa (RICHTER, 2004).

Como os Osteolepimorpha e os tetrápodes basais possuíam dentição labirintodonte, fica difícil diferenciar os dentes destes grupos. Por exemplo, RAGONHA (1978), em sua dissertação de mestrado, não identificou a presença de tetrápodes, mas apenas peixes ripidístios, ao contrário da opinião de TOLEDO (2001) que colocou todos os dentes labirintodontes da Formação Corumbataí em Tetrapoda. CHAHUD (2003b) aventou a possibilidade da presença de dentes labirintodontes de ambos os grupos no Permiano da Bacia do Paraná.

Formas como a encontrada no exemplar GP/2E - 6309 (Fig. 132) geram dúvidas de como classificá-los. O fóssil é bastante estriado na parte inferior, possui uma cúspide arredondada indicando forte abrasão. Tem a forma cônica robusta ligeiramente encurvada e com algumas fraturas ou rachaduras superficiais. 


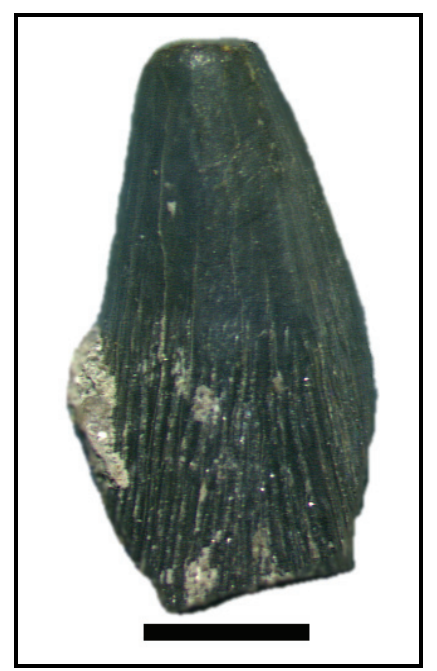

Figura 132 - Possível dente labirintodonte (GP/2E-6309). Escala 2mm.

Pelas características morfológicas como estrias na base e uma cavidade pulpar central diferem de Palaeonisciformes e Chondrichthyes. Apresentam características semelhantes a dentes de tetrápodes basais e Osteolepimorpha (RICHTER et al. 2004), porém como a zona de inserção com a mandíbula não foi preservada e não foi possível a caracterização do dobramento de dentina, característico de dentes tipo labirintodontes, não foi possível identificá-lo com segurança.

Apesar do fóssil ilustrado GP/2E - 6309 ter sua identificação duvidosa, outros indícios, como a associação com possíveis ossos apendiculares (Fig. 133), também foram encontrados e a possibilidade de pequenos tetrápodes ou Osteolepimorpha não deve ser descartada.

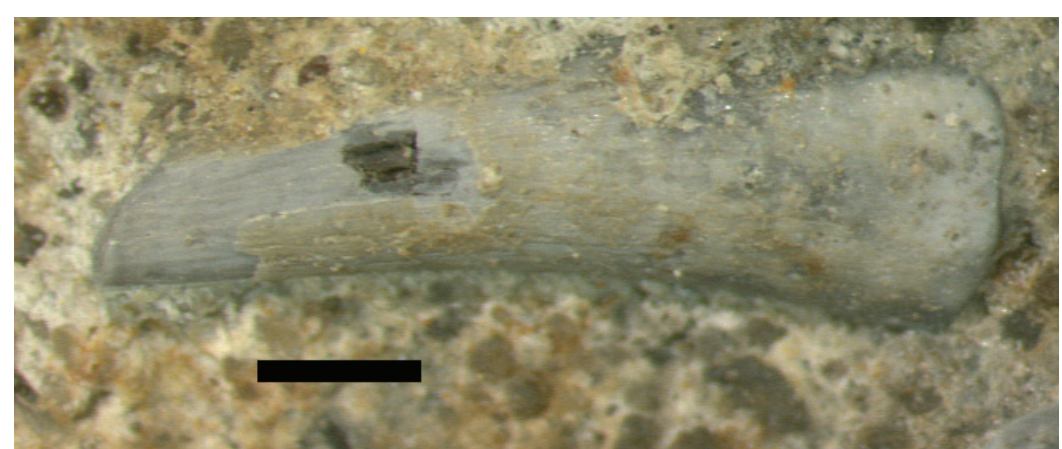

Figura 133 - Osso de vertebrado não identificado (GP/2E-6457), possivel osso longo de Sarcopterygii. Escala $1 \mathrm{~mm}$.

\subsection{Temnospondyli}

Os tetrápodes surgiram no Devoniano e sobrevivem até os dias atuais em diferentes formas de animais terrestres e aquáticos. Desde o Paleozóico diversos grupos são incluídos com morfologias, número de dígitos e reprodução variáveis. O grupo 
paleozóico mais abundante são os Temnospondyli, representados por grandes animais do Neopaleozóico, declinando no Mesozóico e desaparecendo durante o Cretáceo.

Os Temnospondyli constituíram um grupo de sucesso no Paleozóico, com mais de 145 gêneros, o que os qualificam como os mais diversificados tetrápodes daqueles tempos. O grupo habitou todos os continentes e segundo DIAS (2000) e CISNEROS et al. (2005), duas superfamílias são encontradas no Brasil, Archegosauroidea, de idade permo-carbonífera, e Rhinesuchoidea, permo-triássica (PRICE, 1948; PUTZER, 1954; BARBERENA, 1972; COX \& HUTCHINSON, 1991; BARBERENA, 1998; DIAS \& BARBERENA, 2001; DIAS \& SCHULTZ, 2003). Sua característica principal é um volumoso crânio, podendo ser robusto ou alongado. Outra feição importante, em diversas espécies desse grupo, é a presença de apoios ossificados para brânquias externas nos indivíduos pequenos, interpretada como evidência de histórias complexas de vida, envolvendo uma fase larval aquática (girino?) e fase adulta terrestre. Com base nas proporções do esqueleto e grau de ossificação dos membros apendiculares, muitos do Temnospondyli do Paleozóico, quando adultos, deviam ter sido totalmente terrestres. Outros aparentemente eram aquáticos a vida toda. ABREU \& DIAS-DA-SILVA (2006) observaram que algumas espécies de temnospondilos podem ser considerados ótimos indicadores bioestratigráficos.

Os Temnospondyli e os primeiros tetrápodes foram alvo de pesquisas paleoambientais, algumas sugerindo ambientes salinos para algumas espécies. Os Tupilakosauridae, Permo-triássico da Europa, América do Norte, África do Sul e Groelândia, foram os primeiros a terem seu paleoambiente discutido a partir de fósseis encontrados em depósitos marinhos da Groelândia, porém OCHEV \& SURKOV (2000) comentam que houve um erro estratigráfico e tafonomico com o espécime da Groelândia. Outros Temnospondyli e até aminiotas foram encontrados em ambientes salinos por transporte ou como carcaça ou fragmentos de ossos.

O caso mais importante está atribuído a Iberospondylus do Carbonífero de Puertollano da Espanha, em que um crânio bem preservado foi encontrado. Tal fóssil foi determinado como eurialino por LAURIN \& SOLER-GIJÓN (2001 e 2006) baseados em analises geolólogicas discutíveis para a bacia de Puertollano. Os autores utilizaram Chondrichthyes que podem ser encontrados em água doce e salina, como Triodus, Sphenacanthus, e Lissodus, para justificar o ambiente salino, desconsideraram a total ausência de fósseis marinhos, a camada de carvão associada e também a possibilidade do fóssil ter sido transportado como carcaça para a bacia. 
SOLER-GIJÓN \& MORATALLA (2001) ao estudar a Bacia de Puertollano a consideraram marinha por causa da possibilidade de acritarcos citados por FONOLLÁ (1988) e salientaram a presença de abundantes assembléias de leiosphaerideos, em vários níveis da seção, baseados em uma comunicação verbal, tal material não foi publicado ou ilustrado. HANNAH et al. (2000) observaram que varios leiosphaerideos poderiam ser encontrados em ambientes de salinidade variável e até depósitos dulceaquícolas. SOLER-GIJÓN \& MORATALLA (2001) ainda comentaram a influência de marés de uma pedreira próxima (pedreira de María Isabel) separada por uma falha geológica em outro tipo de rocha (SOLER-GIJÓN \& MORATALLA, 2001) para justificar o, possível, ambiente marinho.

As análises geoquímicas também não são associadas as camadas de estudo e sim superiores que cobrem a seção (SOLER-GIJÓN \& MORATALLA, 2001) por isso não devem ser consideradas como argumento válido para a caracterização de ambiente marinho.

\subsubsection{Tetrápodes basais encontrados na base do Membro Taquaral}

Subclasse TETRAPODA Broili, 1913

Classe AMPHIBIA Linnaeus, 1758

Ordem TEMNOSPONDYLI Zittel, 1888

Figs 134 e 135.

Material - GP/2T-202 (Fig. 134), Dente isolado e GP/2T-203 (Fig. 135), Fragmento mandibular.

\section{Descrição de espécimes}

Dente - O dente GP/2T-202 (Fig. 134) é alongado com o ápice muito desgastado e parte da face labial quebrada. Tem forma cônica curva, sendo que a curvatura está voltada para a região lingual, com leve concavidade.

A face labial exibe certa convexidade, mais acentuada na região central do dente, onde se observa brusco achatamento. As faces laterais (ântero-posterior) apresentam desgaste e polimento, mas em uma das faces, distingue-se uma discreta crista longitudinal lisa percorrendo todo o comprimento do dente.

A base apresenta inúmeras estrias longitudinais, que tendem a diminuir em tamanho e quantidade distalmente, desaparecendo por completo a, aproximadamente, 3/5 da distância da base até o ápice do dente. 
O dente tem comprimento total de $30,3 \mathrm{~mm}$. Em vista transversal o exemplar é ligeiramente elíptico, com eixo menor no sentido labial-lingual, de $14,1 \mathrm{~mm}$ e eixo maior entre a região ântero-posterior, de $15,5 \mathrm{~mm}$. Na base observa-se parte da estrutura da dentina irregular.
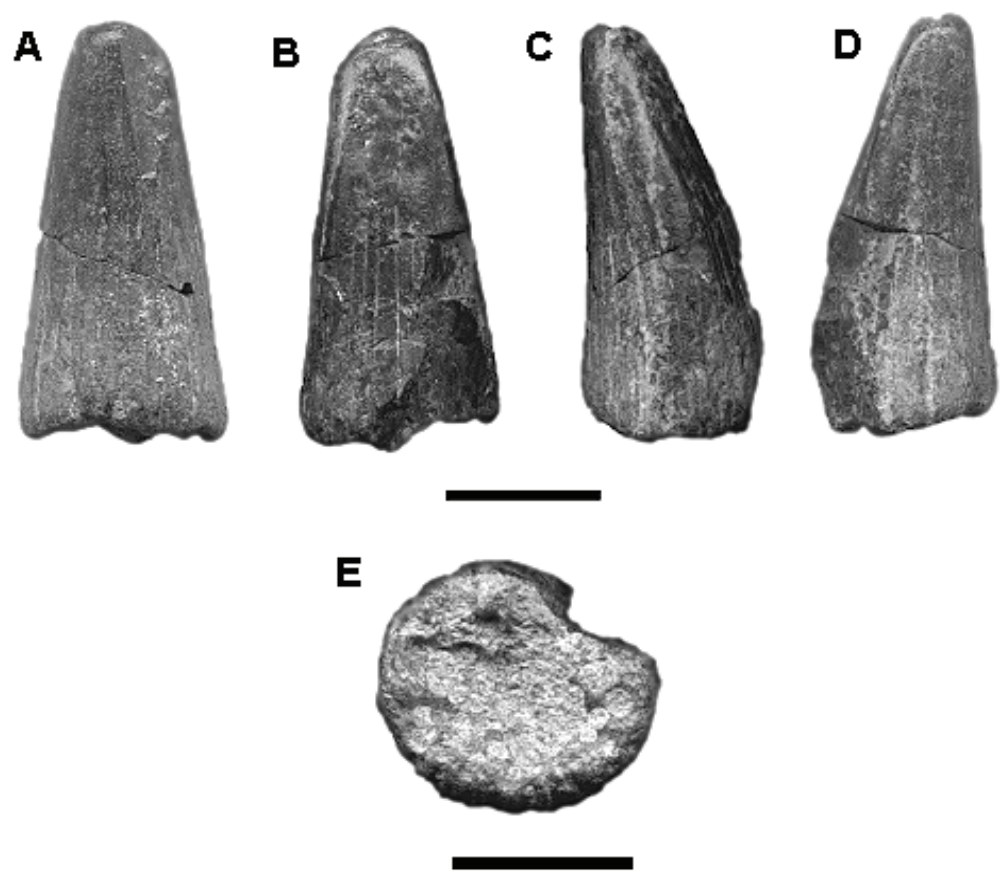

Figura 134 - Dente labirintodonte descoberto no Afloramento 1 (GP/2T-202). A) face lingual, B) face labial, C e D) vistas laterais, E) vista inferior da base. Escalas $10 \mathrm{~mm}$.

Fragmento mandibular - O espécime GP/2T-203 (Fig. 135) é um fragmento mandibular contendo a parte basal de um grande dente. A camada óssea é irregular, mais espessa onde se localiza o dente. No lado oposto ocorre uma face plana desgastada, com fraturas, que ainda preservam parte da morfologia original (possíveis marcas musculares na superfície óssea). As partes frontal e posterior da parte óssea, por estarem muito fragmentadas, desgastadas e alteradas, não apresentam sinais de como era a articulação (Fig 135A e 135B).

O dente localiza-se próximo de uma das laterais da parte óssea e está inclinado para a região lingual (interna do maxilar). Em vista transversal, a face labial apresenta ondulações mais acentuadas na parte externa, em contato com o osso do que na face lingual. A cavidade pulpar central está mal preservada, mas tem forma semelhante à do dente isolado descrito acima. 
A superfície do dente, no fragmento ósseo, está muito polida e arredondada, com estrias, muito apagadas, apenas observadas na face lingual.

O comprimento máximo da peça é $38,6 \mathrm{~mm}$, a largura é $30,5 \mathrm{~mm}$ e a espessura na região do dente, é $17,6 \mathrm{~mm}$. O dente mede 13,5mm na face ântero-posterior e 10,4 mm no sentido labial - lingual. A cavidade pulpar central ocupa $40 \%$ da seção transversal do dente. Por causa do extenso desgaste da peça, não foi possível observar detalhes da dentina interna.
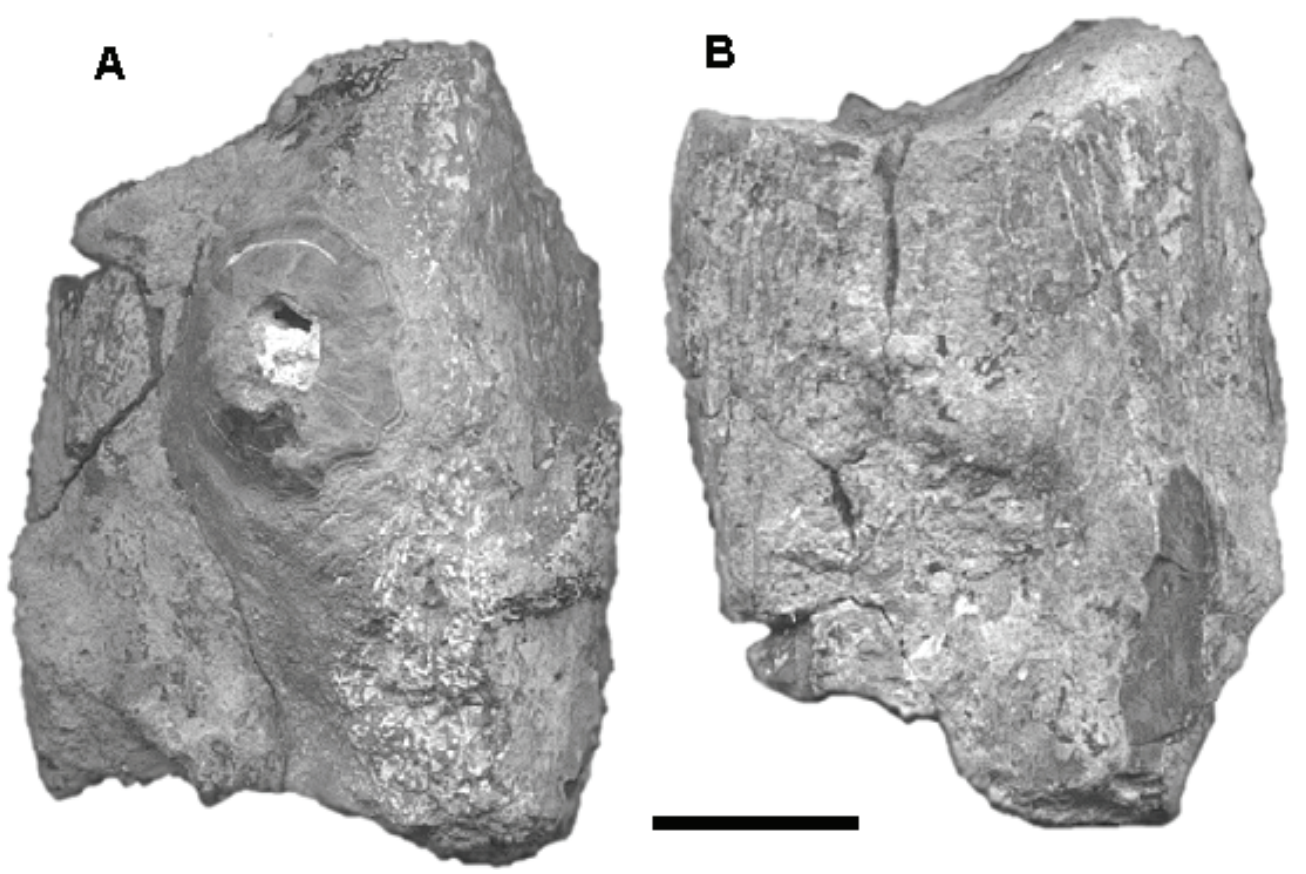

Figura 135 - Fragmento mandibular de labirintodonte (GP/2T-203). A) face interna, B) face externa. Escala $10 \mathrm{~mm}$.

Discussão - As estrias longitudinais proeminentes na base do dente, o grande tamanho, o padrão complexo da cavidade pulpar interna (observada no exemplar isolado) e ausência de um capuz apical de acrodina no dente isolado identificam os exemplares como de sarcopterígios ou de tetrápodes primitivos.

Os dentes descritos possuem as mesmas proporções em tamanho aos atribuídos à Temnospondyli de grande porte, do Eopermiano da Bacia do Parnaíba e do Neopermiano da Bacia do Paraná, Prionosuchus plummeri, Bageherpeton longignathus e Australerpeton cosgriffi (PRICE, 1948; COX \& HUTCHINSON, 1991; BARBERENA, 1998; BARBERENA \& DIAS, 1998; DIAS \& BARBERENA, 2001; DIAS \& SCHULTZ; 2003; VEGA-DIAS et al. 2008). 
A parte óssea preservada em GP/2T-203 é muito semelhante à parte do maxilar de Prionosuchus plummeri da Formação Pedra do Fogo. Contudo, seriam necessários fósseis em melhor estado de preservação para a obtenção de dados mais conclusivos.

Os fósseis aqui apresentados são raros e mesmo pertencentes ao mesmo individuo, provavelmente foram transportados e provavelmente não pertenciam ao ambiente em questão.

\subsection{Tafonomia de vertebrados}

Os estudos tafonômicos da paleoictiofauna presente nos afloramentos 1-5 envolveram a base do Membro Taquaral em contato com a Formação Tatuí. O material é representado basicamente por escamas, dentes e partes ósseas de peixes e tetrápodes basais.

\subsubsection{Coleta e obtenção de dados}

Devido ao tamanho reduzido dos afloramentos fossilíferos, vinte amostras de cada afloramento foram coletadas para o estudo de assinaturas tafonômicas em laboratório. O exame de 20 amostras mostrou-se suficiente para obter dados representativos em cada afloramento, referentes à densidade espacial, presença ou não de agregados/acumulações fósseis e seleção de partes ósseas.

Foram medidos quadrados de um centímetro de cada lado. As amostras tiveram tamanho similar. Nas análises e estudos relacionados ao arranjo e densidade espacial, foram selecionados os fósseis de tamanho superior a $0,5 \mathrm{~mm}$ de comprimento, pois espécimes menores não ofereciam margem de segurança na diferenciação de fósseis vertebrados de materiais orgânicos não identificáveis e inorgânicos de coloração e formato semelhantes.

\subsubsection{Afloramentos 1 e 2: Sítio Santa Maria}

Os afloramentos 1 e 2, localizados no interior do Sítio Santa Maria, estão muito próximos um do outro, 190 metros de distância, e por isso apresentam características sedimentológicas e fossilíferas idênticas. Suas espessuras são muito próximas $(9,5 \mathrm{~cm}$ para o Afloramento 1 e 15 centímetros para o Afloramento 2).

Não foram observadas diferenças entre os dois, logo os dados obtidos com amostras no Afloramento 1 são consistentes para análise de densidade espacial, arranjo, diversidade fóssil e tipo de preservação. 
Para os estudos tafonômicos foram utilizados dados do Afloramento 1 que apresentou maior área de exposição, maior facilidade para a coleta de dados e material em abundância.

A concentração fóssil da camada da base do Membro Taquaral, no Afloramento 1, está exposta em planta num pavimento de $8 \times 20$ metros e em seção ao longo de um perfil com $9,5 \mathrm{~cm}$ de altura e $20 \mathrm{~m}$ de comprimento.

O Afloramento 2 exibe um corte em degrau, com exposição de 40 metros de comprimento, aproximadamente 0,5 metros de largura e 15 centimetros de espessura. Esta camada é constituída de arenitos finos a médios conglomeráticos, com grânulos e pequenos seixos milimétricos. Ocorrem alguns clastos angulosos e arredondados dispersos, de tamanhos centimétricos, próximo do contato basal da unidade.

A densidade espacial dos fósseis, (medida em mais de 50 amostras no afloramento 1 e algumas amostras do afloramento 2) é um pouco maior que 1 fóssil $/ \mathrm{cm}^{2}$, para fósseis maiores que $0,5 \mathrm{~mm}$. Os fósseis estão dispersos na rocha, sem contato entre si, e, como os clastos inorgânicos, são suportados pela matriz. Ocorrem concentrações isoladas fracamente empacotadas, onde os bioclastos chegam a se tocar. Estas acumulações, no entanto, não ultrapassam $0,5 \mathrm{~cm}^{2}$ em área.

Em ambos os afloramentos foi observada diminuição na quantidade e tamanho dos fósseis com a granodecrescência ascendente típica destes afloramentos. Próximo ao contato com o folhelho síltico do Membro Taquaral não são observados Chondrichthyes e os fragmentos ósseos, dentes e escamas de Osteichthyes, estão bastante dispersos.

Vistos em planta no afloramento 1, os fósseis (principalmente dentes e escamas de paleonisciformes) não exibem nenhuma orientação (Fig. 136). Em perfil o material fóssil geralmente se dispõe concordante ao acamamento (Fig. 137), mesmo nas porções com estratificação cruzada irregular. 


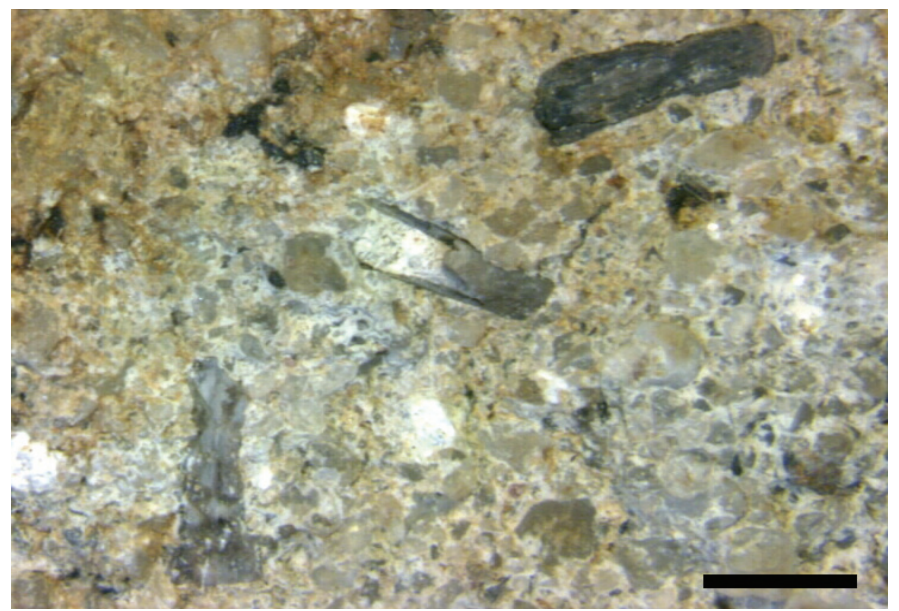

Figura 136 - Vista em planta com ossos orientados em diferentes posições. Escala 2mm.

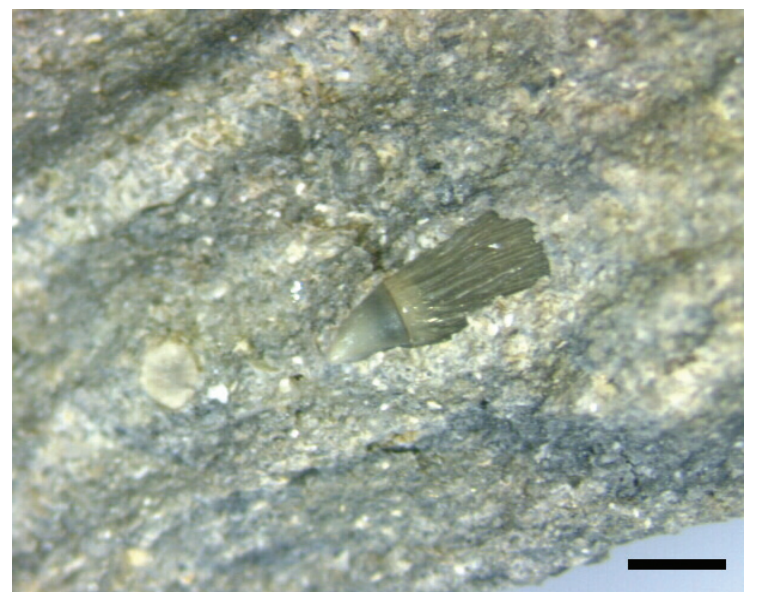

Figura 137 - Vista em perfil com um dente de Palaeonisciformes orientado concordantemente ao acamamento. Escala $1 \mathrm{~mm}$.

Os agregados e acumulações pontuais são muito raros e quase sempre são de bioclastos fragmentados e de tamanho muito reduzido (menor que 0,5mm). Foram observados poucos fósseis maiores que $0,5 \mathrm{~cm}$, representados por associação de escamas de paleoniscídeos, desarticuladas, próximas entre si, formando um pequeno agregado.

Os agregados aparecem na região onde a granulometria é maior e de pior seleção.

O exemplar GP/2E-6383 é o mais impressionante, pois exibe escamas de tamanho próximo de $1 \mathrm{~cm}$ e provavelmente deva ter sido parte de um peixe ainda articulado no momento da deposição (Fig. 138). 


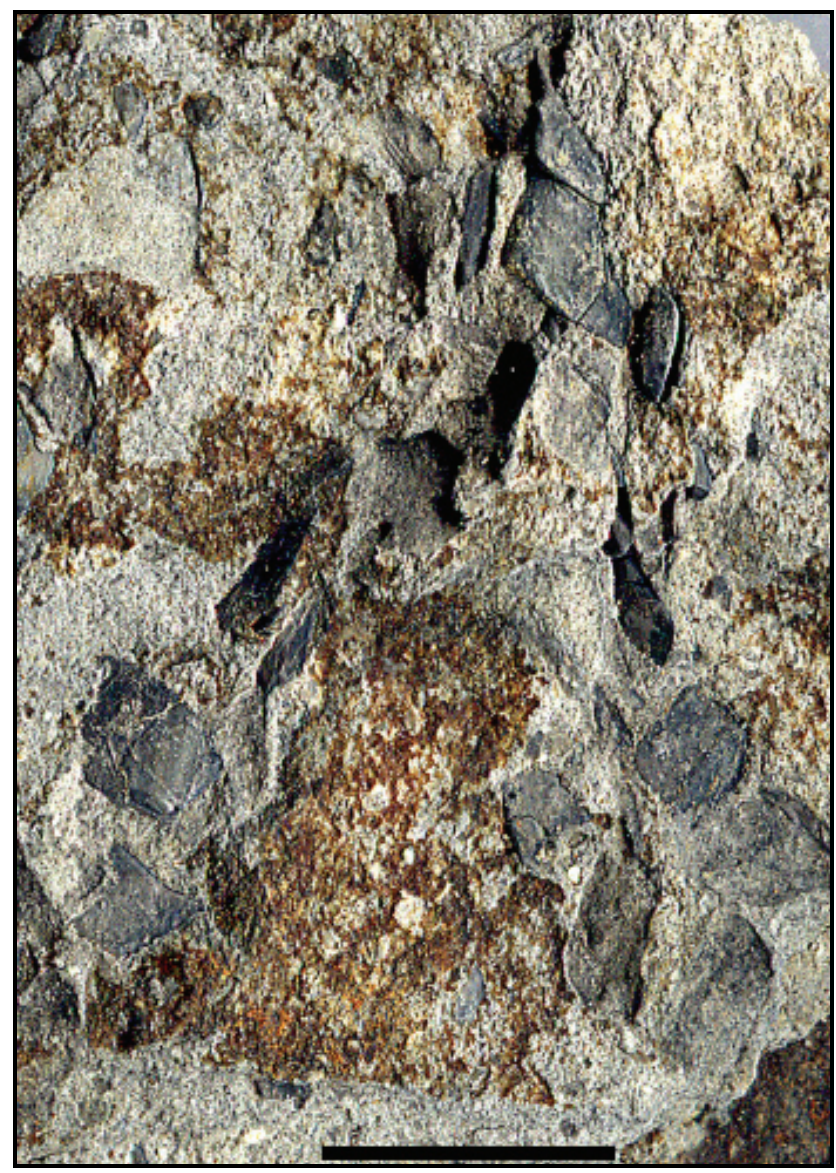

Figura 138 - Vista em planta de acumulação de escamas de Palaeonisciformes. Única evidência de associação encontrada no Afloramento 1 (GP/2E-6383). Escala 1cm.

O número de táxons identificados neste afloramento 1 é maior do que em qualquer outro afloramento estudado e inclui animais de origens continental (anfíbios), fluvial (Rhipidistias) e de água salgada (Petalodontiformes).

A lista dos diversos grupos encontrados no afloramento incluem:

Classe Chondrichthyes

Incertae Ordinis - dentes cladodontes $\dagger$ Ordem Orodontiformes $\dagger$

Subclasse Elasmobranchi

Euselachi indeterminados $\uparrow$

Ordem Ctenacanthiformes $\dagger$

Ordem Xenacanthiformes $\uparrow$

Subclasse Holocephali

Ordem Petalodontiformes $\uparrow$

Classe Actinopterygii

Ordem Palaeonisciformes (Parafilético) $\dagger$

Classe Sarcopterygii

Subclasse Coelacanthimorpha (Actinistia)

Superclasse Tetrapoda

Subclasse Osteolepimorpha $\dagger$

$(†$ extinto) 
O Afloramento 2 apenas não registrou Tetrapoda, dentes cladodontes e Orodontiformes, muito raros no Afloramento 1. Os Petalodontiformes e Xenacanthiformes são representados apenas pelas formas mais comuns.

A composição taxonômica do material é politípica, consistindo de escamas, dentes, espinhos, ossos e coprolitos, e poliespecífíca, pois o material representa diversos taxa acima do nível de família das classes Chondrichthyes e Osteichthyes.

Nenhum fóssil exibe partes articuladas, com possível exceção de pequenos agregados isolados, como os mencionados acima, todo o resto está isolado e disperso na rocha.

Não se observou evidência de seleção de fósseis por classe de tamanho, pois os bioclastos variam em comprimento de menos de $0,5 \mathrm{~mm}$ até mais de $10 \mathrm{~mm}$, independente do estado de completude do fóssil e posição dentro da camada.

Muitos fósseis, como alguns espinhos de Ctenacanthiformes, exibem cúspides e ornamentações muito bem preservadas com pouca abrasão. Outros, como alguns dentes petalodontes e os dentes de xenacantídeos, labirintodontes e grandes escamas de Palaeonisciformes (Fig. 139) exibem alterações que evidenciam, claramente, o retrabalhamento físico. O grau de abrasão varia muito independente de tamanho e táxon.

As cúspides dos dentes de cladodontes e do Xenacanthiformes Taquaralodus exibem pouco desgaste, comparável ao Estágio 1 ou, no máximo, Estágio 2 (baixa abrasão) da classificação de BENTON (1997).

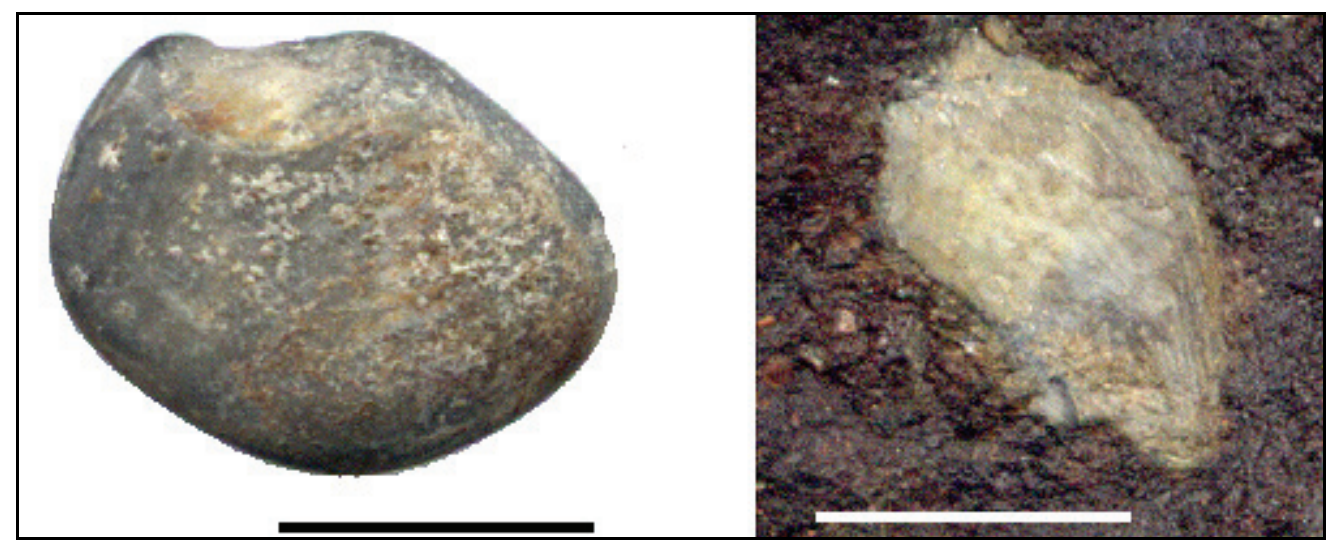

Figura 139 - Escamas de peixes ósseos que sofreram abrasão, arredondamento e desgaste da superfície. Escala $0,5 \mathrm{~cm}$. 


\subsubsection{Afloramento 3: Rio da Cabeça, divisa de Rio Claro com Ipeúna}

Este afloramento é muito parecido com os Afloramentos 1 e 2 em composição litológica e paleontológica, mas a quantidade de fósseis é menor, embora a espessura da camada da base da Formação Irati seja muito maior. A camada tem cinco metros de comprimento máximo, $43 \mathrm{~cm}$ de espessura e mergulha 10 graus para $\mathrm{NE}$ (N45W/10NE). Diferencia-se dos demais pelo mergulho que alcança três graus.

A densidade espacial dos fósseis é 0,5 fóssil $/ \mathrm{cm}^{2}$. O afloramento é composto de dentes e escamas de Palaeonisciformes. Não existe orientação dos fósseis em planta (Fig. 140), com diversas direções. Em perfil, dentes e espinhos normalmente estão concordantes ao acamamento (Fig. 141), porém é possível observar alguns com pequena obliqüidade em relação à camada. Agregados e acumulações pontuais não foram observados.

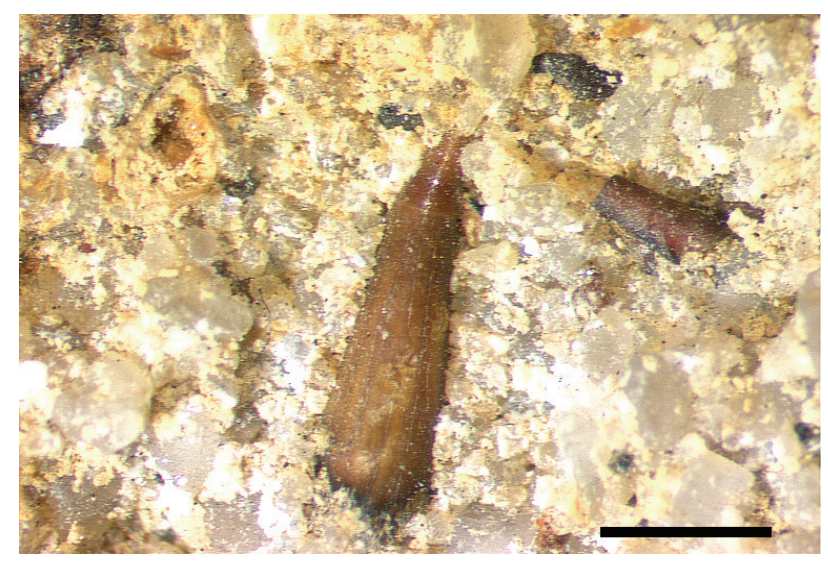

Figura 140 - Vista em planta destacando dentes de paleoniscideos em diferentes posições. Escala $1 \mathrm{~mm}$.

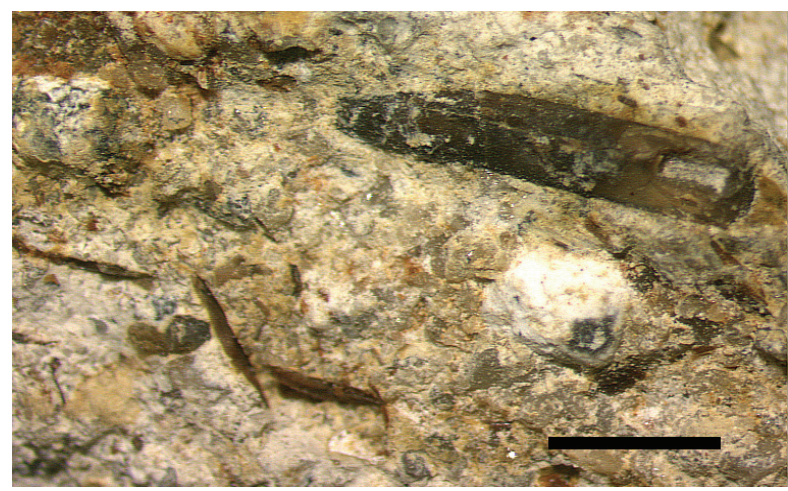

Figura 141 - Vista em perfil mostrando ossos e dentes concordantes e oblíquos. Escala 2mm.

O número de táxons é baixo comparado ao Afloramento 1. Possui composição taxonômica politípica, restos de vertebrados, escamas e dentes, e poliespecífica, porém com poucos exemplares de Chondrichthyes. Os grupos encontrados são: 
Classe Chondrichthyes

\author{
Ordem Xenacanthiformes (exemplares raros) $\dagger$ \\ Subclasse Holocephali \\ Ordem Petalodontiformes $\uparrow$ \\ Classe Actinopterygii \\ Ordem Palaeonisciformes (Parafilético) $\dagger$ \\ $(\dagger$ extinto)
}

Como no Afloramento 1, os fósseis são mal selecionados, desarticulados, e dispersos na rocha.

O material fóssil identificável é representado por escamas, dentes e espinhos, com muitos exemplares inteiros e em geral poucas quebras. Existem, no entanto, muitos fragmentos ósseos não identificáveis também de tamanho variado.

Abrasão é intensa nos poucos exemplares de Petalodontiformes, exibindo detalhes da dentina interna e arredondamento. Muitos dentes e escamas de Palaeonisciformes, de tamanho variado, foram encontrados inteiros, associados a fragmentos com muito desgaste e polimento, caracterizando mistura de elementos em diferentes estados de preservação.

Os Xenacanthiformes são muito raros neste afloramento e representados por três indivíduos, dois muito desgastados (Fig. 142) e outro, GP/2E-6456, em melhor estado de preservação (Fig. 92, pag. 153) que representam as formas incomuns da família Xenacanthidae, encontrada no Afloramento 1. O Diplodoselachidae Taquaralodus, comum na unidade, não foi até o momento encontrado neste afloramento. Como a densidade espacial é menor é possível que exista Taquaralodus, porém não deve ter sido comum ou, até mesmo, menos abundante que os Xenacanthidae.

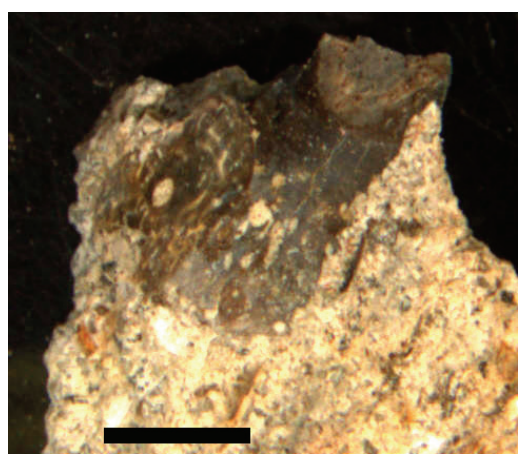

Figura 142 - Maior exemplar de Xenacanthidae indeterminado, fragmentado, encontrado no Afloramento 3. Escala $1 \mathrm{~mm}$. 


\subsubsection{Afloramento 4: Ponte sobre o Rio Passa Cinco}

O afloramento é dividido em duas partes pelo Rio Passa Cinco. A análise sedimentológica indica o mesmo tipo de litologia e estruturas dos afloramentos 1 e 2, porém os clastos maiores são muito mais abundantes, caracterizando um conglomerado com pouca matriz na base e um arenito conglomerático no topo. $\mathrm{O}$ afloramento mostra silicificação que aparentemente não afetou os fósseis e a camada possui $8 \mathrm{~cm}$ de espessura.

A densidade espacial é 0,1 fósseis por centímetro quadrado, o menor índice de todos os afloramentos fossilíferos. Em análise com fósseis maiores que 0,5mm, verificou-se que muitas amostras são aparentemente afossilíferas ou com fragmentos muito pequenos. Em ambas partes do afloramento, os fósseis estão dispersos, sem nenhuma orientação preferencial em planta ou em perfil. Agregados e acumulações pontuais não ocorrem.

O número de fósseis encontrados é o menor de todos afloramento, por isso poucos foram os táxons observados.

Classe Chondrichthyes Incertae Ordinis (possível Petrodus)

Subclasse Holocephali

Ordem Petalodontiformes $\uparrow$

Classe Actinopterygii

Ordem Palaeonisciformes (Parafilético) $\dagger$

Classe Sarcopterygii (ossos indeterminados?)

$(†$ extinto)

Nenhum fóssil encontrado apresenta articulação ou associação de espécimes, a dispersão de fósseis é grande. A seleção granulométrica dos fósseis é má, como nos afloramentos 1-3.

A abrasão e fragmentação são mais acentuadas nos fósseis deste afloramento do que nos outros (Fig. 143). O desgaste dos dentes de petalodontes expôs a dentina tubular, exibindo a pontuação da superfície. Ocorrem muitos fragmentos, de tamanho variado, de escamas e possíveis dentes não identificáveis, angulosos ou com a superfície polida. 


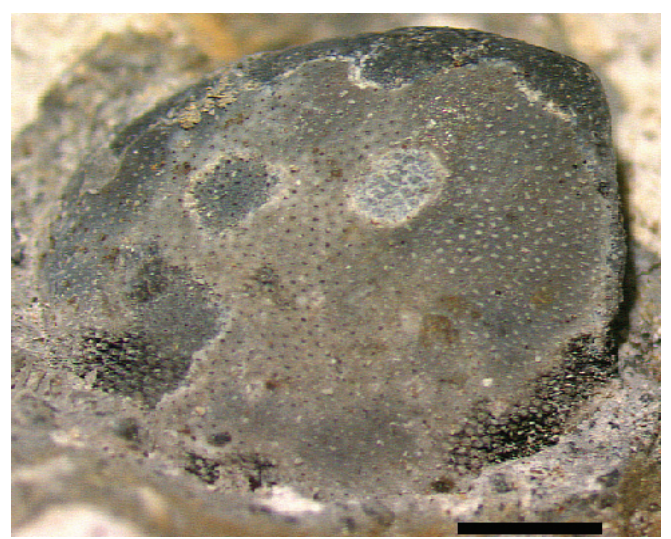

Figura 143 - Dente de Petalodonte (GP/2E-5921B) encontrado no Afloramento 3, muito desgastado pela abrasão, expondo todo o sistema de dentina tubular. Escala $1 \mathrm{~mm}$.

Apesar da maioria dos fósseis apresentar desgaste e quebras, alguns indivíduos de diferentes taxa praticamente ocorrem intactos sem nenhum tipo de retrabalhamento, como ocorre em outros afloramentos da região (Fig. 144). Isso pode indicar que muitos animais viveram na região durante a deposição e portanto o retrabalhamento não foi apenas resultado de transporte.

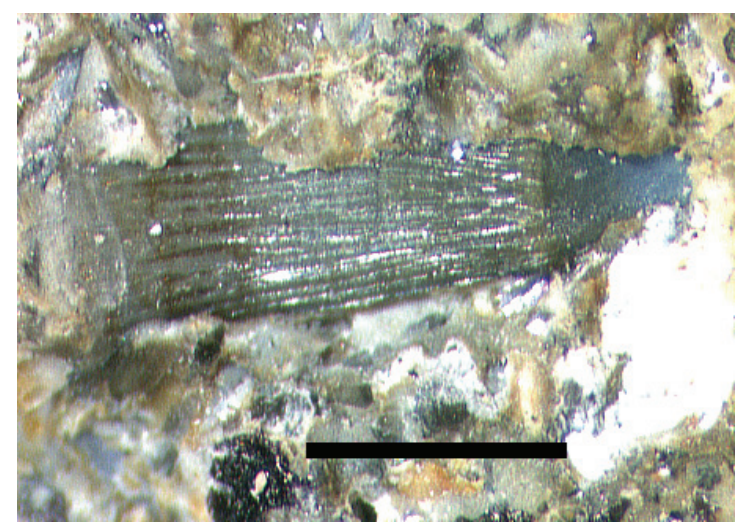

Figura 144 - Dente Palaeonisciformes sem desgaste com estrutura superficial intacta. Escala: $1 \mathrm{~mm}$.

\subsubsection{Afloramentos 12: Fazenda Ponte Nova Ponto C}

O Afloramento 12, Fazenda Ponte Nova, ponto C, ocorre uma camada da base da Formação Irati de aproximadamente $12 \mathrm{~cm}$ de espessura, mas variando localmente até a metade deste valor devido a erosão que afetou o afloramento.

A constituição sedimentológica, de arenitos mal selecionados a conglomeráticos, é parecida com a dos afloramentos do Sítio Santa Maria, porém no contato com a Formação Tatuí, a granulomentria varia de arenito grosso a muito grosso, com clastos e bioclastos maiores. 
A concentração fóssil é similar a do Afloramento 3, aproximadamente 0,5 fóssil $/ \mathrm{cm}^{2}$, mas os fósseis não estão dispersos e ocorrem como pequenas acumulações e agregados.

Os maiores fósseis estão concentrados na base, em contato com a Formação Tatuí

Como nos demais afloramentos, em planta não há orientação dos fósseis, contudo, em perfil, o material fóssil geralmente se apresenta concordante ao acamamento.

O número de táxons identificados neste afloramento é semelhante a do afloramento 1 e incluem:

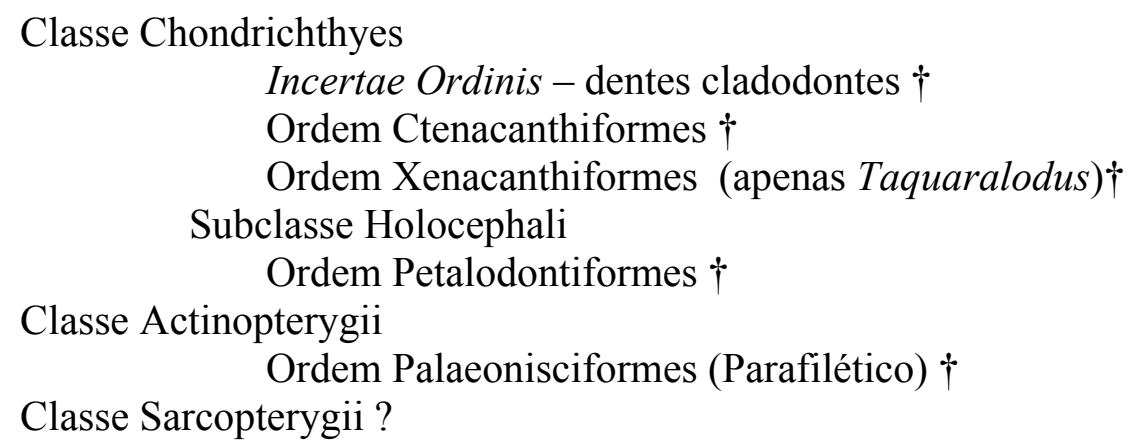

A composição taxonômica do material é politípica, consistindo de escamas, dentes, espinhos e ossos, e poliespecífíca, pois o material representa diversos taxa acima do nível de família das classes Chondrichthyes e Osteichthyes.

Apesar de serem encontrados agregados nenhum consistia de restos do mesmo indivíduo sendo encontrados Chondrichthyes e Osteichthyes juntos (Fig. 145).

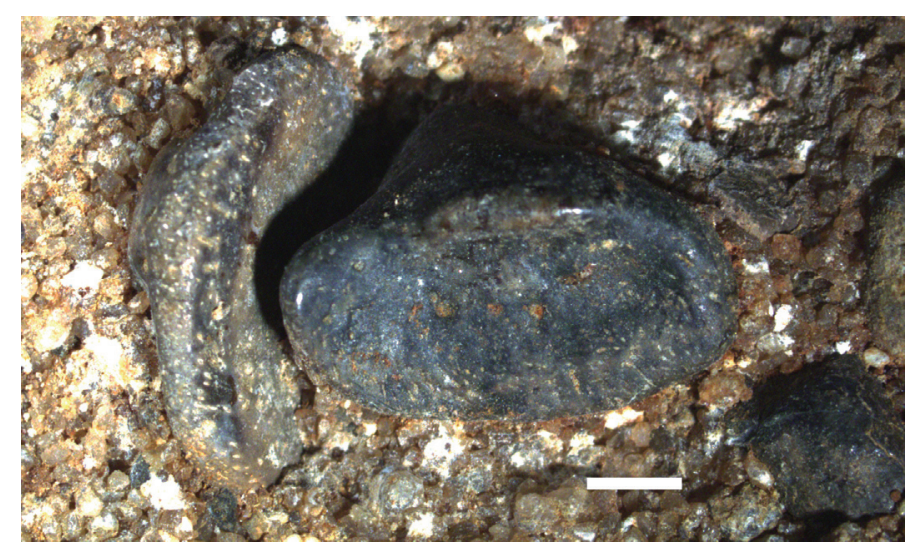

Figura 145 - Dentes de Taquaralodus próximos de um dente menor fragmentado de Palaeonisciformes. Escala $2 \mathrm{~mm}$. 
Não se observou evidência de seleção de fósseis por classe de tamanho, pois os bioclastos variam em comprimento de menos de $0,5 \mathrm{~mm}$ até mais de $50 \mathrm{~mm}$. A forte abrasão fragmentou e poliu muitos fósseis, entre eles escamas de Palaeonisciformes (Fig. 146)

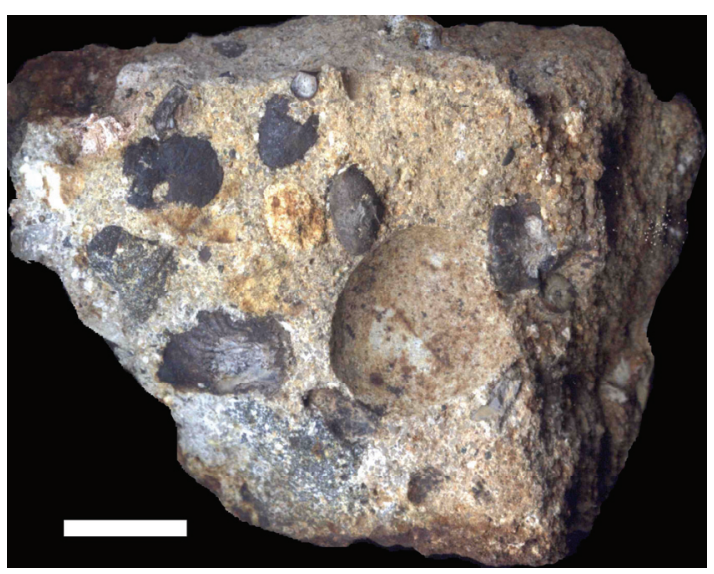

Figura 146 - Amostra proveniente da base do Membro Taquaral no ponto C do Afloramento 12 com inúmeras escamas de tamanho variado acumuladas sem orientação em planta. Escala $1 \mathrm{~cm}$.

\subsubsection{Afloramento 5: Próximo ao Rio Passa Cinco (ocorrências de Clarkecaris)}

Este afloramento expõe uma camada de $10 \mathrm{~cm}$ de espessura nos dois lados do acostamento de uma estrada que dá acesso ao Rio Passa Cinco. Difere dos outros afloramentos por tratar-se de uma faixa de arenitos finos com raros clastos de $0,5 \mathrm{e}$ $1 \mathrm{~mm}$ em todo o pacote.

Ao contrário dos outros afloramentos, a concentração varia de fracamente até densamente empacotada, com muitos fósseis em contato direto, chegando a mais de 10 fósseis por centímetro quadrado b(Fig. 147). Estas diferenças condicionaram a colocação deste afloramento por último.

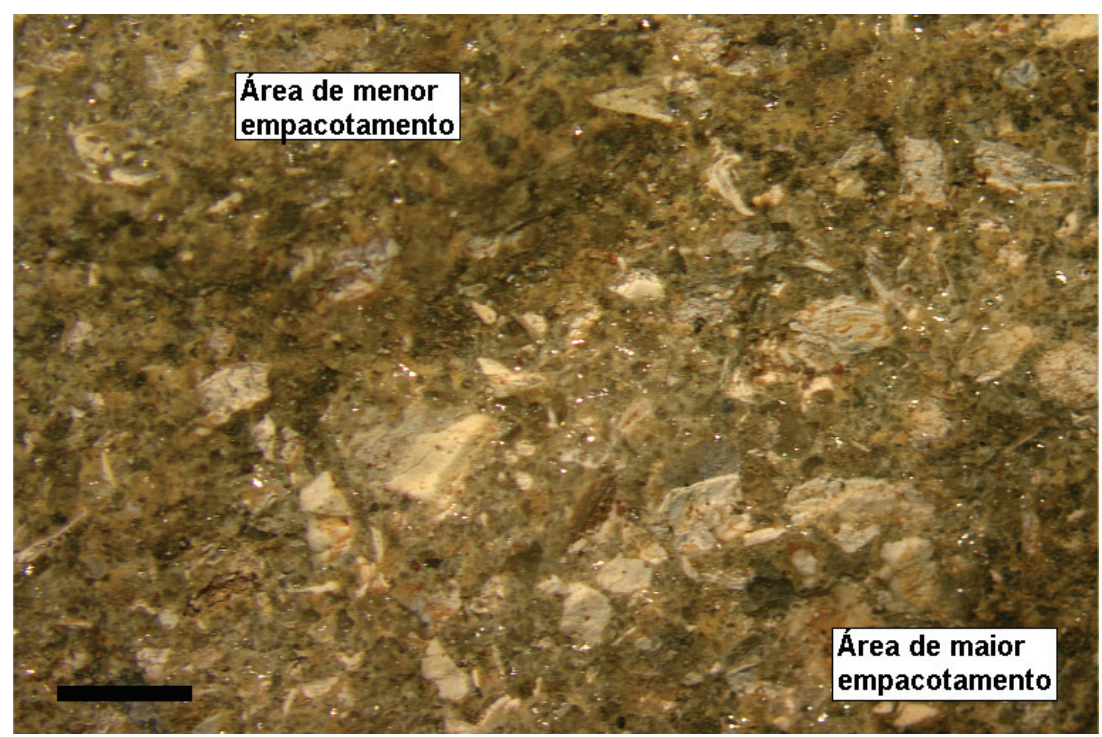

Figura 147 - Região com densidade de empacotamento diferenciado. Escala $2 \mathrm{~mm}$. 
Não há nenhuma orientação em planta (Fig. 148) e alguns fósseis concordantes ao acamamento em vista de perfil (Fig. 149). Os agregados ocorrem como concentrações mais densas, em locais com alto grau de empacotamento.

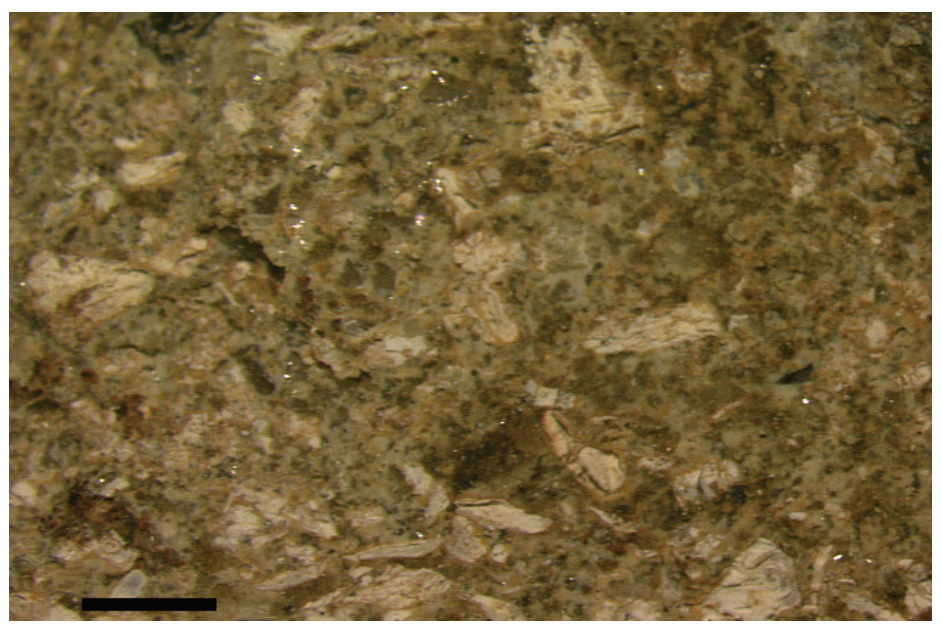

Figura 148 - Vista em planta de amostra proveniente do Afloramento 5. Escala $2 \mathrm{~mm}$.

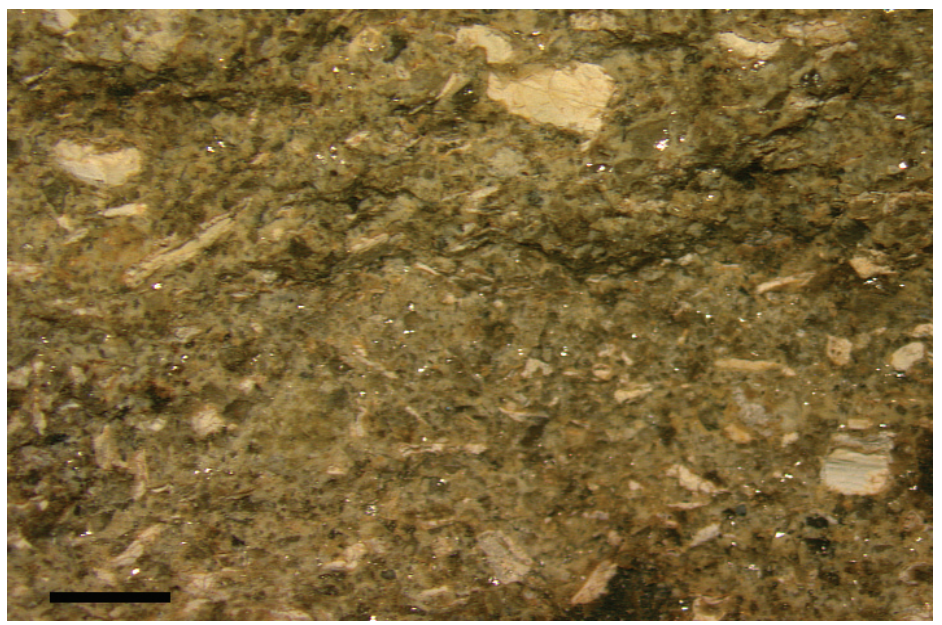

Figura 149 - Vista em perfil de amostra proveniente do Afloramento 5. Escala 2mm.

Os táxa são representados basicamente por escamas, ossos e dentes de peixes ósseos fragmentados ou pulverizados.

Classe Actinopterygii

Ordem Palaeonisciformes (Parafilético) $\dagger$

Classe Sarcopterygii (ossos indeterminados)

$(†$ extinto) 
Apesar da alta densidade de fósseis, não é possível caracterizar uma relação de articulação ou associação de espécimes. Ao contrário dos afloramentos 1 a 3 , a seleção dos fósseis é boa, a maioria com tamanho similar.

A quebra é a assinatura tafonômica predominante neste afloramento e a principal causa da destruição de muitos fósseis, visto que a abrasão não foi muito extensa, pois muitos bioclastos são angulosos e pouco polidos.

\subsection{Discussão da tafonomia e hipóteses paleoambientais}

Os arenitos conglomeráticos dos afloramentos $1-4$ e 12 são produtos de ambiente de alta energia e possuem um conjunto de características sedimentológicas e tafonômicas que apontam para uma origem semelhante. Esta interpretação se baseia nas seguintes observações: seleção muito má do material sedimentar e dos fósseis, fragmentação dos bioclastos, poucos fósseis articulados, abrasão evidente em escamas e dentes e a disposição caótica dos fósseis em planta.

Associados ao material fragmentado são observados: A) fósseis em bom estado de preservação, como dentes com pouca ou nenhuma abrasão pequenas quebras; B) "anfíbios" de grande porte ainda mantendo alguma articulação, dente ainda articulado em partes ósseas (GP/2T-203). Todas estas características são evidências de pequeno transporte e pouco retrabalhamento ou de um menor período de tempo na Zona Tafonômicamente Ativa (TAZ), não podendo estar relacionado a processos de retrabalhamento de depósitos antigos.

A diferença da densidade espacial dos fósseis entre o afloramento 3, de maior espessura, 4 de maior granulometria e menor densidade espacial de fósseis e o Afloramento 1, de maior densidade espacial estaria ligada a variações de distâncias da área fonte. Esta hipótese é reforçada pela observação das espessuras da camada nos três afloramentos do Sitio Santa Maria. O afloramento mais ao sul, afloramento 3, tem espessura de $43 \mathrm{~cm}$, o afloramento 2 , a $700 \mathrm{~m}$ de distância, tem $15 \mathrm{~cm}$ e o afloramento 1 mais ao norte tem $9,5 \mathrm{~cm}$ de espessura.

Granodecrescência ascendente é a estrutura presente nos afloramentos 1-4 e 12, independente de suas esessuras (Fig.150). os clastos dos arenitos conglomeráticos e conglomerados na base destes afloramentos, teriam sido concentrados provavelmente por ondas de energia relativamente alta. Uma transgressão provocou aumento gradativo da profundidade da água, resultando na granodecrescência. 


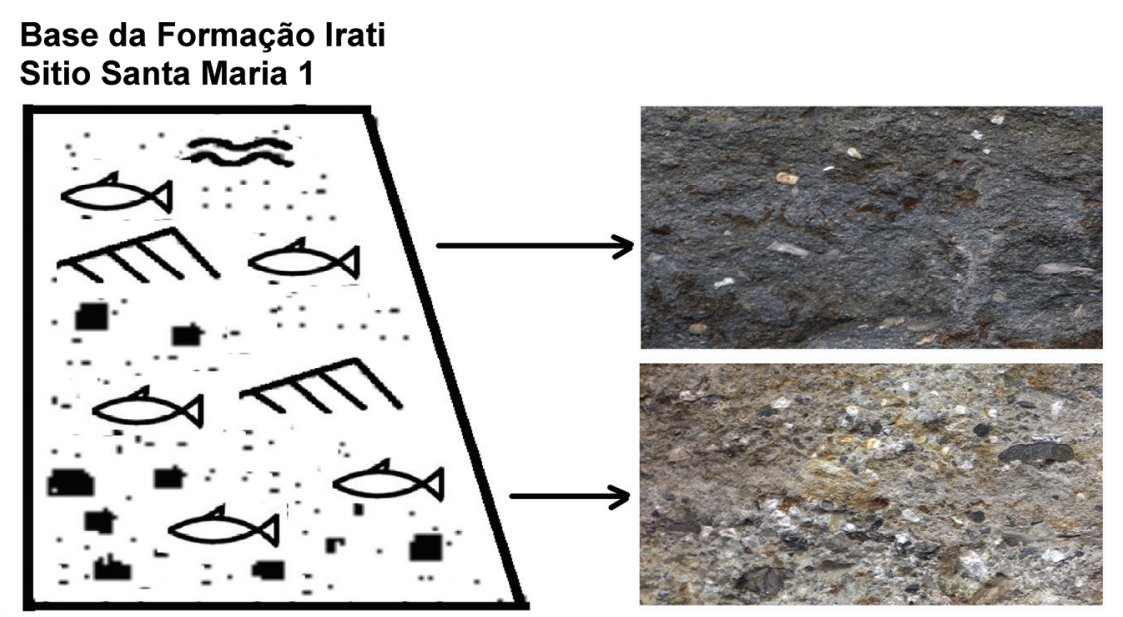

Figura 150- Comparação da base e topo da Camada da base da Formação Irati no Afloramento 1

Estas observações reforçam a proposta de ASSINE et al. (2003) para o retrabalhamento de depósitos residuais transgressivos formados no início de deposição do Membro Taquaral da Formação Irati.

Os depósitos residuais seriam resultado de mudanças do nível de um grande corpo de água: Transgressão acompanhando os eventos de retrabalhamento de depósitos sedimentares pré-existentes na região da linha de costa. O resultado deste processo é a remobilização dos sedimentos mais finos e a manutenção de sedimentos mais grossos, com grânulos e seixos, e concentrações de fósseis mais resistentes e de difícil transporte. A camada resultante raramente alcança $1 \mathrm{~m}$ de espessura (WALKER \& JAMES, 1992; HOLZ \& SIMÕES, 2002).

HOLZ \& SIMÕES (2002) sugeriram que os "Lags" (depósitos residuais) transgressivos indicariam um grande período de tempo de deposição, pois o alto grau de retrabalhamento dos elementos esqueléticos indicaria prolongada exposição e transporte. Por causa destes fatores a mistura espacial e temporal dos fósseis seria comum. Para ASSINE et al. (2003) os sedimentos fluviais depositados anteriormente na fácies Ibicatu da Formação Tatuí foram retrabalhados por ondas com a transgressão, sofrendo processo de joeiramento. Neste processo, os sedimentos mais finos são removidos pelas correntes e a fração grossa fica concentrada como depósitos residuais (lags) sobre superfícies de ravinamento por onda. Tanto para HOLZ \& SIMÕES (2002) como para ASSINE et al. (2003) processos deste tipo são basicamente contínuos que acabariam por resultar na fragmentação dos fósseis, praticamente excluindo fósseis em bom estado de preservação, que de fato não acontece nos pontos estudados, com a existência de fósseis não retrabalhados ou bem conservados. 
Duas hipóteses podem ser consideradas para este caso; A) O estado de preservação variado dos fósseis (dentes e espinhos em bom estado e escamas com muita abrasão) poderia ser causado por mudança repentina de energia do ambiente provocada pela deposição rápida de um evento episódico de maior energia, intensificando o retrabalhamento por ondas e levando material grosso mais para dentro da bacia, B) uma enxurrada causada por um rio durante épocas chuvosas, nesse caso modificando o tipo de sistema deposicional.

Em ambos os casos o aporte sedimentar aumentaria, preservando alguns fósseis mais frágeis e acarretando a mistura temporal.

Observando amostras dos afloramentos 1-4 e 12 foi constatada a presença laminações irregulares de material fino entre camadas de material grosso (Fig. 151) Ocasionalmente estas camadas são de silte ou arenito fino e são mais comuns no Afloramento 1. Uma hipótese estaria no fato de que o depósito seria resultado de eventos episódicos. Eventos de maior energia ocasionavam depósitos grossos, mal selecionados com ictiólitos que poderiam ser encontrados dentro do folhelho síltico do Membro Taquaral. Tal observação foi constatada em uma seção ilustrada por RICCOMINI et al. (1997) na Fazenda Biri, região de Rio Claro e Ipeúna. O evento episódico nesses afloramentos foi predominante, favorecendo a preservação de alguns ictiofósseis mais frágeis, como espinho de Ctenacanthiformes.

A diferença de espessuras em afloramentos do Sítio Santa Maria (1-3) reforça a hipótese de eventos episódicos atuantes, com ondas de maior energia ou uma enxurada vinda do continente acarretando maior aporte sedimentar próximo da rocha fonte, contudo os fósseis de paleoambientes salinos seriam mais facilmente carregados para áreas mais profundas e os de água doce teriam as mesmas proporções nos afloramentos próximos ou distantes (os fósseis de água doce poderiam ser mais comuns nos afloramentos proximos da rocha fonte). Isto é constatado no Afloramento 3, de maior espessura, baixa densidade fóssil, pouquíssimos petalodontes, a ausência, até o momento, do Diplodoselachidae Taquaralodus e de espinhos e a existência de raros Xenacanthidae, estes prováveis fósseis de água doce (Tabela 4).

Em um afloramento da região de Assistência, de mais de $40 \mathrm{~cm}$ de espessura pesquisado por RAGONHA (1978), os espinhos são muito raros, tendo sido visto apenas um exemplar infantil. O afloramento da região de Itapetininga, estudado por RAGONHA (1978), apresentou $1 \mathrm{~cm}$ de espessura e ofereceu maior número de petalodontes do que o Afloramento de Assistência (68 contra 74 em Itapetininga), mas a 
quantidade de Taquaralodus era inversa. Esta análise é discutível uma vez que boa parte do material de Ragonha não tinha características diagnósticas preservadas, por vezes, apenas a base estava preservada. $\mathrm{O}$ autor não cogitou a presença de uma segunda espécie de Xenacanthidae, que poderiam ser atribuídos a estes dentes fragmentados.

Nos afloramentos 1-4 e 12 (Tabela 4) os melhores fósseis e de maior tamanho estão sempre associados a granulometria mais grossa da unidade. É possível que este material tenha se depositado em um evento episódico logo no inicio do evento transgressivo que originariam os folhelhos sílticos do Membro Taquaral. A parte mais fina apenas contém restos ósseos, escamas e dentes de Palaeonisciformes e Actinistia de tamanho variado, como observado no folhelho do Membro Taquaral. Esta observação foi constatada anteriormente por RAGONHA (1978) em um afloramento da região de Assistência, em que havia fósseis apenas na rocha mais grossa e mal selecionada.

Evidências de eventos episódicos são também observadas no Afloramento 5, onde a base da camada possui intercalações com o arenito fino a síltico. Estas intercalações milimétricas de arenito fino desaparecem a medida que se sobe na estratigrafia. Este tipo de intercalação representa as primeiras etapas da mudança entre as formações Tatuí e Irati, segundo HACHIRO (1997).

O afloramento 5 provavelmente represente uma extensão geográfica mais distante dos afloramentos citados anteriormente, onde os clastos menores e fragmentos milimétricos de fósseis se acumularam por decantação.Como os bioclastos são mais leves que a rocha, a acumulação fóssil foi muito maior que nos outros afloramentos, aumentando a densidade espacial, porém como são apenas fragmentos pequenos e retrabalhados, não foram observados fósseis em bom estado de preservação.

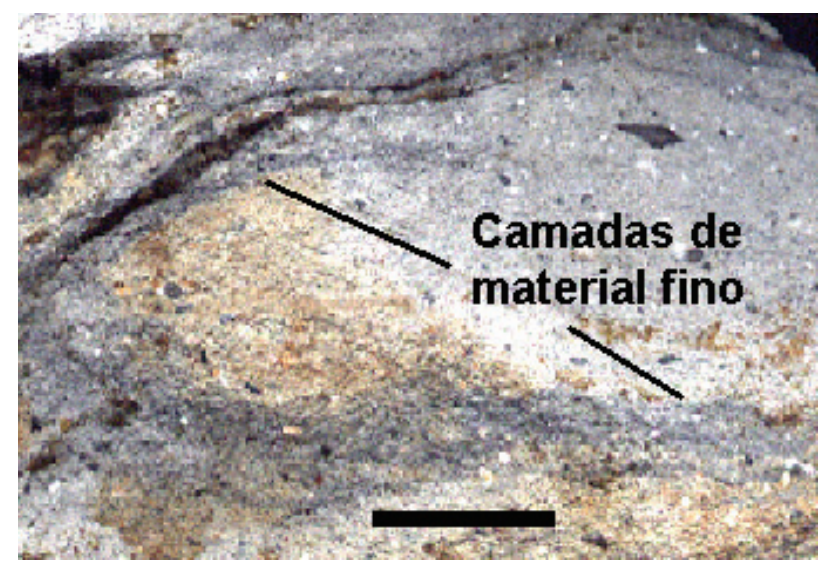

Figura 151 - Amostra proveniente do Afloramento 1 exibindo camadas mais finas entre as mais grossas. Escala $2 \mathrm{~cm}$. 


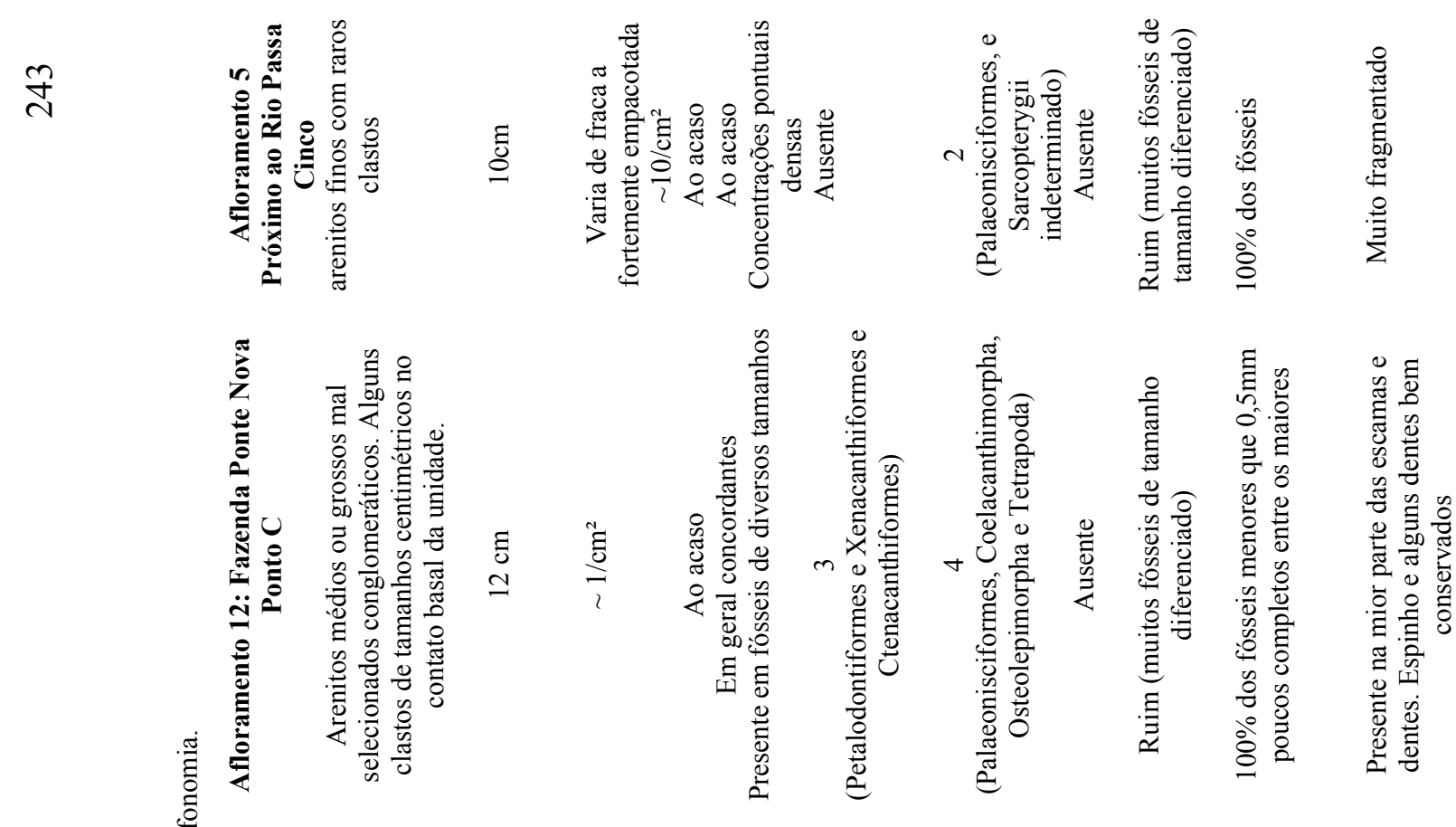

II

InI

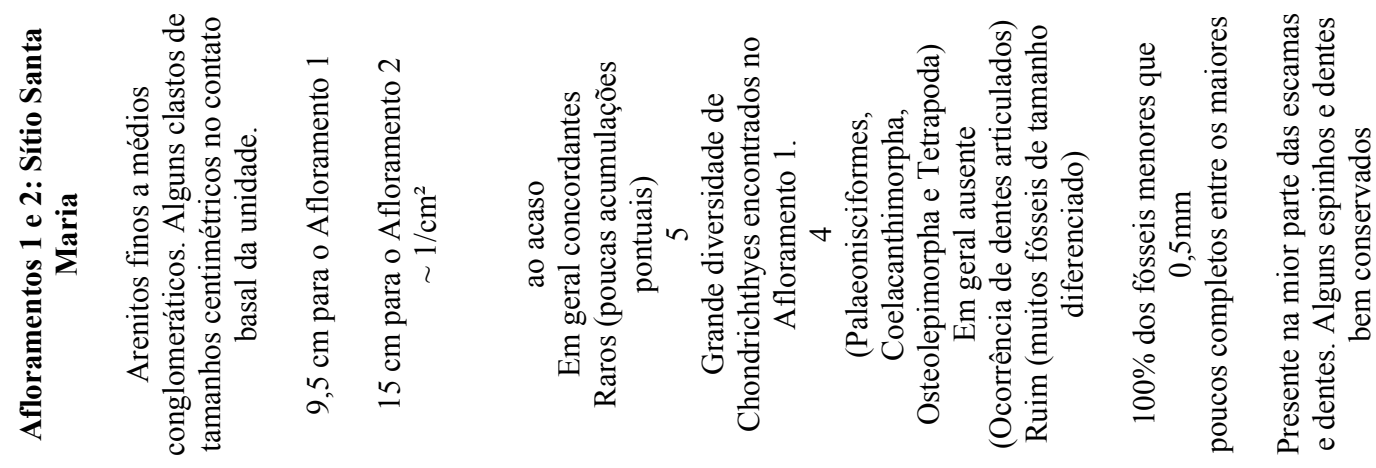

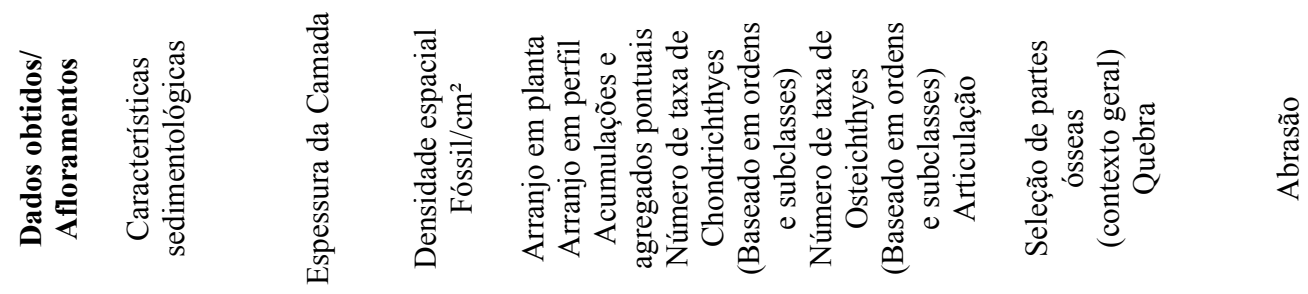




\subsection{Hipóteses sobre a origem da paleoictiofauna}

O repentino aparecimento e desaparecimento de Chondrichthyes eurialinos ou de ambientes salinos, como Petalodontes e Diplodoselachidae (encontrados apenas na base da camada arenosa, fácies Iai) sugere que os peixes estavam limitados a determinado tipo de ambiente (provavelmente costeiro) e que provavelmente o contato entre bacias ou com o oceano aberto em que originou estes grupos de peixes tenha sido repentino ou de curta duração, similar aos eventos quaternários que formaram o atual Mar Negro (RYAN et al., 1997, SOROKIN \& KUPRIN, 2007) e o Mar Báltico (BRENNER, 2005) e após isso teria levado os peixes a extinção.

Esta hipótese encontra resistência exatamente na evolução e origem dos peixes, pois alguns grupos aparentemente ocorrem na Bacia do Paraná anteriormente a este possível evento, como Sphencanthus, provavelmente relacionado com Ctenacanthus gondwanus da Formação Rio Bonito, além de Amelacanthus de características similares às encontradas em fósseis mais antigos, do Mississipiano, como Amelacanthus sulcatus (MAISEY, 1982) muito similar ao descrito no Membro Taquaral. Contudo estes argumentos não excluem a possibilidade de conexão fornecedora de águas salinas para a Bacia do Paraná durante esta época, baseado em peixes não observados anteriormente na Bacia do Paraná e identificados em outras bacias, como Taquaralodus e Itapyrodus da Bacia do Parnaíba.

A presença de ictiofósseis da Bacia do Parnaíba na Bacia do Paraná sugere que nesta época houve intercâmbio de faunas entre as duas bacias. Na história geológica do mundo é possível observar esta relação entre peixes migrando de uma bacia para outra. Em tempos recentes houve a migração de um peixe, Proterorhinus marmoratus, do Mar Cáspio para o Mar Báltico a partir de rios com conexões nas cabeceiras (ANTSULEVICH, 2007).

Atividade fluvial fornecendo fósseis de vertebrados como raros Xenacanthidae e anfíbios provavelmente contribuiu para a formação da assembléia fossilífera.

\section{PALEONTOLOGIA DO FOLHELHO SÍLTICO DO MEMBRO TAQUARAL}

A maior parte do Membro Taquaral da Formação Irati é basicamente constituída de folhelhos siltico-argilosos, cinza escuros e não-betuminosos podendo ocorrer em sua base, arenitos conglomeráticos e arenitos finos. 
Os folhelhos sílticos do Membro Taquaral, quando não estão alterados, são de coloração cinza escura a clara, com cristais disseminados de pirita. Apresenta laminação plano-paralela e fissilidade, mas em alguns casos a laminação é diminuta e de difícil observação. Os folhelhos podem ser completamente argilosos e a laminação continua muito fina.

HACHIRO (1997) observou a ocorrência de camadas betuminosas, rochas carbonáticas e silexítos, subordinados. Essas litologias se situam no contato gradual com o Membro Assistência, sobrejacente. Tais fácies não foram observados no presente estudo, restringindo-se a rochas siltica-argilosas.

\subsection{Estudo de Clarkecaris brasilicus}

Classe MALACOSTRACA Latreille, 1806 Superordem SYNCARIDA Packard, 1885 Ordem ANASPIDACEA Calman, 1904 Família CLARKECARIDIDAE Brooks, 1962 Genus Clarkecaris Mezzalira, 1952 Clarkecaris brasilicus (Clarke, 1920)

Figs. 152 - 153

\section{Sinonímias}

Gampsonix brasilicus Clarke, 1920

Gampsonix brasilicus Clarke, Mezzalira, 1946

Uronectes brasilicus (Clarke, 1920) Mezzalira, 1948

Clarkecaris brasilicus (Clarke, 1920) Mezzalira, 1952

Clarkecaris brasilicus (Clarke, 1920) Mezzalira, 1954

Clarkecaris brasilicus (Clarke, 1920) Brooks, 1962

Clarkecaris brasilicus (Clarke, 1920) Brooks, 1969

Holótipo - Gampsonix brasilicus Clarke, 1920; New York State Museum; Numero de coleção 9738, 9739.

Material - Cinco exemplares de Clarkecaris incompletos. (Fig. 152)GP/1E5689, GP/1E-5690a, GP/1E-5691, GP/1E-5692, GP/1E-5693.

Localização - Provenientes do Afloramento 5 Proximo ao Rio Passa Cinco. 


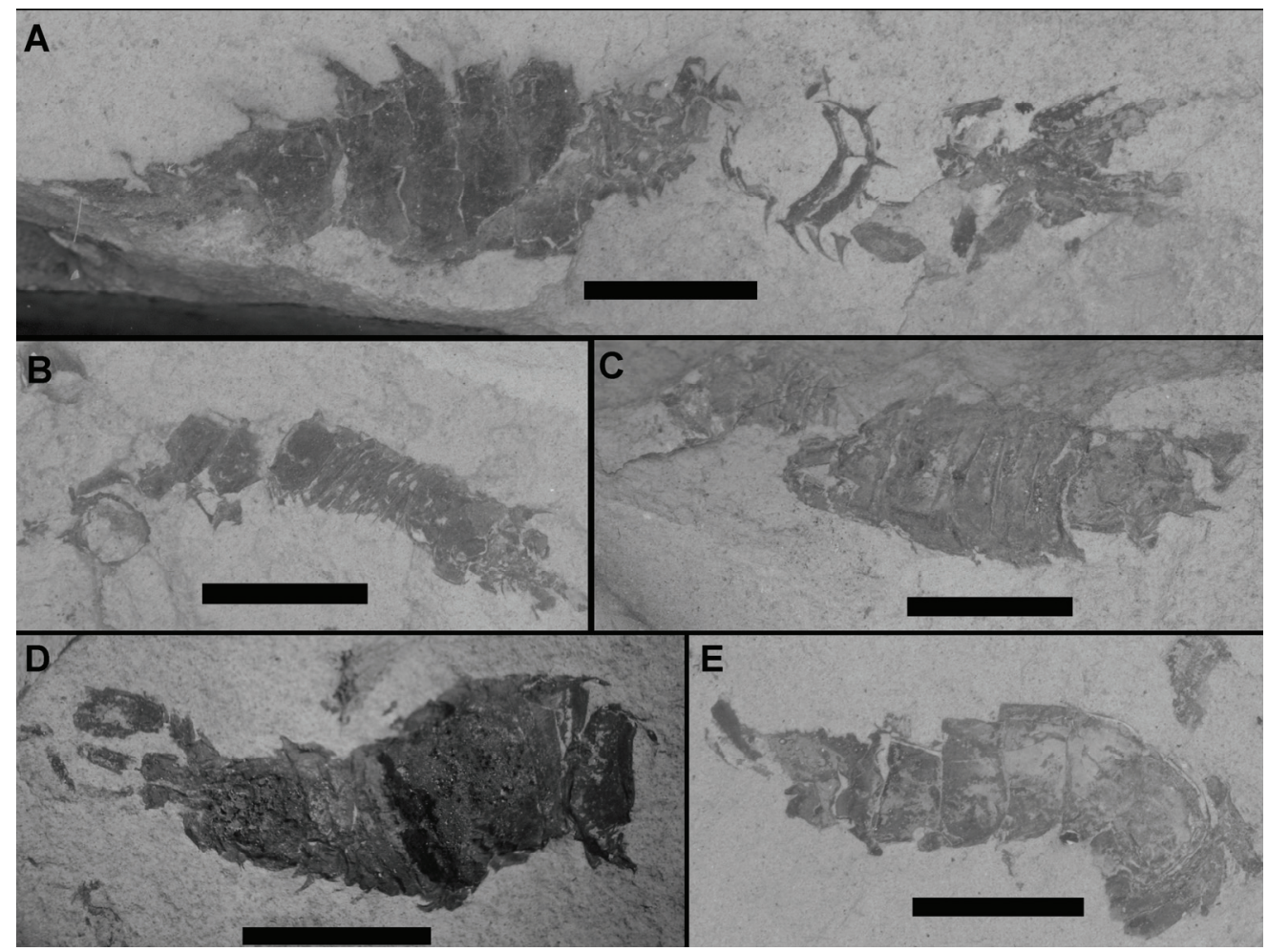

Figura 152 - Exemplar de Clarkecaris encontrado em Rio Claro. A) GP/1E-5691. B) GP/1E-5689; C) GP/1E-5692; D) GP/1E-5693; E) GP/1E-5690a, Escala: 5 mm.

\section{Diagnose (adaptada de MEZZALIRA, 1952 e PINTO, 1985)}

Corpo estreito, alongado, carapaça ausente; somitos torácicos em numero de 8 , estreitos e pustulosos; somitos abdominais em numero de 6 , distintamente mais largos e sem pustulação em série. Telson longo, bífido, com expansões laterais, uma de cada lado, achatadas e terminando em ponta ou em furca. Sulcos transversais fortes dividem o encéfalo em duas partes. Ambas apresentam dois espinhos pterygostomiais grandes. Olhos pedunculados; segunda antena com escafocerita. Sutura entre a cabeça e o primeiro tergito torácico, vestigial; espinho torácico longo e pleura abdominal direcionada tanto anteriormente quanto posteriormente; dois grandes espinhos supraorbitais e dois espinhos dorsais hepáticos (Fig.153).

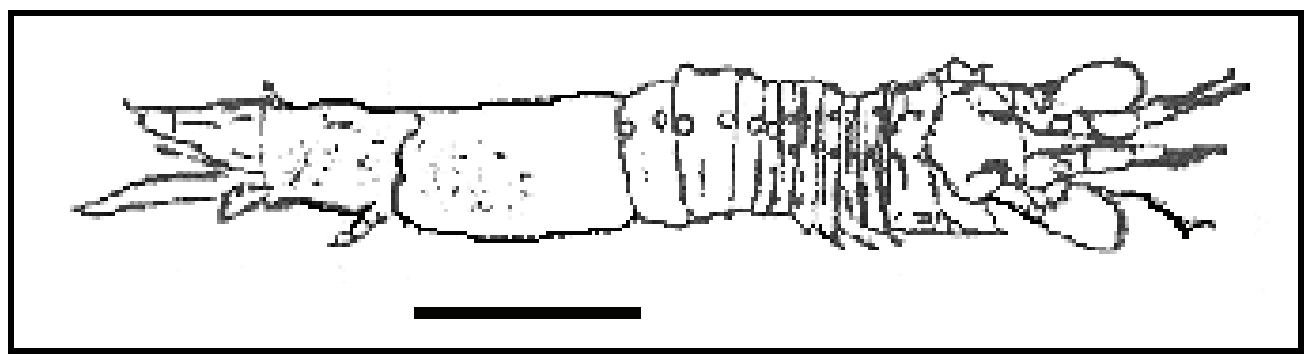

Figura 153 - Reconstituição de Clarkecaris (BRITO et al. 2000). Escala 4mm. 
Características gerais e discussão - Os crustáceos do gênero Clarkecaris são reconhecidos facilmente nos folhelhos do Membro Taquaral no Estado de São Paulo. Os apresentados aqui são representantes típicos, não somente pelas suas características, como também pela preservação. São fósseis comuns, mas raramente foram encontrados exemplares completos. Isso prejudicou a análise de diversos pesquisadores que trabalharam com o gênero.

O corpo é estreito e alongado em todos os exemplares. Em três exemplares foram bem preservados apenas os segmentos abdominais. A carapaça, em geral, não é preservada no exemplar GP/1E-5691 (Fig. 152A) foram preservados os espinhos pterygostomiais.

Os somitos torácicos são lisos e sem ornamentação, como podem ser observados nos exemplares GP/1E-5689 e GP/1E-5692 (Figs. 152B e 152C) e os somitos abdominais são largos dotados de pequenos espinhos nas extremidades voltadas para a parte posterior do indivíduo (Fig. 152A e 152E) (GP/1E-5691 e GP/1E-5690a).

Os fosseis estão comprimidos em praticamente todos os indivíduos. Os somitos torácicos e abdominais podem ocorrer imbricados, como observado no exemplar GP/1E-5693 (Fig. 152D).

Originalmente descobertos no município de Guareí, Estado de São Paulo, estes crustáceos foram identificados por CLARKE (1920) como uma nova espécie de Gampsonyx, baseado em dois espécimes fragmentados que apenas possuíam tórax, abdômen e a região caudal.

Em revisão MEZZALIRA (1952), com espécimes melhores, forneceu detalhes do cefalotórax, abdômen e télson, que o levou a propor um novo gênero, Clarkecaris, dentro da família Uronectidae.

BROOKS (1962), baseado em um exemplar de uma coleção na América do Norte, discordou que o gênero pertencesse à família Uronectidae e o colocou em uma família própria Clarkecarididae dentro da ordem Anaspidacea. Para o autor não existe relação evolutiva direta com os Anaspidacea atuais. BROOKS (1969) e PINTO (1985) sugeriram a ordem Stygocaridacea, porém esta ordem atualmente está inclusa dentro de Anaspidacea.

MEZZALIRA (1971) e PINTO (1985) descreveram características do céfalo como apêndices cefálicos e espinhos pterygostomiais. Um dos exemplares de PINTO é o único, descrito na literatura encontrado fora do Estado de São Paulo, no Estado do Paraná, é um dos pouquíssimos completos. Este fóssil, descrito inicialmente por BRITO 
\& QUADROS (1978), exibe detalhes do céfalo que permitiram a PINTO (op. cit.) completar a diagnose proposta por MEZZALIRA (1952).

Ao todo a diagnose de Clarkecaris brasilicus foi baseada em 10 exemplares incompletos com detalhes anatômicos que auxiliaram na compreensão da espécie.

\subsubsection{Estratigrafia, Paleoambiente e Paleogeografia de Clarkecaris brasilicus}

A colocação do Membro Taquaral como parte da Formação Irati e, conseqüentemente, a consideração de dois membros para a formação (Taquaral e Assistência) foi proposta por BARBOSA \& GOMES (1958) com base na ocorrência de crustáceos em ambos os membros. Contudo Clarkecaris é exclusivo do Membro Taquaral. Além disso a presença de determinados fosseis não deve ser utilizada para definir unidades litoestratigraficas. Contudo, a posição do Membro Taquaral dentro da Formação Irati teve aceitação unânime entre os estratígrafos desde proposição de BARBOSA \& GOMES (1958). Não só pela ausência de discordância entre os dois como também por evidenciar evolução gradativa das condições paleoambientais (HACHIRO, 1997)

O gênero Clarkecaris é exclusivo dos estados de São Paulo e Paraná, não ocorrendo em outros locais e na África do Sul. O paleoambiente habitado por Clarkecaris é controverso, sendo discutido se habitou ambientes salinos ou dulciaquícolas. BEURLEN (1931) aventou a possibilidade de que este fóssil fosse de água doce, baseado nos Anaspidacea atuais, porém está observação não seria suficiente para considerar o paleoambiente como de água doce. MEZZALIRA (1952) discutiu o paleoambiente de Clarkecaris e apesar de alguns gêneros próximos filogenéticamente (Anaspidites) preferirem água doce, não sentiu-se seguro sobre o ambiente onde vivia Clarkecaris, águas salinas ou doces. BEURLEN (1931) e MEZZALIRA (1952) concordaram que este gênero provavelmente habitasse regiões costeiras e não na parte mais profunda da Bacia do Paraná. Este fato tem fundamento, pois os exemplares encontrados estão em regiões mais próximas da borda da bacia.

Clarkecaris brasilicus foi comparado com os Syncarida Paleocaridacea do Carbonífero, Squillites e Palaeocaris. Segundo SCHRAM \& SCHRAM (1974) Clarkecaris representaria um elo de transição entre os Paleocaridacea, mais primitivos, e os Anaspidacea atuais do gênero Anaspidites. O paleoambiente de Squillites é duvidoso, pois seus fósseis foram encontrados associados a animais de água doce e eurialinos. Outro gênero Palaeocaris foi durante muito tempo considerado de água 
doce, mas foram encontrados fósseis associados a paleoambientes estuarinos ou de salinidade variável (SCHULTZE, 2009). SCHRAM (1977) e SCHRAM \& SCHRAM (1974) consideraram os mais primitivos Syncarida do Devoniano, marinhos, passando no Eocarbonífero para águas menos salinas e também doces. Muitos grupos de Syncarida Anaspidacea se restringiram aos continentes sul-americano e australiano tendo o Gondwana como refúgio no final do Paleozóico.

SCHRAM (1977, 1978), contudo, erroneamente acreditou que Clarkecaris e Paulocaris estivessem associados na Formação Irati.

Um estudo significativo sobre a migração de seres vivos marinhos para água doce foi realizada por PARK \& GIERLOWSKI-KORDESCHB (2007) que observaram grande aumento de depósitos lacustres entre o Devoniano e o Carbonífero que teria favorecido a passagem para o novo ambiente para a fauna e flora, antes marinha, favorecendo o inicio do domínio terrestre.

\subsection{Crustáceo indeterminado}

Superordem "Incertae sedis"

Figs. 154

Material - GP/1E-6173A e GP/1E-6173B (parte e contraparte) (Fig. 154A e 154B).GP/1E-6174 (Fig. 154C)

Localização - Provenientes do Afloramento 5 Proximo ao Rio Passa Cinco.

Descrição - Os exemplares apresentam apenas a carapaça preservada. O formato do encéfalo é ovalado com o rostro proeminente. O rostro é triangular podendo ter um prolongamento do "dente rostral", este irregular. Não foram observadas ornamentações no rostro. Os exemplares coletados exibem quelas de dois tipos quanto ao seu desenvolvimento.

No exemplar de quelas de maior porte (Fig. 154C) foram observados espinhos muito pequenos semelhantes as das lagostas e camarões atuais. No exemplar de quelas menores não foi observada, talvez pelo pequeno tamanho.

Os quelípodes são bastante reduzidos (Figs. 154A, 154B e 154C) comparado com os Decapoda atuais, porém as articulações são muito semelhantes. Ocorrem deformações em ambos os fósseis por achatamento por diagênese.

O comprimento da quela do exemplar GP/1E-6174 tem $7 \mathrm{~mm}$, a largura da quela maior; $2 \mathrm{~mm}$, comprimento das quelípodes; $11 \mathrm{~mm}$, sendo igual nas duas quelípodes. $\mathrm{O}$ 
comprimento da carapaça sem as quelípodes é de $12 \mathrm{~mm}$ e a largura $6,5 \mathrm{~mm}$, o rostro tem $3,4 \mathrm{~mm}$ de comprimento máximo.
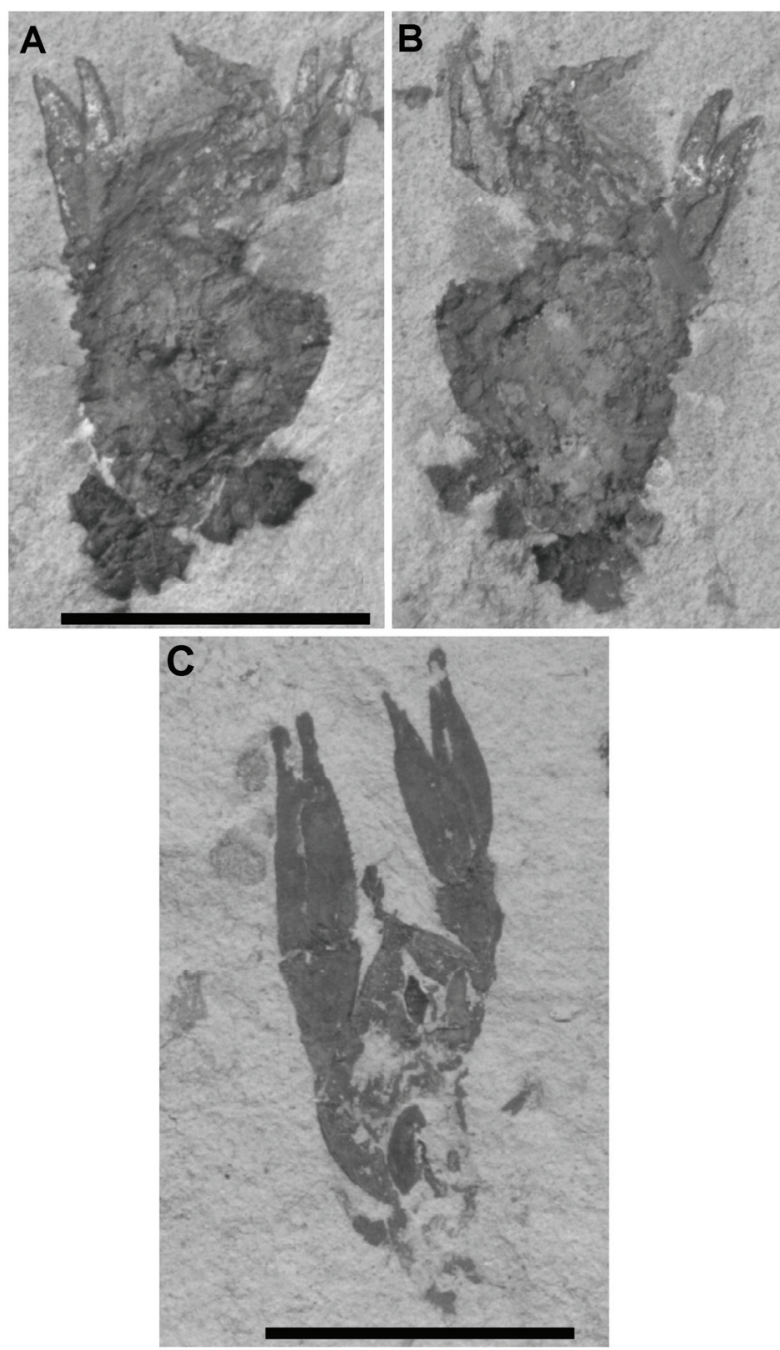

Figura 154 - Crustáceo indeterminado. A) GP/1E-6173A parte e B) GP/1E-6173B contraparte. C) Exemplar GP/1E-6174. Escala 10mm.

O comprimento da quela do exemplar GP/1E-6173A é de $2 \mathrm{~mm}$, largura de $1 \mathrm{~mm}$, o comprimento das quelípodes $7 \mathrm{~mm}$ (medido no preservado). O comprimento da carapaça sem as quelípodes é de $18 \mathrm{~mm}$ e a largura $8 \mathrm{~mm}$, o rostro, $3,4 \mathrm{~mm}$

As quelas de um dos exemplares é muito maior em comprimento em relação a largura. 3,5/1 no exemplar com quelas maiores (GP/1E-6174) e 2/1 no exemplar com quelas menores (GP/1E-6173).

A largura da carapaça do exemplar com quelas maiores é menor, porém isto pode estar relacionado à preservação do individuo. 
Discussão - Nenhum pereonito ou somito torácico está preservado, como também outras partes do animal. As quelas são a característica principal deste crustáceo. Podendo ter o tamanho aproximado do rostro ou então muito maior e aparentemente mais fortes e robustas em comparação com o outro exemplar. Esta variação anatômica poderia ser indicativa de dimorfismo sexual, como ocorre em diversos grupos de artrópodes (FAIRBAIRN \& PREZIOSI, 1994).

Os exemplares foram coletados no mesmo afloramento onde foram encontrados os exemplares de Clarkecaris e são os únicos crustáceos paleozóicos da Bacia do Paraná com quelas e quelípode. Dadas as articulações dos quelípodes é possível inferir que seria um Malacostraca, porém seriam necessárias maiores informações para afirmar a que ordem pertence.

O novo exemplar apresenta pinças, uma característica incomum, raramente observada em espécies paleozóicas (SCHRAM, 1980 e 1981). Apesar de fragmentada a carapaça também difere de muitos grupos de crustáceos da época (SCHRAM, 1974, 1978 e 1981).

FOEHRINGER \& LANGER, (2003 e 2004) foram os primeiros a observar essa nova forma de crustáceo, sugerindo que pertenceria aos Decapoda, subordem Reptantia, baseados nas quelas e carapaça.

Decapodos e Eucarida são raros no Paleozóico e formado por poucas espécies, normalmente desproviodos de quelas (SCHRAM, 1980, 2006)

A sugestão de FOEHRINGER \& LANGER, (2003 e 2004) pode ter sido precipitada, pois a possibilidade de ser um Tanaidacea deve ser considerada, visto existirem fósseis com quelas, provenientes do Neopaleozóico, como Ophtalmapseudes rhenanus do Permiano da Europa (KNOPF et al. 2006). Nesta espécie, os quelípodes são reduzidos e as quelas estão voltadas para traz e para baixo, enquanto nos exemplares aqui descritos, as quelípodes são voltadas para frente. A falta de somitos torácicos e do abdômen, infelizmente impedem a confirmação deste fóssil como Decapoda ou Tanaidacea.

\subsection{Classe Actinopterygii (Palaeonisciformes)}

$$
\begin{gathered}
\text { Superclasse OSTEICHTHYES Huxley, } 1880 \\
\text { Classe ACTINOPTERYGII Cope, } 1887 \\
\text { Ordem "PALAEONISCIFORMES" (parafilético) }
\end{gathered}
$$

Família incertae sedis

Fig. 155. 
Material: Escamas (Fig. 155A-155D) (GP/2E-6222a, GP/2E-6222b GP/2E6223, GP/2E-6225) e uma maxila (Fig. 155E) (GP/2E-6231).

Localização: Fósseis provenientes de dois afloramentos. O exemplar (GP/2E6223) provém do afloramento 1, Sítio Santa Maria 1 Os demais do afloramento 5 próximo ao Rio Passa Cinco.

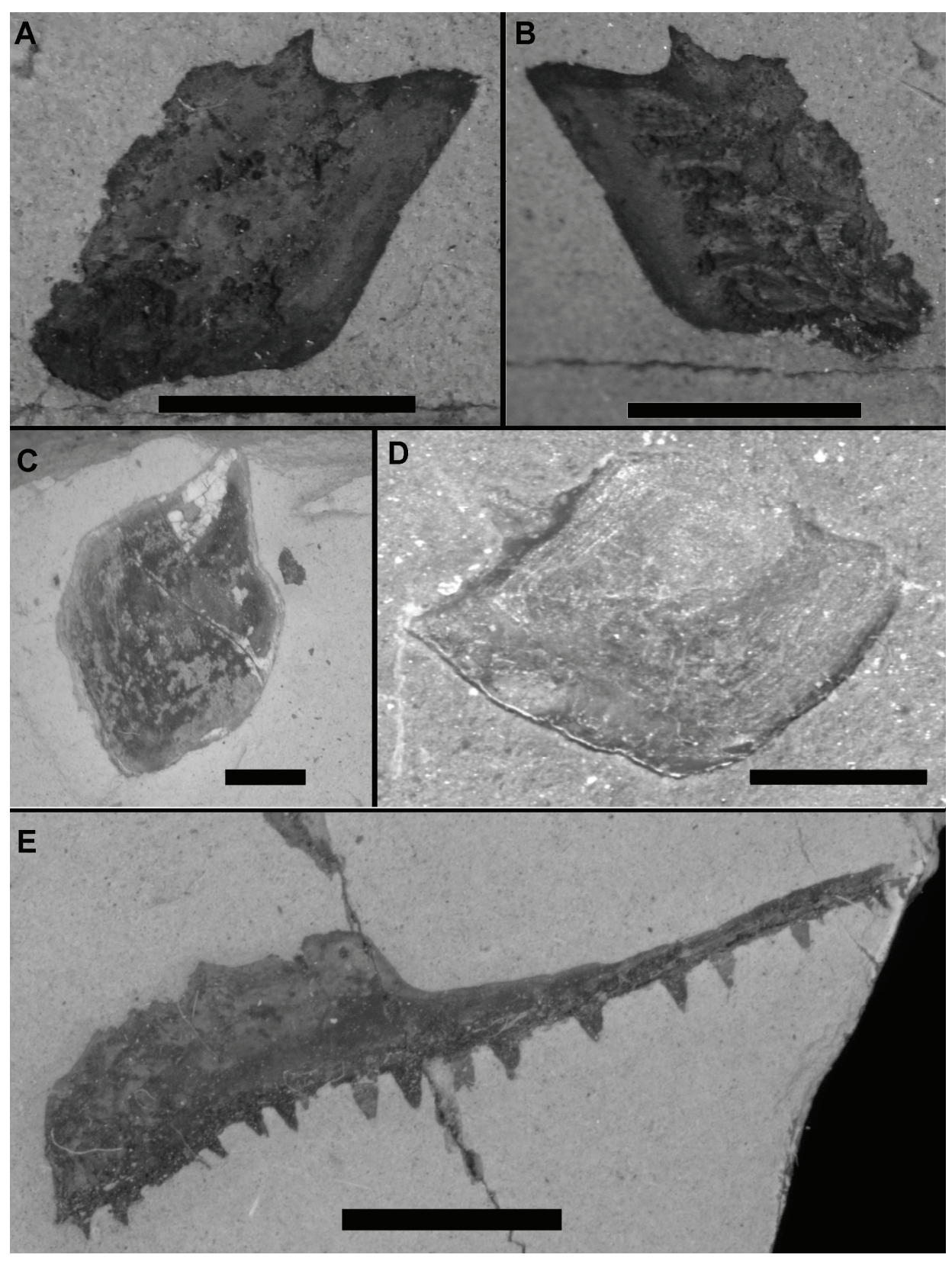

Figura 155 - A) Escama Palaeonisciformes (GP/2E-6222a); B) Contraparte da escam de A) (GP/2E6222b) com evidência de ornamentação na superfície e articulação "peg-and-socket" na lateral superior.

B) Escama (GP/2E-6225) com articulação "peg-and-socket" em destaque como uma "ponta" na extremidade da escama. D) Escama de Palaeonisciformes (GP/2E-6223). Escalas para escamas de $2 \mathrm{~mm}$ E) Maxila de Palaeonisciformes (GP/2E-6231), Escala 4mm. 
Características gerais das escamas - As escamas normalmente são bem preservadas, de formas romboédricas e losangulares em vista superior. Em geral as escamas encontradas possuem margens lisas, sem a articulação preservada. Em algumas, porém, o sistema articulatório "peg-and-socket" é claramente visível (Fig. 155A-155D). Em alguns exemplares esta característica é proeminante apresentando-se como uma grande "ponta" (Fig. 155C) em uma das extremidades da escama e em outro é discreto, localizado nas laterais (Fig. 155A, 155B e 155D).

O tamanho das escamas varia tanto em comprimento quanto em largura, entre 0,5-15 mm de comprimento.

Poucas foram às escamas com algum tipo de ornamentação superficial. O exemplar GP/2E-6222 (Fig. 155B) exibe evidências de ornamentação, porém seu estado de preservação não permite descrevê-la detalhadamente.

Maxila - A maxila (GP/2E-6231) (Fig. 155E) é composta de um osso único, dividido em um sub-orbital frontal, abaixo da região ocular, e um pós orbital atrás da região ocular. O sub-orbital é estreito, afinando-se na face frontal com a região pósteroventral, alongada, projetada para articulação com a mandíbula inferior. Mede 16,7 $\mathrm{mm}$ de comprimento e $2.9 \mathrm{~mm}$ de altura na porção pós-orbital. A região mais fina do suborbital é praticamente reta sem curvatura e a região pós-orbital é alta e alongada, 7,9 $\mathrm{mm}$ de comprimento, com a presença de dentículos em toda a face inferior.

Aparentemente a superfície de osso era ornamentada ou apresentava irregularidades, porém pouco pode - se observar em vista do estado de preservação.

Os minúsculos dentes são cônicos e robustos, nenhum alcança $1 \mathrm{~mm}$ de comprimento. São mais comuns na face interna próximo do pós-orbital do que no suborbital.

Discussão - Baseado na classificação de RICHTER et al. (1985), as escamas aqui observadas foram classificadas em escamas lisas (P-1 ou P-5 de RICHTER et al. 1985). A escama com ornamentação aparentemente pertence a classe P-3, sendo a única pertencente a este tipo na coleção.

Além de escamas rômbicas (ou romboédricas), foram encontradas poucas formas irregulares que podem ser associadas a diversos ossos dérmicos e escamas fulcrais. O formato dessas partes ósseas e escamas variam de retangulares, estiradas ou alongadas. As escamas retangulares são semelhantes às formas observadas por SCHULTZE \& BARDACK (1987), atribuídas a partes de nadadeiras de Elonichthys do hemisfério norte. 
A maxila tem o padrão típico de "Palaeonisciformes", porém não foram encontradas outras que tivessem características morfológicas idênticas as do exemplar. A morfologia alongada do pós-orbital é registrada tanto em formas primitivas, como Paratarrassius, Eocarbonífero (LUND \& POPLIN, 2002), como em formas de idades mais novas do Permiano, como Brasilichthys (COX \& HUTCHINSON, 2001) da Bacia do Parnaíba.

Entre os fósseis descritos do Neopermiano da Bacia do Paraná, o pós-orbital e o sub-orbital são retos e muito alongados, diferindo dos de Tholonotus e Angatubichthys (DUNKLE \& SCHAEFFER, 1956; FIGUEIREDO \& CARVALHO, 2004) da Formação Corumbataí, Neopermiano, da Bacia do Paraná no Estado de São Paulo. A maxila também difere de espécimes encontrados em outras unidades da Bacia do Paraná, como Roslerichthys, Formação Rio do Sul (HAMEL, 2005) e Santosichthys, Formação Corumbataí (FIGUEIREDO \& GALLO, 2006a, 2006b). Provavelmente essa maxila pertença a uma espécie nova de paleoniscóide. Em todos estes casos as maxillas não possuíam o pós-orbital alongado como no espécime encontrado no Membro Taquaral.

O gênero Wendyichthys do Eocarbonífero do calcário Bear Gulch (LUND \& POPLIN, 1997) dos EUA, tem uma maxila com o suborbital estreito e um pós-orbital alongado como observado no exemplar descrito. Possivelmente o referido gênero seria aparentado com os espécimes encontrados no Membro Taquaral, porém somente com fósseis completos será possível chegar-se a uma conclusão definitiva.

\subsection{Classe Sarcopterygii}

Classe SARCOPTERYGII Romer, 1955

Subclasse ACTINISTIA Cope, 1871

Ordem COELACANTHIFORMES Berg, 1937

Família Incertae sedis

Figs 156

Material - Escamas isoladas em parte e contraparte (Fig. 156): GP/2E-5969a e GP/2E-5969b e GP/2E-6233a e GP/2E-6233b.

Localização: Fósseis provenientes de dois afloramentos. O exemplar GP/2E5969 provém do Afloramento 1, Sítio Santa Maria 1 o outro espécime do afloramento 5 próximo do Rio Passa Cinco.

Descrição - Os espécimes consistem de parte e contraparte de escama em bom estado de conservação, que revela detalhes completos de sua anatomia. 
A região de imbricação representa um terço da área da escama e é marcada por diversas costelas longitudinais, curtas e longas, que por vezes se sobrepõem, mas não se ramificam (Figs. 156A-156E). As costelas são lisas, com a forma de pequenos tubos cilíndricos irregulares de tamanho variado.

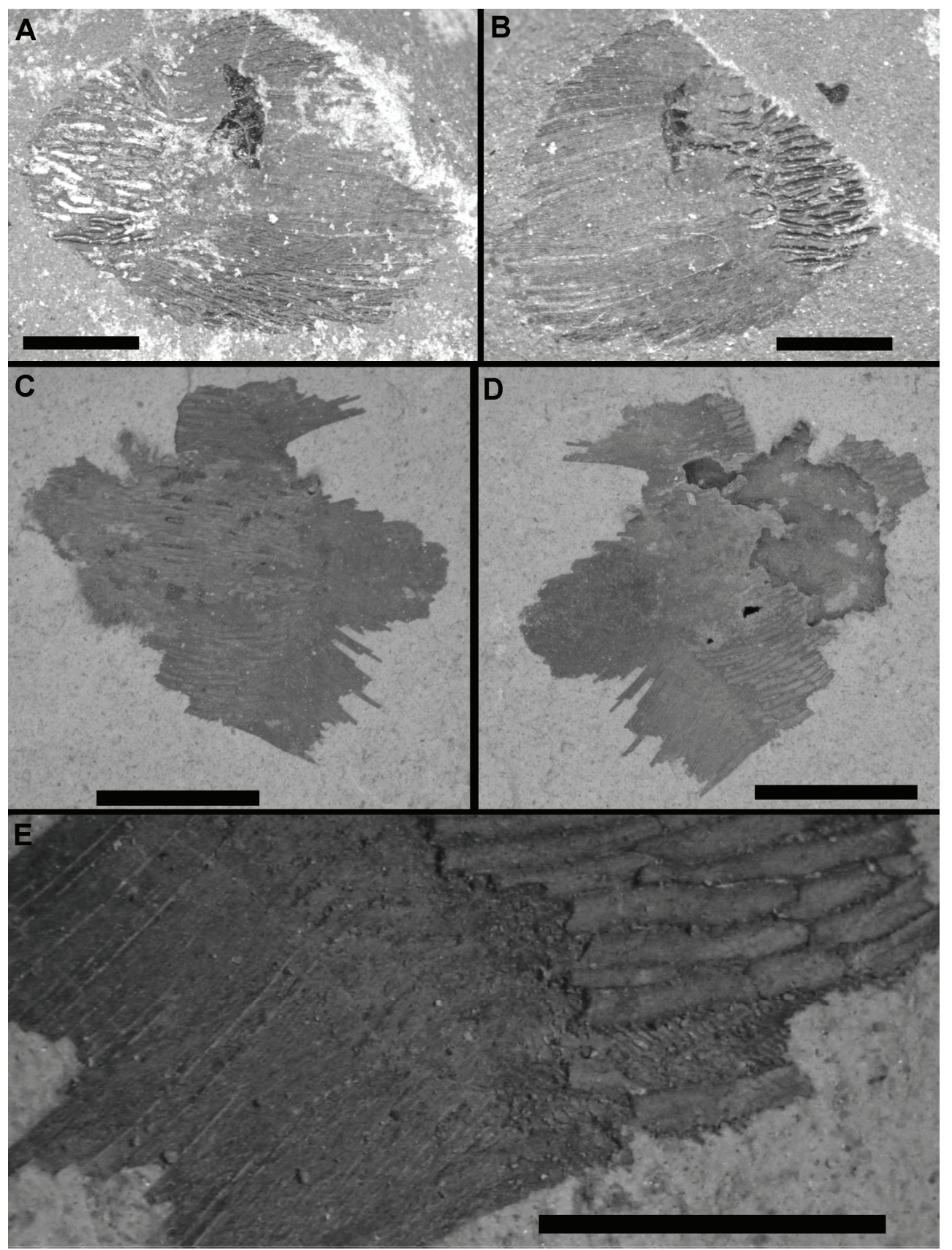

Figura 156 - A) Escama de Actinistia Parte (GP/2E-5969a); B) Escama de Actinistia contraparte (GP/2E5969b). Escalas 2mm. C) Escama Actinistia parte (GP/2E-6233a) e D) contraparte (GP/2E-6233b).

Escala 10mm. E) Detalhe da zona de articulação e das linhas de crescimento do exemplar GP/2E-6233d. Escala $2 \mathrm{~mm}$

As linhas de crescimento na região próxima da zona de imbricação são unidas e ligeiramente encurvadas. No entanto, à medida que se afastam em sentido distal, elas se separam com orientações variadas. 
O comprimento da escama GP/2E-5969 (Figs. 156A e 156B) é de 6,8 mm e a largura de 6,2 $\mathrm{mm}$. Foi possível medir a espessura, 0,1 $\mathrm{mm}$. O comprimento da parte distal é 4,5 mm e da zona de imbricação, aproximadamente 2,3 mm. A região articulatória possui largura menor que a largura máxima da escama, 4,0 mm.

O exemplar GP/2E-6233 (Figs. 156C-156E) é maior e tem o comprimento de 12 $\mathrm{mm}$ e a largura de $12,8 \mathrm{~mm}$. A espessura não supera, $0,1 \mathrm{~mm}$. O comprimento da parte distal é variável, pois está bastante incompleto, porém foi possível medir a zona de imbricação tendo aproximadamente $8,5 \mathrm{~mm}$. A região articulatória possui largura de $10,0 \mathrm{~mm}$.

Discussão - A grande semelhança das escamas descritas com as de celacantídeos atuais do Oceano Índico (Latimeria) justifica sua classificação dentro dos actinístios.

Os exemplares encontrados no Membro Taquaral são muito semelhantes no formato das linhas de crescimento e na zona articulatória, ao material descrito por BRYANT (1929) e BARCELLOS (1975) respectivamente do Carbonífero do Subgrupo Itararé, de São Paulo e do Eopermiano do mesmo subgrupo no Rio Grande do Sul. Também são muito parecidos com a escama identificada por RICHTER (1985) da Formação Irati do Rio Grande do Sul e com as escamas descritas por MARANHÃO (1995) da Formação Corumbataí de São Paulo, no que diz respeito a zona de imbricação.

Embora atualmente sejam ótimos indicadores de ambiente marinho, os Actinistia, durante o Paleozóico, habitaram águas doces e salgadas, não sendo, portanto, bons indicadores paleoambientais.

\subsection{Outros fósseis}

Além dos fósseis ilustrados, são citados na literatura cientifica, diversos outros fósseis, restritos a uma única ocorrência ou simples citações não comprovadas ou ilustradas.

Acumulações de bivalves, muito raros, também foram citadas em finas camadas calcárias que se intercalam nos folhelhos próximos ao topo do Membro Taquaral (KAZUBEK \& SIMOES, 2003a). Estudos recentes revelaram grande quantidade de bivalves de $5 \mathrm{~mm}$ de comprimento médio que, pelas características sedimentares e estratigráficas, podem ser consideradas como topo do membro Taquaral no Estado do Paraná ou uma fase transicional para o Membro Assistência (KAZUBEK \& SIMOES, 2003a e 2003b; ROHN et al., 2003, LAGES, 2004). 
CLARKE (1920) observou gastrópodes do gênero Loxonema e Bellerophon associados aos primeiros Clarkecaris descritos. BEURLEN (1931) ao estudar os fósseis de CLARKE (op. cit.), não confirmou a existência destes gastrópodes na coleção. Também não foram observados gastrópodes na Formação Irati em toda a sua extensão e espessura (AMARAL, 1971; HACHIRO, 1997; CHAHUD, 2007).

Estudos palinológicos foram realizados no Membro Taquaral por diversos autores, tendo sido encontrados alguns grupos de grãos de pólen, acritarcos e a alga Bothryococcus (CAZZULO-KLEPZIG et al. 1989, SOUZA et al. 1992; HOLZ \& DIAS 1998; LAGES, 2004, CARDOSO, 2010)

Segundo HACHIRO (1997) os fósseis citados por CAMPANHA (1985), provenientes de testemunho de sondagem perfurado no município de Marília no estado de São Paulo (localidade onde não aflora o Membro Taquaral), pertenceriam a um braquiópode, Lingula, foraminíferos aglutinantes, Ammodiscus e Sorosphaera, e ostracodes, Bairdia, ocupando o topo do Membro Taquaral ou base do Membro Assistência, não havendo segurança de sua posição estratigráfica.

Estes fósseis não foram observados em nenhum outro testemunho de sondagem ou afloramento e atualmente estão "perdidos" (CAMPANHA, comunicação verbal), não existindo descrições e ilustrações.

Outros fósseis, não identificáveis, são encontrados como impressões ou fragmentos de partes orgânicas (Fig. 157).

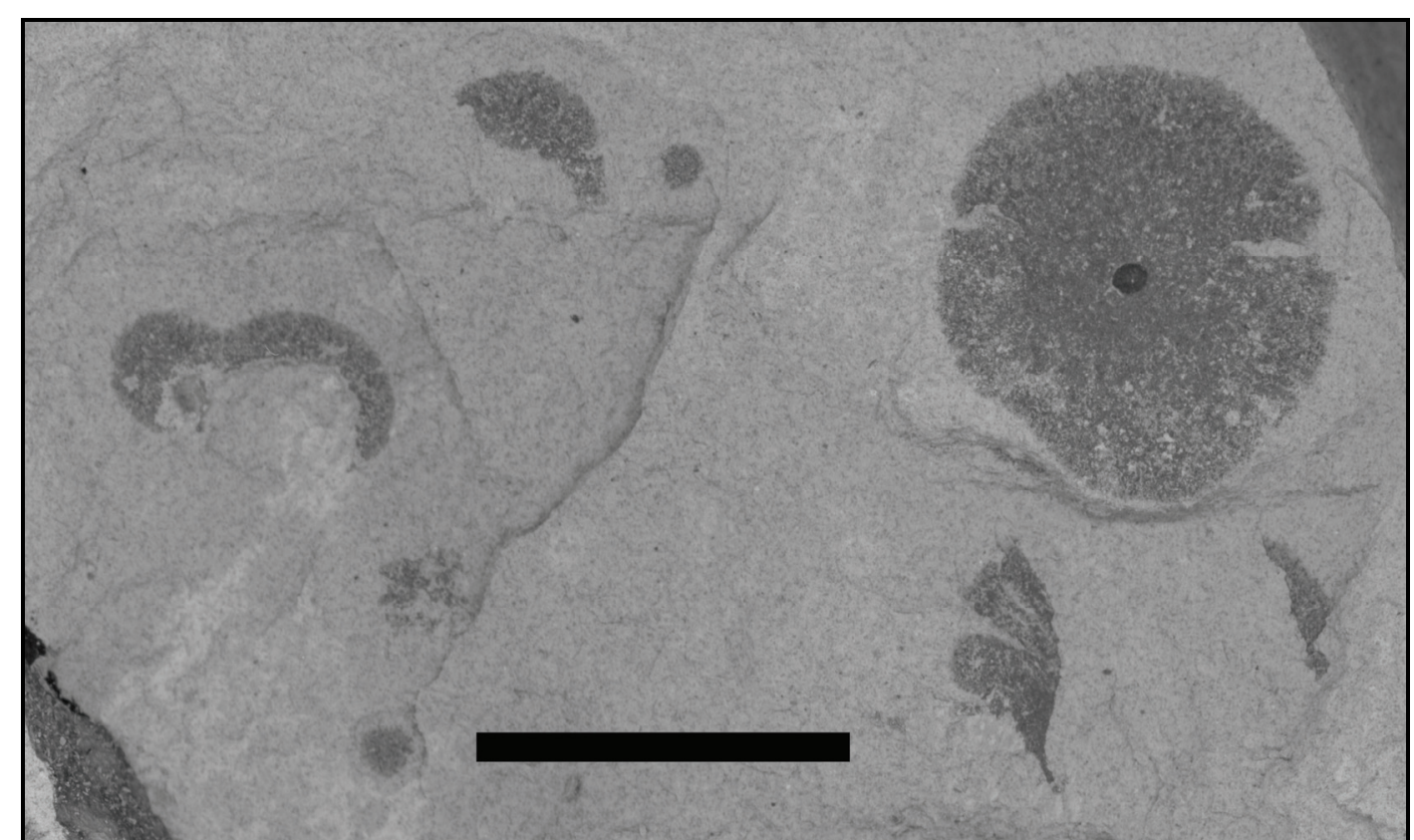

Figura 157 - Restos organicos fósseis dispersos provenientes do Afloramento 5, Próximo do Rio Passa Cinco no município de Rio Claro. Escala 10mm. 


\subsection{Discussão sobre as assinaturas tafonômicas}

A maior parte dos fósseis dos folhelhos sílticos do Membro Taquaral, tanto de invertebrados como de vertebrados, são fragmentos de poucos milímetros a alguns centímetros, praticamente preservados em duas dimensões. Todos os fósseis dos depósitos síltico-argilosos do Membro Taquaral mostram indícios de achatamento e compressão.

Os fósseis de crustáceos do Membro Taquaral exibem estado de preservação muito variado. São observados diversos fragmentos de quitina, somitos (Fig. 158) e formas desarticuladas de partes corpóreas. Ocorrem, também, exemplares completos ou semi -completos do gênero Clarkecaris.

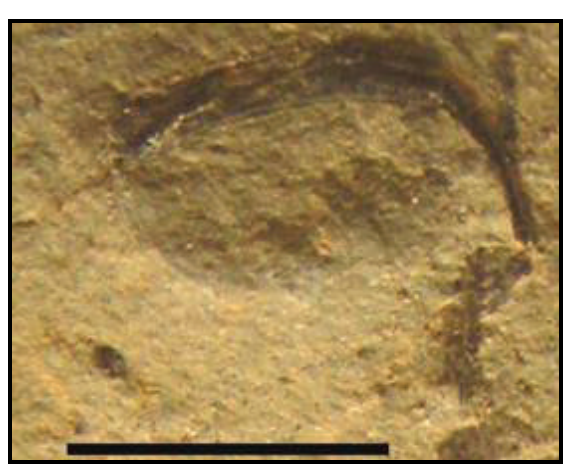

Figura 158 - Fragmento de crustáceo encontrado no Afloramento 1. Possíveis somitos. Escala 2mm.

Entre os Clarkecaris com melhor preservação, destacam-se os indivíduos dobrados, imbricados ou estirados. O comportamento dobrado ou com algum dobramento foi observado em trilobitas, como resultado de defesa ou de distúrbios ambientais (SILVA \& FONSECA 2005), porém ao contrário de trilobites, não existe um padrão em Clarkecaris e por isso tal característica não está relacionada a processos bioestratinômicos ou ao modo de vida desses animais, mas possivelmente a processos diagenéticos.

A parte frontal do cefalotórax dos Clarkecaris raramente se preserva, observação feita também por MEZZALIRA (1952), que sugeriu que a parte frontal seria composta de partes menos resistentes, facilmente decompostas. A presença de exemplares completos de Clarkecaris em folhelhos do Taquaral nas proximidades de Irati, no Estado do Paraná (BRITO \& QUADROS, 1978) e no centro-leste do Estado de São Paulo (MEZZALIRA, 1952 e 1954) poderia ser o resultado do aumento brusco de aporte sedimentar que teria sufocado indivíduos da espécie, com uma nuvem muito densa de material muito fino. Contudo, o grande aporte sedimentar aumentaria a chances de mortandade em massa que se acumularia em alguns níveis, o que não foi 
observado no campo. Outra explicação para a ocorrência esporádica de crustáceos completos ou semi-completos indicaria mudança ambiental, causada por variação pequena de salinidade, resultando na morte de poucos indivíduos.

Os vertebrados encontrados nos folhelhos sílticos do Membro Taquaral são raros e muito dispersos, não havendo acumulações, como também é o caso de fósseis dos crustáceos, mencionados anteriormente. A maior parte dos restos de vertebrados são escamas isoladas de Actinistia e Actinopterygii, algumas em associação com partes ósseas, em bom estado de preservação e pouca fragmentação. As escamas preservaram estruturas articulatórias e boa parte da morfologia externa e interna.

Partes ósseas isoladas, como a maxila, de Palaeonisciformes, descrita foram preservadas, porém, até o momento, em nenhuma localidade, foram encontradas partes articuladas de ictiofósseis.

Ocasionalmente são encontradas acumulações pontuais de escamas de Coelacanthiformes ou Palaeonisciformes. Estas acumulações são desarticuladas e mal preservadas, não necessariamente pertencentes ao mesmo animal (Fig. 159).

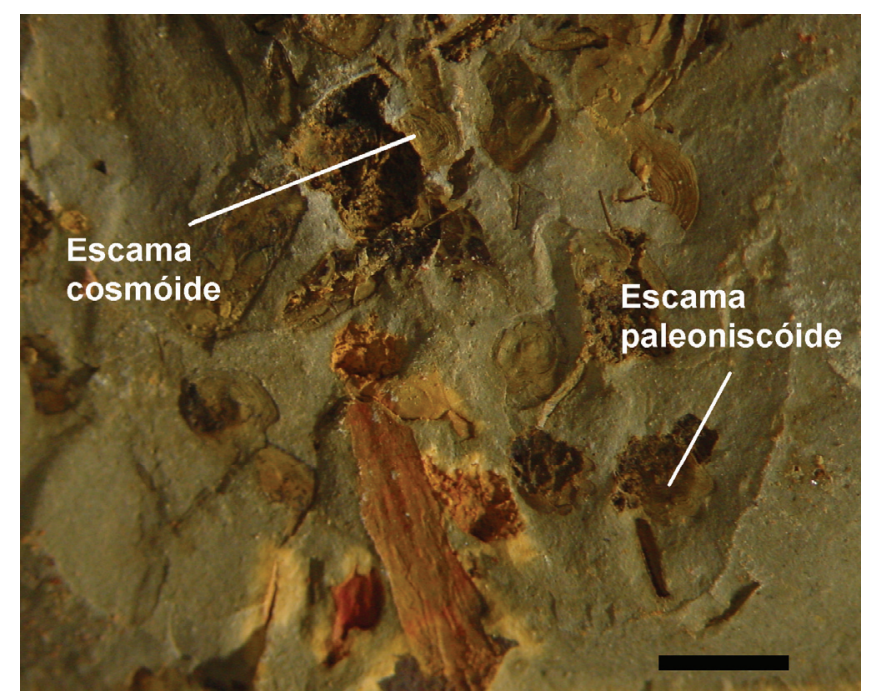

Figura 159 - Acumulação pontual de escamas e partes ósseas encontradas no Afloramento 1. GP/2E6232. Escala $2 \mathrm{~mm}$

Pode-se inferir que a pouca ocorrência de escamas Coelacanthiformes na camada arenosa e a maior ocorrência observada nos folhelhos estejam relacionadas ao grau de energia do paleoambiente. A elevada energia deposicional da base arenosa do Membro Taquaral teria favorecido o aumento da proporção de restos de Chondrichthyes (CHAHUD, 2007, CHAHUD \& PETRI, 2008a). Nos folhelhos sílticos a menor energia do paleoambiente não favoreceu o acúmulo de Chondrichthyes. 
A hipótese alternativa para ausência de Chondrichthyes nos folhelhos seria maior tempo de exposição e à ação de bioturbadores que destruiriam os fósseis, porém a presença de restos de Coelacanthiformes, muito frágeis, escamas paleoniscoides, além de crustáceos completos ou quase completos desqualifica essa hipótese.

O mais provável motivo para o empobrecimento repentino da fauna seria grande mudança paleoambiental, possivelmente gerada por variações de salinidade ocasionada por maior fluxo de água doce durante a deposição dos folhelhos do Membro Taquaral. A hipótese é reforçada pela presença de Anaspidacea, crustáceos que preferem águas doces ou no caso de Clarkecaris com baixa salinidade, em substituição aos fósseis da base arenosa do Membro Taquaral de salinidade maiores (MARASCO et al. 1993; CHAHUD et al. 2010).

\subsection{Discussão sobre os estudos com o siltito Taquaral}

A macrofauna predominante dos folhelhos do Membro Taquaral é constituída principalmente do crustáceo Clarkecaris e de escamas e partes ósseas de Osteichthyes. Os peixes ósseos predominantes são de Palaeonisciformes, pouco presentes os Actinistia.

Até o momento não foram encontrados Tetrapoda ou Chondrichthyes nos folhelhos. Tais fósseis estão até agora restritos à camada arenosa (CHAHUD, 2007) e só voltariam a aparecer no topo do Membro Assistência e nas unidades sobrepostas, formações Corumbataí e Serra Alta (WÜRDIG-MACIEL, 1975; TOLEDO, 2001).

A presença de fósseis eurialinos na unidade e a ausência de fósseis estenoalinos, sugerem que o Membro Taquaral deveria ter salinidade baixa. Provavelmente a unidade era mantida por rios de água doce, como observado atualmente no Mar Cáspio, um corpo d'água isolado.

O Anaspidacea Clarkecaris é endêmico no Membro Taquaral dos Estados de São Paulo e Paraná e pode ter-se originado de espécies surgidas em ambiente de água salgada, migrando para águas menos salinas. Com o possível confinamento do paleoambiente responsável pela deposição do Membro Taquaral, a família Clarkecarididae evoluiu em condições de isolamento.

Nenhum fóssil encontrado no Membro Taquaral apresenta características exclusivas de ambiente marinho, porém alguns fósseis ocorrem em paleoambientes variáveis de salinidades como acritarcos, lingulídeos e os possíveis foraminíferos aglutinantes citados. Os lingulídeos, acritarcos e foraminíferos já foram referidos nas 
formações Palermo ou Tatuí (FÚLFARO et al. 1984; HOLZ et al. 1998) e dada a capacidade de adaptação à variação de salinidade, alguns podem ter sobrevivido às mudanças paleoambientais e chegado ao topo do Membro Taquaral, ficando restritos a condições especificas da bacia, como ocorrem atualmente nos mares internos do Cáspio e Aral (ZENKEVICH, 1957).

O contato com o oceano aberto eventualmente, teria ocorrido durante a deposição da Formação Tatuí ou da Formação Palermo (equivalente da Formação Tatuí, no sul da Bacia do Paraná) e não deve ter sido de longa duração, pois a biota encontrada é pouco variada e tem como características, fácil locomoção e proliferação, podendo ter ocupado rapidamente o novo paleoambiente. Seres viventes em "mar aberto" como: a maior parte dos equinodermos, briozoários, fusulinídeos, foraminíferos calcários, cefalópodes e corais necessitariam de maior intervalo de tempo e de maior estabilidade ambiental, resultado de um contínuo contato entre a bacia e o oceano, como observado em moluscos do Mar Negro, onde animais típicos de água doce foram substituídos por uma fauna marinha (RYAN et al., 1997; SOROKIN \& KUPRIN, 2007).

\section{CONSIDERAÇÕES SOBRE A IDADE DAS UNIDADES DE ESTUDO}

Apesar de muitos trabalhos de cunho estratigráfico, paleoambiental e paleontológico terem sido realizados, foram poucos os que destacaram as idades das unidades, mas todos os trabalhos consideram as unidades em questão como tendo idades permianas, baseadas em paleobotânica e palinologia.

BEURLEN (1953) considerou o Supergrupo Tubarão de idade pensilvaniana (Neocarbonífero) e o Grupo Passa Dois permiana, baseado em macrofósseis e tectônica.

Os trabalhos visando idades utilizaram inicialmente métodos palinológicos. DAEMON \& QUADROS (1970) citaram o primeiro esquema informal de zonas biostratigráficas baseado em palinomorfos e as designaram de $\mathrm{G}$ a $\mathrm{L}$ para rochas neopaleozóicas da Bacia de Paraná. Neste esquema, o Grupo Guatá e a Formação Irati estão dentro das zonas J, K e L, que representariam o Kazaniano (= Guadalupiano) e Tatariano para o Irati do Estado de São Paulo.

DAEMON (1974 apud MEZZALIRA, 1989) analisou 10 metros acima do contato entre os membros Taquaral e Assistência no Estado de São Paulo, registrando idade kazaniana entres os intervalos L2 superior e L3.

MARQUES-TOIGO (1991) detalhou e formalizou o zoneamento palinostratigráfico das zonas K e L para o Supergrupo Tubarão e a Formação Irati nos 
estados de Santa Catarina e Rio Grande do Sul. Esta zona de acordo com a recente revisão de SOUZA \& MARQUES-TOIGO (2003), primeiro surgiu na parte sul da bacia no topo da Formação Rio Bonito e na base da formação Palermo e desapareceu em níveis estratigráficos do topo da Formação Irati.

Uma idade absoluta estabelecida para a Bacia do Paraná apresenta um valor de $267.1 \pm 3.4 \mathrm{Ma}(\mathrm{U} / \mathrm{Pb})$ obtida através de MATOS et al. (2001) na base da Formação Rio Bonito do Rio Grande do Sul. Essa datação foi baseada no zircão mais novo encontrado.

COUTINHO \& HACHIRO (2005) dataram a Formação Irati em 263 milhões de anos, baseados na análise de U-Pb em cinzas vulcânicas, sem especificações detalhdas de como ela foi realizada.

SANTOS et al. (2006) combinaram datações isotópicas U-Pb e de correlação

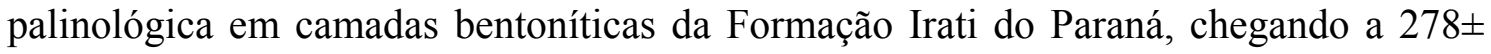
2.2Ma que corresponde ao final do Cisuraliano (Eopermiano). Para ANJOS (2008) a fonte das cinzas datadas por SANTOS et al (2006) seria similar ao do Grupo Mitu, na porção central dos Andes.

MARQUES et al. (2007) analisaram pequenos zircões euédricos de $40 \mu \mathrm{m}$ e obtiveram uma idade para a Formação Rio Bonito em torno de $278 \pm 1.8 \mathrm{Ma}$ (Artinskiano).

ROCHA-CAMPOS et al. (2007) utilizando zircões detríticos do Grupo Itararé e do folhelho Passinho, porção superior do Itararé, obtiveram idades máximas de $356.9 \pm 22 \mathrm{Ma}$ (início do Eotournasiano) e $326.6 \pm 15 \mathrm{Ma}$ (Serpukhoviano) respectivamente. Baseados em zircões vulcânicos dataram quatro camadas da Formação Rio Bonito, em torno de 298.5 $\pm 2.6 \mathrm{Ma}$ (Gzeliano-Asseliano). As formações Irati e Mangrullo foram duas datações: 279.9 $\pm 4.8 \mathrm{Ma}$ e $276.4 \pm 3.7 \mathrm{Ma}$ (Artinskiano) e 275.9 $\pm 4.8 \mathrm{Ma}$ e $269.8 \pm 6.6 \mathrm{Ma}$ (Artinskiano-Kunguriano), respectivamente. A formação Teresina teria $278.9 \pm 1.5 \mathrm{Ma}$ (Artinskiano) e as formações Rio do Rasto/Yaguari: 275.1 $\pm 5.4 \mathrm{Ma}$ (Kunguriano) e 273.5 $\pm 5.4 \mathrm{Ma}$ (Kunguriano), respectivamente.

Comparando as datações realizadas nos estados da região sul e em São Paulo, aparentemente a passagem dos grupos Tubarão para Passa Dois teria ocorrido entre o Artinskiano superior a Guadalupiano inferior (JIN et al., 1997; GRADSTEIN et al., 2004), ou seja, fim do Eopermiano.

Estes dados novos, junto com recentes investigações palinológicas, reforçam a hipótese de idade eopermiana (Artinskiano, Cisuraliano) para o período de transição entre as formações Tatuí e Irati, comparável a idades de camadas equivalentes na África 
do Sul e Argentina (STOLLHOFEN et al., 2000, SOUZA, 2006, SANTOS et al., 2006; AZCUY et al., 2007; MILANI et al., 2007; MILANI \& de WIT,2008).

As idades conhecidas para os grupos de Chondrichthyes fósseis e discutidos anteriormente, não permitem refinamento adicional para a idade artinskiana sugerido por estudos palinológicos e geocronológicos recentes. Por exemplo, Petalodontiformes, o gênero Orodus, e o gênero de Ctenacanthidae Sphenacanthus ocorrem em ambos os períodos, Carbonífero e Permiano, mas a maior diversificação ocorreu no Carbonífero (MOY-THOMAS E MILES, 1971, ZANGERL, 1981, JANVIER, 1996, ELLIOT et al. 2004). SILVA-SANTOS (1990) comparou Itapyrodus punctatus aos gêneros do Carbonífero e Eopermiano Chomatodus e Climaxodus de Europa e América do Norte e MERINO-RODO \& JANVIER (1986) que, com reservas, colocou o petalodonte boliviano (Formação de Copacabana) no gênero Megactenopetalus do Eopermiano da América do Norte e Neopermiano da China (HANSEN, 1978). Tendo em vista que Orodus ipeunaensis é similar a espécies do Carbonífero e Permiano do hemisfério Norte (ELLIOTT et al. 2004) é possível considerar a idade eopermiana como a mais adequada para a base da Formação Irati.

Uma comparação de idades obtidas na Bacia do Paraná no Brasil e na África usando dados recentes pode ser vista na tabela 5 .

O gênero Amelacanthus recém descoberto e a possível relação de Taquaralodus com Dicentrodus contribuem para hipóstese de idades mais antigas, pois tanto Dicentrodus como Amelacanthus são gêneros típicamente do Mississipiano (MAISEY, 1982, HAMPE, 2003) com poucas ocorrências no Pensilvaniano (HAMPE, 2003, ELLIOT et al. 2004). Provavelmente ocorreu o endemismo destes gêneros que ficaram confinados no início do Carbonífero na Bacia do Paraná. Essa hipóstese encontra uma dificuldade, pois nessa época a Bacia do Paraná possuía uma forte glaciação e não foram encontrados estes gêneros associados ao clima frio por isso maiores estudos deverão ser realizados. 
Tabela 5 - Tabelas de idades atribuídas ao permo-triassico da Bacia do Paraná comparando com outras localidades

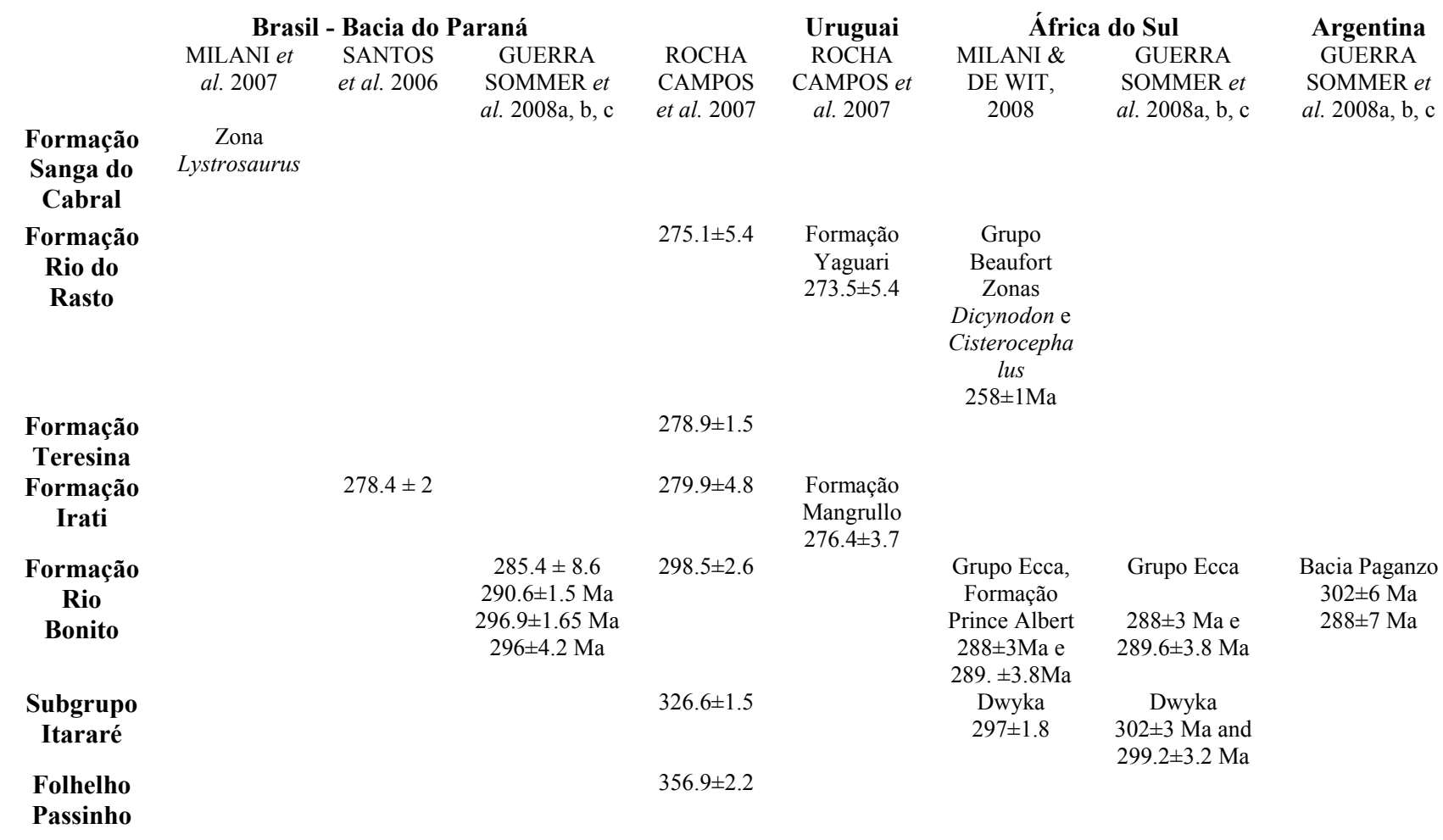

\section{CONCLUSÕES}

Os afloramentos estudados compreendem seis fácies distintas, quatro da Formação Tatuí e duas pertencentes ao Membro Taquaral da Formação Irati.

O Afloramento 12 foi o único que apresentou todas as fácies estudadas da Formação Tatuí, sendo que a basal não tem equivalentes em outros pontos. A fácies siltico-arenosa (Tsa) é a predominante na Formação Tatuí e pode fazer contato direto com a Formação Irati ou associar-se a fácies arenitos grossos (Tag).

A fácies de arenitos grossos ou conglomerados está relacionada às camadas Ibicatu de SOARES (1972), com base na composição sedimentológica. Ocorre, geralmente, a poucos metros abaixo do contato com a Formação Irati, mas em alguns locais o contato pode ser direto como no afloramento 9, seção tipo de Ibicatu (STEVAUX et al. 1986).

A fácies arenitos finos (Taf) ocorre de duas maneiras, com grandes estratificações cruzadas e estratificações "hummocky" ou como maciça com laminações e estratificações cruzadas localizadas e, raros, fósseis no topo.

A principal atividade tectônica nos afloramentos e pedreiras estudados está relacionada ao magmatismo cretáceo que ocasionou fraturas, falhas até deformações 
(afloramento 3) e silicificação na fácies areníticas do Membro Taquaral (afloramento 4) e nas folhelho sílticas (afloramentos 5 e 12).

Os icnofósseis foram observados apenas em três fácies na Formação Tatuí. O primeiro são estruturas verticais atribuídas, provavelmente, ao icnogênero Arenicolites encontrado na fácies basal do Tatuí do afloramento 12 .

O segundo tipo são pistas sem orientação observadas, na fácies arenitos grossos do Afloramento 7. O icnogênero que mais se aproximou foi Palaeophicus, também encontrado no Grupo Guatá da Região Sul (NETTO, 2000).

O terceiro tipo de icnofósseis são estruturas verticais irregulares encontradas no topo da Formação Tatuí em contato direto com o Membro Taquaral no Afloramento 1 (Sitio Santa Maria 1). Não foi possível caracterizá-lo com segurança, contudo aparentemente foram formados em paleoambientes aéreo ou subaéreo. Estes icnofósseis registraram os primeiros momentos deposicionais da Fornação Irati tendo sido imediatamente preenchidos por sedimentos da camada sobrejacente do Membro Taquaral. Observando seu paleoambiente gerador é possível correlacioná-los à icnofácies Psilonichnus.

Os fósseis vegetais encontrados na Formação Tatuí são atribuídos a caules de pteridófitas e espermatófitas. As pteridófitas são os fósseis mais comuns e aparentemente pertenceriam ao gênero Tietea.

As espermatófitas (gimnospermas e pteridospermas) não puderam ser identificadas com segurança, mas foi possível observar a ausência de anéis de crescimento contínuos, apenas vistos aneis interrompidos. Esta informação sugere que não houve grande variação climática durante o período deposicional destes fósseis.

Nenhum fóssil vegetal foi encontrado em posição de vida, mas em posições geradas por transporte e todos apresentavam deformações diagenéticas (compressão).

Os conchostráceos, indicadores de água doce, foram os fósseis mais abundantes da Formação Tatuí e apenas encontrados na fácies síltico-arenosa (Tsa) do Afloramento 12, porém não foi possível determinar a espécie ou família. Entre os exemplares em melhor estado de preservação foi possível verificar que as valvas são geralmente ovais, com contorno arredondado e poucas bandas de crescimento visíveis.

Os fósseis estão compactados e ocasionalmente aparecem como impressões simples de conchas de diferentes tamanhos. Podem ser carapaças isoladas ou valvas fechadas. A concentração varia lateralmente e verticalmente, com fósseis fortemente empacotados (coquinas) e dispersos em várias direções. 
É possível que a composição da água ou sua oxigenação tenha sofrido alterações temporárias causando a morte de grande quantidade de conchostráceos, uma vez que não há perturbação sedimentar. Tais eventos poderiam também estar relacionados ao aumento de salinidade.

Associados aos conchostráceos são observados fragmentos de outros crustáceos ou artrópodes indeterminados e escamas de Palaeonisciformes, sugestivos de que o paleoambiente deposicional não foi de curta duração.

Os vertebrados encontrados na Formação Tatuí incluem escamas e dentes de peixes ósseos no topo, apenas verificado no Afloramento 5.

Dois contextos paleoambientais geraram as litologias do topo da Formação Tatuí no centro-leste do Estado de São Paulo. O primeiro está relacionado com a Fácies Ibicatu em que são encontrados caules de pteridófitas e espermatófitas de grande porte transportados a partir de depósitos de alta energia provavelmente associados a canais contínuos durante grandes enxurradas. A presença de domínio de água doce é reforçada pela presença de depósitos lacustres com conchostraceos formados na mesma época. Este período é marcado pelo domínio dulceaquicola e continental dos depósitos.

O segundo contexto paleoambiental é representado pelo avanço de um grande corpo de água, Mar Palermo, onde se depositaram arenitos finos com estratificação cruzada de grande porte e "hummockies" e em alguns locais, ao sul, nos afloramentos 7 e 11, o retrabalhamento do topo dos depósitos de Ibicatu, criando estratificações sigmóides e "espinha de peixe", possível evidência de marés atuantes na região.

Duas fácies constituem o Membro Taquaral, uma, basal, composta de arenitos com ictiofósseis (Iai) e a, predominante, constituída de folhelhos siltico-argilosos (Isa). A fácies basal do Membro Taquaral possui abundante conteúdo fóssil de vertebrados em camada de arenito fino a médio mal selecionado, de granodecrescência ascendente, de tonalidade cinza clara a média nas porções mais grossas e cinza mais escura nas porções mais finas. Em outros locais pode ser um arenito bem selecionado com muito mais fósseis, porém fragmentados. A fácies Isa é a unidade mais homogênea da sucessão e é constituída de rocha síltico - argilosa de coloração cinza-escura (quando alterada é avermelhada), com laminação plano-paralela.

O levantamento paleoictiólogico da fácies basal do Membro Taquaral revelou rica fauna de Chondrichthyes e abundante quantidade de dentes e escamas de Palaeonisciformes em diferentes estados de preservação. 
Os dentes cladodontes da base arenosa do Membro Taquaral se diferenciam em três formas.

Espinhos de Euselachi apenas encontrados na região basal e de maior granulometria da fácies arenosa do Membro Taquaral.

Os espécimes do gênero Amelacanthus são pela primeira vez registrados, contudo a idade Eopermiana os coloca entre os mais recentes do gênero.

Uma nova espécie endêmica de Euselachi da Bacia do Paraná, Iratiacanthus santamariaensis, foi descrita com base em espinhos isolados. É o maior Chondrichthyes com espinho observado na unidade e caracteriza-se por finas costelas longitudinais lisas, espinho robusto e ausência de curvatura.

O gênero Sphenacanthus ocorre com duas espécies: A primeira representada por Sphenacanthus sanpauloensis e uma nova forma indeterminada, caracterizada por fortes dentículos na parte posterior do espinho, costelas lisas ou com pequenos tubérculos espaçados nas faces laterais.

Os tubarões Xenacanthiformes, presentes nos arenitos da base do Membro Taquaral, são divididos em duas famílias; Diplodoselachidae e Xenacanthidae.

A família Diplodoselachidae é a mais comum no Membro Taquaral, frequentemente representada por dentes isolados de Taquaralodus albuquerquei. Esta espécie é endêmica nas bacias do Paraná e Parnaíba e caracteriza-se pela grande cúspide, que ocupa parte das regiões central e lateral do dente e o botão apical alongado e reduzido.

Os Xenacanthidae são caracterizados por, pelo menos, duas espécies, porém são muito raros e os dentes estão muito desgastados.

Os Holocephali constituíam o grupo de Chondrichthyes mais comum nos afloramentos estudados.

A maior parte dos dentes são de Petalodontiformes, associados à espécie Itapyrodus punctatus, originalmente descrita na Formação Pedra do Fogo (SILVA SANTOS, 1990). Entre os fósseis encontrados estão dentes sinfisianos laterais, frontais, dentes póstero-laterais e dentes intermediários entre póstero-laterais e sinfisianos.

Formas similares às de $I$. punctatus também foram descobertas, podendo ser associadas ao mesmo gênero, porém a espécies diferentes. Estas formas são caracterizadas pela face lingual muito desenvolvida, ao contrario de I. punctatus em que as faces labial e lingual são do mesmo tamanho ou a face labial é um pouco maior. 
Os petalodontes brasileiros diferem de petalodontes descritos no mundo por estarem associados com fósseis de vertebrados não marinhos. Isto sugere que os petalodontes brasileiros possam ter-se adaptado a condições menos salinas.

Outros dentes bradiodontes, de coroa muito baixa, como os encontrados nos gêneros Helodus e Lagarodus, foram observados na base arenosa do Membro Taquaral. Também foi descoberta uma nova forma de Holocephali de coroa muito alta, com o formato da letra "A", com classificação incerta, podendo estar associada aos petalodontes.

Dentes pertencentes à ordem Orodontiformes, batizado como Orodus ipeunaensis (CHAHUD et al. 2010), representam a mais antiga evidência desta ordem na América do Sul e a primeira ocorrência no Estado de São Paulo.

Os Palaeonisciformes são os fósseis mais abundantes, representados por escamas lisas e costeladas, dentes retos, curvos e lisos ou costelados, além de um fragmento de um dentário. As escamas de Actinistia são raras, provavelmente pela sua constituição mais frágil.

Estudos sedimentológicos e tafonômicos dos afloramentos 1-4 revelaram que o material sedimentar e os fósseis são mal selecionados. Bioclastos são fragmentados e desarticulados. Escamas e dentes com abrasão, disposição dos fósseis caótica em planta, mas concordante com o acamamento em perfil. Características de concentrações depositadas em um ambiente de alta energia.

Associados ao material fragmentado são observados fósseis em bom estado de preservação, dentes Diplodoselachidae, Petalodontiformes, dentes e escamas de Palaeonisciformes com pouca ou nenhuma abrasão e apenas pequenas quebras. Tais fósseis foram pouco retrabalhados e podem ser indicativos que seriam autóctones ou parautóctones e que sua boa preservação estaria relacionada com algum evento episódico ou simplesmente transportados de fontes próximas

A presença de anfíbios, Xenacanthidae raros e os clastos angulosos são evidências de influência continental nos depósitos.

No afloramento 5 a camada parece representar uma variante do depósito residual evidente nos afloramentos 1-4, depositada em regiões mais afastada da influência continental ou da área fonte dos sedimentos.

A fácies basal do Membro Taquaral não se apresenta ao norte do Afloramento 1, nem a oeste como observado no Afloramento 10 e ao sul de Piracicaba no Afloramento 
6. Esta ausência sugere que os depósitos teriam sido gerados em regiões afastada da costa, não recebendo os sedimentos retrabalhados.

O crustáceo Clarkecaris, exclusivo do Membro Taquaral dos estados de São Paulo e Paraná, pertence aos Anaspidacea, cujos representantes atuais são animais de água doce. De acordo com MUSSA et al. (1980) os depósitos do Membro Taquaral teriam se desenvolvido em lagos de água doce, porém comparações feitas com fósseis do crustáceo primitivo Squillites spinosus por SCHRAM \& SCHRAM (1974) sugerem que anaspidáceos do Neopaleozóico teriam sido eurialinos e que Clarkecaris poderia tolerar salinidades maiores. Apesar desta possibilidade, os depósitos síltico-argilosos do Membro Taquaral não foram gerados em meio marinho, pela ausência de macrofósseis claramente marinhos. Provavelmente a salinidade deveria ter sido baixa a ponto de apenas suportar possíveis acritarcos (LAGES, 2004, CARDOS, 2010), mais resistentes.

Os Clarkecaris ocorrem nos mais variados tipos de preservação, com fósseis articulados completos, semi-articulados e fragmentados. A presença de fósseis completos de Clarkecaris seria o resultado de mudança ambiental esporádica, aumento ou diminuição da salinidade ou eventos de tempestade.

Não foram encontrados fósseis completos de peixes, apenas partes ósseas ou escamas isoladas bem preservadas e algumas acumulações pontuais. Como também não foi relatado na literatura, a presença de peixes completos é provável que os peixes tenham escapado dos eventos que matariam os Clarkecaris.

Os Chondrichthyes não são encontrados no folhelho, o que poderia indicar mudança ambiental que teria restringido estes peixes a determinadas áreas na bacia que ainda mantinham características toleráveis de salinidade.

A presença de fósseis eurialinos na unidade e a ausência de fósseis estenoalinos, sugerem que o siltito do Membro Taquaral deveria ter salinidade baixa. Provavelmente a unidade era mantida por rios de água doce, como observado atualmente no Mar Cáspio ou no Mar Báltico.

Durante o inicio da deposição do Membro Taquaral da Formação Irati ocorreu o contato com o oceano aberto ou com outras bacias contendo água salina, evidenciado pela existência dos Chondrichthyes Itapyrodus punctatus e Taquaralodus albuquerquei, também na Formação Pedra do Fogo, Bacia do Parnaíba, sendo exclusivos das duas bacias. Tal ligação não deve ter sido de longa duração, pois a biota encontrada é pouco variada e tem como características, fácil locomoção e proliferação, podendo ter ocupado rapidamente o novo ambiente. Seres típicos de "mar aberto" como: a maior parte dos 
equinodermos, briozoários, cefalópodes e corais necessitariam de maior intervalo de tempo e de ambiente estável, resultado de um contínuo contato entre a bacia e o oceano, como observado em moluscos do Mar Negro, onde animais típicos de água doce foram substituídos por uma fauna marinha (SOROKIN \& KUPRIN, 2007).

\section{REFERÊNCIAS BIBLIOGRÁFICAS}

ABREU, N. C. G. \& DIAS-DA-SILVA, S. 2006. Proposta icnográfica para anfíbios fósseis: uma ferramenta em sistemática filogenética. GAEA. 2(1):3 - 8 .

AFONSO, J. C.; CARDOSO, J. N.; SCHMAL, M. 1992. Distribution and origin of organic sulphur compounds in lrati shale oil. Fuel.71: 409-415.

AFONSO, J. C.; SCHMAL, M.; CARDOSO, J. N. 1994. Hydrocarbon distribution in the lrati shale oil. Fuel. 73(3): 363-366.

ALLISON, P.A. \& BRIGGS, D.E.G. 1991 Taphonomy: Releasing the Data Locked in the Fossil Record. Plenum Press, New York. 560p.

ALMEIDA. F.F.M. \& BARBOSA, O.1953. Geologia das quadrículas de Piracicaba e Rio Claro. Estado de São Paulo. Rio de Janeiro. Boletim do DNPM/DGM, (143): 96p.

ALVES, L. S. R. \& GUERRA-SOMMER, M. 2005. Growth Rings in Fóssil Woods and Paleoclimates in Applied Stratigraphy.. In: KOUTSOUKOS. E. (Org.). Applyed Stratigraphy. New York: Springer. 23: 181-193.

AMARAL, S.E. 1971. Geologia e petrologia da Formação Irati (Permiano) no Estado de São Paulo. Bol. Inst. Geoc. Astron. USP, São Paulo. (2):3-82.

AMENÁBAR, C. R.; PASQUO, M.; CARRIZO; H. A.; AZCUY. C. L. 2006. Palynology of the Chigua (Devonian) and Malimán (Carboniferous) formations in the Volcán Range, San Juan Province, Argentina. Part I. Paleomicroplankton and acavate smooth and ornamented spores. Ameghiniana. 43(2): 339-375.

ANJOS, C. W. D. 2008. Fatores condicionantes na gênese dos argilominerais dos folhelhos negros e pelitos associados da Formação Irati no norte da Bacia do Paraná. Tese de doutorado. Faculté des Sciences Fondamentales et Appliquées. 124p.

ANTSULEVICH, A. 2007. First records of the tubenose goby Proterorhinus marmoratus (Pallas, 1814) in the Baltic Sea. Aquatic Invasions. 2(4): 468-470

ARAÚJO, L. M.; RODRIGUES, R.; SCHERER, C. M. S. 2004. Interrelação entre a fábrica sedimentar, o conteúdo orgânico e o potencial redox do ambiente deposicional, deduzida das litofácies de rampa distal das seqüências deposicionais da Formação Irati, Permiano da Bacia do Paraná. Boletim de Geociências da Petrobras, 12(2): 429-434.

ARAÚJO-BARBERENA, D.C. 1993. Uma interpretação sobre o conhecimento paleoecológico e bioestratigráfico da Formação Irati. In: I SIMPÓSIO DE CRONOESTRATIGRAFIA DA BACIA DO PARANÁ. Rio Claro, FUNDUNESP. Boletim de Resumos. 64-70.

ARRIBAS, A. \& PALMQVIST, P. 1998. Taphonomy and palaeoecology of na assemblage of large mammals: Hyaenid activity in the lower pleistocene site at Vent Micena (Orce, Guadix-Baza Basin, Granada, Spain). Geobios, 31(3):3-47.

ASSINE, M.L.; ZACHARIAS, A.A.; PERINOTTO, J.A.J. 1999. O trato deposicional Tatuí e a transgressão Taquaral no Centro-Leste do Estado de São Paulo. In: VI SIMPÓSIO DE GEOLOGIA DO SUDESTE - SBG/UNESP. Boletim de resumos. 53.

ASSINE, M.L.; ZACHARIAS, A.A.; PERINOTTO, J.A.J. 2003. Paleocorrentes, paleogeografia e seqüências deposicionais da Formação Tatuí, centro-leste do Estado de São Paulo. Revista Brasileira de Geociências. 33(1): 33-40.

AZCUY, C., BERI, A., BERNARDES-DE-OLIVEIRA, M.E.C., CARRIZO, H.A., DI PASQUO, M., DIAZ-SARAVIA, P., GONZÁLEZ, C., IANNUZZI, R., LEMOS, V.B., MELO, J.H.G., PAGANI, 
A., ROHN, R., AMENÁBAR, C.R., SABATTINI, N., SOUZA, P. A., TABOADA, A., VERGEL, M.M., 2007. Bioestratigrafía del Paleozoico Superior de América del Sur: primera etapa de trabajo hacia uma nueva propuesta cronoestratigráfica. Asociación Geológica Argentina, Publicación Especial No. 11, pp. 9-65.

BACOCCOLI, G. 1971. Os deltas holocênicos brasileiros: Uma tentativa de classificação: Boletim Técnico da Petrobrás. 74(1/2):5-38.

BADGLEY,C. 1986a. Counting Individuals in Mammalian Fossil Assemblages from Fluvial Environments. Palaios. 12(3): 328-338.

BADGLEY,C. 1986b. Taphonomy of mammalian fossil remains from Siwalik rocks of Pakistan. Paleobiology. 12(2):119-142.

BAIRD, O. 1978. Studies on Carboniferous freshwater fishes. American Museum Novitates, New York, (1641):1-22.

BARBERENA, M. C. 1972. South America Late Paleozoic tetrapods. Anais da Academia Brasileira de Ciências Suplemento, Rio de Janeiro. 44: 67-75,

BARBERENA, M.C. 1998. Australerpeton cosgriffi n.g., n.sp. a Late Permian rhinesuchoid amphibian from Brazil. Anais da Academia Brasileira de Ciencias, 70(1): 125-147.

BARBERENA, M.C.; DIAS, E. V. 1998. On the presence of a short - snouted rhinesuchoid amphibian in the Rio do Rastro Formation (Late Permian of Paraná Basin, Brazil). Anais da Academia Brasileira de Ciências. 70 (3): 465-467.

BARBOSA O. \& ALMEIDA F.F.M. 1949a. Nota sobre a estratigrafia da Série Tubarão em São Paulo. Anais da Academia Brasileira de Ciências. 21(1): 65-68.

BARBOSA O. \& ALMEIDA F.F.M. 1949b. A Série Tubarão na bacia do Rio Tietê, Estado de São Paulo. Boletim do DNPM-DGM, 48, 16p.

BARBOSA, O.; GOMES, F.A. 1958. Pesquisa de petróleo na bacia do rio Corumbataí. Rio de Janeiro, Boletim do DNPM/DGM. 171: 40p.

BARCELlOS, M.T. 1975. Estudo de escamas e dentes de peixes da Fácies Budó, Subgrupo Itararé , RGS. Boletim Paranaense de Geociências. (32): 3-65.

BEHRENSMEYER, A.K. 1978. Taphonomic and ecologic information from bone weathering. Paleobiology. 4(2):150-162.

BEHRENSMEYER, A.K. 1982. Time resolution in fluvial vertebrate assemblages. Paleobiology. 8(3): 211-227.

BEHRENSMEYER, A.K. 1991. Terrestrial vertebrate accumulations. In: ALLISON, P.A. \& BRIGGS, D. E. (eds), Taphonomy: releasing the data Locked in the fossil record. Plenum Press, New York: 291-327.

BEHRENSMEYER, A.K.; KIDWELL, S.M. 1985. Taphonomy's contributions to paleobiology, Paleobiology. 11: 105-107.

BENTON, M. J. 1997. Vertebrate palaeontology. $2^{\mathrm{a}}$ ed. London: Chapman and Hall. 452p.

BERNARDES-DE-OLIVEIRA, M.E.C. 1977. Tafoflora eogondvânica da camada Irapuá, Formação Rio Bonito (Grupo Tubarão), SC. Instituto de Geociências, Universidade de São Paulo, São Paulo, Tese de Doutoramento, 301p. (2 vol.).

BEURLEN, K. 1931. Crustaceenreste aus den Mesosaurierschiten (Unterperm) Von Brasilien (S. Paulo). Palaeontologische Zeitschr. 13: 35-50.

BEURLEN, K. 1953a. Estratigrafia e Paleogeografia das formações gondwânicas no sul do Brasil. DGM/DNPM Notas Preliminares e Estudos. Rio de Janeiro. 59: 1-10.

BICUDO, C. E. M. \& MENEZES, M. 2006. Gêneros de algas de águas continentais do Brasil chave para identificação e descrições. Segunda edição. RIMA Artes e Textos. 502p.

BOARDMAN, D. R. 2006. Tafoflora de Taió, Santa Catarina (Permiano Inferior, Formação Rio Bonito, Bacia do Paraná). Dissertação de mestrado. Instituto de Geociências da Universidade Federal do Rio Grande do Sul. 112p. 
BRAIN C.K. 1980. Some criteria for the recognition of bone-collecting agencies in African caves. In: BEHRENSMEYER, A. K. \& HILL A. P. (eds), Fossils in the making. The University of Chicago Press, Chicago.p. 107-130.

BRAZEAU, M. D. 2009. The braincase and jaws of a Devonian 'acanthodian' and modern gnathostome origins. Nature. 457: 305-308

BRENNER W. W. 2005. Holocene environmental history of the Gotland Basin (Baltic Sea) - a micropalaeontological model. Palaeogeography, Palaeoclimatology, Palaeoecology. 220: 227241

BRITO, I.M.; CARVALHO, I.S; VICALVI, M.A. CARVALHO, M.G.P. 2000. Artrópodes. In: CARVALHO. I. S. (eds) Paleontologia. Rio de Janeiro, Editora Interciência. p. 423-451.

BRITO, I.M. \& QUADROS, L.P., 1978. Ocorrência inédita de Clarkecaris brazilicus (Crustacea Malacostraca) no Permiano do Estado do Paraná. Anais da Academia Brasileira de Ciências, Rio de Janeiro, 50(3):417-421.

BROOKS, H. K. 1962. On the fossil Anaspidacea, a revision of the classification of the Syncarida. Crustaceana, 4, 229-242.

BROOKS, H. K. 1969. Syncarida. In: MOORE, R. C. (eds), Treatise on invertebrate paleontology, Part R, Arthropoda 4(I): 345-359.

BRYANT. W. L. 1929. Fossil fish remains from the Permian tillite of Brazil. Bulletin Geological Society American. New York. 40: 424-426.

CABRAL JR. M.; CAMPANHA, V. A.; MOTTA, J. F. M.; SAAD, A. R. 1988. Contribuição à estratigrafia e paleogeografia da interface Itararé e Tatuí (P) e considerações sobre sua potencialidade para carvão no Estado de São Paulo. XXXV CONGRESSO BRASILEIRO DE GEOLOGIA, Belém. Pará. Anais... 2: 879-892.

CALÇA, C. P. 2008. Micropaleontologia do sílex da Formação Irati (Permiano), Estado de São Paulo. Programa de Pós-graduação em Geologia Sedimentar. IGc-USP. São Paulo. Dissertação de Mestrado. 80p.

CAMPANHA, V.A. 1985. Ocorrência de braquiópodos inarticulados na Formação Irati no Estado de São Paulo. In: Anais da Academia Brasileira de Ciências. Resumo de Comunicações. Rio de Janeiro. 57(1): 115-116.

CAMPANHA, V.A. \& ZAINE, M.F. 1989. Foraminíferos da Formação Irati no Estado de São Paulo. In: XI CONGRESSO BRASILEIRO DE PALEONTOLOGIA. Boletim de Resumos. 38.

CARDOSO, T.R. M. 2010. Registro marinho no Membro Taquaral (Formação Irati), Permiano Superior da Bacia do Paraná, Brasil. XIII SBPP - SIMPÓSIO BRASILEIRO DE PALEOBOTÂNICA E PALINOLOGIA, Salvador, Bahia. p.147

CARVALHO, I.S. \& FERNADES, A.C.S. 2000. Icnofósseis. In: CARVALHO. I. S. (eds) Paleontologia. Rio de Janeiro, Editora Interciência. p. 95-118

CASE, G. R. 1982. A Pictorial Guide to Fossils. VNR, Ontario, Canada. 514p.

CASTRO, J. C. 1993. Eventos, Ritmos e Ciclos do Membro Assistência (Formação Irati) na Margem Leste da Bacia do Paraná. In: I SIMPÓSIO DE CRONOESTRATIGRAFIA DA BACIA DO PARANÁ. Rio Claro, FUNDUNESP. Boletim de Resumos; 75-76.

CASTRO, J.C., MICHEL U., ALVES C.F.C., GRECCHI R.C. 1993a. O Subgrupo Guatá na margem nordeste da Bacia do Paraná: uma revisão. In: I SIMPÓSIO DE CRONOESTRATIGRAFIA DA BACIA DO PARANÁ. Rio Claro, FUNDUNESP. Boletim de Resumos; 55-56.

CASTRO, J. C.; SAMPAIO, R. F.; SCHNEIDER, R. L. 1993b. Eventos e ciclos T-R na evolução dos membros Paraguaçu e Siderópolis (FM. Rio Bonito), porção sudeste da Bacia do Paraná. In: I SIMPÓSIO DE CRONOESTRATIGRAFIA DA BACIA DO PARANÁ. Rio Claro, FUNDUNESP. Boletim de Resumos; 52-53.

CAZZULO-KLEPZIG, M. ; PICCOLI, A. E. M. ; MARQUES-TOIGO, M. 1989. Reconhecimento de um marco estratigráfico com significado paleoecológico no Permiano da Bacia do Paraná (Grupos Guatá e Passa Dois). In: XI CONGRESSO BRASILEIRO DE PALEONTOLOGIA, Curitiba. Anais... 2: 971-982. 
CHAHUD, A. 2001. Caracterização tafonômica da assembléia de vertebrados fósseis (PleistocenoHoloceno) do Abismo Ponta de Flecha, Iporanga, SP. Projeto PIBIC - CNPq. (Projeto de iniciação científica Inédito).45p.

CHAHUD, A. 2003a. Caracterização tafonômica de restos quaternários de anura, Abismo Ponta de Flecha, Iporanga, SP. Paleo 2003. In: Paleontologia em Destaque. Boletim de Resumos. 44: 44.

CHAHUD, A 2003b. Paleoictiologia do topo da Formação Tatuí e base da Formação Taquaral (Subgrupo Irati), Permiano, Alto Estrutural de Pitanga, região de Rio Claro, SP. Monografia de Trabalho de Formatura. IGc/USP. 49p.

CHAHUD, A. 2007. Paleontologia de Vertebrados da Transição entre os grupos Tubarão e Passa Dois no Centro-Leste do Estado de São Paulo. Programa de Pós-graduação em Geologia Sedimentar. IGc-USP. São Paulo. Dissertação de Mestrado. 172p.

CHAHUD, A. \& FAIRCHILD, T. R. 2003a. Paleoictiologia da transição das Formações Tatuí e Taquaral (Permiano), no Alto Estrutural do Pitanga. In: XVIII CONGRESSO BRASILEIRO DE PALEONTOLOGIA. Brasília, Boletim de Resumos. p. 321.

CHAHUD, A. \& FAIRCHILD, T. R 2003b Paleoictiologia do topo da Formação Tatuí e base da Formação Taquaral (Subgrupo Irati), Permiano, Alto Estrutural de Pitanga, região de Rio Claro, SP. PALEO 2003. In: Paleontologia em Destaque. Boletim de Resumos. 44: 43.

CHAHUD, A. \& FAIRCHILD, T. R. 2005. Tubarões paleozóicos da transição entre os Grupos Tubarão e Passa Dois (Permiano), no Alto Estrutural de Pitanga, SP. In: XIX CONGRESSO BRASILEIRO DE PALEONTOLOGIA E VI CONGRESSO LATINO AMERICANO DE PALEONTOLOGIA. Aracaju, Sergipe. Boletim de Resumos. Publicado em CD Room.

CHAHUD, A. \& FAIRCHILD, T. R. 2006a. Cladodontes da Transição dos Grupos Tubarão e Passa Dois na região de Rio Claro, SP. In: V SIMPÓSIO BRASILEIRO DE PALEONTOLOGIA DE VERTEBRADOS. Santa Maria. Boletim de Resumos. 17.

CHAHUD, A. \& FAIRCHILD, T. R. 2006b. Levantamento inicial do potencial paleontológico da Transição Tatuí - Irati no Centro - Leste do Estado de São Paulo. PALEO 2006. Núcleo Paraná Santa Catarina. In: Paleontologia em Destaque. Boletim de Resumos. 10.

CHAHUD, A., FAIRCHILD, T. R., PETRI, S. 2010. Chondrichthyans from the base of the Irati Formation (Early Permian, Paraná Basin), São Paulo Brazil. Gondwana Research, 18: 528-537.

CHAHUD, A.; PETRI, S. 2008a. Chondrichthyes no Membro Taquaral, base da Formação Itati, no centro-leste do Estado de São Paulo, Brasil. Revista de Geologia (Fortaleza). 21: 169 - 179.

CHAHUD, A.; PETRI, S. 2008b. Registro de Paleoniscóides na base do Membro Taquaral, Formação Irati, Permiano da Bacia do Paraná. Revista do Instituto Geológico. 29: 33- 40.

CHAHUD, A.; PETRI, S. 2010. Anfíbio e Paleonisciformes da Porção Basal do Membro Taquaral, Formação Irati (Permiano), Estado de São Paulo, Brasil. Geologia USP. Série Científica. 10(1): 29-37.

CHEN, P. J. \& HUDSON, J.D. 1991. The Conchostracan fauna of the Great Estuarine Group, Middle Jurassic, Scotland. Palaeontology. 15(3) 515-545.

CIONE, A. L.; GOUIRIC-CAVALLI, S.; MENNUCCI, J. A.; CABRERA, D. A.; FREIJE. R. H. 2010. First vertebrate body remains from the Permian of Argentina (Elasmobranchii and Actinopterygii).Proceedings of the Geologists' Association. 121(3): 301-312

CISNEROS, J. C.; ABDALA, F.; MALABARBA, M. C. 2005. Pareiasaurids from the Rio do Rasto Formation, Southern Brazil: Bioestratigraphic Implications for Permian Faunas of the Paraná Basin. Revista Brasileira de Paleontologia. 8(1):13-24.

ClARKE, J. M. 1920. Novos Crustáceos Paleozóicos - Crustáceos do Permiano de São Paulo, Brasil. Bull. N. Y. States Mus. 219 - 220. Traduzido por Sergio Mezzalira e publicada na Revista O. I. G. G. IV(1): 1-4.

COATES, M.I. \& SEQUEIRA, S.E.K. 2001. A new stethacanthid chondrichthyan from the Lower Carboniferous of Bearsden, Scotland. Journal of Vertebrate Paleontology. 21(3): 438-459.

CORRÊA DA SILVA, Z.C., BORTOLUZZI, C.A., CAZZULO-KLEPZIG, M., DIAS-FABRICIO, M.E., GUERRA-SOMMER, M., MARQUES-TOIGO, M., PALM, P.S.G., PICCOLI, A.E.M.; SILVA 
FILHO, B.C. 1984. Geology of Santa Rita coal basin, Rio Grande do Sul, Brazil. International Journal of Coal Geology. 3: 383--400.

COUTINHO, J. M. V. \& HACHIRO, J. 2005. Distribution, mineralogy, petrography, provenance and significance of Permian ash-carryng deposits in the Parana Basin. Revista do Instituto de Geociências. Geologia USP, Série Cientifica. 9: 29-36.

COX, C. B. \& HUTCHINSON, P. 1991. Fishes and amphibians from the Late Permian Pedra do Fogo Formation of Northern Brazil. Palaeontology, 34(3): 561-573.

CPRM, 2006. Coluna Estratigráfica da Bacia Sedimentar do Paraná. Site: http://www.cprm.gov.br/coluna/index.html

CRUZ, N.M.C. 2000. Acritarcos. In: CARVALHO. I. S. (eds) Paleontologia. Rio de Janeiro, Editora Interciência. p. 223-227.

DAEMON, R.F. \& QUADROS, L.P. 1970. Bioestratigrafia do Neopaleozóico da Bacia do Paraná. In: XXIV CONGRESSO BRASILEIRO DE GEOLOGIA. Anais..., Brasília, Sociedade Brasileira de Geologia. 359-412.

DALY, E. 1973. A Lower Permian Vertebrate Fauna from Southern Oklahoma. Journal of Paleontology. 47(3):562-589

DARRAS, L.; DERYCKE, C.; BLIECK, A.; VACHARD. D. 2008. The oldest holocephalan (Chondrichthyes) from the Middle Devonian of the Boulonnais (Pas-de-Calais, France). Comptes Rendus Palevol. 7 (5): 297-304.

DAVIS, J. W. 1892. On the fossil fish-remains of the coal measures of the British Islands. The Scientific Transactions of the Royal Dublin Society 4, $703 \pm 48$.

DELLAZZANA J. G. 1976. Contribuição à palinologia da Formação Irati (Permiano) Rio Grande do Sul, Brasil. Ameghiniana. 13: 1-42.

DELSATE, D.; SMET, F.; WILE, E. 2003 New Ichthyoliths from the Lower Carboniferous of Belgium. Ferrantia. Paléontologie au Luxenbourg. (36): 29-38.

DERBY, O. A. 1915. Illustrations of the stem structure of Tietea singularis, American Journal of Science 36 (4): 251-260.

DIAS, E. V. 2000. Anfíbios. In: CARVALHO. I. S. (eds) Paleontologia. Rio de Janeiro, Editora Interciência, p. 525-541.

DIAS, E. V.; BARBERENA, M. C. 2001. A Temnospondyl amphibian from the Rio do Rasto Formation, Upper Permian of southern Brazil. Anais da Academia Brasileira de Ciências, Rio de Janeiro. 73 (1): $135-143$.

DIAS, E. V. \& SCHULTZ, C. L. 2003. The First Paleozoic Temnospondyl Postcranial Skeleton from South America. Revista Brasileira de Paleontologia. 6:29-42.

DIAZ-SARAVIA, P. 2001. Upper Carboniferous fish micro-remains from Western Argentina. Revista Española de Micropaleontología, 33(2):123-133.

DICK, J. R. F. 1998. Sphenacanthus, a Paleozoic freshwater shark. Zoological Journal of the Linnean Society. 122:9-25.

DUFFIN, C. J. \& GINTER, M. 2006. Comments on the selachian genus Cladodus Agassiz, 1843. Journal of Vertebrate Paleontology, 26(2): 253-266.

DUFFIN, C., RICHTER, M., NEIS, P. A. 1996. Shark remains from the late Carboniferous of the Amazon Basin, brazil. Neues Jahrbuch fur Geologie und Palaontologie, Mh., Stuttgart. 4: 232256.

DUNKLE, D. H. \& SCHAEFFER, B. 1956. Preliminary description of a paleoniscoid fish from the Late Paleozoic of Brazil. Boletim da Faculdade de Filosofia, Ciências e Letras, Universidade de São Paulo. Série Geologia,(13):5-22.

ELliOTT, D. K. IRMIS, R. B.; HANSEN, M.C.; OLSON T.J. 2004. Chondrichthyans from the Pennsylvanian (Desmoinesian) Naco Formation of Central Arizona. Joumal of Vertebrate Paleontology, 24(2):268-280. 
FAIRBAIRN, D.J. \& PREZIOSI, R.F. 1994. Sexual selection and the evolution of allometry for sexual size dimorphism in the water strider, Aquarius remigis. The American Naturalist.144: 101-118.

FAURE, K \& COLE, D. 1999. Geochemical evidence for lacustrine microbial blooms in the vast Permian Main Karoo, Paraná, Falkland Islands and Huab basins of southwestern Gondwana. Palaeogeography, Palaeoclimatology, Palaeoecology 152: 189-213

FERNANDES, J.A.B. 2004. Análise estratigráfica da Formação Tatuí na região de Rio Claro-Ipeúna $(S P)$. Monografia de Trabalho de Formatura (Inédita). IGc/USP. 45p.

FERNANDES, J.M.G. 2000. Poríferos. In: CARVALHO, I. S. (eds) Paleontologia. Rio de Janeiro, Editora Interciência. 341-350.

FERNANDES, A. C. S.; BORGHI, L.; CARVALHO, I. S.; ABREU, C. J. 2002. Guia dos Icnofósseis de Invertebrados do Brasil. Rio de Janeiro: Editora Interciência. 260 p.

FERREIRA DE OLIVEIRA, L.G. 2007. Conchostráceos permianos da Bacia do Paraná: taxonomia, evolução, bioestratigrafia e paleobiogeografia. Tese de doutoramento (Inédita), Universidade Estadual Paulista, Rio Claro, Brasil. 241p.

FIGUEIREDO, F. J. \& CARVALHO B. C. M. C. 2004. A new Actinopterygian Fish from the Late Permian of The Paraná Basin, Southern Brazil. Arquivos do Museu Nacional. Rio de Janeiro. 62(4): 531-547.

FIGUEIREDO, F. J. ; GALLO, V. 2006a. Actinopterígios paleopterígios: morfologia e taxonomia. In: GAllO, V.; BRITO, P.; SILVA, H. M. A.; FIGUEIREDO. F. J. (eds.) Paleontologia de Vertebrados: Grandes Temas e Contribuições Cientificas. Rio de Janeiro: Interciência.1-24.

FIGUEIREDO, F. J. ; GALLO, V. 2006b. Uma história de actinopterígios paleopterígios. In: GALLO, V.; BRITO, P.; SILVA, H. M. A.; FIGUEIREDO. F. J. (eds.) Paleontologia de Vertebrados: Grandes Temas e Contribuições Científicas. Rio de Janeiro: Interciência. 25-46.

FLORENCE, G. 1907. Notas Geológicas Sobre o Rio Tietê em o trecho estudado pela turma em 1905. Relatório da Comissão Geográfica e Geológica. São Paulo. 9-15.

FOEHRINGER, K.J.A. \& LANGER, M.C. 2003. A descoberta de um decápodo reptântio (Crustacea, Malacostracea) da Formação Irati (Permiano da Bacia do Paraná). In: XVIII CONGRESSO BRASILEIRO DE PALEONTOLOGIA. Brasília, Boletim de Resumos. 132.

FOEHRINGER, K.J.A. \& LANGER, M.C. 2004. Relações do crustáceo reptântio da Formação Irati (Permiano Superior) In: PALEO 2004. São Carlos. Boletim de Resumos.12.

FONOLLÁ, F. 1988. Palinofacies del Pérmico en Europa Occidental y en otras regiones. Boletín Geológico y Minero de Espana. 99:156-164.

FOREY, P.L. 1981. The coelacanth Rhabdoderma in the Carboniferous of the British Isles. Palaeontology. 24(1): 283-229.

FREY, R.W., CURRAN, H.A., and PEMBERTON, S.G., 1984, Tracemaking activities of crabs and their environmental significance; the ichnogenus Psilonichnus: Journal of Paleontology, 58: 333-350.

FÚlfFARO, V. J. 1970. Contribuição à Geologia da região de Angatuba; Estado de São Paulo. Boletim do DNPM/ DGM. 253. 108p

FÚlfaro, V. J.; STEVAUX, J. C.; SOUZA-FILHO, E. E.; BARCELOS, J.H. 1984. A Formação Tatuí (P) no Estado de São Paulo. In: XXIII CONGRESSO BRASILEIRO DE GEOLOGIA. Rio de Janeiro, Sociedade Brasileira de Geologia. Anais...(2): 711-723.

FÜRSICH, F.T., 1981, Invertebrate trace fossils from the Upper Jurassic of Portugal: Comunicacoes Servicos Geologicos de Portugal, 67: 153-168.

GAMA Jr. E. G.. 1976. Análise de tendência de espessuras do Membro Marituba da Formação Piaçabuçu da Bacia de Sergipe-Alagoas. In: In: XXIX CONGRESSO BRASILEIRO DE GEOLOGIA, Ouro Preto, MG. Sociedade Brasileira de Geologia Anais...2: 234-239.

GAMA Jr. E. G.; BANDEIRA Jr., A. N.; FRANÇA, A. B. 1982. Distribuição Espacial e Temporal das Unidades Litoestratigráficas Paleozóicas na Parte Central da Bacia do Paraná. Revista Brasileira de Geociências. 12: 578-589. 
GEOVANI, W.F.; SALATI,E.; MARINI,O.J. \& FRIEDMAN ,I. 1974. Unusual isotopic composition of carbonates from the Irati Formation, Brazil. GSA Bulletin. 85(1): 41-44.

GIMENEZ, N. L. B. \& CHANG, M. R. C. 1997. Diagênese dos arenitos da Formação Tatuí no NE da Bacia do Paraná. In: V SIMPÓSIO DE GEOLOGIA DO SUDESTE. 54 - 55.

GINGRAS, M.K., HUBBARD, S.M., PEMBERTON, S.G., SAUNDERS, T.A., 2000, The significance of Pleistocene Psilonichnus at Willapa Bay, Washington: Palaios, 15: 142-151.

GINTER, M. 2002. Taxonomic notes on "Phoebodus heslerorum" and Symmorium reniforme (Chondrichthyes, Elasmobranchii). Acta Palaeontologica Polonica 47:547-555.

GINTER, M.; HAIRAPETIAN, V.; KLUG, C. 2002. Famennian chondrichthyans from the shelves of North Gondwana. Acta Geologica Polonica. 52(2): 169-215.

GINTER, M.; HAMPE, O.; DUFFIN, C. J. 2010. Chondrichthyes. Paleozoic Elasmobranchii: Teeth. In: SCHULTZE H.P. (ed.), Handbook of Paleoichthyology, Volume 3D. Verlag Dr. Friedrich Pfeil, München. 168 p.

GINTER, M.; IVANOV, A. 1992. Devonian phoebodont shark teeth. Acta Palaeontologica Polonica, 37, $55-75$.

GINTER, M.; IVANOV, A.; LEBEDEV, O. 2005. The revision of "Cladodus" occidentalis, a late Paleozoic ctenacathiform shark. Acta Paleontologica Polonica. 50(3): 623-631.

GINTER, M.; MAISEY. J.G. 2007. The braincase and jaws of Cladodus from the Lower Carboniferous of Scotland. Palaeontology 50(2): 305--322.

GORDON JR. M. 1947. Classificação das formações gondwânicas do Paraná, Santa Catariana e Rio Grande do Sul. Boletim do DNPM-DGM. 1:374-385.

GRADSTEIN, F.M.; OGG, J.G.; SMITH, A.G.; AGTERBERG, F.P.; BLEEKER, W.; COOPER, R.A.; DAVYDOV, V.; GIBBARD, P.; HINNOV, L.; HOUSE, M.R.; LOURENS, L.; LUTERBACHER, H.-P.; MCARTHUR, J.; MELCHIN, M.J.; ROBB, L.J.; SHERGOLD, J.; VILLENEUVE, M.; WARDLAW, B.R.; ALI, J.; BRINKHUIS, H.; HILGEN, F.J.; HOOKER, J.; HOWARTH, R.J.; KNOLL, A.H.; LASKAR, J.; MONECHI, S.; POWELL, J.; PLUMB, K.A.; RAFFI, I.; RÖHL, U; SANFILIPPO, A.; SCHMITZ, B.; SHACKLETON, N.J.; SHIELDS, G.A.; STRAUSS, H.; VAN DAM, J.; VAN KOLFSCHOTEN, T.; VEIZER, J. \& WILSON, D. 2004. A Geologic Time Scale 2004. New York, Columbia University Press.

GRICE, K.; TWITCHETT, R.J.; ALEXANDER, R.; FOSTER, C.B.; LOOY, C. 2005. A potential biomarker for the Permian-Triassic ecological crisis. Earth and Planetary Science Letters. 236: $315-321$.

GROGAN, E. D., \& LUND. R. 2000. Debeerius ellefseni (Fam. Nov., Gen. Nov., Spec. Nov.), an autodiastylic chondrichthyan from the Mississippian Bear Gulch Limestone of Montana (USA), the relationships of the Chondrichthyes, and comments on gnathostome evolution. Journal of Morphology. 243:219-245.

GROGAN, E. D. \& LUND. R. 2004. The origin and relationships of early chondrichthyans; In: CARRIER, J. C.; MUSICK, J. A.; HEITHAUS M. R. (EDS), Biology of Sharks and Their Relatives. CRC press, Boca Raton, Florida. p.3-32

GUERRA-SOMMER, M., CAZZULO-KLEPZIG, M., FORMOSO, M.L.L., MENEGAT, R., MENDONÇA FILHO, J.G., 2008a. U-Pb dating of the tonstein layer from a coal succession of the southern Paraná Basin, Brazil: a new geochronological approach. Gondwana Research. 14, 474482

GUERRA-SOMMER, M., CAZZULO-KLEPZIG, M., MENEGAT, R., FORMOSO, M.L.L., BASEI, M.A.S., BARBOZA, E.G., SIMAS, M.W. 2008b. Geochronological data from the Faxinal coal succession, southern Paraná Basin, Brazil: a preliminary approach combining radiometric U-Pb dating and palynostratigraphy. Journal of South American Earth Sciences 25. 246-256.

GUERRA-SOMMER, M., CAZZULO-KLEPZIG, M., SANTOS, J.O.S.,HARTMANN, L.A.,KETZER, J.M.,FORMOSO, M.L.L. 2008c. Radiometric age determination of tonsteins and stratigraphic constraints for the Lower Permian coal succession in southern Paraná Basin, Brazil. International Journal of Coal Geology. 74, 13-27. 
HACHIRO, J. 1991. Litotipos, associaçoes faciológicas e sistemas deposicionais da Formação Irati no estado de São Paulo. Dissertação de Mestrado IGc-USP (Inédita), São Paulo, 175p.

HACHIRO, J. 1997. O Subgrupo Irati (Neopermiano) da Bacia do Paraná. Programa de Pós-graduação em Geologia Sedimentar. IGc-USP, São Paulo. Tese de Doutoramento. 196p.

HACHIRO, J. \& COIMBRA, A. 1991a. Sucessões sedimentares e ciclos transgressivo-regressivos da Formação Irati no Estado de São Paulo. In: II SIMPÓSIO DE GEOLOGIA DO SUDESTE. Atas... SBG/SP-RJ: 45-52.

HACHIRO, J. \& COIMBRA, A. 1991b. Sistemas deposicionais da Formação Irati no Estado de São Paulo. In: II SIMPÓSIO DE GEOLOGIA DO SUDESTE. Atas... SBG/SP-RJ: 405-413.

HACHIRO, J. \& COIMBRA, A.M. 1992. Bone beds e shell beds como feições diagnósticas de tempestitos da Formação Irati no Estado de São Paulo. In: SBG, CONGRESSO BRASILEIRO DE GEOLOGIA, 37, São Paulo, 1992. Anais..., p. 511-512.

HACHIRO, J. \& COIMBRA, A. 1993. Ciclos de Milankovitch nas seqüências rítmicas da Unidade Irati. In: I SIMPÓSIO DE CRONOESTRATIGRAFIA DA BACIA DO PARANÁ. Rio Claro, FUNDUNESP. Boletim de Resumos; 72-73.

HACHIRO, J.; COIMBRA, A. \& MATOS, S.L.F. 1993. O caráter cronoestratigráfico da unidade Irati. In: I SIMPÓSIO DE CRONOESTRATIGRAFIA DA BACIA DO PARANÁ. Rio Claro, FUNDUNESP. Boletim de Resumos; 62-63.

HAMEL, M. H. 2005. A new lower actinopterygian from the early Permian of the Paraná Basin, Brazil. Journal of Vertebrate Paleontology. 25(1):19-26.

HAMPE, O. 2003. Revision of the Xenacanthida (Chondrichthyes: Elasmobranchii) from the Carboniferous of the British Isles. Transaction of the Royal Society of Edimburg: Earth Sciences. 93: 191-237.

HAMPE, O.; LONG, J. A. 1999. The histology of Middle Devonian chondrichthyan teeth from southern Victoria Land, Antarctica. Records of the Western Australian Museum Supplements 57, 23-36.

HAMPE, O.; JOHNSON, G.D.; TURNER, S. 2006. Dicentrodus (Chondrichthyes: Xenacanthida) from the Early Carboniferous (Visean: upper St Louis Formation) of Iowa, USA. Geological Magazine, 143(4): 545-549.

HANNAH, M.J.; WILSON G.J., WRENN. J.H. 2000. Oligocene and Miocene Marine Palynomorphs from CRP-2/2A, Victoria Land Basin, Antarctica. Terra Antartica. 7(4):503-511.

HANSEN, M. C. 1978. A presumed lower dentition and a spine of a Permian petalodontiform chondrichthyan, Megactenopetalus kaibabanus. Journal of Paleontology, 52:55-60.

HERBST, R. 1987. Studies on Psaroniaceae.II. Tuvichapteris solmsi nov.gen. et. SP. From the Permian of Paraguay and Uruguay. In: CONGRESSO LATINO- AMERICANO DE PALEONTOLOGIA, 4., 1987, Bolívia. Anais... Bolívia: p.267-282.

HOLZ, M. 1998. Tafonomia de Vertebrados: a arte de decifrar a origem do registro de paleotetrápodes. Ciência \& Ambiente, 16:106-117.

HOLZ, M. \& DIAS, M. E. 1998. Taphonomy Of Palynological Records In A Sequence Stratigraphic Framework: An Example From The Early Permian From The Paraná Basin In Southern Brazil. Review of Palaeobotany and Palynology, Amsterdam/ Holland. 99, p. 217-233.

HOLZ, M. \& SIMÕES M. G. 2002. Elementos Fundamentais de Tafonomia. Editora da Universidade/UFRGS Porto Alegre. 231p.

HOLZ, M.; ZWETSCH, G.; SIMÕES, M. G.; CARLUCCI, R. 1998. Tafonomia dos invertebrados na Formação Palermo (Kunguriano) da Bacia do Paraná no Rio Grande do Sul: Lingulídeos desarticulados em fácies de tempestitos. XL CONGRESSO BRASILEIRO DE GEOLOGIA, Belo Horizonte. Anais...453.

HUSSAKOF, L. 1930. Alguns restos de peixes do Permiano e do Triássico do Brasil. Boletim do Serviço Geológico e Mineralógico do Brasil. 49:1-11.

IRMIS, R.B. \& ELLIOTT, D.K. 2006. Taphonomy of a Middle Pennsylvanian marine vertebrate assemblage and an actualistic model for marine abrasion of teeth. Palaios. 21: 466-479. 
ITANO, W. M.; HOUK, K. J.; LOCKLEY. M. J. 2003. Ctenacanthus and other chondrichthyan spines and denticles from the Minturn Formation (Pennsylvanian) of Colorado. Journal of Paleontology 77: 524-535.

IVANOV, A. 2005. Early Permian Chondrichthyans of the Middle and South Urals. Revista Brasileira de Paleontologia 8(2):127-138.

JANVIER, P. 1996. Early Vertebrates. Oxford Science Publications. 393p.

JANVIER, P. \& MELO, J.H.G. 1987. Late Devonian Actinopterygian Scales from the Upper Amazon Basin, Northwestern Brazil. Anais da Academia Brasileira de Ciências. 59(3):213-218.

JANVIER, P. \& MELO, J.H.G. 1988. Acanthodian fish remains from Upper Silurian or Lower Devonian of the Amazon Basin, Brazil. Palaeontology. 31:771-777.

JANVIER, P. \& MELO, J.H.G. 1992. New Acanthodii and Chondrichthyan remain from the Lower and Middle Devonian of Brazil. Neues Jahrbuch fur Geologie und Paleontologie, Monatshefte. 4:193206.

JIN, Y.G.; WARDLAW, B.R. \& KOLATA, D.R. 1997. Permian chronostratigraphic subdivisions. Episodes, 20: 0-20.

JOHNSON, G. 1980. Xenacanthodii (Chondrichthyes) from the Tecovas Formation (Late Triassic) of West Texas. Journal of Paleontology. 54(5):923-932.

JOHNSON, G. 1981. Hybodontoidei (Chondrichthyes) from the Wichita Albany Group (Early Permian) of Texas. Journal of Vertebrate Paleontology, 1(1):1-41.

JOHNSON. G. 1999. Dentitions of Late Palaeozoic Orthacanthus species and new species of ?Xenacanthus (Chondrichthyes: Xenacanthiformes) from North América. Acta Geologica Polonica. 49 (3): 215-266.

JOHNSON, G. 2003. Dentitions of Barbclabornia (new genus, Chondrichthyes: Xenacanthiformes) from the Upper Palaeozoic of North America. Mitteilungen aus dem Museum für Naturkunde in Berlin, Geowissenschaftliche Reihe. 6:125-146.

JOHNSON, G. 2005a. An unusual tricuspid chondrichthyan tooth from the Lower Permian of Texas, U.S.A. Revista Brasileira de Paleontologia. 8:159-164.

JOHNSON. G. 2005b. Underdeveloped and unusual xenacanth shark teeth from the Lower Permian of Texas. Proceedings of the South Dakota Academy of Science, 84. 215-223.

KAZUBEK, M. F. \& SIMOES, M. G. 2002. The lost fauna unearthed: Permian bivalves of the Irati Formation (Passa Dois Group), Paraná Basin, Brazil.. In: PALEO-2002, PR-SC., 2002, Florianóplois, SC. Paleontologia em Destaque, SBP.. Porto Alegre, RS: SBP.40:31-32.

KAZUBEK, M. F.; SIMOES, M. G. 2003a. Permian bivalves of the Irati Formation (Passa Dois Group, Paraná Basin) and their paleoecological significance.. In: XVIII CONGRESSO BRASILEIRO DE PALEONTOLOGIA. Brasília. Boletim de Resumos.161-161.

KAZUBEK, M. F. \& SIMOES, M. G. 2003b. Feições sedimentológicas, bioestratinômicas e estratigráficas das concentrações de bivalves do Membro Taquaral (Formação Irati, Grupo Passa Dois, Bacia do Paraná) e seus significados. In: PALEO-2003. PR-SC. Paleontologia em Destaque. Curitiba. 44: 29-29.

KIDWELL, S. M, \& HOLLAND, S. M. 1991. Field description of course bioclastic fabrics. Palaios. 6: 426-434.

KNOPF,F.; KOENEMANN,S.; SCHRAM, F.R.; WOLFF, C. 2006. The urosome of the Pan- and Peracarida. Contributions to Zoology, 75 (1/2) 1-21.

KOBAYASHI, T., 1954. Fossil Estherians and allied fossils. Journal of the Faculty of Science, University of Tokyo, Section 2, 9(1): 1-192.

LAGES . L. C. 2004. A Formação Irati (Grupo Passa Dois, Permiano, Bacia do Paraná) no furo de sondagem FP-01-PR (Sapopema, PR). Dissertação de Mestrado. Pós-Graduação em Geociências. Universidade Estadual Paulista/Instituto de Geociências e Ciências Exatas. Rio Claro. 117p. 
LAURIN, M., \& SOLER-GIJÓN. R. 2001. The oldest stegocephalian from the Iberian Peninsula: evidence that temnospondyls were euryhaline. Comptes Rendus de l'Académie des Sciences de Paris, Sciences de la Vie 324:495-501.

LAURIN, M., \& SOLER-GIJÓN. R. 2006. The oldest known stegocephalian (Sarcopterygii: Temnospondyli) from Spain. Journal of Vertebrate Paleontology, 26(2):284-299

LAVINA, E.L.; ARAÚJO-BARBERENA, D.C. A.; AZEVEDO, S. 1981. Tempestades de Inverno e Altas Taxas de Mortalidade de Répteis Mesossauros: um exemplo a partir do afloramento Passo São Borja, RS. Pesquisas, 18(1): 64-70.

LEBEDEV, O. 2008. Systematics and dental system reconstruction of the durophagous chondrichthyan Lagarodus JAEKEL, 1898. Acta Geologica Polonica, 58 (2): 199-204

LEIDY, J., 1859. Xystracanthus, Cladodus and Petalodus from the Carboniferous of Kansas. Proceedings Academy Natural Science Philadelphia, (11):3. Artigo retirado da internet disponível em < http://www.oceansofkansas.com/Leidy1859.html>.

LIAO, J.C.; GINTER, M.; VALENZUELA-RIOS, J.I. 2007. Chondrichthyan microremains from the Givetian of the Aragonian Pyrenees (Spain). Bulletin de la Société géologique de France, 178: 171-178

LIMA, M. R.; SAAD, A. R.; CARVALHO, R. G.; SANTOS, P. R. 1976. Foraminíferos arenáceos e outros fósseis do Subgrupo Itararé (Neopaleozóico), Bacia do Paraná, São Paulo, Brasil. In: ANAIS DO XXIX CONGRESSO BRASILEIRO DE GEOLOGIA. Ouro Preto 2: 49-65.

LISBOA, A. C. 2006. Caracterização Geoquímica Orgânica dos Folhelhos neo-permianos da Formação Irati-Borda da Bacia do Paraná, São Paulo. Dissertação de Mestrado em Engenharia Civil COPPE/UFRJ - Universidade Federal do Rio de Janeiro. 153 p.

LONG, J. A. 1993. Morphological characteristics of Palaeozoic vertebrates used in biostratigraphy. In: LONG, J. A. (eds) Palaeozoic vertebrate biostratigraphy and biogeography. Belhaven, London. 3-24.

LONG, J. A. 1995. The Rise of Fishes: 500 Million Years of Evolution. University of New South Wales Press, Sydney. 223p.

LOWNEY, K. A. 1980. A revision of the family Haplolepidae (Actinopterygii, Palaeonisciformes) from Linton, Ohio (Westphalian D, Pennsylvanian. Journal of Paleontology. 54 (5):942-953.

LUGER, P. 1988. Campanian to Paleocene agglutinated foraminifera from freshwater influenced marginal marine (deltaic) sediments of southern Egypt. Abh. Geol. B.-A.41:255-263.

LUND, R., 1989. New petalodonts (Chondrichthyes) from the Upper Missisippian Bear Gulch Limestone (Namurian E2b) of Montana. Journal of Vertebrate Paleontology: 9(3):350-368.

LUND R. \& GROGAN, E. D. 1997 - Relationships of the Chimaeriformes and the basal radiation of the Chondrichthyes. Reviews of Fish Biology and Fisheries, 7, 59p.

LUND, R. \& POPLIN, C. 1997. The Rhadinichthyids (Paleoniscoid Actinopterygians) from the Bear Gulch limestone of Montana (USA, Lower Carboniferous). Journal of Vertebrate Paleontology: 17(3):466-486.

LUND, R. \& POPLIN, C. 2002. Cladistic analysis of the relationships of the tarrasiids (Lower Carboniferous Actinopterygians). Journal of Vertebrate Paleontology: 22(3):480-486.

OCHEV, V.G. \& SURKOV, M.V. 2000. The history of excavation of Permo-Triassic vertebrates from Eastern Europe. In: BENTON, M.J., SHISHKIN, M.A., UNWIN, D.M. \& KUROCHKIN, E.N. (eds) The Age of Dinosaurs in Russia and Mongolia. Cambridge University Press, Cambridge, 116.

OELOFSEN, B. \& ARAÚJO, D. C. 1983. Paleoecological implications of the distribuition of mesosaurid reptiles in the Permian Irati Sea (Parana Basin), South America. Revista Brasileira de Geociências. 13(1): 1-6.

OLESEN, J., 1998. A phylogenetic analysis of the Conchostraca and Cladocera (Crustacea, Branchiopoda, Diplostraca). Zoological Journal Linnean Society. 122, 491-536. 
OLESEN, J., MARTIN, J.W., ROESSLER, E.W., 1996. External morphology of the male of Cyclestheria hislopi (Baird, 1859) (Crustacea, Branchiopoda, Spinicaudata), with a comparison of male claspers among the Cochostraca and Cladocera and its bearing on phylogeny of the "bivaled" Branchiopoda. Zoologica Scripta. 25, 291-316.

MAISEY, J.G. 1981. Studies on the Paleozoic selachian genus Ctenacanthus Agassiz. No. 1. Historical review and revised diagnosis of Ctenacanthus, with a list of referred taxa. American Museum Novitates. 2718:1 -22.

MAISEY, J.G. 1982. Studies on the Paleozoic selachian genus Ctenacanthus Agassiz. No. 2. Bythiacanthus St. John and Worthen, Amelacanthus, New Genus, Eunemacanthus St. John and Worthen, Sphenacanthus Agassiz, and Wodnika Münster. American Museum Novitates. 2722:1 24.

MAISEY, J.G. 1984. Studies on the Paleozoic selachian genus Ctenacanthus Agassiz. No. 3. Nominal species referred to Ctenacanthus. American Museum Novitates, 2774:1-20.

MAISEY, J.G. 1991. Santana Fossils. An Ilustrated Atlas. Ed. T.F.H.. United States of America. 459p.

MAISEY, J.G. 1994. Gnathostomes (jawed vertebrates). In: PROTHERO, D. R. \& SCHOCH, R.M. (eds) Major Features of Vertebrate Evolution, Knoxville, The Paleontologicial Society, Short Courses in Paleontology, (7): 38-56.

MANCUSO, A. C. 2003. Continental fish taphonomy: a case study in the Triassic of Argentina. Journal of South America Earth Sciences. 16: 275-286.

MARANHÃO, M. S. A. S. 1995. Fósseis das Formações Corumbataí e Estrada Nova do Estado de São Paulo: Subsídios ao conhecimento Paleontológico e Bioestratigráfico. Programa de PósGraduação em Geologia Sedimentar, Instituto de Geociências da Universidade de São Paulo, Tese de Doutoramento (Inédita). 2 volumes. 79p.

MARASCO, S.A.; SOUZA, P.A.; PIRES, F.A. 1993. Ocorrência de paleomicroplâncton marinho (Acritarcha) associado a ictiofósseis na base do Membro Taquaral, Formação Iratí (Permiano Superior da bacia do Paraná), região de Itapetininga, Estado de São Paulo. In: XIII CONGRESSO BRASILEIRO DE PALEONTOLOGIA E I SIMPÓSIO PALEONTOLÓGICO DO CONE SUL, São Leopoldo, RS. Sociedade Brasileira de Paleontologia, UNISINOS, Boletim de Resumos. 60.

MARQUES, J. C.; CHEMALE JR., F.; LOPES, R. C.; SOUZA, P. A.; JUSTINO, D.; DUSSIN, I. A. 2007. LA-ICP-MS U-Pb Zircon Age from an Ash Fall Rock of the uppermost Rio Bonito Formation, Southern Paraná Basin. In: IV SIMPÓSIO DE CRONOESTRATIGRAFIA DA BACIA DO PARANÁ. Búzios. Boletim de Resumos; 32.

MARQUES-TOIGO, M. 1991. Palynobiostratigraphy of the southern Brazilian Neopaleozoic Gondwana sequence. In: VII INTERNATIONAL GONDWANA SYMPOSIUM. Proceedings, São Paulo. 503-515.

MARQUES-TOIGO, M.; DIAS-FABRÍCIO, M. E.; CAZZULO-KLEPZIG, M. 1984. A sucessão da microflora nas camadas de carvão da Bacia Carbonífera de Charqueadas - Formação Rio Bonito, RS, Brasil. Boletim IG-USP: Série Científica. 15: 65-72.

MARTILL D.M. \& HARPER L. 1990. An application of critical point drying to the comparison of modern and fossilized soft tissue of fishes. Palaeontology. 33(2). 423-428.

MARTIN, J.W. \& CASH-CLARK, C.E., 1995. The external morphology of the onychopod "cladoceran", genus Bythotrephes (Crustacea, Branchiopoda, Onychopoda, Cercopagididae), with notes on the morphology and phylogeny of the order Onychopoda. Zoologica Scripta. 24, 61-90.

MARTIN, J. W. \& DAVIS, G. E. 2001. An Updated Classification of the Recent Crustacea. Natural History Museum of Los Angeles, Science Series. 39. 124p

MARTÍNEZ, M. A.; PRÁMPARO, M. B.; QUATTROCCHIO, M. E.; ZAVALA, C. A. 2008. Depositional environments and hydrocarbon potential of the Middle Jurassic Los Molles Formation, Neuquén Basin, Argentina: palynofacies and organic geochemical data. Revista Geológica de Chile 35 (2): 279-305.

MARTINS-NETO, R. G. 2005. Estágio atual da paleoartropodologia brasileira: hexápodes, miriápodes, crustáceos (Isopoda, Decapoda, Eucrustacea e Copepoda) e quelicerados. Arquivos do Museu Nacional. 63 (3): 471-494. 
MATOS, S.L.F.; YAMAMOTO, J.K.; RICCOMINI, C.; HACHIRO, J. \& TASSINARI, C.C.G.. 2001. Absolute dating of Permian ash-fall in the Rio Bonito Formation, Paraná Basin. Gondwana Research, 4:421-426.

MATSUDA, N. S.; DINO, R.; FILHO, W. R. J. 2004. Revisão litoestratigráfica do Grupo Tapajós, Carbonífero Médio - Permiano da Bacia do Amazonas. Boletim de Geociências da Petrobras. Rio de Janeiro. CENPES, v. 12 (2): 435-431.

MEDEIROS, R. A. 1993. Transgressões e regressões cíclicas e a origem das formações do Rio Bonito e Palermo da Bacia do Paraná. In: I SIMPÓSIO DE CRONOESTRATIGRAFIA DA BACIA DO PARANÁ. Rio Claro, FUNDUNESP. Boletim de Resumos: 44-49.

MERINO-RODO, D. \& JANVIER, P. 1986. Chondrichthyan and Actinopterygian remains from the Lower Permian Copacabana Formation of Bolivia. Geobios. 19(4): 479-493.

MEZZALIRA, S. 1952. Clarkecaris, novo gênero de crustáceo Syncarida do Permiano. Boletim da Sociedade Brasileira de Geologia. 1(1): 46-52.

MEZZALIRA, S. 1954. Novas ocorrências de crustáceos fósseis da Formação Iratí do sul do Brasil. In: Paleontologia do Paraná Volume comemorativo do $1^{\circ}$ Centenário do estado do Paraná. 165-173.

MEZZALIRA, S. 1959. Nota preliminar sobre as recentes descobertas paleontológicas no Estado de São Paulo, no período 1958-1959.Instituto Geográfico e Geológico. São Paulo. Notas prévias. (2): 1-9.

MEZZALIRA, S. 1971. Contribuição ao conhecimento da Geologia de sub-superfície e da Paleontologia da Formação Irati, no Estado de São Paulo. Anais da Academia Brasileira de Ciências. (Suplemento). 43: 273-336.

MEZZALIRA, S. 1989. Os fósseis do Estado de São Paulo. 2 ed. ver. atual. São Paulo, Secretaria do Meio Ambiente, Instituto Geológico. Série Pesquisa. 142p.

MEZZALIRA, S. 2000. Os fósseis do Estado de São Paulo. Parte II. Período 1987 (parcial) - 1996. São Paulo, Instituto Geológico. Boletim do Instituto Geológico, 15, 70 p.

MEZZALIRA, S. \& MARTINS-NETO, R.G. 1992. Novos crustáceos paleozóicos do Estado de São Paulo com descrição de novos taxa. Acta Geológica Leopoldensia. Estudos Tecnológicos. São Leopoldo. 15(36): 49-65.

MILANI, J. \& DE WIT, M. J. 2008. Correlations between the classic Paraná and Cape-Karoo sequences of South America and southern Africa and their basin infills flanking the Gondwanides: du Toit revisited. Geological Society, London, Special Publications. 294: 319-342

MILANI, E. J.; MELO, J. H. G.; SOUZA, P. A.; FERNANDES, L. A.; FRANCA, A. B. 2007. Bacia do Paraná. Boletim de Geociências da Petrobrás, 15, 265-287.

MOCHIZUKI, A. H. 2001. Arquitetura Estratigráfica e reservatórios do Subgrupo Guatá (Eopermiano) na margem aflorante leste de São Paulo. Monografia de Trabalho de Formatura (Inédito). UNESPANP. Rio Claro. SP. 41p.

MORALES, N.; PERINOTTO, J. A. J.; D’AFFONSECA, F. M. 1997. Evidencias de Tectônica distensiva sindeposicional à Formação Tatuí na região de Limeira-SP. In: V SIMPÓSIO DE GEOLOGIA DO SUDESTE. 60-61.

MOY-THOMAS, J. A. \& MILES, R. 1971. Palaeozoic Fishes. Sauders, Philadelphia. 259p.

MUSSA, D. 1982. Lignitafofloras Permianas da Bacia do Paraná, Brasil (Estados de São Paulo e Santa Catarina). Instituto de Geociências, Universidade de São Paulo, São Paulo, Tese de Doutoramento, 461p, (2 vol.).

MUSSA, D. 1986a. As formas gondwanicas do Grupo Solenóide e sua distribuição estratigráfiça. Anais da Academia Brasileira de Ciências, 58(1): 61-98.

MUSSA, D. 1986b. Esteios gondwanicos de medula diafragmada e sua posição estratigráfica. Boletim do Instituto de Geociencias da USP, 17: 11-26.

MUSSA, D. CARVALHO, R.G.; SANTOS, P.R. 1980. Estudo estratigráfico e Paleoecológico em Ocorrências Fossilíferas da Formação Irati, Estado de São Paulo, Brasil. Boletim do IG/USP. 11: 31-189. 
MUTTER, R.J.; RIEBER, H. 2005. Pyknotylacanthus spathianus gen. et sp. nov., a new ctenacanthoid from the Early Triassic of Bear Lake (Idaho, USA). Revista Brasileira de Paleontologia 8(2): 139148.

NELSON, J.S. 2006. Fishes of the World. 4th ed., John Wiley \& Sons, New Jersey, 601p.

NESBITT, E. A.; CAMPBELL, K. A. 2006. The Paleoenvironmental Significance of Psilonichnus. Palaios; 21; no. 2; p. 187-196.

NETTO, R.G. 2000. Paleoicnologia do Rio Grande do Sul. In: HOLZ, M.;DE ROS, L. F.. (2000). $A$ paleontologia do Rio Grande do Sul. Porto Alegre. 25-43

OLIVEIRA, E. P. 1940. História da pesquisa do petróleo no Brasil. Ministério da Agricultura.15: 1-208.

PARKER, S. 1990. Peixes. Aventura Visual. A Dorling Kindersley Book. Museu de História Natural de Londres. 64p.

PARK, L. E.; GIERLOWSKI-KORDESCHB, E. H. 2007. Paleozoic lake faunas: Establishing aquatic life on land. Palaeogeography, Palaeoclimatology, Palaeoecology. 249 (1-2): 160-179.

PARRISH, W. C. 1978. Paleoenvironmental analysis of a Lower Permian bonebed and adjacent sediments, Wichita County, Texas. Palaeogeography, Palaeoclimatology, Palaeoecology. 24(3):209-237

PEREZ, M. A. \& MALABARBA, M.C.S.L. 2002. A Triassic freshwater fish fauna from the Paraná Basin, in southern Brazil. Revista Brasileira de Paleontologia, 4:27-33

PERINOTTO, J.A. 1992. Análise estratigráfica da Formação Palermo (P) na Bacia do Paraná, Brasil. Tese de Doutorado, Instituto de Geociências e Ciências Exatas - UNESP, Rio Claro/SP, 115p.

PERINOTTO, J.A. \& FÚlfFARO, V.J. 1993. Possibilidades de fatiamento cronoestratigráfico da Formação Palermo e sua extensão no Estado de São Paulo. In: I SIMPÓSIO DE CRONOESTRATIGRAFIA DA BACIA DO PARANÁ. Rio Claro, FUNDUNESP. Boletim de Resumos: 57-58.

PETRI, S. 1964. Grupo Tubarão. Boletim do Instituto Geográfico e Geológico. 41: 56-63.

PETRI, S. \& FULFARO, V. J. 1966. Considerações sobre a geologia da área balizada pelas cidades de Barra das Garças e Guiratinga (Mato Grosso) e Jataí e Amoninópolis (Goiás). In: SOCIEDADE BRASILEIRA DE GEOLOGIA - NÚCLEO RIO DE JANEIRO. 1: 66-67.

PETRI,S. \& FULFARO,V.J. 1983. Geologia do Brasil (Fanerozóico).TAQ-EDUSP, São Paulo: 631p.

PINTO, I. D. 1970. Reconstituição de Pygaspis Beurlen, 1934 (Crustacea - Pygocephalomorpha). Sua posição sistemática, seu significado e de outros fosseis para o Gondwana. Anais da Academia Brasileira de Ciências. Suplemento. Rio de Janeiro. 42: 387-400.

PINTO, I. D. 1972a. Late Paleozoic insects and crustaceans from Paraná Basin and Their bearing on chronology and continental drift. Anais da Academia Brasileira de Ciências. Suplemento. Rio de Janeiro. 44: 247-259.

PINTO, I. D. 1972b. Permian insects from Parana Basin, South Brazil I. Mecoptera. Revista Brasileira de Geociências. 2: 105-116.

PINTO, I. D. 1985. New data on the genus Clarkecaris Mezzalira, 1952. Boletim do DNPM, Brasília.(27): 253-259.

PINTO, I. D. 1987a. Permian insects from Parana Basin, South Brazil IV. Coleoptera. Pesquisas. Porto Alegre. 19: 5-12.

PINTO, I. D. 1987b. Permian insects from Parana Basin, South Brazil IV. Homóptera - 2 - Cicadídea. Pesquisas. Porto Alegre. 19: 13-22.

PINTO, I. D. 1990. Permian insects from Parana Basin, South Brazil VI. Homóptera - 3 Fulgoringruidae. Pesquisas. 17(1-2): 3-6.

PINTO, I. D. \& ORNELLAS, L. P. 1978. Carboniferous Insects (Protorthoptera and Paraplecoptera) from the Gondwana (South America, Africa and Asia). Pesquisas. Porto Alegre. 11: 305-321. 
PIRES, F.A. \& PETRI, S. 1993. Estratigrafia da Bacia do Paraná (Carbonífero Superior - Triássico Inferior) no Estado de São Paulo. In: I SIMPÓSIO DE CRONOESTRATIGRAFIA DA BACIA DO PARANÁ. Rio Claro, FUNDUNESP. Boletim de Resumos: 60-61.

POPLIN, C.M. \& LUND, R. 2002. Two Carboniferous fine-eyed palaeoniscoids (Pisces, Actinopterygii) from Bear Gulch (USA). Journal of Paleontology, 76(6):1014-1028.

PRICE, L. I. 1948. Um anfíbio labirintodonte da Formação Pedra do Fogo, Estado do Maranhão. Boletim do DNPM/DGM. 124:7-33.

PUTZER, H. 1954. Divisão da Formação Palermo no sul de Santa Catarina e tentativa de interpretação genética. Boletim da Sociedade Brasileira de Geologia. 3(1);1-28.

QUADROS, L. P. 2002. Acritarcos e Tasmanites do permo-carbonífero da Bacia do Paraná. Revista do Instituto Geológico, 23(1), 39-50.

RAGONHA, E.W. 1978. Chondrichthyes do Membro Taquaral (Formação Irati) no Estado de São Paulo. Dissertação de Mestrado (Inédita). São Paulo. IGc-USP, 65p.

RAGONHA, E.W. 1984. Taxionomia de dentes e espinhos isolados de Xenacanthodii (Chondrichthyes, Elasmobranchii) da Formação Corumbataí. Considerações cronológicas e paleoambientais. Instituto de Geociências da Universidade de São Paulo, Tese de Doutoramento (inédita). 166p.

RAGONHA, E. W. 1985. Um Palaeonisciforme da Formação Irati, Estado de São Paulo. Rio de Janeiro. Anais da Academia Brasileira de Ciências, 57(1):118.

RICCOMINI, C. 1992a. Estilos Estruturais da região do Domo de Pitanga, Bacia do Paraná, SP. Boletim do IG-USP, Publicação Especial. 12:93-94.

RICCOMINI, C. 1992b. Evidencias geológicas de atividade neotectônica no Estado de São Paulo e regiões adjacentes. Boletim do IG-USP. Publicação Especial. 12: 95-96.

RICCOMINI, C. 1995. Tectonismo gerador e deformador dos depósitos sedimentares pós-gondvânicos da porção centro-oriental do Estado de São Paulo e áreas vizinhas. Tese de livre docência apresentada ao Instituto de Geociências da USP. São Paulo, 100p.

RICCOMINI, C.; SANT’ANNA, L.G. \& COIMBRA, A.M. 1997 Sílica microcristalina (Trípoli) em rochas sedimentares permianas do flanco leste da bacia do Paraná, Estado de São Paulo, Brasil. Revista Brasileira de Geociências. 27(4). 395-402.

RICHTER, M. 1980. Ultra-estrutura de dentes de Paleoniscídeos (Pisces) do Grupo Passa Dois, RS, Brasil. Iheringia, Série Geologia., Porto Alegre. (8):131-145.

RICHTER, M. 1985. Situação da Pesquisa Paleoictiólogica no Paleozóico Brasileiro. In: Coletânea de Trabalhos Paleontológicos. DNPM, Série Geologia. Seção de Paleontologia e Estratigrafia. Brasília. 2(27):105-110.

RICHTER, M. 2002. A ray-finned fish (Osteichthyes) from the Late Permian of the State of Santa Catarina (Paraná Basin), Southern Brazil. Revista Brasileira de Paleontologia. 3: 56-61.

RICHTER, M. 2005. A new xenacanthid shark (Chondrichthyes) from the Teresina Formation, Permian of the Paraná Basin, Southern Brazil. Revista Brasileira de Paleontologia. 8(2):149-158.

RICHTER, M. ; NEIS, P. A. ; SMITH, M. M. 1999. Acanthodian and Actinopterygian fish remains from the Itaituba Formation, Late carboniferous of the Amazon Basin, Brazil, with a note on acanthodian ganoin. Neues Jahrbuch fur Geologie und Palaontologie, Mh., Stuttgart. 12: 728-744.

RICHTER, M.; PICCOLI, A.M.M.; LIMA, M.C.S. 1985. Variação morfológica de restos de paleoniscídeos (Pisces) no Permiano da Bacia do Paraná. In: Coletânea de Trabalhos Paleontológicos. DNPM, Série Geologia. Seção de Paleontologia e Estratigrafia. Brasília. 2(27):111-122.

RICHTER, M.; VIANA, M.S.S. \& MALABARBA, M.C.S.L. 2004. Agnatos e Peixes. In: CARVALHO. I. S. (eds.) Paleontologia. Rio de Janeiro, Editora Interciência, (1) 41:733-761.

ROBB III, A. J. 2003. Notes on the occurrence of some petalodont shark fossils from the Upper Pennsylvanian rocks of northeastern Kansas. Transactions of The Kansas Academy of Science. 106 (1/2): 71-80. 
ROCHA-CAMPOS, A.C. 1967. The Tubarão Group in the Brazilian portion of the Paraná Basin. In: BIGARELlA, J.J.; DECKER, R.D.; PINTO, I.D. (eds.), Problems in Brazilian Gondwana Geology, Instituto de Geologia, Universidade Federal do Paraná, p.27-102.

ROCHA-CAMPOS, A. C. 1970. Moluscos Permianos da Formacao Rio Bonito (Subgrupo Guatá), Santa Catarina. Boletim Divisão de Geologia e Mineralogia, DNPM, 251: 1-89.

ROCHA-CAMPOS, A. C.; BASEI, M. A. S.; NUTMAN, A. P.; SANTOS, P. R. 2007. SHRIMP U-Pb zircon ages of the late Paleozoic sedimentary sequence, Paraná Basin, Brazil. In: IV SIMPÓSIO DE CRONOESTRATIGRAFIA DA BACIA DO PARANÁ. Búzios. Boletim de Resumos; 33.

ROCHA-CAMPOS, A. C.; SIMÕES, M. G. 1993. Australomya sinuosa sp. n., um novo megadesmídeo (Mollusca, Pelecypoda) da formação Rio Bonito (Permiano), Bacia do Paraná, Brasil. Anais da Academia Brasileira de Ciências. 65:29-39.

ROHN, R.; LAGES, L. C.; PENNATTI, J. R. R. 2003. Litofácies da Formação Irati no furo de sondagem FP-01-PR (Permiano, borda leste da Bacia do Paraná). CONGRESSO BRASILEIRO DE P\&D EM PETRÓLEO \& GÁS, 2.: UFRJ. Rio de Janeiro. 1: 1-6.

RÖSLER, O.; ROHN, R.; ALBAMONTE, L. 1981. Libélula permiana do Estado de São Paulo, Brasil (Formação Irati): Gondvanoptilon brasiliense Gen. et sp. nov. In: ANAIS DO II CONGRESSO LATINO-AMERICA DE PALEONTOLOGIA. (1): 221-232.

RYAN, W.B.F.; PITMAN, III, W.C.; MAJOR, C.O.; SHIMKUS, K.; MASKALENKO, V.; JONES, G.A.; DIMITROV, P.; GÖRÜR, N.; SAKINÇ M.; YÜCE, H., 1997. An abrupt drowning of the Black Sea shelf. Marine Geology.138: 119-126.

SAAD, A. R. 1977. Projeto: Estratigrafia do Grupo Tubarão no Estado do Paraná. Relatório final ao CNPq (proc. 1111.3919/77). $11 \mathrm{p}$.

SAAD, A. R.; SANTOS, P. R.; ROCHA CAMPOS, A. C. 1979. Evolução tecto-sedimentar do Grupo Tubarão (Neopaleozóico), na Margem Nordeste da Bacia do Paraná. Anais da Academia Brasileira de Ciências. 51(2); 333-343.

SANTOS, K. R. S.; SAKAMOTO, A. Y.; LAURENT, B.; QUEIROZ NETO, J. P. 2004. Ficoflora do Pantanal da Nhecolândia, MS, Brasil: um levantamento preliminar em três lagoas salinas e uma salitrada. In: IV SIMPÓSIO SOBRE RECURSOS NATURAIS E SÓCIO-ECONOMICOS DO PANTANAL. Corumbá/MS. Artigo completo publicado na internet. $7 \mathrm{p}$.

SANTOS, M. E. C. M. 1994. Províncias biogeográficas e variação do nível do mar no Neopaleozóico da Bacia do Parnaíba. In: XXXVIII CONGRESSO BRASILEIRO DE GEOLOGIA. Camboriú, SC. Boletim de Resumos expandidos. 3: 224-226.

SANTOS, R. V.; SOUZA, P. A. ALVARENGA, C.J.S.; DANTAS, E.L.; PIMENTEL, E.L.; OLIVEIRA, C.G.; ARAÚJO, L.M. 2006. Shrimp U-Pb Zircon Dating and Palynology of Bentonitic Layers from the Permian Irati Formation Parana Basin, Brazil. Gondwana Research. 9:456-463.

SANTOS-NETO, E. V. \& CERQUEIRA, J. R. 1993. Aplicação da geoquímica orgânica na cronoestratigrafia e paleogeografia da Formação Irati, Bacia do Paraná. In: I SIMPÓSIO DE CRONOESTRATIGRAFIA DA BACIA DO PARANÁ. Rio Claro, FUNDUNESP. Boletim de Resumos; 71.

SCHAEFFER, B. 1952. The Triassic Coelacanth Fish Diplurus, with observations on the evolution of the Coelacanthini. Bulletin of the American Museum of Natural History. 99(2):25-78.

SCHAEFFER, B. \& DALQUEST, W. W. 1978. A Palaeonisciform Braincase from the Permian of Texas, With comments on cranial fissures and the posterior myodome. American Museum Novitates. 2658: $1-15$

SCHMINKE, H.K., 1981. Adaptation of Bathynellacea (Crustacea, Syncarida) to life in the interstitial (“Zoea Theory"). Internationale Revue gesamten Hydrobiologie. 66, 575-637.

SCHNEIDER, R.L.; MUHLMANN, H.; TOMMASI, E.; MEDEIROS, R. A.; DAEMON, R. F.; NOGUEIRA, A. A. 1974. Revisão estratigráfica da Bacia do Paraná. In: XXVIII CONGRESSO BRASILEIRO DE GEOLOGIA, Porto Alegre. Anais..., Porto Alegre,1: 41-65.

SCHRAM, F R. 1977. Paleozoogeography of Late Paleozoic and Triassic Malacostraca. Systematic Zoology. 26(4):367-379. 
SCHRAM, F. R.. 1978. Jerometichenoria grandis n. gen., n. sp. (Crustacea Mysidacea) from the Lower Permian of Soviet Union. Journal of Paleontology. 52(3): 605-607.

SCHRAM F. R. 1980. Miscellaneous Late Paleozoic Malacostraca of the Soviet Union. Journal of Paleontology. 54(3):542-547.

SCHRAM F. R. 1981. Late Paleozoic Crustacean Communities. Journal of Paleontology, 55:(1):126-137

SCHRAM F. R. 2006. Lobetelson mclaughlinae n. gen., n. sp.,a new genus and species of belotelsonid malacostracan from the Pennsylvanian of the Mazon Creek area. Zoosystema. 28 (2) : 277-284.

SCHRAM, J. M. \& SCHRAM, F. R. 1974. Squillites spinosus Scott 1938 (Syncarida Malascostraca) from the Mississipian Heath shale of Central Montana. Journal of Paleontology. 48(1): 95 - 104.

SCHULTZE, H. P. 2009. Interpretation of marine and freshwater paleoenvironments in PermoCarboniferous deposits. Palaeogeography, Palaeoclimatology, Palaeoecology. 281: 126-136.

SCHULTZE, H. P. \& BARDACK, D. 1987. Diversity and size changes in palaeonisciform fishes (Actinopterygii, Pisces) from the Pannsylvanian Mazon Creek Fauna, Illinois, U.S.A. Journal of Vertebrate Paleontology: 7(1):1-23.

SILVA, C. F.; FONSECA, V. M. M. 2005. Hábitos de vida dos Trilobitas das Formações Maecuru e Ererê, Devoniano da bacia do Amazonas, Brasil. Revista Brasileira de Paleontologia. 8(1): 73-82.

SILVA SANTOS, R. 1946, Duas novas formas de elasmobranquios do Paleozóico do Meio Norte do Brasil. Anais da Academia Brasileira de Ciências, 18(4):281-285.

SILVA SANTOS, R. 1947, Um Ctenacanthus do Gondwana Brasileiro. Anais da Academia Brasileira de Ciências, 19(4):282-284.

SILVA SANTOS, R. 1967. Sobre um cladodontídeo do Carbonífero do Rio Parauarí, Amazonas. Atas do simpósio sobre a Biota Amazônica. (1):425-430.

SILVA SANTOS, R. 1990. Paleoictiofáunula da Formação Pedra do Fogo, Nordeste do Brasil: Holocephali - Petalodontidae. Anais da Academia Brasileira de Ciências. (62)4: 347-355.

SILVA SANTOS, R. 1991. Palaeonisciformes da Estado de São Paulo. In: XII CONGRESSO BRASILEIRO DE PALEONTOLOGIA. IG-USP. São Paulo. Boletim de Resumos. 11.

SILVA SANTOS, R. \& SALGADO, M. S. 1970, Um Espinho de Xenacanthus do Carbonífero do Estado do Maranhão. Anais da Academia Brasileira de Ciências, 42(2):5-9.

SIMÕES, M. G. 1992. Pelecípodes da Formação Palermo (Permiano)de São Sepé (RS) e Guiratinga (MT): implicações na evoluçãoda fauna neopaleozóica da Bacia do Paraná, Brasil. 286p. Tesede Doutoramento, Instituto de Geociências, Universidade de SãoPaulo, São Paulo, SP.

SIMÕES, M. G. 2000. Assembléias de Invertebrados Marinhos do Neopaleozóico da Bacia do Paraná, no Estado do Rio Grande do Sul. In: HOLZ, M. \& ROS, L. F . 2000. Paleontologia do Rio Grande do Sul. Porto Alegre : UFRGS/CIGO. 107-125.

SIQUEIRA, L. F. S. 2007. Análise geométrica e tectonismo gerador do alto estrutural de Pitanga, SP. Monografia de Trabalho de Formatura - São Paulo: IGc/USP. 30p

SOARES, M. B. 2003. A taphonomic model for the mesosaur assemblage of the Irati Formation, Paraná Basin, Brazil. Acta Geologica Hispanica, Barcelona. 1(4): 349-361,

SOARES, P.C. 1972. O limite glacial/pós-glacial do Grupo Tubarão no Estado de São Paulo. Anais da Academia Brasileira de Ciências, 44(suplemento):333-342.

SOARES, P. C. 1974. Elementos estruturais da parte nordeste da Bacia do Paraná: Classificação e Gênese. In: ANAIS DO XXVIII CONGRESSO BRASILEIRO DE GEOLOGIA. 4: 107 - 121.

SOARES, P.C. \& LANDIM, P.M.B. 1973. Aspectos regionais da estratigrafia da bacia do Paraná no seu flanco nordeste. In: XXVII Congresso Brasileiro de Geologia, Aracaju (SE). Anais, 1: 243-256.

SOARES, P. C.; LANDIM, P. M. B.; FÚLFARO, V. J. 1974. Avaliação preliminar da evolução geotectônica das bacias intracratônicas brasileiras. In: ANAIS DO XXVIII CONGRESSO BRASILEIRO DE GEOLOGIA. 4: 61-83. 
SOLER-GIJÓN, R. 1997a. Orthacanthus meridionalis, a new xenacanth shark (Elasmobranchii) from the Upper Carboniferous of the Puertollano basin, Spain. Neues Jahrbuch fuer Geologie und Palaeontologie Abhandlungen 204(2), 141-69.

SOLER-GIJÓN, R. 1997b. New discoveries of xenacanth sharks from the Late Carboniferous of Spain (PuertollanoBasin) andEarly Permian of Germany (Saar-Nahe Basin): Implications for the phylogenyof xenacanthiformand anacanthous sharks. Neues Jahrbuch fuer Geologie und Palaeontologie Abhandlungen 205(1), 1-31.

SOLER-GIJÓN, R. 2000. Phylogenetic relationships of Lebachacanthidae Soler-Gijo n 1997 (Xenacanthiformes; Elasmobranchii). Palaeontologische Zeitschrift 74(3), 363-377.

SOLER-GIJÓN, R. \& MORATALlA, J. J. 2001. Fish and tetrapod trace fossils from the Upper Carboniferous of Puertollano, Spain. Palaeogeography, Palaeoclimatology, Palaeoecology. 171(1-2): 1-28.

SOLMS-LAUBACH, H., 1913. Tietea singularis. Ein neuer Pteridinenstamm aus Brasilien. Zeitschrift für Botanik. 5, 673-700.

SOROKIN, V. M. \& KUPRIN, P. N. 2007. On the character of Black Sea level rise during the Holocene. Moscow University Geology Bulletin. 62(5): 334-341.

SOUZA, P.A., 2006. Late Carboniferous palynostratigraphy of the Itararé Subgroup, northeastern Paraná Basin. Review of Palaeobotany \& Palynology, 138, 9-29.

SOUZA, P. A. \& CALlEGARI, L. M. 2004. An Early Permian Palynoflora from the Itararé Subgroup, Paraná Basin, Brazil. Revista Española de Micropaleontología, 36(3): 439-450.

SOUZA, P.A. \& MARQUES-TOIGO, M. 2003. An overview on the palynostratigraphy of the Upper Paleozoic Brazilian Paraná Basin. Revista Museo Argentino de Ciencias Naturales, 5:205-214.

SOUZA, P.A., SANTOS, P.R., LIMA, M.R. 1992. Contribuição à palinologia da Formação Irati no Estado de Goiás. 485-486. In: SBG, CONGRESSO BRASILEIRO DE GEOLOGIA, 24, Brasília, Boletim de Resumos Expandidos, (2):485-486.

SOUZA FILHO, E. E. 1983. Tectônica da Região de Rio Claro - Piracicaba Domo de Pitanga. ATAS DO IV SIMPÓSIO REGIONAL DE GEOLOGIA, SBG-SÃO PAULO. 191-196.

STAHL, B. J. 1999. Chondrichthyes III: Holocephali. SCHULTZE H. P. (eds.). Handbook of Paleoichthyology, Vol. 4. Verlag Dr. Friedrich Pfeil, München. 164 pp.

STEVAUX, J. C.; SOUZA FILHO, E. E.; LANDIM, P. M. B. 1983. Marcas de ondas simétricas do topo do Subgrupo Itararé e seu significado paleogeográfico. In: ATAS DO IV SIMPOSIO REGIONAL DE GEOLOGIA, SBG - SÃO PAULO. 175-183.

STEVAUX, J.C.; SOUZA-FILHO, E. E. \& FÚLFARO, V.J. 1986. Trato deposicional da Formação Tatuí (P) na área aflorante do NE da Bacia do Paraná, Estado de São Paulo. In: XXXIV CONGRESSO BRASILEIRO DE GEOLOGIA, Goiânia. Sociedade Brasileira de Geologia. Anais. 1: 219-229.

STOLlhOFEN, H., STANISTREeT, I.G., BANGERT, B., GRILL, H., 2000. Tuffs, tectonism and glacially related sea-level changes, Carboniferous-Permian, southern Namibia. Palaeogeography Palaeoclimatololy Palaeoecology. 161, 127-150.

TAVARES, T.M.V., 2007. Filicíneas Permianas permineralizadas da Formação Corumbataí, Nordeste da Bacia do Paraná. Dissertação, Universidade Estadual Paulista, Rio Claro, Brasil. 135p.

TOLEDO, C. E. V. 2001. Análise paleontológica da Formação Corumbataí na Região de Rio Claro, Estado de São Paulo. Dissertação de Mestrado (inédita). Instituto de Geociências e Ciências Exatas da UNESP, Rio Claro. 146p.

TOLEDO, C. E. V.; BERTINI, R. J.; SANTUCCI, R.M. 2005. Nota preliminar sobre uma nova ocorrência de Xenacanthiformes na Formação Irati do Estado de São Paulo, Grupo Passa Dois, Permiano da Bacia do Paraná. In: XIX CONGRESSO BRASILEIRO DE PALEONTOLOGIA E VI CONGRESSO LATINO AMERICANO DE PALEONTOLOGIA. Aracaju, Sergipe Boletim de Resumos. Publicado em CD Room.

TURNER, S. 1982. Middle Palaeozoic elasmobranch remains from Australia. Journal of Vertebrate Paleontology 2:117-131. 
TURNER, S. \& BURROW, C. J. 2011. A Lower Carboniferous Xenacanthiform Shark from Australia. Journal of Vertebrate Paleontology, 31(2):241-257.

TURNER, S. \& MILLER, R. F. 2005. New Ideas About Old Sharks. American Scientist. 93: 244-252.

TURNER, S. \& YOUNG. G. C. 1987. Shark teeth from the Early-Middle Devonian Cravens Peak Beds, Georgina Basin, Queensland. Alcheringa. 11:233-244.

TURNER S. \& YOUNGQUIST, W. 1995 - Late Devonian phoebodont (Pisces Chondrichthyes) from the Confusion Range, Utah. Geobios. 19 : 389-392.

VEGA-DIAS, C.; ENNES-SILVA, R. A.; DIAS, E. V.; CHIMENTÃO, F. G. 2008. Novos espécimes de tetrápodes fósseis da Formação Rio do Rasto, Permiano da Bacia do Paraná, Brasil. In: SIMPÓSIO BRASILEIRO DE PALEONTOLOGIA DE VERTEBRADOS, 6. 2008, Ribeirão Preto. Paleontologia em Destaque - Boletim da Sociedade Brasileira de Paleontologia. 1: 202203.

VIEIRA, P. C.; MEZZALIRA, S.; FERREIRA, F. J. F. 1991. Mesossaurídeo (Stereosternum tumidum) e crustáceo (Liocaris huenei) no Membro Assistência da Formação Irati (P) nos municípios de Jataí e Montevidiu, Estado de Goiás. Revista Brasileira de Geociências. 21(3): 224-235.

VOORHIES, M. R. 1969. Taphonomy and population dynamics of an Pliocene vertebrate fauna, Knox County, Nebraska. Contributions Geological University Wyoming Special. 16:661-672.

WALKER, R. G. \& JAMES, N.P. 1992. Facies Models - response to sea level change. Geological Association of Canada, 409p.

WASHBURNE, C. W. 1930. Petroleum geology of the State of São Paulo - Brazil. São Paulo, Boletim da Comissão Geográfica e Geológica do Estado de São Paulo, 22: 282p.

WHITE, I. C. 1908. Relatório sobre as Coal Measures e rochas associadas do sul do Brasil. In: COMISSÃO ESTADUAL DAS MINAS DE CARVÃO DE PEDRA DO BRASIL. Relatório Final. 617p.

WILLIAMS, M. E. 1985. The "cladodont level' sharks of the Pennsylvanian black shales of central North America. Palaeontographica A. 190:83-158.

WILLIAMS, M. E. 1998. A new specimen of Tamiobatis vetustus (Chondrichthyes, Ctenacantoidea) from the late Devonian Cleveland Shale of Ohio. Journal Vertebrate Paleontology. 18(2): 251260.

WILLIAMS, M.E. 2001. Tooth retention in cladodont sharks: with a comparison between primitive grasping and swallowing, and modern cutting and gouging feeding mechanisms. Journal of Vertebrate Paleontology. 21: 214-226.

WOODWARD, A. S. 1919. On the Dentition of the Petalodont Shark, Climaxodus. Quarterly Journal of the Geological Society. 75: 1-6.

WPS. 2002. Paleozoic Shark Teeth. http://www.reocities.com/atrypa/matrix.html

WÜRDIG-MACIEL, N.L. 1975. Ichtiodontes e ichtiodorulitos (Pisces) da Formação Estrada Nova e sua aplicação na estratigrafia do Grupo Passa Dois. Pesquisas, 5:7-165.

YOCHELSON, E. L. \& ROCHA-CAMPOS, A. C. 1966. The Late Paleozoic Gastropod Warthia in Brazil. Journal of Paleontology. 40(3): 750-751.

YOUNG, G.C. 1982. Devonian sharks from Australia and Antarctica. Palaeontology 25, 817-43.

ZACHARIAS A. A. \& ASSINE. M. L. 2004. Modelo de preenchimento de vales incisos por associações de fácies estuarinas, Formação Rio Bonito no norte do Estado do Paraná. Revista Brasileira de Geociências. 35(4):573-583.

ZANGERL, R. 1981 Chondrichthyes I - Paleozoic Elasmobranchii. In: Schultze H.P. (ed.), Handbook of Paleoichthyology 3A. Stuttgart, New York. Gustav Fischer Verlag. 115p.

ZANGERL, R. \& RICHARDSON, E.S. 1963. The palaeoecological history of two Pennsylvanian black shales. Fieldiana: Geology Memoirs, 4, $352 \mathrm{pp}$.

ZENKEVITCH, L., 1957. Caspian and Aral Seas. In: Treatise on marine ecology and paleoecology 1. Ed. J.W. Hedgpeth, Memoir Geological Society of American., 67, 891-916. 
Anexos 


\section{LISTA DE ESPÉCIMES}

Relação dos principais espécimes de fósseis examinados e utilizados durante o desenvolvimento da pesquisa no mestrado (CHAHUD, 2007) e doutorado.

\begin{tabular}{|c|c|c|c|c|c|}
\hline Instituição & Táxon & Procedência & Unidade geológica & Idade & $\begin{array}{l}\text { Número de } \\
\text { registro }\end{array}$ \\
\hline IGc/USP & Icnofósseis & $\begin{array}{l}\text { Ipeúna, } \\
\text { Afloramento } 12\end{array}$ & $\begin{array}{l}\text { Formação Tatuí } \\
\text { Fácies Tab }\end{array}$ & Eopermiano & GP/7E-352 \\
\hline IGc/USP & Icnofósseis & $\begin{array}{l}\text { Rio Claro, } \\
\text { Afloramento } 1\end{array}$ & $\begin{array}{l}\text { Formação Tatuí } \\
\text { Fácies Taf }\end{array}$ & Eopermiano & GP/7E-349a \\
\hline IGc/USP & Icnofósseis & $\begin{array}{l}\text { Rio Claro, } \\
\text { Afloramento 1 }\end{array}$ & $\begin{array}{l}\text { Formação Tatuí } \\
\text { Fácies Taf }\end{array}$ & Eopermiano & GP/7E-349b \\
\hline IGc/USP & Icnofósseis & $\begin{array}{l}\text { Rio Claro, } \\
\text { Afloramento 1 }\end{array}$ & $\begin{array}{l}\text { Formação Tatuí } \\
\text { Fácies Taf }\end{array}$ & Eopermiano & GP/7E-350a \\
\hline IGc/USP & Icnofósseis & $\begin{array}{l}\text { Rio Claro, } \\
\text { Afloramento 1 }\end{array}$ & $\begin{array}{l}\text { Formação Tatuí } \\
\text { Fácies Taf }\end{array}$ & Eopermiano & GP/7E-351a \\
\hline IGc/USP & Tietea (?) & $\begin{array}{l}\text { Ibicatu, } \\
\text { Afloramento } 9\end{array}$ & $\begin{array}{l}\text { Formação Tatuí } \\
\text { Fácies Tag }\end{array}$ & Eopermiano & GP/3E-9183 \\
\hline IGc/USP & Tietea (?) & $\begin{array}{l}\text { Ibicatu, } \\
\text { Afloramento } 9\end{array}$ & $\begin{array}{l}\text { Formação Tatuí } \\
\text { Fácies Tag }\end{array}$ & Eopermiano & GP/3E-9184 \\
\hline IGc/USP & Tietea $(?)$ & $\begin{array}{l}\text { Ibicatu, } \\
\text { Afloramento } 9\end{array}$ & $\begin{array}{l}\text { Formação Tatuí } \\
\text { Fácies Tag }\end{array}$ & Eopermiano & GP/3E-9185 \\
\hline IGc/USP & Espermatófita & $\begin{array}{l}\text { Ibicatu, } \\
\text { Afloramento } 9\end{array}$ & $\begin{array}{l}\text { Formação Tatuí } \\
\text { Fácies Tag }\end{array}$ & Eopermiano & GP/3E-9186 \\
\hline IGc/USP & Espermatófita & $\begin{array}{l}\text { Ibicatu, } \\
\text { Afloramento } 9\end{array}$ & $\begin{array}{l}\text { Formação Tatuí } \\
\text { Fácies Tag }\end{array}$ & Eopermiano & GP/3E-9187 \\
\hline IGc/USP & Conchostráceos & $\begin{array}{l}\text { Ipeúna, } \\
\text { Afloramento } 12\end{array}$ & $\begin{array}{l}\text { Formação Tatuí } \\
\text { Fácies Tsa }\end{array}$ & Eopermiano & GP/1E-6196 \\
\hline IGc/USP & Conchostráceos & $\begin{array}{l}\text { Ipeúna, } \\
\text { Afloramento } 12\end{array}$ & $\begin{array}{l}\text { Formação Tatuí } \\
\text { Fácies Tsa }\end{array}$ & Eopermiano & GP/1E-6197 \\
\hline IGc/USP & Conchostráceos & $\begin{array}{l}\text { Ipeúna, } \\
\text { Afloramento } 12\end{array}$ & $\begin{array}{l}\text { Formação Tatuí } \\
\text { Fácies Tsa }\end{array}$ & Eopermiano & GP/1E-6198 \\
\hline IGc/USP & Conchostráceos & $\begin{array}{l}\text { Ipeúna, } \\
\text { Afloramento } 12\end{array}$ & $\begin{array}{l}\text { Formação Tatuí } \\
\text { Fácies Tsa }\end{array}$ & Eopermiano & GP/1E-6199 \\
\hline IGc/USP & Conchostráceos & $\begin{array}{l}\text { Ipeúna, } \\
\text { Afloramento } 12\end{array}$ & $\begin{array}{l}\text { Formação Tatuí } \\
\text { Fácies Tsa }\end{array}$ & Eopermiano & GP/1E-6200 \\
\hline IGc/USP & Conchostráceos & $\begin{array}{l}\text { Ipeúna, } \\
\text { Afloramento } 12\end{array}$ & $\begin{array}{l}\text { Formação Tatuí } \\
\text { Fácies Tsa }\end{array}$ & Eopermiano & GP/1E-6201 \\
\hline IGc/USP & Conchostráceos & $\begin{array}{l}\text { Ipeúna, } \\
\text { Afloramento } 12\end{array}$ & $\begin{array}{l}\text { Formação Tatuí } \\
\text { Fácies Tsa }\end{array}$ & Eopermiano & GP/1E-6202 \\
\hline IGc/USP & Conchostráceos & $\begin{array}{l}\text { Ipeúna, } \\
\text { Afloramento } 12\end{array}$ & $\begin{array}{l}\text { Formação Tatuí } \\
\text { Fácies Tsa }\end{array}$ & Eopermiano & GP/1E-6203 \\
\hline IGc/USP & Conchostráceos & $\begin{array}{l}\text { Ipeúna, } \\
\text { Afloramento } 12\end{array}$ & $\begin{array}{l}\text { Formação Tatuí } \\
\text { Fácies Tsa }\end{array}$ & Eopermiano & GP/1E-6204 \\
\hline IGc/USP & $\begin{array}{l}\text { Crustáceo } \\
\text { indeterminado }\end{array}$ & $\begin{array}{l}\text { Ipeúna, } \\
\text { Afloramento } 12\end{array}$ & $\begin{array}{l}\text { Formação Tatuí } \\
\text { Fácies Tsa }\end{array}$ & Eopermiano & GP/1E-6205 \\
\hline IGc/USP & $\begin{array}{l}\text { Escama de } \\
\text { Palaeonisciformes }\end{array}$ & $\begin{array}{l}\text { Ipeúna, } \\
\text { Afloramento } 12\end{array}$ & $\begin{array}{l}\text { Formação Tatuí } \\
\text { Fácies Tsa }\end{array}$ & Eopermiano & GP/2E-6585 \\
\hline IGc/USP & $\begin{array}{l}\text { Ictiodonte curvo de } \\
\text { Palaeonisciformes }\end{array}$ & $\begin{array}{l}\text { Rio Claro, } \\
\text { Afloramento } 4 \\
\end{array}$ & $\begin{array}{l}\text { Membro Tatuí } \\
\text { Fácies Taf }\end{array}$ & Eopermiano & GP/2E-5952 \\
\hline IGc/USP & Dente cladodonte & $\begin{array}{l}\text { Rio Claro, } \\
\text { Afloramento 1 }\end{array}$ & $\begin{array}{l}\text { Membro Taquaral } \\
\text { Fácies Iai }\end{array}$ & Eopermiano & GP/2E-5918 \\
\hline IGc/USP & Dente cladodonte & $\begin{array}{l}\text { Rio Claro, } \\
\text { Afloramento 1 }\end{array}$ & $\begin{array}{l}\text { Membro Taquaral } \\
\text { Fácies Iai }\end{array}$ & Eopermiano & GP/2E-5919 \\
\hline IGc/USP & Dente cladodonte & $\begin{array}{l}\text { Rio Claro, } \\
\text { Afloramento 1 }\end{array}$ & $\begin{array}{l}\text { Membro Taquaral } \\
\text { Fácies Iai }\end{array}$ & Eopermiano & GP/2E-5920 \\
\hline IGc/USP & Dente cladodonte & Rio Claro, & Membro Taquaral & Eopermiano & GP/2E-6306 \\
\hline
\end{tabular}




\begin{tabular}{|c|c|c|c|c|c|}
\hline & & Afloramento 1 & Fácies Iai & & \\
\hline IGc/USP & Itapyrodus punctatus & $\begin{array}{l}\text { Rio Claro, } \\
\text { Afloramento } 1\end{array}$ & $\begin{array}{l}\text { Membro Taquaral } \\
\text { Fácies Iai }\end{array}$ & Eopermiano & $\begin{array}{l}\text { GP/2E-3756 } \\
\text { e GP/2T-207 }\end{array}$ \\
\hline IGc/USP & Itapyrodus punctatus & $\begin{array}{l}\text { Rio Claro, } \\
\text { Afloramento } 4\end{array}$ & $\begin{array}{l}\text { Membro Taquaral } \\
\text { Fácies Iai }\end{array}$ & Eopermiano & GP/2E-5921a \\
\hline IGc/USP & Itapyrodus punctatus & $\begin{array}{l}\text { Rio Claro, } \\
\text { Afloramento } 4\end{array}$ & $\begin{array}{l}\text { Membro Taquaral } \\
\text { Fácies Iai }\end{array}$ & Eopermiano & GP/2E-5921b \\
\hline IGc/USP & Itapyrodus punctatus & $\begin{array}{l}\text { Rio Claro, } \\
\text { Afloramento } 1 \\
\end{array}$ & $\begin{array}{l}\text { Membro Taquaral } \\
\text { Fácies Iai }\end{array}$ & Eopermiano & GP/2E-5922 \\
\hline IGc/USP & Itapyrodus punctatus & $\begin{array}{l}\text { Rio Claro, } \\
\text { Afloramento } 1 \\
\end{array}$ & $\begin{array}{l}\text { Membro Taquaral } \\
\text { Fácies Iai }\end{array}$ & Eopermiano & GP/2E-5923 \\
\hline IGc/USP & Itapyrodus punctatus & $\begin{array}{l}\text { Rio Claro, } \\
\text { Afloramento } 1\end{array}$ & $\begin{array}{l}\text { Membro Taquaral } \\
\text { Fácies Iai }\end{array}$ & Eopermiano & GP/2E-5924 \\
\hline IGc/USP & Itapyrodus punctatus & $\begin{array}{l}\text { Rio Claro, } \\
\text { Afloramento } 1\end{array}$ & $\begin{array}{l}\text { Membro Taquaral } \\
\text { Fácies Iai }\end{array}$ & Eopermiano & GP/2E-5925 \\
\hline IGc/USP & Itapyrodus punctatus & $\begin{array}{l}\text { Rio Claro, } \\
\text { Afloramento } 1\end{array}$ & $\begin{array}{l}\text { Membro Taquaral } \\
\text { Fácies Iai }\end{array}$ & Eopermiano & $\begin{array}{l}\text { GP/2E-5926 } \\
\text { e e GP/2T- } \\
206\end{array}$ \\
\hline IGc/USP & Itapyrodus punctatus & $\begin{array}{l}\text { Rio Claro, } \\
\text { Afloramento } 1\end{array}$ & $\begin{array}{l}\text { Membro Taquaral } \\
\text { Fácies Iai }\end{array}$ & iano & $\begin{array}{l}\text { GP/2E-5927 } \\
\text { e GP/2T-208 }\end{array}$ \\
\hline IGc/USP & Itapyrodus punctatus & $\begin{array}{l}\text { Rio Claro, } \\
\text { Afloramento } 1\end{array}$ & $\begin{array}{l}\text { Membro Taquaral } \\
\text { Fácies Iai }\end{array}$ & Eopermiano & $\begin{array}{l}\text { GP/2E-5928 } \\
\text { e GP/2T-209 }\end{array}$ \\
\hline IGc/USP & Itapyrodus punctatus & $\begin{array}{l}\text { Rio Claro, } \\
\text { Afloramento } 1 \\
\end{array}$ & $\begin{array}{l}\text { Membro Taquaral } \\
\text { Fácies Iai }\end{array}$ & Eopermiano & GP/2E-6290 \\
\hline IGc/USP & Itapyrodus punctatus & $\begin{array}{l}\text { Rio Claro, } \\
\text { Afloramento } 1 \\
\end{array}$ & $\begin{array}{l}\text { Membro Taquaral } \\
\text { Fácies Iai }\end{array}$ & Eopermiano & GP/2E-6304 \\
\hline IGc/USP & Itapyrodus punctatus & $\begin{array}{l}\text { Rio Claro, } \\
\text { Afloramento } 1\end{array}$ & $\begin{array}{l}\text { Membro Taquaral } \\
\text { Fácies Iai }\end{array}$ & Eopermiano & GP/2E-6258 \\
\hline IGc/USP & Itapy & $\begin{array}{l}\text { Rio Claro, } \\
\text { Afloramento } 1\end{array}$ & $\begin{array}{l}\text { Membro Taquaral } \\
\text { Fácies Iai }\end{array}$ & ano & GP/2E-6458 \\
\hline IGc/USP & Itapyrodus punctatus & $\begin{array}{l}\text { Ipeúna, } \\
\text { Afloramento } 12\end{array}$ & $\begin{array}{l}\text { Membro Taquaral } \\
\text { Fácies Iai }\end{array}$ & Eopermiano & GP/2E-6589 \\
\hline IGc/USP & Itapyrodus sp. & $\begin{array}{l}\text { Rio Claro, } \\
\text { Afloramento } 1 \\
\end{array}$ & $\begin{array}{l}\text { Membro Taquaral } \\
\text { Fácies Iai }\end{array}$ & niano & GP/2E-6307 \\
\hline IGc/USP & Itapyrodus sp. & $\begin{array}{l}\text { Rio Claro, } \\
\text { Afloramento } 1\end{array}$ & $\begin{array}{l}\text { Membro Taquaral } \\
\text { Fácies Iai }\end{array}$ & Eopermiano & GP/2E-6308 \\
\hline IGc/USP & $\begin{array}{l}\text { Holocephali } \\
\text { indeterminado }\end{array}$ & $\begin{array}{l}\text { Rio Claro, } \\
\text { Afloramento } 1 \\
\end{array}$ & $\begin{array}{l}\text { Membro Taquaral } \\
\text { Fácies Iai }\end{array}$ & Eopermiano & GP/2E-6263 \\
\hline IGc/USP & $\begin{array}{l}\text { Holocephali } \\
\text { indeterminado }\end{array}$ & $\begin{array}{l}\text { Rio Claro, } \\
\text { Afloramento 1 }\end{array}$ & $\begin{array}{l}\text { Membro Taquaral } \\
\text { Fácies Iai }\end{array}$ & Eopermiano & GP/2E-6432 \\
\hline IGc/USP & $\begin{array}{l}\text { Chondrichthyes } \\
\text { indeterminado }\end{array}$ & $\begin{array}{l}\text { Rio Claro, } \\
\text { Afloramento 1 }\end{array}$ & $\begin{array}{l}\text { Membro Taquaral } \\
\text { Fácies Iai }\end{array}$ & Eopermiano & GP/2E-6459 \\
\hline IGc/USP & $\begin{array}{l}\text { Chondrichthyes } \\
\text { indeterminado }\end{array}$ & $\begin{array}{l}\text { Rio Claro, } \\
\text { Afloramento } 1\end{array}$ & $\begin{array}{l}\text { Membro Taquaral } \\
\text { Fácies Iai }\end{array}$ & Eopermiano & GP/2E-5929 \\
\hline IGc/USP & $\begin{array}{l}\text { Chondrichthyes } \\
\text { indeterminado }\end{array}$ & $\begin{array}{l}\text { Rio Claro, } \\
\text { Afloramento } 1\end{array}$ & $\begin{array}{l}\text { Membro Taquaral } \\
\text { Fácies Iai }\end{array}$ & Eopermiano & GP/2E-6252 \\
\hline IGc/USP & $\begin{array}{l}\text { Chondrichthyes } \\
\text { indeterminado }\end{array}$ & $\begin{array}{l}\text { Rio Claro, } \\
\text { Afloramento } 1 \\
\end{array}$ & $\begin{array}{l}\text { Membro Taquaral } \\
\text { Fácies Iai }\end{array}$ & Eopermiano & GP/2E-6253 \\
\hline IGc/USP & $\begin{array}{l}\text { Taquaralodus } \\
\text { albuquerquei }\end{array}$ & $\begin{array}{l}\text { Rio Claro, } \\
\text { Afloramento } 1 \\
\end{array}$ & $\begin{array}{l}\text { Membro Taquaral } \\
\text { Fácies Iai }\end{array}$ & Eopermiano & GP/2E-3752 \\
\hline IGc/USP & $\begin{array}{l}\text { Taquaralodus } \\
\text { albuquerquei }\end{array}$ & $\begin{array}{l}\text { Rio Claro, } \\
\text { Afloramento } 1 \\
\end{array}$ & $\begin{array}{l}\text { Membro Taquaral } \\
\text { Fácies Iai }\end{array}$ & Eopermiano & GP/2E-3753 \\
\hline IGc/USP & $\begin{array}{l}\text { Taquaralodus } \\
\text { albuquerquei }\end{array}$ & $\begin{array}{l}\text { Rio Claro, } \\
\text { Afloramento } 1 \\
\end{array}$ & $\begin{array}{l}\text { Membro Taquaral } \\
\text { Fácies Iai }\end{array}$ & Eopermiano & $\begin{array}{l}\text { GP/2E-3754 } \\
\text { e GP/2T-210 }\end{array}$ \\
\hline IGc/USP & $\begin{array}{l}\text { Taquaralodus } \\
\text { albuquerquei }\end{array}$ & $\begin{array}{l}\text { Rio Claro, } \\
\text { Afloramento } 1\end{array}$ & $\begin{array}{l}\text { Membro Taquaral } \\
\text { Fácies Iai }\end{array}$ & Eopermiano & GP/2E-5930 \\
\hline IGc/USP & $\begin{array}{l}\text { Taquaralodus } \\
\text { albuquerquei }\end{array}$ & $\begin{array}{l}\text { Rio Claro, } \\
\text { Afloramento } 1 \\
\end{array}$ & $\begin{array}{l}\text { Membro Taquaral } \\
\text { Fácies Iai }\end{array}$ & Eopermiano & $\begin{array}{l}\text { GP/2E-5931 } \\
\text { e GP/2T-211 }\end{array}$ \\
\hline IGc/USP & Taquaralodus & Rio Claro, & Membro Taquaral & Eopermiano & GP/2E-5932 \\
\hline
\end{tabular}




\begin{tabular}{|c|c|c|c|c|c|}
\hline & albuquerquei & Afloramento 1 & Fácies Iai & & e GP/2T-212 \\
\hline IGc/USP & $\begin{array}{l}\text { Taquaralodus } \\
\text { albuquerquei }\end{array}$ & $\begin{array}{l}\text { Rio Claro, } \\
\text { Afloramento } 1\end{array}$ & $\begin{array}{l}\text { Membro Taquaral } \\
\text { Fácies Iai }\end{array}$ & Eopermiano & GP/2E-6251 \\
\hline IGc/USP & $\begin{array}{l}\text { Taquaralodus } \\
\text { albuquerquei }\end{array}$ & $\begin{array}{l}\text { Rio Claro, } \\
\text { Afloramento 1 }\end{array}$ & $\begin{array}{l}\text { Membro Taquaral } \\
\text { Fácies Iai }\end{array}$ & Eopermiano & $\begin{array}{l}\text { GP/2E-6306 } \\
\text { e GP/2T-213 }\end{array}$ \\
\hline IGc/USP & $\begin{array}{l}\text { Taquaralodus } \\
\text { albuquerquei }\end{array}$ & $\begin{array}{l}\text { Rio Claro, } \\
\text { Afloramento 1 }\end{array}$ & $\begin{array}{l}\text { Membro Taquaral } \\
\text { Fácies Iai }\end{array}$ & Eopermiano & $\begin{array}{l}\text { GP/2E-6314 } \\
\text { e GP/2T-214 }\end{array}$ \\
\hline IGc/USP & $\begin{array}{l}\text { Taquaralodus } \\
\text { albuquerquei }\end{array}$ & $\begin{array}{l}\text { Rio Claro, } \\
\text { Afloramento } 1\end{array}$ & $\begin{array}{l}\text { Membro Taquaral } \\
\text { Fácies Iai }\end{array}$ & Eopermiano & GP/2E-6251 \\
\hline IGc/USP & $\begin{array}{l}\text { Taquaralodus } \\
\text { albuquerquei }\end{array}$ & $\begin{array}{l}\text { Ipeúna, } \\
\text { Afloramento } 12\end{array}$ & $\begin{array}{l}\text { Membro Taquaral } \\
\text { Fácies Iai }\end{array}$ & Eopermiano & GP/2E-6580 \\
\hline IGc/USP & $\begin{array}{l}\text { Taquaralodus } \\
\text { albuquerquei }\end{array}$ & $\begin{array}{l}\text { Ipeúna, } \\
\text { Afloramento } 12\end{array}$ & $\begin{array}{l}\text { Membro Taquaral } \\
\text { Fácies Iai }\end{array}$ & Eopermiano & GP/2E-6581 \\
\hline IGc/USP & Xenacanthus sp. & $\begin{array}{l}\text { Rio Claro, } \\
\text { Afloramento } 1\end{array}$ & $\begin{array}{l}\text { Membro Taquaral } \\
\text { Fácies Iai }\end{array}$ & Eopermiano & $\begin{array}{l}\text { GP/2E-6291 } \\
\text { e GP/2T-215 }\end{array}$ \\
\hline IGc/USP & $\begin{array}{l}\text { Xenacanthidae } \\
\text { indeterminado }\end{array}$ & $\begin{array}{l}\text { Rio Claro, } \\
\text { Afloramento } 1\end{array}$ & $\begin{array}{l}\text { Membro Taquaral } \\
\text { Fácies Iai }\end{array}$ & Eopermiano & $\begin{array}{l}\text { GP/2E-6292 } \\
\text { e GP/2T-216 }\end{array}$ \\
\hline IGc/USP & $\begin{array}{l}\text { Xenacanthidae } \\
\text { indeterminado }\end{array}$ & $\begin{array}{l}\text { Rio Claro, } \\
\text { Afloramento 1 }\end{array}$ & $\begin{array}{l}\text { Membro Taquaral } \\
\text { Fácies Iai }\end{array}$ & Eopermiano & $\begin{array}{l}\text { GP/2E-6254 } \\
\text { e GP/2T-217 }\end{array}$ \\
\hline IGc/USP & $\begin{array}{l}\text { Xenacanthidae } \\
\text { indeterminado }\end{array}$ & $\begin{array}{l}\text { Rio Claro, } \\
\text { Afloramento } 3 \\
\end{array}$ & $\begin{array}{l}\text { Membro Taquaral } \\
\text { Fácies Iai }\end{array}$ & iano & GP/2E-6300 \\
\hline IGc/USP & $\begin{array}{l}\text { Xenacanthidae } \\
\text { indeterminado }\end{array}$ & $\begin{array}{l}\text { Rio Claro, } \\
\text { Afloramento } 3\end{array}$ & $\begin{array}{l}\text { Membro Taquaral } \\
\text { Fácies Iai }\end{array}$ & Eopermiano & GP/2E-6456 \\
\hline IGc/USP & $\begin{array}{l}\text { Sphenacanthus } \\
\text { sanpauloensis }\end{array}$ & $\begin{array}{l}\text { Rio Claro, } \\
\text { Afloramento } 1\end{array}$ & $\begin{array}{l}\text { Membro Taquaral } \\
\text { Fácies Iai }\end{array}$ & iano & $\begin{array}{l}\text { GP/2E-3756 } \\
\text { e GP/2T-204 }\end{array}$ \\
\hline IGc/USP & $\begin{array}{l}\text { Sphenacanthus } \\
\text { sanpauloensis }\end{array}$ & $\begin{array}{l}\text { Rio Claro, } \\
\text { Afloramento 1 }\end{array}$ & $\begin{array}{l}\text { Membro Taquaral } \\
\text { Fácies Iai }\end{array}$ & Eopermiano & $\begin{array}{l}\text { GP/2E- } 6583 \\
\text { e GP/2T-204 }\end{array}$ \\
\hline IGc/USP & Sphenacanthus sp. & $\begin{array}{l}\text { Rio Claro, } \\
\text { Afloramento 1 }\end{array}$ & $\begin{array}{l}\text { Membro Taquaral } \\
\text { Fácies Iai }\end{array}$ & Eopermiano & GP/2E- 6582 \\
\hline IGc/USP & Amelacanthus sp. & $\begin{array}{l}\text { Ipeúna, } \\
\text { Afloramento } 1\end{array}$ & $\begin{array}{l}\text { Membro Taquaral } \\
\text { Fácies Iai }\end{array}$ & niano & GP/2E-6461 \\
\hline IGc/USP & Amelacanthus sp. & $\begin{array}{l}\text { Ipeúna, } \\
\text { Afloramento } 1\end{array}$ & $\begin{array}{l}\text { Membro Taquaral } \\
\text { Fácies Iai }\end{array}$ & Eopermiano & GP/2E-6584a \\
\hline IGc/USP & Amelacanthus sp. & $\begin{array}{l}\text { Ipeúna, } \\
\text { Afloramento } 1\end{array}$ & $\begin{array}{l}\text { Membro Taquaral } \\
\text { Fácies Iai }\end{array}$ & iano & GP/2E-6584b \\
\hline IGc/USP & Amelacanthus sp. & $\begin{array}{l}\text { Ipeúna, } \\
\text { Afloramento } 12\end{array}$ & $\begin{array}{l}\text { Membro Taquaral } \\
\text { Fácies Iai }\end{array}$ & Eopermiano & GP/2E-6579 \\
\hline IGc/USP & $\begin{array}{l}\text { Iratiacanthus } \\
\text { santamariaensis }\end{array}$ & $\begin{array}{l}\text { Ipeúna, } \\
\text { Afloramento } 1\end{array}$ & $\begin{array}{l}\text { Membro Taquaral } \\
\text { Fácies Iai }\end{array}$ & Eopermiano & GP/2E-6455 \\
\hline IGc/USP & $\begin{array}{l}\text { Iratiacanthus } \\
\text { santamariaensis }\end{array}$ & $\begin{array}{l}\text { Ipeúna, } \\
\text { Afloramento } 1\end{array}$ & $\begin{array}{l}\text { Membro Taquaral } \\
\text { Fácies Iai }\end{array}$ & Eopermiano & GP/2E-6462 \\
\hline IGc/USP & Orodus ipeunaensis & $\begin{array}{l}\text { Rio Claro, } \\
\text { Afloramento } 1 \\
\end{array}$ & $\begin{array}{l}\text { Membro Taquaral } \\
\text { Fácies Iai }\end{array}$ & Eopermiano & $\begin{array}{l}\text { GP/2E-3750 } \\
\text { e GP/2T-205 }\end{array}$ \\
\hline IGc/USP & Orodus & $\begin{array}{l}\text { Rio Claro, } \\
\text { Afloramento 1 }\end{array}$ & $\begin{array}{l}\text { Membro Taquaral } \\
\text { Fácies Iai }\end{array}$ & Eopermiano & GP/2E- 3751 \\
\hline IGc/USP & Orodus ipeunaensis & $\begin{array}{l}\text { Rio Claro, } \\
\text { Afloramento 1 }\end{array}$ & $\begin{array}{l}\text { Membro Taquaral } \\
\text { Fácies Iai }\end{array}$ & Eopermiano & GP/2E-5933 \\
\hline IGc/USP & $\begin{array}{l}\text { Chondrichthyes } \\
\text { indeterminado }\end{array}$ & $\begin{array}{l}\text { Rio Claro, } \\
\text { Afloramento } 3 \\
\end{array}$ & $\begin{array}{l}\text { Membro Taquaral } \\
\text { Fácies Iai }\end{array}$ & Eopermiano & GP/2E-5934 \\
\hline IGc/USP & $\begin{array}{l}\text { Escama indeterminada } \\
\text { de Chondrichthyes? } \\
\text { Petrodus (?) }\end{array}$ & $\begin{array}{l}\text { Rio Claro. } \\
\text { Afloramento } 4\end{array}$ & $\begin{array}{l}\text { Membro Taquaral } \\
\text { Fácies Iai }\end{array}$ & Eopermiano & GP/2E-5935a \\
\hline IGc/USP & $\begin{array}{l}\text { Dentário de } \\
\text { Palaeonisciformes }\end{array}$ & $\begin{array}{l}\text { Rio Claro, } \\
\text { Afloramento } 1 \\
\end{array}$ & $\begin{array}{l}\text { Membro Taquaral } \\
\text { Fácies Iai }\end{array}$ & Eopermiano & $\begin{array}{l}\text { GP/2E-3761 } \\
\text { e GP/2T-201 }\end{array}$ \\
\hline IGc/USP & Caixa craniana & $\begin{array}{l}\text { Rio Claro, } \\
\text { Afloramento 1 }\end{array}$ & $\begin{array}{l}\text { Membro Taquaral } \\
\text { Fácies Iai }\end{array}$ & Eopermiano & GP/2E-6929 \\
\hline IGc/USP & $\begin{array}{l}\text { Dentes de } \\
\text { Palaeonisciformes }\end{array}$ & $\begin{array}{l}\text { Rio Claro, } \\
\text { Afloramento } 1 \\
\end{array}$ & $\begin{array}{l}\text { Membro Taquaral } \\
\text { Fácies Iai }\end{array}$ & Eopermiano & GP/2E-5936 \\
\hline IGc/USP & Dente de & Rio Claro, & Membro Taquaral & Eopermiano & GP/2E-5937 \\
\hline
\end{tabular}




\begin{tabular}{|c|c|c|c|c|c|}
\hline & Palaeonisciformes & Afloramento 1 & Fácies Iai & & \\
\hline IGc/USP & $\begin{array}{l}\text { Dente de } \\
\text { Palaeonisciformes }\end{array}$ & $\begin{array}{l}\text { Rio Claro, } \\
\text { Afloramento 1 }\end{array}$ & $\begin{array}{l}\text { Membro Taquaral } \\
\text { Fácies Iai }\end{array}$ & Eopermiano & GP/2E-5938 \\
\hline IGc/USP & $\begin{array}{l}\text { Escama de } \\
\text { Palaeonisciformes }\end{array}$ & $\begin{array}{l}\text { Rio Claro, } \\
\text { Afloramento 1 }\end{array}$ & $\begin{array}{l}\text { Membro Taquaral } \\
\text { Fácies Iai }\end{array}$ & Eopermiano & GP/2E-5939 \\
\hline IGc/USP & $\begin{array}{l}\text { Escama de } \\
\text { Palaeonisciformes }\end{array}$ & $\begin{array}{l}\text { Rio Claro, } \\
\text { Afloramento 1 }\end{array}$ & $\begin{array}{l}\text { Membro Taquaral } \\
\text { Fácies Iai }\end{array}$ & Eopermiano & GP/2E-5940 \\
\hline IGc/USP & $\begin{array}{l}\text { Ictiodonte de fuste lisa } \\
\text { de } \\
\text { Palaeonisciformes }\end{array}$ & $\begin{array}{l}\text { Rio Claro, } \\
\text { Afloramento } 1\end{array}$ & $\begin{array}{l}\text { Membro Taquaral } \\
\text { Fácies Iai }\end{array}$ & Eopermiano & GP/2E-5941 \\
\hline IGc/USP & $\begin{array}{l}\text { Ictiodonte de fuste lisa } \\
\text { de } \\
\text { Palaeonisciformes }\end{array}$ & $\begin{array}{l}\text { Rio Claro, } \\
\text { Afloramento } 3\end{array}$ & $\begin{array}{l}\text { Membro Taquaral } \\
\text { Fácies Iai }\end{array}$ & Eopermiano & GP/2E-5942 \\
\hline IGc/USP & $\begin{array}{l}\text { Ictiodonte de fuste lisa } \\
\text { de } \\
\text { Palaeonisciformes }\end{array}$ & $\begin{array}{l}\text { Rio Claro, } \\
\text { Afloramento } 4\end{array}$ & $\begin{array}{l}\text { Membro Taquaral } \\
\text { Fácies Iai }\end{array}$ & Eopermiano & GP/2E-5943 \\
\hline IGc/USP & $\begin{array}{l}\text { Ictiodonte reto de fuste } \\
\text { costelada de } \\
\text { Palaeonisciformes }\end{array}$ & $\begin{array}{l}\text { Rio Claro, } \\
\text { Afloramento } 1\end{array}$ & $\begin{array}{l}\text { Membro Taquaral } \\
\text { Fácies Iai }\end{array}$ & Eopermiano & GP/2E-5944 \\
\hline IGc/USP & $\begin{array}{l}\text { Ictiodonte reto de fuste } \\
\text { costelada de } \\
\text { Palaeonisciformes }\end{array}$ & $\begin{array}{l}\text { Rio Claro, } \\
\text { Afloramento } 1\end{array}$ & $\begin{array}{l}\text { Membro Taquaral } \\
\text { Fácies Iai }\end{array}$ & Eopermiano & GP/2E-5945 \\
\hline IGc/USP & $\begin{array}{l}\text { Ictiodonte reto de fuste } \\
\text { costelada de } \\
\text { Palaeonisciformes }\end{array}$ & $\begin{array}{l}\text { Rio Claro, } \\
\text { Afloramento } 3\end{array}$ & $\begin{array}{l}\text { Membro Taquaral } \\
\text { Fácies Iai }\end{array}$ & Eopermiano & GP/2E-5946 \\
\hline IGc/USP & $\begin{array}{l}\text { Ictiodonte reto de fuste } \\
\text { costelada de } \\
\text { Palaeonisciformes }\end{array}$ & $\begin{array}{l}\text { Rio Claro, } \\
\text { Afloramento } 4\end{array}$ & $\begin{array}{l}\text { Membro Taquaral } \\
\text { Fácies Iai }\end{array}$ & iano & GP/2E-5935b \\
\hline IGc/USP & $\begin{array}{l}\text { Ictiodonte reto de fuste } \\
\text { costelada de } \\
\text { Palaeonisciformes }\end{array}$ & $\begin{array}{l}\text { Rio Claro, } \\
\text { Afloramento } 5\end{array}$ & $\begin{array}{l}\text { Membro Taquaral } \\
\text { Fácies Iai }\end{array}$ & Eopermiano & GP/2E-5947 \\
\hline IGc/USP & $\begin{array}{l}\text { Ictiodonte reto de fuste } \\
\text { costelada de } \\
\text { Palaeonisciformes }\end{array}$ & $\begin{array}{l}\text { Rio Claro, } \\
\text { Afloramento } 4\end{array}$ & $\begin{array}{l}\text { Membro Taquaral } \\
\text { Fácies Iai }\end{array}$ & iano & GP/2E-5948 \\
\hline IGc/USP & $\begin{array}{l}\text { Ictiodonte curvo de } \\
\text { Palaeonisciformes }\end{array}$ & $\begin{array}{l}\text { Rio Claro, } \\
\text { Afloramento 1 }\end{array}$ & $\begin{array}{l}\text { Membro Taquaral } \\
\text { Fácies Iai }\end{array}$ & Eopermiano & GP/2E-5949 \\
\hline IGc/USP & $\begin{array}{l}\text { Ictiodonte curvo de } \\
\text { Palaeonisciformes }\end{array}$ & $\begin{array}{l}\text { Rio Claro, } \\
\text { Afloramento } 1\end{array}$ & $\begin{array}{l}\text { Membro Taquaral } \\
\text { Fácies Iai }\end{array}$ & Eopermiano & GP/2E-5950 \\
\hline IGc/USP & $\begin{array}{l}\text { Ictiodonte curvo de } \\
\text { Palaeonisciformes }\end{array}$ & $\begin{array}{l}\text { Rio Claro, } \\
\text { Afloramento 1 }\end{array}$ & $\begin{array}{l}\text { Membro Taquaral } \\
\text { Fácies Iai }\end{array}$ & Eopermiano & GP/2E-5951 \\
\hline IGc/USP & $\begin{array}{l}\text { Ictiodonte de } \\
\text { Palaeonisciformes }\end{array}$ & $\begin{array}{l}\text { Rio Claro, } \\
\text { Afloramento 1 }\end{array}$ & $\begin{array}{l}\text { Membro Taquaral } \\
\text { Fácies Iai }\end{array}$ & Eopermiano & GP/2E-6312 \\
\hline IGc/USP & $\begin{array}{l}\text { Ictiodonte de } \\
\text { Palaeonisciformes }\end{array}$ & $\begin{array}{l}\text { Rio Claro, } \\
\text { Afloramento 1 }\end{array}$ & $\begin{array}{l}\text { Membro Taquaral } \\
\text { Fácies Iai }\end{array}$ & Eopermiano & GP/2E-6343 \\
\hline IGc/USP & $\begin{array}{l}\text { Ictiodonte de } \\
\text { Palaeonisciformes }\end{array}$ & $\begin{array}{l}\text { Rio Claro, } \\
\text { Afloramento } 1\end{array}$ & $\begin{array}{l}\text { Membro Taquaral } \\
\text { Fácies Iai }\end{array}$ & Eopermiano & GP/2E-6384 \\
\hline IGc/USP & $\begin{array}{l}\text { Ictiodonte de } \\
\text { Palaeonisciformes }\end{array}$ & $\begin{array}{l}\text { Rio Claro, } \\
\text { Afloramento 1 }\end{array}$ & $\begin{array}{l}\text { Membro Taquaral } \\
\text { Fácies Iai }\end{array}$ & Eopermiano & GP/2E-6385 \\
\hline IGc/USP & $\begin{array}{l}\text { Ictiodonte de } \\
\text { Palaeonisciformes }\end{array}$ & $\begin{array}{l}\text { Rio Claro, } \\
\text { Afloramento 1 }\end{array}$ & $\begin{array}{l}\text { Membro Taquaral } \\
\text { Fácies Iai }\end{array}$ & Eopermiano & GP/2E-6386 \\
\hline IGc/USP & $\begin{array}{l}\text { Ictiodonte de } \\
\text { Palaeonisciformes }\end{array}$ & $\begin{array}{l}\text { Rio Claro, } \\
\text { Afloramento } 1\end{array}$ & $\begin{array}{l}\text { Membro Taquaral } \\
\text { Fácies Iai }\end{array}$ & Eopermiano & GP/2E-6387 \\
\hline IGc/USP & $\begin{array}{l}\text { Ictiodonte de } \\
\text { Palaeonisciformes }\end{array}$ & $\begin{array}{l}\text { Rio Claro, } \\
\text { Afloramento } 1\end{array}$ & $\begin{array}{l}\text { Membro Taquaral } \\
\text { Fácies Iai }\end{array}$ & Eopermiano & GP/2E-6388 \\
\hline IGc/USP & $\begin{array}{l}\text { Ictiodonte de } \\
\text { Palaeonisciformes }\end{array}$ & $\begin{array}{l}\text { Rio Claro, } \\
\text { Afloramento 1 }\end{array}$ & $\begin{array}{l}\text { Membro Taquaral } \\
\text { Fácies Iai }\end{array}$ & Eopermiano & GP/2E-6389 \\
\hline IGc/USP & $\begin{array}{l}\text { Ictiodonte de } \\
\text { Palaeonisciformes }\end{array}$ & $\begin{array}{l}\text { Rio Claro, } \\
\text { Afloramento 1 }\end{array}$ & $\begin{array}{l}\text { Membro Taquaral } \\
\text { Fácies Iai }\end{array}$ & Eopermiano & GP/2E-6390 \\
\hline IGc/USP & Ictiodonte de & Rio Claro, & Membro Taquaral & Eopermiano & GP/2E-6391 \\
\hline
\end{tabular}




\begin{tabular}{|c|c|c|c|c|c|}
\hline & Palaeonisciformes & Afloramento 1 & Fácies Iai & & \\
\hline IGc/USP & $\begin{array}{l}\text { Ictiodonte de } \\
\text { Palaeonisciformes }\end{array}$ & $\begin{array}{l}\text { Rio Claro, } \\
\text { Afloramento } 1\end{array}$ & $\begin{array}{l}\text { Membro Taquaral } \\
\text { Fácies Iai }\end{array}$ & Eopermiano & GP/2E-6392 \\
\hline IGc/USP & $\begin{array}{l}\text { Ictiodonte de } \\
\text { Palaeonisciformes }\end{array}$ & $\begin{array}{l}\text { Rio Claro, } \\
\text { Afloramento } 1\end{array}$ & $\begin{array}{l}\text { Membro Taquaral } \\
\text { Fácies Iai }\end{array}$ & Eopermiano & GP/2E-6393 \\
\hline IGc/USP & $\begin{array}{l}\text { Ictiodonte de } \\
\text { Palaeonisciformes }\end{array}$ & $\begin{array}{l}\text { Rio Claro, } \\
\text { Afloramento } 1\end{array}$ & $\begin{array}{l}\text { Membro Taquaral } \\
\text { Fácies Iai }\end{array}$ & Eopermiano & GP/2E-6394 \\
\hline IGc/USP & $\begin{array}{l}\text { Ictiodonte de } \\
\text { Palaeonisciformes }\end{array}$ & $\begin{array}{l}\text { Rio Claro, } \\
\text { Afloramento } 1\end{array}$ & $\begin{array}{l}\text { Membro Taquaral } \\
\text { Fácies Iai }\end{array}$ & Eopermiano & GP/2E-6395 \\
\hline IGc/USP & $\begin{array}{l}\text { Ictiodonte de } \\
\text { Palaeonisciformes }\end{array}$ & $\begin{array}{l}\text { Rio Claro, } \\
\text { Afloramento } 1\end{array}$ & $\begin{array}{l}\text { Membro Taquaral } \\
\text { Fácies Iai }\end{array}$ & Eopermiano & GP/2E-6396 \\
\hline IGc/USP & $\begin{array}{l}\text { Ictiodonte de } \\
\text { Palaeonisciformes }\end{array}$ & $\begin{array}{l}\text { Rio Claro, } \\
\text { Afloramento } 1\end{array}$ & $\begin{array}{l}\text { Membro Taquaral } \\
\text { Fácies Iai }\end{array}$ & Eopermiano & GP/2E-6397 \\
\hline IGc/USP & $\begin{array}{l}\text { Ictiodonte de } \\
\text { Palaeonisciformes }\end{array}$ & $\begin{array}{l}\text { Rio Claro, } \\
\text { Afloramento } 1\end{array}$ & $\begin{array}{l}\text { Membro Taquaral } \\
\text { Fácies Iai }\end{array}$ & Eopermiano & GP/2E-6398 \\
\hline IGc/USP & $\begin{array}{l}\text { Ictiodonte de } \\
\text { Palaeonisciformes }\end{array}$ & $\begin{array}{l}\text { Rio Claro, } \\
\text { Afloramento } 1\end{array}$ & $\begin{array}{l}\text { Membro Taquaral } \\
\text { Fácies Iai }\end{array}$ & Eopermiano & GP/2E-6399 \\
\hline IGc/USP & $\begin{array}{l}\text { Ictiodonte de } \\
\text { Palaeonisciformes }\end{array}$ & $\begin{array}{l}\text { Rio Claro, } \\
\text { Afloramento } 1\end{array}$ & $\begin{array}{l}\text { Membro Taquaral } \\
\text { Fácies Iai }\end{array}$ & Eopermiano & GP/2E-6400 \\
\hline IGc/USP & $\begin{array}{l}\text { Ictiodonte de } \\
\text { Palaeonisciformes }\end{array}$ & $\begin{array}{l}\text { Rio Claro, } \\
\text { Afloramento } 1\end{array}$ & $\begin{array}{l}\text { Membro Taquaral } \\
\text { Fácies Iai }\end{array}$ & Eopermiano & GP/2E-6401 \\
\hline IGc/USP & $\begin{array}{l}\text { Ictiodonte de } \\
\text { Palaeonisciformes }\end{array}$ & $\begin{array}{l}\text { Rio Claro, } \\
\text { Afloramento 1 }\end{array}$ & $\begin{array}{l}\text { Membro Taquaral } \\
\text { Fácies Iai }\end{array}$ & Eopermiano & GP/2E-6402 \\
\hline IGc/USP & $\begin{array}{l}\text { Ictiodonte de } \\
\text { Palaeonisciformes }\end{array}$ & $\begin{array}{l}\text { Rio Claro, } \\
\text { Afloramento } 1\end{array}$ & $\begin{array}{l}\text { Membro Taquaral } \\
\text { Fácies Iai }\end{array}$ & iano & -6403 \\
\hline IGc/USP & $\begin{array}{l}\text { Ictiodonte de } \\
\text { Palaeonisciformes }\end{array}$ & $\begin{array}{l}\text { Rio Claro, } \\
\text { Afloramento } 1\end{array}$ & $\begin{array}{l}\text { Membro Taquaral } \\
\text { Fácies Iai }\end{array}$ & Eopermiano & GP/2E-6404 \\
\hline IGc/USP & $\begin{array}{l}\text { Ictiodonte de } \\
\text { Palaeonisciformes }\end{array}$ & $\begin{array}{l}\text { Rio Claro, } \\
\text { Afloramento } 1\end{array}$ & $\begin{array}{l}\text { Membro Taquaral } \\
\text { Fácies Iai }\end{array}$ & Eopermiano & GP/2E-6405 \\
\hline IGc/USP & $\begin{array}{l}\text { Ictiodonte de } \\
\text { Palaeonisciformes }\end{array}$ & $\begin{array}{l}\text { Rio Claro, } \\
\text { Afloramento 1 }\end{array}$ & $\begin{array}{l}\text { Membro Taquaral } \\
\text { Fácies Iai }\end{array}$ & Eopermiano & GP/2E-6406 \\
\hline IGc/USP & $\begin{array}{l}\text { Ictiodonte de } \\
\text { Palaeonisciformes }\end{array}$ & $\begin{array}{l}\text { Rio Claro, } \\
\text { Afloramento 1 }\end{array}$ & $\begin{array}{l}\text { Membro Taquaral } \\
\text { Fácies Iai }\end{array}$ & Eopermiano & GP/2E-6407 \\
\hline IGc/USP & $\begin{array}{l}\text { Ictiodonte de } \\
\text { Palaeonisciformes }\end{array}$ & $\begin{array}{l}\text { Rio Claro, } \\
\text { Afloramento } 1\end{array}$ & $\begin{array}{l}\text { Membro Taquaral } \\
\text { Fácies Iai }\end{array}$ & Eopermiano & GP/2E-6408 \\
\hline IGc/USP & $\begin{array}{l}\text { Ictiodonte de } \\
\text { Palaeonisciformes }\end{array}$ & $\begin{array}{l}\text { Rio Claro, } \\
\text { Afloramento } 1\end{array}$ & $\begin{array}{l}\text { Membro Taquaral } \\
\text { Fácies Iai }\end{array}$ & Eopermiano & GP/2E-6409 \\
\hline IGc/USP & $\begin{array}{l}\text { Ictiodonte de } \\
\text { Palaeonisciformes }\end{array}$ & $\begin{array}{l}\text { Rio Claro, } \\
\text { Afloramento } 1 \\
\end{array}$ & $\begin{array}{l}\text { Membro Taquaral } \\
\text { Fácies Iai }\end{array}$ & Eopermiano & GP/2E-6410 \\
\hline IGc/USP & $\begin{array}{l}\text { Ictiodonte de } \\
\text { Palaeonisciformes }\end{array}$ & $\begin{array}{l}\text { Rio Claro, } \\
\text { Afloramento } 1\end{array}$ & $\begin{array}{l}\text { Membro Taquaral } \\
\text { Fácies Iai }\end{array}$ & Eopermiano & GP/2E-6411 \\
\hline IGc/USP & $\begin{array}{l}\text { Ictiodonte de } \\
\text { Palaeonisciformes }\end{array}$ & $\begin{array}{l}\text { Rio Claro, } \\
\text { Afloramento } 1\end{array}$ & $\begin{array}{l}\text { Membro Taquaral } \\
\text { Fácies Iai }\end{array}$ & Eopermiano & $\mathrm{GP} / 2 \mathrm{E}-6412$ \\
\hline IGc/USP & $\begin{array}{l}\text { Ictiodonte de } \\
\text { Palaeonisciformes }\end{array}$ & $\begin{array}{l}\text { Rio Claro, } \\
\text { Afloramento } 1\end{array}$ & $\begin{array}{l}\text { Membro Taquaral } \\
\text { Fácies Iai }\end{array}$ & Eopermiano & GP/2E-6413 \\
\hline IGc/USP & $\begin{array}{l}\text { Ictiodonte de } \\
\text { Palaeonisciformes }\end{array}$ & $\begin{array}{l}\text { Rio Claro, } \\
\text { Afloramento } 1 \\
\end{array}$ & $\begin{array}{l}\text { Membro Taquaral } \\
\text { Fácies Iai }\end{array}$ & Eopermiano & GP/2E-6414 \\
\hline IGc/USP & $\begin{array}{l}\text { Ictiodonte de } \\
\text { Palaeonisciformes }\end{array}$ & $\begin{array}{l}\text { Rio Claro, } \\
\text { Afloramento } 1 \\
\end{array}$ & $\begin{array}{l}\text { Membro Taquaral } \\
\text { Fácies Iai }\end{array}$ & Eopermiano & GP/2E-6415 \\
\hline IGc/USP & $\begin{array}{l}\text { Ictiodonte de } \\
\text { Palaeonisciformes }\end{array}$ & $\begin{array}{l}\text { Rio Claro, } \\
\text { Afloramento } 1\end{array}$ & $\begin{array}{l}\text { Membro Taquaral } \\
\text { Fácies Iai }\end{array}$ & Eopermiano & GP/2E-6416 \\
\hline IGc/USP & $\begin{array}{l}\text { Ictiodonte de } \\
\text { Palaeonisciformes }\end{array}$ & $\begin{array}{l}\text { Rio Claro, } \\
\text { Afloramento } 1\end{array}$ & $\begin{array}{l}\text { Membro Taquaral } \\
\text { Fácies Iai }\end{array}$ & Eopermiano & GP/2E-6418 \\
\hline IGc/USP & $\begin{array}{l}\text { Ictiodonte de } \\
\text { Palaeonisciformes }\end{array}$ & $\begin{array}{l}\text { Rio Claro, } \\
\text { Afloramento } 1\end{array}$ & $\begin{array}{l}\text { Membro Taquaral } \\
\text { Fácies Iai }\end{array}$ & Eopermiano & GP/2E-6419 \\
\hline IGc/USP & $\begin{array}{l}\text { Osso de } \\
\text { Palaeonisciformes }\end{array}$ & $\begin{array}{l}\text { Rio Claro, } \\
\text { Afloramento } 1\end{array}$ & $\begin{array}{l}\text { Membro Taquaral } \\
\text { Fácies Iai }\end{array}$ & Eopermiano & GP/2E-6420 \\
\hline IGc/USP & $\begin{array}{l}\text { Ictiodonte de } \\
\text { Palaeonisciformes }\end{array}$ & $\begin{array}{l}\text { Rio Claro, } \\
\text { Afloramento } 1 \\
\end{array}$ & $\begin{array}{l}\text { Membro Taquaral } \\
\text { Fácies Iai }\end{array}$ & Eopermiano & GP/2E-6421 \\
\hline
\end{tabular}




\begin{tabular}{|c|c|c|c|c|c|}
\hline IGc/USP & $\begin{array}{l}\text { Ictiodonte de } \\
\text { Palaeonisciformes }\end{array}$ & $\begin{array}{l}\text { Rio Claro, } \\
\text { Afloramento 1 }\end{array}$ & $\begin{array}{l}\text { Membro Taquaral } \\
\text { Fácies Iai }\end{array}$ & Eopermiano & GP/2E-6422 \\
\hline IGc/USP & $\begin{array}{l}\text { Ictiodonte de } \\
\text { Palaeonisciformes }\end{array}$ & $\begin{array}{l}\text { Rio Claro, } \\
\text { Afloramento 1 }\end{array}$ & $\begin{array}{l}\text { Membro Taquaral } \\
\text { Fácies Iai }\end{array}$ & Eopermiano & GP/2E-6423 \\
\hline IGc/USP & $\begin{array}{l}\text { Ictiodonte e ossos de } \\
\text { Palaeonisciformes }\end{array}$ & $\begin{array}{l}\text { Rio Claro, } \\
\text { Afloramento 1 }\end{array}$ & $\begin{array}{l}\text { Membro Taquaral } \\
\text { Fácies Iai }\end{array}$ & Eopermiano & GP/2E-6424 \\
\hline IGc/USP & $\begin{array}{l}\text { Ictiodonte de } \\
\text { Palaeonisciformes }\end{array}$ & $\begin{array}{l}\text { Rio Claro, } \\
\text { Afloramento 1 }\end{array}$ & $\begin{array}{l}\text { Membro Taquaral } \\
\text { Fácies Iai }\end{array}$ & Eopermiano & GP/2E-6425 \\
\hline IGc/USP & $\begin{array}{l}\text { Ictiodonte de } \\
\text { Palaeonisciformes }\end{array}$ & $\begin{array}{l}\text { Rio Claro, } \\
\text { Afloramento 1 }\end{array}$ & $\begin{array}{l}\text { Membro Taquaral } \\
\text { Fácies Iai }\end{array}$ & Eopermiano & GP/2E-6426 \\
\hline IGc/USP & $\begin{array}{l}\text { Ictiodonte de } \\
\text { Palaeonisciformes }\end{array}$ & $\begin{array}{l}\text { Rio Claro, } \\
\text { Afloramento 1 }\end{array}$ & $\begin{array}{l}\text { Membro Taquaral } \\
\text { Fácies Iai }\end{array}$ & Eopermiano & GP/2E-6428 \\
\hline IGc/USP & $\begin{array}{l}\text { Ictiodonte de } \\
\text { Palaeonisciformes }\end{array}$ & $\begin{array}{l}\text { Rio Claro, } \\
\text { Afloramento 1 }\end{array}$ & $\begin{array}{l}\text { Membro Taquaral } \\
\text { Fácies Iai }\end{array}$ & Eopermiano & GP/2E-6429 \\
\hline IGc/USP & $\begin{array}{l}\text { Ictiodonte e ossos de } \\
\text { Palaeonisciformes }\end{array}$ & $\begin{array}{l}\text { Rio Claro, } \\
\text { Afloramento 1 }\end{array}$ & $\begin{array}{l}\text { Membro Taquaral } \\
\text { Fácies Iai }\end{array}$ & Eopermiano & GP/2E-6430 \\
\hline IGc/USP & $\begin{array}{l}\text { Ictiodonte de } \\
\text { Palaeonisciformes }\end{array}$ & $\begin{array}{l}\text { Rio Claro, } \\
\text { Afloramento 1 }\end{array}$ & $\begin{array}{l}\text { Membro Taquaral } \\
\text { Fácies Iai }\end{array}$ & Eopermiano & GP/2E-6431 \\
\hline IGc/USP & $\begin{array}{l}\text { Dente ou Osso de } \\
\text { Palaeonisciformes }\end{array}$ & $\begin{array}{l}\text { Rio Claro, } \\
\text { Afloramento 1 }\end{array}$ & $\begin{array}{l}\text { Membro Taquaral } \\
\text { Fácies Iai }\end{array}$ & aiano & -6433 \\
\hline IGc/USP & $\begin{array}{l}\text { Ictiodonte de } \\
\text { Palaeonisciformes }\end{array}$ & $\begin{array}{l}\text { Rio Claro, } \\
\text { Afloramento 1 }\end{array}$ & $\begin{array}{l}\text { Membro Taquaral } \\
\text { Fácies Iai }\end{array}$ & Eopermiano & GP/2E-6434 \\
\hline IGc/USP & $\begin{array}{l}\text { Ictiodonte de } \\
\text { Palaeonisciformes }\end{array}$ & $\begin{array}{l}\text { Rio Claro, } \\
\text { Afloramento 1 }\end{array}$ & $\begin{array}{l}\text { Membro Taquaral } \\
\text { Fácies Iai }\end{array}$ & Eopermiano & GP/2E-6435 \\
\hline IGc/USP & $\begin{array}{l}\text { Ictiodonte e ossos de } \\
\text { Palaeonisciformes }\end{array}$ & $\begin{array}{l}\text { Rio Claro, } \\
\text { Afloramento 1 }\end{array}$ & $\begin{array}{l}\text { Membro Taquaral } \\
\text { Fácies Iai }\end{array}$ & Eopermiano & GP/2E-6436 \\
\hline IGc/USP & $\begin{array}{l}\text { Ictiodonte de } \\
\text { Palaeonisciformes }\end{array}$ & $\begin{array}{l}\text { Rio Claro, } \\
\text { Afloramento 1 }\end{array}$ & $\begin{array}{l}\text { Membro Taquaral } \\
\text { Fácies Iai }\end{array}$ & Eopermiano & GP/2E-6437 \\
\hline IGc/USP & $\begin{array}{l}\text { Dente ou Osso de } \\
\text { Palaeonisciformes }\end{array}$ & $\begin{array}{l}\text { Rio Claro, } \\
\text { Afloramento 1 }\end{array}$ & $\begin{array}{l}\text { Membro Taquaral } \\
\text { Fácies Iai }\end{array}$ & Eopermiano & -6438 \\
\hline IGc/USP & $\begin{array}{l}\text { Ictiodonte de } \\
\text { Palaeonisciformes }\end{array}$ & $\begin{array}{l}\text { Rio Claro, } \\
\text { Afloramento 1 }\end{array}$ & $\begin{array}{l}\text { Membro Taquaral } \\
\text { Fácies Iai }\end{array}$ & Eopermiano & GP/2E-6439 \\
\hline IGc/USP & $\begin{array}{l}\text { Ictiodonte de } \\
\text { Palaeonisciformes }\end{array}$ & $\begin{array}{l}\text { Rio Claro, } \\
\text { Afloramento 1 }\end{array}$ & $\begin{array}{l}\text { Membro Taquaral } \\
\text { Fácies Iai }\end{array}$ & Eopermiano & GP/2E-6440 \\
\hline IGc/USP & $\begin{array}{l}\text { Ictiodonte e ossos de } \\
\text { Palaeonisciformes }\end{array}$ & $\begin{array}{l}\text { Rio Claro, } \\
\text { Afloramento 1 }\end{array}$ & $\begin{array}{l}\text { Membro Taquaral } \\
\text { Fácies Iai }\end{array}$ & Eopermiano & GP/2E-6441 \\
\hline IGc/USP & $\begin{array}{l}\text { Ictiodonte de } \\
\text { Palaeonisciformes }\end{array}$ & $\begin{array}{l}\text { Rio Claro, } \\
\text { Afloramento 1 }\end{array}$ & $\begin{array}{l}\text { Membro Taquaral } \\
\text { Fácies Iai }\end{array}$ & Eopermiano & GP/2E-6442 \\
\hline IGc/USP & $\begin{array}{l}\text { Ictiodonte de } \\
\text { Palaeonisciformes }\end{array}$ & $\begin{array}{l}\text { Rio Claro, } \\
\text { Afloramento 1 }\end{array}$ & $\begin{array}{l}\text { Membro Taquaral } \\
\text { Fácies Iai }\end{array}$ & Eopermiano & GP/2E-6443 \\
\hline IGc/USP & $\begin{array}{l}\text { Ictiodonte de } \\
\text { Palaeonisciformes }\end{array}$ & $\begin{array}{l}\text { Rio Claro, } \\
\text { Afloramento 1 }\end{array}$ & $\begin{array}{l}\text { Membro Taquaral } \\
\text { Fácies Iai }\end{array}$ & Eopermiano & GP/2E-6444 \\
\hline IGc/USP & $\begin{array}{l}\text { Ictiodonte de } \\
\text { Palaeonisciformes }\end{array}$ & $\begin{array}{l}\text { Rio Claro, } \\
\text { Afloramento 1 }\end{array}$ & $\begin{array}{l}\text { Membro Taquaral } \\
\text { Fácies Iai }\end{array}$ & Eopermiano & GP/2E-6445 \\
\hline IGc/USP & $\begin{array}{l}\text { Ictiodonte de } \\
\text { Palaeonisciformes }\end{array}$ & $\begin{array}{l}\text { Rio Claro, } \\
\text { Afloramento 1 }\end{array}$ & $\begin{array}{l}\text { Membro Taquaral } \\
\text { Fácies Iai }\end{array}$ & Eopermiano & GP/2E-6446 \\
\hline IGc/USP & $\begin{array}{l}\text { Ictiodonte de } \\
\text { Palaeonisciformes }\end{array}$ & $\begin{array}{l}\text { Rio Claro, } \\
\text { Afloramento 1 }\end{array}$ & $\begin{array}{l}\text { Membro Taquaral } \\
\text { Fácies Iai }\end{array}$ & Eopermiano & GP/2E-6447 \\
\hline IGc/USP & $\begin{array}{l}\text { Ictiodonte de } \\
\text { Palaeonisciformes }\end{array}$ & $\begin{array}{l}\text { Rio Claro, } \\
\text { Afloramento 1 }\end{array}$ & $\begin{array}{l}\text { Membro Taquaral } \\
\text { Fácies Iai }\end{array}$ & Eopermiano & GP/2E-6448 \\
\hline IGc/USP & $\begin{array}{l}\text { Ictiodonte de } \\
\text { Palaeonisciformes }\end{array}$ & $\begin{array}{l}\text { Rio Claro, } \\
\text { Afloramento 1 }\end{array}$ & $\begin{array}{l}\text { Membro Taquaral } \\
\text { Fácies Iai }\end{array}$ & Eopermiano & GP/2E-6449 \\
\hline IGc/USP & $\begin{array}{l}\text { Ictiodonte de } \\
\text { Palaeonisciformes }\end{array}$ & $\begin{array}{l}\text { Rio Claro, } \\
\text { Afloramento 1 }\end{array}$ & $\begin{array}{l}\text { Membro Taquaral } \\
\text { Fácies Iai }\end{array}$ & Eopermiano & GP/2E-6450 \\
\hline IGc/USP & $\begin{array}{l}\text { Ictiodonte de } \\
\text { Palaeonisciformes }\end{array}$ & $\begin{array}{l}\text { Rio Claro, } \\
\text { Afloramento 1 }\end{array}$ & $\begin{array}{l}\text { Membro Taquaral } \\
\text { Fácies Iai }\end{array}$ & Eopermiano & GP/2E-6451 \\
\hline IGc/USP & $\begin{array}{l}\text { Ictiodonte de } \\
\text { Palaeonisciformes }\end{array}$ & $\begin{array}{l}\text { Rio Claro, } \\
\text { Afloramento 1 }\end{array}$ & $\begin{array}{l}\text { Membro Taquaral } \\
\text { Fácies Iai }\end{array}$ & Eopermiano & GP/2E-6452 \\
\hline IGc/USP & Ictiodonte de & Rio Claro, & Membro Taquaral & Eopermiano & GP/2E-6453 \\
\hline
\end{tabular}




\begin{tabular}{|c|c|c|c|c|c|}
\hline & Palaeonisciformes & Afloramento 1 & Fácies Iai & & \\
\hline IGc/USP & $\begin{array}{l}\text { Escama de } \\
\text { Palaeonisciformes }\end{array}$ & $\begin{array}{l}\text { Rio Claro, } \\
\text { Afloramento 1 }\end{array}$ & $\begin{array}{l}\text { Membro Taquaral } \\
\text { Fácies Iai }\end{array}$ & Eopermiano & GP/2E-3757 \\
\hline IGc/USP & $\begin{array}{l}\text { Escama de } \\
\text { Palaeonisciformes }\end{array}$ & $\begin{array}{l}\text { Rio Claro, } \\
\text { Afloramento 1 }\end{array}$ & $\begin{array}{l}\text { Membro Taquaral } \\
\text { Fácies Iai }\end{array}$ & Eopermiano & GP/2E-3758 \\
\hline IGc/USP & $\begin{array}{l}\text { Escama de } \\
\text { Palaeonisciformes }\end{array}$ & $\begin{array}{l}\text { Rio Claro, } \\
\text { Afloramento 1 }\end{array}$ & $\begin{array}{l}\text { Membro Taquaral } \\
\text { Fácies Iai }\end{array}$ & Eopermiano & GP/2E-3759 \\
\hline IGc/USP & $\begin{array}{l}\text { Escama de } \\
\text { Palaeonisciformes }\end{array}$ & $\begin{array}{l}\text { Rio Claro, } \\
\text { Afloramento 1 }\end{array}$ & $\begin{array}{l}\text { Membro Taquaral } \\
\text { Fácies Iai }\end{array}$ & Eopermiano & $\mathrm{GP} / 2 \mathrm{E}-3760$ \\
\hline IGc/USP & $\begin{array}{l}\text { Escama de } \\
\text { Palaeonisciformes }\end{array}$ & $\begin{array}{l}\text { Rio Claro, } \\
\text { Afloramento } 3\end{array}$ & $\begin{array}{l}\text { Membro Taquaral } \\
\text { Fácies Iai }\end{array}$ & Eopermiano & GP/2E-5953 \\
\hline IGc/USP & $\begin{array}{l}\text { Escama de } \\
\text { Palaeonisciformes }\end{array}$ & $\begin{array}{l}\text { Rio Claro, } \\
\text { Afloramento } 1\end{array}$ & $\begin{array}{l}\text { Membro Taquaral } \\
\text { Fácies Iai }\end{array}$ & Eopermiano & GP/2E-5954 \\
\hline IGc/USP & $\begin{array}{l}\text { Escama de } \\
\text { Palaeonisciformes }\end{array}$ & $\begin{array}{l}\text { Rio Claro, } \\
\text { Afloramento 1 }\end{array}$ & $\begin{array}{l}\text { Membro Taquaral } \\
\text { Fácies Iai }\end{array}$ & Eopermiano & GP/2E-5955 \\
\hline IGc/USP & $\begin{array}{l}\text { Escama de } \\
\text { Palaeonisciformes }\end{array}$ & $\begin{array}{l}\text { Rio Claro, } \\
\text { Afloramento 1 }\end{array}$ & $\begin{array}{l}\text { Membro Taquaral } \\
\text { Fácies Iai }\end{array}$ & Eopermiano & GP/2E-5956 \\
\hline IGc/USP & $\begin{array}{l}\text { Escama de } \\
\text { Palaeonisciformes }\end{array}$ & $\begin{array}{l}\text { Rio Claro, } \\
\text { Afloramento 1 }\end{array}$ & $\begin{array}{l}\text { Membro Taquaral } \\
\text { Fácies Iai }\end{array}$ & Eopermiano & GP/2E-5957 \\
\hline IGc/USP & $\begin{array}{l}\text { Escama de } \\
\text { Palaeonisciformes }\end{array}$ & $\begin{array}{l}\text { Rio Claro, } \\
\text { Afloramento 1 }\end{array}$ & $\begin{array}{l}\text { Membro Taquaral } \\
\text { Fácies Iai }\end{array}$ & Eopermiano & GP/2E-5958 \\
\hline IGc/USP & $\begin{array}{l}\text { Escama de } \\
\text { Palaeonisciformes }\end{array}$ & $\begin{array}{l}\text { Rio Claro, } \\
\text { Afloramento 1 }\end{array}$ & $\begin{array}{l}\text { Membro Taquaral } \\
\text { Fácies Iai }\end{array}$ & Eopermiano & GP/2E-5959 \\
\hline IGc/USP & $\begin{array}{l}\text { Escama de } \\
\text { Palaeonisciformes }\end{array}$ & $\begin{array}{l}\text { Rio Claro, } \\
\text { Afloramento 1 }\end{array}$ & $\begin{array}{l}\text { Membro Taquaral } \\
\text { Fácies Iai }\end{array}$ & no & -5960 \\
\hline IGc/USP & $\begin{array}{l}\text { Escama de } \\
\text { Palaeonisciformes }\end{array}$ & $\begin{array}{l}\text { Rio Claro, } \\
\text { Afloramento 1 }\end{array}$ & $\begin{array}{l}\text { Membro Taquaral } \\
\text { Fácies Iai }\end{array}$ & Eopermiano & GP/2E-5961 \\
\hline IGc/USP & $\begin{array}{l}\text { Escama de } \\
\text { Palaeonisciformes }\end{array}$ & $\begin{array}{l}\text { Rio Claro, } \\
\text { Afloramento 1 }\end{array}$ & $\begin{array}{l}\text { Membro Taquaral } \\
\text { Fácies Iai }\end{array}$ & Eopermiano & GP/2E-5962 \\
\hline IGc/USP & $\begin{array}{l}\text { Escama de } \\
\text { Palaeonisciformes }\end{array}$ & $\begin{array}{l}\text { Rio Claro, } \\
\text { Afloramento 1 } \\
\end{array}$ & $\begin{array}{l}\text { Membro Taquaral } \\
\text { Fácies Iai }\end{array}$ & Eopermiano & GP/2E-5963 \\
\hline IGc/USP & $\begin{array}{l}\text { Escama de } \\
\text { Palaeonisciformes }\end{array}$ & $\begin{array}{l}\text { Rio Claro, } \\
\text { Afloramento 1 }\end{array}$ & $\begin{array}{l}\text { Membro Taquaral } \\
\text { Fácies Iai }\end{array}$ & Eopermiano & GP/2E-5964 \\
\hline IGc/USP & $\begin{array}{l}\text { Escama de } \\
\text { Palaeonisciformes }\end{array}$ & $\begin{array}{l}\text { Rio Claro, } \\
\text { Afloramento 1 }\end{array}$ & $\begin{array}{l}\text { Membro Taquaral } \\
\text { Fácies Iai }\end{array}$ & niano & GP/2E-6250 \\
\hline IGc/USP & $\begin{array}{l}\text { Escama de } \\
\text { Palaeonisciformes }\end{array}$ & $\begin{array}{l}\text { Rio Claro, } \\
\text { Afloramento 1 }\end{array}$ & $\begin{array}{l}\text { Membro Taquaral } \\
\text { Fácies Iai }\end{array}$ & Eopermiano & GP/2E-6254 \\
\hline IGc/USP & $\begin{array}{l}\text { Escama de } \\
\text { Palaeonisciformes }\end{array}$ & $\begin{array}{l}\text { Rio Claro, } \\
\text { Afloramento 1 }\end{array}$ & $\begin{array}{l}\text { Membro Taquaral } \\
\text { Fácies Iai }\end{array}$ & Eopermiano & GP/2E-6259 \\
\hline IGc/USP & $\begin{array}{l}\text { Escama de } \\
\text { Palaeonisciformes }\end{array}$ & $\begin{array}{l}\text { Rio Claro, } \\
\text { Afloramento 1 }\end{array}$ & $\begin{array}{l}\text { Membro Taquaral } \\
\text { Fácies Iai }\end{array}$ & Eopermiano & GP/2E-6271 \\
\hline IGc/USP & $\begin{array}{l}\text { Ossos e escamas de } \\
\text { Palaeonisciformes }\end{array}$ & $\begin{array}{l}\text { Rio Claro, } \\
\text { Afloramento } 1\end{array}$ & $\begin{array}{l}\text { Membro Taquaral } \\
\text { Fácies Iai }\end{array}$ & Eopermiano & $\mathrm{GP} / 2 \mathrm{E}-6272$ \\
\hline IGc/USP & $\begin{array}{l}\text { Escama e ossos de } \\
\text { Palaeonisciformes }\end{array}$ & $\begin{array}{l}\text { Rio Claro, } \\
\text { Afloramento 1 }\end{array}$ & $\begin{array}{l}\text { Membro Taquaral } \\
\text { Fácies Iai }\end{array}$ & Eopermiano & GP/2E-6279 \\
\hline IGc/USP & $\begin{array}{l}\text { Escama de } \\
\text { Palaeonisciformes (?) }\end{array}$ & $\begin{array}{l}\text { Rio Claro, } \\
\text { Afloramento 1 }\end{array}$ & $\begin{array}{l}\text { Membro Taquaral } \\
\text { Fácies Iai }\end{array}$ & Eopermiano & GP/2E-6286 \\
\hline IGc/USP & $\begin{array}{l}\text { Escama de } \\
\text { Palaeonisciformes }\end{array}$ & $\begin{array}{l}\text { Rio Claro, } \\
\text { Afloramento 1 }\end{array}$ & $\begin{array}{l}\text { Membro Taquaral } \\
\text { Fácies Iai }\end{array}$ & Eopermiano & GP/2E-6315 \\
\hline IGc/USP & $\begin{array}{l}\text { Escama de } \\
\text { Palaeonisciformes }\end{array}$ & $\begin{array}{l}\text { Rio Claro, } \\
\text { Afloramento } 1\end{array}$ & $\begin{array}{l}\text { Membro Taquaral } \\
\text { Fácies Iai }\end{array}$ & Eopermiano & GP/2E-6316 \\
\hline IGc/USP & $\begin{array}{l}\text { Escama de } \\
\text { Palaeonisciformes }\end{array}$ & $\begin{array}{l}\text { Rio Claro, } \\
\text { Afloramento 1 }\end{array}$ & $\begin{array}{l}\text { Membro Taquaral } \\
\text { Fácies Iai }\end{array}$ & Eopermiano & GP/2E-6317 \\
\hline IGc/USP & $\begin{array}{l}\text { Escama de } \\
\text { Palaeonisciformes }\end{array}$ & $\begin{array}{l}\text { Rio Claro, } \\
\text { Afloramento 1 }\end{array}$ & $\begin{array}{l}\text { Membro Taquaral } \\
\text { Fácies Iai }\end{array}$ & Eopermiano & GP/2E-6318 \\
\hline IGc/USP & $\begin{array}{l}\text { Escama de } \\
\text { Palaeonisciformes }\end{array}$ & $\begin{array}{l}\text { Rio Claro, } \\
\text { Afloramento } 1\end{array}$ & $\begin{array}{l}\text { Membro Taquaral } \\
\text { Fácies Iai }\end{array}$ & Eopermiano & GP/2E-6319 \\
\hline IGc/USP & $\begin{array}{l}\text { Escama de } \\
\text { Palaeonisciformes }\end{array}$ & $\begin{array}{l}\text { Rio Claro, } \\
\text { Afloramento } 1 \\
\end{array}$ & $\begin{array}{l}\text { Membro Taquaral } \\
\text { Fácies Iai }\end{array}$ & Eopermiano & GP/2E-6320 \\
\hline
\end{tabular}




\begin{tabular}{|c|c|c|c|c|c|}
\hline IGc/USP & $\begin{array}{l}\text { Escama de } \\
\text { Palaeonisciformes }\end{array}$ & $\begin{array}{l}\text { Rio Claro, } \\
\text { Afloramento 1 }\end{array}$ & $\begin{array}{l}\text { Membro Taquaral } \\
\text { Fácies Iai }\end{array}$ & Eopermiano & GP/2E-6321 \\
\hline IGc/USP & $\begin{array}{l}\text { Escama de } \\
\text { Palaeonisciformes }\end{array}$ & $\begin{array}{l}\text { Rio Claro, } \\
\text { Afloramento } 1\end{array}$ & $\begin{array}{l}\text { Membro Taquaral } \\
\text { Fácies Iai }\end{array}$ & Eopermiano & GP/2E-6322 \\
\hline IGc/USP & $\begin{array}{l}\text { Escama de } \\
\text { Palaeonisciformes }\end{array}$ & $\begin{array}{l}\text { Rio Claro, } \\
\text { Afloramento } 1\end{array}$ & $\begin{array}{l}\text { Membro Taquaral } \\
\text { Fácies Iai }\end{array}$ & Eopermiano & GP/2E-6323 \\
\hline IGc/USP & $\begin{array}{l}\text { Escama de } \\
\text { Palaeonisciformes }\end{array}$ & $\begin{array}{l}\text { Rio Claro, } \\
\text { Afloramento 1 }\end{array}$ & $\begin{array}{l}\text { Membro Taquaral } \\
\text { Fácies Iai }\end{array}$ & Eopermiano & GP/2E-6324 \\
\hline IGc/USP & $\begin{array}{l}\text { Escama de } \\
\text { Palaeonisciformes }\end{array}$ & $\begin{array}{l}\text { Rio Claro, } \\
\text { Afloramento 1 }\end{array}$ & $\begin{array}{l}\text { Membro Taquaral } \\
\text { Fácies Iai }\end{array}$ & Eopermiano & GP/2E-6325 \\
\hline IGc/USP & $\begin{array}{l}\text { Escama de } \\
\text { Palaeonisciformes }\end{array}$ & $\begin{array}{l}\text { Rio Claro, } \\
\text { Afloramento } 1\end{array}$ & $\begin{array}{l}\text { Membro Taquaral } \\
\text { Fácies Iai }\end{array}$ & Eopermiano & GP/2E-6326 \\
\hline IGc/USP & $\begin{array}{l}\text { Escama de } \\
\text { Palaeonisciformes }\end{array}$ & $\begin{array}{l}\text { Rio Claro, } \\
\text { Afloramento 1 }\end{array}$ & $\begin{array}{l}\text { Membro Taquaral } \\
\text { Fácies Iai }\end{array}$ & Eopermiano & GP/2E-6327 \\
\hline IGc/USP & $\begin{array}{l}\text { Escama de } \\
\text { Palaeonisciformes }\end{array}$ & $\begin{array}{l}\text { Rio Claro, } \\
\text { Afloramento 1 }\end{array}$ & $\begin{array}{l}\text { Membro Taquaral } \\
\text { Fácies Iai }\end{array}$ & Eopermiano & GP/2E-6328 \\
\hline IGc/USP & $\begin{array}{l}\text { Escama de } \\
\text { Palaeonisciformes }\end{array}$ & $\begin{array}{l}\text { Rio Claro, } \\
\text { Afloramento 1 }\end{array}$ & $\begin{array}{l}\text { Membro Taquaral } \\
\text { Fácies Iai }\end{array}$ & Eopermiano & GP/2E-6329 \\
\hline IGc/USP & $\begin{array}{l}\text { Escama de } \\
\text { Palaeonisciformes }\end{array}$ & $\begin{array}{l}\text { Rio Claro, } \\
\text { Afloramento 1 }\end{array}$ & $\begin{array}{l}\text { Membro Taquaral } \\
\text { Fácies Iai }\end{array}$ & Eopermiano & $\overline{\mathrm{GP}} / 2 \mathrm{E}-6330$ \\
\hline IGc/USP & $\begin{array}{l}\text { Escama de } \\
\text { Palaeonisciformes }\end{array}$ & $\begin{array}{l}\text { Rio Claro, } \\
\text { Afloramento } 1\end{array}$ & $\begin{array}{l}\text { Membro Taquaral } \\
\text { Fácies Iai }\end{array}$ & Eopermiano & GP/2E-6331 \\
\hline IGc/USP & $\begin{array}{l}\text { Escama de } \\
\text { Palaeonisciformes }\end{array}$ & $\begin{array}{l}\text { Rio Claro, } \\
\text { Afloramento 1 }\end{array}$ & $\begin{array}{l}\text { Membro Taquaral } \\
\text { Fácies Iai }\end{array}$ & Eopermiano & GP/2E-6332 \\
\hline IGc/USP & $\begin{array}{l}\text { Escama de } \\
\text { Palaeonisciformes }\end{array}$ & $\begin{array}{l}\text { Rio Claro, } \\
\text { Afloramento 1 }\end{array}$ & $\begin{array}{l}\text { Membro Taquaral } \\
\text { Fácies Iai }\end{array}$ & Eopermiano & GP/2E-6333 \\
\hline IGc/USP & $\begin{array}{l}\text { Escama de } \\
\text { Palaeonisciformes }\end{array}$ & $\begin{array}{l}\text { Rio Claro, } \\
\text { Afloramento 1 }\end{array}$ & $\begin{array}{l}\text { Membro Taquaral } \\
\text { Fácies Iai }\end{array}$ & Eopermiano & GP/2E-6334 \\
\hline IGc/USP & $\begin{array}{l}\text { Escama de } \\
\text { Palaeonisciformes }\end{array}$ & $\begin{array}{l}\text { Rio Claro, } \\
\text { Afloramento 1 }\end{array}$ & $\begin{array}{l}\text { Membro Taquaral } \\
\text { Fácies Iai }\end{array}$ & iiano & -6335 \\
\hline IGc/USP & $\begin{array}{l}\text { Escama de } \\
\text { Palaeonisciformes }\end{array}$ & $\begin{array}{l}\text { Rio Claro, } \\
\text { Afloramento } 1 \\
\end{array}$ & $\begin{array}{l}\text { Membro Taquaral } \\
\text { Fácies Iai }\end{array}$ & Eopermiano & GP/2E-6336 \\
\hline IGc/USP & $\begin{array}{l}\text { Escama de } \\
\text { Palaeonisciformes }\end{array}$ & $\begin{array}{l}\text { Rio Claro, } \\
\text { Afloramento 1 }\end{array}$ & $\begin{array}{l}\text { Membro Taquaral } \\
\text { Fácies Iai }\end{array}$ & Eopermiano & GP/2E-6337 \\
\hline IGc/USP & $\begin{array}{l}\text { Escama de } \\
\text { Palaeonisciformes }\end{array}$ & $\begin{array}{l}\text { Rio Claro, } \\
\text { Afloramento } 1\end{array}$ & $\begin{array}{l}\text { Membro Taquaral } \\
\text { Fácies Iai }\end{array}$ & Eopermiano & GP/2E-6338 \\
\hline IGc/USP & $\begin{array}{l}\text { Escama de } \\
\text { Palaeonisciformes }\end{array}$ & $\begin{array}{l}\text { Rio Claro, } \\
\text { Afloramento 1 }\end{array}$ & $\begin{array}{l}\text { Membro Taquaral } \\
\text { Fácies Iai }\end{array}$ & Eopermiano & GP/2E-6339 \\
\hline IGc/USP & $\begin{array}{l}\text { Escama de } \\
\text { Palaeonisciformes }\end{array}$ & $\begin{array}{l}\text { Rio Claro, } \\
\text { Afloramento 1 }\end{array}$ & $\begin{array}{l}\text { Membro Taquaral } \\
\text { Fácies Iai }\end{array}$ & Eopermiano & GP/2E-6340 \\
\hline IGc/USP & $\begin{array}{l}\text { Escama de } \\
\text { Palaeonisciformes }\end{array}$ & $\begin{array}{l}\text { Rio Claro, } \\
\text { Afloramento 1 }\end{array}$ & $\begin{array}{l}\text { Membro Taquaral } \\
\text { Fácies Iai }\end{array}$ & Eopermiano & GP/2E-6341 \\
\hline IGc/USP & $\begin{array}{l}\text { Escama de } \\
\text { Palaeonisciformes }\end{array}$ & $\begin{array}{l}\text { Rio Claro, } \\
\text { Afloramento 1 }\end{array}$ & $\begin{array}{l}\text { Membro Taquaral } \\
\text { Fácies Iai }\end{array}$ & Eopermiano & GP/2E-6343 \\
\hline IGc/USP & $\begin{array}{l}\text { Escama de } \\
\text { Palaeonisciformes }\end{array}$ & $\begin{array}{l}\text { Rio Claro, } \\
\text { Afloramento 1 }\end{array}$ & $\begin{array}{l}\text { Membro Taquaral } \\
\text { Fácies Iai }\end{array}$ & Eopermiano & GP/2E-6344 \\
\hline IGc/USP & $\begin{array}{l}\text { Escama de } \\
\text { Palaeonisciformes }\end{array}$ & $\begin{array}{l}\text { Rio Claro, } \\
\text { Afloramento } 1\end{array}$ & $\begin{array}{l}\text { Membro Taquaral } \\
\text { Fácies Iai }\end{array}$ & Eopermiano & GP/2E-6345 \\
\hline IGc/USP & $\begin{array}{l}\text { Escama de } \\
\text { Palaeonisciformes }\end{array}$ & $\begin{array}{l}\text { Rio Claro, } \\
\text { Afloramento } 1\end{array}$ & $\begin{array}{l}\text { Membro Taquaral } \\
\text { Fácies Iai }\end{array}$ & Eopermiano & GP/2E-6346 \\
\hline IGc/USP & $\begin{array}{l}\text { Escama de } \\
\text { Palaeonisciformes }\end{array}$ & $\begin{array}{l}\text { Rio Claro, } \\
\text { Afloramento 1 }\end{array}$ & $\begin{array}{l}\text { Membro Taquaral } \\
\text { Fácies Iai }\end{array}$ & Eopermiano & GP/2E-6347 \\
\hline IGc/USP & $\begin{array}{l}\text { Escama de } \\
\text { Palaeonisciformes }\end{array}$ & $\begin{array}{l}\text { Rio Claro, } \\
\text { Afloramento 1 }\end{array}$ & $\begin{array}{l}\text { Membro Taquaral } \\
\text { Fácies Iai }\end{array}$ & Eopermiano & GP/2E-6348 \\
\hline IGc/USP & $\begin{array}{l}\text { Escama de } \\
\text { Palaeonisciformes }\end{array}$ & $\begin{array}{l}\text { Rio Claro, } \\
\text { Afloramento 1 }\end{array}$ & $\begin{array}{l}\text { Membro Taquaral } \\
\text { Fácies Iai }\end{array}$ & Eopermiano & GP/2E-6349 \\
\hline IGc/USP & $\begin{array}{l}\text { Escama de } \\
\text { Palaeonisciformes }\end{array}$ & $\begin{array}{l}\text { Rio Claro, } \\
\text { Afloramento } 1 \\
\end{array}$ & $\begin{array}{l}\text { Membro Taquaral } \\
\text { Fácies Iai }\end{array}$ & Eopermiano & GP/2E-6350 \\
\hline IGc/USP & Escama de & Rio Claro, & Membro Taquaral & Eopermiano & GP/2E-6351 \\
\hline
\end{tabular}




\begin{tabular}{|c|c|c|c|c|c|}
\hline & Palaeonisciformes & Afloramento 1 & Fácies Iai & & \\
\hline IGc/USP & $\begin{array}{l}\text { Escama de } \\
\text { Palaeonisciformes }\end{array}$ & $\begin{array}{l}\text { Rio Claro, } \\
\text { Afloramento } 1\end{array}$ & $\begin{array}{l}\text { Membro Taquaral } \\
\text { Fácies Iai }\end{array}$ & Eopermiano & GP/2E-6352 \\
\hline IGc/USP & $\begin{array}{l}\text { Escama de } \\
\text { Palaeonisciformes }\end{array}$ & $\begin{array}{l}\text { Rio Claro, } \\
\text { Afloramento } 1\end{array}$ & $\begin{array}{l}\text { Membro Taquaral } \\
\text { Fácies Iai }\end{array}$ & Eopermiano & GP/2E-6353 \\
\hline IGc/USP & $\begin{array}{l}\text { Escama de } \\
\text { Palaeonisciformes }\end{array}$ & $\begin{array}{l}\text { Rio Claro, } \\
\text { Afloramento } 1\end{array}$ & $\begin{array}{l}\text { Membro Taquaral } \\
\text { Fácies Iai }\end{array}$ & Eopermiano & GP/2E-6354 \\
\hline IGc/USP & $\begin{array}{l}\text { Escama de } \\
\text { Palaeonisciformes }\end{array}$ & $\begin{array}{l}\text { Rio Claro, } \\
\text { Afloramento } 1\end{array}$ & $\begin{array}{l}\text { Membro Taquaral } \\
\text { Fácies Iai }\end{array}$ & Eopermiano & GP/2E-6355 \\
\hline IGc/USP & $\begin{array}{l}\text { Escama de } \\
\text { Palaeonisciformes }\end{array}$ & $\begin{array}{l}\text { Rio Claro, } \\
\text { Afloramento } 1\end{array}$ & $\begin{array}{l}\text { Membro Taquaral } \\
\text { Fácies Iai }\end{array}$ & Eopermiano & GP/2E-6356 \\
\hline IGc/USP & $\begin{array}{l}\text { Escama de } \\
\text { Palaeonisciformes }\end{array}$ & $\begin{array}{l}\text { Rio Claro, } \\
\text { Afloramento } 1\end{array}$ & $\begin{array}{l}\text { Membro Taquaral } \\
\text { Fácies Iai }\end{array}$ & Eopermiano & GP/2E-6357 \\
\hline IGc/USP & $\begin{array}{l}\text { Escama de } \\
\text { Palaeonisciformes }\end{array}$ & $\begin{array}{l}\text { Rio Claro, } \\
\text { Afloramento } 1\end{array}$ & $\begin{array}{l}\text { Membro Taquaral } \\
\text { Fácies Iai }\end{array}$ & Eopermiano & GP/2E-6358 \\
\hline IGc/USP & $\begin{array}{l}\text { Escama de } \\
\text { Palaeonisciformes }\end{array}$ & $\begin{array}{l}\text { Rio Claro, } \\
\text { Afloramento } 1\end{array}$ & $\begin{array}{l}\text { Membro Taquaral } \\
\text { Fácies Iai }\end{array}$ & Eopermiano & GP/2E-6359 \\
\hline IGc/USP & $\begin{array}{l}\text { Escama de } \\
\text { Palaeonisciformes }\end{array}$ & $\begin{array}{l}\text { Rio Claro, } \\
\text { Afloramento } 1\end{array}$ & $\begin{array}{l}\text { Membro Taquaral } \\
\text { Fácies Iai }\end{array}$ & Eopermiano & GP/2E-6360 \\
\hline IGc/USP & $\begin{array}{l}\text { Escama de } \\
\text { Palaeonisciformes }\end{array}$ & $\begin{array}{l}\text { Rio Claro, } \\
\text { Afloramento } 1\end{array}$ & $\begin{array}{l}\text { Membro Taquaral } \\
\text { Fácies Iai }\end{array}$ & Eopermiano & GP/2E-6361 \\
\hline IGc/USP & $\begin{array}{l}\text { Escama de } \\
\text { Palaeonisciformes }\end{array}$ & $\begin{array}{l}\text { Rio Claro, } \\
\text { Afloramento 1 }\end{array}$ & $\begin{array}{l}\text { Membro Taquaral } \\
\text { Fácies Iai }\end{array}$ & Eopermiano & GP/2E-6362 \\
\hline IGc/USP & $\begin{array}{l}\text { Escama de } \\
\text { Palaeonisciformes }\end{array}$ & $\begin{array}{l}\text { Rio Claro, } \\
\text { Afloramento } 1\end{array}$ & $\begin{array}{l}\text { Membro Taquaral } \\
\text { Fácies Iai }\end{array}$ & iano & 6363 \\
\hline IGc/USP & $\begin{array}{l}\text { Escama de } \\
\text { Palaeonisciformes }\end{array}$ & $\begin{array}{l}\text { Rio Claro, } \\
\text { Afloramento } 1\end{array}$ & $\begin{array}{l}\text { Membro Taquaral } \\
\text { Fácies Iai }\end{array}$ & Eopermiano & GP/2E-6364 \\
\hline IGc/USP & $\begin{array}{l}\text { Escama de } \\
\text { Palaeonisciformes }\end{array}$ & $\begin{array}{l}\text { Rio Claro, } \\
\text { Afloramento } 1\end{array}$ & $\begin{array}{l}\text { Membro Taquaral } \\
\text { Fácies Iai }\end{array}$ & Eopermiano & GP/2E-6365 \\
\hline IGc/USP & $\begin{array}{l}\text { Escama de } \\
\text { Palaeonisciformes }\end{array}$ & $\begin{array}{l}\text { Rio Claro, } \\
\text { Afloramento 1 }\end{array}$ & $\begin{array}{l}\text { Membro Taquaral } \\
\text { Fácies Iai }\end{array}$ & Eopermiano & GP/2E-6366 \\
\hline IGc/USP & $\begin{array}{l}\text { Escama de } \\
\text { Palaeonisciformes }\end{array}$ & $\begin{array}{l}\text { Rio Claro, } \\
\text { Afloramento 1 }\end{array}$ & $\begin{array}{l}\text { Membro Taquaral } \\
\text { Fácies Iai }\end{array}$ & Eopermiano & GP/2E-6367 \\
\hline IGc/USP & $\begin{array}{l}\text { Escama de } \\
\text { Palaeonisciformes }\end{array}$ & $\begin{array}{l}\text { Rio Claro, } \\
\text { Afloramento } 1\end{array}$ & $\begin{array}{l}\text { Membro Taquaral } \\
\text { Fácies Iai }\end{array}$ & Eopermiano & -6368 \\
\hline IGc/USP & $\begin{array}{l}\text { Escama de } \\
\text { Palaeonisciformes }\end{array}$ & $\begin{array}{l}\text { Rio Claro, } \\
\text { Afloramento } 1\end{array}$ & $\begin{array}{l}\text { Membro Taquaral } \\
\text { Fácies Iai }\end{array}$ & Eopermiano & GP/2E-6369 \\
\hline IGc/USP & $\begin{array}{l}\text { Escama de } \\
\text { Palaeonisciformes }\end{array}$ & $\begin{array}{l}\text { Rio Claro, } \\
\text { Afloramento } 1 \\
\end{array}$ & $\begin{array}{l}\text { Membro Taquaral } \\
\text { Fácies Iai }\end{array}$ & Eopermiano & GP/2E-6370 \\
\hline IGc/USP & $\begin{array}{l}\text { Escama de } \\
\text { Palaeonisciformes }\end{array}$ & $\begin{array}{l}\text { Rio Claro, } \\
\text { Afloramento } 1\end{array}$ & $\begin{array}{l}\text { Membro Taquaral } \\
\text { Fácies Iai }\end{array}$ & Eopermiano & GP/2E-6371 \\
\hline IGc/USP & $\begin{array}{l}\text { Escama de } \\
\text { Palaeonisciformes }\end{array}$ & $\begin{array}{l}\text { Rio Claro, } \\
\text { Afloramento } 1\end{array}$ & $\begin{array}{l}\text { Membro Taquaral } \\
\text { Fácies Iai }\end{array}$ & Eopermiano & GP/2E-6372 \\
\hline IGc/USP & $\begin{array}{l}\text { Escama de } \\
\text { Palaeonisciformes }\end{array}$ & $\begin{array}{l}\text { Rio Claro, } \\
\text { Afloramento } 1\end{array}$ & $\begin{array}{l}\text { Membro Taquaral } \\
\text { Fácies Iai }\end{array}$ & Eopermiano & GP/2E-6373 \\
\hline IGc/USP & $\begin{array}{l}\text { Escama de } \\
\text { Palaeonisciformes }\end{array}$ & $\begin{array}{l}\text { Rio Claro, } \\
\text { Afloramento } 1 \\
\end{array}$ & $\begin{array}{l}\text { Membro Taquaral } \\
\text { Fácies Iai }\end{array}$ & Eopermiano & GP/2E-6374 \\
\hline IGc/USP & $\begin{array}{l}\text { Escama de } \\
\text { Palaeonisciformes }\end{array}$ & $\begin{array}{l}\text { Rio Claro, } \\
\text { Afloramento } 1 \\
\end{array}$ & $\begin{array}{l}\text { Membro Taquaral } \\
\text { Fácies Iai }\end{array}$ & Eopermiano & GP/2E-6375 \\
\hline IGc/USP & $\begin{array}{l}\text { Escama de } \\
\text { Palaeonisciformes }\end{array}$ & $\begin{array}{l}\text { Rio Claro, } \\
\text { Afloramento } 1\end{array}$ & $\begin{array}{l}\text { Membro Taquaral } \\
\text { Fácies Iai }\end{array}$ & Eopermiano & GP/2E-6376 \\
\hline IGc/USP & $\begin{array}{l}\text { Escama de } \\
\text { Palaeonisciformes }\end{array}$ & $\begin{array}{l}\text { Rio Claro, } \\
\text { Afloramento } 1\end{array}$ & $\begin{array}{l}\text { Membro Taquaral } \\
\text { Fácies Iai }\end{array}$ & Eopermiano & GP/2E-6377 \\
\hline IGc/USP & $\begin{array}{l}\text { Escama de } \\
\text { Palaeonisciformes }\end{array}$ & $\begin{array}{l}\text { Rio Claro, } \\
\text { Afloramento } 1\end{array}$ & $\begin{array}{l}\text { Membro Taquaral } \\
\text { Fácies Iai }\end{array}$ & Eopermiano & GP/2E-6378 \\
\hline IGc/USP & $\begin{array}{l}\text { Escama de } \\
\text { Palaeonisciformes }\end{array}$ & $\begin{array}{l}\text { Rio Claro, } \\
\text { Afloramento } 1\end{array}$ & $\begin{array}{l}\text { Membro Taquaral } \\
\text { Fácies Iai }\end{array}$ & Eopermiano & GP/2E-6379 \\
\hline IGc/USP & $\begin{array}{l}\text { Escama de } \\
\text { Palaeonisciformes }\end{array}$ & $\begin{array}{l}\text { Rio Claro, } \\
\text { Afloramento } 1 \\
\end{array}$ & $\begin{array}{l}\text { Membro Taquaral } \\
\text { Fácies Iai }\end{array}$ & Eopermiano & GP/2E-6381 \\
\hline
\end{tabular}




\begin{tabular}{|c|c|c|c|c|c|}
\hline IGc/USP & $\begin{array}{l}\text { Escama de } \\
\text { Palaeonisciformes }\end{array}$ & $\begin{array}{l}\text { Rio Claro, } \\
\text { Afloramento 1 }\end{array}$ & $\begin{array}{l}\text { Membro Taquaral } \\
\text { Fácies Iai }\end{array}$ & Eopermiano & GP/2E-6382 \\
\hline IGc/USP & $\begin{array}{l}\text { Acumulado de Escamas } \\
\text { Palaeonisciformes }\end{array}$ & $\begin{array}{l}\text { Rio Claro, } \\
\text { Afloramento 1 }\end{array}$ & $\begin{array}{l}\text { Membro Taquaral } \\
\text { Fácies Iai }\end{array}$ & Eopermiano & GP/2E-6383 \\
\hline IGc/USP & $\begin{array}{l}\text { Escamas de } \\
\text { Palaeonisciformes }\end{array}$ & $\begin{array}{l}\text { Ipeúna, } \\
\text { Afloramento } 12\end{array}$ & $\begin{array}{l}\text { Membro Taquaral } \\
\text { Fácies Isa }\end{array}$ & Eopermiano & GP/2E-6587 \\
\hline IGc/USP & $\begin{array}{l}\text { Escama de } \\
\text { Coelacanthimorpha }\end{array}$ & $\begin{array}{l}\text { Rio Claro, } \\
\text { Afloramento } 4\end{array}$ & $\begin{array}{l}\text { Formação Tatuí } \\
\text { Fácies Taf }\end{array}$ & Eopermiano & GP/2E-5965 \\
\hline IGc/USP & $\begin{array}{l}\text { Escama de } \\
\text { Coelacanthimorpha }\end{array}$ & $\begin{array}{l}\text { Rio Claro, } \\
\text { Afloramento 1 }\end{array}$ & $\begin{array}{l}\text { Membro Taquaral } \\
\text { Fácies Iai }\end{array}$ & Eopermiano & GP/2E-5966 \\
\hline IGc/USP & $\begin{array}{l}\text { Escama de } \\
\text { Coelacanthimorpha }\end{array}$ & $\begin{array}{l}\text { Rio Claro, } \\
\text { Afloramento 1 }\end{array}$ & $\begin{array}{l}\text { Membro Taquaral } \\
\text { Fácies Iai }\end{array}$ & Eopermiano & GP/2E-5967 \\
\hline IGc/USP & $\begin{array}{l}\text { Escama de } \\
\text { Coelacanthimorpha }\end{array}$ & $\begin{array}{l}\text { Rio Claro, } \\
\text { Afloramento 1 }\end{array}$ & $\begin{array}{l}\text { Membro Taquaral } \\
\text { Fácies Iai }\end{array}$ & Eopermiano & GP/2E-5968 \\
\hline IGc/USP & $\begin{array}{l}\text { Escama de } \\
\text { Coelacanthimorpha }\end{array}$ & $\begin{array}{l}\text { Rio Claro, } \\
\text { Afloramento 1 }\end{array}$ & Formação Irati & Eopermiano & GP/2E-5969 \\
\hline IGc/USP & $\begin{array}{l}\text { Escama de } \\
\text { Coelacanthimorpha }\end{array}$ & $\begin{array}{l}\text { Rio Claro, } \\
\text { Afloramento 1 }\end{array}$ & Formação Irati & Eopermiano & GP/2E-5970 \\
\hline IGc/USP & Dente labirintodonte & $\begin{array}{l}\text { Rio Claro, } \\
\text { Afloramento 1 }\end{array}$ & $\begin{array}{l}\text { Membro Taquaral } \\
\text { Fácies Iai }\end{array}$ & Eopermiano & $\begin{array}{l}\text { GP/2E-3762 } \\
\text { e GP/2T-202 }\end{array}$ \\
\hline IGc/USP & Dente labirintodonte & $\begin{array}{l}\text { Rio Claro, } \\
\text { Afloramento 1 }\end{array}$ & $\begin{array}{l}\text { Membro Taquaral } \\
\text { Fácies Iai }\end{array}$ & Eopermiano & GP/2E-6309 \\
\hline IGc/USP & $\begin{array}{l}\text { Fragmento mandibular } \\
\text { labirintodonte }\end{array}$ & $\begin{array}{l}\text { Rio Claro, } \\
\text { Afloramento 1 }\end{array}$ & $\begin{array}{l}\text { Membro Taquaral } \\
\text { Fácies Iai }\end{array}$ & Eopermiano & $\begin{array}{l}\text { GP/2E-5971 } \\
\text { e GP/2T-203 }\end{array}$ \\
\hline IGc/USP & Osso & $\begin{array}{l}\text { Rio Claro, } \\
\text { Afloramento 1 }\end{array}$ & $\begin{array}{l}\text { Membro Taquaral } \\
\text { Fácies Iai }\end{array}$ & Eopermiano & GP/2E-6256 \\
\hline IGc/USP & Osso & $\begin{array}{l}\text { Rio Claro, } \\
\text { Afloramento 1 }\end{array}$ & $\begin{array}{l}\text { Membro Taquaral } \\
\text { Fácies Iai }\end{array}$ & Eopermiano & GP/2E-6257 \\
\hline IGc/USP & Osso & $\begin{array}{l}\text { Rio Claro, } \\
\text { Afloramento 1 }\end{array}$ & $\begin{array}{l}\text { Membro Taquaral } \\
\text { Fácies Iai }\end{array}$ & iano & -6268 \\
\hline IGc/USP & Osso & $\begin{array}{l}\text { Rio Claro, } \\
\text { Afloramento 1 }\end{array}$ & $\begin{array}{l}\text { Membro Taquaral } \\
\text { Fácies Iai }\end{array}$ & Eopermiano & GP/2E-6457 \\
\hline IGc/USP & Osso & $\begin{array}{l}\text { Rio Claro, } \\
\text { Afloramento 1 }\end{array}$ & $\begin{array}{l}\text { Membro Taquaral } \\
\text { Fácies Iai }\end{array}$ & Eopermiano & GP/2E-6311 \\
\hline IGc/USP & $\begin{array}{l}\text { Coprólito de } \\
\text { Chondrichthyes (?) }\end{array}$ & $\begin{array}{l}\text { Rio Claro, } \\
\text { Afloramento 1 }\end{array}$ & $\begin{array}{l}\text { Membro Taquaral } \\
\text { Fácies Iai }\end{array}$ & Eopermiano & GP/2E-6301 \\
\hline IGc/USP & Dente fragmentado & $\begin{array}{l}\text { Rio Claro, } \\
\text { Afloramento 1 }\end{array}$ & $\begin{array}{l}\text { Membro Taquaral } \\
\text { Fácies Iai }\end{array}$ & Eopermiano & GP/2E-5972 \\
\hline IGc/USP & $\begin{array}{l}\text { Dente de } \\
\text { Palaeonisciformes }\end{array}$ & $\begin{array}{l}\text { Rio Claro, } \\
\text { Afloramento } 3 \\
\end{array}$ & $\begin{array}{l}\text { Membro Taquaral } \\
\text { Fácies Iai }\end{array}$ & Eopermiano & GP/2E-5973 \\
\hline IGc/USP & Clarkecaris & $\begin{array}{l}\text { Rio Claro, } \\
\text { Afloramento 1 }\end{array}$ & $\begin{array}{l}\text { Membro Taquaral } \\
\text { Fácies Isa }\end{array}$ & Eopermiano & GP/1E-5694 \\
\hline IGc/USP & Clarkecaris & $\begin{array}{l}\text { Rio Claro, } \\
\text { Afloramento 1 }\end{array}$ & $\begin{array}{l}\text { Membro Taquaral } \\
\text { Fácies Isa }\end{array}$ & Eopermiano & GP/1E-5695 \\
\hline IGc/USP & Clarkecaris & $\begin{array}{l}\text { Rio Claro, } \\
\text { Afloramento 1 }\end{array}$ & $\begin{array}{l}\text { Membro Taquaral } \\
\text { Fácies Isa }\end{array}$ & Eopermiano & GP/1E-5696 \\
\hline IGc/USP & Clarkecaris & $\begin{array}{l}\text { Rio Claro, } \\
\text { Afloramento } 5\end{array}$ & $\begin{array}{l}\text { Membro Taquaral } \\
\text { Fácies Isa }\end{array}$ & Eopermiano & GP/1E-5689 \\
\hline IGc/USP & Clarkecaris & $\begin{array}{l}\text { Rio Claro, } \\
\text { Afloramento } 5\end{array}$ & $\begin{array}{l}\text { Membro Taquaral } \\
\text { Fácies Isa }\end{array}$ & Eopermiano & GP/1E-5690a \\
\hline IGc/USP & Clarkecaris & $\begin{array}{l}\text { Rio Claro, } \\
\text { Afloramento } 5 \\
\end{array}$ & $\begin{array}{l}\text { Membro Taquaral } \\
\text { Fácies Isa }\end{array}$ & Eopermiano & GP/1E-5690b \\
\hline IGc/USP & Clarkecaris & $\begin{array}{l}\text { Rio Claro, } \\
\text { Afloramento } 5 \\
\end{array}$ & $\begin{array}{l}\text { Membro Taquaral } \\
\text { Fácies Isa }\end{array}$ & Eopermiano & GP/1E-5691 \\
\hline IGc/USP & Clarkecaris & $\begin{array}{l}\text { Rio Claro, } \\
\text { Afloramento } 5\end{array}$ & $\begin{array}{l}\text { Membro Taquaral } \\
\text { Fácies Isa }\end{array}$ & Eopermiano & GP/1E-5692 \\
\hline IGc/USP & Clarkecaris & $\begin{array}{l}\text { Rio Claro, } \\
\text { Afloramento } 5\end{array}$ & $\begin{array}{l}\text { Membro Taquaral } \\
\text { Fácies Isa }\end{array}$ & Eopermiano & GP/1E-5693 \\
\hline IGc/USP & Crustáceos & Rio Claro, & Membro Taquaral & Eopermiano & GP/1E-5698 \\
\hline
\end{tabular}




\begin{tabular}{|c|c|c|c|c|c|}
\hline & fragmentados & Afloramento 5 & Fácies Isa & & \\
\hline IGc/USP & $\begin{array}{l}\text { Crustáceo } \\
\text { Indeterminado }\end{array}$ & $\begin{array}{l}\text { Rio Claro, } \\
\text { Afloramento } 5\end{array}$ & $\begin{array}{l}\text { Membro Taquaral } \\
\text { Fácies Isa }\end{array}$ & Eopermiano & GP/1E-6173a \\
\hline IGc/USP & $\begin{array}{l}\text { Crustáceo } \\
\text { Indeterminado }\end{array}$ & $\begin{array}{l}\text { Rio Claro, } \\
\text { Afloramento } 5\end{array}$ & $\begin{array}{l}\text { Membro Taquaral } \\
\text { Fácies Isa }\end{array}$ & Eopermiano & GP/1E-6173b \\
\hline IGc/USP & $\begin{array}{l}\text { Crustáceo } \\
\text { Indeterminado }\end{array}$ & $\begin{array}{l}\text { Rio Claro, } \\
\text { Afloramento } 5\end{array}$ & $\begin{array}{l}\text { Membro Taquaral } \\
\text { Fácies Isa }\end{array}$ & Eopermiano & GP/1E-6174 \\
\hline IGc/USP & $\begin{array}{l}\text { Escamas } \\
\text { Palaeonisciformes }\end{array}$ & $\begin{array}{l}\text { Rio Claro, } \\
\text { Afloramento } 1\end{array}$ & $\begin{array}{l}\text { Membro Taquaral } \\
\text { Fácies Isa }\end{array}$ & Eopermiano & GP/2E-6223 \\
\hline IGc/USP & $\begin{array}{l}\text { Escamas } \\
\text { Palaeonisciformes }\end{array}$ & $\begin{array}{l}\text { Rio Claro, } \\
\text { Afloramento } 5\end{array}$ & $\begin{array}{l}\text { Membro Taquaral } \\
\text { Fácies Isa }\end{array}$ & Eopermiano & GP/2E-6222a \\
\hline IGc/USP & $\begin{array}{l}\text { Escamas } \\
\text { Palaeonisciformes }\end{array}$ & $\begin{array}{l}\text { Rio Claro, } \\
\text { Afloramento } 5\end{array}$ & $\begin{array}{l}\text { Membro Taquaral } \\
\text { Fácies Isa }\end{array}$ & Eopermiano & GP/2E-6222b \\
\hline IGc/USP & $\begin{array}{l}\text { Escamas } \\
\text { Palaeonisciformes }\end{array}$ & $\begin{array}{l}\text { Rio Claro, } \\
\text { Afloramento } 5\end{array}$ & $\begin{array}{l}\text { Membro Taquaral } \\
\text { Fácies Isa }\end{array}$ & Eopermiano & GP/2E-6224 \\
\hline IGc/USP & $\begin{array}{l}\text { Escamas } \\
\text { Palaeonisciformes }\end{array}$ & $\begin{array}{l}\text { Rio Claro, } \\
\text { Afloramento } 5\end{array}$ & $\begin{array}{l}\text { Membro Taquaral } \\
\text { Fácies Isa }\end{array}$ & Eopermiano & GP/2E-6225 \\
\hline IGc/USP & $\begin{array}{l}\text { Escamas } \\
\text { Palaeonisciformes }\end{array}$ & $\begin{array}{l}\text { Rio Claro, } \\
\text { Afloramento } 5 \\
\end{array}$ & $\begin{array}{l}\text { Membro Taquaral } \\
\text { Fácies Isa }\end{array}$ & Eopermiano & GP/2E-6228 \\
\hline IGc/USP & $\begin{array}{l}\text { Escamas } \\
\text { Palaeonisciformes }\end{array}$ & $\begin{array}{l}\text { Rio Claro, } \\
\text { Afloramento } 5\end{array}$ & $\begin{array}{l}\text { Membro Taquaral } \\
\text { Fácies Isa }\end{array}$ & Eopermiano & -6225 \\
\hline IGc/USP & $\begin{array}{l}\text { Escamas } \\
\text { Palaeonisciformes }\end{array}$ & $\begin{array}{l}\text { Rio Claro, } \\
\text { Afloramento } 5\end{array}$ & $\begin{array}{l}\text { Membro Taquaral } \\
\text { Fácies Isa }\end{array}$ & Eopermiano & GP/2E-6226 \\
\hline IGc/USP & $\begin{array}{l}\text { Escamas } \\
\text { Palaeonisciformes }\end{array}$ & $\begin{array}{l}\text { Rio Claro, } \\
\text { Afloramento } 5\end{array}$ & $\begin{array}{l}\text { Membro Taquaral } \\
\text { Fácies Isa }\end{array}$ & Eopermiano & GP/2E-6229 \\
\hline IGc/USP & $\begin{array}{l}\text { Escamas } \\
\text { Palaeonisciformes }\end{array}$ & $\begin{array}{l}\text { Rio Claro, } \\
\text { Afloramento } 5\end{array}$ & $\begin{array}{l}\text { Membro Taquaral } \\
\text { Fácies Isa }\end{array}$ & Eopermiano & GP/2E-6230 \\
\hline IGc/USP & $\begin{array}{l}\text { Maxila de } \\
\text { Palaeonisciformes }\end{array}$ & $\begin{array}{l}\text { Rio Claro, } \\
\text { Afloramento } 5\end{array}$ & $\begin{array}{l}\text { Membro Taquaral } \\
\text { Fácies Isa }\end{array}$ & Eopermiano & GP/2E-6231 \\
\hline IGc/USP & Fragmentos ósseos & $\begin{array}{l}\text { Rio Claro, } \\
\text { Afloramento } 5\end{array}$ & $\begin{array}{l}\text { Membro Taquaral } \\
\text { Fácies Isa }\end{array}$ & Eopermiano & GP/2E-6225 \\
\hline IGc/USP & Fragmento ósseo & $\begin{array}{l}\text { Rio Claro, } \\
\text { Afloramento } 5 \\
\end{array}$ & $\begin{array}{l}\text { Membro Taquaral } \\
\text { Fácies Isa }\end{array}$ & Eopermiano & GP/2E-6225 \\
\hline IGc/USP & $\begin{array}{l}\text { Escamas } \\
\text { Coelacanthimorpha }\end{array}$ & $\begin{array}{l}\text { Rio Claro, } \\
\text { Afloramento } 5\end{array}$ & $\begin{array}{l}\text { Membro Taquaral } \\
\text { Fácies Isa }\end{array}$ & Eopermiano & GP/2E-6233a \\
\hline IGc/USP & $\begin{array}{l}\text { Escamas } \\
\text { Coelacanthimorpha }\end{array}$ & $\begin{array}{l}\text { Rio Claro, } \\
\text { Afloramento } 5\end{array}$ & $\begin{array}{l}\text { Membro Taquaral } \\
\text { Fácies Isa }\end{array}$ & Eopermiano & GP/2E-6233b \\
\hline IGc/USP & Escama (?) & $\begin{array}{l}\text { Rio Claro, } \\
\text { Afloramento } 5\end{array}$ & $\begin{array}{l}\text { Membro Taquaral } \\
\text { Fácies Isa }\end{array}$ & Eopermiano & GP/2E-6234 \\
\hline IGc/USP & $\begin{array}{l}\text { Escamas } \\
\text { Palaeonisciformes }\end{array}$ & $\begin{array}{l}\text { Rio Claro, } \\
\text { Afloramento } 5 \\
\end{array}$ & $\begin{array}{l}\text { Membro Taquaral } \\
\text { Fácies Isa }\end{array}$ & Eopermiano & GP/2E-6239a \\
\hline IGc/USP & $\begin{array}{l}\text { Escamas } \\
\text { Palaeonisciformes }\end{array}$ & $\begin{array}{l}\text { Rio Claro, } \\
\text { Afloramento } 5 \\
\end{array}$ & $\begin{array}{l}\text { Membro Taquaral } \\
\text { Fácies Isa }\end{array}$ & Eopermiano & GP/2E-6239b \\
\hline IGc/USP & Osso & $\begin{array}{l}\text { Rio Claro, } \\
\text { Afloramento } 5\end{array}$ & $\begin{array}{l}\text { Membro Taquaral } \\
\text { Fácies Isa }\end{array}$ & Eopermiano & GP/2E-6240a \\
\hline IGc/USP & Osso & $\begin{array}{l}\text { Rio Claro, } \\
\text { Afloramento } 5\end{array}$ & $\begin{array}{l}\text { Membro Taquaral } \\
\text { Fácies Isa }\end{array}$ & Eopermiano & GP/2E-6240b \\
\hline IGc/USP & Dente Palaeonisciforme & $\begin{array}{l}\text { Ipeúna, } \\
\text { Afloramento } 12\end{array}$ & $\begin{array}{l}\text { Membro Taquaral } \\
\text { Fácies Isa }\end{array}$ & Eopermiano & GP/2E-6586 \\
\hline IGc/USP & $\begin{array}{l}\text { Escama } \\
\text { Coelacanthimorpha }\end{array}$ & $\begin{array}{l}\text { Ipeúna, } \\
\text { Afloramento } 12\end{array}$ & $\begin{array}{l}\text { Membro Taquaral } \\
\text { Fácies Isa }\end{array}$ & Eopermiano & GP/2E-6588 \\
\hline
\end{tabular}

